\title{
Antroponimija zagrebačkih Židova od početka XIX. st. do drugog svjetskog rata
}

Kusin, Igor

Doctoral thesis / Disertacija

2020

Degree Grantor / Ustanova koja je dodijelila akademski / stručni stupanj: University of Zagreb, University of Zagreb, Faculty of Humanities and Social Sciences / Sveučilište u Zagrebu, Filozofski fakultet

https://doi.org/10.17234/diss.2020.5170

Permanent link / Trajna poveznica: https://urn.nsk.hr/urn:nbn:hr:131:428971

Rights / Prava: In copyright/Zaštićeno autorskim pravom.

Download date / Datum preuzimanja: 2023-04-26

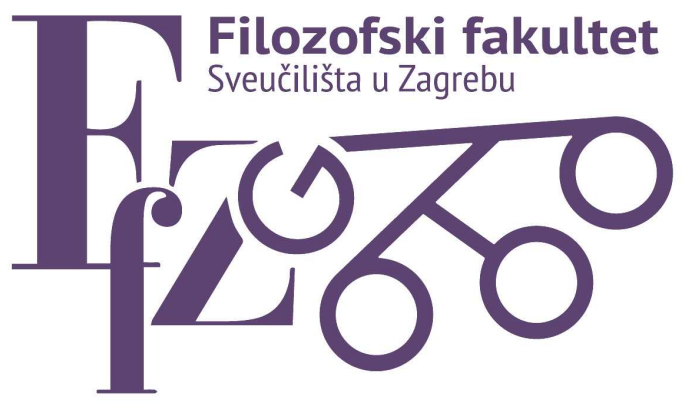

Repository / Repozitorij:

ODRAZ - open repository of the University of Zagreb

Faculty of Humanities and Social Sciences
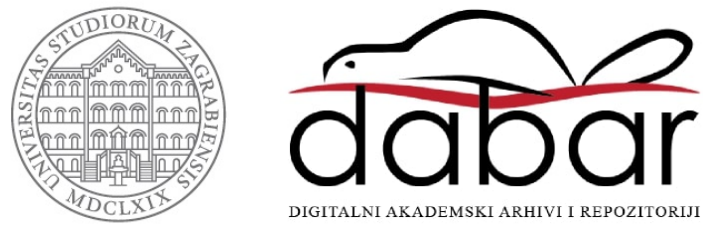


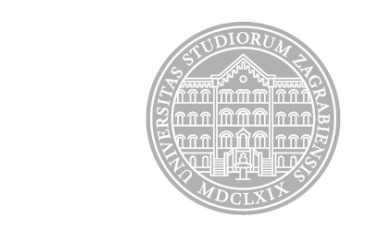

Sveučilište u Zagrebu

Filozofski fakultet

\author{
Igor Kusin
}

\title{
ANTROPONIMIJA ZAGREBAČKIH ŽIDOVA OD POČETKA XIX. ST. DO DRUGOG SVJETSKOG RATA
}

\author{
DOKTORSKI RAD
}

\author{
Mentori: \\ Dr. sc. Domagoj Vidović \\ Dr. sc. Ranko Matasović
}

Zagreb, 2020. 



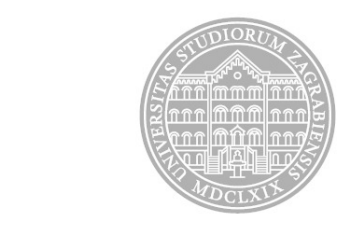

University of Zagreb

Faculty of Humanities and Social Sciences

Igor Kusin

\title{
ANTHROPONYMY OF ZAGREB JEWS FROM THE BEGINNING OF THE $19^{\text {TH }}$ CENTURY UNTIL WORLD WAR II
}

\author{
DOCTORAL THESIS
}

Supervisors:

Domagoj Vidović, Ph. D.

Ranko Matasović, Ph. D.

Zagreb, 2020. 



\section{KRATKE BIOGRAFIJE MENTORA}

\section{Dr. sc. Domagoj Vidović,}

viši znanstveni suradnik pri Odjelu za onomastiku i etimologiju Instituta za hrvatski jezik i jezikoslovlje

Domagoj Vidović rođen je 20. studenoga 1979. u Metkoviću. Osnovnu je školu pohađao u Metkoviću i Pučišćima na otoku Braču, a gimnaziju u Metkoviću. Diplomu profesora lingvistike i hrvatskoga jezika i književnosti stekao je u ožujku 2004. na Filozofskome fakultetu u Zagrebu obranivši rad Nacrt za vidonjsku antroponimiju i toponimiju. Od 1. rujna 2004. zaposlen je u Institutu za hrvatski jezik i jezikoslovlje. Iste je godine upisao poslijediplomski znanstveni studij lingvistike te doktorirao u travnju 2011. s temom Antroponimija i toponimija Zažablja pod mentorstvom Dunje Brozović Rončević. Danas radi na projektima Odjela za onomastiku i etimologiju te je voditeljem podružnice Instituta u Metkoviću. Predmetom je njegova užega zanimanja onomastika na rubnim hrvatskim prostorima i akcentologija, a bavi se i prevođenjem s esperanta. Objavio je tri samostalne knjige i jednu u suautorstvu, dvadesetak izvornih znanstvenih radova i sudjelovao na nekoliko međunarodnih znanstvenih skupova. Objavljuje i popularnoznanstvene članke o podrijetlu neretvanskih i bračkih rodova u mjesnim časopisima (Metkovski vjesnik, Vrutak i Veselje svetog Jere), na portalima (metkovic.hr, likemetkovic.hr) te na društvenim mrežama (stranice Pučišća i Radija Narona na Facebooku), urednikom je antroponomastičke rubrike Od Mile do Drage u časopisu Hrvatski jezik te je članom uredništva Hrvatskoga neretvanskog zbornika (od 2014. i glavnim urednikom) i povremenim članom uredništva Humskoga zbornika. Godine 2013. i 2014. bio je članom Organizacijskoga odbora Neretvanskih književnih, znanstvenih i kulturnih susreta koji se održavaju u južnohrvatskim gradovima Metkoviću, Pločama, Opuzenu, Neumu i Čapljini. Stalnim je kolumnistom Hrvatskoga slova bio od lipnja 2012. do srpnja 2015., nakon čega jezikoslovnu kolumnu objavljuje na e-stranicama BK Neretva (podstranica Rodu o jeziku). Članom je Hrvatskoga filološkog društva, Odbora za onomastiku HAZU-a i Odbora za dijalektologiju HAZU-a, ICOS-a (Međunarodnoga vijeća za onomastičke znanosti) i Hrvatskoga saveza za esperanto, članom je suradnikom Južnohrvatskoga ogranka Društva hrvatskih književnika, surađuje s Društvom dubrovačkih pisaca te književne tekstove objavljuje u časopisima Literat i Stolačko kulturno proljeće. Kao jedan od autora Školskoga rječnika hrvatskog jezika dobitnik je Nagrade Grada Zagreba 2013. Dobitnik je godišnje državne nagrade za popularizaciju i promidžbu znanosti u području 
humanističkih znanosti Hrvatskoga sabora za 2014. godinu. Godine 2016. dobio je nagradu Narona u području znanosti koju dodjeljuje Grad Metković. Članom je Radne skupine Odbora za imenovanje naselja, ulica i trgova Gradske skupštine Grada Zagreb bio od svibnja 2014. do travnja 2017. 


\section{Dr. sc. Ranko Matasović,}

redoviti profesor na Katedri za poredbenu lingvistiku Odsjeka za lingvistiku Filozofskog fakulteta Sveučilišta u Zagrebu

Na Filozofskom fakultetu Sveučilišta u Zagrebu studirao je opću lingvistiku i filozofiju. Magistrirao je 1992., a doktorirao 1995. obranivši tezu o rekonstrukciji teksta u indoeuropeistici (mentor: prof. dr. Radoslav Katičić). Od 1996. predstojnik je Katedre za poredbenu indoeuropsku lingvistiku na Odsjeku za lingvistiku Filozofskoga fakulteta u Zagrebu; 1996. je postao docentom, 2000. izvanrednim profesorom, a 2004. redovnim profesorom na Odsjeku za lingvistiku Filozofskoga fakulteta u Zagrebu. Od 2009. je u trajnom zvanju. Stručno se usavršavao na sveučilištima u Beču (1993.) i Oxfordu (1995.). Bio je stipendist Fulbrightove zaklade za poslijedoktorski studij na Sveučilištu države Wisconsin u Madisonu u SAD-u za 1997./1998., a koristio se i stipendijom Zaklade Alexander von Humboldt za 2002./2003. na Sveučilištu u Bonnu. U ljetnom semestru 2008. boravio je u Nizozemskoj kao gost Odsjeka za poredbenu lingvistiku Sveučilišta u Leidenu. Član je lingvističkoga društva The Philological Society (London) i međunarodnoga udruženja indoeuropeista Indogermanische Gesellschaft (Wiesbaden). Predsjednik je Odbora za etimologiju Hrvatske akademije i član Odbora za baltoslavistiku Međunarodnoga slavističkog kongresa. Od 2004. do 2009. sudjelovao je u projektu izrade indoeuropskoga etimološkog rječnika Sveučilišta u Leidenu.

Objavio je trinaest knjiga, među kojima se ističu Kratka poredbeno povijesna gramatika latinskoga jezika (Zagreb, 1997., 2. prošireno izdanje 2010.), Uvod u poredbenu lingvistiku (Zagreb, 2001.), Jezična raznolikost svijeta (Zagreb, 2005., 2. prošireno izdanje 2011.) te Poredbenopovijesna gramatika hrvatskoga jezika (Zagreb, 2008.), Gender in Indo-European (Heidelberg, 2004.), A Theory of Textual Reconstruction in Indo-European Linguistics (Frankfurt a/M \& New York, 1996.) i Etymological Dictionary of Proto-Celtic (Leiden, 2009.). Istaknuo se kao urednik lingvističkih edicija i kao prevoditelj s različitih jezika. Dobitnik je Nagrade Hrvatske akademije za 2002. za trajan doprinos znanosti na području filologije, a godine 2006. izabran je za člana suradnika Hrvatske akademije znanosti i umjetnosti. 2012. izabran je za redovitog člana HAZU. 



\section{ZAHVALE}

U uvodu ovog rada želim zahvaliti svojim roditeljima, Vlasti i Branku, svojim mentorima, dr. sc. Domagoju Vidoviću, višem znanstvenom suradniku u Institutu za hrvatski jezik i jezikoslovlje, i prof. dr. sc. Ranku Matasoviću s Odsjeka za lingvistiku, na savjetima i sugestijama prilikom oblikovanja i pisanja doktorskoga rada, kao i svim kolegama i prijateljima koji su me u mom pothvatu podržavali.

Zahvale upućujem i prof. dr. sc. Anđeli Frančić s Odsjeka za kroatistiku za pomoć i podršku, dr. sc. Tatjani Paić-Vukić, višoj znanstvenoj suradnici u Arhivu HAZU-a, koja mi je pomogla razriješiti neke nedoumice oko arapskih imena te dr. sc. Danijelu Berkoviću s Teološkog fakulteta Matija Vlačić Ilirik za ponuđenu pomoć u prijevodu i etimologiji hebrejskih osobnih imena i sintagma. 



\section{SAŽETAK}

Iako je nazočnost pojedinih Židova u gradu potvrđena i ranije, njihov kontinuirani boravak u Zagrebu možemo pratiti od početka XIX. st. i prvih popisa iz 1808. g. (za gradsku jurisdikciju) i iz 1812. g. (za biskupsku jurisdikciju). Prateći antroponimiju zagrebačkih Židova od tih popisa do početka II. svjetskog rata u gradu Zagrebu (u kojem je zajednica desetkovana) ovaj rad analizira više njezinih komponenata: građanska osobna imena /kinnūy/ "nadimak") zagrebačkih Židova, njihovu čestoću, podrijetlo i jezike iz kojih su neposredno preuzeta s dijakronijskim pristupom čestoći pojedinih izvorišnih jezika osobnih imena i jezika iz kojih su osobna imena neposredno preuzeta; zatim židovska osobna imena

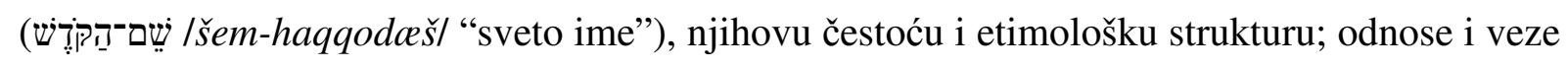
između pojedinih građanskih i pojedinih židovskih osobnih imena te dijakronijski prikaz čestoće najfrekventnijih njihovih kombinacija. Sva se ova istraživanja izvode zasebno za muška i zasebno za ženska osobna imena. U prezimenā se analizira njihova etimologija, te Čestoća pojedinih izvorišnih jezika prezimenā, kao i promjene prezimena te prezimena zabilježena hebrejskim pismom. 


\section{SUMMARY}

Although the presence of some Jews in the city has been confirmed in earlier ages, their continuous stay in Zagreb can be traced back to the beginning of the $19^{\text {th }}$ century and the first censuses from 1808 (for the municipal jurisdiction) and 1812 (for the bishopric jurisdiction). Following the anthroponymy of Zagreb Jews from these censuses to the beginning of World War Two in today's Croatia (in which the community was decimated), this paper analyses several of its components based on three sources: Gavro Schwarz's book Povijest zagrebačke židovske općine od osnutka do 50-tih godina 19. vijeka (History of the Zagreb Jewish community from its foundation to the 1850s; Zagreb, 1939), the Jewish registers of birth from 1849 until 1898. (omitting the year 1857), and the data collected from the Jewish section of the Old Cemetery at Mirogoj, which is threefold: inscriptions in Latin script, inscriptions in Hebrew script and the Gradska groblja database available on-line.

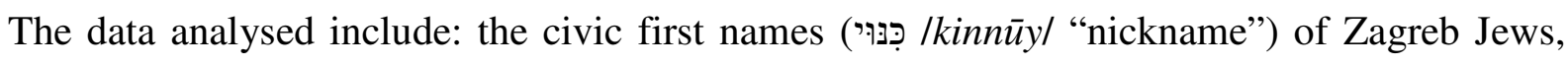
their frequency, origin and languages from which they were directly loaned, with a diachronic approach to the frequency of particular source languages of first names and languages from

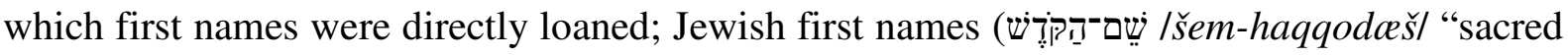
name"), their frequency and their etymological structure; relationships and links between individual civil and individual Jewish first names and diachronic representation of the frequency of their most popular combinations. All these researches are performed separately for male first names and for female first names. As far as family names are concerned, their etymology is analysed, as well as the frequency of individual source languages. We also analyse the changes of family names and the family names recorded in Hebrew script.

\section{Civic First Names of Zagreb Jews}

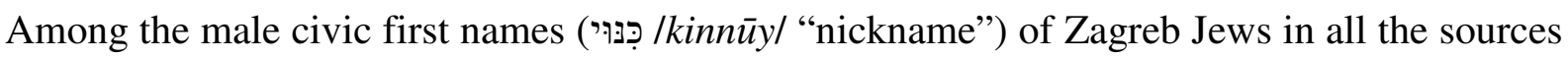
the most frequent are those derived from two Hebrew first names: יחוֹסֵף

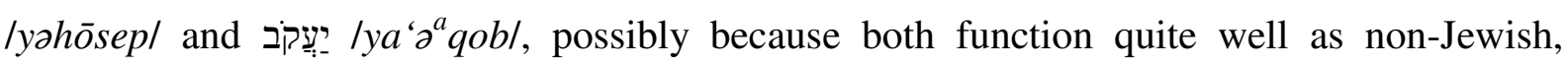

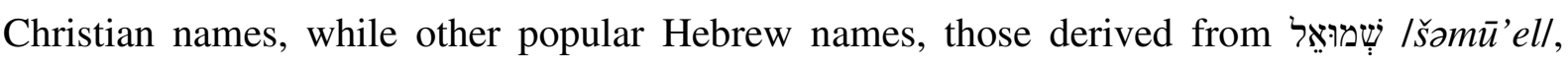

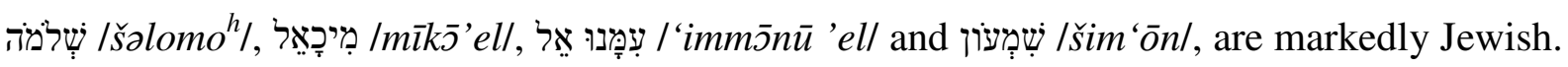
Several others are connected with a given Hebrew name in one way or another: Leopoldus/ 


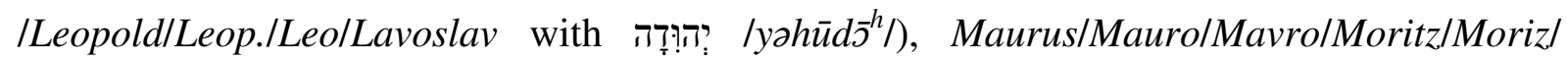

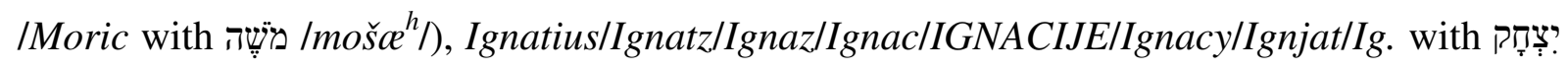
/yiṣḩ̄ōq/), and Adalbert/Albert/Alberto with אָבְרָהָם /'abrōhōm/).

Concerning the known etymologia remota of male civic first names (for 3.8\% individuals and $8.26 \%$ name forms the etymologia remota is unknown), the languages of origin can be classified in the following categories: Germanic (31.88\% of individuals, $23.88 \%$ name forms), Semitic (Hebrew and Aramaic; 23.55\%, 25.22\%), Latin (20.11\%, 13.62\%), Slavic $(10.43 \%, 12.05 \%)$, Greek $(6.96 \%, 10.71 \%)$, Celtic $(1.2 \%, 0.45 \%)$, Romance $(1,05 \%, 2.9 \%)$, Hungarian $(0.91 \%, 2.46 \%)$, Turkic $(0.07 \%, 0.22 \%)$, and Persian $(0.04 \%, 0.22 \%)$.

Throughout the observed period (1789-1898), dominant among male civic first names are those of Germanic origin. The first first name of Slavic origin (Lavoslav) was registered in 1859. The number of boys whose first name was of Slavic origin reached its maximum in 1897, with 14 individuals (33.33\%) and 9 different first names - Božidar (2), Dragutin, Lavoslav (2), Ljudevit, Milan (4), Radivoj, Srećko, Stanko and Vladimir.

Concerning the known etymologia proxima of male civic first names (for $6.49 \%$ individuals and $55.8 \%$ name forms the etymologia remota is unknown), the languages from which the name was directly borrowed can be classified in the following categories: Germanic $(48.12 \%$, 9.82\%), Croatian $(35.64 \%, 20.09 \%)$, Hungarian $(5.5 \%, 5.36 \%)$, Italian $(1.51 \%$, ), French $(1.17 \%, 1.34 \%)$, Latin $(0.8 \%, 1.56 \%)$, Yiddish $(0.56 \%, 1.56 \%)$, Polish $(0.6 \%, 0.22 \%)$, and Turkish $(0.6 \%, 0.22 \%)$.

Until 1896 male civic first names borrowed from German dominate. The year after, Croatian first names take over the leadership of 17 individuals versus 10 German ones, only for the latter to become completely absent in 1898. The decisive year seems to be 1879 , when Croatian names reached the number of 5 holders - the record for non-German names up to that point, achieved by Italian ones in 1867. From then until 1896 Croatian first names outnumber all the rest except German. In the last year for which we have secure data, 1898, 
Croatian first names make up $91.67 \%$ of all male names, while the remaining $8.33 \%$ regards Italian first names.

There are only two female civic first names derived from Hebrew ones, חִָּ $/$ hann ${ }^{h} /$ and

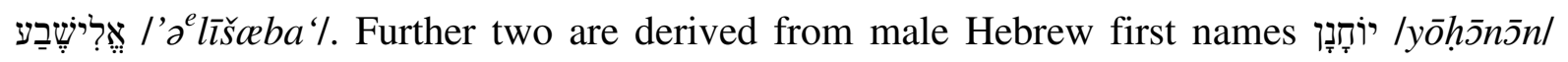

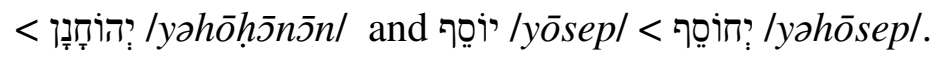

Among the female civic first names (for $10.06 \%$ individuals and $20.5 \%$ name forms the etymologia remota is unknown), the languages of origin can be classified in the following categories: Semitic (Hebrew and Aramaic, 21.13\%, 17.99\%), Germanic (18,42\%, 14.85\%), Latin $(15.71 \%, 12.97 \%)$, Romance(15.71\%, 12.97\%), Slavic (10.15\%, 9\%), Greek (7.30\%, $10.04 \%)$, first names from poetry $(1.01 \%, 0.84 \%)$, and Hungarian $(0.51 \%, 0.84 \%)$.

Among the female civic first names in the observed period there is no language of origin that would dominate. The first first name of Slavic origin (Russian Olga) among girls appeared in 1858, a year before it appeared among boys. The number of girls whose first name was of Slavic origin reached its maximum of 1897 with 15 individuals (35.29\%) and 9 different first names - Darinka, Dragica (2), Jelka, Ljudevita, Nada, Olga (4), Vera 3), Zdenka and Zora.

Among the female civic first names (for $62.89 \%$ individuals and $67.47 \%$ name forms the etymologia remota is unknown), the languages from which the name was directly borrowed can be classified into the following categories: German (18.51\%, 13.57\%), Croatian (11.98\%, $11.52 \%)$, Russian $(2.32 \%, 0.56 \%)$, Italian $(1.98 \%, 2.79 \%)$, Hungarian $(1.63 \%$, ), French $(0.34 \%, 0.93 \%)$, and Polish $(0.04 \%, 0.19 \%)$.

Female Croatian first names borrowed from German dominate until 1894, and in 1895 Croatian first names occupied the leading position. Croatian first names raised somewhat above others in 1879 when four individuals were recorded, which no other language but German was able to achieve. Croatian female fist names reached its record high in 1897 with 19 individuals, while in the year after, the last for which we have accurate data, their number fell to $11(78.57 \%)$. 


\section{Jewish First Names Of Zagreb Jews}

Concerning male Jewish first names, ten of the most popular ones are Hebrew: אבְרָדָם

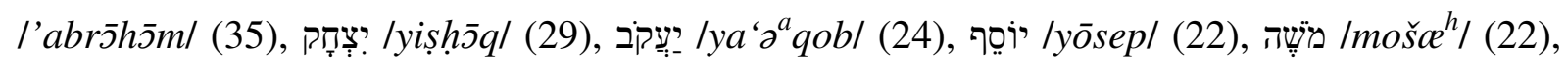

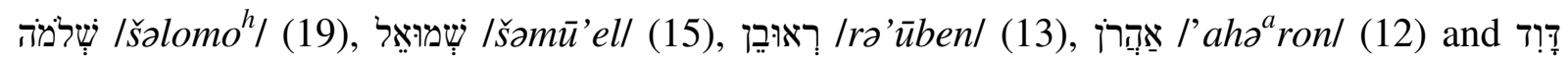
/d̄̄wid/ (11), while among those with a double-digit number of individuals includes two more:

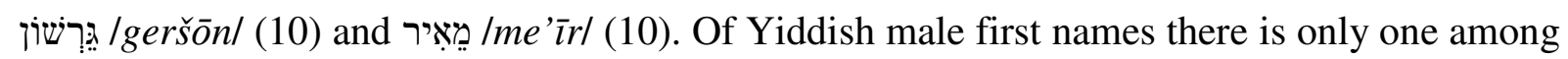
the ten most popular, ליב ליב /leyb/ (11).

\section{Correlations of Civic and Jewish First Names of Zagreb Jews}

The most common combination of a male civic and Jewish first name is one that includes the first names Joseph/Josef/Josip (one of the two most popular male civic names) and /yōsep/. There are several more cases of a "Europeanised", Christian, and original, Hebrew

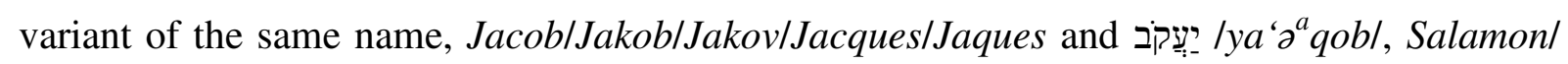

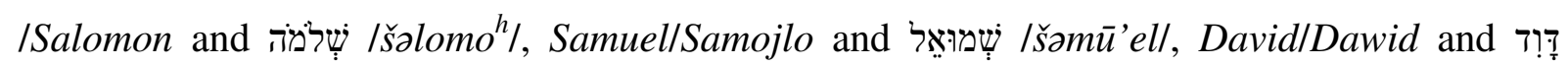

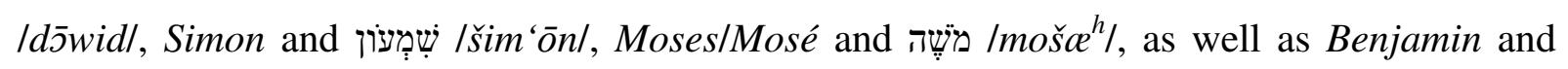

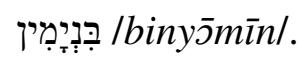

Frequent combinations are also Albert and אַבְרָדָם /'abrōhs̄m/, and Moritz/Moriz/Moric/Mavro

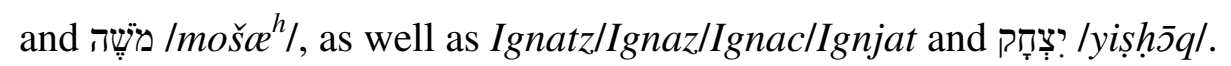

Among the combinations whose connection stems from the Torah, from comparisons and metaphors used by Jacob concerning his sons in his testament from Genesis 49 as well as from Moses's blessing of the Israeli tribes in Deuteronomy 33, the most frequent are those related to the term "lion", most often including folk etymology: Leopold and ליב /leyb/,

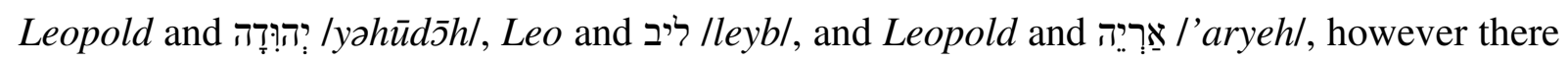

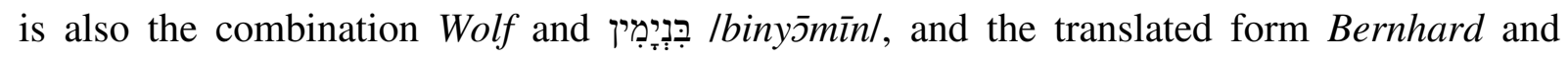
/ber/berl/. 
There are even more examples of fist name association based on the similarity of the material forms of the two names, especially first names sharing the same initial letter/sound, but also those with some consonants in common.

The following combinations of first personal names: Leopold and לִבְרָָָם /leyb/, Albert and

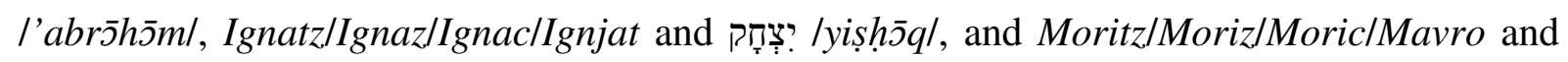
משֶֶה /moš $\check{c}^{h} /$ occur throughout the observed period, with their frequency decreasing toward its end.

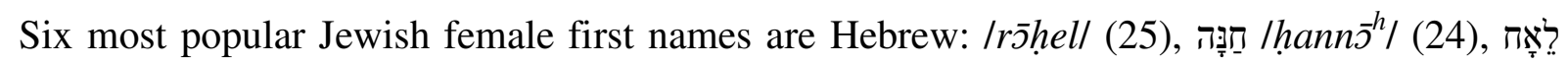

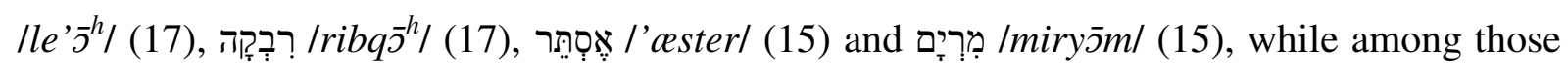
with a double-digit number of bearers there is another one: מלכה /malk $\bar{\nu}^{h} /$ or $/ m i l k{ }^{h} /(12)$. Four of the ten most popular female Jewish first names are Yiddish ones: גילה /gitl/ (15), ביטל Ibeyle/ (14), שיילה /heyle/ (10) and שרל /serl/ (10).

Among female first names, the only rule of association between a particular civil and a particular Jewish name is the similarity of the material forms of the two names. The most frequent pairs of first names are Marie/Maria/Marija and מִּרִיָ /mirys̄m/ (two variants of the same first name, Christian and Hebrew), Johanna/Ivana and חַּ /

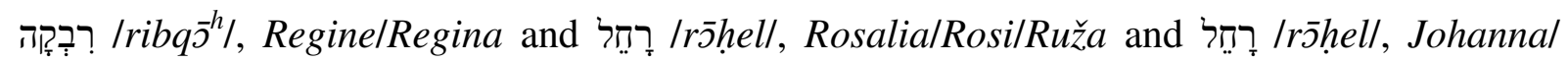
/Johana and פינדל /hindl/, Paola/Paula/Pauline and, Theres/Therese/Theresal

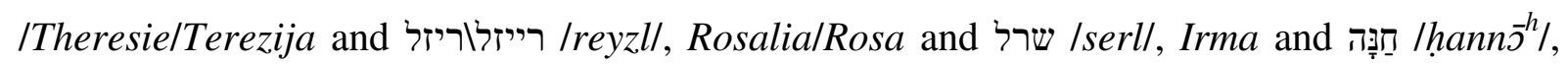

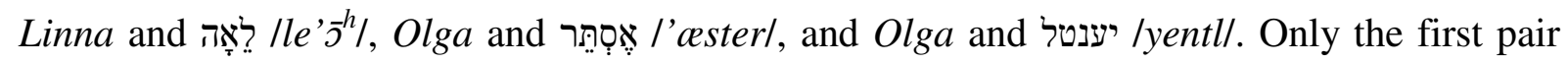
listed above has a double-digit number of individuals -10 . 


\section{Family Names of Zagreb Jews}

The most common family name is Schwarz with its variants and translations, followed by Koen/Kohn/Kon, Neuman/Neumann, Spitzer/Špicer, Weis/Weiß/Weiss/Weisz, Dajč/Deutsch/ Maceljski/Njemčić, Hirschl/Hiršl and Miller/Müller/Mueller.

Based on their etymology, the family names can be divided into those of Yiddish, Czech, Hungarian and Russian origins (Ashkenazi surnames), Sephardi (including those of Arabian etymology), Italian, including both Ashkenazi and Sephardi ones, Hebrew and Croatian ones.

There are 786 Ashkenazi family names plus three more potential ones, 90 Croatian ones, 19 Italian ones, 11 Sephardi and 11 Hebrew ones, one English one, one Greek one, one Yiddishised Hebrew one, one Croatised Hebrew one, one Latin one, as well as 34 family names whose etymology cannot be established with certainty.

\section{Changes of Family Names among Zagreb Jews}

In most cases of family names changes (35) both the old and the new family name share the same initial letter. Fourteen family names have been changed by translating them into another language. In the case of five family name the change involved transcribing the original family name phonetically into the orthography of another language. In seven cases, the original family name was adapted to the usual rules of Croatian family names formation, and in four the original and new family names share a similar material form.

\section{Family Names of Zagreb Jews written in Hebrew Script}

Most of the family names written in the Hebrew script follow the Yiddish orthography that is in use today, with some exceptions, such as spelling of geminates typical of German, but not Yiddish orthography, spelling of digraphs $<d t>$ and $<t h>$ common in German family names (in other words in archaic German spelling) instead of letters $\langle\nu\rangle$ and transliteration letter by 
letter from the German Latin alphabet into the Yiddish square one. All of these non-Yiddish phenomena have not been carried on consistently, but only in some surnames, while others follow the Yiddish orthography rules. In two cases the spelling of the family name follows the Hebrew orthography. A Sephardi family name was written down with a spelling typical not only for Hebrew but also for Judeo-Spanish, some variants of Yiddish and some other Jewish languages. 


\section{Ključne riječi}

Zagrebački Židovi, osobna imena, prezimena, židovska imena, židovska prezimena, promjena prezimena

\section{Key Words}

Zagreb Jews, first names, family names, Jewish first names, Jewish family names, change of family names 



\section{Sadržaj}

$1 \mathrm{Uvod}$

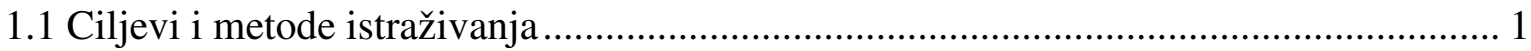

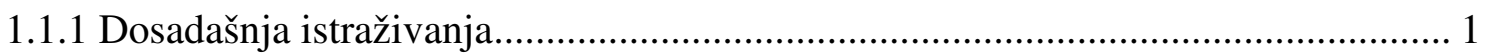

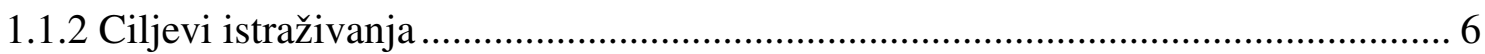

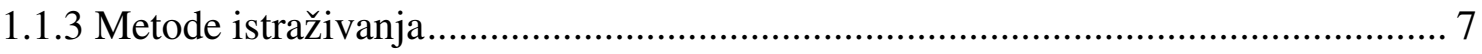

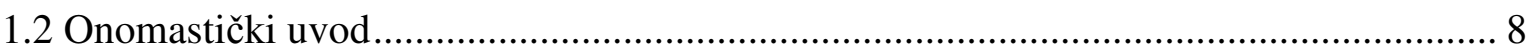

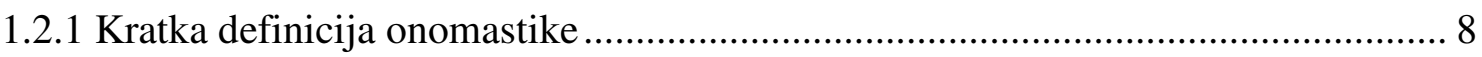

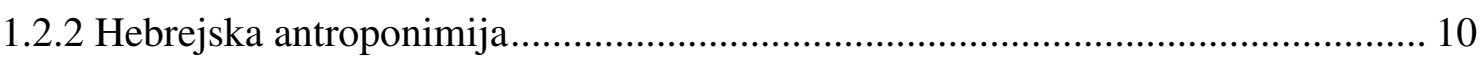

1.2.2.1 Razvoj imenske formule u Židovā ........................................................... 13

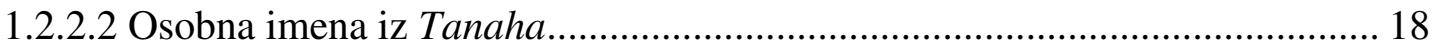

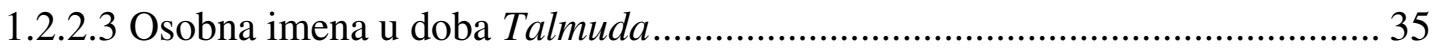

1.2.2.4 Srednji vijek i osobna imena na govornim jezicima .................................. 44

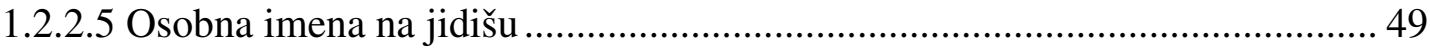

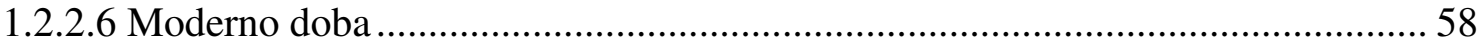

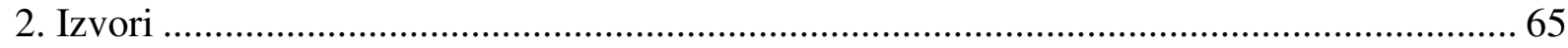

2.1 Knjiga Povijest zagrebačke židovske općine od osnutka do 50-tih godina 19. vijeka

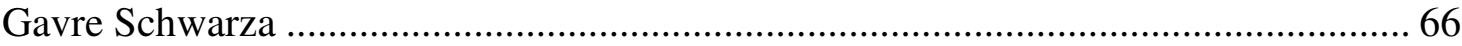

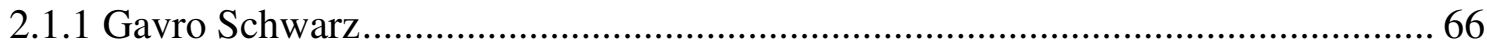

2.1.2 Povijest zagrebačke židovske općine od osnutka do 50-tih godina 19. vijeka ...... 67

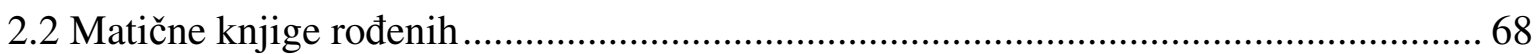

2.3 Izraelitski odjel zagrebačkog groblja Mirogoj...................................................... 71

2.3.1 Židovski i nežidovski simboli na Mirogoju................................................. 71

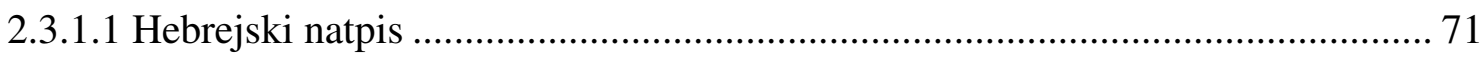

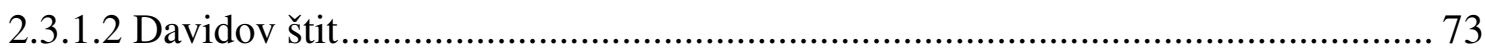


2.3.1.3 Kohenske šake 78

2.3.1.4 Vrč 79

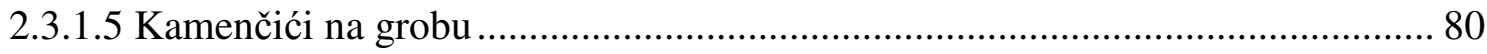

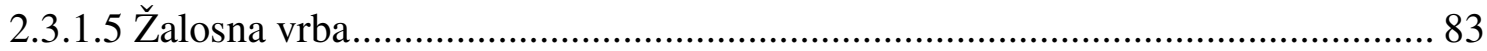

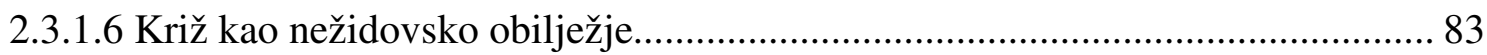

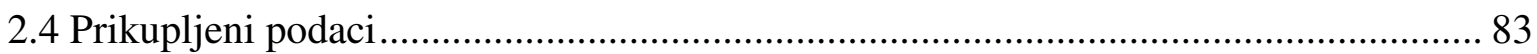

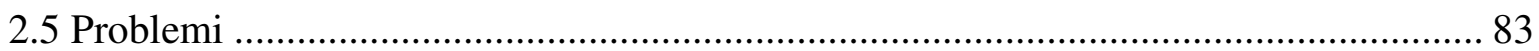

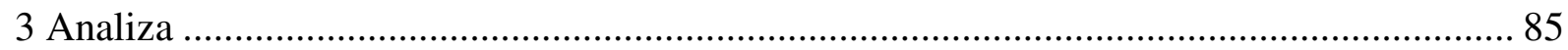

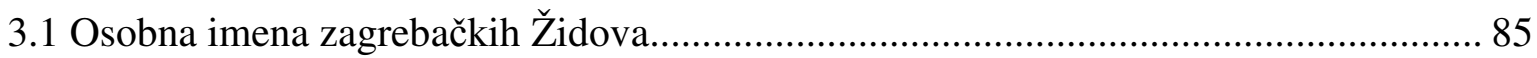

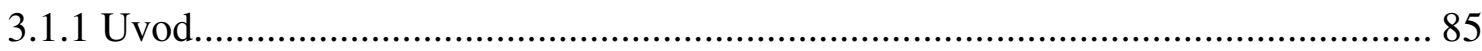

3.1.2 Građanska osobna imena zagrebačkih Židova.............................................. 95

3.1.2.1 Najčešća građanska osobna imena u pojedinim izvorima....................... 96

3.1.2.1.1 Najčešća muška građanska osobna imena u pojedinim izvorima...... 96

3.1.2.1.2 Najčešća ženska građanska osobna imena u pojedinim izvorima ... 101

3.1.2.2 Najčešća građanska osobna imena u užem korpusu............................. 108

3.1.2.2.1 Najčešća muška građanska osobna imena u užem korpusu ............ 108

3.1.2.2.2 Najčešća ženska građanska osobna imena u užem korpusu ............ 115

3.1.2.3 Etymologia remota građanskih osobnih imena u užem korpusu............. 123

3.1.2.3.1 Etimološka struktura građanskih osobnih imena u užem korpusu .. 123

3.1.2.3.1.1 Etimološka struktura muških građanskih osobnih imena u užem korpusu

3.1.2.3.1.2 Etimološka struktura ženskih građanskih osobnih imena u užem korpusu

3.1.2.3.1.3 Usporedba etimoloških strukturā muških i ženskih građanskih osobnih imena u užem korpusu 126

3.1.2.3.2 Dijakronijska analiza građanskih osobnih imena zagrebačkih Židova 128 
3.1.2.3.2.1 Dijakronijska analiza muških građanskih osobnih imena zagrebačkih Židova

3.1.2.3.2.2 Dijakronijska analiza ženskih građanskih osobnih imena zagrebačkih Židova

3.1.2.4 Etymologia proxima građanskih osobnih imena u užem korpusu.

3.1.2.4.1 Etimološka struktura građanskih osobnih imena u užem korpusu .. 132

3.1.2.4.1.1 Etimološka struktura muških građanskih osobnih imena u užem korpusu

3.1.2.4.1.2 Etimološka struktura ženskih građanskih osobnih imena u užem korpusu 133

3.1.2.4.1.3 Usporedba etimoloških strukturā muških i ženskih građanskih osobnih imena u užem korpusu 135

3.1.2.4.2 Dijakronijska analiza građanskih osobnih imena zagrebačkih Židova 136

3.1.2.4.2.1 Dijakronijska analiza muških građanskih osobnih imena zagrebačkih Židova

3.1.2.4.2.2 Dijakronijska analiza ženskih građanskih osobnih imena zagrebačkih Židova

3.1.3 Židovska osobna imena zagrebačkih Židova.

3.1.3.1 Muška židovska osobna imena zagrebačkih Židova 140

3.1.3.2 Ženska židovska osobna imena zagrebačkih Židova 167

3.1.4 Suodnos građanskih i židovskih osobnih imena zagrebačkih Židova 185

3.1.4.1 Suodnos muškog građanskog i židovskog osobnog imena 186

3.1.4.1.1 Dijakronijska analiza suodnosa čestih parova muških osobnih imena. 189

3.1.4.2 Suodnos ženskog građanskog i židovskog osobnog imena 193

3.2 Prezimena zagrebačkih Židova 194

3.2.1 Statistička analiza prezimenā. 198 
3.2.1.1 Knjiga Povijest zagrebačke židovske općine od osnutka do 50-tih godina 19. vijeka Gavre Schwarza

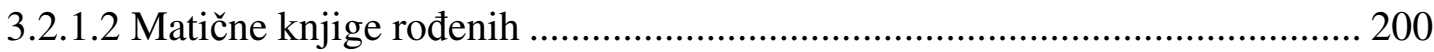

3.2.1.3 Izraelitski odjel zagrebačkog groblja Mirogoj .......................................... 201

3.2.1.4 Najčešća prezimena u sva tri izvora......................................................... 205

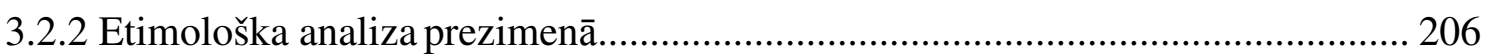

3.2.2.1 Statistička analiza prezimenā prema podrijetlu ....................................... 287

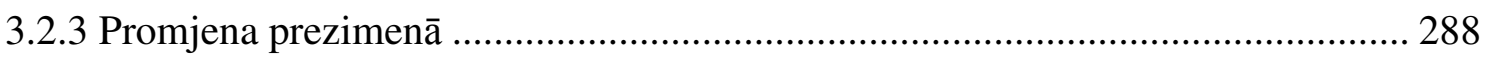

3.2.3.1 Opažanja vezana uz promjene prezimenā .............................................. 300

3.2.4 Prezimena pisana hebrejskim pismom.......................................................... 301

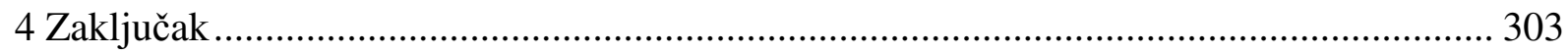

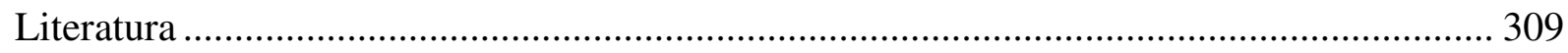

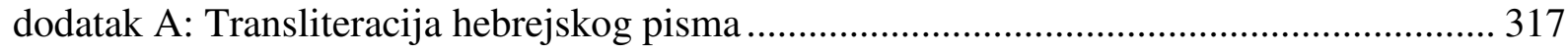

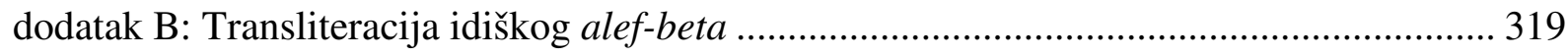

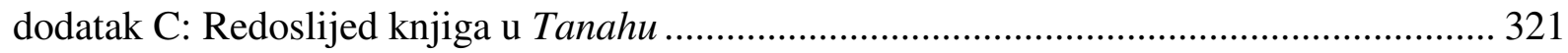

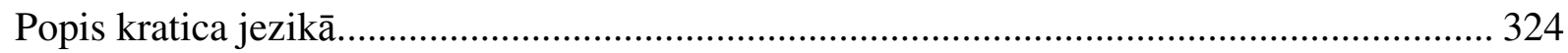

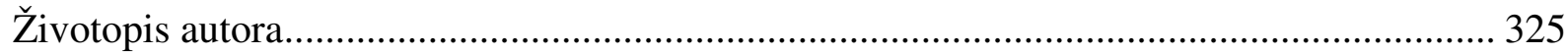




\section{UVOD}

\subsection{Ciljevi i metode istraživanja}

\subsubsection{Dosadašnja istraživanja}

Dok su židovska osobna imena iz Tanaha ${ }^{1}$ stoljećima bila predmet proučavanja židovskih i kršćanskih autora, ona poslijebiblijska nisu izazivala toliko zanimanje, posebice u kršćanā. Prva su djela o njima pisali rabini u namjeri da kodificiraju grafički oblik tradicionalnih

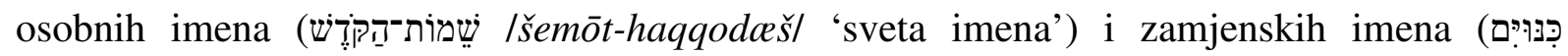
/kinnūyìm/ 'nadimci' ${ }^{2}$ ) s ciljem da se prva ispravno navode u dokumentima vezanima uz vjerske obrede, a posebice u onima o razvodu. Najpoznatije su među tim studijama one

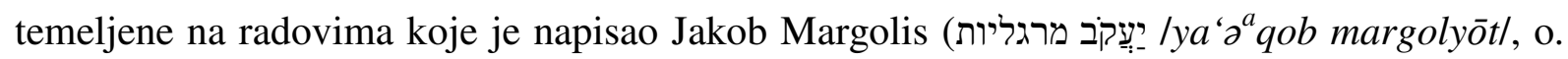
1430. - 1501.), vrhovni rabin u Nürnbergu i Regensburgu, objavljenima krajem XVI. i

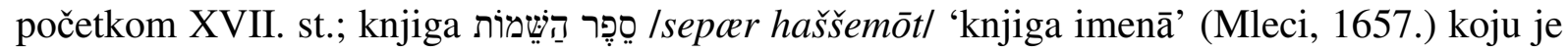

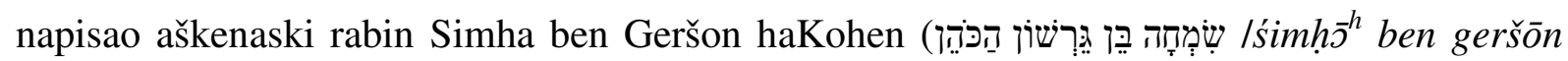

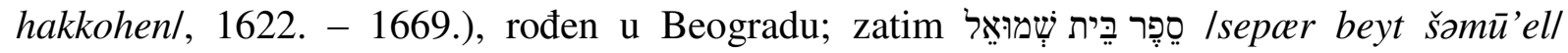
'knjiga kuće Samuelove' - najpoznatija među njima - s kraja XVII. st., a koju je napisao

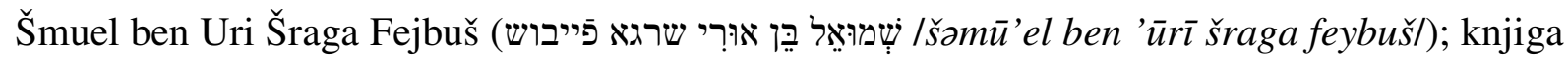

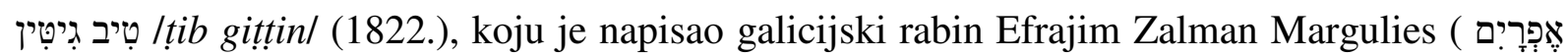

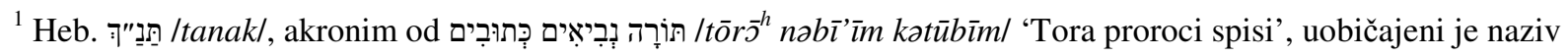
koji se koristi za židovsku Bibliju (odnosno hebrejsku, iako ima ponekih dijelova koji nisu na hebrejskome), te je međunarodno (i međujezično) prihvaćen kao točniji od sintagme »židovska Biblija«. Kao što i same sastavnice akronima govore, sastoji se od tri dijela: Tore (Mojsijeva petoknjižja: Postanka, Izlaska, Levitskog zakonika, Brojeva i Ponovljenog zakona); Prorokā (podijeljenih na Rane proroke: Jošuu, Suce, dvije Knjige o Samuelu i dvije Knjige o kraljevima, te Kasnije proroke: Izaiju, Jeremiju, Ezekijela i dvanaestoricu Hošeu, Joela, Amosa, Obadiju, Jonu, Miheja, Nahuma, Habakuka, Sefaniju, Hagaja, Zahariju i Malahiju) i (ostalih) Spisa (Knjige istine ili Poetske knjige: Psalmi, Mudre izreke i Job; Pet svitaka: Pjesma nad pjesmama, Rut, Tužaljke, Propovjednik i Estera; te Ostale knjige: Danijel, Ezra - Nehemija i dvije Knjige ljetopisā). Kao što se vidi iz navedenoga, taj se kanon ne poklapa s katoličkim starozavjetnim. U nastavku će se rada na »židovsku Bibliju« primjenjivati naziv Tanah.

Svi su prijevodi i transkripcije na hrvatski navođeni iz izdanja Biblija 1969.

Više o strukturi Tanaha v. prilog C.

O transkripciji hebrejskoga v. prilog B

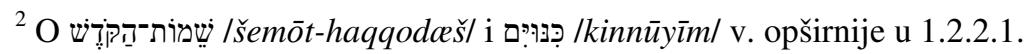




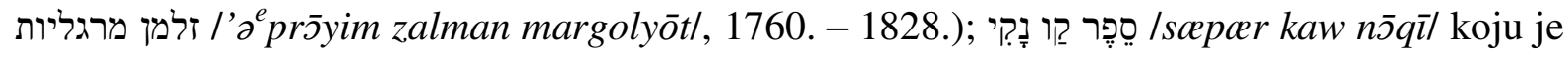

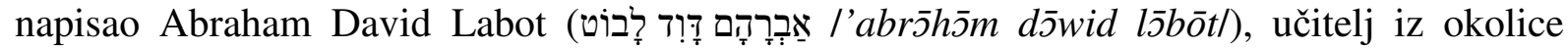

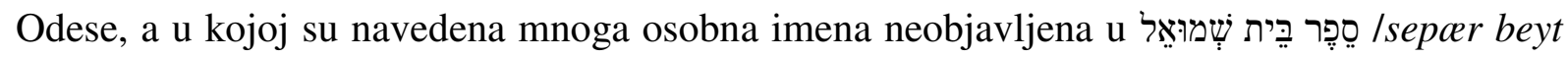

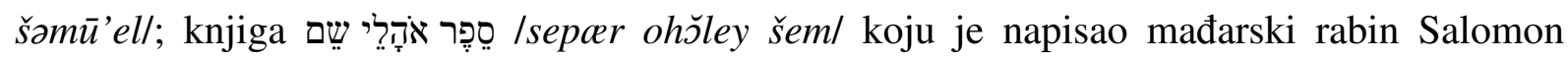

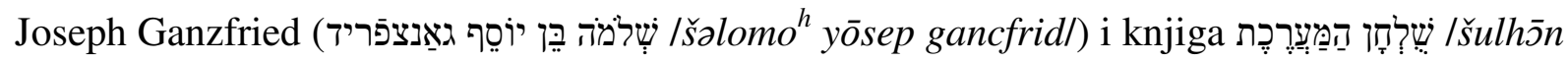

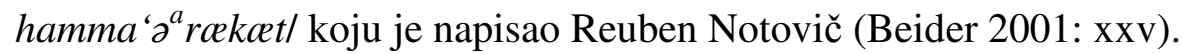

Prva se djela znanstvenog pristupa o osobnim imenima Židovā pojavljuju tek u XIX. st. Pionirom se na tom polju smatra judaist Leopold Zunz (1794. - 1886.) koji je svojim djelom, Namen der Juden, objavljenim 1837. g., uveo povijesni pristup proučavanju židovske onomastike, podijelivši proučavanje na povijesna razdoblja: grčko, rimsko, srednjovjekovno i moderno (do 1871. g.), te je ono postalo polazištem svih kasnijih studija. Godine je 1911. rabin Max Grunwald (1871. - 1953.) u svom članku Zur jüdischen Namenkunde kompilirao osobna imena iz četrdesetak izvora objavljenih nakon Zunzova djela, a I. I. Kulišer je objavio knjigu Сборник для согласования разновидностей имен: библейских, национальных, талмудических, заимствованных и других, употребляемых евреями в России (Zbirka konkordance biblijskih, narodnih. talmudskih. posuđenih i imena drugih vrsta kojima se služe ruski Židovi) u ruskoj i hebrejskoj inačici (Beider 2001: xxv-xxvi, Beider 2003: 41).

Lingvistički je pristup židovskim osobnim imenima uveo slavist Edward Stankiewicz (1920. 2013.) u svojem članku Derivational Pattern of Yiddish Personal (Given) Names (1969.), analiziravši fonetske oblike osobnih imena, odnose između različitih oblika izvedenih iz istog korijena i funkcije varijanata. Do podataka je došao intervjuirajući izvorne govornike jidiša iz istočne Europe čime je prikupio neformalne oblike koji se rijetko pojavljuju u službenim dokumentima (Beider 2001: xxvi, Beider 2003: 41).

\footnotetext{
${ }^{3}$ Porodica je Kulišer dala više znamenitih pojedinaca koji su se bavili Židovima i židovstvom, no nijednom od njih inicijali nisu I. I.: povjesničar, etnograf, odvjetnik i društveni aktivist Михаил Игнатьевич Кулишер (1847. - 1919.) i njegovi sinovi, ekonomist i povjesničar Иосиф Михайлович Кулишер (1878. - 1934.), pravnik i povjesničar prava Евгений Михаилович Кулишер (1881. - 1956.) i pravnik i sociolog Александр Михаилович Кулишер (1890. - 1942.) (http://eleven.co.il/jews-of-russia-and-ussr/education-secularculture/12256/, pristupljeno 21. travnja 2018. g.).

Pretraga na internetskim stranicama Ruske nacionalne knjižnice (http://nlr.ru/ecase3/sc2.php/web_gak/lc/49444/44\#pict) otkriva da je autor Иосиф Михаилович Кулишер, koji je knjigu objavio pod drugim imenom: Иссер Исаевич Кулишер.
} 
Treba spomenuti još dvojicu autora koji se nisu upustili u dublju analizu židovske antroponimije, kojima je ona bila tek rubno područje proučavanja. Njemački je rabin Siegmund Salfeld (1843. - 1926.) djelu Das Martyrologium des Nürnberger Memorbuches (1898.), popisu žrtava srednjovjekovnih progona Židovā u Njemačkoj, priložio prijedlog etimologija nesemitskih osobnih imena, uglavnom ispravnih, iz izvora kojim se poslužio.

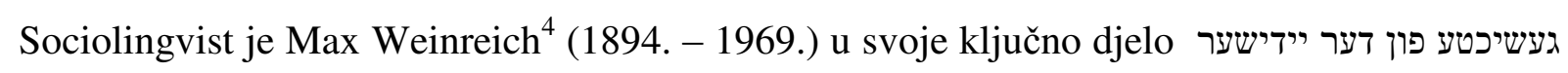
Igešixte fun der yidišer šprax: bagrifn. faktn. metodn/ 'povijest jidiškog jezika: pojmovi. činjenice. metode' iz 1973. g. uvrstio i mnoge pronicljive opaske o etimologijama jidiških osobnih imena (Beider 2003: 41-42).

Neki su se od kasnijih autora okrenuli istraživanju antroponimije malo poznatih, egzotičnih židovskih zajednica na istoku. Edwin D. Lawson (r. 1923.) je proučavao onomastiku Židovā u Gruziji, Kočinu (hebrejski: קוגין/kogin/) na jugozapadnoj obali Indije i gorskih Židova u Azerbajdžanu. Aaron Demsky (r. 1938.) se pak okrenuo Židovima u Kaifengu, prijestolnici dinastije Sjeverni Song (960. - 1127.) na kraju (odnosno početku) Puta svile. Židovi su onamo dospjeli s muslimanskim trgovcima sa zapada i ondje imali svoju zajednicu od XII. do početka XIX. st. postupno se asimilirajući s okolnim stanovništvom. Demsky se usredotočio na tri pitanja: kako su nazivali sami sebe, koja su prezimena preuzeli i koja osobna imena koristili (Demsky 2003). Chana Tolmas je istraživala laqab u Židovā u Buhari u današnjem Uzbekistanu. Laqab je nadimak, neslužbeni dio imenske formule u kojoj dolazi iza osobnog imena. Laqaba je bilo dvije vrste: pojedinačni i skupni, rodovski, klanovski. Ovi drugi su u XIX. i XX. st. postali prezimenima u novouvedenoj ruskoj imenskoj formuli. Kao i u ostalih zajednica, takvi nam nadimci govore o kulturnom životu zajednice, socijalnom statusu i zanimanju pojedinca, hrani, obitavalištu i govornom jeziku (Tolmas 2003). Yona Sabar (r. 1938.) je istraživao osobna imena, nadimke i prezimena među kurdistanskim Židovima. Njihova se hebrejska osobna imena često izgovaraju drukčije negoli u masoretskim tekstovima, katkad su u pitanju arapske inačice osobnih imena iz Tanaha, a osim toga je među tamošnjim Židovima moguće naći i perzijsko-kurdska, turska i arapska osobna imena (Sabar 1974).

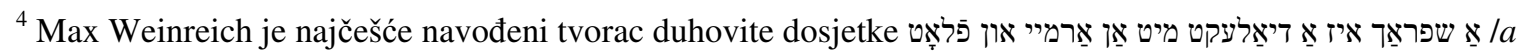
šprax iz a dialekt mit an armey un flot/ 'jezik je dijalekt s vojskom i mornaricom', no on je sâm izjavio da je tek naveo riječi nekog od nazočnih na jednom od svojih predavanja.
} 
Drugi su se pak bavili osobnim imenima i prezimenima Sefarada. Ora (Rodrigue) Schwarzwald (r. 1944.) je proučavala osobna imena u sefardskim zajednicama, razvrstala ih u skupine, zasebno muška (iz Tanaha, opće imenice ili pridjevi), a zasebno ženska (junakinje iz Tanaha i midraške literature, opće imenice), njihovu čestoću i sufikse kojima su modificirana (Schwarzwald 2010). Leah Bornstein-Makovetsky je proučavala osobna imena solunskih Židova u XIX. st., njihovu etničku narav, socioreligijsku poruku osobnih imena, rasprostranjenost osobnih imena u XVIII. i XIX. st., narav, izričajnost i popularnost muških i ženskih osobnih imena te korištenje i narav nadimaka. U nadijevanju je osobnih imena solunska zajednica bila vrlo konzervativna sve dok u Osmanskom Carstvu nije započeo proces europeiziranja, zbog kojeg se zajednica sekularizirala (Bornstein-Makovetsky 2003).

Vittore Colorni (1912. - 2005.) proučavao je suodnos hebrejskih i lokalnih osobnih imena u talijanskih Židova (Colorni 1983). Pišući o dvojezičnosti (ne samo) Židovā donosi i drugdje potvrđenu činjenicu da ovi u spisima pisanima hebrejskim pismom koriste tradicionalna osobna imena iz Tanaha ili mlađa, dok si u komunikaciji s drugima nadijevaju popularna ili lokalna osobna imena (Colorni 1983: 68) ${ }^{5}$.

Dijakronijske je promjene obrazaca nadijevanja osobnih imena u vremenu sa statističkog stajališta proučavala Rita Bredefeldt, i to u dvije zajednice u Švedskoj, onoj ortodoksnoj u Malmöu (uključujući Lund) i onoj reformnoj u Stockholmu, u tri petogodišnja razdoblja između 1865. i 1921. g. Obje su zajednice na prijelazu stoljeća doživjele znatan priljev ortodoksnih Židova iz istočne Europe. Bez obzira na razlike među zajednicama, u obje su primjetne tendencije opadanja broja židovskih osobnih imena u korist nežidovskih, te u obje žene rjeđe dobivaju židovska osobna imena od muškaraca (Bredefeldt 2003).

Nešto su bliže Židovima iz ovog rada oni čija je osobna imena istražio Stanley Lieberson (1933. - 2018.). Njega su zanimali trendovi porasta nadijevanja osobnih imena iz Tanaha židovskoj djeci u SAD-u kao i preklapanja popularnosti nekih osobnih imena iz Tanaha i među Židovima i među kršćanima (Lieberson 2003) ${ }^{6}$.

\footnotetext{
${ }^{5} \mathrm{U}$ bilješci autor donosi nekolika imena autora i naslove njihovih djela koji se bave ovim fenomenom u XVII., XVIII. i XIX. st.

${ }^{6}$ O povećanoj sklonosti Židovā u SAD-u spram osobnih imena iz Tanaha nakon godinā asimilacije govore i Sarah Bunin Benor te Heinrich W. i Eva H. Guggenheimer (Bunin Benor 2016: 441, 445, 449;

Guggenheimer H. W. i Guggenheimer E. H. 1992: x).
} 
Osobnim se imenima Židovā najbližih onima iz korpusa ovog rada bavio Alexander Beider (r. 1963.) u svom ključnom dijelu A Dictionary of Ashkenazic Given Names: Their Origins, Structure, Pronunciation, and Migrations, koje osim leksikona osobnih imena donosi i opsežan teorijski uvod te temeljitu analizu onomastike srednjoeuropskih i istočnoeuropskih Aškenaza. Nakon uvoda u kojem donosi pregled dotadašnjih istraživanja i definicije osnovnih pojmova (Beider 2001: xxv-xliii), Beider piše o osobnim imenima u aškenaskoj tradiciji (Beider 2001: 1-19). Slijedi poglavlje o početnom razvoju osobnih imena, o njihovom nastanku i/ili preuzimanju i prevođenju (Beider 2001: 20-45) te dva opširna poglavlja: o raznovrsnim tvorbama odmilica i umanjenica (Beider 2001: 46-102) i o fonetskim (i fonološkim) promjenama tipičnima za jidiš, a koje su se odrazile u različitim likovima osobnih imena (Beider 2001: 103-151). Završno poglavlje govori o podrijetlu aškenaskih zajednica (Beider 2001: 152-213). Nakon toga dolazi nekoliko dodataka: o glavnim izvorima (Beider 2001: 214-229), o dvostrukim osobnim imenima u sjeveroistočnoj Poljskoj (Beider 2001: 230-232), o najpopularnijim osobnim imenima (Beider 2001: 233-236), o pravilima transliteracije (Beider 2001: 237-239), o pokrajinama i regijama navedenima u knjizi (Beider 2001: 240-243) te o jidiškim osobnim imenima u istočnoj Europi (Beider 2001: 244-248). Na kraju se nalaze dva rječnika aškenaskih osobnih imena: muških (Beider 2001: 271-474) i ženskih (Beider 2001: 475-610). Beiderova se analiza i zemljopisno najviše približila našim krajevima spomenom Ptuja (Pettau) među gradovima i pokrajinama u kojima ima osobnih imena s deminutivnim dočetkom -(e)l (Beider 2001: 57).

Drugo je važno djelo, kad su u pitanju prezimena, knjiga Jewish Family Names and Their Origins: An Etymological Dictionary Heinricha W. i Eve H. Guggenheimer. I ona započinje uvodom u kojem se govori o židovskim osobnim imenima (Guggenheimer H. W. i

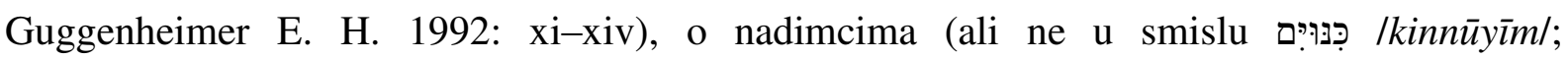
Guggenheimer H. W. i Guggenheimer E. H. 1992: xiv-xviii), o osobnim imenima izvedenima od zanimanja i toponima (Guggenheimer H. W. i Guggenheimer E. H. 1992: xviii-xxii), o modifikacijama osobnih imena (Guggenheimer H. W. i Guggenheimer E. H. 1992: xxii-xviii) i o pravopisu (Guggenheimer H. W. i Guggenheimer E. H. 1992: xxviii-xxx), nakon kojih slijedi sâm rječnik (Guggenheimer H. W. i Guggenheimer E. H. 1992: 1-882). 


\subsubsection{Ciljevi istraživanja}

Ciljevi su istraživanja iznesenih u ovom radu:

1. ustanoviti čestoću pojedinih muških i ženskih građanskih osobnih imena zagrebačkih Židova, kako u pojedinim izvorima, tako i u jedinstvenom užem korpusu osoba kojima su poznati i osobno ime/osobna imena i prezime(na) i godina rođenja

2. ustanoviti iz kojeg jezika pojedino građansko osobno ime potječe (etymologia remota) ako je to moguće ustanoviti iz materijala sadržanog u korpusu

3. utvrditi kakva je statistička struktura etimologija muških i ženskih građanskih osobnih imena zagrebačkih Židova, odnosno koliki udio zauzimaju pojedini izvorišni jezici osobnih imena

4. konstruirati dijakronijski prikaz kretanja broja osobnih imena prema polazišnom jeziku podrijetla, s posebnim osvrtom na pitanje kako se u tom prikazu ponašaju osobna imena slavenske etimologije

5. ustanoviti iz kojeg je jezika pojedino građansko osobno ime neposredno preuzeto (etymologia proxima) ako je to moguće ustanoviti iz materijala sadržanog u korpusu

6. utvrditi kakva je statistička struktura muških i ženskih građanskih osobnih imena zagrebačkih Židova prema jezicima iz kojih su neposredno preuzeta, odnosno koliki udio zauzimaju pojedini jezici

7. konstruirati dijakronijski prikaz kretanja broja osobnih imena prema jezicima iz kojih su ova neposredno preuzeta, s posebnim osvrtom na pitanje kako se u tom prikazu ponašaju osobna imena preuzeta iz slavenskih jezika

8. ustanoviti čestoću pojedinih muških i ženskih židovskih osobnih imena zagrebačkih Židova

9. analizirati suodnos određenog građanskog i određenog židovskog osobnog imena, ustanoviti postoje li neke kombinacije koje se pojavljuju češće negoli druge, kombinacije s tradicijom te kakva je njihova dijakronijska čestoća

10. ustanoviti čestoću pojedinih prezimena zagrebačkih Židova

11. ustanoviti etimologiju pojedinih prezimena

12. utvrditi kakva je statistička struktura etimologija prezimena zagrebačkih Židova

13. istražiti promjene prezimena među zagrebačkim Židovima

14. analizirati korpus prezimena pisanih hebrejskim pismom. 


\subsubsection{Metode istraživanja}

Metode se istraživanja primijenjene u ovom radu ugrubo mogu podijeliti u dvije skupine: etimološku analizu i statističku analizu.

Uz pomoć će se dostupnih priručnika ${ }^{7}$ ustanoviti motivacija pojedinih osobnih imena i prezimenā te istodobno iz kojeg jezika određeno osobno ime ili prezime potječe. Na taj će se način osobna imena i prezimena moći klasificirati prema podrijetlu. $\mathrm{S}$ druge će se strane pokušati odrediti, u mjeri u kojoj to bude moguće, iz kojeg je jezika osobno ime preuzeto, te će se u skladu s tim druga klasifikacija obaviti prema tom kriteriju. Vjerojatno se za sva osobna imena neće moći ustanoviti njihova etymologia remota (posebno u slučajevima odmilica i umanjenica koje se mogu odnositi na veći broj osobnih imena) i/ili njihova etymologia proxima (posebno u slučajevima u kojima se isto osobno ime pisano na isti način nalazi u različitim, a vjerojatnim jezicima posrednicima).

Statističkom će se analizom ustanoviti čestoća pojedinih osobnih imena, kako građanskih (osobnih imena koja su Židovi službeno koristili u komunikaciji s nežidovskom okolinom) tako i onih židovskih (osobnih imena koja su Židovi službeno koristili unutar svoje zajednice, posebice u njezinim pisanim dokumentima). Uspostavit će se dijakronijska čestoća građanskih odnosno židovskih osobnih imena prema jeziku podrijetla i prema jeziku iz kojeg su neposredno preuzeta (uz ograničenja navedena u prethodnom odlomku). Usporedbom će se građanskih i židovskih osobnih imena odrediti čestoća pojedinih njihovih kombinacija te promotriti dijakronijska čestoća najčešćih među njima. U vezi s dijakronijskim proučavanjima treba svakako imati na umu da osobna imena brojčano nisu ravnomjerno raspoređena po vremenskom pravcu, da za neke godine imamo jedno jedino osobno ime, a za druge desetke njih. Zbog toga statistički pokazatelji promjene čestoće pojedinih osobnih imena odnosno jezika iz kojih potječu i iz kojih su preuzeta ne mogu biti osobito pouzdani.

\footnotetext{
${ }^{7}$ Pri određivanju etimologije, a time podrijetla, pojedinih osobnih imena koristio sam se ovim izvorima: Amerl 1997, Beider 2001, Bushell 1996, Campbell i Campbell, Čilaš Šimpraga, Ivšić Majić i Vidović 2018, Dodig 2015, Dodig 2017, Etimološki... 2016, Guggenheimer H. W. i Guggenheimer E. H. 1992, Gluhak 1993, Gorr 1992, Klaić 1978, Lauden, Weinbach i Shani 1998, qBible, Silvan i Levenston 1968, Skok 1974, Šimundić 1988, Šimunović 2006 i Šimunović 2009.
} 


\subsection{Onomastički uvod}

\subsubsection{Kratka definicija onomastike}

Najjednostavnija definicija onomastike ili imenoslovlja jest da je riječ o specijalnoj lingvističkoj disciplini koja se bavi izučavanjem sustava imenā (Основен систем... 1983: 123; Škiljan 1994: 100). U hrvatskoj je jezikoslovnoj terminologiji sam pojam »ime« dvoznačan. S jedne je strane ime $_{1}$ skupina promjenjivih dijelova diskursa (vrsta riječi) koji se mijenjaju po rodu, broju i padežu, dok je s druge ime 2 element podskupa onih imenica koje imaju (jedinstveni) referent, ali nemaju značenja (onim ${ }^{8}$ ), za razliku od općih imenica, koje uglavnom nemaju jedinstvenog referenta, ali imaju značenje ${ }^{9}$ (Ducrot i Todorov 1987: II 147; Основен систем... 1983: 132-133).

Stoga bi prvo trebalo definirati pojmove predmeta proučavanja onomastike. Ona se ne bavi imenima $_{1}$, već samo imenima ${ }_{2}{ }^{10} . \mathrm{S}$ obzirom na razine značenja, treba razlikovati hiperonim

\footnotetext{
${ }^{8}$ Основен систем... navodi apelativ na dva različita mjesta u dva različita značenja:
}

Сопствено име (оним) или апелатив / Onym oder Apellativum

[Osobno ime (onim) ili opća imenica] (Основен систем... 1983: 132);

odnosno

Именка која, за разлика од сопственото име, служи првенствено за именување на вид, поим според определени општи признаци; во конкретните случаи може да се однесува и на одделно лице. / Im Gegensatz zum Namen das Substantiv, das in seiner Hauptfunktion die Gattung, den Begriff nach bestimmten gemeinsamen Merkmalen bezeichnet, sich aber in konkreten Äusserungen auch auf das Einzelne beziehen kann.

[Imenica koja je, za razliku od osobnog imena, prvenstveno namijenjena imenovanju neke vrste, pojma prema određenim zajedničkim obilježjima, ali se u konkretnim slučajevima može odnositi i na određenu osobu.]

(Основен систем... 1983: 134).

${ }^{9}$ Općenito uzevši, imena $a_{2}$ mogu imati više referenata, primjerice postoji više osoba na koje se može referirati imenom $_{2}$ Igor, no u konkretnom je komunikacijskom aktu u konkretnom kontekstu jasno na kojeg se Igora od mnoštva njih referira.

S obzirom na rečeno, Crystalova definicija da je onomastika grana semantike (discipline koja se bavi označenim, planom sadržaja, značenjem) koja proučava etimologiju (koja nužno mora obuhvaćati i označitelja, plan izraza, formu) imena 2 zvuči ponešto kontradiktorno (Crystal 2008: 339).

${ }^{10}$ Predmet proučavanja onomastike možemo zvati i idionimom, jezičnim znakom pridruženim pojmu kao znaku za jedan član u skupu, za razliku od koinonima koji je pridružen svim članovima skupa (Putanec 1976: VI). 
ime $_{2}$ (u daljnjem tekstu: ime), njegove hiponime antroponim, toponim $\mathrm{i}$ sl. te hiponime antroponima: osobno ime, prezime, patronim, metronim, nadimak,... (Frančić 2006: 78).

Onomastika je, dakle, specijalna lingvistička disciplina koja se bavi izučavanjem sustava imenā kao što su antroponimi (osobno ime, prezime, patronim, metronim, nadimak), toponimi i sl. Specifičnije je moguće reći da je onomastika znanost o imenima kao jezičnim, izvanjezičnim i kulturnim spomenicima, često najstarijim, a katkad i jedinim preživjelim jezičnim spomenicima nekog jezika, koji nerijetko nadžive i sam jezik iz kojeg su potekli. Onomastika proučava vlastita imena ljudi, drugih živih bića, zemljopisnih pojmova, kao i imena raznovrsnih institucija i fenomena koje je stvorio čovjek, pa se ona dijeli na više disciplina (Šimunović 2009: 5):

1. antroponimiju, koja proučava bionime, imena živih bića

2. toponimiju, koja proučava geonime, imena zemljopisnih objekata te

3. krematonimiju, koja proučava krematonime, imena predmeta, pojava i odnosa nastalih ljudskom djelatnošću ${ }^{11}$.

Sinkronijski gledano, u osnovi svakog imena leži opća imenica. Početni je jezični znak uvijek na razini opće imenice, te ga samo svjesni čin imenovanja pretvara u ime (idionim) mijenjajući semantički sadržaj znaka. Ime potom ostaje imenom kao konvencionalni jezični znak za jednu jedinku u skupu. Ime se kasnije može protegnuti na cijeli skup jedinki, pa ponovno postaje općom imenicom (Putanec 1976: VI). Primjera u hrvatskome ima u nazivima određenih proizvoda: digitron 'džepno računalo' (< Digitron, tvrtka iz Buja koja je prva proizvodila džepna računala u Jugoslaviji), flomaster 'pisaljka pustenoga vrha' (< Flo-Master, marka tintā i markera iz SAD-a), kalodont 'zubna pasta' (< Kalodont, marka popularne zubne

${ }^{11}$ Valentin Putanec dijeli idionime (imena) u tri skupine (Putanec 1976: VI, VII):

a) za fenomene u prostoru: mjesno ime, ime naseobine, ime zemlje, ime zgrade, ime društva, sportskog kluba, ime firme, lokala, ime kipa, slike, predmeta, knjige, predmeta-prostora u pokretu, kao ime broda, zvijezde i sl. (toponimi i neki krematonimi)

b) za žive jedinke: ime osobe, ime skupa osoba zamišljenih kao jedinka, ime naroda, ime životinje, ime za poosobljavanje i personifikaciju konkretnih i apstraktnih pojmova, alegorija (antroponimi i neki krematonimi)

c) za jedinke u vremenu: idionim za historijski, društveni, politički, ekonomski, kulturni, sportski i vojni događaj, imena blagdana, praznika (ostali krematonimi).

Za prve predlaže naziv stereoidionim (< grč $\sigma \tau \varepsilon \rho \varepsilon o ́ \varsigma$ 'kubičan, prostoran’), za druge bioidionim (< grč ßío $\varsigma$ ‘život'), a za treće pragmaidionim (< grč. $\pi \rho \alpha ́ \gamma \mu \alpha$ ‘čin'). 
paste s kraja XIX. i početka XX. st. koja je u Europi gotovo stekla monopolski status), letraset 'slova i drugi znakovi koji se trljanjem preslikavaju na podlogu' ( $<$ Letraset, britanska tvrtka koja je prva počela proizvoditi arke takvog tipa sa slovima i drugim znakovima), selotejp 'samoljepljiva vrpca' (< Sellotape, britanska marka samoljepljivih vrbaca), žilet 'britvica' (< Gillette, proizvođač britvica i drugih proizvoda i pribora za osobnu higijenu iz SAD-a).

Onomastika se ispomaže drugim disciplinama kao pomoćnim znanostima, zemljopisom, poviješću, etnologijom, zoologijom, botanikom, a istodobno služi kao pomoćna znanost istim tim disciplinama, ali i nekim drugima, npr. prirodnim znanostima općenito (Putanec 1976: VI).

Osobna imena nastaju i nestaju u povijesti. Ona prate svojevrsnu antroponimsku modu. U monoteističkim se religijama često nameće nadijevanje osobnih imena iz određenih popisa, a odbacuju se sva druga, pa i tradicionalna. Politička događanja također utječu na čestoću nekih osobnih imena i odbacivanje drugih. Uvođenje je novih osobnih imena postalo posebno uočljivim otkako je televizija puku u Hrvatskoj približila svijet, pa su domaćoj svijesti postala dostupna i raznovrsna antroponimska dostignuća iz nekih udaljenih dijelova zemaljske kugle. I drugi čimbenici utječu na čestoću davanja određenog osobnog imena djeci u određenom razdoblju. Jedan je od njih, posebno u manjinskim zajednicama, želja za asimilacijom, za čim bezbolnijim uključenjem u većinsko okruženje.

\subsubsection{Hebrejska antroponimija}

Near the beginning of his [1966 Hebrew Teachers College commencement] address, Cohen ${ }^{12}$ cites Bar Kappara's ${ }^{13}$ sermon: "Owing to four factors were the people of Israel redeemed from the land of Egypt: they did not alter their names (i.e., Egyptianize them); they did not change their language; they did not spread malicious gossip; and they were free of sexual license." It makes sense that a rabbinic sermon would focus on issues of morality, such as sexual behavior and

\footnotetext{
${ }^{12}$ Gerson David Cohen (1924.-1991.) bijaše židovski povjesničar, konzervativni rabin i rektor Jewish Theological Seminary of America od 1972. do 1986. g.

13 Šimon bar Kappara (שמעון בר קפרא) bijaše rabin s kraja II. i početka III. st., a djelovao je u Cezareji od oko 180. do 220. g.
} 
gossip. But why are language and names important enough to mention? Bar Kappara composed these words because of his anxiety about the Jews around him assimilating culturally rather than maintaining distinctively Jewish language and names. Cohen counters this stance, saying, "To a considerable degree, the Jews survived as a vital group and as a pulsating culture because they changed their names, their language, their clothing, and their patterns of thought and expression." ${ }^{14}$ (Bunin Benor 2016: 440)

Antroponimija je Židova danas složen i šarolik sustav koji odražava burnu povijest tog naroda. Edwin D. Lawson, primjerice, klasificira židovska osobna imena na ovaj način (Lawson 2005) ${ }^{15}$ :

1. hebrejska:

1. iz Tanaha (uključujući apokrifne knjige)

1. poznati likovi (Noah, Avraham, Rachel)

2. manje poznati likovi (Baruch, Yigal, Shulamit)

2. ne iz Tanaha

1. tradicionalna (Dov, Malka, Mazal, Rachamim)

2. suvremena (Dror, Ahuva)

2. nehebrejska

1. tradicionalna (Alexander, Kalman)

2. suvremena

1. aškenaska (uključujući ruska, njemačka, jidiška i engleska)

1. starija jidiška osobna imena (Bluma, Yenta, Hersh)

2. suvremenija europska osobna imena (Albert, Boris, Rosa)

\footnotetext{
${ }^{14}$ Na početku svoga obraćanja [povodom početka rada Teachers College 1966. g.], Cohen navodi Bar Kapparinu propovijed: »Zahvaljujući četirima čimbenicima, Izraelićani su bili otkupljeni iz zemlje egipatske: nisu mijenjali imena (tj. egipatizirali ih); nisu promijenili svoj jezik; nisu širili zlonamjerne tračeve; te nisu prihvatili spolne slobode.«Rabinsko propovijedanje usredotočeno na pitanja moralnosti, kao što su spolno ponašanje i tračevi, ima smisla. Ali zašto je bilo važno spomenuti jezik i imena? Bar Kappara je sročio ove riječi zbog svog osjećaja tjeskobe zbog Židova koji se oko njega kulturno asimiliraju, umjesto da održavaju izrazito židovski jezik i imena. Cohen se suprotstavlja tome stavu, rekavši: »U znatnoj su mjeri Židovi preživjeli kao vitalna skupina i pulsirajuća kultura zato što su promijenili svoja imena, jezik, odjeću i svoje obrasce mišljenja i izražavanja«.

${ }^{15} \mathrm{U}$ ovoj su klasifikaciji osobna imena ostavljena u liku koji navodi autor.
} 
2a. sefardska iz sjeverne Afrike (Yahya)

2b. francuska (Armand, Charles, Maurice)

3. iranska (Fairuz, Sabikha, Samila)

4. judeo-tatska (gorski Židovi iz Azerbejdžana) (Grigory, Nazim, Nazila)

3. ostala (neka se preklapaju s već navedenima)

1. bogonosna (osobna imena u kojima se nalazi naziv za Boga) (Eliezer, Emanuel, Amalya, Batya)

2. opisna (opisuju koje svojstvo pojedinca) (David, Naim, Simcha, Bina, Shira)

3. apotropska (osobna imena koja štite od smrti) (Haim, Vita, Alter, Mercado)

4. zamjenska imena (osobna imena na lokalnom jeziku povezana s hebrejskim osobnim imenom) (Leo)

5. osobna imena iz prirode (biljke ili životinje) (Dov, Shoshana)

Klasifikacija je koju donosi Shmuel Gorr (koji se usredotočuje na aškenaske imenodavne tradicije) nešto jednostavnija (Gorr $1992: \mathrm{x}$ ):

1. a) hebrejska osobna imena

b) aramejska osobna imena

c) jidiška osobna imena

d) nežidovska osobna imena

2. prijevodna osobna imena onih iz prve skupine

3. umanjenice i dvostruke umanjenice osobnih imena iz prve i druge skupine
a) starovisokonjemačke
b) njemačke u više lokalnih oblika
c) slavenske

4. pokraćeni likovi osobnih imena iz svih prethodnih skupina

5. fonetske derivacije

Klasifikaciju po drukčijim kriterijima donosi Alexander Beider (Beider 2001: xxix-xxxi, Beider 2003: 42-43):

1) osobna imena (given names)

U ovu skupinu uključuje: temeljno osobno ime - osobno ime koje dijete dobiva odmah nakon rođenja (base given name), izvedenice iz tog osobnog imena (umanjenice, odmilice, prijevodna osobna imena), osobno ime koje useljenik preuzima u novoj sredini, zaštitničko 
osobno ime (apotropsko) koje osobu koja ga dobiva (katkad poslije u životu) štiti od bolesti i drugih zala.

2) nadimci (nicknames, sobriquets)

Osobine nadimaka: pojedinačnost (posebno važno u stara vremena kad je svaki pojedinac imao samo jedno, osobno ime), dodaju se uz osobno ime i uza nj igraju drugotnu ulogu, mogu biti privremeni (postojati u određenom kontekstu); onaj tko na određenu osobu referira nadimkom uglavnom poznaje i njezino osobno ime, osoba je koja nadijeva nadimak svjesna motivacije istoga.

3) imena izvedena od osobnih imena članova obitelji ili porodice (patronimi, metronimi, imena temeljena na osobnim imenima djedova ili baka)

4) imena koja se prenose s koljena na koljeno (prezimena, imena koja označavaju pripadnost određenoj društvenoj skupini).

Rita Bredefeldt na jednostavan način objašnjava što su to židovska osobna imena (Bredefeldt 2003: 79):

It is important to make clear the fact that Jewish names do not have any inherent quality of "Jewishness". They are simply "names common within the Jewish tradition", which mostly means biblical names, especially for the male population. ${ }^{16}$

\subsubsection{Razvoj imenske formule u Židovā}

Razvoj se imenske formule može djelomično pratiti i u knjigama Tanaha, posebno onima koje obrađuju (mitološku) povijest Izraelićana ${ }^{17}$. Osobna su se imena likovima iz najstarije

\footnotetext{
${ }^{16}$ Važno je naglasiti činjenicu da židovska imena nemaju nikakvu inherentnu kakvoću »židovstva«. Ona su jednostavno »imena uobičajena unutar židovske tradicije«, što uglavnom znači biblijska imena, posebno za mušku populaciju.

${ }^{17}$ Dok je pojam »židovi«, pisan malim slovom, jednoznačan u obilježavanju pripadnika židovske vjeroispovijesti, kod pojmova za etničku i jezičnu pripadnost vlada veća nedoumica, u kojoj se miješa nekolicina međusobno nadređenih i podređenih pojmova. Osnovni je hiperonim među njima »Hebreji«, koji označava sve narode koji su govorili hebrejskim jezikom, a u starom su vijeku to po svemu sudeći bili i Edomci, Moapci, Amonci, Midjanci i dr. Uz njih su tim jezikom govorili i potomci Jakova - Izraela, odnosno njegovih dvanaestorice sinova, rodonačelnika dvanaestoro plemena, pripadnike kojih bi valjalo nazivati »Izraelićanima« (pridjev »izraelitski«). (Taj pojam treba razlikovati od pojma »Izraelac « koji označava stanovnika današnje Države Izrael.) Kad su Asirci osvojili sjeverno kraljevstvo Izrael i odveli njegov puk u
} 
predaje (Knjige postanka) uglavnom davala prilikom rođenja, pa često i opisuju okolnosti u kojima je dotični lik rođen. Stoga se osobna imena rijetko kad ponavljaju, jer je svako rođenje jedinstveno, pa tako i osobno ime koje odražava okolnosti upravo tog rođenja mora biti drukčije od svih drugih.

Ponavljanje je osobnih imena u različitim naraštajima iste porodice postalo učestalije tek nakon povratka iz babilonskog sužanjstva (u VI. st. pr. n. e. $)^{18}$. Već je u ranijim knjigama Tanaha primjetno da samo osobno ime nije uvijek bilo dovoljno da se identificira pojedinac.

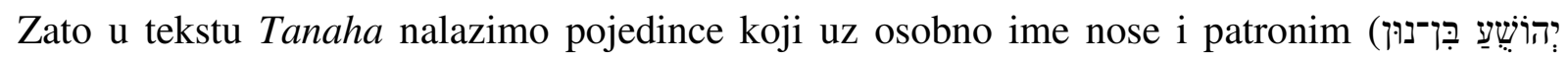

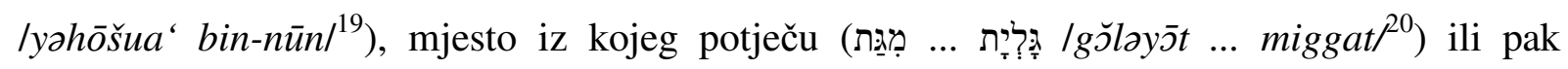

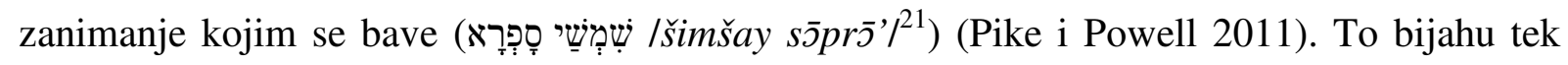
individualizirani priimci koji su obilježavali pojedinca te se nisu nasljeđivali. U talmudsko su doba takvi priimci ostajali trajnima najviše tri naraštaja. Tek kad su se osobna imena u obitelji počela ponavljati postalo je nužno imensku formulu proširiti patronimom (možebitno i nadimkom) kako bi se sa sigurnošću mogao identificirati pojedinac o kojemu je riječ. Tako je nastala uobičajena imenska formula:

Babilonsko sužanjstvo, on se ondje asimilirao, te mu se gubi svaki trag, otud legende o deset izgubljenih plemena. Više od stoljeća potom Novobabilonsko je Carstvo osvojilo južno kraljevstvo Judu i odvelo tamošnji puk u sužanjstvo. On je međutim sačuvao svoj identitet. Pojam »Židovi«, koji etimološki i potječe od Judina imena (Skok I: 748), treba, dakle, ograničiti samo na njih i njihove potomke, današnje Židove.

Ovakvu hijerarhiju predstavljaju i rodoslovlja iz Knjige postanka u kojoj se među Šemovim (eponim Semita) potomcima spominje unuk mu (Post 10,24), odnosno praunuk (Post 11:14) Eber, eponim Hebreja. Jedan je od njegovih daljih potomaka Jakov (Post 25, 26), nazvan Izraelom (Post 32,29). Njegov je pak sin Juda (Post 29,35).

${ }^{18}$ V. i Lk 1,59-61. U prijevodu Ljudevita Rupčića:

${ }^{59}$ Osmoga se dana okupe da obrežu dječaka. Htjedoše ga prozvati imenom njegova oca - Zaharija,

${ }^{60}$ no mati se njegova usprotivi: »Nipošto, nego zvat će se Ivan!«

${ }^{61}$ Rekoše joj na to: »Ta nikoga nema od tvoje rodbine koji bi se tako zvao.«

${ }^{19}$ Izl 33,11. U prijevodu Silvija Grubišića: Jošua, sin Nunov.

${ }^{20} 1$ Sam 17,4. U prijevodu Antuna Sovića: Golijat ... iz Gata.

${ }^{21}$ Ezr 4,8. U prijevodu Antuna Sovića: tajnik Šimšaj. 


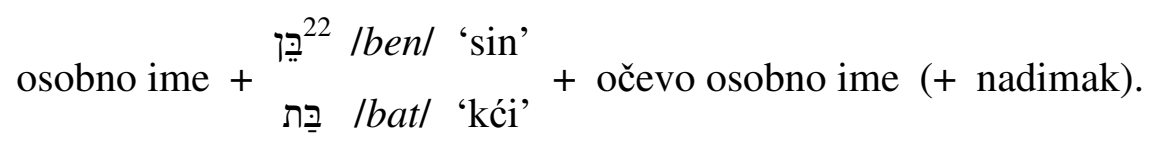

U zadnjim je stoljećima pr. n. e. aramejski, tadašnja lingua franca Bliskog istoka, zamijenio hebrejski kao govorni jezik Židovā u zemlji u koju su se vratili iz babilonskog sužanjstva, te su se i aramejska osobna imena polagano uvlačila u židovsku antroponimiju. S helenizacijom carstva Aleksandra Velikoga slijedila su ih grčka osobna imena, a s rimskim osvajanjima i

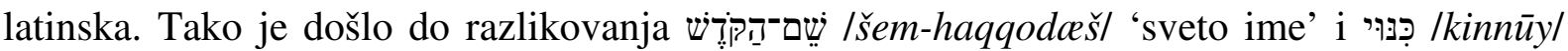
'nadimak'. Prvo je od njih ono koje se koristi u službenim vjerskim situacijama, kao što su prozivanje pojedinca da čita tjedni odlomak iz Tore u sinagogi, dokumenti o razvodu braka, ali i bilo koji drugi dokument pisan hebrejskim jezikom. Ono je hebrejskoga ili aramejskoga podrijetla (iako ne nužno - neka su, posebno grčka osobna imena dovoljno rano ušla u

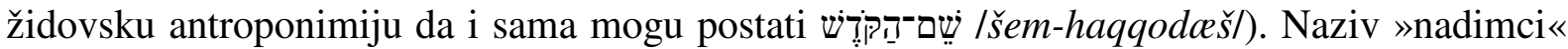

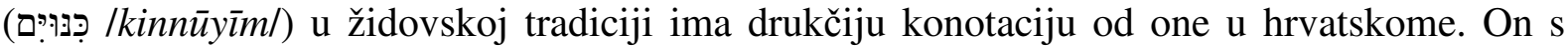
jedne strane označava osobno ime, ne nužno hebrejskog podrijetla, pod kojim je pojedinac poznat izvan židovske zajednice, ali i osobno ime (ili više njih) pod kojim je pojedinac poznat izvan uobičajene imenske formule $X$ sin/kći $Y$ - $a$. Ta distinkcija, međutim, postoji samo kad je

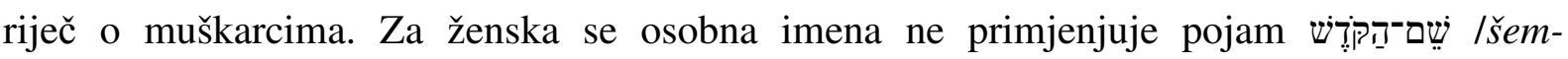
haqqodæešl, jer žene (osim u najnovije doba u nekim neortodoksnim zajednicama, mahom u SAD-u) nisu nikada zvane da čitaju Toru, iako se njihova osobna imena nužno moraju pojavljivati barem u dokumentima o sklapanju braka i o razvodu. Iz srednjeg su nam vijeka poznate imenske formule $X$ zvana $Y$, analogne onima za muškarce, u kojima bi $X$ bilo židovsko osobno ime, a $Y$ svjetovno, građansko. U svijetu je muških osobnih imena s

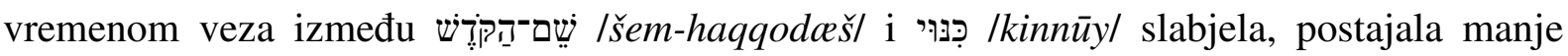
krutom, elastičnijom, tako da su i nadimci postajali neovisnim osobnim imenima koja su i sama mogla dobiti neki nadimak, pa su do vremena koje obuhvaća ovaj rad pod prvim pojmom obuhvaćena tradicionalna židovska (hebrejska, aramejska, grčka, latinska, jidiška,...) osobna imena, a pod drugim službeno, građansko osobno ime pod kojim je pojedinca vodila

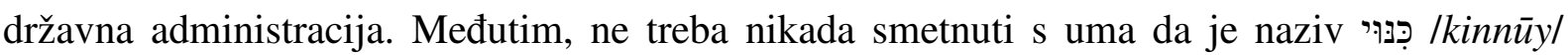
izvorno naziv za nadimak koji se prvotno vezao uz određeno osobno ime zbog neke

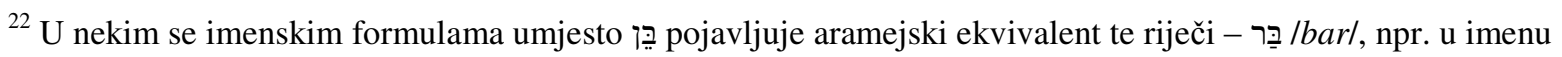
židovskog vojskovođe Šimon bar Kohba (שִׁמְוֹן בַּר כוכבא) koji je 132. g. započeo rat protiv Rima, uspostavio neovisnu državu, te se odupirao moćnijem protivniku dvije i pol godine, sve dok ga Rimljani nisu porazili i ubili 135. g.
} 
povezanosti između njih (Beider 2001: 1-5). Podvojenost se židovskih i građanskih osobnih imena Židova očituje i u našem korpusu ${ }^{23}$.

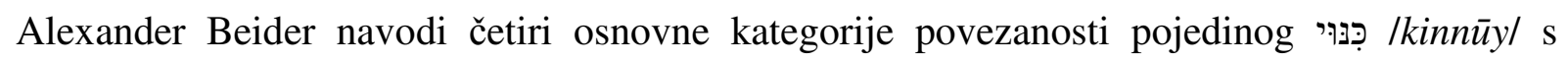

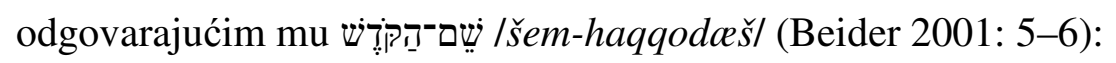

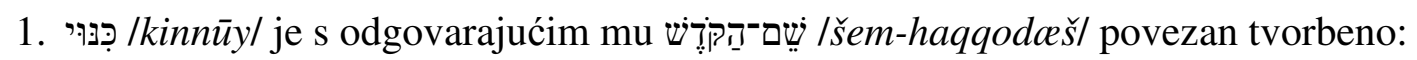

1.a. odmilice (pokraćeni likovi, likovi sa sufiksima ili oboje)

1.b. kršćanski likovi osobnih imena iz Tanaha i likovi izvedeni od njih

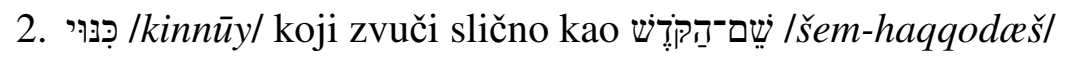

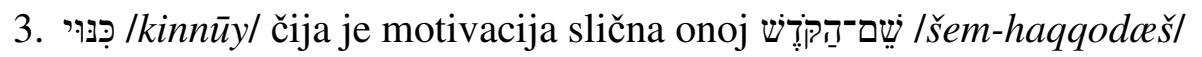

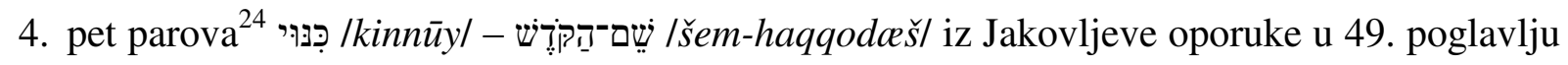
Knjige postanka i Mojsijeva blagoslova izraelskih plemena iz 33. poglavlja Ponovljenog zakona iz Tanaha:

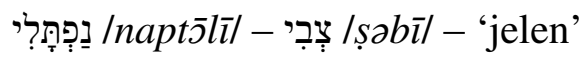

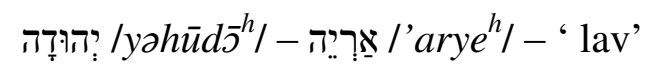

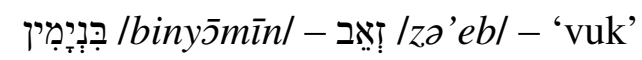

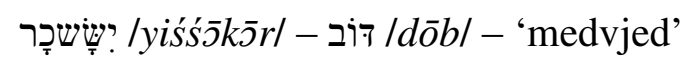

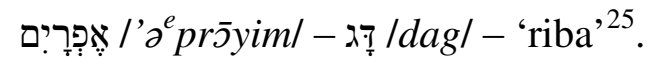

Ovu pojavu treba razlikovati od nadijevanja djeci više ravnopravnih osobnih imena, najčešće

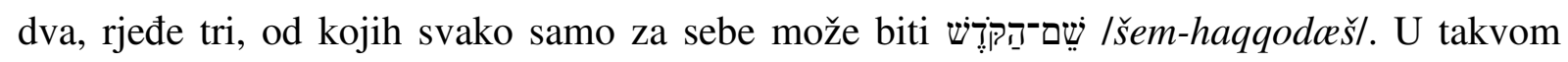
slučaju među osobnim imenima nema povezanosti poput one navedene u Beiderovoj

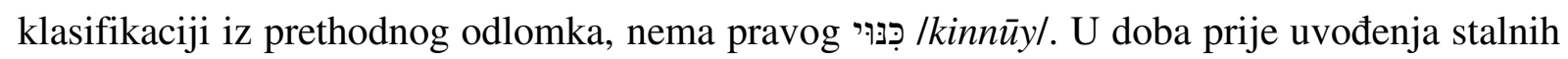
prezimena, a uz relativno mali broj raspoloživih osobnih imena, kombinacije su dvaju (ili triju) osobnih imena omogućavale lakšu identifikaciju pojedinca (Beider 2001: 8-13).

Rečeno je da su priimci (patronimi, etnici, zanimanja,...) u talmudsko doba ostajali nepromjenjivima najviše tri naraštaja. Nasljedna su prezimena u rabinskih porodica bila poznata još u X. i XI. st., a među španjolskim i portugalskim Židovima bila su uobičajena i

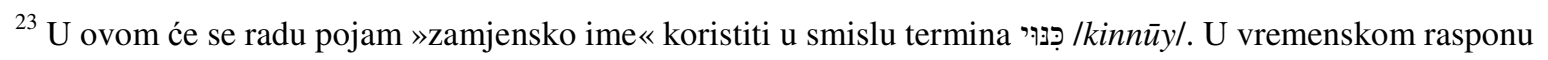

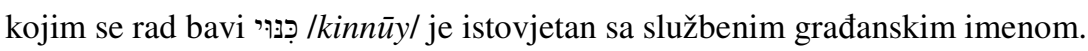

${ }^{24}$ Odnosno dvostrukih parova: kada je hebrejski naziv odgovarajuće životinje postao samostalno osobno ime,

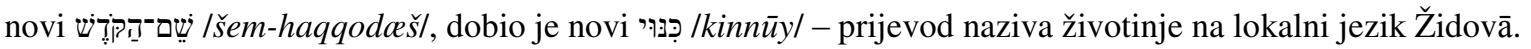

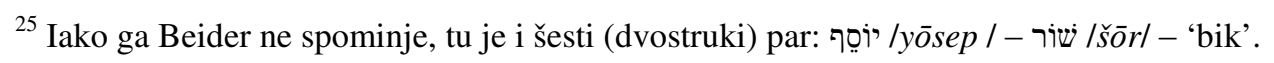


prije pojave inkvizicije, što je bila praksa preuzeta od muslimana. Mnoga njihova prezimena nisu prepoznatljiva kao židovska jer su ili arapskog podrijetla (većina onih koja počinju samoglasnikom a-l'all '(određeni) član') ili povezana s toponimima na iberskom poluotoku. S druge strane, za većinu Židova, poglavito Aškenaze, nasljedna su i nepromjenjiva prezimena antroponimska pojava novijeg datuma. U većini aškenaskih zajednica nepromjenjivih prezimenā nije bilo sve do kraja XVIII. i početka XIX. st. U aškenaskim se dokumentima prije druge polovine XIX. st. stalna prezimena susreću vrlo rijetko. Njih su ustalila tek zakonodavstva i administracije pojedinih država pod vlašću apsolutističkih vladara kako bi lakše organizirala oporezivanje i novačenje (Beider 2001: xxxi; Demsky 2003: 99; Guggenheimer H. W. i Guggenheimer E. H. 1992: ix; Lawson 2005).

Ustaljivanju su nepromjenjivih prezimena u katoličkom svijetu, u kojem su živjeli Židovi čiji su antroponimi predmet proučavanja ovog rada, najviše pridonijele odluke Tridentskog koncila (1545. - 1563.), čija je prvotna namjera bila pomirenje protestantizma s papinstvom. Papinska je vlast u želji da uspostavi jaču kontrolu nad pučanstvom naložila uvođenje matičnih knjiga rođenih, vjenčanih i umrlih, koje bi vodili župnici. S tim su u vezi bili i zaključci o uvođenju isključivo kršćanskih osobnih imena (iz zapadne tradicije) umjesto »poganskih« (narodnih) te dodavanje priimka uz osobno ime pojedinca uvedenog u matične knjige. Taj je priimak postao stalnim, nasljednim i nepromjenjivim, postao je prezimenom (Šimunović 2009: 16). Potrebe popisivanja kmetova i njihovih obveza feudalnom gospodaru pridonijele su ustaljivanju porabe prezimena uz osobna imena: navođenje prezimena se pojavljuje u urbarima, registrima i kvadernama iz XV. st., a u XVI. je st. ono obvezatno (Putanec 1976: XII). U Habsburškoj je monarhiji završni pečat uvođenju prezimena dao Jozefinski patent iz 1780. g. Ediktom o toleranciji istog vladara iz 1782. g. uvedene su velike promjene za Židove na tlu Habsburške monarhije, a za temu je ovog rada najvažnija obaveza preuzimanja prezimena. Odredbom od 23. srpnja 1787. g. u Habsburškoj je Monarhiji regulirana poraba osobnih imena i stalnih prezimena, te su rabini obvezani da vode matične knjige rođenih, vjenčanih i umrlih. Pripremljeni su popisi s kojih se moglo birati (građansko) osobno ime, dok je izbor prezimena ostao slobodan (Brandl 2015 ${ }^{\text {b }}$ :54). Zakonom su iz 1878. g. Židovi u Habsburškoj Monarhiji morali vlastima prijaviti prezime, a onima su koji to nisu učinili na vrijeme prezime nadjenule vlasti. Napoleon je 1808. g. odredio uvođenje prezimena za Židove, a u Pruskoj je 1812. g. uvedena obveza usvajanja prezimena za Židove u roku od šest mjeseci (Chazan 2007: 769-770; Lawson 2005). 
Ustaljivanje je prezimena u pojedinim državama pratila još jedna zakonodavna promjena čiji je cilj bio ograničiti broj osobnih imena Židovā, koji su u procesu emancipacije sve više usvajali osobna imena iz svoje okoline, te se tako osobnim imenom više nisu eksplicitno deklarirali kao Židovi. Austrijski je edikt iz 1878. g., primjerice, odredio da Židovi mogu nositi isključivo osobna imena iz Tanaha (Chazan 2007: 769).

U korpusu koji ovaj rad proučava nalazimo imensku formulu kako slijedi

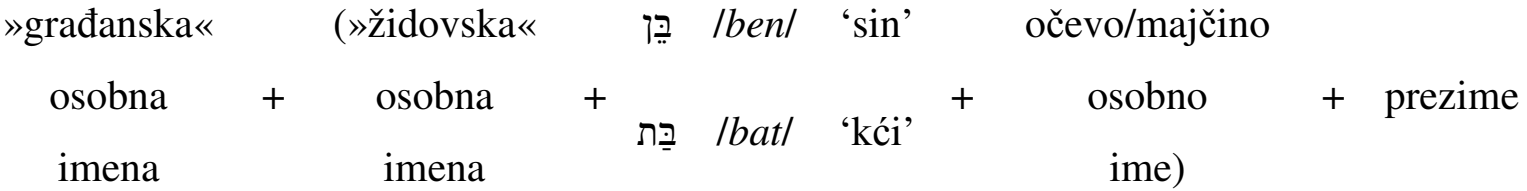

\subsubsection{Osobna imena iz Tanaha}

Tanah je po svemu sudeći najbogatiji izvor najstarijih židovskih osobnih imena koji posjedujemo. U pisanim spomenicima starijima od Tanaha osobna se imena pojavljuju tek sporadično i to četrdesetak osobnih imena u ostrakima iz Samarije (o. 850. - 750. g. pr. n. e.), dva u ostraku iz Mesada Hašavjahu (o. 639. - 609. g. pr. n. e.), pet u natpisu iz Ekrona (o. 600. g. pr. n. e.) te dvanaest u ostrakima iz Lahiša (o. 598. g. pr. n. e.) ${ }^{26}$. Nasuprot tome, Tanah nam nudi oko tisuću različitih muških i ženskih osobnih imena ${ }^{27}$. Nešto osobnih imena nalazimo i u papirusima s otoka Elefantine na Nilu, danas dijelu grada Asuana u Egiptu, koji potječu iz V. st. pr. n. e., kao i na babilonskim glinenim pločicama iz Perzijskog razdoblja (VI. st. pr. n. e.) (Stamm 2007: 764).

Etimologije su mnogih židovskih osobnih imena protumačene i u samom tekstu Tanaha. Pri oslanjanju na to ne treba smetnuti s uma da je Tanah zapisana tradicionalna predaja (više njih

\footnotetext{
${ }^{26}$ Transkripcije i prijevode je, uz dodatne podatke o pronalasku pojedinih spomenika, moguće naći na internetskoj stranici:

http://www.kchanson.com/ANCDOCS/westsem/westsem.html

Pristupljeno 31. kolovoza 2017. g.

${ }^{27}$ V. popis muških i ženskih osobnih imena s tumačenjima u Amerl 1997.
}

Alexander Beider o tome piše (Beider 2001: xxx):

"In the Bible 15,000 persons cited are covered by only 2,800 different names."

[U Bibliji je navedeno 15000 pojedinaca koje pokriva tek 2800 različitih imena.] 
ustvari) izraelitskoga naroda te da se u njoj može kriti mnoga pučka i propovjedna (homiletička) etimologija ${ }^{28}$.

Johann Jakob Stamm navodi kako su u sklopu onomastičkoga kompleksa kojemu pripadaju, hebrejska osobna imena tvorbom izrazito arhaična, te su time bliža starojužnoarapskima, istočno- odnosno prakanaanskima i ugaritskima, dok su ona fenička, aramejska, akadska i iako ne spadaju u semitska - staroegipatska inovativnija, te predstavljaju otklon od najstarijih načina imenovanja (Stamm 2007: 764).

Kad govorimo o Tanahu, moramo razlikovati različite povijesne trenutke povezane s njim.

1. Vrijeme opisanih događaja

Biblijska povijest obuhvaća povijesna razdoblja od stvaranja svijeta do povratka iz babilonskog sužanjstva i obnove Hrama. Prema židovskom kalendaru trenutno teče 5778. g. od stvaranja svijeta, što bi taj događaj smještalo u našu 3759. g. pr. n. e. Na drugom kraju biblijske povijesti perzijski je kralj Kir II. dekretom Židovima dopustio povratak u Jeruzalem 538 g. pr. n. e., u godinama 520. - 515. pr. n. e. uslijedio je povratak i početak gradnje drugog Hrama, koji je bio dovršen i posvećen 516. g. pr. n. e.

2. Vrijeme nastanka tekstova

Najstarijim se slojevima smatraju Mojsijeva Pjesma YHWH-и и čast (zvana i Pjesma mora) iz Knjige izlaska 15,1-18 i Pjesma Debore i Baraka iz Knjige o sucima 5. Obje su pisane jezikom i stilom arhaičnijim od onoga teksta koji ih okružuje, te su zasigurno najstariji dijelovi Tanaha, za koje se procjenjuje da su mogli nastati između XIII. i V. st. pr. n. e. (Wong 2007: 1). Najmlađim se djelom (i dijelom) Tanaha smatra Knjiga o Danielu, koja je nastala oko 165. g. pr. n. e. O njezinoj »mladosti« govori i činjenica da je dijelom pisana na aramejskom, jeziku koji se kao govorni među Židovima proširio u doba povratka iz Babilonskog sužanjstva. Knjige nastale nakon 150. g. pr. n. e. nisu mogle ući u židovski kanon. Tome je bilo lako doskočiti pripisivanjem knjige nekom starijem autoru ili pak nekoj starijoj epohi. Knjiga o Danijelu je dobar primjer za to jer iako formalno govori o vremenima Babilonskog sužanjstva, suvremenim je čitateljima bilo jasno da je riječ o razdoblju kad su židovskom domovinom zavladali Seleukidi. Danijelove su vizije budućnosti (kojoj je autor bio suvremenik), naime, vrlo jasne, dok je opis vremena u kojem

\footnotetext{
${ }^{28}$ Robert Graves i Raphael Patai pišu (Graves i Patai 1969: 222): »Postanak pruža pučke etimologije za imena dvanaestorice patrijarha, od kojih je mali dio uvjerljiv.«
} 
je navodno živio pun pogrešaka i anakronizama ${ }^{29}$ (Asimov 1969: 596-598; Harrington 1993: 416-417). S druge strane imamo Knjigu proroka Izaije, koji je prema predaji djelovao u drugoj polovici VIII. st. pr. n. e. (Asimov 1969: 524-526; Harrington 1993: 209-210). U četrdesetom se poglavlju knjige pojavljuje pleme Judino u progonstvu, čije očajanje liječe poticajni stihovi Deuteroizaije, drugog autora koji je u drugo doba (između dvije pobjede perzijskog kralja Kira II. Velikog, one nad Lidijom 546. g. pr. n. e. i zauzeća Babilona 539. g. pr. n. e.) pisao drugim stilom, autora koji odstupa od dotadašnjeg henoteizma, vjerovanja da lokalna božanstva imaju apsolutnu moć isključivo nad zemljama u kojima su štovana (Asimov 1969: 547-549; Harrington 1993: 233-234). Od 56. se pak poglavlja pojavljuje treći autor, Tritoizaija, koji je živio u vrijeme povratka iz izgnanstva (poslije 538. g. pr. n. e.) (Asimov 1969: 553; Harrington 1993: 238). Cjelovita je knjiga, dakle, kakvu danas poznajemo morala biti dovršena barem tri stoljeća nakon Izaijine smrti. Spomenimo još i Knjigu o Jobu, koja govori o liku kojega ne možemo točno locirati ni vremenski (obično se smješta u doba patrijarhā) ni prostorno (po svemu sudeći Edom), no književna se vrsta kojoj sama knjiga pripada pojavljuje još u babilonskoj književnosti. I ovdje su poetski dijelovi arhaičniji od okolnog proznog teksta. Knjiga je najvjerojatnije nastala potkraj V. st. pr. n. e. ${ }^{30}$ (Asimov 1969: 474-478; Harrington 1993: 282).

3. Vrijeme iz kojeg nam potječu najstariji sačuvani hebrejski rukopisi.

U Kumranu je od 1947. g. nađeno više od 200 rukopisa tekstova iz svih knjiga Tanaha osim Knjige o Esteri. Procjenjuje se da su nastali između 150. g. pr. n. e. i 70. g. n. e. Između toga doba i Kodeksa iz Alepa (o. 920. g.) te Lenjingradskog kodeksa (o. 1008. g.) nema sačuvanih biblijskih rukopisa na hebrejskome. Doduše, iz 587. - 586. g. pr. n. e. potječu amuleti sa svećeničkim blagoslovom kakav je zabilježen u Knjizi brojeva 6, 23-27,

${ }^{29}$ Vrhunac anakronizama u Bibliji zasigurno predstavlja Knjiga o Juditi (koja nije dio židovskog kanona). Isaac Asimov o njoj piše (Asimov 1969: 692):

"We have the Assyria of the seventh century B.C. under the rule of Nebuchadnezzar of the sixth century B.C., which sends its army under a general [Holofernes] of the fourth century B.C. to attack a re-established Judea of the fifth century B.C. Not a century is left out."

[(Ovdje) imamo Asiriju iz sedmog stoljeća pr. n. e. pod vladavinom Nabukodonozora iz šestog stoljeća pr. $n$. e., koji šalje svoju vojsku pod generalom [Holoferno] iz četvrtog stoljeća, pr. n. e. da napadne ponovno uspostavljenu Judeju iz petog stoljeća pr. n. e. Nije izostavljeno ni jedno stoljeće.]

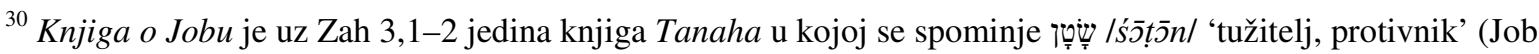
1,6; u transkripciji Antuna Sovića: Satan), što upućuje na vrijeme nastanka knjige poslije Babilonskog sužanjstva, kad je judaizam proživio utjecaj perzijskog zoroastrizma (Asimov 1969: 478). 
no to su fragmenti (dva biblijska retka!) koji teško da se mogu usporediti s kumranskim tekstovima.

Velika se većina hebrejskih osobnih imena iz Tanaha može kategorizirati prema trima kriterijima. Prema svojoj se strukturi osobna imena mogu podijeliti na jednostavna i složena, a ova se pak, poput onih u ostalim starosemitskim jezicima, mogu razvrstati u dvije skupine: rečenična i sintagmatska. Prema nazočnosti odnosno izočnosti jednog od naziva za Boga, hebrejska se osobna imena mogu podijeliti na bogonosna (teoforična) i svjetovna (sekularna) osobna imena. Prema trećem kriteriju razlikujemo muška i ženska osobna imena (Pike i Powell 2011; Stamm 2007: 764).
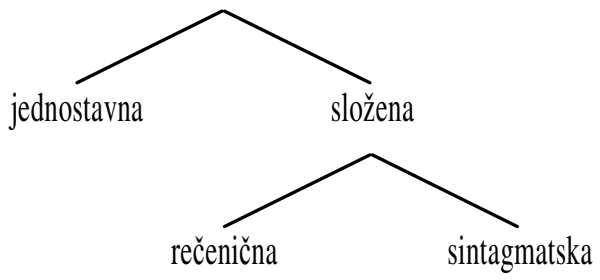

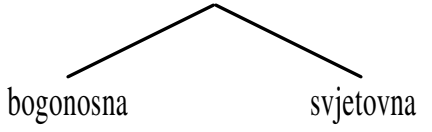

svjetovna

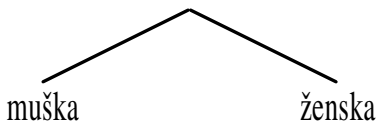

Rečenična osobna imena predstavljaju neproširenu prostu rečenicu, koja se sastoji samo od subjekta i predikata. Predikat u njoj može biti glagolski, ili pak imenski.

U osobnih imena oblika rečenice s glagolskim predikatom glagol najčešće dolazi u svršenom vidu (perfektu), nešto rjeđe u nesvršenom (imperfektu), dok su osobna imena koja sadržavaju imperativ rijetka, ali i njih ima, poglavito među kasnije potvrđenim osobnim imenima: עִשֶׁיאל

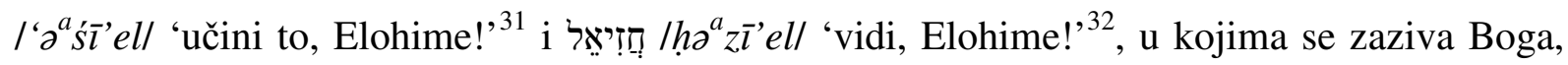

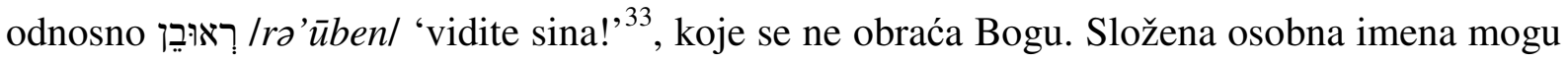

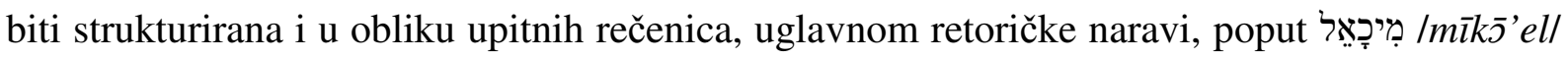
‘tko je kao Elohim?’34. Podskupinu ovakvih osobnih imena čine ona tvorena upitnom

\footnotetext{
${ }^{31} 1$ Ljet 4,35. U transkripciji Antuna Sovića: Asiel.

${ }^{32} 1$ Ljet 23,9. U transkripciji Antuna Sovića: Haziel.

${ }^{33} \mathrm{Br} 26,5$. U transkripciji Silvija Grubišića: Ruben.
}

Robert Graves i Raphael Patai o etimologiji ovog osobnog imena pišu (Graves i Patai 1969: 222, 249):

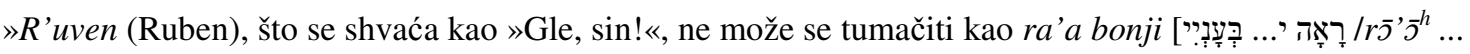

bə‘̌̆nyīl], »On pogleda jad moj«.

$\cdots$

Josip Flavije i drugi pišu Ruben kao »Rubel« ['pogledaj Elohima/Elohime'?], što bi moglo biti najraniji oblik tog imena.«

${ }^{34} \mathrm{Br} .13,13$. U transkripciji Silvija Grubišića: Mikael. 


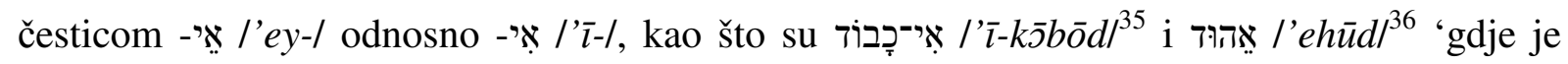

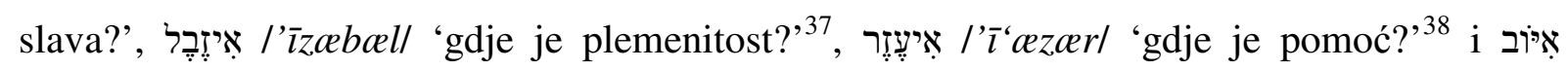
/'̌yōb/ 'gdje je otac?'39 (Pike i Powell 2011; Stamm 2007: 764, 766).

Rečenična osobna imena slijede sintaksu klasičnog hebrejskoga, te je u njima najčešći

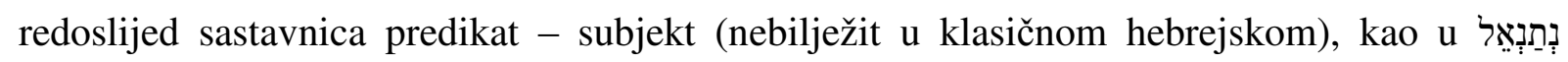
Inətanə'el/ ‘dao je Elohim, ${ }^{40}$ s glagolom u perfektu. Među osobnim imenima s dotičnim glagolskim vidom ima i onih s redoslijedom subjekt - predikat (uobičajenijim u suvremenom

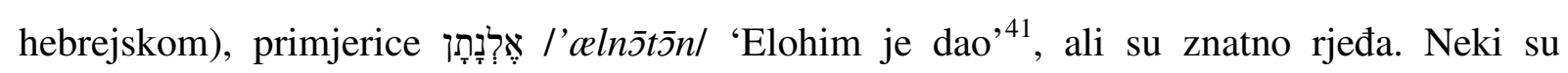
pojedinci u pojedinim knjigama Tanaha imenovani rečeničnim osobnim imenima s istim subjektom i predikatom, ali različitim njihovim redoslijedom, npr. Bat-Šebin se otac na

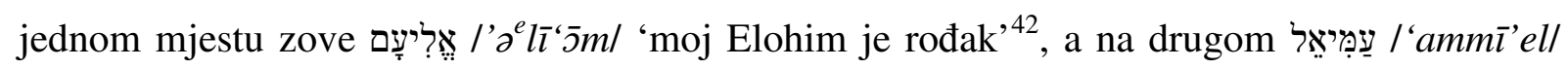
'moj rođak je Elohim'43 (Guggenheimer H. W. i Guggenheimer E. H. 1992: xi). Među osobnim imenima s glagolom u imperfektu, osobna imena s redoslijedom subjekt - predikat,

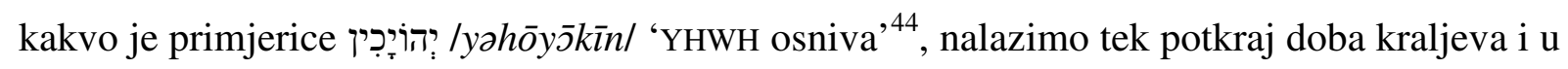
doba poslije povratka iz babilonskog sužanjstva (Stamm 2007: 764-5).

Kako u hebrejskom jeziku glagol ה.י. ה $/ h-y-h /$ 'biti' nema prezentskih oblika, u prostim rečenicama s imenskim predikatom u prezentu nema spone (kopule), već se one sastoje samo određenog subjekta ${ }^{45}$ i neodređenog imenskog predikata.

\footnotetext{
${ }^{35} 1$ Sam 4,21. U transkripciji Antuna Sovića: Ikabod

${ }^{36} 1$ Ljet 7,10. U transkripciji Antuna Sovića: Ahud.

${ }^{37} 1 \mathrm{Kr}$ 16,31. U transkripciji Antuna Sovića: Izebela.

${ }^{38} \mathrm{Br} 26,30$. U transkripciji Silvija Grubišića: Jezer.

3919 Job 1,1. U transkripciji Antuna Sovića: Job.

V. bilj. 139 za drugo tumačenje njegova osobnog imena.

Odgovarajuće arapsko osobno ime: أَيُوب /'ayūb/ ‘koji je našao utok; koji se kaje; progonjen’ (Agić 1996: 34).

${ }^{40} \mathrm{Br} 1$,8. U transkripciji Silvija Grubišića: Netanel.

${ }^{41} 2$ Kr 24,8. U transkripciji Antuna Sovića: Elnatan.

${ }^{42} 2$ Sam 11,3. U transkripciji Antuna Sovića: Eliam

${ }^{43} 1$ Ljet 3,5. U transkripciji Antuna Sovića: Amiel

${ }^{44} 2 \mathrm{Kr}$ 24,8. U transkripciji Antuna Sovića: Jojakin.

${ }^{45} \mathrm{U}$ hebrejskom se jeziku semantički određenima smatraju imena $a_{1}$ s članom (u hebrejskom nema neodređenog člana), osobna imena, lične zamjenice i posvojne konstrukcije.
} 
Bogonosna osobna imena mogu biti isključivo složena, jer bi se jednostavna bogonosna osobna imena mogla sastojati jedino od Božjeg osobnog imena, što nije prihvatljivo ${ }^{46}$. Stoga su sva bogonosna osobna imena složena, bilo kao rečenica u kojoj je Bog subjekt, bilo kao opisna sintagma koja uključuje naziv za Boga. U najstarijoj tradiciji sadržanoj u Tanahu nalazimo dvije predaje koje se razlikuju po nazivu koje koriste za Boga ${ }^{47}$. U jednoj se Bog

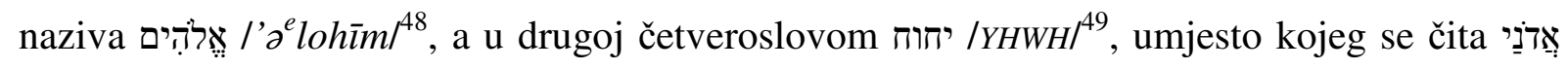
/’a donay/ $\left.\right|^{50}$ (Pike i Powell 2011).

\footnotetext{
${ }^{46} \mathrm{U}$ skladu s trećom božjom zapovijedi (s drugom u katolika, pošto ovi redovito preskaču zabranu pravljenja slika) iz Izl 20,7 i Pnz 5,11. U prijevodu Silvija Grubišića:
}

$»$ Ne uzimaj uzalud imena YHWH, Boga svoga, jer YHWH ne oprašta onome koji uzalud izgovara ime njegovo.«

${ }^{47}$ Na samom početku Tanaha nalazimo dva izvještaja o stvaranju svijeta, prvi (Post 1,1-2,4) pripada tzv. elohističkoj predaji, a drugi (Post 2,5-24) tzv. jahvističkoj. I kasnije možemo prepoznati predaju kojoj pojedini dijelovi teksta pripadaju prema nazivu za Boga koji koriste.

Ustvari su u Petoknjižju skupljene četiri predaje:

1. jahvistička, po svemu sudeći podrijetlom iz Jude (južnog kraljevstva) u vrijeme vladavine kralja Salomona (vladao od oko 970. do 931. g. pr. n. e.);

2. elohistička, po svemu sudeći podrijetlom iz Izraela (sjevernog kraljevstva) nešto kasnije (od 850. g. pr. n.

e.) te spojena s prvom nakon pada sjevernog kraljevstva 721. g. pr. n. e.;

3. deuteronomistička, uobličena u vrijeme reforme kralja Jošije (o. 649. - 609.) - knjiga je Ponovljenog zakona (odnosno njezin dio) vjerojatno bila ona koju su svećenici našli u Hramu u 2 Kr 22,8 - zadnja priključena Petoknjižju;

4. svećenička (koja koristi isti naziv za Boga kao i jahvistička), oblikovana u doba babilonskog sužanjstva (597. - 538. g. pr. n. e.), pripojena prvim dvjema predajama nakon povratka iz njega (Harrington 1993: 122-146).

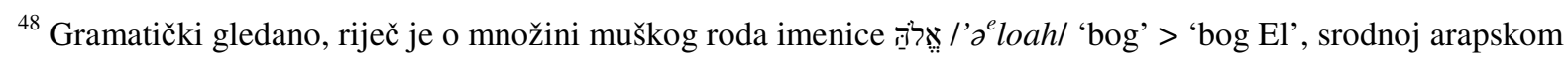
božjem osobnom imenu آَّا /'allāh/. Bog je El inače bio vrhovni bog kanaanskog i feničkog panteona (Graves i Patai 1969: 24), a odgovarali su mu Ilu među Asircima i Babiloncima, El u Ugaritu i Il/Ilum u južnoj Arabiji, dok u suvremenom hebrejskom jeziku riječ אֵ /'ell znači bilo koje božanstvo (Pike i Powell 2011). Iako je riječ o množinskoj tvorbi, u hebrejskim se tekstovima s njom u pravilu slažu jedninski oblici. Zanimljivo je da u samoj Knjizi postanka na dva mjesta Bog o sebi govori u množini:

Post 3,22 (u prijevodu Silvija Grubišića): Zatim reče Bog: »Evo, čovjek postade kao jedan od nas - znajući dobro i zlo! Da ne bi sada pružio ruku, ubrao sa stabla života pa pojeo i živio navijeke!«

Post 11,7 (u prijevodu Silvija Grubišića): Hajde da siđemo i jezik im pobrkamo, da jedan drugome govora ne razumije. «

${ }^{49}$ Moguće je da je ovo osobno ime izvedeno od glagolskog korijena ה. ה. $/ h-y-h /$ 'biti (glagol egzistencije)'.

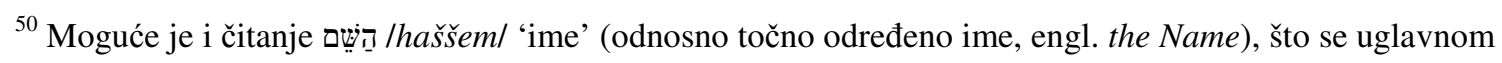
bilježi kao ' $ה$, pokrata koju ćemo naći i u židovskim osobnim imenima iz korpusa. 


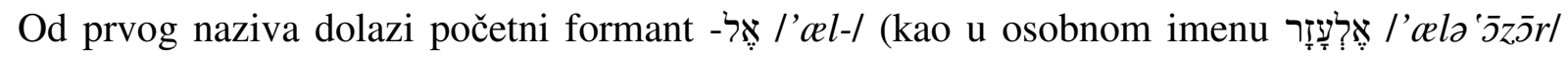

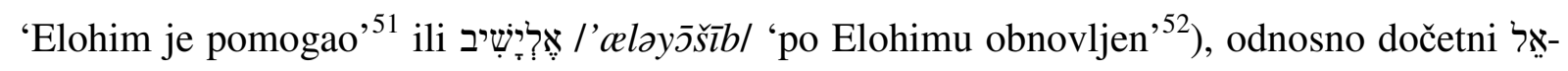

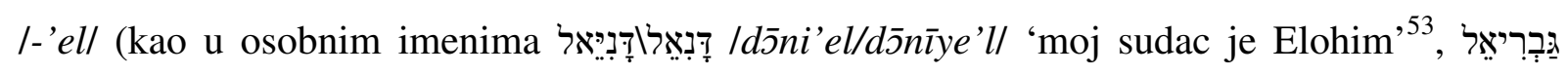

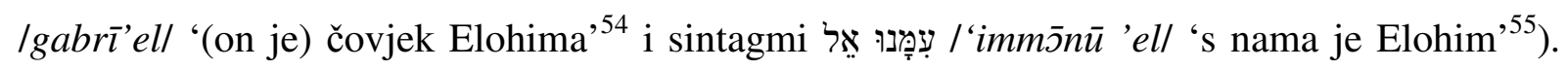

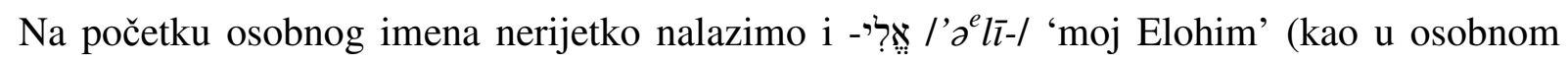

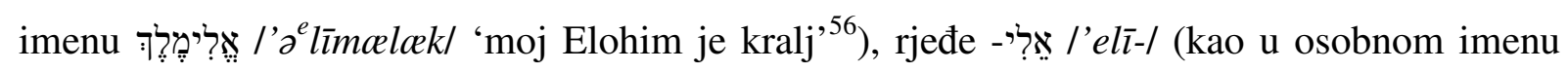

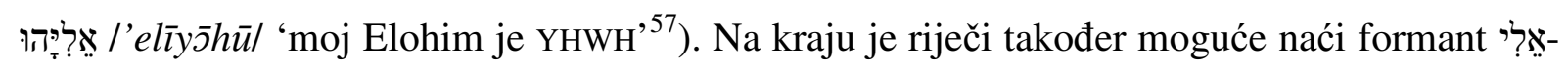
/-'elī/ (kao u osobnom imenu אַרְאָ /'ar'elīl 'lav je moj Elohim' ili 'lav mog Elohima,58), ali i

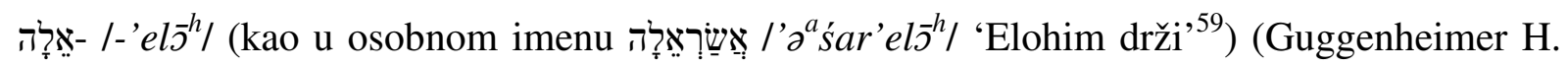
W. i Guggenheimer E. H. 1992: xi).

Od drugog pak naziva, koji se smatra pravim, osobnim božjim osobnim imenom i kao takvim neprimjerenim za izgovor, imamo više mogućih formanata. Na početku je riječi moguće naići

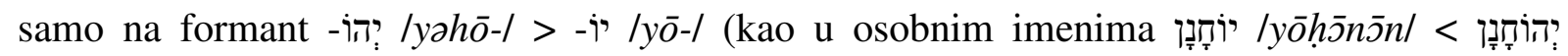

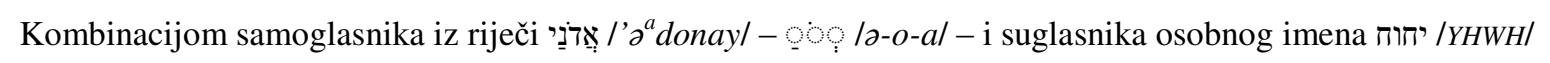
dobiva se popularno koliko i problematično čitanje božjeg osobnog imena nin: ne odgovara onome kako se osobno ime izvorno (nije) izgovaralo. Grčka transkripcija 'I $\alpha \beta \varepsilon$ /iabél, koju nalazimo u Teodoreta iz Kira, teologa i biskupa iz V. st., i Epifanija iz Salamine, biskupa iz IV. st., upućuje na moguć izvorni vokalizam ९९/a-ə-cel. (Brown, Driver i Briggs 1906: 218; preslik stranice dostupan na: https://en.wikisource.org/wiki/Page:A_Hebrew_and_English_Lexicon_(Brown-Driver-Briggs).djvu/242 Pristupljeno 7. rujna 2017.)

${ }^{51}$ Izl 6,23. U transkripciji Silvija Grubišića: Eleazar.

${ }^{52} 1$ Ljet 3,24. U transkripciji Antuna Sovića: Elijašib.

${ }^{53}$ Ez 14,14, Dn 1,6. U transkripciji Antuna Sovića: Daniel.

${ }^{54}$ Dn 8,16. U transkripciji Antuna Sovića: Gabriel.

${ }^{55}$ Iz 7,14. Zapisano kao dvije riječi. U prijevodu Antuna Sovića transkribirano kao jedna riječ:

${ }^{14}$ Zato, sâm će vam Gospodin dati znak: Evo, začet će djevica i roditi sina i nadjenut će mu ime Emanuel! Tek su kasnije one srasle u jedinstvenu riječ, novo osobno ime, kako ga i bilježi navedena Sovićeva transkripcija. U hrvatskom prijevodu Biblije tek je u Evanđelju po Mateju 1,23 dano prvotno značenje osobnog imena, u prijevodu Ljudevita Rupčića:

${ }^{23}$ Evo, Djevica će začeti i roditi sina i nadjenut će mu se ime Emanuel - što znači: S nama Bog!

${ }^{56}$ Rut 1,2. U transkripciji Antuna Sovića: Elimelek.

${ }^{57} 1 \mathrm{Kr}$ 17,1. U transkripciji Antuna Sovića: Ilija.

Odgovarajuće arapsko osobno ime: إلَّْلَاس /'ilyās/ 'Allah je moj Bog' (Agić 1996: 53).

${ }^{58}$ Post 46,16. U transkripciji Silvija Grubišića: Areli.

${ }^{59} 1$ Ljet 25,2. U transkripciji Antuna Sovića: Asarela. 


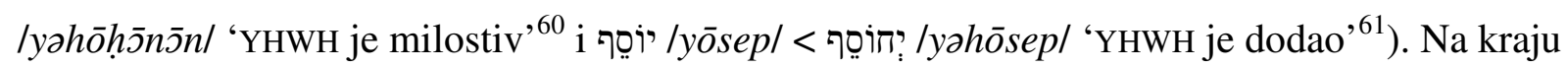

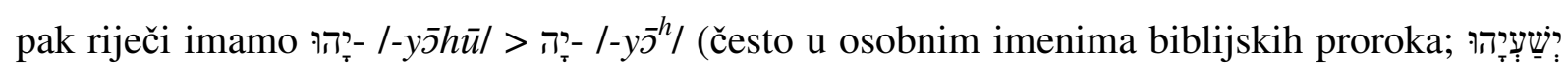

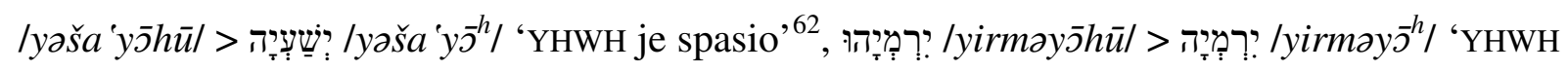

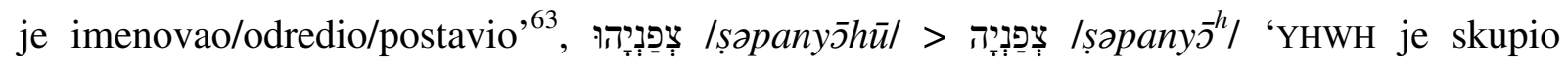

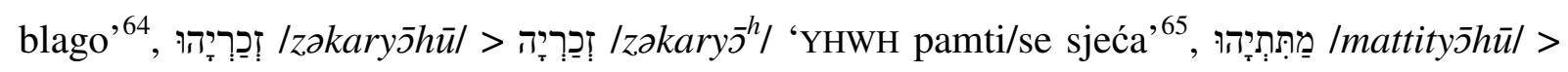

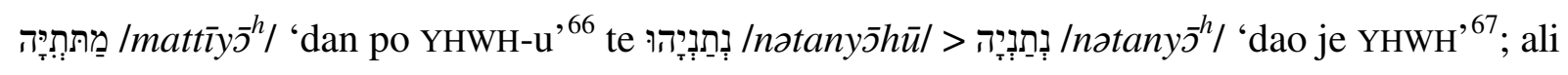

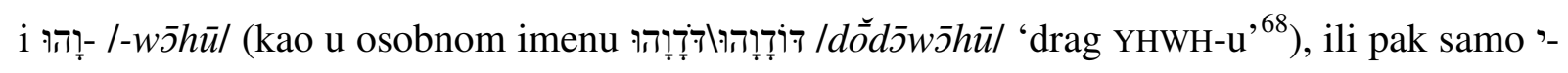
/-y/ (kao u osobnom imenu Tִּ /hidday/ 'radost YHWH-a' ${ }^{69}$ ). Božje se osobno ime pojavljuje i

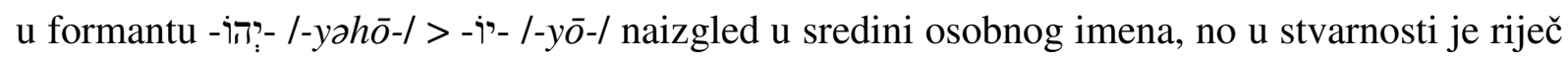
o Božjem osobnom imenu kojem prethodi prijedlog אצֶ /'ael-/ 'prema, pri', tako da je zapravo

${ }^{60} 1$ Ljet 26,3, 2 Kr 25,23. U transkripciji Antuna Sovića: Johanan.

Odgovarajuće arapsko osobno ime: يَخَilyahyāl 'preporoditelj, oživotvoritelj' (Agić 1996: 55).

${ }^{61}$ Ps 81,5 (Ps 81,6 u hrv. pr.), Post 30,24. U transkripciji Filiberta Gassa i Antuna Sovića: Josip

V. bilj. 108 za drukčije tumačenje osobnog imena.

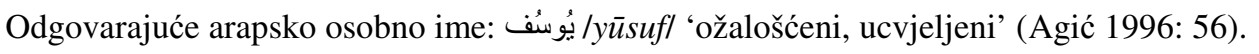

${ }^{62} 2 \mathrm{Kr}$ 19,2, Ezr 8,7. U transkripciji Antuna Sovića: Izaija.

${ }^{63} 2 \mathrm{Kr}$ 23,31, Jer 27,1. U transkripciji Antuna Sovića: Jeremija.

O ovom osobnom imenu u sefardskim zajednicama Ora (Rodigue) Schwarzwald piše (Schwarzwald 2010: 194):

"The name Yirmiya (the prophet) was infrequently given to babies as it was associated with the phrase Yirmiya el yoron "crying Jeremiah; pessimist; someone easily reduced to tears," ${ }^{15}$ probably because the authorship of the book of Lamentations is attributed to him.

${ }^{15}$ Another proverb related to this name is Yirmiya el marido, Yirmiya la mujer, "the husband is Jeremiah, the wife is Jeremiah; very pessimistic people." Compare the English noun jeremiad, "a long mournful lament." " [Ime (proroka) Yirmiya je rijetko nadijevano djeci jer je bilo povezano s izrazom Yirmiya el yoron »Jeremija plačljivac; pesimist; netko tko se lako rasplače «, ${ }^{15}$ vjerojatno zbog toga što se autorstvo knjige Tužaljaka pripisuje пјети.

${ }^{15}$ Druga je poslovica koja se odnosi na ovo ime Yirmiya el marido, Yirmiya la mujer, »suprug Jeremija, supruga Jeremija; vrlo pesimistični ljudi.« Usporedite imenicu jeremijada 'dugo žalosno naricanje'.]

${ }^{64} 2 \mathrm{Kr}$ 25,18, Jr 29,29. U transkripciji Antuna Sovića: Sefanija.

${ }^{65} 2$ Kr 14,29. U transkripciji Antuna Sovića: Zaharija.

Odgovarajuće arapsko osobno ime: زَكَرِ /zakariyyāl 'onaj koji se sjeća Boga; Bog me se sjetio; Bog misli na mene' (Agić 1996: 116).

${ }^{66} 1$ Ljet 16,5. U transkripciji Antuna Sovića: Matitja.

${ }^{67} 1$ Ljet 25,2. U transkripciji Antuna Sovića: Netanija.

${ }^{68} 2$ Ljet 20,37. U transkripciji Antuna Sovića: Dodavahu.

${ }^{69} 2$ Sam 23,30. U transkripciji Antuna Sovića: Hidaj. 


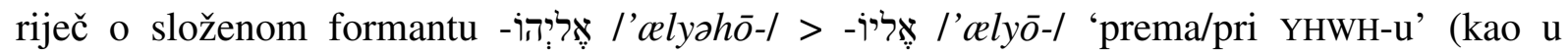
osobnom imenu אֶלִ /'a'alyō'enay/ 'prema/pri YHWH-u moje oči $^{70}$ ) (Guggenheimer H. W. i Guggenheimer E. H. 1992: xi).

Prva osoba u Bibliji koja je nosila osobno ime koje je uključivao dio naziva Elohim jest

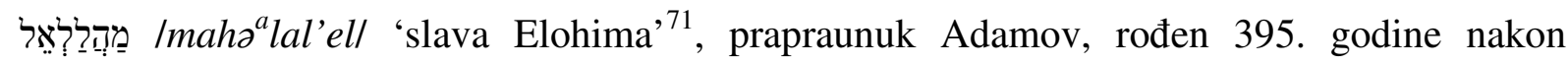
stvaranja svijeta. Prvi pak lik Biblije koji je nosio osobno ime koje je u sebi imalo dio

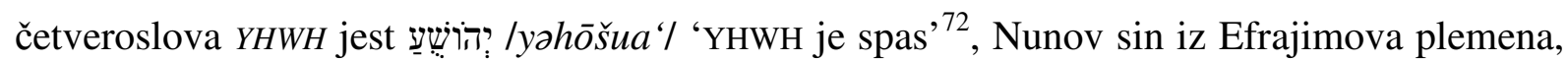
Mojsijev pobočnik i vođa Izraelaca poslije Mojsijeve smrti. Njegovo je prvotno osobno ime

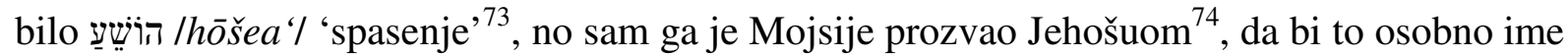
u Nehemijino doba bilo pokraćeno u $\mathrm{u}$ '

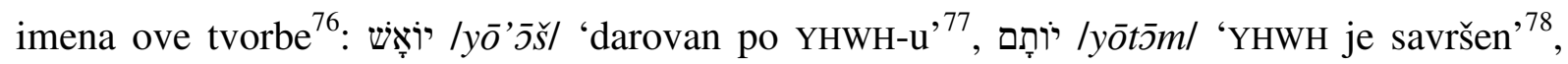

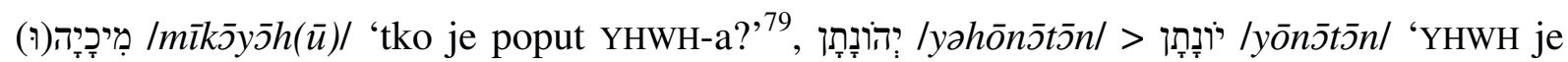
dao, ${ }^{80}$, da bi u doba kraljeva dotična tvorba postala ne samo učestalom, već i jednom od dominantnih (Stamm 2007: 765-766). Znači li činjenica da su osobna imena tvorena nazivom Elohim starija od onih tvorenih Božjim osobnim imenom $Y H W H$ da je naziv Elohim i s njim elohistička tradicija starija od jahvističke ${ }^{81}$, ili je pak tabu nad osobnim imenom Božjim, $Y H W H$, bio toliko jak da se dugo nitko nije usudio od njega tvoriti ljudsko osobno ime?

\footnotetext{
${ }^{70} 1$ Ljet 7,8. U transkripciji Antuna Sovića: Elijoenaj.

${ }^{71}$ Post 5,13-17. U transkripciji Silvija Grubišića: Mahalalel.

${ }^{72}$ Izl 17,9. U transkripciji Silvija Grubišića: Jošua.

${ }^{73}$ Br 13,8. U transkripciji Silvija Grubišića: Hošea

${ }^{74} \mathrm{Br} 13,16$.
}

Na zagrebačkom je Mirogoju osobno ime rabina Hosee Jacobija hebrejskim pismom zapisano u akrostihu kao יהושע /yəhōšua\% (2 I 16).

${ }^{75}$ Neh 8,17 .

${ }^{76}$ Johann Jakob Stamm navodi i peto osobno ime, יוֹאیרo' /yol/ 'YHWH je Elohim' (Stamm 2007: 766), no ono se ne spominje u Knjizi o sucima, već u Prvoj knjizi o Samuelu (1 Sam 8), obje Knjige Ljetopisa (1 Ljet 6,21, 4,35, 5,4-8, 5,12, 7,3, 11,38, 15,7; 23,8; 26,22, 27,20, 2 Ljet 29,12), Ezri-Nehemiji (Ezra 10, 43, Neh 11,9) i Knjizi proroka Joela (Joel 1,1). U transkripciji Antuna Sovića: Joel.

${ }^{77}$ Suci 6,11. U transkripciji Antuna Sovića: Joaš.

${ }^{78}$ Suci 9,5. U transkripciji Antuna Sovića: Jotam.

${ }^{79}$ Suci 17,1. U transkripciji Antuna Sovića: Mikajehu.

${ }^{80}$ Suci 18,30. U transkripciji Antuna Sovića: Jonatan.

${ }^{81}$ V. Izl 6,2-3, u prijevodu Silvija Grubišića:

${ }^{03}$ Abrahamu, Izaku i Jakovu objavljivao sam se kao El Šadaj. Ali njima se nisam očitovao pod svojim 
Međutim, čini se kao da je imati dio naziva za boga u osobnom imenu muški zabran, da ženama takva osobna imena »ne priliče«. To pokazuje i relativno skromna skupina ženskih osobnih imena koja u sebi uključuju naziv za Boga u Popisu vlastitih imena iz Tanaha uključenih na kraju Amerlova rječnika (Amerl 1997) ${ }^{82}$. Ondje je moguće naći tek pet ženskih

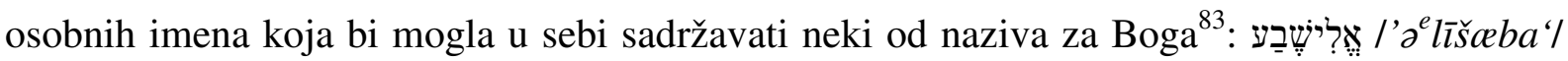

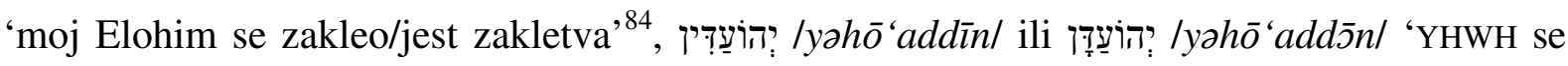

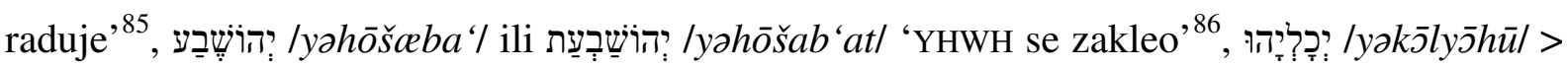

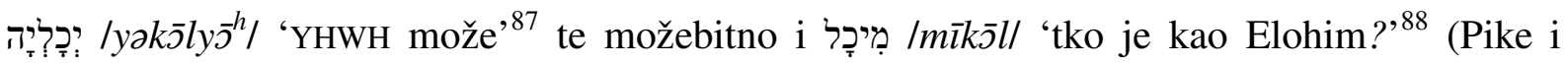

imenom - YHWH.

S druge strane, u Post 4,26, također u prijevodu Silvija Grubišića, stoji:

${ }^{26}$ Šetu se [Adamovu i Evinu trećem sinu] rodi sin, komu on nadjenu ime Enoš. Tada se počelo zazivati ime YHWH-Ovo.

${ }^{82}$ Nažalost taj popis nije krajnje pouzdan, što je manje pogreška samog autora, a više problem određivanja spola (pa samim tim i roda) nositelja pojedinih osobnih imena u Tanahu. Najbolji primjer za to predstavlja

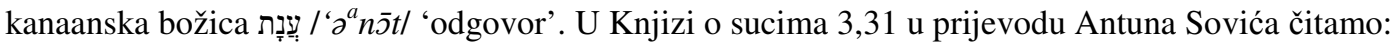
»Poslije njega bijaše Šamgar, sin Anatov. On je pobio šest stotina Filistejaca ostanom volujskim. Tako je i on spasio Izraela.«

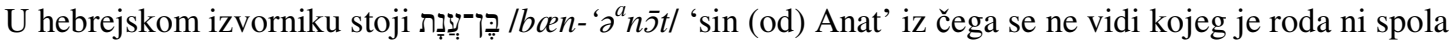
roditelj(ica).

Osobno je ime i dan-danas žensko, nose ga Izraelke, ali ne i Izraelci. Osobno je to ime Baalove sestre, stare semitske božice ljubavi, Kraljice Neba, krvožedne djevice potvrđene u ugaritskom panteonu (grčka boginja Hera se na jednom mjestu poistovjećuje s Anat; Graves i Patai 1969: 183). Kako se iz Biblije morala izbrisati svaka natruha nekadašnjeg mnogoboštva, a pogotovo mogućnost postojanja nekog ženskog božanstva (i još k tome takvih atributa!), tako su i mnoge božice i ine žene svoj opstanak u Knjizi postanka platile spolom (Graves i Patai 1969: 8, 23, 24-5, 58). Alemko Gluhak pak navodi da je Anat bila supruga sjeverozapadnosemitskog boga YHWH, u to doba tek jednog od mnogih iz mnogobožačkog semitskog panteona (Gluhak 1993: 280).

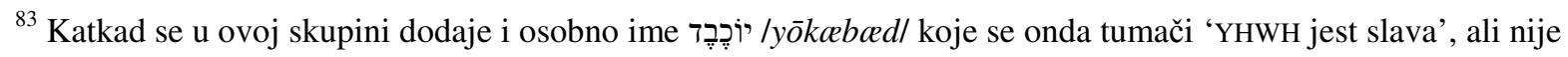
posve sigurno da ono sadržava Božje osobno ime (Stamm 2007: 765). Kad bi ga sadržavalo, bilo bi to najstarije takvo osobno ime spomenuto u Tanahu.

Izl 6,20; Br 26,59. U transkripciji Silvija Grubišića: Jokebeda.

${ }^{84}$ Izl 6,23. U transkripciji Silvija Grubišića: Elišeba.

${ }^{85} 2 \mathrm{Kr}$ 14,2; 2 Ljet 25,1. U transkripciji Antuna Sovića: Joadana.

${ }^{86} 2 \mathrm{Kr}$ 11,2, 2 Ljet 22,11. U transkripciji Antuna Sovića: Jošeba.

${ }^{87} 2 \mathrm{Kr}$ 15,2, 2 Ljet 26,3. U transkripciji Antuna Sovića: Jekolija.

881 Sam 14,49. U transkripciji Antuna Sovića: Mikala.

Izočnost slova א/'/ čini ovo tumačenje osobnog imena sumnjivim, iako se dotični fonem, kad zatvara slog, 
Powell 2011). Usto ima i nekoliko osobnih imena koja u hebrejskoj Bibliji nose i muškarci i

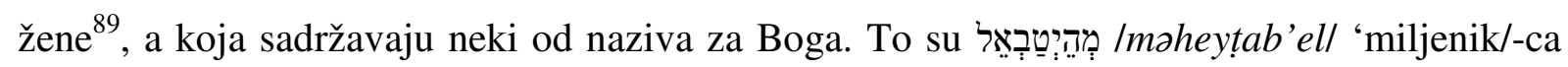

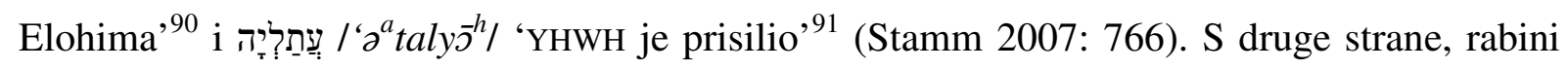
danas ne gledaju dobrohotno na nadijevanje ženskoj djeci osobnih imena koja sadržavaju u sebi naziv za Boga ${ }^{92}$.

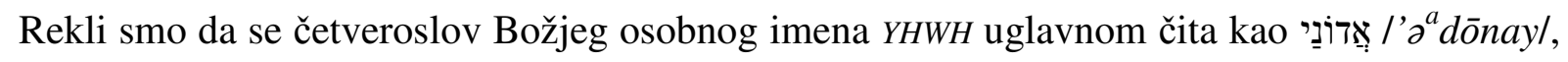
te i nazočnost ove riječi u nečijem osobnom imenu ( ִָ /’a'donīrōm/ 'moj Gospodin je uzvišen, ${ }^{93}$ ) nedvojbeno upućuje na Boga, no sama ta riječ nije Božje osobno ime, već ono što se izgovara umjesto neizgovorljivoga. Postoje i neke druge riječi kojima se metaforički opisuje Bog, a koje, usprkos činjenici što same nisu naziv za Boga, mogu tvoriti podrazred antroponima u kojima se na Boga upućuje neizravno. Takve su riječi one koje označuju

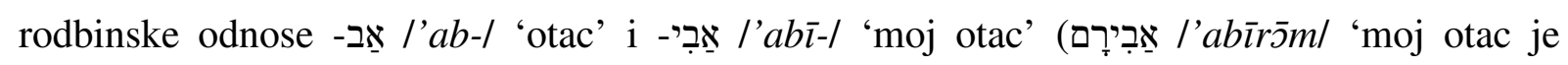

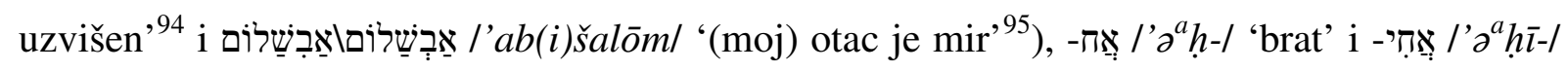

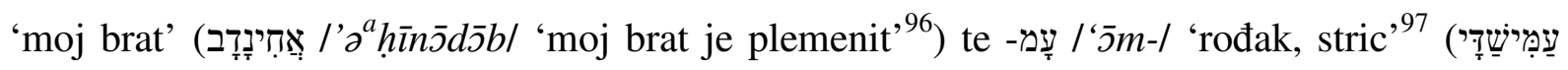

ustvari ne izgovara. Podjednako bi uvjerljivo bilo ovo osobno ime čitati ‘tko je cio?' ili jednostavno 'moć, snaga'.

${ }^{89}$ Moguće je da je i ovdje riječ o izvorno ženskim likovima, koji su pod pritiskom patrijarhalnog društva u kasnijim knjigama Tanaha promijenili spol.

${ }^{90}$ Post 36,39, 1 Ljet 1,50. U transkripciji Silvija Grubišića i Antuna Sovića: Mehetabela (kći Matredova i supruga edomskog kralja Hadada).

Neh 6,10. U transkripciji Antuna Sovića: Mehetabel (otac Šemajinog oca Delaje).

${ }^{91} 1$ Ljet 8,26. U transkripciji Antuna Sovića: Atalija (Jerohamov sin iz plemena Benjaminova)

Ezr 8,7. U transkripciji Antuna Sovića: Atalija (roditelj Izaijin od potomaka Elamovih koji se s Ezrom vratio iz babilonskog sužanjstva, no ni po čemu se iz samog teksta ne vidi da bi morala biti riječ o muškarcu)

2 Kr 11,1 i 2 Ljet 22,2. U transkripciji Antuna Sovića: Atalija (kći kralja Ahaba i njegove supruge Jezabele i supruga judejskoga kralja Jorama)

${ }^{92} \mathrm{O}$ tome je između ostaloga govorio i članak Rabini ne preporučuju ime Ariel objavljen 5. studenog 2005. g. u Jutarnjem listu.

Adresa internetske stranice na kojoj je objavljen popis podobnih osobnih imena: http://www.moriya.org.il/Name/Name1.asp\#.

${ }^{93} 1 \mathrm{Kr} 5,28$. U transkripciji Antuna Sovića: Adoniram.

${ }^{94} \mathrm{Br} 16,1,1 \mathrm{Kr}$ 16,34. U transkripciji Silvija Grubišića i Antuna Sovića: Abiram.

${ }^{95} 2$ Sam 3,3, 2 Ljet 11,20. U transkripciji Antuna Sovića: Abšalom.

${ }^{96} 1$ Kralj 4,14. U transkripciji Antuna Sovića: Ahinadab.

${ }^{97}$ Kao samostalna, ova se riječ piše עָָ, sa završnim oblikom slova mem - ๑. Kako se u ovom kontekstu ona tretira kao morfem, a ne dovršena riječ, napisana je s nezavršnim oblikom slova mem - מ. 
/'ammī̌sadd̄̄y/ 'moj rođak/stric je svemoguć' ${ }^{98}$ ). Problem je s ovim osobnim imenima u tome što te riječi mogu označavati i stvarnog srodnika, najčešće pokojnoga, za kojega se drži da je novorođenče preuzelo njegovo mjesto u porodici. U zadnjem navedenom primjeru imamo još

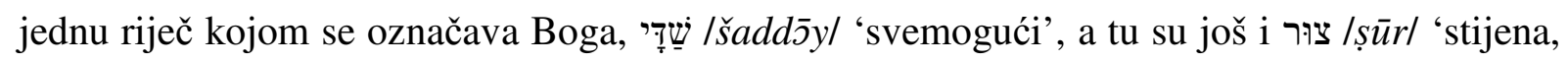

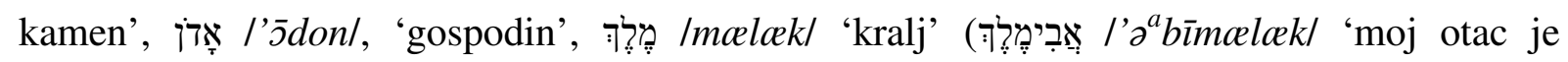

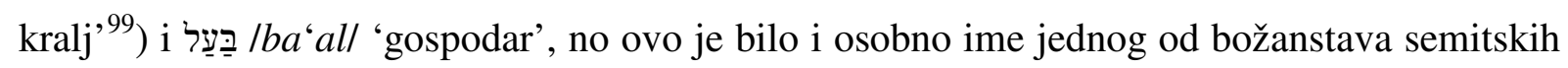
naroda koji su okruživali Izraelićane, pa je moglo imati dvojnu motivaciju (Guggenheimer H. W. i Guggenheimer E. H. 1992: xi; Pike i Powell 2011; Stamm 2007: 766).

U skupinu bi složenih osobnih imena trebalo ubrojiti i ona koja tvore rečenice s neizrečenim subjektom, koja se sastoje samo od finitnoga glagolskog oblika, kakva su bila učestala od doba patrijarhā do vremena sudaca. Ta jedna jedina riječ sama može tvoriti zaokruženu

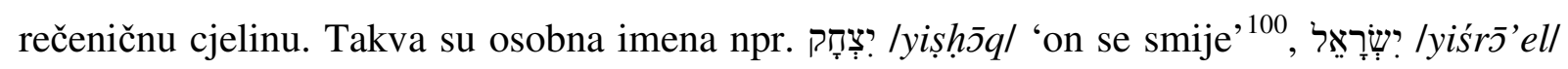

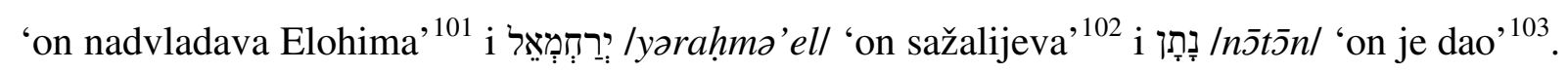
U posljednjem se osobnom imenu podrazumijeva tko je subjekt, tko je agens, tko je onaj koji sve daje. Ono je primjer osobnog imena koje podrazumijeva Boga, ali ga eksplicitno ne

\footnotetext{
${ }^{98} \mathrm{Br} 1,12$. U transkripciji Silvija Grubišića: Amišadaj

${ }^{99}$ Post 20,2, Suci 8,31, 2 Sam 11,21. U transkripciji Silvija Grubišića i Antuna Sovića: Abimelek
}

U Knjizi o sucima Abimelek je sin Gideona, jednog od sudaca koji su sudili Izraela nakon osvajanja Kanaana, a prije uspostave monarhije. Pošto je Gideon izvojevao veliku pobjedu nad Midjancima, narod je od njega tražio da se on i njegova porodica zakralje nad njima. Prema tekstu u Tanahu Gideon je to odbio. (Suci 8,22-23) Osobno se ime njegova sina, 'moj otac je kralj', stoga ne mora nužno pozivati na nebeskog Oca, već se može odnositi i na ovozemaljskoga (Asimov 1969: 244).

${ }^{100}$ Post 21,5. U transkripciji Silvija Grubišića: Izak.

Odgovarajuće arapsko osobno ime: إَِِِْ /'ishaq/ 'razveselitelj; nasmijani; onaj koji je radostan' (Agić 1996: 54). Ovdje, međutim postoje fonološke nepodudarnosti: hebrejsko צ/ș/ fonološki odgovara arapskima ص/ș/

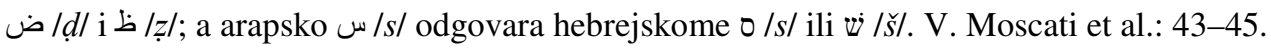

${ }^{101}$ Post 32,29. U transkripciji Silvija Grubišića: Izrael.

Robert Graves i Raphael Patai o značenju ovog osobnog imena pišu (Graves i Patai 1969: 235):

»Objašnjenje imena Izrael u Postanku 32: 29 predstavlja pučku etimologiju. U teoforičnim nazivima element koji sadržava ime božanstva je subjekt, ne objekt. Izrael stoga znači »El se bori«, a ne »On se borio s Elom«; jednako kao što izvorni oblik imena Jakov, Ja 'qobel, znači »El štiti« i jednako kao što izvorno značenje imena Jerobaal nije bilo »On se bori protiv Baala«, nego »Baal se bori«. Svrha imena poput ovih bila je dobivanje Božje pomoći za one koji su ih nosili. Izrael je tako značio »El se bori protiv mojih neprijatelja«.«

1021 Ljet 2,9. U transkripciji Antuna Sovića: Jerahmeel.

${ }^{103} 1$ Ljet 2,36. U transkripciji Antuna Sovića: Natan. 
iskazuje, osobno ime u kojem je Bog (ne)izražen svojevrsnim nultim morfemom. Takvo je i

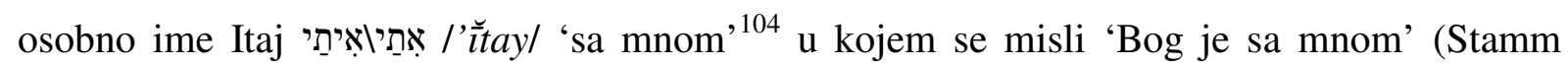
2007: 765).

Kako nesvršeni glagolski vid može imati i jusivno značenje ${ }^{105}$, neka se osobna imena mogu

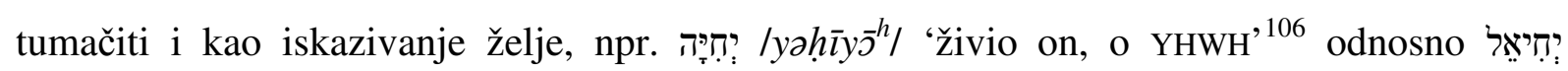

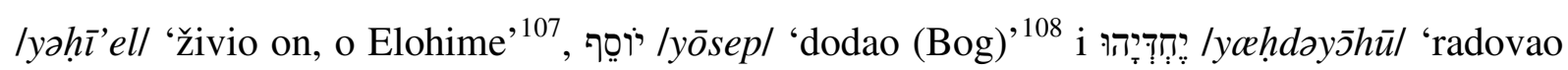

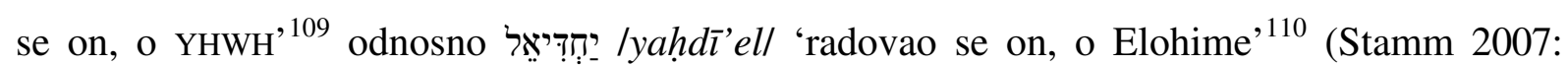
$765)$.

Složena hebrejska osobna imena rijetko sadržavaju glagolski pridjev (particip), te u Tanahu

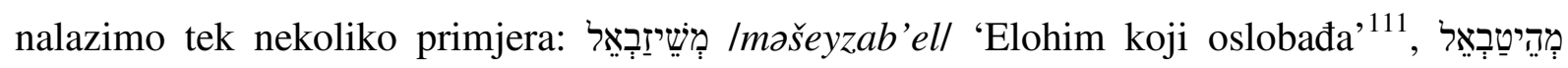

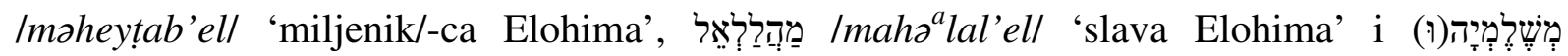
Iməšalacmyah( $\bar{u}) /$ "prijateljstvo YHWH-a ${ }^{112}$. S druge su strane prilično učestala osobna imena

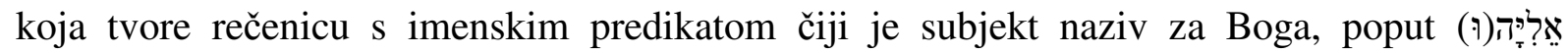

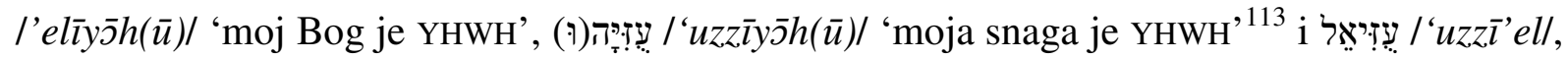
'moja snaga je Elohim,114. Ta osobna imena u sebi sadržavaju posvojni sufiks prvog lica jednine - /-ìl, a koji se može odnositi na samo dijete koliko i na njegove roditelje, što nije slučaj s osobnim imenima kakva su

\footnotetext{
${ }^{104} 1$ Ljet 11,31, 2 Sam 18,2. U transkripciji Antuna Sovića: Itaj

105 Jusiv može izražavati nalog izdan trećem licu, slično hrvatskomu »neka (on/ona/ono, oni/one/ona)...«, no isto tako može izražavati želju poput optativa. Jusivni se oblik glagola odgovarajućeg mu imperfektskoga razlikuje po kraćenju zadnjeg samoglasnika u riječi (ako je to moguće).

1061 Ljet 15,24. U transkripciji Antuna Sovića: Jehija.

1071 Ljet 15,18. U transkripciji Antuna Sovića: Jehiel.

V. bilj. 122 za drukčije tumačenje ovog osobnog imena.

${ }^{108}$ V. bilj. 61.

${ }^{109} 1$ Ljet 24,20. U transkripciji Antuna Sovića: Jehdeja.

${ }^{110} 1$ Ljet 5,24. U transkripciji Antuna Sovića: Jahdiel.

${ }^{111}$ Neh 3,4. U transkripciji Antuna Sovića: Mešezabel.

1121 Ljet 9,21. 1 Ljet 26,1. U transkripciji Antuna Sovića: Mešelemja.

1132 Ljet 26,9. U transkripciji Antuna Sovića: Uzija.

${ }^{114} 1$ Ljet 15,20. U transkripciji Antuna Sovića: Uziel.

1151 Ljet 4,14. U transkripciji Antuna Sovića: Joab.
} 


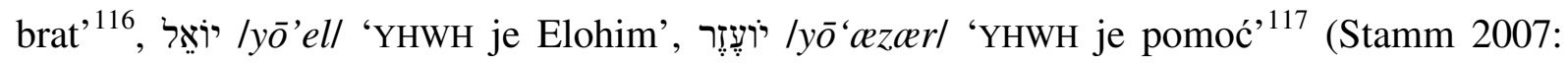
765).

Semantički gledano, motivacija se složenih bogonosnih osobnih imena može podijeliti u dvije skupine (Stamm 2007: 765):

1) Bog je dao, stvorio ili dodao imenovano dijete;

2) Bog je dodijelio roditeljima imenovanog djeteta, pomogao im, spasio ih, smilovao im se, poštedio ih, povratio im pravdu i izliječio ih.

U njima nalazimo različite vrste motivacija: izraz roditeljskog prihvaćanja božje pomoći

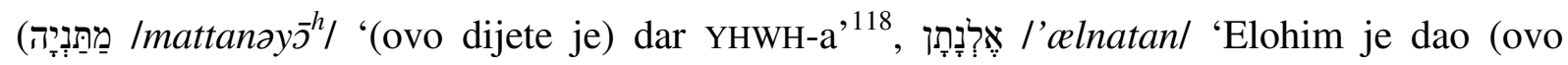

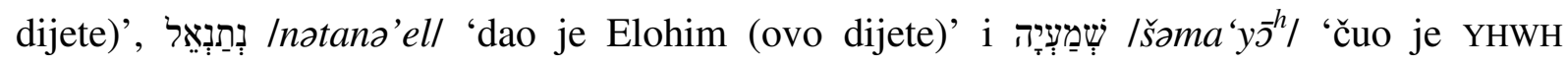

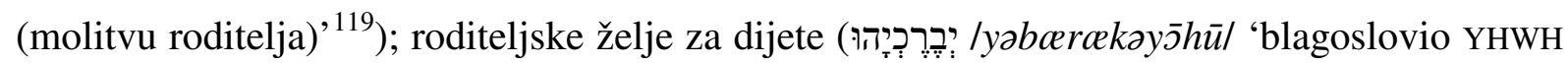

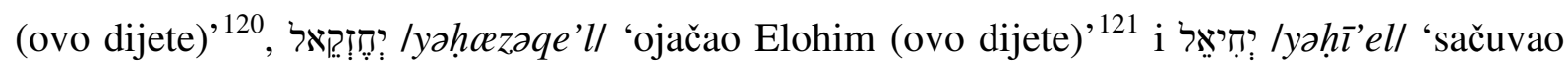

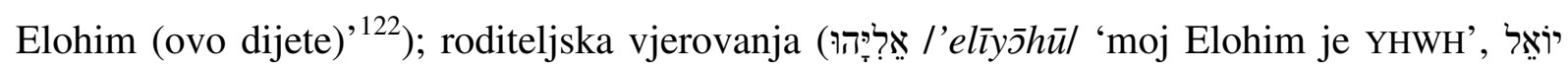

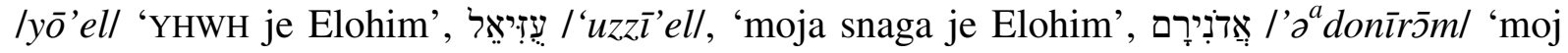

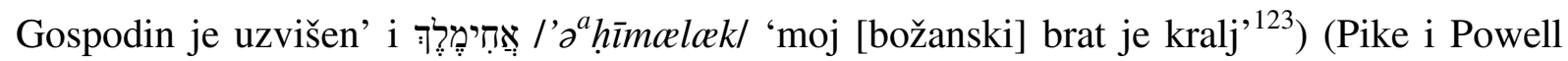
2011; Stamm 2007: 766).

Podaci koje donosi Tanah govore o tome da, razdobljima otpada od jednoboštva unatoč, uključivanje osobnih imena drugih bogova u osobno ime nije bila raširena pojava, barem ne $u$ doba od izlaska iz Egipta do pada u babilonsko sužanjstvo (Pike i Powell 2011).

Kod opisnih svjetovnih osobnih imena nalazimo pak druge vrste motivacija: dan rođenja (תַגֵּ

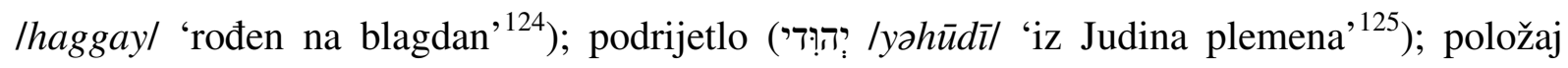

\footnotetext{
1161 Ljet 6,6. U transkripciji Antuna Sovića: Joah.

1171 Ljet 12,7. U transkripciji Antuna Sovića: Joezer.

1181 Ljet 9,15. U transkripciji Antuna Sovića: Matanija

1191 Ljet 3,22. U transkripciji Antuna Sovića: Šemaja

${ }^{120}$ Iz 8,2. U transkripciji Antuna Sovića: Berekja.

${ }^{121}$ Ez 1,2. U transkripciji Antuna Sovića: Ezekiel.

${ }^{122}$ V. bilj. 107.

${ }^{123} 1$ Sam 21,2. U transkripciji Antuna Sovića: Ahimelek.

${ }^{124} \mathrm{Hag}$ 1,1. U transkripciji Antuna Sovića: Hagaj.

${ }^{125}$ Jer 36,14. U transkripciji Antuna Sovića: Jehudi.
} 


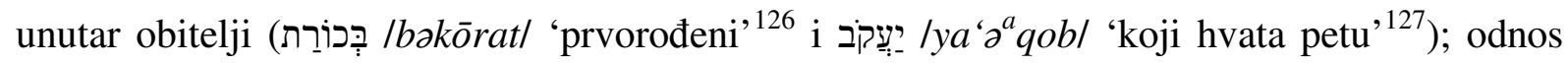

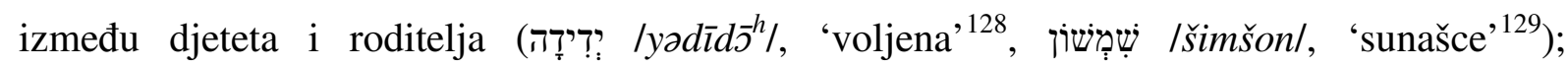

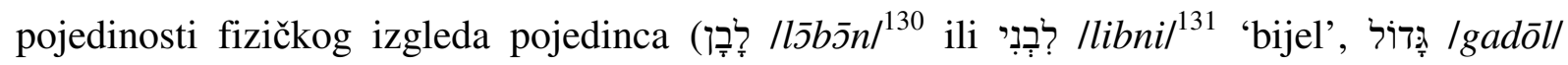

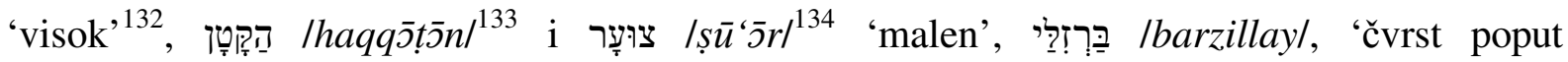

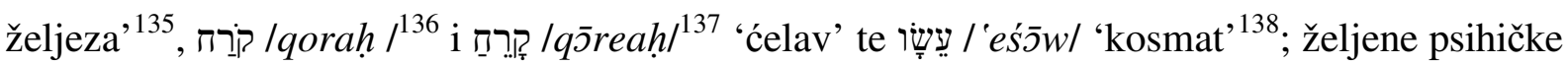

${ }^{126} 1$ Sam 9,1. U transkripciji Antuna Sovića: Bekorat.

${ }^{127}$ Post 25,26. U transkripciji Silvija Grubišića: Jakov.

Odgovarajuće arapsko osobno ime: يَعْقُب /ya 'qūb/ 'onaj koji je vezan za Boga' (Agić 1996: 55).

O ovom osobnom imenu Robert Graves i Raphael Patai kažu (Graves i Patai 1969: 197):

»Biblijsko tumačenje imena Jakov kao »onaj što hvata za petu«ili se »podmeće umjesto drugoga« (Postanak 25: 26; 27: 36) pučka je etimologija, ili možda igra riječi s tim imenom, poput Jeremijinih riječi (9: 3):

»Svaki brat vara $\left(\mathrm{Ja}{ }^{\prime} q o v\right) \ll$. Izvorno je značenje tog imena bilo teoforično i u punom obliku, Ja'qob-el, ono znači »Bog štiti«. Brojne varijante tog imena poznate su kako iz židovskih izvora (Ja'qova, 'Aqavja, 'Aqiva ili Akiba, itd), tako i iz susjednih zemalja (Ja'qob-har, 'Aqab-elaha, itd).«

Heinrich W. Guggenheimer Eva H. Guggenheimer strukturu ovog osobnog imena tumače kao optativ ‘štitio YHWH' (Guggenheimer H. W. i Guggenheimer E. H. 1992: 362).

${ }^{128} 2 \mathrm{Kr} 22,1$. U transkripciji Antuna Sovića: Jedida.

${ }^{129}$ Suci 13,24. U transkripciji Antuna Sovića: Samson.

Isaac Asimov primjećuje sličnost junaka iz Tanaha koji je nosio ovo osobno ime s likovima raznovrsnih mitova o Suncu (Asimov 1969: 250):

"The very name Samson ("Shimshon" in Hebrew) bears a striking resemblance to the word shemesh, meaning "sun." Only two miles south of Zorah [dom Samsonova oca] was the town of Beth-shemesh ("house of the sun") believed to be a center of sun-worship."

[Samo ime Samson (»Šimšon « na hebrejskome) zapanjujuće je slično riječi šemeš, što znači 'Sunce'. Samo dvije milje južno od Sore [doma Samsonova oca] bio je grad Bet-Šemeš ('kuća Sunca') za koji se vjeruje da je bio središte štovanja Sunca.]

U sefardskim je zajednicama ovo jedino osobno ime nekog od sudaca koje se nadijevalo djeci (Schwarzwald 2010: 196).

${ }^{130}$ Post 24,29. U transkripciji Silvija Grubišića: Laban.

${ }^{131}$ Izl 6,17. U transkripciji Silvija Grubišića: Libni.

${ }^{132}$ Ovo osobno ime ne potječe iz Tanaha, već iz papirusa nađenih u pismohrani pravnih isprava i pisama na otoku Elefantini na Nilu, danas dijelu grada Asuana u južnom Egiptu. Dokumenti pisani aramejskim jezikom govore o nazočnosti židovske zajednice na otoku oko V. st. pr. n. e.

Moguće je i drukčije tumačenje ovog osobnog imena, kao hipokoristik osobnog imena ‘velik je YHWH'. 1 Ljet 25,3. U transkripciji Antuna Sovića: Gedalija. U tom bi slučaju odmilicu trebalo

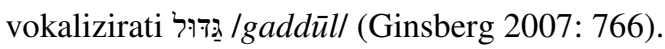

${ }^{133}$ Ezr 8,12. U transkripciji Antuna Sovića: Hakatan.

${ }^{134} \mathrm{Br} 1,8$. U transkripciji Silvija Grubišića: Suar.

${ }^{135} 2$ Sam 21,8. U transkripciji Antuna Sovića: Barzilaj. 


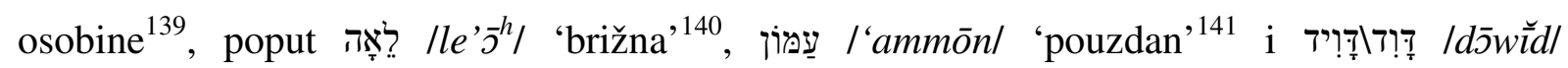
'obljubljen'142; predmeti, primjerice

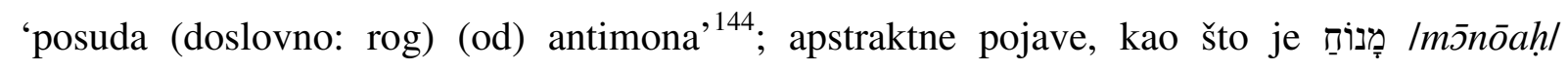

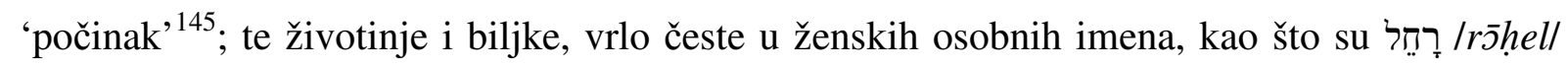

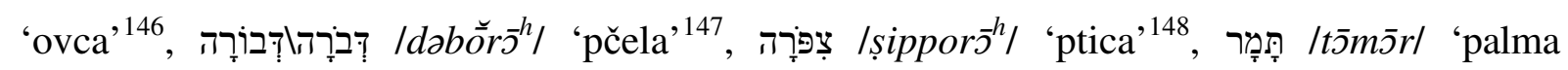

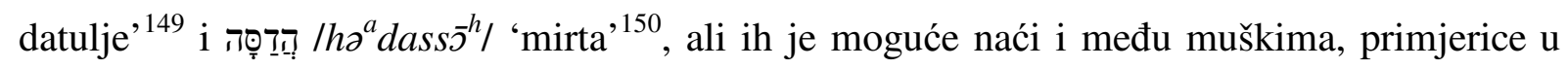

${ }^{136}$ Post 36,5. U transkripciji Silvija Grubišića: Korah

${ }^{137} 2 \mathrm{Kr} 25,23$. U transkripciji Antuna Sovića: Kareah.

${ }^{138}$ Post 25,25. U transkripciji Silvija Grubišića: Ezav.

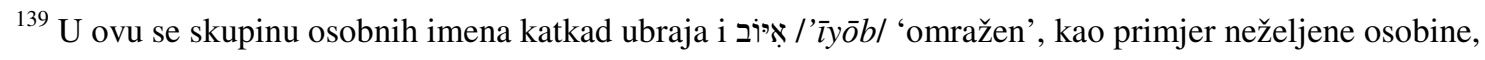
profilaktičko osobno ime (naravno da je moguć i obrat: da je junak dotične pripovijesti naknadno nazvan prema svojoj zloj kobi), no za nj postoji i drugo tumačenje, navedeno gore u tekstu. V. bilj. 39.

${ }^{140}$ Post 29,16. U transkripciji Silvija Grubišića: Lea.

Robert Graves i Raphael Patai o etimologiji ovog osobnog imena pišu (Graves i Patai 1969: 223):

»Lea (»Divlja krava«) i Rahela (»Ovca«) su imena božica. Divlja krava je kanaanska božica mjeseca, koja se pojavljuje pod različitim imenima; «

${ }^{141}$ Post 19,38. U transkripciji Silvija Grubišića: Amon.

${ }^{142}$ Rut 4,17. U transkripciji Antuna Sovića: David.

Robert Graves i Raphael Patai u vezi s ovim osobnim imenom pišu (Graves i Patai 1969: 224):

»Pitanje rasnog [sic] podrijetla plemena Benjamin postaje još složenije zbog postojanja jedne etničke skupine sjeverno od Palestine, koja se nazivala Benē-jamina a čiji je poglavica imao naslov Dāwidum, odakle je možda poteklo ime »David«.«

Odgovarajuće arapsko osobno ime: دَاؤد/dāwud/ 'izuzetno pobožan, pobožnjak; voljeni, dragi' (Agić 1996: 29).

${ }^{143} 1$ Sam 1,2. U transkripciji Antuna Sovića: Penina.

${ }^{144}$ Job 42,14. U transkripciji Antuna Sovića: Keren-Hapuk.

${ }^{145}$ Suci 13,2. U transkripciji Antuna Sovića: Manoah.

${ }^{146}$ Post 29,16. U transkripciji Silvija Grubišića: Rahela.

Robert Graves i Raphael Patai o etimologiji ovog osobnog imena pišu (Graves i Patai 1969: 223):

»Lea (»Divlja krava«) i Rahela (»Ovca«) su imena božica. ... boginji-ovci, materi boga-ovna, vjerojatno su se klanjali pastiri naseljeni u Gošenu.«

${ }^{147}$ Suci 4,5. U transkripciji Antuna Sovića: Debora.

${ }^{148}$ Izl 2,21. U transkripciji Silvija Grubišića: Sipora.

${ }^{149}$ Post 38,6. U transkripciji Silvija Grubišića: Tamara.

Robert Graves i Raphael Patai o ovom osobnom imenu kažu (Graves i Patai 1969: 254):

»Tamar znači »palma«, a to je drvo bilo posvećeno boginji ljubavi i poroda Izidi, poznatoj i pod imenom

Ištar ili, među Arapima, Lāt odnosno 'Ilāt. Arapi su se klanjali velikoj palmi u Nedžranu, ovijajući je jednom godišnje ženskom odjećom i uresima. Latin sin, Apolon Delski - Lat se sada obično poistovećuje s Letonom 


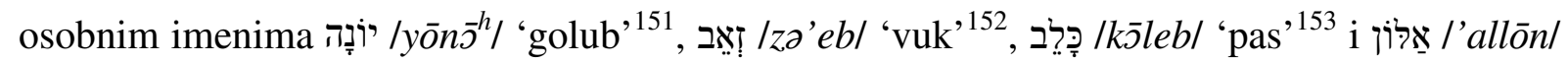
'hrast' 154 (Pike i Powell 2011; Stamm 2007: 766).

Zasebnu skupinu kako složenih tako i jednostavnih osobnih imena čine tzv. nadomjesna osobna imena, kojima se u osobnom imenu novorođenčeta održava uspomena i sjećanje na preminule rođake. Takva složena osobna imena mogu biti bogonosna, npr. אֶלְיָקים /'aelayj̄kim/

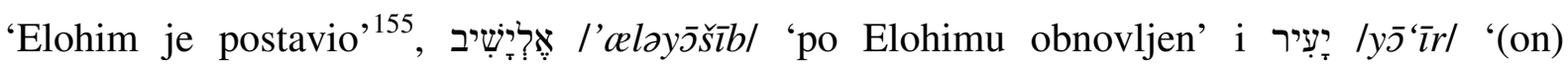

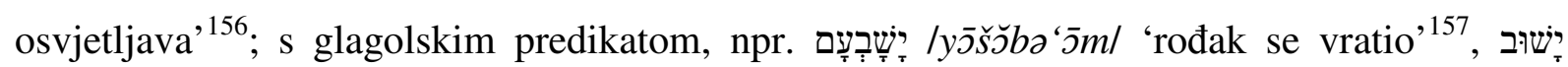
/yašūb/ '[pokojnik] se vratio'158); s imenskim predikatom, npr. אַבְירָם /'abīrōm/ 'moj otac (je)

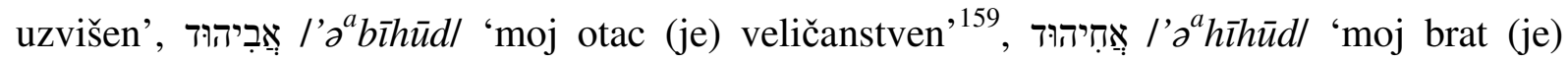
veličanstven' ${ }^{\prime 60}$ i עִַּ̣ /'ammīhūd/ 'moj rođak (je) veličanstven') ${ }^{161}$. Kad su u pitanju jednostavna osobna imena, djetetu se nadijeva epitet rođaka kojega je svojim rođenjem

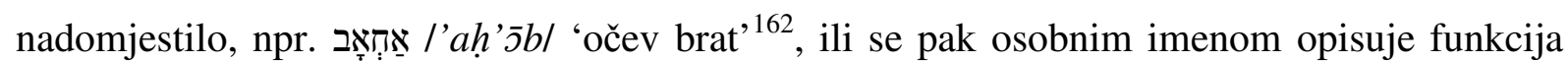

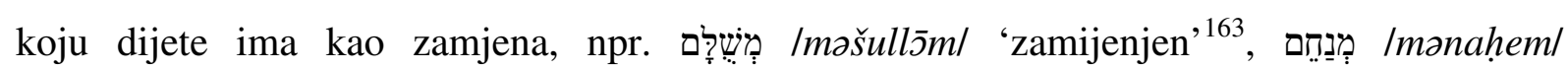

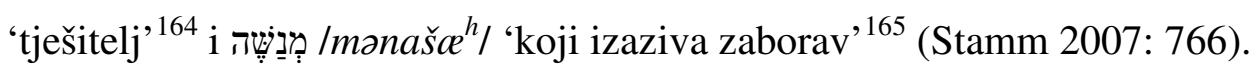

ili Latonom - i nabatejski Bog Duzar rodili su se oboje pod palmom: Apolon na Ortigiji (Prepeličjem otoku).«

${ }^{150}$ Est 2,7. U transkripciji Antuna Sovića: Hadasa.

Isaac Asimov o ovom osobnom imenu piše (Asimov 1969:467-468):

"The name Hadassah, by which Esther was originally known within the family, is closely related to a Babylonian word for "bride," which is used as a title for Ishtar."

[Ime Hadasa, po kojemu je Ester izvorno bila znana u svojoj obitelji, usko je povezan s babilonskom riječju za 'mladenku', koja se koristi kao jedan od naslova boginje Ištar.]

151 Jona 1,1. U transkripciji Antuna Sovića: Jona.

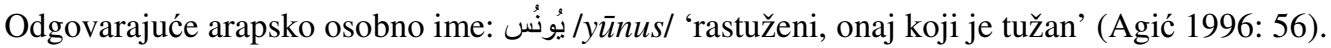

${ }^{152}$ Suci 7,25. U transkripciji Antuna Sovića: Zeeb.

${ }^{153}$ Br 13,6. U transkripciji Silvija Grubišića: Kaleb.

${ }^{154} 1$ Ljet 4,37. U transkripciji Antuna Sovića: Alon.

${ }^{155} 2 \mathrm{Kr} 18,18$. U transkripciji Antuna Sovića: Elijakim.

${ }^{156}$ Br 32,41. U transkripciji Silvija Grubišića: Jair.

${ }^{157} 1$ Ljet 27,2. U transkripciji Antuna Sovića: Jašobam.

${ }^{158} \mathrm{Br} 26,24$. U transkripciji Silvija Grubišića: Jašub.

${ }^{159} 1$ Ljet 8,3. U prijevodu Antuna Sovića: Ehudov otac.

${ }^{160} \mathrm{Br} 34,27$. U transkripciji Silvija Grubišića: Ahihud.

${ }^{161}$ Br 1,10. U transkripciji Silvija Grubišića: Amihud.

${ }^{162} 1 \mathrm{Kr}$ 16,28. U transkripciji Antuna Sovića: Ahab.

${ }^{163} 2 \mathrm{Kr}$ 22,3. U transkripciji Antuna Sovića: Mešulam. 
Kao što vidimo, sve kombinacije nisu moguće. Vidjeli smo da je jednostavno osobno ime koje bi u sebi sadržavalo naziv za Boga nedopušteno i da su ženska osobna imena koja u sebi sadržavaju naziv za Boga prije iznimka negoli pravilo. Preostaju nam, dakle:

1. muška jednostavna osobna imena koja u sebi ne sadržavaju naziv za Boga,

2. muška složena osobna imena koja u sebi ne sadržavaju naziv za Boga,

3. muška složena osobna imena koja u sebi sadržavaju naziv za Boga,

4. ženska jednostavna osobna imena koja u sebi ne sadržavaju naziv za Boga,

5. ženska složena osobna imena koja u sebi ne sadržavaju naziv za Boga.

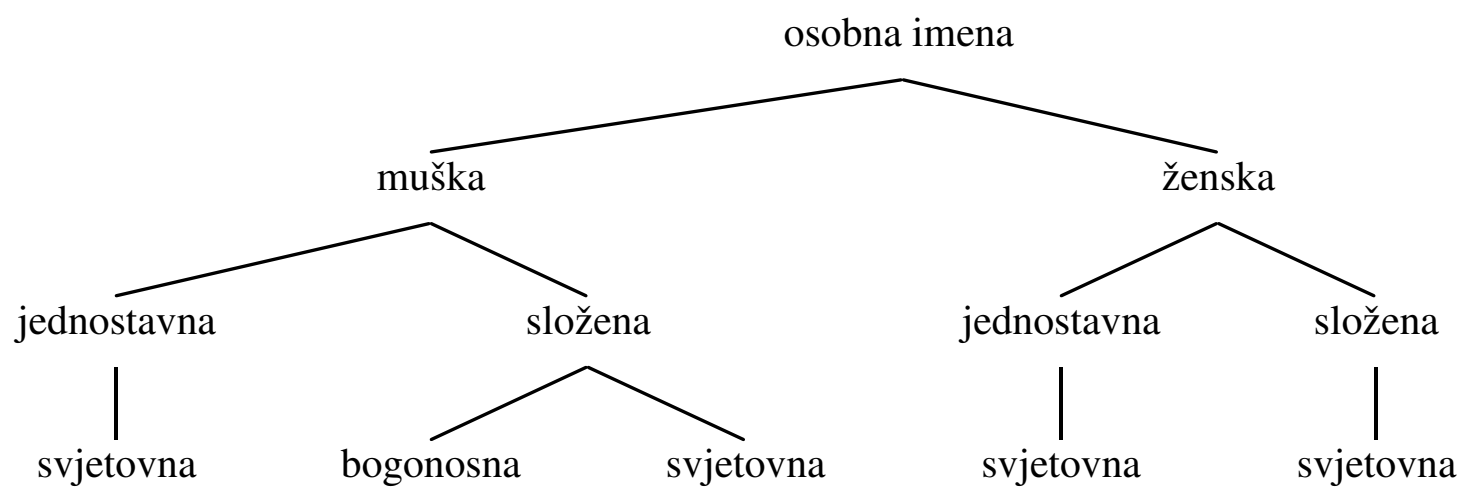

Osobna su imena iz Tanaha osnovica na kojoj se gradi sva kasnija židovska antroponimija, te je njima posvećen nešto veći prostor.

\subsubsection{Osobna imena u doba Talmuda}

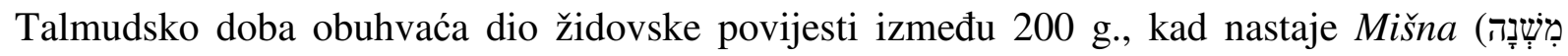
Imišn $\bar{s}^{h} /$ '(učenje) ponavljanje(m)'), pisani sažetak usmene Tore rabinskog judaizma, i 500. g.,

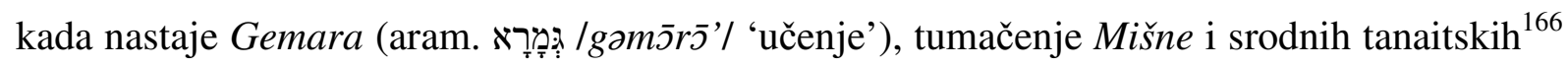
spisa, a koja se često dotiče i drugih tema i opširno tumači Tanah. Ta dva djela (ili pak sama Gemara) čine Talmud (תָּ Italmūd/ 'poučavanje, učenje'). Pod tim se naslovom obično misli na Babilonski Talmud (iako postoji i dvjestotinjak godina stariji Jeruzalemski Talmud).

\footnotetext{
${ }^{164} 2 \mathrm{Kr} 15,14$. U transkripciji Antuna Sovića: Menahem.

${ }^{165}$ Post 41,51. U transkripciji Silvija Grubišića: Manaše.

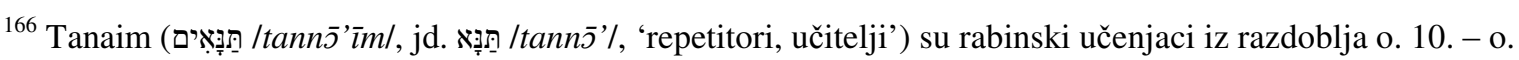
200. g. čije su misli zabilježene u Mišni. S druge strane, amoraim (aram. אָמוֹרָא / אָמוֹרָאָים l'万̄mōrō'/ 'kazivači, govornici') su židovski učenjaci iz doba o. 200. - o. 500. g. čije su pravne rasprave kodificirane u Gemari.
} 
Pisan je poslijeklasičnim, poslijebiblijskim tanatiskim hebrejskim i židovskobabilonskim aramejskim. To je doba kad Babilon postaje centrom židovske učenosti. Učenja sadržana u Talmudu (posebno u Mišni) vjerojatno potječu od usmene predaje još iz doba drugog Hrama (536. g. pr. n. e. -70 g. n. e.).

U ovom razdoblju židovsku antroponimiju obilježavaju tri pojave koje će značajno obilježiti daljnju židovsku onomastičku povijest: preuzimanje nehebrejskih osobnih imena, nasljeđivanje osobnih imena te dvo- i višeimenost.

Prodor je stranih, nehebrejskih osobnih imena u židovsku antroponimiju nastupio i prije toga doba, od oko 200 g. pr. n. e. nadalje. Kako je u zadnjim stoljećima pr. n. e. aramejski, tadašnja lingua franca Bliskog istoka, zamijenio hebrejski kao govorni jezik Židovā u zemlji u koju su se vratili iz babilonskog sužanjstva, tako su i aramejska osobna imena polagano ulazila u židovsku antroponimiju. S helenizacijom carstva Aleksandra Velikoga slijedila su ih grčka osobna imena, a s rimskim osvajanjima i latinska.

Takve su tendencije izazvale reakcije autora komentara u Talmudu, koji navode primjere Židova sa stranim osobnim imenima, ali i primjere pojedinaca s više osobnih imena kao i osobna imena nepoćudna za Židova ${ }^{167}$, a sve u težnji da se djeci daju hebrejska osobna imena te da se već nadjenuta hebrejska osobna imena ne zamjenjuju stranima, što se držalo očiglednim znakom svjesne asimilacije.

$\ldots$ the majority of Jews in the Diaspora have the same names as the gentiles ${ }^{168}$

(Git. 11b)

Međutim, isto vrijedi i za Židove u Zemlji Izraelovoj (Rabinowitz 2007: 767).

U skladu se s time pojavljuje i svojevrsni neformalni popis hebrejskih osobnih imena koja ne treba nadijevati djeci, potaknut retkom iz Mudrih izreka (Izr 10,7, u prijevodu Antuna Sovića):

${ }^{7}$ Pravednikov je spomen blagoslovljen, a opakom se ime proklinje.

\footnotetext{
${ }^{167}$ Jedna od zabrana u vezi s davanjem osobnih imena izričito spomenutih u Talmudu (ARN 12) jest ona o nedavanju anđeoskih osobnih imena poput רָָָָאָל Antuna Sovića: Rafael. Zanimljivo je da se u tom odlomku Rafael spominje kao osobno ime jednog od

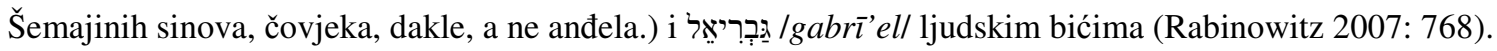
168 ... većina Židova u dijaspori nosi ista imena kao i nežidovi
} 
Ovo se drugo u prvom redu odnosi na osobna imena negativnih likova iz Tanaha, onih koji su se suprotstavljali bilo sinovima Izraelovim bilo volji njihova Boga ${ }^{169}$ (Beider 2001: 15; Guggenheimer H. W. i Guggenheimer E. H. 1992: xi; Rabinowitz 2007: 767). Usuprot tome, djeci valja davati osobna imena velikana Tanaha.

I u osobnim imenima samih autora tekstova skupljenih u Talmudu nalazimo primjere antroponimskog šarenila toga doba.

U antroponimskom korpusu Talmuda nalazimo hebrejska osobna imena velikana iz Tanaha,

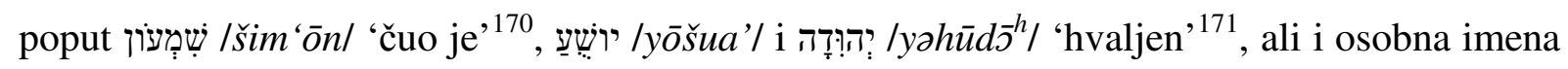

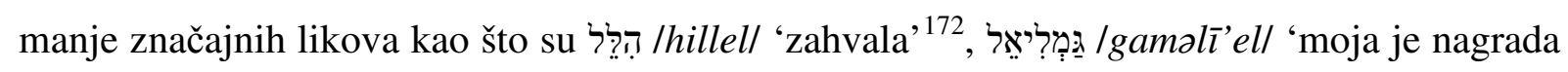

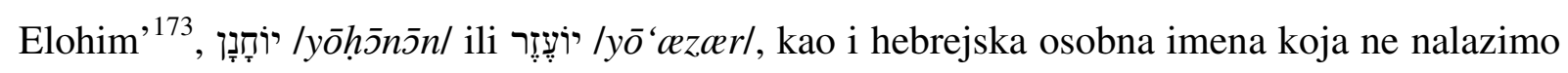

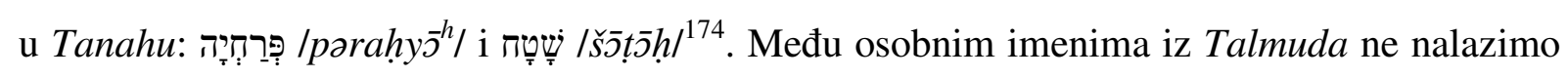

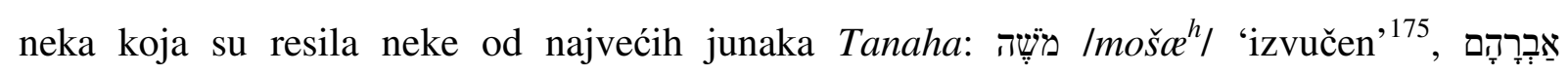

${ }^{169} \mathrm{U}$ suvremeno se doba pojavljuju i takva osobna imena, moguće kao izraz ateizma pojedinaca (Guggenheimer H. W. i Guggenheimer E. H. 1992: xi).

${ }^{170}$ Post 29,33. U transkripciji Silvija Grubišića: Šimun.

${ }^{171}$ Post 29,35. U transkripciji Silvija Grubišića: Juda.

${ }^{172}$ Suci 12,13. U transkripciji Antuna Sovića: Hilel.

${ }^{173} \mathrm{Br} 1,10$. U transkripciji Silvija Grubišića: Gamliel.

${ }^{174}$ Nijedan rječnik židovskih osobnih imena ne navodi ova dva imena. Upitno je jesu li uopće podrijetlom iz hebrejskog ili aramejskog.

${ }^{175}$ Izl 2,10. U transkripciji Silvija Grubišića: Mojsije.

Odgovarajuće arapsko osobno ime: مُوسَى /mūsāl 'onaj koji pluta, koga voda nosi' (Agić 1996: 76).

Isaac Asimov u vezi s tumačenjem ovog osobnog imena primjećuje (Asimov 1969: 128):

"The priestly editors of the Hexateuch [Torah + Joshua] saw in the word "Mosheh" a similarity to the Hebrew mashah, meaning "to draw out," and therefore gave that as the derivation of the name:

Exodus 2:10. ... Pharaoh's daughter ... called his name Moses: and she said, Because I drew him out of the water.

Now an Egyptian princess is scarcely going to turn to the Hebrew language for a name (even if she could be imagined as bothering to learn the slaves' language in the first place). Besides, Moses happens to have a much more straightforward and natural meaning in Egyptian. It means "son." (Thus Thutmose means "son of Thoth" and Rameses means "son of Ra," both Thoth and Ra being Egyptian gods.)"

[Svećenički urednici Šestoknjǐ̌ja [Tora + Jošua] vidjeli su u riječi »Moše« sličnost s hebrejskim maša, značenja 'izvući', te su stoga ponudili izvođenje imena:

Izlazak 2,10. ... faraonovoj kćeri ... Nadjene mu ime Mojsije, »jer sam ga«, reče, »iz vode izvadila«.

Teško da će egipatska princeza posegnuti za hebrejskim jezikom radi imena (čak i ako bi bilo zamislivo da se 


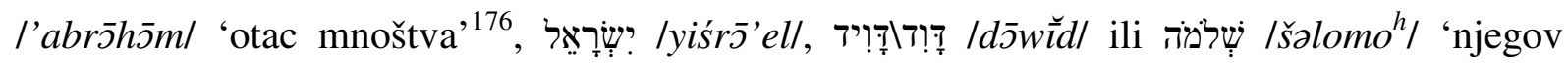

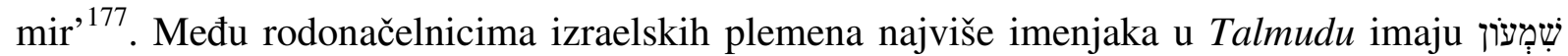

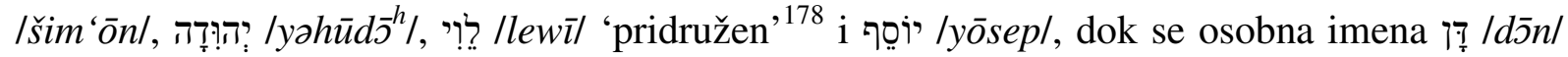
'presudio je'179,

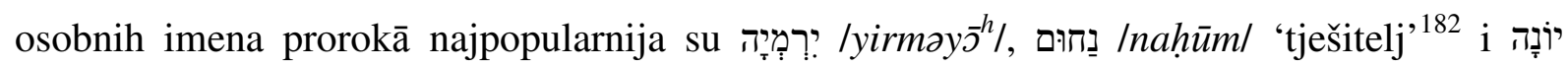

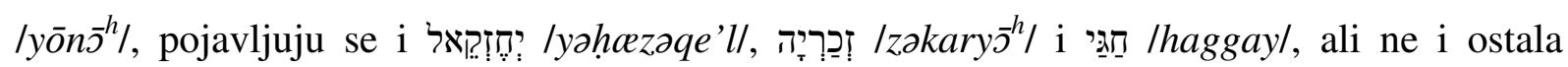
(Rabinowitz 2007: 768).

Aramejski je sloj zastupljen i kroz arameizirana hebrejska osobna imena, poput יוסא /yose/

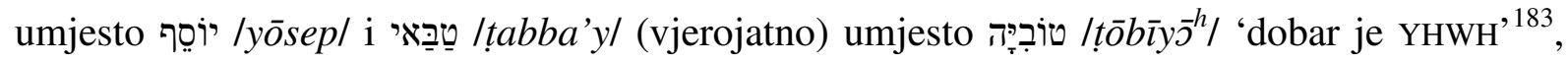

potrudi naučiti jezik robova). Osim toga, Mojsije ima znatno jasnije i prirodnije značenje na egipatskome. Na tom jeziku ono znači 'sin'. (Tako Tutmozis znači 'sin Tota', a Ramzes znači 'sin Raa', i Tot i Ra su egipatski bogovi.)]

${ }^{176}$ Post 17,5. U transkripciji Silvija Grubišića: Abraham

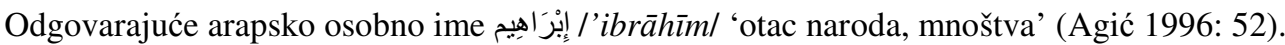

1772 Sam 5,14. U transkripciji Antuna Sovića: Salomon.

Odgovarajuće arapsko osobno ime سَُّلَيَْان/sulaymān/ 'mudrac, miroljubiv' (Agić 1996: 99).

${ }^{178}$ Post 29,34. U transkripciji Silvija Grubišića: Levi.

${ }^{179}$ Post 30,6. U transkripciji Silvija Grubišića: Dan.

Robert Graves i Raphael Patai o etimologiji ovog osobnog imena pišu (Graves i Patai 1969: 222): »Isto tako, premda je »Dan« ispravno izvedeno od korijena dan, »suditi«, na oba mjesta u Postanku (30: 6 i

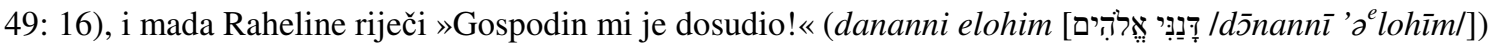
odgovaraju akadskom šamaš idinanni, »neka mi Šamaš sudi!« te imaju paralela u amorejskim i katabanskim imenima - ipak je vjerojatnije da je Dan bio epitet plemenskog božanstva-zaštitnika. »Dina« [jedina u Tanahu spomenuta kći Jakova Izraela] je ženski oblik od »Dan«.«

${ }^{180}$ Post 30,11. U transkripciji Silvija Grubišića: Gad.

Robert Graves i Raphael Patai o etimologiji ovog osobnog imena pišu (Graves i Patai 1969: 223):

»Zilpina dva sina, Gad i Ašer, nose imena aramejsko-kanaanskih božanstava. Gad je bio bog dobre sreće, a to značenje ima njegovo ime u hebrejskom, aramejskom, sirijskom i arapskom, dok se njegov kult proširio i na

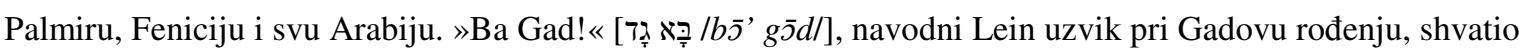
bi se jednostavno kao »Sretno!« «

${ }^{181}$ Post 30,13. U transkripciji Silvija Grubišića: Ašer.

Robert Graves i Raphael Patai o etimologiji ovog osobnog imena pišu (Graves i Patai 1969: 223): »Zilpina dva sina, Gad i Ašer, nose imena aramejsko-kanaanskih božanstava. ... Ašer je amorejski Ašir, muški oblik od »Ašera«, imena božice plodnosti koju su poštovali na širokom području, a čija su druga imena bila Aterat, Aširat, Aširtu ili Ašratu.«

${ }^{182}$ Nah 1,1. U transkripciji Antuna Sovića: Nahum.

${ }^{183}$ Neh 2,10. U transkripciji Antuna Sovića: Tobija. 
kao i kroz čista aramejska osobna imena kao što je נתאי /nittai/. Tu su i grčka osobna imena

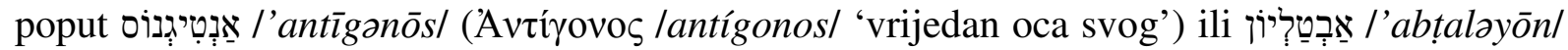

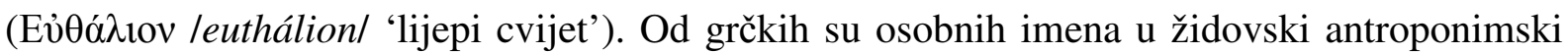

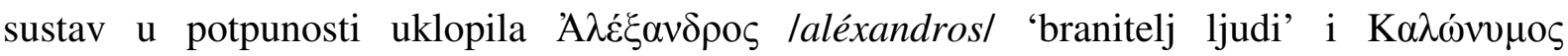

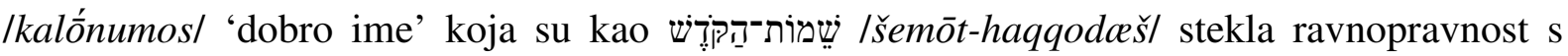
hebrejskima i aramejskima. Uz njih se pojavljuju i grecizirani likovi hebrejskih osobnih imena, svojevrsni kalkovi poput דוסיתאוס ( דְתַנְאהל

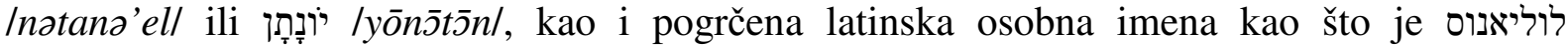
/lulianus/ (Iulianus?) (Rabinowitz 2007: 767).

Neka su od navedenih osobnih imena postala svojevrsni ekvivalenti onima iz $\operatorname{Tanaha}^{184}$ : Rofe

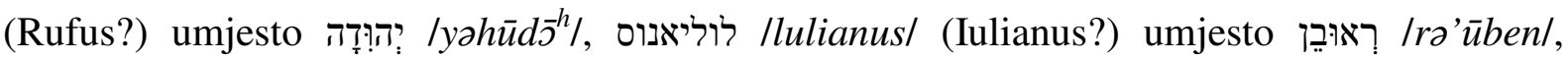

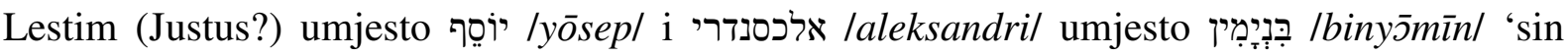
desnice $^{185}$ (Rabinowitz 2007: 767).

Davanje stranih osobnih imena nije bio proces podudaran s napuštanjem židovske tradicije, jer nailazimo na pojedince nehebrejskih osobnih imena koji su svojoj djeci davali hebrejska,

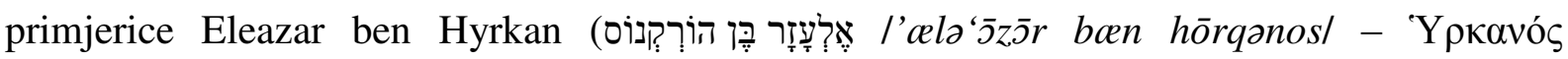
/hyrkanós/ 'čovjek iz Hirkanije (Varkâne u Perziji)'), kao i obrnute slučajeve, npr.

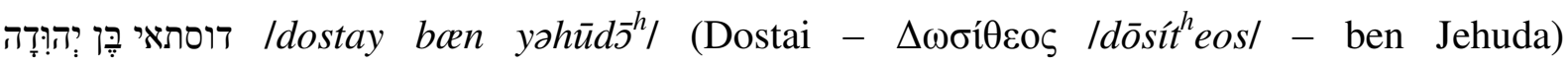
(Rabinowitz 2007: 767).

Talmud spominje još jedan fenomen, onaj da ista osoba u različitim krugovima bude poznata pod različitim osobnim imenima. Spominju se primjeri čovjeka osobnim imenom יוסף איש הוצל lyōsep 'ר̌š hūṣall 'Josef čovjek (iz) Huṣala' koji je zvan i איסי בן גור אריה /isi ben gur arjel 'isi

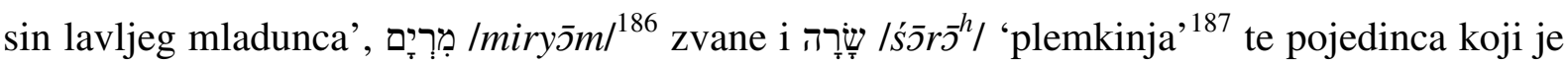

\footnotetext{
${ }^{184}$ Louis Isaac Rabinowitz ne eksplicira u kojem su to smislu ona ekvivalenti, ali je iz konteksta jasno da misli

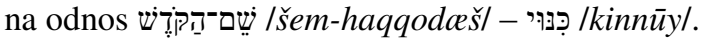

${ }^{185}$ Post 35,18. U transkripciji Silvija Grubišića: Benjamin.

${ }^{186}$ Izl 15,20. U transkripciji Silvija Grubišića: Mirjam.

Osobno se ime tumači na različite načine, vezane uz hebrejske korijene značenja 'gorak', 'voda', 'pobuna' ili 'uzdizanje'.

I odgovarajuće je arapsko osobno ime: مَرْيَ /maryam/ nejasne etimologije (Agić 1996: 160).

${ }^{187}$ Post 17,15 . U transkripciji Silvija Grubišića: Sara.
} 
u Zemlji Izraelovoj bio poznat pod osobnim imenom יוֹחָדָנן /yōsep/, a u Babilonu kao /yōḥ̄n̄̄n/ ${ }^{188}$ (Rabinowitz 2007: 767). Tu pojavu, međutim, nalazimo i u samom Tanahu. Tako

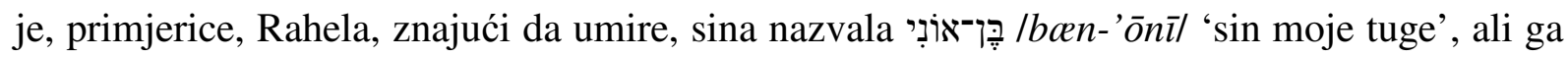

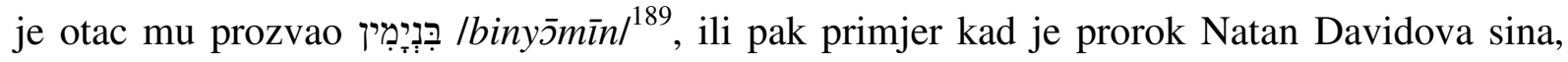

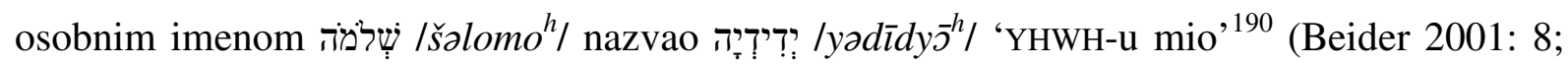
Pike i Powell 2011; Rabinowitz 2007: 768).

Što se nasljeđivanja osobnih imena tiče, pravilo je u židovstvu nalagalo da novorođenče dobije osobno ime svoga djeda ili bake, ovisno o spolu djeteta, što je po Talmudu preuzeto od Grka (Rabinowitz 2007: 767), ali D. M. Pike i M. A. Powell navode da običaj, koji oni nazivaju paponimijom (papponymy), potječe iz kasnog perzijskog doba, s kraja VI. st. pr. n. e. (Pike i Powell 2011). Međutim, tragove toga običaja nalazimo već u Abramovu rodoslovlju u Tanahu: sam je Abram naslijedio osobno ime djeda si po majci, dok je njegov po svemu

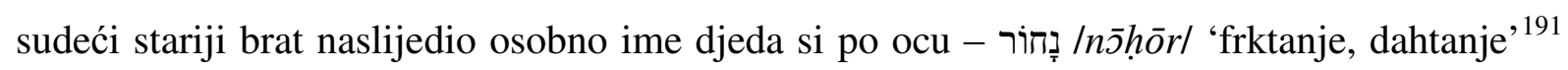
(Graves i Patai 1969: 135). U vezi s nasljeđivanjem osobnih imena predaka u drugom koljenu

${ }^{188}$ Osobno znam za dva slučaja u kojem je obitelj osobu zvala jednim osobnim imenom, dok je službeno osobno ime glasilo sasvim drukčije, s time da dva osobna imena nisu bila ni na koji način povezana: u prvom su slučaju (službenog) Franju kod kuće zvali Damir, a u drugom (službenog) Marka Zlatko. Pojava, po svemu sudeći, i nije tako neuobičajena.

${ }^{189}$ Post 35,16-18. U prijevodu Silvija Grubišića:

${ }^{16}$ Potom odu iz Betela. Još bijaše malo puta do Efrate, a Rahela se nađe pri porođaju. Napali je teški trudovi.

${ }^{17} \mathrm{Kad}$ su joj porođajni bolovi bili najteži, reče joj babica: »Ne boj se jer ti je i ovo sin!«

${ }^{18} \mathrm{Kad}$ se rastavljala s dušom - jer umiraše Rahela - nadjenu sinu ime Ben Oni; ali ga otac prozva Benjamin. Robert Graves i Raphael Patai o etimologiji ovog osobnog imena pišu (Graves i Patai 1969: 223): ».. a »Benjamin« (»sin moje desnice« ili »sin juga«) je značio da je to pleme zaposjelo južni Efrajim. Ali »Ben Oni«, izvorno ime, može se protumačiti kao »sinovi Ona« - egipatskog grada koji se spominje u Postanku 41: 45 [ אزן /’on/ 'snaga, krepkost'; u transkripciji Silvija Grubišića: On] kao prebivalište Josipova tasta, odakle je Benjamin možda pošao u seobu s dva Rahelina plemena [Efrajim i Manaše] i svećeničkim klanom Levi.«

${ }^{190} 2$ Sam 12,24-25. U prijevodu Antuna Sovića:

${ }^{24}$ Potom David utješi svoju ženu Bat-Šebu. Dođe k njoj i leže s njom. Ona zatrudnje i rodi sina komu nadjenu ime Salomon. YHWH ga zamilova

${ }^{25}$ i objavi to po proroku Natanu. Ovaj ga nazva imenom Jedidja, po riječi YHWH-ovoj.

${ }^{191}$ Post 22,24-26. U prijevodu Silvija Grubišića:

${ }^{24} \mathrm{Kad}$ je Nahoru bilo dvadeset i devet godina, rodi mu se Terah.

${ }^{25}$ Po rođenju Terahovu Nahor je živio sto i devetnaest godina te mu se rodilo još sinova i kćeri.

${ }^{26} \mathrm{Kad}$ je Terahu bilo sedamdeset godina, rode mu se: Abram, Nahor i Haran. 
u Aškenazā postoji ograničenje: ono je moguće samo ako je imenodavac preminuo. Osobna se imena živih osoba nikada nisu nasljeđivala ${ }^{192}$. Stoga gotovo da i nema slučaja postojanja imenske formule $X \sin X$ - $a$, osim kada je riječ o posmrtno rođenom djetetu. Nijedna židovska zajednica, naime, ne dopušta da dijete dobije osobno ime živućeg oca. Katkad će se u

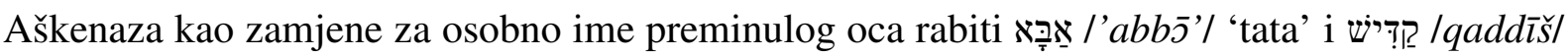
'molitva sina za preminulog roditelja'. Djeca, dakle, u pravilu nasljeđuju osobna imena svojih pokojnih djedova odnosno baka, ali to nije moguće ako živi otac nosi isto osobno ime kao i pokojni punac mu, odnosno ako živa majka nosi isto osobno ime kao i pokojna joj svekrva (Beider 2001: 14; Gorr 1992: xiii; Guggenheimer H. W. i Guggenheimer E. H. 1992: xvii-xviii; Schwarzwald 2010: 193).

Kasnije je ta navada omogućila da se među Židovima sve do XVIII. i XIX. st. sačuvaju posuđena osobna imena, posebice ženska, koja su među okolnim kršćanima odumrla već poslije XIII. st., kao što su u Italiji to bila Bella, Belladonna, Brunetta, Diamante, Fioretta, Fiammetta, Gentile i Perla, no našlo se tu i muških, poput Bonaiuto, Bellomo, Lustro (Colorni 1983: 72). U svakom je slučaju takav običaj išao usuprot u imenovanju uobičajenoj inovaciji, već je čuvao tradicionalna osobna imena (Beider 2001: xxv, bilješka 1, 14).

Svakako je najpoznatiji primjer dvoimenosti Židova onaj naveden u Prvoj knjizi o

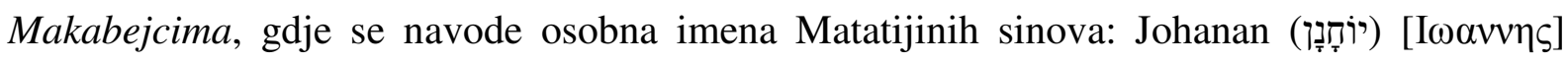

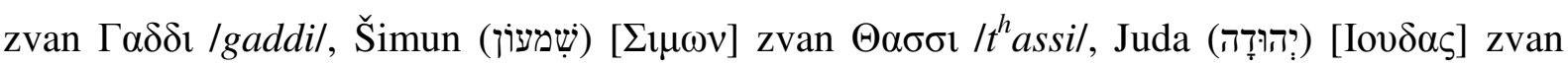

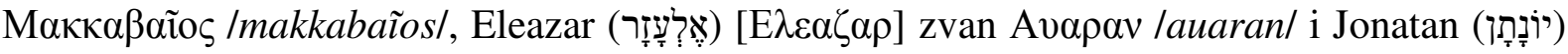
$[\mathrm{I} \omega v \alpha \theta \eta \varsigma]$ zvan A $\pi \varphi$ ov $/$ app $^{h}$ ous ${ }^{193}$. Običaj se zadržao među vladarima hašmonejske

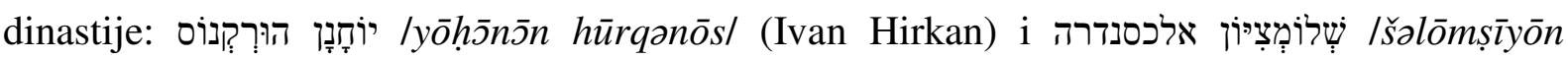
'lksndr'/ (Saloma Aleksandra) ${ }^{194}$ (Rabinowitz 2007: 767).

\footnotetext{
${ }^{192}$ Prema navodu iz Tanaha u prethodnoj bilješci, Nahor stariji je još bio živ kad se rodio Nahor mlađi, imao je 99 godina, a umro je sa 119 godina.

193 1 Mak 2,2-5. U prijevodu Antuna Sovića:

${ }^{2}$ A imao je pet sinova: Ivana prozvana Gadi,

${ }^{3}$ Šimuna prozvana Tasi,

${ }^{4}$ Judu prozvana Makabej,

${ }^{5}$ Eleazara prozvana Avaran, Jonatu prozvana Afus.

${ }^{194}$ Pojedinaca s dva osobna imena ima i prije toga. Osobno je ime Jonatanova sina, Šaulova unuka, u 2 Sam 4,4

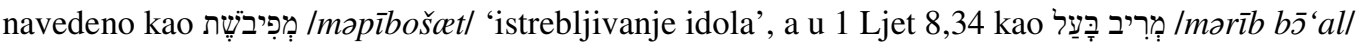
‘istrebljivanje Baala’ (Asimov 1969, 407).
} 
U Talmudu se pak na jednom mjestu spominje da je R. Yose b. Halafta (רבי יוסי בן חלפתא) imao petoricu sinova: Išmaela, Eleazara, Halaftu, Abtilusa i Menahema (Shab. 118b). Na

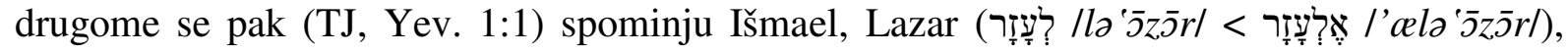
Menahem, Ḥalafta i Avdimos (Eudymos) te se dodaje još jedan zvan Vardimon. Od sinova čija se osobna imena podudaraju na oba mjesta Išmael, Eleazar i Menahem nose čista

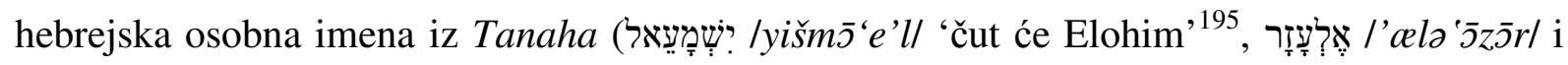

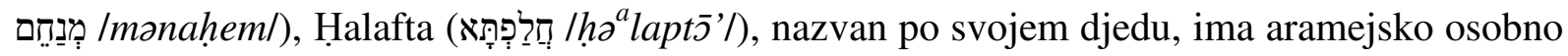
ime, dok je Abtilosovo/Avdimosovo (אבטילסlאבדימוס /'btyls/'bdymws/) osobno ime grčko

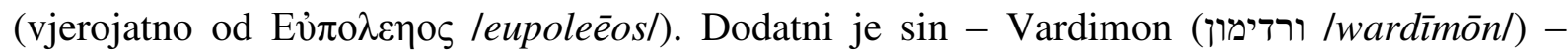
propovjedno (homiletički) istumačen kao nadimak Menahemov, koji je dobio zato što mu »je

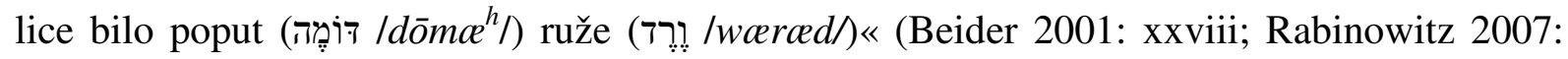
767). Kao što vidimo, jedan je od sinova R. Yosea b. Halafta dobio osobno ime svog djeda po ocu, Halafta.

U okviru ovog fenomena možemo govoriti i o običaju koja će prevladati u vremenima koja dolaze, onome davanja dvojnih osobnih imena (odnosno osobnog imena i apozicije) na temelju poredaba i metafora za svakoga od Jakovljevih sinova sadržanih u njegovoj oporuci u 49. poglavlju Knjige postanka i onih iz Mojsijeva blagoslova izraelskih plemena iz 33.

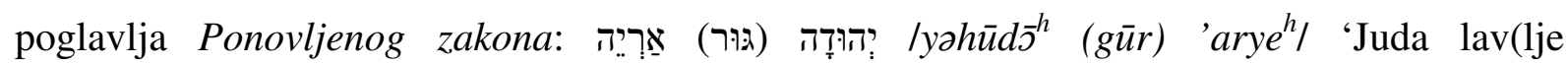

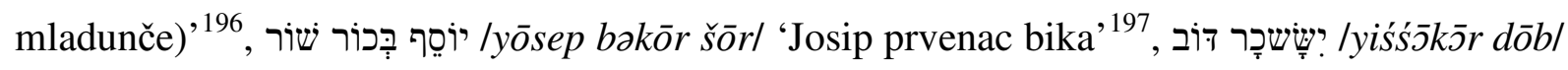

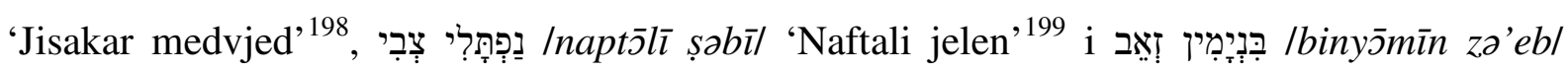

Zanimljivo da Antun Sović u svojem prijevodu na oba mjesta koristi isto osobno ime u dvije različite grafije Meribaal (2 Sam 4,4) i Merib Baal (1 Ljet 8,34).

${ }^{195}$ Post 16,11. U transkripciji Silvija Grubišića: Jišmael.

Odgovarajuće arapsko osobno ime: إِسمَّاعِيل /'isma ‘ỉll 'veličina Božja, Bog čuje, Bog je uslišao' (Agić 1996: 54).

${ }^{196}$ Post 49,9. U prijevodu Silvija Grubišića:

${ }^{9}$ Judo, laviću mali! Plijenom si se, sine, udebljao; poput lava, poput lavice legao potrbuške! Tko bi ga dražiti smio?

${ }^{197}$ Pnz 33,17. U prijevodu Silvija Grubišića:

${ }^{17} \mathrm{~K}$ 'o prvenac bika on je veličanstven, rozi su mu rogovi bivolji, njima on nabada narode sve do krajeva zemaljskih.

${ }^{198}$ U Post 49,14-15 ustvari piše (u prijevodu Silvija Grubišića):

${ }^{14}$ Jisakar je koščat magarac polegao među ogradama.

${ }^{15}$ Vidje da je odmor ugodan, a zemlja lijepa, te leđa svoja pod teret podmetnu i na tlaku pristade. 


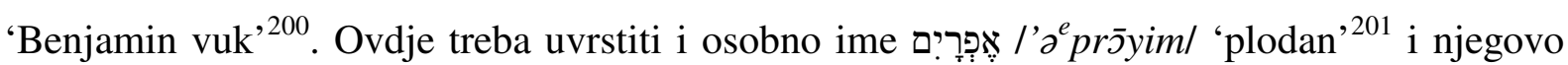
zamjensko ime spominju $^{202}$. Povezivanje tri zadnja navedena osobna imena s odgovarajućim riječima za životinje tipično je aškenaski fenomen (Beider 2001: 6, 313), dok primjere za ostale veze nalazimo i u antroponimijama drugih židovskih zajednica ${ }^{203}$. Ako za primjer razvoja odnosa

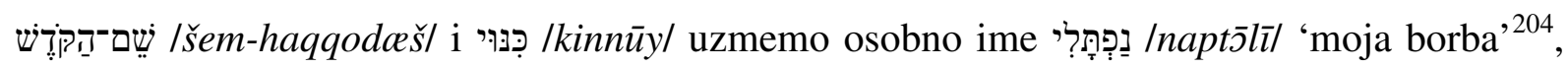
biblijsko se pleme Naftalijevo u Post 49,21 uspoređuje s košutom. Otud zamjensko ime /șabīl 'jelen', koje je u međuvremenu i samo postalo osobnim imenom, te dobilo svoje zamjensko ime na jidišu - הירש /hirš/ ‘jelen'. To je zamjensko ime, kao i ono iz kojeg je izvedeno, i samo postalo osobnim imenom, te je moguće da i ono ima svoje zamjensko ime $e^{205}$ (Beider 2001: 5-6; Guggenheimer H. W. i Guggenheimer E. H. 1992: xv-xvi; Rabinowitz 2007: 768).

Međutim, kako biti magarcem u Europi nije bilo laskavo, ovaj je simbol snage zamijenjen prikladnijim medvjedom (Beider 2001: 287)

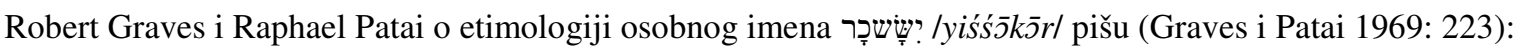
» »Jisakar « vjerojatno znači »Sakarov čovjek«; Sakar ili Sokar je bio egipatski bog Memfisa.«

${ }^{199}$ Post 49,21. U prijevodu Silvija Grubišića:

${ }^{21}$ Naftali je košuta lakonoga koja krasnu lanad mladi.

${ }^{200}$ Post 49,27. U prijevodu Silvija Grubišića:

${ }^{27}$ Benjamin je vuk grabežljivi, lovinu on jutrom jede, a navečer plijen dijeli.

${ }^{201}$ Post 41,52. U transkripciji Silvija Grubišića: Efrajim.

Robert Graves i Raphael Patai o etimologiji ovog osobnog imena pišu (Graves i Patai 1969: 223):

»Pleme Efrajimovo dobilo je svoje plemensko ime »pojas plodne zemlje« po nizu brežuljaka i brda bogatih vodom, koje su zaposjeli oko 1230. pr. n. e. u toku osvajanja Palestine; «

${ }^{202}$ Prema Post. 48,16 u kojem Jakov blagoslivlja sinove Josipove, u prijevodu Silvija Grubišića:

${ }^{16} \mathrm{U}$ mnoštva se mnogobrojna po zemlji razmnožili!«

Prema nekim se nazorima tekst može tumačiti i kao:

${ }^{16} \mathrm{U}$ mnoštva se mnogobrojna poput riba po zemlji razmnožili!«

(https:/www.biblegateway.com/passage/? search=Genesis+48iversion=ESV)

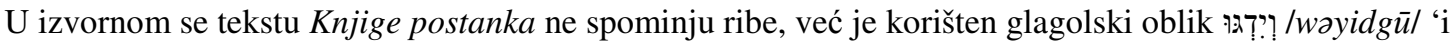
namnožit će se' izveden od korijena T.ג/d-g-h/, nalik onomu iz kojeg je izvedena imenica Ț̣̦/dag/ 'riba'.

${ }^{203}$ Među Sefardima je nadijevanje osobnih imena prema životinjama izrazito rijetko (Schwarzwald 2010: 195196).

${ }^{204}$ Post 30,8. U transkripciji Silvija Grubišića: Naftali.

${ }^{205}$ Alexander Beider donosi podatke koji pokazuju da su među Aškenazima »životinjska« (i neka druga) osobna imena na govornom jeziku potvrđena ranije od analognih na hebrejskome (Beider 2001: 21-23). 
Kako su Aškenazi dobivali osobno ime djedova (odnosno bakā), postojala je mogućnost da novorođenče od jednoga naslijedi tradicionalno osobno ime, a od drugoga zamjensko ime, te se tako stvarala nova veza između jednoga i drugoga ${ }^{206}$.

Mnoga su od zamjenskih imena o kojima je ovdje bila riječ, pa tako i navedeno הירש/hiršl, koje se često transkribira njemačkom grafijom kao Hirsch, postala prezimenima.

\subsubsection{Srednji vijek i osobna imena na govornim jezicima}

As the Jews moved from area to area, through many linguistic milieus, they were affected, in varying degrees, by the patterns of nomenclature in the societies around them. The tendency toward adoption of names in vogue with the nonJewish majority - discernible throughout the Middle Ages - accelerated during the late $18^{\text {th }}$ and $19^{\text {th }}$ centuries with intensification of the process of emancipation. As modern Jews reaped the benefits of this emancipation, they increasingly

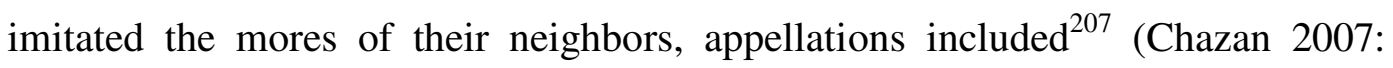
768).

Židovska je dijaspora praktički započela Babilonskim sužanjstvom. Sjeverno je kraljevstvo, Izrael, 722. g. pr. n. e. podleglo asirskoj vojnoj sili pod Sargonom II. (o. 765. - 705. g. pr. n. e.) i prestalo postojati. Deset je sjevernih plemena deportirano u neki drugi dio moćnog carstva i ondje su se stopila s lokalnim stanovništvom. Prekid je veza, naime, između naroda i zemlje i, još gore, naroda i njegova henoteističkog božanstva demoraliziralo puk i olakšalo gubitak njegova identiteta. Otud raznovrsne kasnije legende o »deset izgubljenih plemena $\mathrm{i}$ njihovoj identifikaciji s pojedinim narodima svijeta. Asirci su na teritorij bivše kraljevine Izrael doselili druge narode koji su se s ostacima Izraelaca stopili i etnički i vjerski, te su tako nastali Samaritanci. Južno je kraljevstvo, Juda, potrajalo daljnjih 125 godina, a onda je i ono

\footnotetext{
${ }^{206}$ Nažalost nam dostupni podaci ne omogućavaju da rekonstruiramo dovoljno razgranata obiteljska stabla da bismo u njima mogli pronaći primjere za ovaj fenomen.

${ }^{207}$ Kako su se Židovi selili s jednog područja na drugo, kroz mnoge jezične sredine, na njih su u različitim intenzitetima utjecali uzorci imenovanja zajednica koje su ih okruživale. Sklonost usvajanju imena u skladu s nežidovskom većinom - uočljiva u srednjem vijeku - povećana je krajem XVIII. i и XIX. stoljeću intenziviranjem procesa emancipacije. Kako su suvremeni Židovi koristili prednosti te emancipacije, sve su više podražavali običaje svojih susjeda, uključujući i imenovanja.
} 
podleglo drugom carstvu, babilonskome, pod Nabukodonozorom II. (o. 634. - o. 562. g. pr. n. e.). Narod je Jude progonstvo preživio, u progonstvu formirao židovstvo kakvo danas znamo, te se nakon proglasa perzijskog cara Kira II. Velikog (598/600. - 530. g. pr. n. e.) iz 539. g. pr. n. e. mogao vratiti u svoju zemlju. Naravno, nisu se svi Židovi vratili, neki su ostali i tako stvorili prvu židovsku dijasporu, na istoku.

Kako su se u srednjem vijeku raseljeni Židovi nalazili u različitim jezičnim okruženjima (u koja su se i sami doseljavali kao superstrat, ali je nerijetko slučaj bio obrnut - Židovi su još od antike živjeli kao jedan od supstrata na područjima kojima je poslije seobe naroda ovladala nova jezična većina kao superstrat), tako su i usvajali (jezike i) običaje imenovanja iz svoje okoline, prilagođavali ih, ali i prenosili u nove, jezično različite okoline (poput Sefarada koji su svoj judeo-španjolski preselili u zemlje pod osmanskom vlašću u kojima su se govorili drugi jezici) (Beider 2001: 13-14; Bunin Benor 2016: 442). Svaka je tolerirana židovska

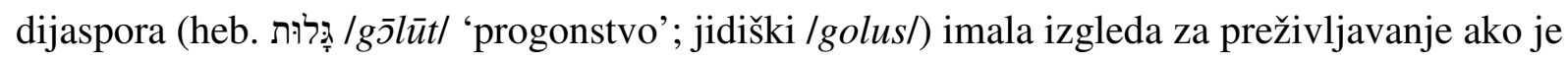
uspijevala dovesti u ravnotežu vlastiti židovski identitet i asimilaciju vrijednosti kulture većinske okoline (Demsky 2003: 95). Židovi su, dakle, prihvaćali osobna imena iz svoje رَسُول okoline, no ne nužno identičnih referencija. Tako među Sefardima arapsko osobno ime Irasūll 'poslanik' aludira na Mojsija, dok među muslimanima ono priziva Muhameda. Isto vrijedi i za njemačka osobna imena. Osobno je ime Meyer, koje Nijemcima znači 'upravitelj', Židovima tek oblik hebrejskog osobnog imena מֵאִיר /me'îr/ 'koji osvjetljava'. Na sličan način osobno ime Schreiber 'pisar' za Židove predstavlja nadimak Mojsijev jer je prema predaji on zapisao Toru (Pet knjiga Mojsijevih) (Guggenheimer H. W. i Guggenheimer E. H. 1992: xiv).

U židovskoj su antroponimskoj tradiciji osobna imena talmudskih i srednjovjekovnih učenjaka stekla status ravnopravan onome velikana Tanaha, primjerice /'abbayey/ (talmudski rabin iz Babilona, u. 339. g.), האי /h'y/ Hai (האי בר שרירא גאון - Hai ben Šerira Gaon, srednjovjekovni teolog, rabin i učenjak, gaon Talmudske akademije u Pumbetiti, 939. 1038.), אלפסי /'lpsy/ Alfasi (إسحاق الفاسي / ר' יצחק אלפסי - Isak ben Jakob Alfasi ha-Kohen, maročki talmudist i rabin, 1013. - 1103.), ili אחא אח אחא, ime više židovskih učenjaka iz III. - VI. st.) (Guggenheimer H. W. i Guggenheimer E. H. 1992: xii).

U hebrejski su antroponimski korpus ušle mnoge hebrejske riječi koje prvotno nisu bila osobna imena, koje kao takve nisu navedene ni u Tanahu ni u Talmudu. To su osobna imena nastala onomastičkom konverzijom ili preobrazbom. Jednu skupinu čine epiteti koji se 


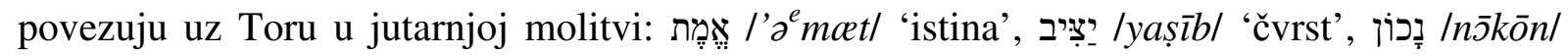

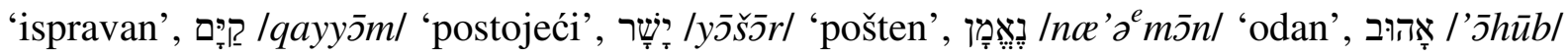

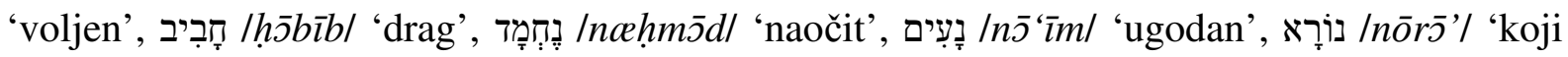

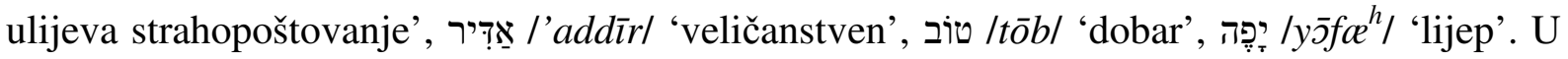

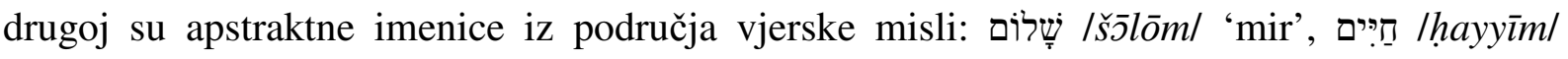
'život'. Treća pak okuplja dvanaest dragulja s naprsnika svećenika ${ }^{208}$, od kojih su osobnim

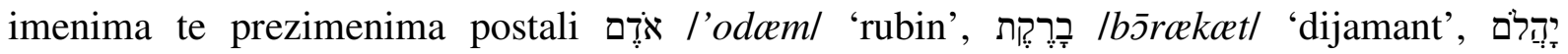

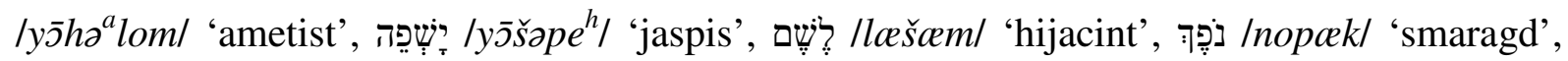

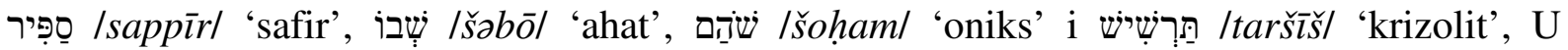

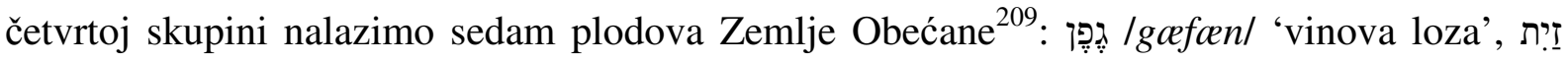

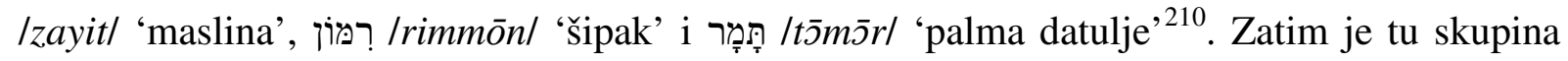
znakova zodijaka koji se poistovjećuju s dvanaest izraelskih plemena. Slijedi skupina osobnih

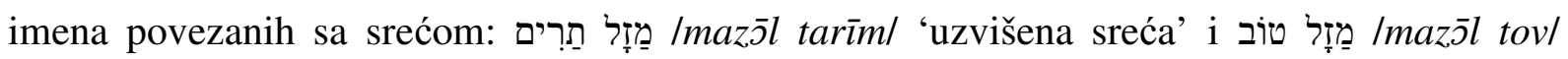
‘dobra sreća' (Guggenheimer H. W. i Guggenheimer E. H. 1992: xii).

Nא אבְרָהָם

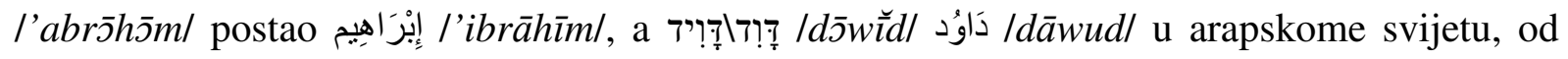

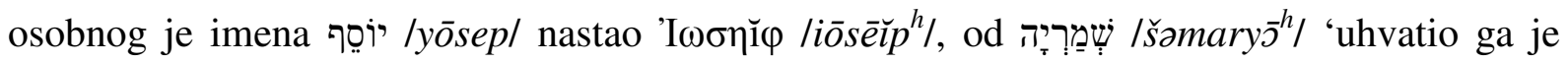

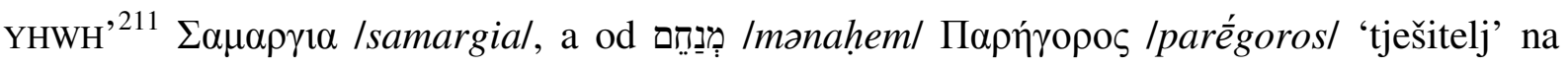

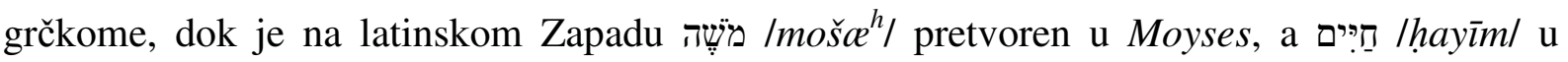
Hagin (Bunin Benor 2016: 441-2; Chazan 2007: 768).

Druga su pak osobna imena udvojena, pa je uz zadržano izvorno židovsko osobno ime dodan i njegov više-manje točan prijevod. Tako je dobiveno hibridno, tautološko, dvojezično dvojno osobno ime nastalo kalkiranjem (Основен систем... 1983: 145; 147, 148). Primjeri bi

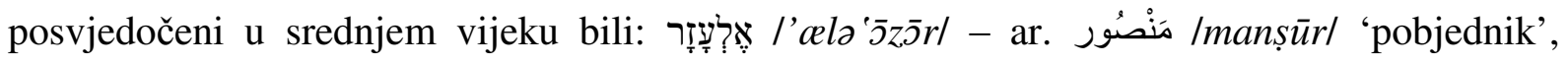

\footnotetext{
${ }^{208}$ Izl 28,17-20. Svaki je od njih predstavljao jedno od dvanaest izraelskih plemena. U prijevodu Silvija Grubišića: rubin, topaz, alem, smaragd, safir, ametist, hijacint, ahat, ledac, krizolit, oniks i jaspis.

${ }^{209}$ Pnz 8,8. U prijevodu Silvija Grubišića: pšenica, ječam, loza, smokva, šipak, med (od datulja) i maslina.

${ }^{210}$ Tamar je i osobno ime lika iz Tanaha, no moralnost je njezina seksualnog ponašanja u priči o njoj i svekru si Judi u najmanju ruku dvojbena, pa je velika vjerojatnost da je osobno ime opstalo u narodu zahvaljujući palmi datulje po kojoj je nazvana, a ne po njoj samoj.

${ }^{211} 2$ Ljet 11,19. U transkripciji Antuna Sovića: Šemarja.
} 


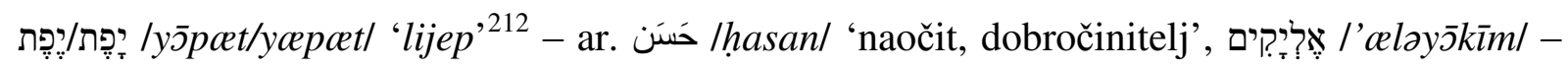

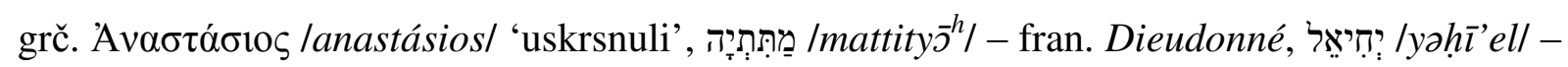
fran. Vivant i חַיִ /hayim/ - fran. Vital (Chazan 2007: 768). Pritom su nastala mnoga prijevodna osobna imena (u oba smjera - i iz hebrejskog u govorni jezik i iz govornoga jezika natrag u hebrejski - ali i iz jednog govornog jezika u drugi ${ }^{213}$ ), od kojih su se neka koristila isključivo u nežidovskim (kršćanskim) dokumentima (Beider 2001: 21-27).

Kod nadijevanja je osobnih imena ženama izbor bio nešto slobodniji negoli je to bio slučaj s muškarcima, te su žene brže usvajale lokalna, nežidovska osobna imena. Alexander Beider nudi četiri razloga za to (Beider 2001: xxviii):

1. temeljna razlika između muškarca i žene u vjerskoj tradiciji i praksi

2. malen broj ženskih osobnih imena u Tanahu u usporedbi s brojem muških, a pogotovo onih koja bi pripadala likovima koji bi mogli poslužiti kao ideal pri imenovanju: tu su

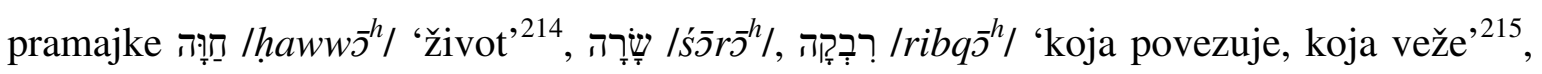

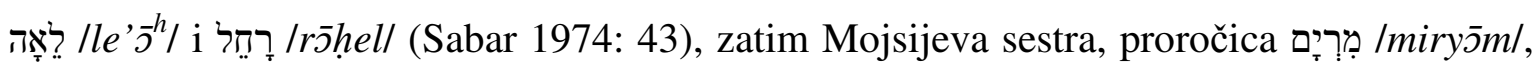
אִֶ /'aster/ ${ }^{216}$, junakinja istoimene knjige iz Tanaha, ali i njezino izvorno, hebrejsko

${ }^{212}$ Post 5,32 i Post 7,13. U transkripciji Silvija Grubišića: Jafet.

${ }^{213}$ U igri je bio i latinski, negovorni, ali službeni jezik u mnogim državama srednjeg, pa i novog vijeka.

${ }^{214}$ Post 3,20. U transkripciji Silvija Grubišića: Eva.

Među Aškenazima je njezino osobno ime pučkom etimologijom povezano s aramejskom riječi חִ̣ /hiwys’/ 'zmija', te je stoga zamijenjeno osobnim imenom חָּ /hayy $\bar{\rho}^{h} /$ 'živuća' (Guggenheimer H. W. i

Guggenheimer E. H. 1992: xi).

Isaac Asimov o ovom osobnom imenu kaže (Asimov 1969: 32):

"Thus the Hebrew name equivalent to our own Eve is Hawah, which has a similarity of sound to hayah, meaning "to live" (Actually, the initial " $h$ " is a guttural sound not found in our language but similar to the German "ch.") Since Eve is regarded as the mother of the human race, it is tempting to equate Hawah and hayah and say that she received the name because she was the mother of all living. This is an example of "folk etymology," in which the Bible abounds. The real meaning of Hawah or Eve is, of course, unknown." [Stoga je hebrejsko ime koje odgovara našoj Evi Hava, zvukom slično riječi haja, što znači 'živjeti' (Ustvari, početno je »h« grleni zvuk kakvog nema u našem jeziku, već je sličan njemačkome »ch.«) Budući da se Eva smatra majkom ljudskog roda, primamljivo je izjednačiti Hava $i$ haya te reći da je dobila ovo ime jer je bila majka svim živima. Ovo je primjer »pučke etimologije«, kojim Biblija obiluje. Pravo je značenje imena Hava ili Eva, naravno, nepoznato.]

${ }^{215}$ Post 22,23. U transkripciji Silvija Grubišića: Rebeka.

${ }^{216}$ Est 2,7. U transkripciji Antuna Sovića: Estera.

Ovo osobno ime nije hebrejsko. Postoje različita tumačenja, od kojih je najšire prihvaćeno ono koje njegovo 


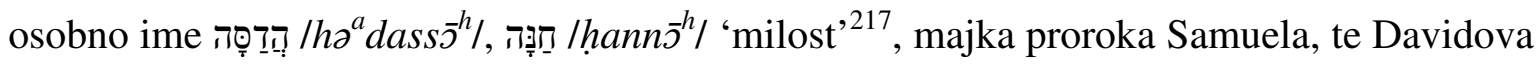
prabaka רוּ /rūt/ 'družica,218

3. semantički moment: osobna su imena motivirana općim imenicama privlačnog značenja uglavnom tvorena na govornom jeziku ${ }^{219}$

4. korpus je ženskih osobnih imena pomodniji

Ako je kćeri nadjenuto hebrejsko osobno ime, ona će u pravilu uza nj dobiti i neko lokalno osobno ime (Beider 2001: 15-16; Colorni 1983: 72). Ženska su osobna imena iz svakodnevnog govornog jezika, dakle, češća i od onih hebrejskih i od onih muških. Stoga nas ne treba čuditi kad među Arapima nalazimo Židovke s osobnim imenom كَسْعُوَدة /mas ' $\bar{u} d a^{t} /$

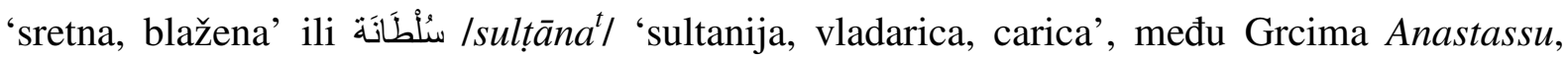
Cali i Z $\omega \eta \dot{~} /\left.z \bar{o} e\right|^{220}$, među Francuzima Angélique, Fleurette i Précieuse, među Španjolcima Esperanza i Gracia te među Talijanima već spomenute Bella, Belladonna, Brunetta, Diamante, Fioretta, Fiammetta, Gentile i Perla (Chazan 2007: 768; Colorni 1983: 72).

podrijetlo nalazi u osobnom imenu mezopotamske boginje ljubavi, plodnosti, pa i rata, Ištar. Ono po svemu sudeći ima semitsku etimologiju povezanu s pojmom navodnjavanja, povezujući tako plodnost i navodnjavanje (Pinker 2005).

Druga je mogućnost izvođenje osobnog imena iz perzijske riječi setareh 'zvijezda' usporedbom Estere sa zvijezdom Danicom.

Isaac Asimov o ovom osobnom imenu piše (Asimov 1969: 467-468):

"As for Esther (the official throne name that came to be carried by Mordecai's cousin), that is even more clearly a form of Ishtar, the chief Babylonian goddess, Indeed, the Aramaic version of that goddess's name is indeed Esther. ... And in Babylonian mythology Marduk and Ishtar are cousins, as are Mordecai and Esther in the Book of Esther."

[Što se tiče imena Estera (službenog prijestolnog imena koje je nosila Mordokajeva rođakinja), ono je još očigledniji lik imena Ištar, glavne babilonske boginje. Doista, aramejska je inačica imena te boginje uistinu Estera. ... I u babilonskoj su mitologiji Marduk i Ištar rođaci, kao što su to i Mordokaj i Estera u Knjizi o Esteri.]

217 Sam 1,2. U transkripciji Antuna Sovića: Ana.

${ }^{218}$ Rut 1,4. U transkripciji Antuna Sovića: Ruta.

${ }^{219}$ Utjecaj pučke etimologije kao i sličnost plana izraza pri izboru osobnog imena nisu zanemarivi. V. Beider 2001: 15-16, bilješka 6, 16-17.

${ }^{220}$ Eva je jedan od rijetkih likova Tanaha čije je osobno ime prevedeno u Septuaginti. Krećući od tumačenja

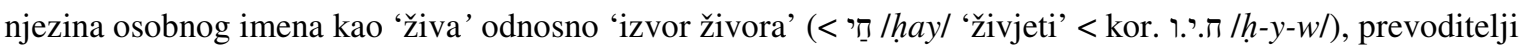

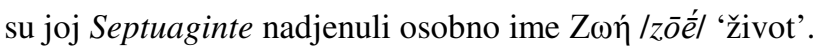


Kad je u jednoj zajednici bilo više pojedinaca istog osobnog imena, identificirali bi se patronimom, označenim bilo hebrejskim većinskog jezika značenja 'sin'. Dodatna je specifikacija pojedinca katkad napravljena navodeći ktetik, toponim, bilo mjesta iz kojeg potječe, bilo mjesta u kojem je živio i radio. Takvi su nadimci bili učestali u Sefarada prognanih s Iberskog poluotoka 1492. g. i naseljenih po tadašnjem Osmanskom Carstvu, poput De Leon, D'Alvo, Zamora, ili Toledano. U takvim nadimcima nalazimo zametak nekih od budućih židovskih prezimena, kao što je to slučaj i s patronimima i s nadimcima nastalima od naziva zanimanja ili pak od fizičkih i psihičkih osobina pojedinaca, pa i cijelih porodica (Chazan 2007: 769).

Još su jedan specifikum srednjeg vijeka akronimi, česti među židovskim učenjacima toga doba. Osoba je poznata kao Rambam (רמב"ם) punim imenom bio Rabin Moše ben Majmon

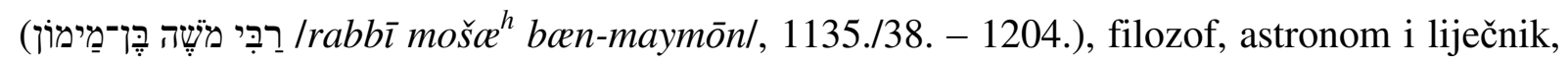

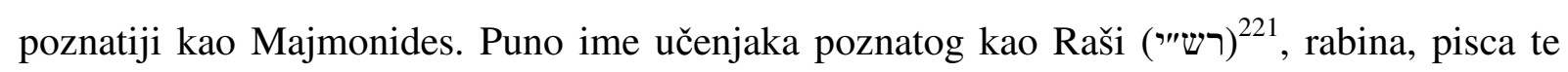

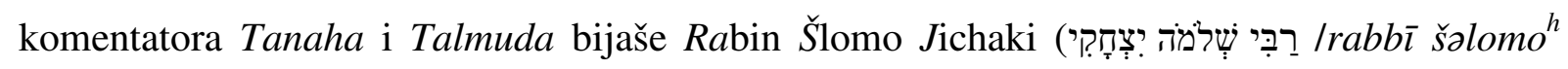

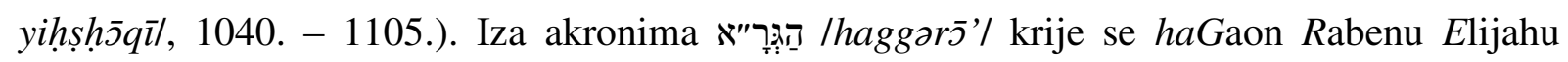

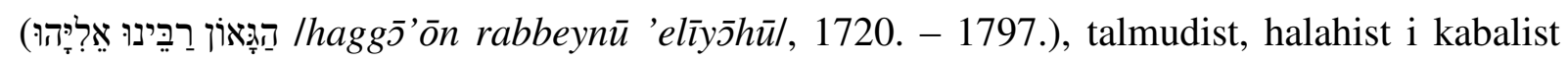

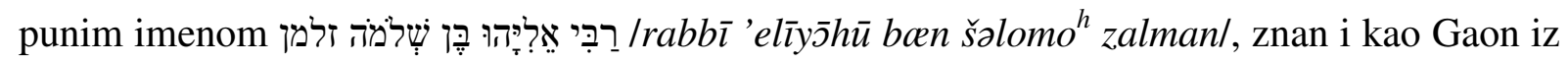
Vilne (Chazan 2007: 769; Guggenheimer H. W. i Guggenheimer E. H. 1992: xii).

\subsubsection{Osobna imena na jidišu}

U suvremeno se doba Židovi Starog svijeta dijele u tri velike skupine ovisno o zemlji u kojoj žive ili su živjeli, o jeziku kojim su se služili i o obredu kojeg su se držali. U Europi su sjeverno od Pirineja i Alpa živjeli Aškenazi, potomci židovskog pučanstva iz rimskih provincija sjeverno od Alpa. Kao glavno sredstvo međusobnog sporazumijevanja u svakodnevnom životu koristili su se jidišem, germanskim jezikom ${ }^{222}$, u našemu židovskom tisku prve polovice XX. st. zvan »židovskim jezikom« (u opreci spram »jevrejskog jezika«). Njihov molitveni obred vuče korijene iz starog palestinskog rituala, koji je bio zastupljen i na

\footnotetext{
${ }^{221}$ Po njemu je nazvano i pismo, temeljeno na sefardskom rukopisnom polukurzivu iz XV. st., kojim se i dandanas tiskaju njegovi komentari kako bi ih se i grafički moglo razlikovati od izvornog teksta koji komentiraju, a koji je redovito tiskan kvadratom.

${ }^{222}$ Obično se navodi da je jidiš podrijetlom srednjosrednjonjemački odnosno srednjovisokonjemački dijalekt, no neke morfološke karakteristike upućuju na bavarsko-austrijski jezični kompleks.
} 
većem dijelu Apeninskog poluotoka. Na Iberskom su poluotoku do 1492. g. živjeli Sefardi, govornici judeo-španjolskoga, odvjetka srednjovjekovnog kastiljskog jezika, koji su u domovini slijedili babilonski molitveni ritual. Nakon protjerivanja su se iz Španjolske i Portugala Sefardi naselili po Osmanskom carstvu. Asimilirajući židovski supstrat na koji su naišli u zemljama koje oplakuje Sredozemno more prihvatili su obred molitvenika iz Livorna. Osim navedenih postoje (odnosno postojale su) i brojne zajednice Židova u Africi, na Bliskom istoku, ali i dalje u azijski kontinent sve do Indije i Kine, tzv. Mizrahi odnosno Istočnjaci, koji čuvaju svoje jezike ${ }^{223}$ i drevne molitvene obrede (Guggenheimer H. W. i Guggenheimer E. H. 1992: xiii-xiv).

Temelj na kojem se razvio jidiš bio je jezik kakvim se govorilo u zemlji kanaanskoj. Ovdje

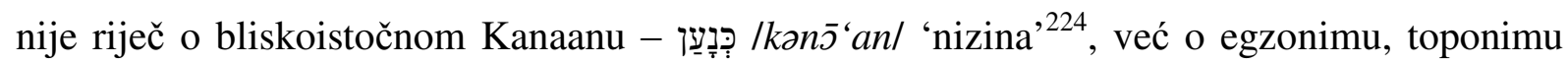
kojim su Židovi tradicionalno nazivali zemlje Saske, Češke, Moravske i Donje Austrije. Taj jezik bijaše srednjosrednjonjemački ${ }^{225}$ odnosno srednjovisokonjemački. Jidiš nije pratio fonološke i druge promjene tipične za razvoj njemačkoga jezika, već je u tome ostao prilično konzervativan $^{226}$. Na istoku su jidiškoga govornog područja u jezik ušle mnoge slavenske posuđenice, uglavnom iz ukrajinskoga i poljskoga (Guggenheimer H. W. i Guggenheimer E. H. 1992: xxii-xxiii).

Jidiš se piše hebrejskim pismom čija su slova prilagođena čistom fonetskom zapisivanju germanskoga jezika. Neka su slova, s masoretskim oznakama za samoglasnike ili bez njih, iskorištena za bilježenje pet jidiških samoglasnika. Druga su slova modificirana kako bi se mogli bilježiti suglasnici kojih u hebrejskom nema, odnosno kontrasti koji su u hebrejskom čiste pozicijske varijante, a u jidišu fonološki elementi jezika. Pritom su se riječi potekle iz hebrejskoga (pa tako i osobna imena) pisale hebrejskim, a ne jidiškim pravopisom, onako kako su izvorno pisane. Međutim je kod hebrejskih osobnih imena s vremenom došlo do

\footnotetext{
${ }^{223}$ Osim jidiša i judeo-španjolskog postoji i cijeli niz lokalnih judeo-... jezikā kojima su govorile veće ili manje zajednice Židova u svijetu. Internetska ih stranica Wikipedia spominje još 36 (https://en.wikipedia.org/wiki/List_of_Jewish_diaspora_languages).

${ }^{224}$ Post 10,6. U transkripciji Silvija Grubišića: Kanaan.

${ }^{225}$ Prvo se »srednjo« odnosi na vrijeme oko 1000. - 1500. g., a drugo na zemljopisni položaj između visoko- i niskonjemačkoga.

${ }^{226}$ Heinrich W. i Eva H. Guggenheimer to objašnjavaju konzervativnim tendencijama samih Židova (Guggenheimer H. W. i Guggenheimer E. H. 1992: xxii).
} 
svojevrsnih pomaka, i na planu izgovora (Gorr 1992: xi), i na planu njihova zapisivanja, pa su i hebrejska osobna imena pisana jidiškim pravopisom. Za primjer nam može poslužiti osobno

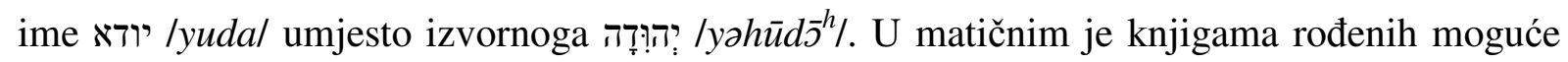
pronaći obje inačice osobnog imena (uz neke druge, npr. יודה) kako se izmjenjuju od pojedinca do pojedinca bez neke kronološke ili druge pravilnosti.

Jidiš je neko vrijeme uživao status jednog od službenih jezika Ukrajinske Narodne Republike, Bjeloruske Sovjetske Socijalističke Republike, Galicijske Sovjetske Socijalističke Republike i Židovske autonomne oblasti (gdje je i dan-danas jedan od službenih jezika) ${ }^{227}$, a tijekom njegove povijesti jezik se pisao i različitim pravopisima temeljenima na hebrejskom pismu ${ }^{228}$.

Najstarijim se spomenikom jidiša, koji je moguće datirati, smatra blagoslov uklopljen u slova hebrejskog teksta בדעתו u molitveniku iz Wormsa, koji potječe iz 1272. g. ${ }^{229}$ Tekst glasi:

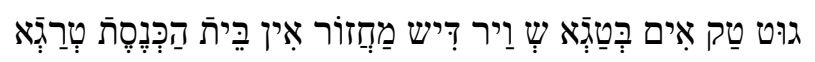

Igut tak im betage se vayr dis maxazor in beis hakneses tragel

'dobar dan došao onome tko ovaj molitvenik u sinagogu unese'.

Tekst je na uglavnom pravilnom srednjovisokonjemačkome uz umetnute dvije hebrejske riječi

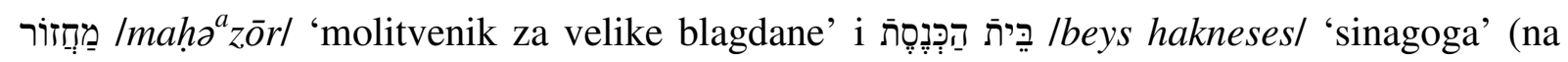
hebrejskome /beyt hakkanasat/).

Jidiški se nazivi jezika kreću od u XII. st. potvrđenih לשון־אַשכנז /lošn-ašknaz/ 'jezik Aškenaza' i טיפטש/taytšl 'njemački' do kolokvijalnog מאַמעילשון /mame-lošn/ 'materinji jezik' (za razliku od לשון־קדש/lošn koydeš/ 'sveti jezik', tj. hebrejski i aramejski). Naziv se

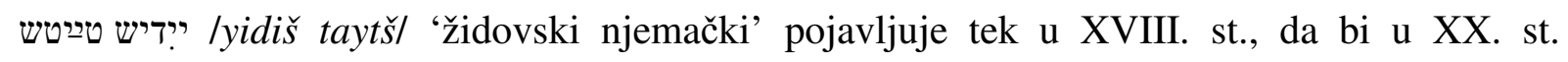
prevladali nazivi židovski ${ }^{230}$ odnosno אידיש|יידיש:idiš/yidiš/.

\footnotetext{
${ }^{227}$ Potvrđeno u korespondencijama na e-popisu Jewish Languages.

${ }^{228}$ Danas je u uporabi ujednačeni pravopis koji se koristi i u ovom radu, a prikazan je na samom početku udžbenika Sheve Zucker (Zucker 1995: xv-xvii). O transkripciji jidiša v. prilog B.

${ }^{229}$ Fotografija se dotične stranice molitvenika može vidjeti na internetskoj stranici http://www.yivoencyclopedia.org/popups/viewmedia.aspx?id=1116 Pristupljeno 1. travnja 2018. g.

${ }^{230} \mathrm{~Pa}$ tako i u domaćem Židovskom tisku iz prve polovine XX. st. - Židovskoj smotri i Židovu.
} 
Dijalekti se jidiša mogu podijeliti u četiri skupine (Beider 2001: 109):

1. srednjoistočni jidiš, poljski jidiš:

Poljska, Galicija, dijelovi Slovačke i Mađarske

2. jugoistočni jidiš, ukrajinski jidiš:

istočna Ukrajina, Besarabija, Rumunjska

3. sjeveroistočni jidiš, litavski jidiš:

Litva, Latvija, Bjelorusija i dio sjeveroistočne Poljske

4. zapadni jidiš:

njemačke zemlje, Alzas, Češka, Moravska, dijelovi Slovačke i Mađarske.

Imena se koja nalazimo među Aškenazima mogu podijeliti u nekoliko skupina (Beider 2001: xxix-Xxxi):

1. osobna imena, koja dijete dobiva odmah poslije rođenja ili koji dan kasnije, ali i iz njih izvedena osobna imena kojima osobu tijekom njezina života zovu članovi obitelji ili prijatelji

2. nadimci, koji su za razliku od osobnih imena pojedinačni, koji se dodaju osobnom imenu i uza nj igraju drugotnu ulogu te čija je motivacija poznata onome koji nadimak nadijeva

3. imena izvedena od osobnih imena srodnika, poput patronima $i$, rjeđe, metronima

4. postojana imena koja se prenose s koljena na koljeno - prezimena, koja se među Aškenazima pojavljuju tek krajem XVIII. i početkom XIX. st.

Mnoga su od osobnih imena navedena u prethodna dva poglavlja jednostavno prevedena na jidiš, kalkirana (Основен систем... 1983: 145). U tu kategoriju pripadaju osobna imena רובין nastala konverzijom od naziva dvanaest dragulja sa svećeničkog naprsnika, kao što su /rubin/ 'rubin', דיאַמאַנד /diamand/ 'dijamant', שמאַראַדג /smaragd/ 'smaragd', סאַפיר /sapir/

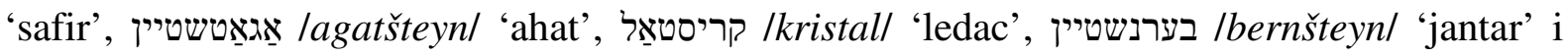
נגֵַגלשטיין /naglšteyn/ 'oniks', ali i boje odgovarajućih dragulja odnosno boje zastava pojedinih plemena, poput רָָט/rot/ 'crven' za osobno ime גראוּבֵן /grin/ 'zelen' za osobno

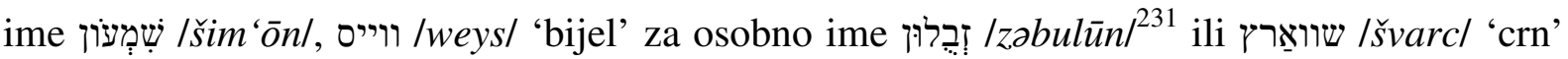

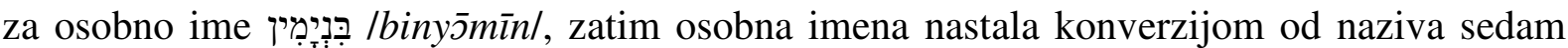

${ }^{231}$ Post 30,20. U transkripciji Silvija Grubišića: Zebulun.

Postoje dva moguća tumačenja ovog osobnog imena, jedno ga povezuje s riječju זִֵֵ /zeved/ ‘dar, miraz', a drugo s glagolom זָָָ /zכ̄ball 'obitavati'. 
plodova Zemlje Obećane, npr. וויייצן /weycn/ 'pšenica', גערשט /geršt/ 'ječam', ויישטק /weynštok/ 'vinova loza', פַייגע /feygel 'smokva', מילגראם /milgram/ 'šipak', אָליבע /olivel 'maslina' i העניג /henig/ 'med' te skupina osobnih imena nastalih konverzijom od pojedinih

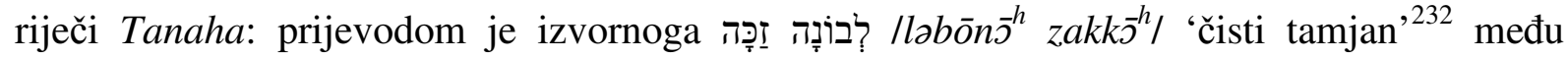
Aškenazima nastalo ריינגעבירץ /reyngevircl 'dobar začin' (Guggenheimer H. W. i Guggenheimer E. H. 1992: xii, xvi-xvii).

Treba navesti i osobna imena nastala konverzijom od usporedaba i metafora iz Jakovljeve oporuke u 49. poglavlju Knjige postanka i onih iz Mojsijeva blagoslova u 33. poglavlju

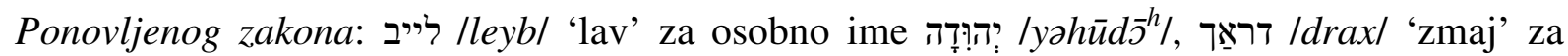

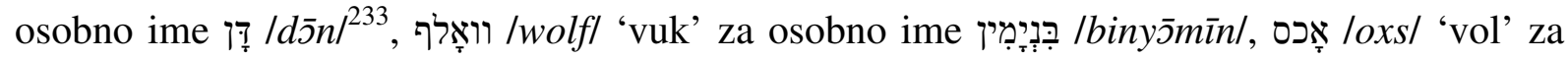
osobno ime יוֹסֵף /yōsep/. Pojavljuju se i drugi nazivi za životinje koji nemaju takvog

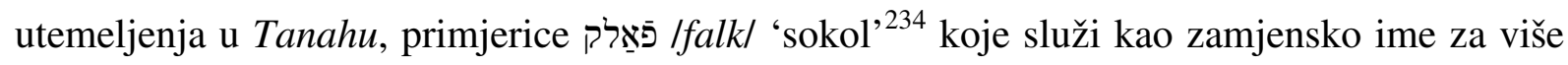

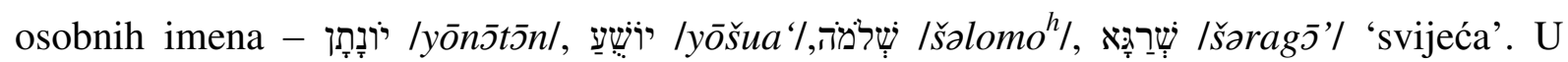
Aškenaza su se pak neki nazivi za životinje konverzijom preobratili u osobna imena isključivo po sličnosti plana izraza odnosno dijela plana izraza. Osobno ime בינע/bine/ 'pčela'

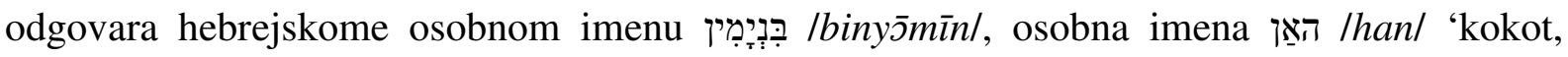
pijetao' i מאַן /man/ ‘čovjek', prijevodi hebrejske riječi הֶֶּ /gabar/ 'čovjek, kokot, pijetao', služe kao zamjenska imena za osobna imena koja u sebi nose taj fonološki niz, kao što su

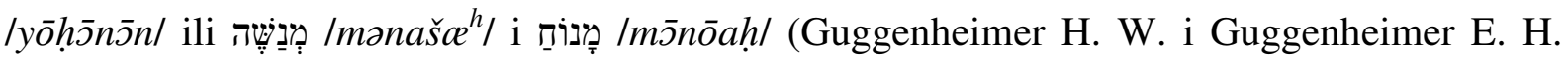
1992: xvi-xvii).

Neka se zamjenska imena povezuju uz pojedina osobna imena likova iz Tanaha na temelju njihovih djela. Abraham je u vojni četvorice velikih kraljeva podijelio svoje snage u dvije čete i napao noću, odatle נאֵכטטיילר /naxtteyler/ 'onaj koji je podijelio noć'. Isak je kao najdugovječniji među patrijarsima postao לעבלאֵנג /leblang/ 'dugo živi' (Guggenheimer H. W. i Guggenheimer E. H. 1992: xvi).

\footnotetext{
${ }^{232}$ Lev 24,7. U prijevodu Silvija Grubišića: miomirisni kâd.

${ }^{233}$ Post 49,16-17. U prijevodu Silvija Grubišića:

${ }^{16}$ Dan će narod svoj suditi kao svako pleme Izraelovo.

${ }^{17}$ Nek' Dan zmija bude na putu, guja pokraj staze što će konja za zglob ujesti, i njegov konjik nauznak će pasti.

${ }^{234}$ Osobno je ime ovoga značenja i često prezime u Sefarada iz arapskih zemalja: ألْبَاز > אלבז /'albāz/ 'jastreb'.
} 
Katkad se osobno ime na lokalnom jeziku kao zamjensko ime povezuje s biblijskim na temelju sličnosti plana izraza. Ta se sličnost može svesti na postojanje istih suglasnika u oba

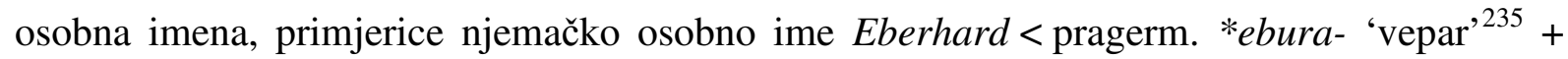
*hardu- 'čvrst, žestok' jest zamjensko ime za osobno ime אַבְרָָָם /'abrōhs̄m/ jer oba sadržavaju suglasnike $b, r$ i $h$, donosno osobno ime Victor<lat. 'pobjednik, osvajač' jest zamjensko ime za osobno ime אַבְיגְּדוֹר /'abīgdōr/236 jer oba sadržavaju suglasnike $v(b$ u postvokalskom položaju u masoretskom i suvremenom izgovoru hebrejskoga), $g / k, d / t$ i $r$ (Beider 2001:268).

Židovi izbjegavaju pejorativne nadimke. Oni koji postoje odnose se na znane fizičke nedostatke likova iz Tanaha. Jakov je nakon hrvanja s anđelom ostao iščašenog kuka, te je nadimak קריפל/kripl/ 'invalid' pripisan njemu. Prema tradiciji je, ako ne i prema Tanahu, Mojsije imao govornu manu, otud nadimak שטאָמלער /štamler/ 'mucavac'. Podrijetlo nadimka שראַם /šram/ 'ožiljak' ipak treba tražiti među nadimcima izvedenih iz podrijetla pojedinca - u ovom slučaju mjesta Schrimm, današnji Śrem u središnjoj Poljskoj na rijeci Warti (Guggenheimer H. W. i Guggenheimer E. H. 1992: xvii).

Osobna se imena mogu kratiti ili produžiti ${ }^{237}$ novim elementima. Kraćenjem /'abrōhōm/ među Aškenazima postaje Aba, Abe, Aber, Brahm te Brom, Rom i Brum,

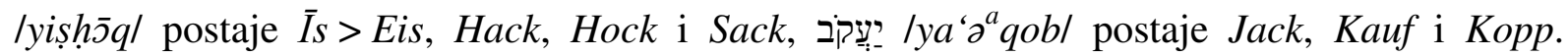
Katkad se tako pokraćena osobna imena produžuju novim jezičnim elementima. Osobna se imena Bono i Gad mogu produžiti u Boniel i Gadiel dodavanjem sufiksa naziva za Boga. Među Aškenazima se osobnim imenima dodaju tipično germanski sufiksi -er i -man, koji mogu igrati ulogu patronimskih/metronimskih sufikasa. U osobno se ime može ubaciti etimološki neopravdani suglasnik, npr. Jondorf < Yomtov, Istrael < Israel. Katkad se takvim

\footnotetext{
${ }^{235}$ Pri preuzimanju ovog osobnog imena Židovi vjerojatno nisu bili svjesni njegove etimologije, jer je teško povjerovati da bi s osobnim imenom svoga praoca povezali išta što ima ikakve veze sa svinjom, obredno nečistom životinjom.

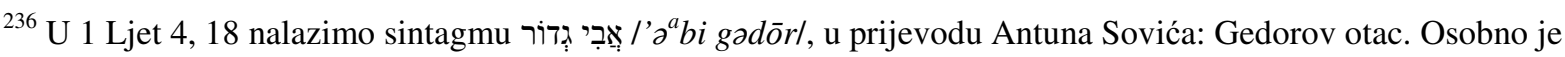
ime jedno od nekoliko njih nadjenutih Mojsiju u Midrašu.

${ }^{237}$ Heinrich W. i Eva H. Guggenheimer koriste riječ amplification (Guggenheimer H. W. i Guggenheimer E. H. 1992: xxiii-xiv).
} 
umetanjem stvara aliteracija ${ }^{238}$, kao u Hufhaizen < Hufeisen 'potkova', Heichhorn < Eichhorn 'vjeverica' i rus. Голергант < Алергант < Allerhand 'trgovac mješovitom robom'. Katkad su tako produžena osobna imena homofona s nekom riječi na jeziku većine, ali drukčije semantički protumačena: poljsko Ordynans i njemačko Ordentlich predstavljaju produženi lik

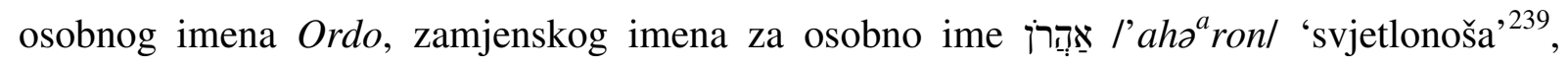
židovsko osobno ime Jupiter je produženo osobno ime Yup, zamjensko ime za osobno ime

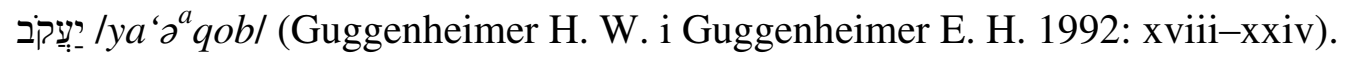

Uobičajena je modifikacija osobnih imena stvaranjem umanjenica ili odmilica. Na jidišu su najčešći deminutivni sufiksi, osim danas uobičajenog njemačkoga -chen, oni tvoreni segmentom -l-, tipični za jezike Bavarske, Austrije i Švicarske, bavarski i alemanski, -lein te njegov pokraćeni oblik -el. Primjeri su Abel umjesto Abe, Koppel umjesto Kopp i Leibel umjesto Löb. Sufiks -chen se često krati u -in, no ovaj se može tumačiti i kao pokraćeni lik patronimskih/metronimskih sufikasa -kin i -kind, npr. Hakin od Hack, što je zamjensko ime za

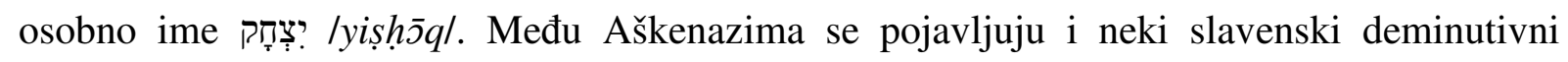
sufiksi kao što su -čik, - čyk i -čuk, primjerice Kalczuk. Umanjenice mogu funkcionirati i kao odmilice, a dodatni način tvorbe odmilica na jidišu jest prefiksom lieb- 'drag' (Gorr 1992: xiii; Guggenheimer H. W. i Guggenheimer E. H. 1992: xxiv).

Pokrate, s kakvima smo se susreli među srednjovjekovnim rabinima, ostaju živim načinom

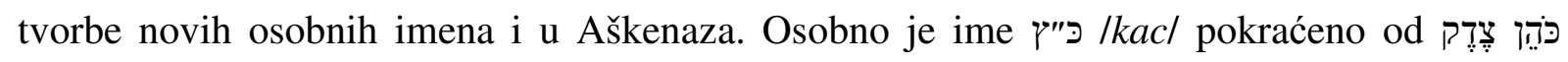

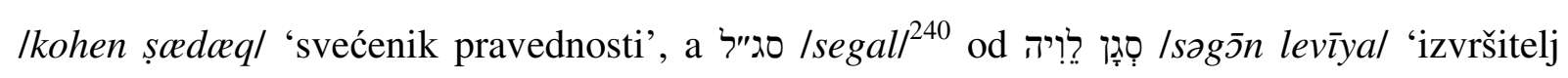
dužnosti Levita u Hramu' (Guggenheimer H. W. i Guggenheimer E. H. 1992: xxv, Lawson 2005).

Kao i na njemačkom jeziku, i na jidišu se tvore složena, obično dvodijelna osobna imena. Njihova tumačenja ne moraju odgovarati onima u njemačkom jeziku. Riječ Wintergrün, primjerice, na njemačkome označava biljku kruščicu (Pyrola sp.), dok je u židovskom tumačenju osobnog imena Winter patronim tvoren od riječi win < pragerm. *weni- 'prijatelj',

\footnotetext{
${ }^{238}$ Aliteracija je osnovna versifikacijska metoda tradicionalne germanske poezije. Je li ta činjenica povezana s ovom pojavom u govornika jidiša, jednog od germanskih jezika?

${ }^{239}$ Izl 4,14. U transkripciji Silvija Grubišića: Aron.
}

Odgovarajuće arapsko osobno ime: هَرُون /harūn/ ‘predragi’ (Agić 1996: 49).

${ }^{240}$ Ali i /sagal/ i /sigel/ jer samoglasnici nisu strogo definirani. 
a grün 'zelen' je boja zastave plemena Šimunova. Mnoga tako tvorena osobna imena predstavljaju patronime/metronime (Guggenheimer H. W. i Guggenheimer E. H. 1992: xxvi).

Više je sufikasa kojima se tvore patronimi i metronimi na jidišu. Jedan je od njih posvojni sufiks -s/-es/-is, npr. u osobnim imenima Abrams i Brahms od osobnog imena אבְרָהָם

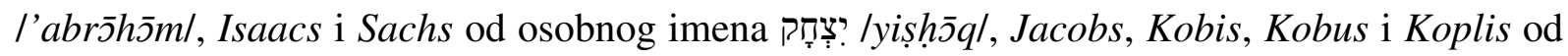

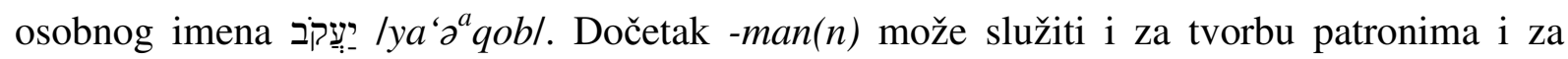
tvorbu metronima ${ }^{241}$, kao što je to slučaj u osobnog imena Bauman $(n)<$ Baum, zamjenskog

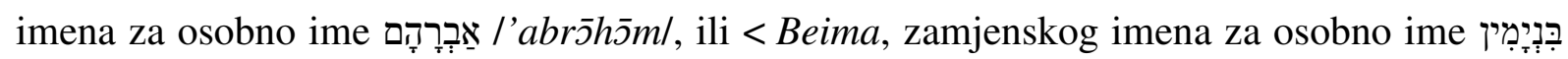

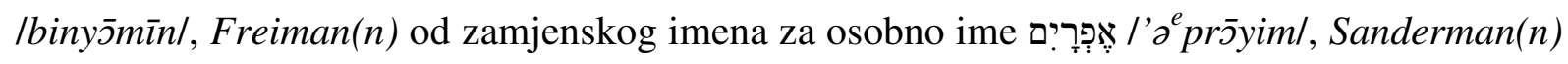
od zamjenskog imena za osobno ime Aleksander ili Sus(s)man(n) od osobnog imena Sus(s) ili Süs(s). Sufiksi -man i -er osim tvorbe patronima mogu i produživati osobna imena, što vrijedi i za neke druge u ovom poglavlju spomenute sufikse. Tipični su patronimski i metronimski sufiksi -sohn, -son 'sin' (Mendelsohn) i -kind 'dijete' (Salkind), posljednji često stegnut u -kin. Pojavljuju se i drugi, poetičnije naravi kao što su -baum 'drvo', -bein 'kost', -heim 'dom,242, -schild 'štit', -stamm 'soj', -stein 'kamen, stijena' i -stern 'zvijezda'. Neka prezimena nose i tipične slavenske patronimske sufikse, npr. poljski -ów i -wicz, ruski -скиŭ i -вич, bugarski i ruski -ов, češki -sky, rumunjski -vici, mađarski -vics i naš -vić (Guggenheimer H. W. i Guggenheimer E. H. 1992: xxvi-xvii).

Mnoga su osobna imena »prevedena« na jezik većine, te su tako dobiveni onomastički kalkovi i hibridna odnosno tautološka osobna imena nastala kalkiranjem (Основен систем... 1983: 142, 145, 147). Primjerice, osobno ime Erle, umanjenica od osobnog imena אַּ̣ l'ahə ${ }^{a}$ ron/, na njemačkom znači 'javor'. Prijevod tog osobnog imena na druge jezika daje cijeli niz osobnih imena pretvorenih u prezimena; Javor na češkom, Jawor na poljskom, Клен na ruskom, Eger na mađarskom. Katkad se prijevod pojavljuje uz izvorno osobno ime, kao u talijanskome Haschetto-Forti, gdje je hebrejski pridjev sufiksom -etto, uparen s talijanskim osobnim imenom izvedenim iz forte 'jak', da bi nastalo novo, koje bi potom postalo prezimenom. U Aškenaza se takav spoj prijevoda i izvornika nerijetko spaja u jednu riječ, tautološko osobno ime (Основен систем... 1983: 148), kao u

\footnotetext{
${ }^{241}$ Formant Man može biti i zamjensko ime za osobno ime מְִ̣̣ /mənahem/.

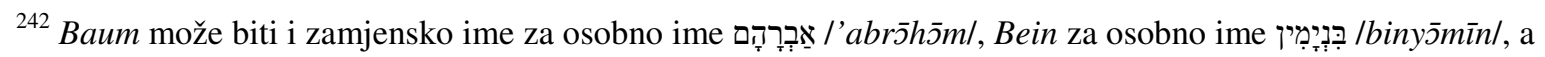
Heim za osobno ime חֵַ /hayyim/.
} 
poljsko-njemačkome Kaminstein, hebrejsko-njemačkome Ebenstein ('kamen' + 'kamen'), mađarsko-njemačkome Borwein ('vino' + 'vino'). Postoje i slučajevi povezivanja sinonima na istom jeziku, npr. poljski Katiblocki ('močvara' + 'blato') (Guggenheimer H. W. i Guggenheimer E. H. 1992: xxvii-xxviii).

Proučavanje motivacije židovskih osobnih imena (i od njih nastalih prezimena) ne olakšava činjenica da je neka osobna imena moguće dvojako tumačiti. Osobno se ime Morgenlander ‘istočnjak’ može odnositi na Abrahama, koji je došao s istoka, iz Ura Kaldejskoga. S druge strane ono isto tako može predstavljati produženi lik osobnog imena Morgen, zamjenskog

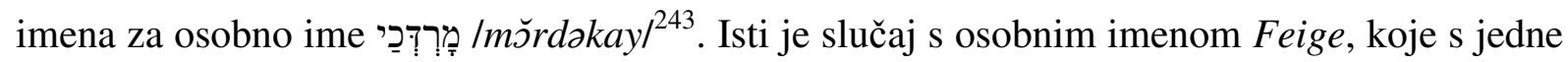
strane može značiti 'smokva', jedan od sedam plodova Zemlje Obećane, a s druge se može izvesti iz riječi Vogel 'ptica', što je izravni prijevod hebrejskog osobnog imena צִפָּּה /șippor $\bar{y}^{h}{ }^{244}$ (Guggenheimer H. W. i Guggenheimer E. H. 1992: xxvii-xviii).

Neka osobna imena u sebi kriju dug put koji su prošla od hebrejskog izvornika do njihove jidiške inačice. U hebrejskom se osobnom imenu אוּרִ /'ūrīl krije korijen značenja 'svjetlo'

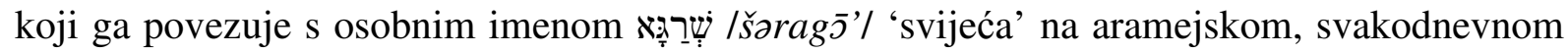
govornom jeziku židovske zemlje od zadnjih stoljeća prije naše ere. Vittore Colorni navodi da se u doba helenizma ova osobna imena povezuju s grčkim Фoĩßos/phoĩbos/ 'svijetao', pridjevkom boga Apolona u ulozi boga Sunca, koje je naposljetku adaptirano na jidiš kao Feibuš, Feibeš, Feivel i sl. (Colorni 1983: 75). Međutim, Alexander Beider tvrdi da je ova pučka etimologija pogrešna, te da je najstariji lik osobnog imena Fejvuš među Aškenazima

${ }^{243}$ Est 2,5. U transkripciji Antuna Sovića: Mordokaj.

Što se tiče značenje ovog osobnog imena, ponuđeni su raznovrsni prijedlozi njegove interpretacije, od kojih se najvjerojatnijom čini ona koja osobno ime povezuje s onim boga Marduka, 'Mardukov

sluga/sljedbenik/privrženik', no židovski su tumači skloniji etimologijama koje se ne povezuju uz nežidovska božanstva, npr.'mali čovjek'.

Isaac Asimov o ovom osobnom imenu piše (Asimov 1969: 467-468):

"The name Mordecai is not Hebrew and, instead, seems to be suspiciously like that of the chief god of the Babylonians, Marduk, which, in its Hebrew form, is Merodach. ... And in Babylonian mythology Marduk and Ishtar are cousins, as are Mordecai and Esther in the Book of Esther."

[Ime Mordokaj nije hebrejsko, već se čini upravo sumnjivo slično onom glavnog boga Babilonaca, Marduka, u hebrejskoj inačici Merodah. ... I u babilonskoj su mitologiji Marduk i Ištar rođaci, kao što su to i Mordokaj i Estera u Knjizi o Esteri.]

${ }^{244}$ Alexander Beider navodi samo drugo tumačenje kao ispravno (Beider 2001: 500). 
glasio Vivus, pa je vjerojatno nastao tijekom srednjeg vijeka kao latinski prijevod osobnog

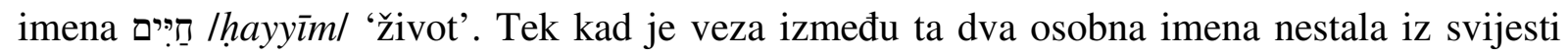
govornikā, pojavila se pučka etimologija koja je osobno ime povezala s grčkim Фoĩßo /phoĩbos/ (Beider 2001: 6-7). Iz druge nam je polovine XVII. st. poznat rabin שמואל בן אורי

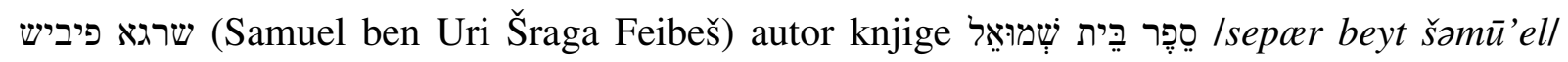
'knjiga kuće Samuelove', čiji je otac nosio tri osobna imena takvom pučkom etimologijom izvedena jedno iz drugoga, hebrejsko, aramejsko i jidiško (Beider 2001, xxv).

Većina se navedenih osobnih imena, zamjenskih imena i njihovih izvedenica te prijevodnih osobnih imena preobrazila u prezimena bez dodatnih afikasa.

\subsubsection{Moderno doba}

Glavno obilježje modernog doba u židovskoj antroponimiji jest promjena. Mijenjaju se osobna imena, mijenjaju se prezimena. Svima je njima zajedničko samo jedno - promjene se ne događaju u odnosu $1: 1$. Isto se prvotno ime u različitim slučajevima može mijenjati u veći broj drugotnih imena, a isto se tako veći broj prvotnih imena može mijenjati u isto drugotno ime (Guggenheimer H. W. i Guggenheimer E. H. 1992: x).

Promjene osobnih imenā, doduše, nalazimo već u Tanahu. Bog je ondje promijenio osobno

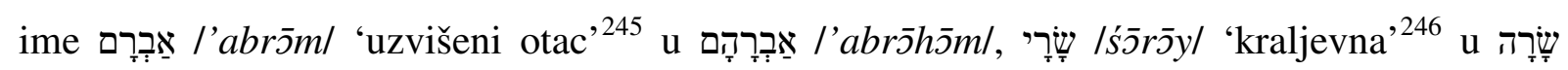

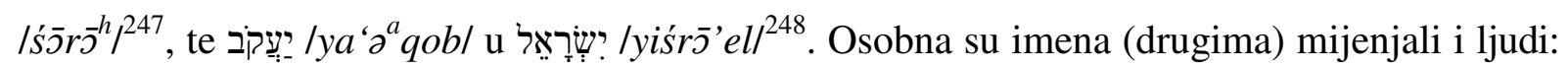

\footnotetext{
${ }^{245}$ Post 11,26. U transkripciji Silvija Grubišića: Abram.

${ }^{246}$ Post 11,29. U transkripciji Silvija Grubišića: Saraja.

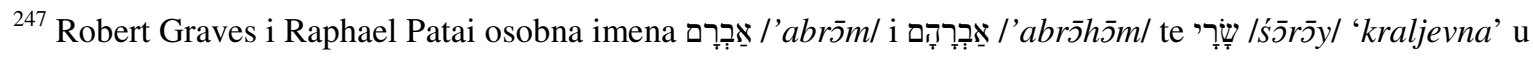

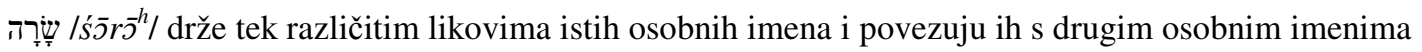
poznatima nam iz drevnog Bliskog istoka: Abamrama i Abiramu, odnosno Šarit i Šarajat (Graves i Patai 1969: 168).

${ }^{248}$ Post 32,29. U prijevodu Silvija Grubišića:

${ }^{29}$ Onaj reče: »Više se nećeš zvati Jakov, nego Izrael, jer si se hrabro borio i s Bogom i s ljudima i nadvladao si.«

Robert Graves i Raphael Patai o ovoj promjeni osobnog imena pišu (Graves i Patai 1969: 234):

»Plemenski junak mijenja ime kad počini ubojstvo, pobjegne iz svog zavičaja i prime ga u drugo pleme - ali to se ne odnosi na Jakova - ili kad se uspne na prijestol, odnosno zauzme neku novu zemlju. Ovo je posljednje, čini se, bilo razlog zbog kojeg je Abraham promijenio ime. Jakovljev prijelaz preko Jaboka
} 


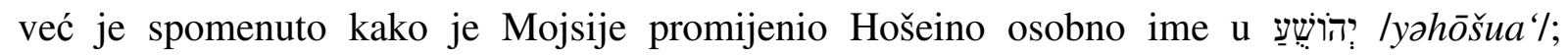

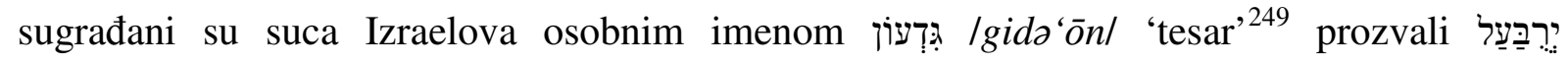
/yarubba'al/ 'Baal će se boriti' ${ }^{250}$ nakon što je ovaj srušio žrtvenik Baalu i podigao drugi

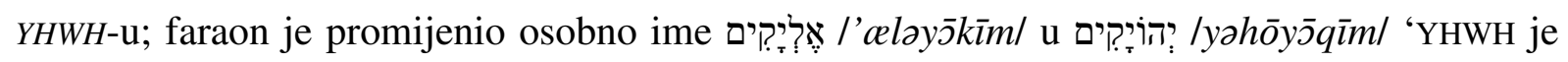
utvrdio' kad je dotičnoga postavio za kralja Jude umjesto svrgnutog mu oca ${ }^{251}$; babilonski je

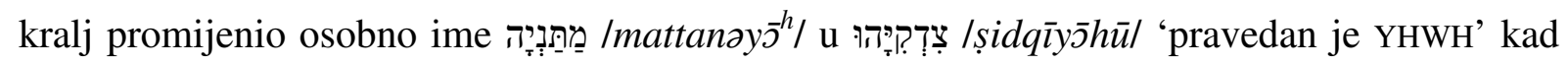
je istoga postavio za kralja Jude umjesto svrgnutog mu nećaka ${ }^{252}$; a dvorjanički je starješina

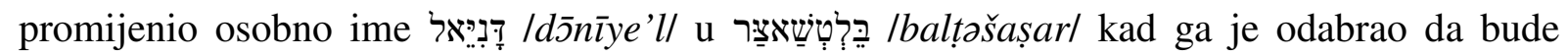
jedan od kraljevih slugu ${ }^{253}$. Uzimanje novog osobnog imena pri stupanju na novu dužnost

označavao je važnu promjenu u njegovu položaju: dotada je bio najmljeni sluga kod Labana, svog tasta; sada postaje nezavisan poglavica, spreman da uđe u zemlju svog plemena i uzme je, osiguran očevim blagoslovom i božanskim obećanjem. «

${ }^{249}$ Suci 5,11. U transkripciji Antuna Sovića: Gideon.

${ }^{250}$ Suci 6,32. U prijevodu Antuna Sovića:

${ }^{32}$ Toga dana prozvali su Gideona Jerubaal jer se govorilo: »Neka sam Baal s njim obračuna što mu je srušio žrtvenik.«

${ }^{251} 2 \mathrm{Kr} 23,34$. U prijevodu Antuna Sovića:

${ }^{34}$ Faraon Neko postavio je za kralja Elijakima, sina Jošijina, na mjesto njegova oca Jošije. I ime mu je promijenio u Jojakim. A Joahaza je uzeo i odveo u Egipat te on umrije ondje.

${ }^{252} 2 \mathrm{Kr} 24,17$. U prijevodu Antuna Sovića:

${ }^{17}$ Babilonski je kralj postavio za kralja mjesto Jojakina njegova strica Mataniju, ali mu je promijenio ime $u$ Sidkija.

${ }^{253}$ Dan 1,7. U prijevodu Antuna Sovića:

${ }^{7}$ Dvorjanički starješina nadjene im imena: Daniel će se zvati Baltazar, Hananija Šadrak, Mišael Mešak, Azarja Abed Nego.

Osobno ime potječe iz akadskoga, a znači 'Bel (dosl. gospodar; ovdje se odnosi na vrhovnog babilonskog boga Marduka) štiti kralja'.

O ovim promjenama osobnih imena Isaac Asimov piše (Asimov 1969: 600):

"The Yahvistic names, in other words, were changed to those involving the names of Babylonian deities. For instance, Daniel ("God is the judge") becomes Belteshazzar ("Bel protect his life"), where Bel is the great Babylonian god, Marduk. Similarly, Azariah ("Yahveh helps") becomes Abednego, or, in proper spelling, Abednebo ("servant of Nebo") . Similarly, Hananiah ("Yahveh is gracious") becomes Shadrach ("Aku commands"), where Aku is, presumably, some lesser deity. Mishael ("who is what God is") becomes Meshach, a word of doubtful meaning, arising, perhaps, through the conversion by the writer of the Hebrew name into one that sounds Babylonian to his ears."

[Drugim riječima, jahvistička su imena promijenjena u ona koja uključuju imena babilonskih božanstava. Primjerice, Daniel ('Bog je sudac') postaje Baltazar ('Bal štititi njegov život'), gdje je Bal veliki babilonski bog, Marduk. Slično Azarja ('Jahve pomaže') postaje Abednego ili, pravilno napisano, Abednebo ('sluga 
ostao je običaj koji se i dan-danas njeguje među vladarima, papama i monarsima ${ }^{254}$, ali i među različitim samozvanim prorocima novih religija ${ }^{255}$ (Graves i Patai 1969: 168; Pike i Powell 2011).

U Starom svijetu Židovi prezimena mijenjaju iz nekoliko razloga, s jedne strane radi lakšeg uklapanja u okolinu osobnim imenom i prezimenom, katkad i pri promjeni vjere, zatim radi moguće veće probitačnosti u poslovnom svijetu ${ }^{256}$, ali i radi pukog čuvanja žive glave. U svijetu u kojem je antisemitizam bio jače ili slabije izražena konstanta svakodnevnog života deklarirati se Židovom svojim osobnim imenom i prezimenom nije uvijek bilo mudro. S nastupom izrazito antisemitskih političkih sustava u drugoj četvrtini XX. stoljeća taj se pristup mogao činiti ispravnim, no nacističke su vlasti i njihovi saveznici zakonski regulirali židovska osobna imena i prezimena. U nacističkoj je Njemačkoj uredbom od 17. kolovoza 1938. g. određeno 185 osobnih imena za Židove i 91 za Židovke, koje su ovi morali ubuduće nositi i koristiti u svim poslovnim i pravosudnim transakcijama. Oni među njima koji su nosili kakvo drukčije osobno ime, prvog su siječnja iduće godine dobili novo - muškarci Abraham,

Nebov'). Slično tome, Hananija ('Jahve je milostiv') postaje Šadrak ('Aku naređuje'), gdje je Aku vjerojatno neko niže božanstvo. Mišael ('tko je Bog') postaje Mešak, riječ dvojbenog značenja, koje možda potječe iz. onoga u što ga je pretvorio pisac hebrejskog imena kako bi njemu zvučalo babilonski.]

${ }^{254}$ Moguće je da tragove ovog običaja nalazimo već u Tanahu. Kralj koji je naslijedio kralja Jošiju na tronu Jude

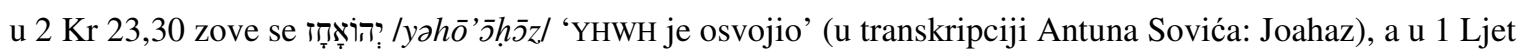

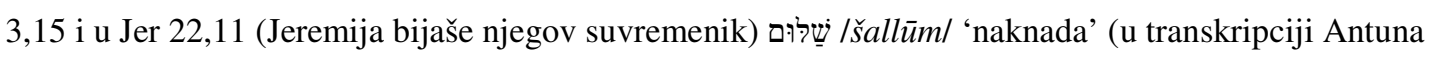
Sovića: Šalum), gdje bi prvo moglo biti njegovo osobno ime kao kralja, a drugo njegovo osobno ime

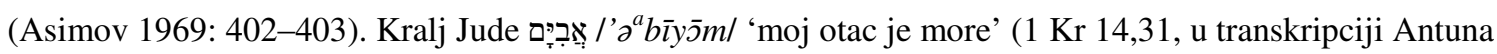

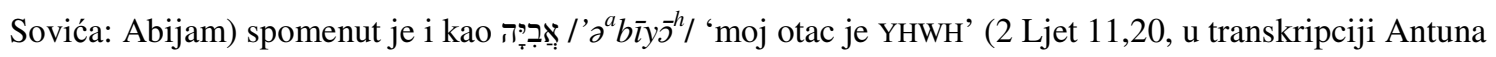
Sovića: Abija), i opet uz mogućnost da prvo bude njegovo osobno ime, a drugo njegovo osobno ime kao

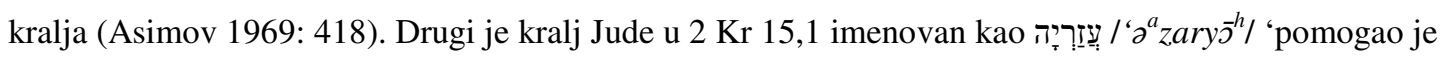

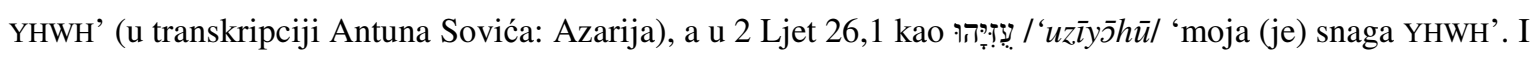
opet je moguće da je prvo bilo njegovo osobno ime, a drugo osobno ime kao kralja (Asimov 1969: 423). Da ovaj fenomen nije u Bibliji vezan samo uz muškarce pokazuje slučaj Ahasverove supruge čije je osobno ime

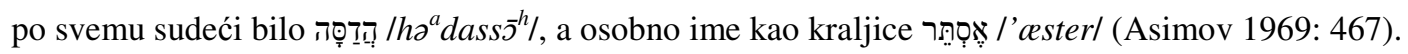

${ }^{255}$ Primjerice, Franjo Milićević iz Bosne i Hercegovine je, pošto je čuo glas koji ga zove, promijenio ime u Aba Aziz Makaja i postao guruom sekte Komaja.

https://www.magicus.info/ostalo/zrnca-za-razgovor/poznati-hercegovci-aba-aziz-makaja-najveci-zivucisvjetski-guru pristupljeno 26. prosinca 2017. g.

${ }^{256}$ O promjenama prezimena kod Židova iz ekonomskih razloga piše Ljiljana Dobrovšak (Dobrovšak 2003: 159). 
a žene Sara (Chazan 2007: 768). Ustaške su pak vlasti Naredbom o promjeni židovskih prezimena broj 336-Z. p. 1941 od 4. lipnja 1941. g. sva do tada promijenjena prezimena Židova vratile u prvobitni lik ${ }^{257}$ (Brandl 2015ª : 677, bilješka 7).

Iseljenici su u SAD i druge države, u želji da svoje imenske formule čim više uklope u lokalne okvire, prvo odbacivali dočetke prezimena koji su ih etiketirali kao useljenike (slavenske -sky ili -witz, ali i tipično jidiške poput -berg ili -stein), a sa svakim su novim pokoljenjem birali osobna imena bliža okolini u kojoj su živjeli umjesto onih tradicionalnih židovskih. Istodobno ondje nailazimo i na drugu tendenciju, koja se kreće u suprotnom smjeru. Među židovskim su vjernicima u dijelovima SAD-a gusto naseljenim Židovima od kraja Drugog svjetskog rata izrazito židovska osobna imena u porastu. Tri pokoljenja nakon masovnih useljavanja u bijegu od šoe u Europi, Židove u SAD-u više ne prati stigma useljenika, stranaca, oni se ondje osjećaju dovoljno kod kuće da mogu opet izražavati svoju različitost, te židovi-vjernici u SAD-u teže uključivanju sve većih utjecaja hebrejskog i jidiša u svoj govor na engleskom jeziku, pa tako i u svoju antroponimiju. Time kao da biraju srednji put između dviju krajnosti, asimilacije i izolacije (Bunin Benor 2016: 441, 445, 449; Guggenheimer H. W. i Guggenheimer E. H. 1992: x). Situaciju slikovito opisuje Shmuel Gorr (Gorr 1992: ix):

The vicissitudes of history have allowed assimilation to cause Jewish names, in cases where they have been given, to be used in a manner not unlike at meetings of secret societies. Who would suspect that Gary is really (in some cases) the transposition of Tzvi Herschel - the "Herschel" being pronounced "Gershel" in Russia, and on migrating to a Western country, the "Gary" was selected as being least obvious as a Jewish derivative? Quite an amazing feat! But do we need such acrobatics? Why not just simply Tzvi, or Tzvi Herschel, or Herschel?

When a Jew is called to the reading of the Torah, he is called up by his full Hebrew/Yiddish name, but on a regular basis, he is known by his non-Jewish name. There are many strictly orthodox Rabbis who are also guilty of this cryptostyle existence. What kind of a name for an orthodox Rabbi is Harav Irving Critton? In truth, his name is Harav Yisrael Kritchevski. ${ }^{258}$

\footnotetext{
${ }^{257}$ To potvrđuju i žigovi s upisanim izvornim prezimenom u matičnim knjigama rođenih.

${ }^{258}$ Nestalnost je povijesti omogućila da se zbog asimilacije židovska imena, u slučajevima kada su bila nadijevana, koriste na način nalik onome na sastancima tajnih društava. Tko bi mogao posumnjati da je Gary ustvari ( u nekim slučajevima) transponirani Tzvi Herschel - »Herschel« se u Rusiji izgovara
} 
U Izraelu su stvari krenule suprotnim tokom. Cionistički je pokret, između ostaloga, probudio želju za učenjem i korištenjem hebrejskog jezika među Židovima, pa i interes za izvornu židovsku antroponimiju. Ta je tendencija dosegla vrhunac nakon useljavanja u Mandatnu Palestinu, a kasnije u Izrael. Osobna su imena i prezimena nastala i uvezena iz stare postojbine mijenjana u hebrejska ili pak osobna imena koja zvuče hebrejski. Tri su osnovna

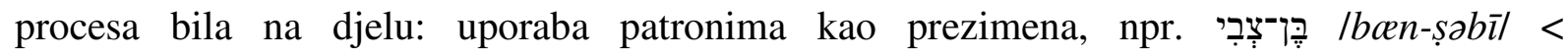
Шимшелевич, jezik te sličan plan izraza nehebrejskog i hebrejskog prezimena, npr. שרת (Šaret) <

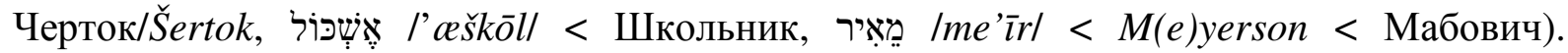
Zanimljiv je slučaj političara, književnika i pjesnika izvornog imena Шнеер Залмен Рубашов (1889. - 1974.), koji je svoje novo prezime שז"ר ( dotadašnje imenske formule. Neka su osobna imena nehebrejskog podrijetla tijekom povijesti doživljavala promjene, te su se tako promijenjena poslije pučkom etimologijom mijenjala u hebrejska osobna imena sasvim druge izvorne motivacije. Shmuel Gorr navodi primjer takve pogrešne interpretacije (ženskog) osobnog imena (Gorr 1992: 8):

fr. Fromentine 'sorta crnog grožđa' Frumet 'pobožna (puč. et.)' חִ $/ h \partial^{a} s \bar{l} d \bar{j}^{h} /$

Zbog velikog je interesa za hebrejska osobna imena i prezimena u sklopu Jewish Agency osnovan Odbor za hebrejsko imenovanje (וַעַד שמוֹן עִברי), koji danas djeluje u sklopu izraelskog Ministarstva unutrašnjih poslova te je počelo sastavljanje Hebrejskog imenara (שמוֹן צִברי), koji donosi kako pravila za hebreizaciju nehebrejskih osobnih imena, tako i informacije o pojedinim hebrejskim osobnim imenima (Guggenheimer H. W. i Guggenheimer E. H. 1992: x, Chazan 2007: 769) $)^{259}$.

Kao primjer promjena osobnog imena i prezimena kroz koje je prošao pojedinac tijekom svoga života može poslužiti sljedeći:

1. rođen je 1924. g. u Budimpešti kao Hoffmann Ferenc

2. poslije Drugog svjetskog rata promijenio je prezime u Kishont Ferenc

»Gershel«, te da je pri preseljenju na Zapad »Gary« odabrano jer najmanje sliči židovskoj izvedenici? Kakvog li podviga! Ipak, trebamo li takvih akrobacija? Zašto ne samo Tzvi, ili Tzvi Herschel, ili Herschel? Kad se Židova poziva da čita Toru, poziva ga se njegovim punim hebrejskim/jidiškim imenom, ali je u svakodnevnom životu poznat po svome nežidovskom imenu. Postoji mnogo strogo ortodoksnih rabina koji su također krivi za ovaj kripto-stil postojanja. Kakvo je to ime za ortodoksnog rabina Harav Irving Critton? Ustvari, njegovo je ime Harav Yisrael Kritchevski.

${ }^{259}$ V. i Kaganoff 1996: 77 
3. nakon useljenja u Izrael 1949. g. promijenjeni su mu i osobno ime i prezime (tako da zvuče

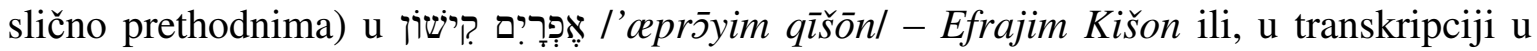
kojoj je poznat u nas, Ephraim Kishon ${ }^{260}$.

${ }^{260}$ Mađarska Wikipedija navodi sve tri imenske formule: https://hu.wikipedia.org/wiki/Efr\%C3\%A1jim_Kishon. Isto tako i hebrejska:

https://he.wikipedia.org/wiki/\%D7\%90\%D7\%A4\%D7\%A8\%D7\%99\%D7\%9D_\%D7\%A7\%D7\%99\%D7\% A9\%D7\%95\%D7\%9F 


\section{IZVORI}

Podaci su za ovaj rad sakupljeni iz triju izvora, iz knjige Gavre Schwarza Povijest zagrebačke židovske općine od osnutka do 50-tih godina 19. vijeka ${ }^{261}$, koja donosi tri popisa zagrebačkih Židova, dva s početka XIX. st., a treći iz sredine istog stoljeća, iz matičnih knjiga rođenih pohranjenih u Hrvatskom državnom arhivu, koje obuhvaćaju godine 1849. - 1998. (uz iznimku godine 1857.) te iz podataka skupljenih s nadgrobnih spomenika na izraelitskom odjelu zagrebačkog groblja Mirogoj, koji su dvopismeni - latinični, na njemačkom i hrvatskom jeziku, te hebrejski - kao i onih iz baze podataka Gradskih grobalja koja je dostupna na internetu ${ }^{262}$.

${ }^{261}$ Zagrebačka je židovska općina u svojoj povijesti nekoliko puta mijenjala ime.

Osnovana je kao Izraelitička bogoštovna općina Zagreb.

»Za vrijeme Kraljevine [Srba, Hrvata i Slovenaca/Jugoslavije], u Zagrebu se postupno uvodi i jevrejsko ime, no i dalje se za općinu koristi službeni naziv izraelitička, a u govornom jeziku, osobito među cionistima, dosljedno se upotrebljava termin Židov i to s velikim Ž. Do 1923. godine izraelitička općina postaje židovskom, no 1929. godine je Zakonom o verskoj zajednici Jevreja u Kraljevini Jugoslaviji propisana uporaba jevrejskog imena, pa općina postaje Jevrejskom, iako se u svakodnevnom govoru, tisku i nekim službenim dokumentima i dalje rabe oba termina« (Brandl 2015' $:$ 45).

Bilješka vezana za isti odlomak glasi:

»Ivo Goldstein, Židovi u Zagrebu 1918.-1941. (Zagreb: Novi liber, 2005.), 5-8. Zanimljivo je da se u Sarajevu upotrebljava i pojam židovski i jevrejski. Autor navodi da se čini da je židovski prevladavao uglavnom u cionističkim i aškenaskim krugovima, dok su sarajevski Sefardi u pravilu koristili termine Jevrej i jevrejski« (Brandl 2015 $:$ 45, bilješka 46).

U drugom odlomku piše:

»Sutradan, 16. svibnja [1941. g.], dopuštena je i obnova rada Općine, prema usmenoj odluci Židovskog odsjeka Ustaškog redarstvenog povjerenstva u Zagrebu, pod nazivom Židovska bogoštovna općina u Zagrebu (ŽBOZ)«(Brandl 2015 $5^{\text {b }: 89) . ~}$

Druga bilješka dalje u tekstu glasi:

»Židovska bogoštovna općina u Zagrebu je postupno od 1946. postala Jevrejska vjeroispovjedna općina Zagreb. Nakon što je iz naziva općine izbačeno vjeroispovijedna, općina u Zagrebu nosila je do 1991., naziv Jevrejska općina Zagreb, a od devedesetih Židovska općina Zagreb (ŽOZ). U tekstu sam slijedila i današnji naziv Općine, između ostalog i radi imena njezinog arhivskog fonda u arhivu JIM-a u Beogradu, ali i naziv Jevrejska vjeroispovjedna općina Zagreb, kao i Jevrejska općina Zagreb, s obzirom da se u većini dokumenata sama naziva tako« (Brandl 2015 : 122, bilješka 233).

Kako bi se izbjegli nesporazumi, u tekstu će se na nju referirati kao na zagrebačku židovsku općinu.

${ }^{262}$ Kako su se osobna imena i prezimena u bazi podataka Gradskih grobalja (Gradska Groblja 2014) pisala verzalom, tako će se navoditi i u radu. Osobna imena i prezimena s nadgrobnih spomenika pisana su verzalnim početnim slovom. 


\subsection{Knjiga Povijest zagrebačke židovske općine od osnutka do 50-tih godina 19. vijeka Gavre Schwarza}

\subsubsection{Gavro Schwarz ${ }^{263}$}

Schwarz Gábor (1872. - 1942.) rođen je u Nádudvaru, gradu u današnjoj Hajdu-biharskoj županiji na istoku Mađarske. Obitelj se prvo preselila u Dardu, a zatim u Požegu, gdje je završio osnovnu školu i niže razrede gimnazije. Godine 1886. upisuje rabinski seminar u Budimpešti te jedanaest godina poslije polaže rabinski ispit.

Rabinom je u Karlovcu imenovan 1896. g., ali je već tri godine prije toga u vrijeme velikih blagdana bio držao propovijedi na hrvatskom jeziku. Preselio se u Zagreb željom i preporukom zagrebačke židovske općine, gdje je brzo napredovao: odmah je postao učiteljem Talmud-Tore u zagrebačkoj židovskoj općini, 1901. je g. postavljen za učitelja židovskog vjeronauka u svim srednjim školama u gradu, od 1906. je g. zamjenik nadrabina, od 1918. je g. nadrabinov koadjutor, 1923. je g. izabran rabinom, a 1926. je g. svečano uveden u dužnost nadrabina. U vrijeme Prvog svjetskog rata djelovao je kao vojni rabin austrougarske vojske na ratištu, u Srbiji.

U prvim danima nakon osnivanja Nezavisne države Hrvatske bio je uhićen, preslušan i pušten s drugim dužnosnicima zagrebačke židovske općine. Sâm nije bio deportiran, ali je deportiranjima svjedočio i umro u doba najžešćih progona Židovā u Zagrebu.

Gavro Schwarz je uza sve svoje dužnosti bio i plodan autor. Godine je 1902. izdao prvi židovski molitvenik s prijevodom na hrvatski jezik. Usto je pisao udžbenike, priručnike, brojne članke i recenzije. Danas su najvažnija njegova djela iz domene židovske povijesti: Povijest Židova od babilonskog sužanjstva do današnjih dana (1899.), prva povijest Židovā objavljena na hrvatskom jeziku, više priloga o povijesti Židovā u Hrvatskoj u Vjestniku kr. hrvatsko-slavonsko-dalmatinskog zemaljskog arkiva i u Jevrejskom glasu te knjiga Povijest zagrebačke židovske općine od osnutka do 50-ih godina 19. vijeka (1939.).

\footnotetext{
${ }^{263}$ Biografija je Gavre Schwarza preuzeta iz neobjavljenog rukopisa Židovskog biografskog leksikona. Dostupno na:

http://zbl.lzmk.hr/?p=2121

Pristupljeno 31. kolovoza 2018.
} 


\subsubsection{Povijest zagrebačke židovske općine od osnutka do 50-tih godina 19. vijeka}

Poticaj je za pisanje knjige o zagrebačkoj židovskoj općini Gavro Schwarz dobio pronašavši pola arka papira s popisom 27 članova Hevre Kadišs ${ }^{264}$ iz godina 1840. - 1843., što ga je nadahnulo da sastavi popis zagrebačkih Židova u pedesetim godinama XIX. st. Kako je sâm 1925. g. preuzeo vođenje matičnih knjiga, i u njima je nalazio podatke koji su mu to omogućili. Imao je pristup i matici Hevre Kadiše s popisom članova, datumima pristupanja Hevri Kadiši i datumima njihovih smrti. Planovi su se za objavljivanje toga popisa zagrebačkih Židova redom izjalovili, Zagrebačka je židovska općina izdala godišnjak za 1927. g, u kojem je objavljen mali dio popisa, no nije nastavila s tom izdavačkom djelatnosti. Propala je i zamisao o spomen-knjizi povodom 150 godina naseljavanja Židovā u Zagrebu i 150 godina Hevre Kadiše 1937. g.

Tek je tada Gavro Schwarz odlučio objaviti knjigu u kojoj će popisu pripojiti tekst o povijesti zagrebačke židovske općine u kojem je objedinio materijale koje je prije toga publicirao u Vjestniku kr. hrvatsko-slavonsko-dalmatinskog zemaljskog arkiva. U sređivanju se popisa koristio sljedećim izvorima: popisom Židova u gradskoj jurisdikciji iz 1808. g., popisom laškouličnih Židova u biskupskoj jurisdikciji iz 1812. g., popisom članova Hevre Kadiše od 1840. do 1843. g., popisom laškouličnih Židova iz 1848 g., još neslužbenim maticama rođenih, vjenčanih i umrlih od 1852. do 1858. g., maticom Hevre Kadiše s popisom svih članova od 1854. g. nadalje, konskripcijama iz 1854. i 1855 g., konskripcijom svih Židova u Zagrebu iz 1858. g. (prije negoli su uvedene službene matice) te službenim maticama od 1858. g. nadalje (Schwarz 1939: 3-4).

Knjiga se sastoji od predgovora (str. 3-5), poglavljā Osnutak općine i njen porast do 1850-tih godina (str. 7-16), Znameniti dogođaji [sic] u tridesetim i četrdesetim godinama (str. 17-42), s potpoglavljima Napadaji trgovaca na Židove g. 1838 (str. 17-21), Nastojanje oko poboljšanja građanskih prava (str. 22-31), Reforme u hramu i razdor u općini (str. 31-38), Osnutak škole (str. 39-40) te Kupovanje posjeda za bogomolju i groblje (str. 41-42), poglavlja Popis članova zagrebačke izr. općine oko godine 1850 (str. 43-93) s potpoglavljima

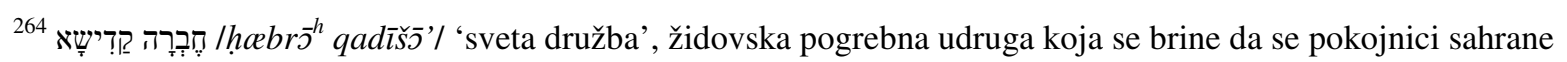
prema židovskim propisima i tradicijama.
} 
Popis iz godina 1840-1843 (str. 45-76) te Alfabetski popis prema konskripciji $C^{265}$ (str. 76-93), Dodatka (str. 94-95) koji donosi Majstorski list Morica Farkaša, Krapina, 1846 (str. 94), Čestitku Humanitäts-Vereina prigodom vjenčanja Morica Farkaša i Roze Spitzer, Zagreb, 1847 (str. 95), Iz dietah siednice Občine laškoulica godine 1850 - 15(4) u Zagrebu deržane zaključak na $\S I I$ (str. 95), zatim Alfabetski popis porodica (str. 96-100), Pregled zemalja i mjesta iz kojih su se Židovi doselili u Zagreb (str. 101-104) te reprodukcije fotografijā: Hram (1867) (između stranicā 16 i 17), Hram (1867) (između stranicā 24 i 25), Zgrada Židovske općine - uredi i škola (1898) (između stranicā 32 i 33), Stanbena zgrada Židovske općine (1927) (između stranicā 48 i 49), Dom Zaklade Lavoslava Schwarza (1910-1931-1939) (između stranicā 64 i 66), Dječji dom Izr. ferijalne kolonije u Crikvenici (1922) (između stranicā 80 i 81) i Dječji dom Izr. ferijalne kolonije u Ravnojgori (1939) (između stranicā 88 i 89).

Za potrebe su ovog rada uz popise zagrebačkih Židova sa str. 43 - 93 važni i popis Židova u gradskoj jurisdikciji iz 1808. g. (nepaginirani prilog između stranicā 8 i 9) i popis laškouličnih Židova iz biskupske jurisdikcije iz 1812. g. $(\text { str. } 13)^{266}$.

\subsection{Matične knjige rođenih}

U Hrvatskom su državnom arhivu pohranjene židovske matične knjige rođenih od 1849. do 1898. g. (uz iznimku 1857. g.). Za godine 1859. do 1870. postoje paralelni zapisi u dvije matične knjige, različitih obrazaca i upisivani različitim rukopisima (Matične knjige rođenih). Prva matična knjiga obuhvaća 20 godina, od 1849. do 1870. g., ali bez 1858. g. ${ }^{267}$ i donosi 165 numeriranih zabilježenih novorođenaca ${ }^{268}$. Podaci su se unosili prema zaglavlju

\footnotetext{
${ }^{265}$ Konskripcija iz 1858. g., prije uvođenja službenih matica.

${ }^{266}$ Pri navođenju podataka iz popisā iz knjige Gavre Schwarza bilježim broj pod kojim je pojedinac zaveden u Popisu iz godina 1840-1843. (Schwarz 1930: 45-76) i Alfabetskom popisu prema konskripciji C iz 1858. g. (Schwarz 1930: 76-93), dok prije brojeva iz popisa gradske jurisdikcije iz 1808. g. bilježim slova $S t$ (Schwarz 1930: nepaginirana stranica između str. 8 i 9), a prije onoga biskupske jurisdikcije iz 1812. g. slovo $A$ (Schwarz 1930: 13), kao što je to činio i on sâm u svojoj knjizi.

${ }^{267}$ U Hrvatskom državnom arhivu ti su zapisi digitalizirani u obliku preslika numeriranih od M01162381 do M01162397.

${ }^{268}$ U matičnim se knjigama neki brojevi upisa pojavljuju dvaput, a neki su brojevi preskočeni, tako da broj upisanih pojedinaca nije nužno identičan službenim brojevima zapisa.
} 
Tablica 1: Zaglavlje Geburts-Protokolla od 1849. do 1870. g. (M01162381-M01162397)

\begin{tabular}{|c|c|c|c|c|c|c|c|c|c|c|c|c|c|c|c|c|}
\hline \multirow{2}{*}{ Trto. } & \multirow{2}{*}{$\begin{array}{c}\text { Tame } \\
\text { der } \mathfrak{G e b o r n e n}\end{array}$} & \multicolumn{3}{|c|}{ Datum der Geburt } & \multicolumn{4}{|c|}{ 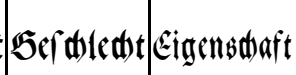 } & \multicolumn{2}{|c|}{ Eltern des $\mathfrak{G e b o r n e n}$} & \multirow{2}{*}{$\left|\begin{array}{l}\text { Bjofhnung } \\
\text { oer Eltern }\end{array}\right|$} & \multirow{2}{*}{$\begin{array}{c}\text { Rame } \\
\text { Der Retbanme }\end{array}$} & \multicolumn{2}{|c|}{$\mathfrak{B e d}$ Rnaben } & \multirow{2}{*}{ 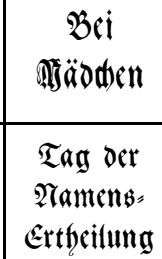 } & \multirow{2}{*}{$\begin{array}{c}\text { Tame } \\
\text { Oer gatfen oder Zeugen }\end{array}$} \\
\hline & & חודש & $\begin{array}{l}\text { יום } \\
\mathfrak{T} a \mathfrak{d}\end{array}$ & 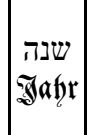 & 默 & 气 & $\stackrel{\Xi}{\Xi}$ & & des baters bor: = und 3 Zuname & $\begin{array}{c}\text { der Mfutter } \\
\text { Sor:= und Zuname }\end{array}$ & & & $\begin{array}{c}\text { Tag } \\
\text { der } \\
\text { Berdencidunt }\end{array}$ & $\begin{array}{c}\text { Ttame des } \\
\text { Beidneidungts } \\
\text { Operateults }\end{array}$ & & \\
\hline
\end{tabular}

Tablica 2: Zaglavlje Geburts-Protokolla od 1858. do 1878. g. (M01162277-M01162366)

\begin{tabular}{|c|c|c|c|c|c|c|c|c|c|c|c|c|c|c|c|c|}
\hline \multirow{2}{*}{ No. } & \multirow{2}{*}{$\begin{array}{c}\text { Trame } \\
\text { der } \\
\text { Geborenen }\end{array}$} & \multicolumn{3}{|c|}{$\begin{array}{l}\text { Datum } \\
\text { der } \\
\text { Seburt }\end{array}$} & \multicolumn{2}{|c|}{$\begin{array}{c}\mathfrak{G} \mathfrak{e}= \\
f \mathfrak{d})(\mathfrak{e} d) t\end{array}$} & \multicolumn{2}{|c|}{$\begin{array}{l}\text { Eigen } \\
\text { fdaft }\end{array}$} & \multicolumn{2}{|c|}{ Eltern des Geborenen } & \multirow{2}{*}{$\left|\begin{array}{c}\text { Bgofunung } \\
\text { der } \\
\text { Eltern }\end{array}\right|$} & \multirow{2}{*}{$\begin{array}{c}\text { Tame } \\
\text { der } \\
\text { Rebamme }\end{array}$} & \multicolumn{2}{|c|}{$\mathfrak{B e i}$ Rnaben } & \multirow{2}{*}{ 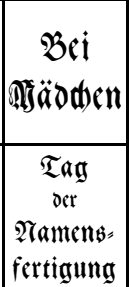 } & \multirow{2}{*}{$\begin{array}{c}\text { Tame } \\
\text { des } \\
\text { gatben ode } \\
\text { Zeugen }\end{array}$} \\
\hline & & Monat & $\mathfrak{T a g}$ & $\begin{array}{c}\text { Safbr, } \\
\text { Efoder d), } \\
\text { Sthanaf }\end{array}$ & :气 & 气 & 气 & 总 & $\begin{array}{c}\text { des } \mathfrak{B a t e r s} \text { bor: } \\
\text { und } \\
\text { Zuname }\end{array}$ & $\begin{array}{c}\text { der Myutter } \mathfrak{b o r}:= \\
\text { und } \\
\text { Zuname }\end{array}$ & & & $\begin{array}{c}\text { Tad } \\
\text { dor } \\
\text { Beidneidung }\end{array}$ & $\begin{array}{c}\text { Tame } \\
\text { des } \\
\text { Operateurs }\end{array}$ & & \\
\hline
\end{tabular}

Tablica 3: Zaglavlje Matice rodjenih, Geburts-Protokolla od 1879. do 1898. g. (M01162101-M01162272)

\begin{tabular}{|c|c|c|c|c|c|c|c|c|c|c|c|c|c|c|c|}
\hline \multirow{2}{*}{ 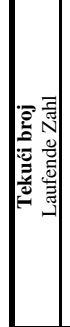 } & \multirow{2}{*}{$\begin{array}{c}\text { Ime rodjenoga } \\
\text { Name des } \\
\text { Geborenen }\end{array}$} & \multicolumn{3}{|c|}{$\begin{array}{c}\text { Vrieme } \\
\text { rodjenja } \\
\text { Zeit der Geburt }\end{array}$} & $\begin{array}{c}\text { Spol } \\
\text { Ge- } \\
\text { schlecht }\end{array}$ & $\begin{array}{c}\text { Vlasti- } \\
\text { tost } \\
\text { Eigenschaft }\end{array}$ & \multicolumn{2}{|c|}{$\begin{array}{l}\text { Roditelji rodjenoga } \\
\text { Eltern des Geborenen }\end{array}$} & \multirow{2}{*}{$\mid \begin{array}{c}\text { Stan rodi- } \\
\text { teljah } \\
\text { Wohnung der } \\
\text { Eltern }\end{array}$} & \multirow{2}{*}{$\begin{array}{c}\text { Ime } \\
\text { primalje } \\
\text { Name } \\
\text { der Hebamme }\end{array}$} & \multicolumn{2}{|c|}{$\begin{array}{l}\text { Kod dječakah } \\
\text { Bei Knaben }\end{array}$} & \multirow{2}{*}{\begin{tabular}{|c|} 
Kod djevo- \\
jakah za \\
upis \\
prijav- \\
ljena \\
Bei Mäd- \\
chen uzr \\
Matrikuli- \\
rung gemel- \\
det
\end{tabular}} & \multirow{2}{*}{$\begin{array}{l}\text { Ime kuma } \\
\text { Name } \\
\text { der Pathen }\end{array}$} & \multirow{2}{*}{$\begin{array}{c}\text { Opazka } \\
\text { Anmerkung }\end{array}$} \\
\hline & & $\begin{array}{l}\text { mjesec } \\
\text { Monat }\end{array}$ & & a & 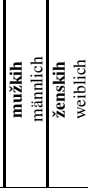 & 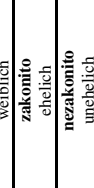 & $\begin{array}{c}\text { Ime i prezime } \\
\text { otca } \\
\text { Vor- und Zuname des } \\
\text { Vaters }\end{array}$ & $\begin{array}{c}\text { Ime i prezime } \\
\text { majke } \\
\text { Vor- und Zuname } \\
\text { der } \\
\text { Mutter }\end{array}$ & & & 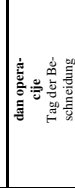 & $\begin{array}{c}\text { Ime operatera } \\
\text { Name des Opera- } \\
\text { teurs }\end{array}$ & & & \\
\hline
\end{tabular}


prikazanom na Tablici 1. Po svemu je sudeći podatke unosila jedna ruka, i to pismom Sütterlin (rukopisnom goticom).

Druga matična knjiga obuhvaća 41 godinu, od 1858. do 1898. g. i donosi 2020 numeriranih zabilježenih novorođenaca. Od 1858. su do 1878. g. podaci o 797 numeriranih prinova unašani prema jednojezičnom, njemačkom zaglavlju prikazanom na Tablici $2^{269}$, a daljnjih je 1223 numeriranih novorođenaca unašano prema dvojezičnom hrvatsko-njemačkom zaglavlju prikazanom na Tablici $3^{270}$. U ovoj su se matičnoj knjizi pojedinci obrojčavali in continuo sve do kraja 1889. g., a u preostalih deset godina numeracija svake godine počinje ispočetka. Podaci su upisivani bilo pismom Sütterlin (rukopisna gotica) bilo latinicom bilo mješavinom jednog i drugoga. ${ }^{271} \mathrm{Za}$ neke je pojedince vidljivo da su podaci upisivani različitim rukopisima, katkad čak i u slučajevima podataka za koje bismo očekivali da moraju biti uneseni istodobno, poput osobnih imena i prezimena djeteta i roditeljā te datuma djetetova rođenja.

Od svih navedenih, u korpus su ušli podaci o broju pod kojim je osoba uvedena, podaci o osobnom imenu i prezimenu, datumu rođenja i spolu (katkad se isti ne da zaključiti iz samog osobnog imena) osobe, te osobna imena i prezimena njezinih roditelja ${ }^{272}$.

Sljedeći su podaci za koje ne postoje rubrike, a koji su u nekim slučajevima upisani: je li riječ o dvojcima, je li dijete mrtvorođeno, o naknadnom upisu ili priznanju djeteta, o promjenama osobnih imena, prezimena i vjere, o sklapanju i razvođenju brakova te o smrti pojedinca. Mnogi su od tih podataka uneseni preko ostalih rubrika, a za neke su postojali i unaprijed pripremljeni žigovi čiji je tekst trebalo nadopuniti podacima o pojedincu.

\footnotetext{
${ }^{269}$ U Hrvatskom državnom arhivu ti su zapisi digitalizirani u obliku preslika numeriranih od M01162277 do M01162366.

${ }^{270}$ U Hrvatskom državnom arhivu ti su zapisi digitalizirani u obliku preslika numeriranih od M01162101 do M01162272.

${ }^{271} \mathrm{U}$ čitanju rukom pisanih podataka u matičnim knjigama rođenih pohranjenima u Hrvatskom državnom arhivu od velike mi je pomoći bio priručnik W. Koppeheela za učenje krasopisa na pismu Sütterlin (rukopisna gotica) (Koppeheel 1914: 18-19).

${ }^{272}$ Pri navođenju podataka iz matičnih knjiga rođenih pohranjenih u Hrvatskom državnom arhivu prvo navodim godinu u kojoj je pojedinac uveden u maticu, a potom redni broj pod kojim je to učinjeno.

Godina u kojoj je pojedinac uveden u maticu ne mora nužno biti i godina rođenja pojedinca, jer ima više slučajeva naknadnog upisa rođenja u matice.
} 


\subsection{Izraelitski odjel zagrebačkog groblja Mirogoj}

Danas židovski (izraelitski) odjel Starog groblja Mirogoj zauzima trinaest polja na jugozapadnom kraju te tri južna paviljona (915-7) i tri polja (924) arkada uz njihov zapadni $\operatorname{rub}^{273}$. Od navedenih je trinaest polja šest $(1,2,3,4,9,10)$ pravilnog četverokutnog oblika približnih dimenzija 70×45 m (prvi red uz Aleju Hermanna Bolléa), pet je $(5,6,7,8,11$ ) pravilnog četverokutnog oblika približnih dimenzija 50×45 m (drugi red), dok su polja 12 i 13 oblikom nepravilnija, što je uvjetovano južnom granicom groblja ${ }^{274}$.

\subsection{1 Židovski i nežidovski simboli na Mirogoju}

Kako je na židovskom odjelu Mirogoja, posebice nakon Drugog svjetskog rata, moguće naći i druge, nežidovske grobove, treba na neki način razlučiti koji podaci s nadgrobnih spomenika dolaze u obzir za analizu, a koje je moguće odbaciti. To se može napraviti zahvaljujući izrazito židovskim obilježjima na samim grobovima, ali i onima izrazito nežidovskima ${ }^{275}$.

\subsubsection{Hebrejski natpis}

Nadgrobni je natpis na hebrejskom jeziku najizrazitiji pokazatelj da je riječ o židovskom grobu. Ti su natpisi sadržajno raznoliki.

Većina njih donosi osobno ime i prezime pokojnika, s time da je prezime (ali i osobno ime, ako nije hebrejskog ili aramejskog podrijetla, što je češće u žena negoli u muškaraca) u najvećem broju slučajeva pisano jidiškim pravopisom ${ }^{276}$. Katkad je osobno ime pokojnika prikazano akrostihom: prva slova pojedinih stihova čitana redom daju osobno ime pokojnika. U pravilu se uz osobno ime piše i osobno ime oca, kojemu prethode riječi 끄 /ben/ 'sin' ili

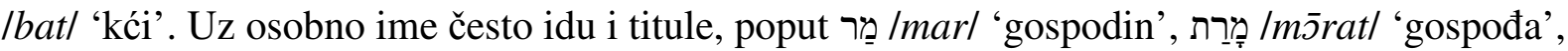

\footnotetext{
${ }^{273}$ Uz navedena postoji još jedno polje, br. 119, na Novom groblju, ali ti podaci nisu ušli u ovaj rad.

${ }^{274}$ Pri navođenju podataka s izraelitskog odjela Starog groblja na Mirogoju slijedim obrazac: broj polja (1-13) ili arkade (915-917, 921-924), razred (I, II/I ili II, odnosno ARKP ili ARKVEL), te broj grobnog mjesta.

${ }^{275}$ O simbolima na židovskim grobovima v. Hershkovitz 2012; Potok 1993.

${ }^{276}$ Jidiš se piše slovima hebrejskog alef-beta, prilagođenog fonološkom sustavu i strukturi riječi dotičnog južnonjemačkog jezika, pri čemu neka slova, koja u hebrejskom sva predstavljaju isključivo suglasnike, postaju oznakama samoglasnika.
} 


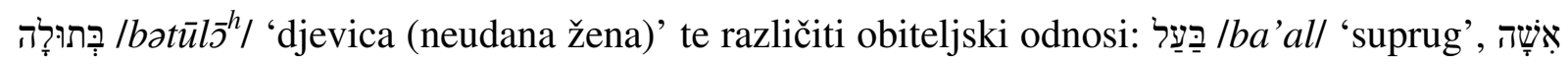

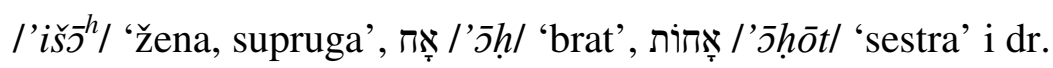

$\mathrm{Na}$ hebrejskim su nadgrobnim spomenicima u pravilu navedeni datum smrti (ne i rođenja) prema židovskom kalendaru, te dob. Sam datum ne mora biti izražen numerički, već se može prikazati i nazivom blagdana koji je pao upravo u taj dan. Sve su brojke napisane hebrejskim slovima koja služe i kao brojevi. Ako se broj sastoji samo od jednog slova, iza njega se stavlja oznaka ', a ako je višeslovan, prije zadnjeg se slova stavlja oznaka ". Ako se donosi godina smrti, poslije same godine izražene brojevnim vrijednostima slova hebrejskog alef-beta dolazi

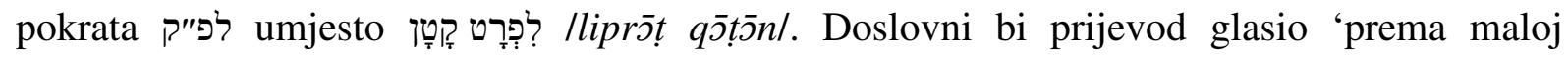
specifikaciji', a značenje pokrate (koja se često prikazuje kao ligatura sva tri slova) jest da se izražavaju samo stotice, desetice i jedinice godine, dok se tisućica (5000. od stvaranja svijeta) podrazumijeva.

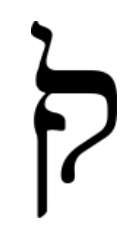

Ne smije se zaboraviti da u židovskoj tradiciji dan ne započinje u pola noći, već zalaskom Sunca, pa se datumi smrti izraženi židovskim i svjetovnim kalendarom katkad razlikuju za jedan dan. Na Mirogoju je moguće naći i primjere pogrešno uklesanog dana odnosno godine smrti hebrejskim slovima ${ }^{277}$.

Najčešći su tekstovi na grobovima tri pokrate ${ }^{278}$ :

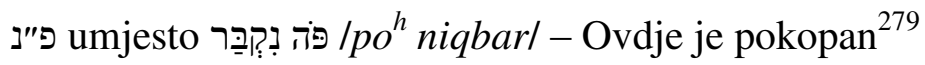

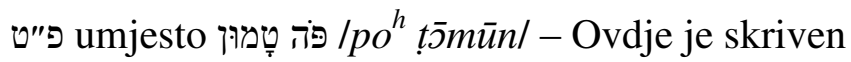

\footnotetext{
${ }^{277}$ Više o židovskom kalendaru u Mugdan 1996, Da-Don 2004: 45-50 i Bushwick 2005: 59-124. Nathan Bushwick donosi i matematičku podlogu za izračunavanje danā, mjeseci i godina židovskog kalendara.

${ }^{278}$ Još se jedna pokrata s nadgrobnih ploča pojavljuje u Hrvatskoj, iako ne i na zagrebačkom groblju. To je צמ"ק

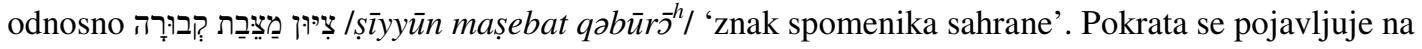
desecima nadgrobnih spomenika iz XVIII. i XIX. st. na (sefardskom) židovskom groblju u Splitu. Izvan Hrvatske je nalazimo u Španjolskoj, na Balearima i u sjevernoj Africi, na području tradicionalno naseljenom Sefardima (Efron i Kečkemet 1973: 11-12). Više o hebrejskim pokratama v. u Doctor 2008

${ }^{279}$ Blatt 1996 i Trauring 2011 nude moguće drukčije tumačenje:
} 


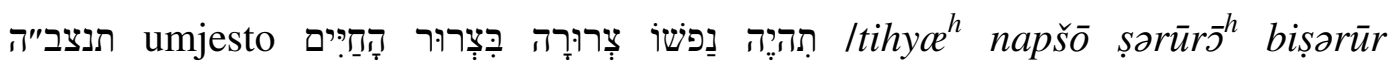

hs̄hayyīm/ - Neka njegova duša bude vezana u snop života

Znakovi nalik na navodnike upućuju da je riječ o akronimu sastavljenom od početnih slova više riječi. Kako iz same pokrate nije vidljiv rod, pa tako ni spol osobe na koju se odnosi, moguća su i tumačenja u ženskom rodu

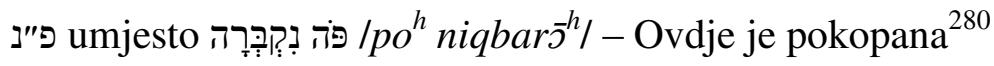

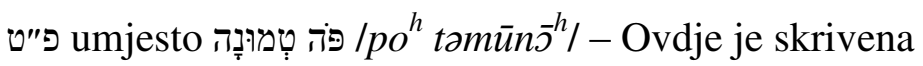

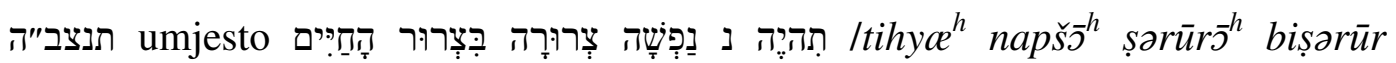

hs̄hayyīm/ - Neka njezina duša bude vezana u snop života

Prve su dvije uklesane na samom vrhu nadgrobne ploče iznad imena, ali uvijek ili jedna ili druga, nikad obje, a treća na kraju hebrejskog teksta.

Treći se akronim temelji na dijelu 1 Sam 25,29

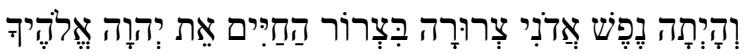

Doslovni bi prijevod glasio:

${ }^{29}$ I bila je duša gospodara moga vezana u snop života YHWH Boga tvoga.

U Bibliji u izdanju Stvarnosti i Kršćanske sadašnjosti iz 1969. g. taj je redak Antun Sović preveo prilično slobodno:

${ }^{29}$ Neka život moga gospodara bude pohranjen u škrinji života kod YHWH, tvoga Boga.

\subsubsection{Davidov štit}

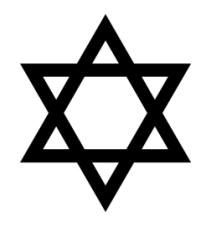

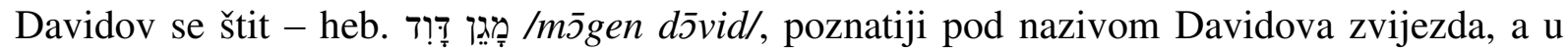
mistici i kao heksagram (Chevalier i Gheerbrant 1994: 187-188), sastoji od dva koncentrična istostranična trokuta međusobno zaokrenuta za $180^{\circ}$ i položena tako da svakom trokutu jedna od stranica leži vodoravno.

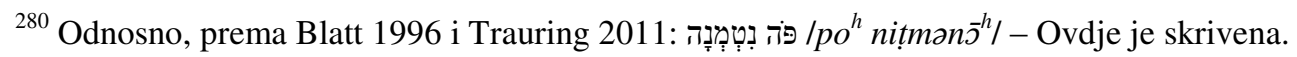


Iako je Davidov štit nesumnjivo najpoznatiji simbol židovstva, ta je njegova uloga relativno novijeg datuma.

Actually the six-pointed star is not a Jewish symbol; a fortiori it could not be "the symbol of Judaism." It has none of the criteria that mark the nature and development of the true symbol. It does not express any "idea," it does not arouse ancient associations rooted in our experiences, and it is not a shorthand representation of an entire spiritual reality, understood immediately by the observer. It does not remind us of anything in Biblical or in rabbinic Judaism ${ }^{281}$ (Scholem 1949: 243).

Šesterokraku je zvijezdu, doduše, moguće naći na nekim starim spomenicima židovstva, sinagogi iz II. - III. st. n. e. u Kapernaumu (rame uz rame sa svastikom!), na pečatu za koji nije ni sigurno je li hebrejski ili fenički, na grobu starijem od VI. st. n. e. u Tarantu, no na svim tim mjestima ona figurira prije svega kao dekorativni element, a ne vjerski simbol. Šesterokrakoj su zvijezdi a posteriori pripisivana i kabalistička tumačenja, ali je riječ bila tek o pogrešnom tumačenju ili čitanju tekstova rabina Isaaka Lurije, kabalista iz XVI. st. (Da-Don 2004: 329).

The Shield of David has neither a Jewish religious "genealogy" nor a Jewish religious significance, either exoterically or esoterically; and it certainly had no place in the mystical world of the devout men of Israel ${ }^{282}$ (Scholem 1949: 245).

U židovstvo su i peterokraka i šesterokraka zvijezda ušle s talismanima i amuletima, koje su Arapi preuzeli iz europske starine i predali ih natrag Europljanima, i kršćanima i židovima. Tada se pojavljuje i naziv Solomonov pečat za niz od sedam pečata koji su osobu koja ih je nosila trebali štititi od zloduha. Među tima su se nalazile i peterokraka i šesterokraka zvijezda. Židovi su, preuzevši taj amulet, naziv Solomonov pečat ograničili samo na te dvije zvijezde. U tome su ih slijedili kršćani.

\footnotetext{
${ }^{281}$ Ustvari šesterokraka zvijezda nije židovski simbol; a fortiori ne može biti »simbol židovstva«. Ona ne posjeduje nijedan kriterij koji označava prirodu i razvoj istinskog simbola. Ona ne izražava nikakvu »ideju«, ne izaziva drevne asocijacije ukorijenjene u našim iskustvima te nije stenografski prikaz cijele duhovne stvarnosti, koju bi promatrač odmah razumio. Ne podsjeća nas bilo na što u biblijskom ili u rabinskom judaizmu.

${ }^{282}$ Davidov štit nema ni židovsko vjersko »rodoslovlje« ni židovsko vjersko značenje, bilo ono egzoterično ili ezoterično; a zasigurno mu nije bilo mjesto u mističnom svijetu pobožnih Izraelićana.
} 
It was not, therefore, as a symbol of the monotheistic faith that the six-pointed star began its Jewish career, but as a magical talisman for protection against the evil spirits; and this remained its primary meaning among the masses of the people until about a hundred years ago ${ }^{283}$ (Scholem 1949: 246).

Sam naziv Davidov štit po svemu sudeći potječe iz srednjovjekovne predaje o zlatnom štitu kralja Davida na kojem je magični tekst ocrtavao bilo šesterokraku zvijezdu bilo menoru, sedmerokraku svjetiljku iz Hrama, no potonja je inačica s vremenom nestala iz tradicije. Do XVII. st. su se nazivi Davidov štit i Solomonov pečat neselektivno koristili i za peterokraku i za šesterokraku zvijezdu, a tek se u XVIII. st., i to u kršćanskoj predaji, naziv Davidov štit ograničio isključivo na ovu drugu. Židovi su tada taj naziv i samu zvijezdu preuzeli kao simbol Davidova kraljevstva i vlasti njegove porodice i nad Izraelom i nad Judom, a ne više

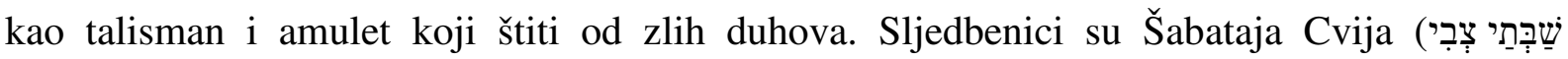
/šabbətay ṣəbī/), lažnog mesije iz XVII. st., bili prvi koji su Davidov štit pretvorili u simbol mesijanskog iskupljenja, u štit sina Davidova, očekivanog mesije.

Službena se poraba Davidova štita kao simbola židovske zajednice prvi put pojavljuje u Pragu u XVII. st. Po svemu sudeći, ovaj su znak izabrali sami Židovi, nije im bio nametnut »odozgo«. U to doba šesterokraka zvijezda već odnosi prevagu nad peterokrakom kao Davidov štit. U XVIII. se st. ta praksa proširila Češkom, Moravskom i Austrijom da bi se u ostatku Europe šesterokraka zvijezda počela pojavljivati kao židovski simbol i u službenim prilikama i kao čisto ukrasni motiv tek početkom XIX. st. (Scholem 1949: 248-249; Da-Don 2004: 329).

Svoje širenje židovskim svijetom Europe u XIX. st. Davidov štit ima prije svega zahvaliti želji emancipiranih Židova da i sami posjeduju neki simbol svoje vjere kao što je to kršćanima bio križ. Jednostavno su u tome htjeli podražavati svoje sugrađane. Takvo se poimanje Davidova štita, koji se počeo pojavljivati po svemu židovskome, od knjiga preko posuđa do sinagoga, širilo prema istoku Europe. Ondje je naišlo na priprost puk kojemu nije

\footnotetext{
${ }^{283}$ Nije, dakle, šesterokraka zvijezda započela svoju židovsku karijeru kao simbol monoteističke vjere, već kao magični talisman za zaštitu od zlih duhova; i to je bilo i ostalo njezino glavno značenje među masama naroda sve do prije sto godina.
} 
bilo teško povezati talismanska i amuletska svojstva Davidova štita, kakva su već poznavali, s novom simbolikom. Zaštitnička je uloga znaka ostala istom (Mishory 2003).

The upshot of the matter is this: in the very days of its greatest popularity the Shield of David was a meaningless symbol of Judaism; and the Judaism of those days, in turn tended to be meaningless. It required more than preachers' sermons, however admirable in intent, to breathe life into a symbol. The successful and empty career of the Shield of David during the $19^{\text {th }}$ century is in some measure a token of the Jewish decadence of that century ${ }^{284}$ (Scholem 1949: 251).

Službeni je status Davidova štita unutar židovstva definitivno zapečaćen 1897. g. kada je na Prvom cionističkom kongresu u Baselu prihvaćen kao simbol cionističkog pokreta. Cionistima je Davidov štit odgovarao jer se kao simbol već bio proširio židovskom Europom, ali ipak nije u sebi nosio nužno vjerske konotacije.

Isti je taj Davidov štit u dvadesetom stoljeću postao mračnim obilježjem pripadnosti »manje vrijednoj rasi«, koje je Židove pratilo od gubljenja građanskih i inih prava do gubljenja samog prava na život. Ta je tragedija židovskog naroda, međutim, još dodatno osnažila simboliku šesterokrake zvijezde.

Some have said: the sign under which they went to destruction and to the gas chambers deserves to be discarded for a sign that will signify life. But it is also possible to think in the opposite fashion: the sign that in our days was sanctified by suffering and torture has won its right to be the sign that will light up the road of construction and life. "The going down is the prelude to the raising up"; where it was humbled, there will you find it exalted ${ }^{285}$ (Scholem 1949: 251).

${ }^{284}$ Ishod je toga ovakav: u danima njegove najveće popularnosti Davidov je štit bio beznačajan simbol židovstva; a židovstvo je tih dana, zauzvrat, težilo gubitku smislenosti. Trebalo je nešto više od propovjedničkih propovijedi, koliko god divljenja vrijedna njihova namjera bila, da udahnu život u simbol. Uspješna i prazna karijera Davidova štita tijekom XIX. stoljeća u određenoj je mjeri znak židovske dekadencije toga stoljeća.

${ }^{285}$ Neki su govorili: znak pod kojim su vođeni u propast i plinske komore zaslužuje biti odbačen kao znak koji bi označavao život. Moguće je također razmišljati i u suprotnom smjeru: znak koji je u našim danima bio posvećen patnjom i mučenjem stekao je pravo da bude znak koji će osvijetliti put izgradnje i života. »Spuštanje je uvod u uspon«; gdje je bio ponižen, ondje će biti uzvišen. 
Nakon osnutka su države Izrael prvi prijedlozi za zastavu i grb nove države sadržavali sedam zlatnih Davidovih štitova, kojima je Theodor Herzl, osnivač cionizma, ilustrirao svoju ideju o sedmosatnom radnom danu. S jedne je strane općerašireni osjećaj među Židovima cionistima u svijetu bio da zastava nove države bude što je moguće sličnija cionističkoj, ali je s druge ministar vanjskih poslova želio da se ova ipak razlikuje od nje. Tako je država Izrael dobila zastavu s jednim modrim Davidovim štitom ${ }^{286}$ na bijeloj podlozi iznad i ispod kojeg cijelom dužinom zastave prolazi po modra crta, boje iste kao i sam štit ${ }^{287}$. Što se grba tiče, prvotna je ideja o heraldičkom lavu ubrzo zamijenjena kombinacijom menore, sedmerokrakog svijećnjaka iz jeruzalemskog Hrama, onog tradicionalnog, i Herzlovih sedam Davidovih štitova, onog inovativnog, koji se međusobno nadopunjavaju. U raspravama unutar Znanstvenog odbora, koji je osnovan da odabere službene oznake novoosnovane države, Davidovi su štitovi pomalo gubili podršku kao nimalo tradicionalan simbol, kao simbol svjetla koji je uz drugi, drevniji, simbol svjetla - menoru - potpuno suvišan te kao podsjetnik na astrologiju, tipično nežidovsku djelatnost. Kako završna verzija nacrta grba (naknadno prihvaćena) više nije prikazivala neku stiliziranu menoru, već je reproducirala onu isklesanu na Titovu slavoluku prikazujući trijumfalni povratak rimske vojske $\mathrm{s}$ bogatstvima opljačkanim u razorenom Jeruzalemu 70 g. n. e., stilizirani se Davidovi štitovi nisu nikako uklapali u takav prikaz, te su na kraju izbačeni, oko menore su prikazane dvije maslinove grančice, a ispod nje se nalazi natpis ישראל /yiśr̄̄'el/ (Handelman i Shamgar-Handelman 1990: 207-216; Mishory 2003).

Često se pokrate פּ"ט između dva slova (umjesto znaka za pokratu)

\section{J \\ 90}

\footnotetext{
${ }^{286}$ U procesu kreiranja novih simbola mlade države u igri je bio i zlatni Davidov štit, čak i svih sedam njih (Handelman i Shamgar-Handelman 1990: 205 ff.).

Prema Pavlu Šosbergeru prilikom procesije za praznik Simhat Tora »posle povorke nosioca Tore nastupaju deca, noseći plavo-bele zastave od papira sa zlatnim Magen Davidom.«(Šosberger 2006: 27) Autor, nažalost, ne navodi otkad taj običaj potječe.

${ }^{287}$ Podloga zastave na koju je postavljen Davidov štit podražava izgled talita, tradicionalnog židovskog molitvenog šala (Mishory 2003; Da-Don 2004: 328).
} 
bilo tako da cijela pokrata bude smještena unutar šesterokuta u sredini Davidova štita.

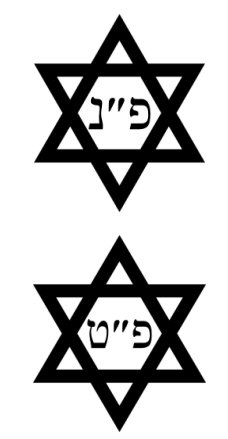

\subsubsection{Kohenske šake}

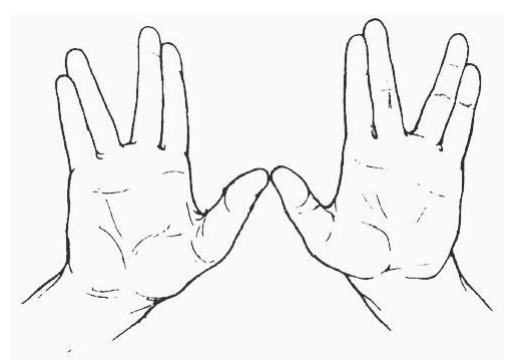

Kohenski blagoslov je blagoslov koji smiju izgovarati samo kohanim, židovski svećenici, potomci Mojsijeva brata Arona, prvog velikog svećenika židovstva. Blagoslov se temelji na biblijskom tekstu iz Knjige brojeva 6,22-27 288

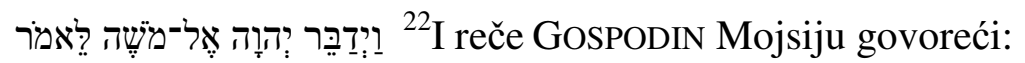
קReci Aronu i sinovima njegovim

govoreći: “Ovako ćete blagoslivljati sinove Izraelove govoreći im:

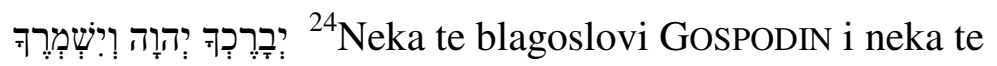
čuva!

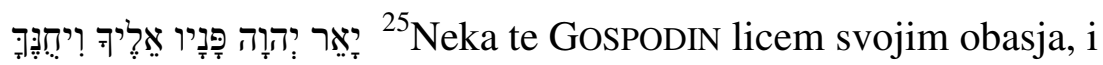
neka ti bude milostiv!

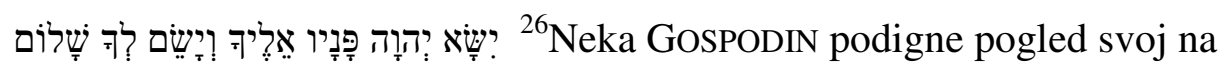
te i donese ti mir!"

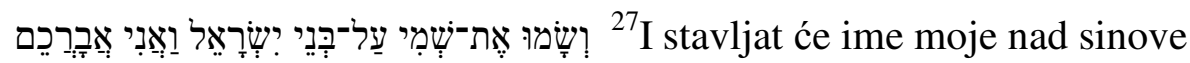
Izraelove, i ja ću ih blagoslivljati.«

\footnotetext{
${ }^{288}$ Blagoslov se spominje i u Psalmu 134,2 (Schwarzman 1993: 22-25). U prijevodu Filiberta Gassa: ${ }^{2}$ Dižite svoje ruke prema Svetištu i YHWH-a blagoslivljajte!
} 
Ovo je ujedno i najstariji biblijski tekst pronađen do danas, napisan na amuletima nađenima u grobovima iz razdoblja Prvog Hrama (X. - VI. st. pr. n. e.).

Prilikom ovog blagoslova kohanim dižu ruke, dlanovima okrenutima prema vjernicima, spajaju palčeve lijeve i desne šake te razmiču prstenjake od srednjaka na obje šake ${ }^{289}$. Tako se dobiva oblik slova šin (ש), koji simbolizira riječ שֵׁِ /šaddaj/, Božji atribut koji se obično prevodi kao 'svemogući', iako je etimologija riječi upitna te postoji više hipoteza o njezinom podrijetlu.

Za vrijeme izgovaranja ovog blagoslova okupljeni vjernici (poglavito ortodoksni) ne gledaju u kohanim, već u zemlju da bi se usredotočili na blagoslov, a da im pritom ništa ne odvlači pozornost, ali i zato što je u doba jeruzalemskog Hrama Božja nazočnost svjetlila s prstiju svećenika, a nitko nije smio gledati izravno u nju iz štovanja prema Bogu. Stoga se vjernici prekrivaju talitom (molitvenom maramom) preko glave i pod talit stavljaju i svoju djecu (Parsons 2003-2016: 2).

Šake se u ovom položaju prikazuju na nadgrobnim spomenicima kohanim, potomaka Aronovih. Neki od njih i danas nose prezime koje ukazuje na njihovo podrijetlo: Kohen, Koen, Kon, ili neku drugu inačicu istih, no nije pravilo da svi koji nose takvo prezime i jesu kohanim, pa na njihovim grobovima nećete naći kohenskih šaka. Isto tako, ne nose svi kojima su na nadgrobnim spomenicima prikazane kohenske šake prezime koje vuče podrijetlo iz riječi כּּה /kohen/ . Kad je trebalo birati prezimena, mnogi kohanim nisu izabrali neko koje bi bilo povezano s vlastitim podrijetlom (Cemetery Scribes 2009).

\subsubsection{Vř̌}

Kao što su grobovi potomaka kohanim obilježeni kohenskim šakama, tako i potomci Levita, ostalih ogranaka plemena Levijeva koji su u drevno doba obavljali dužnosti raznovrsnih poslužitelja i glazbenika u Hramu na svoje grobove stavljaju specifične oznake. I baš kao i u

\footnotetext{
${ }^{289}$ Takav je oblik šake u popularnoj kulturi proširio glumac židovskog podrijetla iz SAD-a, Leonard Nimoy, pretvorivši ga u pozdravnu gestu Vulkanaca, vrste čijeg je pripadnika, Mr. Spocka, glumio u seriji Zvjezdane staze.
} 
slučaju kohanim, nije nužno da potomci Levijevi nose njegovo osobno ime kao prezime niti je prezime proisteklo iz osobnog imena Levi nužna oznaka potomaka Levita.

Jedna je od dužnosti Levita bila da iz obrednog vrča liju vodu na ruke kohanim u ritualu pranja ruku. Ruka koja drži vrč ili iz njega lijeva vodu bilo po rukama bilo u drugu posudu najčešći je nadgrobni simbol Levita (Schwarzman 1993: 31), no na Mirogoju ga nema. Ondje je, međutim, moguće naći prikaz samog vrča, bez ruke koja ga drži i bez vode koja teče iz njega.

\subsubsection{Kamenčići na grobu}

Motiv po kojemu je moguće prepoznati židovski grob čak i prije nego se vidi što piše na nadgrobnoj ploči jesu nesumnjivo kamenčići poslagani na njemu.

Židovi ostavljaju kamenčiće na grobu lijevom rukom. Neki ne uzimaju nasumce koji god kamenčić, već biraju poseban oblik ili boju ili pak donose kamenčić s nekog mjesta koje je za pokojnika imalo posebno značenje za života ${ }^{290}$. Za razliku od u nas uobičajenije svijeće, koja simbolizira prolaznost - upali se, gori, pa se utrne - kamenčić označava postojanost sjećanja na osobu i njezin život ${ }^{291}$.

Židovski je običaj položiti na grob kamen ili grudu zemlje, koji simboliziraju jednostavnost i čovjekov korijen nastanka iz praha te njegov povratak u ono iz čega je nastao (Da-Don 2004: 460).

Nije rijetko da se razlozi, uzroci, povodi nekog običaja izgube u maglama prošlosti, pa tako ni za ostavljanje kamenčića na grobovima nema jedinstvenog objašnjenja. Dovoljno je potražiti neku informaciju o tome na internetu da bi se dobio cijeli niz tumačenja.

Jedni traže korijene ovog običaja u drevnim vremenima kad se tijelo nije polagalo u lijesove, nego se pokapalo povijeno u molitveni šal pojedinca. Tijelo bi se prekrilo zemljom, a potom bi se na nju naslagalo kamenje kako strvinari ne bi mogli do njega. Tkogod bi pohodio grob,

\footnotetext{
${ }^{290} \mathrm{http}: / / \mathrm{www} . \mathrm{myjewishlearning.com/article/ask-the-expert-stones-on-graves/}$

${ }^{291} \mathrm{http} / / / \mathrm{www} . \mathrm{myj}$ ewishlearning.com/article/ask-the-expert-stones-on-graves/ http://agraveinterest.blogspot.hr/2012/04/leaving-stones-on-graves.html http://www.myjewishlearning.com/article/putting-stones-on-jewish-graves/
} 
dodao bi još koji kamen da ga dodatno osigura, te je tako veća kamena hrpa označavala mjesto posljednjeg počivališta osobe koje se mnogi sjećaju ${ }^{292}$.

Drugi se pozivaju na doba kad nije bio običaj grobove posebno označavati. Kako bi spriječili da se kohanim, svećenici u Hramu, onečiste blizinom mrtve osobe (Da-Don 2004: 455), na grobove bi poslagali hrpicu kamenja kao upozorenje za kohanim da im se ne približavaju ${ }^{293}$. Kohanim, naime, ne smiju nazočiti pogrebu niti ući na groblje te pogreb mogu pratiti samo izdaleka (Šosberger 2006: 37).

U Talmudu se navodi kako se kamenje postavljalo na grob ekskomuniciranih članova zajednice i onih za koje se posmrtno utvrdilo da su počinili kakav grijeh. Kamenje je na grobu u tim slučajevima simboliziralo kamenovanje, kaznu za svakog otpadnika od vjere ${ }^{294}$.

Tu je i tumačenje da se polaganjem kamenčića na grob pokazuje poštovanje spram preminule osobe ostavljanjem znaka da je netko pohodio grob. Što je više kamenčića na grobu, to je više onih koji se sjećaju pokojnika i pohode njegov $\operatorname{grob}^{295}$.

\footnotetext{
${ }^{292}$ https://www.jcam.org/Pages/Foundation/visitationstones.htm https://www.jcam.org/Pages/Foundation/Education/articles/stones-left-on-monuments.php http://www.reformjudaism.org/practice/ask-rabbi/why-do-jews-put-small-stones-tombstones-when-visitingcemetery-0

http://agraveinterest.blogspot.hr/2012/04/leaving-stones-on-graves.html http://www.shiva.com/learning-center/commemorate/stone/

${ }^{293} \mathrm{http}: / / w w w . m y j e w i s h l e a r n i n g . c o m / a r t i c l e / a s k-t h e-e x p e r t-s t o n e s-o n-g r a v e s /$ http://www.shiva.com/learning-center/commemorate/stone/ http://www.shiva.com/learning-center/commemorate/stone/

${ }^{294} \mathrm{http} / / / \mathrm{www}$. aish.com/atr/Stones_on_Graves.html http://ohr.edu/ask/ask222.htm http://www.shiva.com/learning-center/commemorate/stone/

${ }^{295}$ http://www.aish.com/atr/Stones_on_Graves.html http://ohr.edu/ask/ask222.htm http://www.chabad.org/library/article_cdo/aid/3002484/jewish/Why-Do-Jews-Put-Pebbles-onTombstones.htm http://agraveinterest.blogspot.hr/2012/04/leaving-stones-on-graves.html
} 
Prema Talmudu čitanje reljefnog (izbočenog) nadgrobnog natpisa može negativno utjecati na učenje Tore (uklesani natpisi ne predstavljaju problem). Polaganjem se kamenčića na takav natpis otežava njegovo čitanje, pa se samim time eliminiraju i negativne posljedice ${ }^{296}$.

Postavljanje se kamenčića na grob tumačilo i kao poziv pokojniku da siđe na svoj nadgrobni kamen i odmara se ondje za vrijeme dok njegov grob pohode. Međutim, isto tumačenje poziva i da se pri odlasku ukloni kamenčić s groba, što danas nije slučaj ${ }^{297}$.

Ovaj se običaj povezuje i s već navedenom pokratom תנצב"ה "neka njegova/njezina duša bude

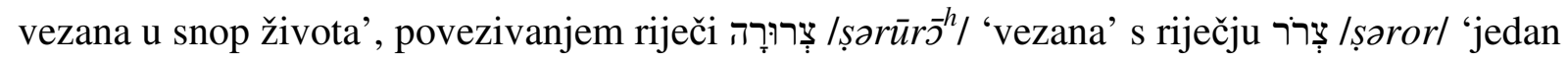
od kamenčića pomoću kojih pastiri prate broj ovaca u stadu'. Naime, koliko je kamenčića u praćki, toliko je ovaca u stadu. Metafora, koju je preuzelo i kršćanstvo, povezuje Boga s pastirom, a vjernike s njegovim stadom ${ }^{298}$.

Postoje i kontroverzna objašnjenja: s jedne strane kamenje na grobu zadržava dušu pokojnika na ovom svijetu (neki to smatraju utješnim, a neki pod utjecajem istočnoeuropskog folklora vjeruju da će tako spriječiti pokojnika da ustane iz groba i opsjeda svoj dom i obitelj ${ }^{299}$ ), dok drugi pak drže da se na taj način demonima onemogućuje ulaz u grob ${ }^{300}$.

Naposljetku, kamen (heb. צוּ /ṣūr/) je česta metafora za Boga u židovskim svetim tekstovima i molitvama. Nadgrobni kamen simbolizira dušu pokojnika, a kamenčić koji ostavljamo na grobu našu vlastitu dušu, obje povezane zapovijedima i metaforom ${ }^{301}$.

\footnotetext{
${ }^{296}$ http://www.chabad.org/library/article_cdo/aid/3002484/jewish/Why-Do-Jews-Put-Pebbles-onTombstones.htm

${ }^{297}$ http://www.chabad.org/library/article_cdo/aid/3002484/jewish/Why-Do-Jews-Put-Pebbles-onTombstones.htm

${ }^{298}$ https://www.jcam.org/Pages/Foundation/visitationstones.htm http://www.myjewishlearning.com/article/ask-the-expert-stones-on-graves/ http://www.myjewishlearning.com/article/putting-stones-on-jewish-graves/

${ }^{299}$ http://agraveinterest.blogspot.hr/2012/04/leaving-stones-on-graves.html http://www.myjewishlearning.com/article/putting-stones-on-jewish-graves/

${ }^{300} \mathrm{http}: / / \mathrm{www} . m y j e w i s h l e a r n i n g . c o m / a r t i c l e / a s k-t h e-e x p e r t-s t o n e s-o n-g r a v e s /$

${ }^{301}$ http://www.shiva.com/learning-center/commemorate/stone/
} 


\subsubsection{5 Žalosna vrba}

Žalosna vrba ne spada u tradicionalna obilježja židovskoga groba. Na izraelitskom je odjelu zagrebačkoga Mirogoja ona relativno čest simbol, vjerojatno preuzet od nežidovskih susjeda.

\subsubsection{Križ kao nežidovsko obilježje}

Križ je jedini simbol po kojemu možemo sa sigurnošću reći da neki grob nije židovski. Među nadgrobnim natpisima moguće je naći i one na kojima supostoje križ i neki od židovskih simbola. Križ je u takvim slučajevima najčešće postavljen u punoj visini imenā na koja se odnosi. Imena pokojnika iznad onih obilježenih križem mogu se računati kao židovska, a ona uza nj već spadaju među kršćane. Katkad je situacija složenija, primjerice kad su križem označena sva imena na nadgrobnom natpisu, a na grobu su svejedno poslagani kamenčići koje su donijeli oni koji su pohodili grob. U takvim slučajevima prednost je dana židovskom spram nežidovskog simbola.

\subsection{Prikupljeni podaci}

U Schwarzovoj knjizi nalazimo ukupno 1213 navedenih pojedinaca u 133 obitelji, u matičnim knjigama rođenih 2202 novorođenčeta uz 803 oca i 970 majki, a na izraelitskom odjelu groblja Mirogoj 2430 pojedinaca. U svim je izvorima popisano 6600 pojedinaca. Među njima je tek 4097 onih kojima znamo i osobno ime, i prezime, i godinu rođenja, koja može biti eksplicitno navedena u nekom od dokumenata ili pak izračunata tako da se dob pojedinca u nekoj godini oduzme od te iste godine (najčešće godine njegove smrti, ali i godine u kojoj je sastavljen koji od popisa zagrebačkih Židova). U drugom slučaju, u kojem postoji mogućnost pogreške od jedne godine, godina je rođenja navedena kosim rezom pisma.

Iz užega korpusa od 4097 pojedinaca njih je 696 navedeno u knjizi Gavre Schwarza, 2322 (uključujući roditelje) u matičnim knjigama rođenih te 1747 u podacima s groblja Mirogoj.

\subsection{Problemi}

Osnovni problem $\mathrm{u}$ identifikaciji pojedinaca $\mathrm{u}$ različitim izvorima jest nepostojanje standardiziranog, službenog lika osobnog imena odnosno prezimena koji bi se poklapao u 
svima njima. I dok je još u osobnim imenima Fani (1105/1885), Franziska (1347/1889), Franciska (28/1894), Fanika (22/1897), Fanike (23/1898), Fany (1178/1886, 1253/1887, 3 I 108) i Fanni (3 I 108) lako prepoznati inačice istog osobnog imena, što reći o osobi koja je u različitim izvorima zavedena kao Emilija (82), Amalie (156/1863), Amalia (45/1859, 94/1861, 229/1865), Minna (335/1868, 391/1869, 589/1875) i Mina (2 I 51)? Tek se usporedbom ostalih podataka vezanih za osobu (osobno ime i prezime supruga, osobna imena djece, godine rođenja i smrti,...) može ustanoviti da je riječ o jednoj te istoj osobi. Što se prezimenā tiče, katkad se čak ni u samim matičnim knjigama lik prezimena djeteta ne slaže s onim roditelja. Najčešće se razlike u prezimenā odnose na alternaciju dočetka -berg/-berger, na pisanje odnosno nepisanje udvojenih slova (npr. -mann/-man), bilježenje obezvučenih konsonanata na kraju riječi ili morfema (npr. - $d t /-t$ ) i pisanje preglašenih samoglasnika (npr. ö/oelole ili ä/aelale) te udvojenog $s(\beta / s z / s s / s)$, što sve odražava opreku njemačkog i jidiškog pravopisa. Neka su prezimena u nekim izvorima pisana i fonetski. Značajne se pogreške nalaze u bazi podataka Gradskih grobalja, vjerojatno kao posljedica pogrešnog čitanja rukom pisanih izvornih dokumenata, primjerice BERUHARD umjesto Bernhard (2 I 341) ili pak KANDERS umjesto Kauders (7 I 5). U takvim se slučajevima u analizi uzima podatak iz drugog izvora, ako postoji. 


\section{ANALIZA}

\subsection{Osobna imena zagrebačkih Židova}

\subsubsection{Uvod}

Velik je problem proučavanja onomastike Židovā nepostojanost grafije pojedinih osobnih imena i prezimena. S jedne su strane dokumenti pisani na različitim jezicima i pismima. S druge različiti dokumenti istu osobu navode pod različitim osobnim imenima, službeni

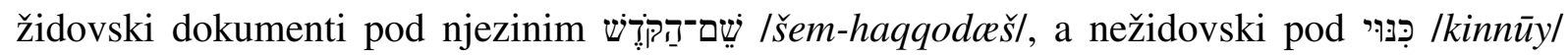
koji opet može biti modificiran raznovrsnim mjesnim i inojezičnim deminutivnim i hipokorističnim sufiksima. Štoviše, zapisi na nežidovskim jezicima osobna imena nerijetko transkribiraju ili prevode na lokalni jezik, bila ona hebrejska (משֶׁה/moš $\mathfrak{c}^{h} /:$ njem. Moses : polj. Mojżesz : rus. Моисей) ${ }^{302}$ ili ne (וואָלף/wolf/ : češ. Vlk; לייב /leyb/ : rus. Левко : polj. Lewko). Kršćanski su autori, naime, bili skloni zamjenjivati židovsko osobno ime kršćanskim ako je drugo bilo izravan prijevod prvoga odnosno ako je drugo zvučalo slično prvome. Stoga osobnim imenima Židovā kako su navedena u kršćanskim izvorima valja pristupati s posebnim oprezom. Pouzdana su ona koja ne potječu iz Tanaha i koja ne nose kršćani, likovi osobnih imena iz Tanaha koji nisu u uporabi među kršćanima te ona koja nisu iz Tanaha, a nadijevaju ih i kršćani, ali koja se u više međusobno neovisnih izvora pojavljuju u istom liku. $\mathrm{S}$ treće strane jidiški pravopis do XX. st. nije bio standardiziran. I dok su tradicionalna židovska (hebrejska, aramejska) osobna imena u židovskim izvorima pisana uz poštvanje njihove izvorne grafije (iako ni to nije uvijek slučaj), za sva ostala zabilježena hebrejskim alef-betom izgovor nije siguran. Hebrejsko pismo, naime, ne bilježi samoglasnike. Dijakritički znakovi za samoglasnike postoje, uvedeni su relativno kasno, u drugoj polovici prvog tisućljeća n. e., no u svakodnevnoj se praksi oni uglavnom ne koriste. Matres lectionis koje su u tu svrhu rabili pisari prije toga primijenjene su i u nekim jidiškim tekstovima, pa ה/- $h /$ na kraju riječi znači da riječ završava nekim samoglasnikom, najčešće na - $a$, rjeđe na -e, a vrlo rijetko na -o. Unutar riječi -ı- /-w-/ može označavati -o-, -u-, pa čak i -oy-, --- /-y-/ može označavati -i-, -e-, -ey- i -oy-, a -א- /-'-/ može označavati bilo koji samoglasnik, najčešće - $a$-. Neka slova mogu predstavljati dva različita suglasnika, primjerice ב može predstavljati $b$ i

\footnotetext{
${ }^{302}$ Ovdje je primjetan velik utjecaj prijevodā Biblije na europske jezike, a posebno utjecaj Vulgate (i posredno Septuaginte) na transkripcije biblijskih osobnih imena (Bushell 1996).
} 
može predstavljati $p$ i $f^{303}$, a $ש$ može predstavljati i $\check{s}$ i $s$ (Beider 2001: xxvi-xxviii). Danas je

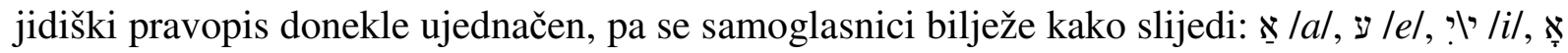

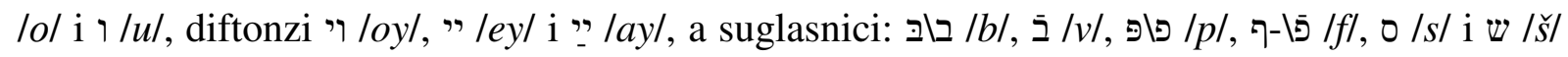
(Zucker 1994: xv-xvii).

Kao dodatni problem pri istraživanju treba spomenuti i slabu dostupnost izvornih dokumenata što posljeduje oslanjanjem na drugotne izvore koji donose tek izvode i prijepise u kojima se nerijetko potkradaju pogreške u prepisivanju, ali i prijevodi i transkripcije izvornih osobnih imena (Beider 2001: xxviii). Od izvora podataka za ovaj rad oni se iz matičnih knjiga mogu smatrati prvotnima, a nadgrobni spomenici na Mirogoju također, ali uz ogradu: na njima ne mora nužno biti upisano službeno osobno ime pojedinca, već obiteljski nadimak. Gavro Schwarz nam donosi podatke iz druge ruke, preuzete iz raznovrsnih mu dostupnih popisa Židovā. U njegovoj je knjizi primijećen određen broj očiglednih omašaka (primjerice pogrešno napisana godina, koja bode oči svojim anakronizmom), pa nije nemoguće da ih ima i u navođenju osobnih imena i prezimenā. Na kraju imamo bazu podataka Gradskih grobalja koja vrvi pogrešno prepisanim osobnim imenima i prezimenima vjerojatno zbog nepoznavanja i arhaičnosti rukopisa i pisma kojim su izvorni dokumenti pisani.

Alexander Beider ističe nužnost razlikovanja tri stilističke inačice osobnih imena pri analizi onih koja su u određenom razdoblju nosili pripadnici određene kulturne zajednice (Beider 2001: xxxi; Beider 2003: 42):

1. puni likovi

stilski neutralni likovi, temeljni imenski likovi

2. odmilice (hypocorisms)

obiteljski, intimni i kolokvijalni likovi, hipokoristični likovi

3. umanjenice (pet forms)

izrazito ekspresivni i emotivni likovi koji nužno sadržavaju deminutivni sufiks, deminutivni likovi.

Svaki se podskup korpusa osobnih imena sastoji od jednog punog lika sa svim odmilicama i umanjenicama izvedenim iz njega, što predstavlja sinkronijsku kulturnu realnost. U načelu svaka odmilica i umanjenica odgovara jednom jedinom punom liku, no ima slučajeva kad

\footnotetext{
${ }^{303} \mathrm{U}$ hebrejskom se svi neemfatički okluzivi $(b, p, d, t, g, k)$ frikativiziraju u postvokalskom položaju osim u slučajevima kad su iz morfoloških razloga udvojeni (Moscati et al. 1964: 26-27).
} 
umanjenica, a poglavito odmilica zbog slične fonetske/slogovne strukture može odgovarati većem broju punih likova što dovodi do nemogućnosti identifikacije toga, a s njime i motivacije te podrijetla osobnog imena. Status pojedinog osobnog imena nije nužno postojan $\mathrm{u}$ vremenu i prostoru, ono može prelaziti iz jedne skupine u drugu. Najčešće umanjenica gubitkom ekspresivnosti prelazi u skupinu odmilica, dok obrnut slučaj nije moguć. U slučajevima kad puni lik osobnog imena nestane te kad se izgubi genetska veza između punog lika i odmilice, ova može zauzeti mjesto punog lika, što je u korpusu potvrđeno navođenjem odmilice kao službenog osobnog imena. Rijetko dolazi do toga da osobno ime prijeđe u nižu skupinu iz više, a najčešći je uzrok tome pučka etimologija i hiperkorektnost (Beider 2001: xxxi-xxxii). U korpusu su kojim se bavi ovaj rad neke osobe imenovane isključivo likovima osobnih imena koji se mogu nazvati odmilicama, bez ijednog spomena punog lika. Takva promocija odmilice u službeno osobno ime uglavnom onemogućuje otkrivanje njegove motivacije jer odmilice često odgovaraju većem broju punih likova osobnih imena. Umanjenice predstavljaju manji problem, jer uglavnom zadržavaju osnovu punog osobnog imena dodajući joj deminutivni sufiks, dok se odmilice mogu tvoriti tako da od punog osobnog imena $\mathrm{u}$ njima ostane malo ili gotovo ništa, primjerice $\mathrm{u}$ ruskome Александр > Саша.

Beider u dvije tablice određuje aktivnosti pri određivanju etimologije nekog osobnog imena. Prva donosi pet dijakronijskih stupnjeva razvoja osobnog imena:

\begin{tabular}{|l|l|l|}
\hline \multicolumn{1}{|c|}{ Stupanj } & \multicolumn{1}{|c|}{ Polazište } & \multicolumn{1}{c|}{ Ishod } \\
\hline početni razvoj & izočnost osobnog imena & osobno ime \\
\hline derivacija & temeljno osobno ime & izvedeno osobno ime \\
\hline $\begin{array}{l}\text { varijacija (fonetska } \\
\text { preoblika) }\end{array}$ & izvorišna inačica & završna inačica \\
\hline $\begin{array}{l}\text { spajanje s drugim osobnim } \\
\text { imenima }\end{array}$ & $\begin{array}{l}\text { osobno ime }_{1}+\text { osobno ime }_{2} \\
+\ldots\end{array}$ & $\begin{array}{l}\text { dvostruko (trostruko,...) } \\
\text { osobno ime }\end{array}$ \\
\hline nestanak & osobno ime & izočnost osobnog imena \\
\hline
\end{tabular}

\footnotetext{
${ }^{304}$ Primjerice, osobno je ime Gite izvedeno od Gute, bilo prijeglasom, bilo dijalekatskim pomakom $u>i$. U prvom slučaju govorimo o derivaciji, a u drugom o varijaciji. Razliku možemo ustanoviti tek iz antroponimskog konteksta. U slučaju derivacije oba lika ostaju u uporabi među govornicima, dok u slučaju varijacije nalazimo samo noviji lik, koji je zamijenio stariji.
} 
Druga donosi pitanja koja mora postaviti svaki istraživač etimologije osobnih imena:

\begin{tabular}{|l|l|l|}
\hline \multicolumn{1}{|c|}{ Pitanje } & \multicolumn{1}{|c|}{ Upitna riječ } & \multicolumn{1}{c|}{ Što treba učiniti? } \\
\hline Što je izvorišna riječ? & Što? & Otkriti izvor. \\
\hline Kako je došlo do tvorbe? & Kako? & Objasniti razliku. \\
\hline Zašto je došlo do tvorbe? & Zašto? & Otkriti razloge. \\
\hline Gdje je došlo do tvorbe? & Gdje? & Definirati zemljopisno područje. \\
\hline Kada je došlo do tvorbe? & Kada? & Definirati povijesno doba. \\
\hline
\end{tabular}

Kombinacijom ove dvije tablice dobivamo dvadeset pet pitanja koja tvore etimološku analizu određenog osobnog imena. Odgovore je na neka pitanja o različitim osobnim imenima moguće generalizirati, a u pojedinim stupnjevima razvoja osobnog imena postoji suodnos između odgovora na više pitanja (Beider 2001: xxxii-xxxiii; Beider 2003: 43-44).

Odgovori se na pitanje $\breve{S} t o$ ? iz druge tablice mogu razvrstati u četiri skupine:

1. opće imenice, pridjevi, glagoli

2. osobna imena suprotnog spola

3. nežidovska osobna imena

4. osobna imena koja nose Židovi u drugim zemljopisnim područjima $\mid \begin{aligned} & \text { nova osobna imena } \mid \text { podrijetlo odgovara tvorb } \\ & \mid \text { stara osobna imena } \mid \text { posuđena osobna imena }\end{aligned}$ dok se oni na pitanje Zašto? mogu razvrstati u pet:

1. početni razvoj asocijacijom na postojeća židovska osobna imena:

a) fonetske asocijacije

b) semantičke asocijacije

c) izravne asocijacije

2. početni razvoj zbog privlačne semantike izvorišne riječi

3. čimbenici mode

4. poštovanje spram židovskih svetih spisa

5. židovske seobe 
Iz tih odgovora Beider izvodi tipologiju podrijetla židovskih osobnih imena:

\begin{tabular}{|l|l|l|}
\hline \multicolumn{1}{|c|}{ Vrsta } & \multicolumn{1}{|c|}{ Što? } & \multicolumn{1}{|c|}{ Zašto? } \\
\hline jednostavne tvorbe & $\begin{array}{l}\text { opće imenice } \\
\text { pridjevi } \\
\text { glagoli }\end{array}$ & privlačna semantika \\
\hline kalkovi & $\begin{array}{l}\text { opće imenice } \\
\text { pridjevi } \\
\text { glagoli }\end{array}$ & semantička asocijacija \\
\hline $\begin{array}{l}\text { posuđena prijevodna osobna } \\
\text { imena }\end{array}$ & nežidovska osobna imena & semantička asocijacija \\
\hline $\begin{array}{l}\text { posuđeni kršćanski likovi } \\
\text { osobnih imena iz Tanaha }\end{array}$ & nežidovska osobna imena & izravna asocijacija \\
\hline fonetske posuđenice & nežidovska osobna imena & fonetska asocijacija \\
\hline semantičke posuđenice & nežidovska osobna imena & privlačna semantika \\
\hline $\begin{array}{l}\text { posuđena česta nežidovska } \\
\text { osobna imena }\end{array}$ & nežidovska osobna imena & moda \\
\hline tvorba ženskih likova od & židovska muška osobna \\
imena osobnih imena & stara osobna imena & izravna asocijacija \\
\hline posuđenice iz tekstova & stara osobna imena & seobe \\
\hline
\end{tabular}

Svi su navedeni tipovi osim zadnjega povezani s općom povijesti židovske kulture. Migrirana se osobna imena ne tiču lingvistike ni općih vidova kulture, već isključivo povijesti. Kako osobna imena migriraju s pojedincima, poredbena analiza osobnih imena koja su u uporabi u različitim zajednicama donose izrazito važne podatke o obrascima seoba i genskim vezama između različitih zajednica. U praksi nije lako zaključiti u koju od navedenih kategorija pojedino židovsko osobno ime svojim podrijetlom spada (Beider 2001: xxxiii-xxxv; Beider 2003: 45-47). Naš korpus kronološki započinje relativno kasno, početkom XIX. st., kad su osobna imena uglavnom već formirana. Isprva se, u doba doseljavanja Židova u Zagreb, susrećemo s migriranim osobnim imenima, koja su doseljenici donijeli sa sobom iz svojih domovina (uglavnom austro-ugarskih i njemačkih zemalja). Kasnije nalazimo i osobna imena koja su Židovi, živeći u Zagrebu već neko vrijeme, počeli preuzimati od nežidovskih sugrađana, među njima i slavenska. Odgovorima će se na pitanja o podrijetlu osobnih imena 
ovaj rad baviti u ograničenoj mjeri, kada riječ bude o tipičnim aškenaskim, jidiškim osobnim imenima i njihovoj povijesti.

Klasifikacija osobnih imena prema jeziku može biti i jedna od najjednostavnijih i jedna od najtežih. Nije teško otkriti iz kojeg jezika neko osobno ime potječe (etymologia remota), no znatno je teže, a katkad i nemoguće sa sigurnošću utvrditi otkuda je osobno ime neposredno došlo u određeni kraj (etymologia proxima). Primjerice, i Alexander su i Offmia (Eufemija) podrijetlom grčka osobna imena, no prvo je u židovski antroponimski korpus ušlo još u doba helenizma dok je drugo nesumnjivo preuzeto od njemačkih kršćana. Prvo bi trebalo klasificirati kao osobno ime preuzeto od Grka, a drugo kao osobno ime preuzeto od Nijemaca. Mnogo se autora još od Leopolda Zunza bavilo etimološkim podrijetlom aškenaskih osobnih imena, svrstavajući ih u semitska (hebrejska i aramejska), grčka, romanska, germanska i slavenska ${ }^{305}$, no malo ih se hvatalo u koštac s jezikom iz kojeg su neposredno preuzeta. To ne treba čuditi, ako se s jedne strane u obzir uzme interna složenost jidiša kao jezika sastavljenog od elemenata različitog podrijetla. Primjerice, žensko osobno ime העניטשקע/henitškel

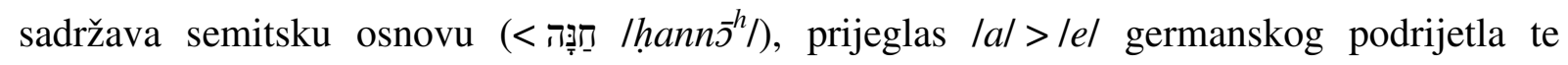
slavenski deminutivni sufiks -ičke (Beider 2001: xxxv-xxxvii; Beider 2003: 53-56). S druge su pak strane biblijska osobna imena, posredovana grčkim i latinskim, u mnogim europskim jezicima identična, pa nije lako reći je li Adam osobno ime u hrvatskome preuzeto izravno iz biblijskih prijevoda ili je pak posredovano njemačkim, francuskim, ruskim, mađarskim,... jezikom. Možemo jedino pretpostaviti da su sva germanska osobna imena izravno preuzeta iz njemačkoga osim onih koji svojim likom pokazuju da su prošla kroz filtre drugih jezika, primjerice Adolfo kroz talijanski, a Žiga kroz mađarski. Usto nam ostaje dovoljno drugih osobnih imena kojima ne možemo jednoznačno odrediti put kojim su prošla od izvorišta do Zagreba.

${ }^{305}$ Takvu će podjelu slijediti i ovaj rad u području etymologia remota, uz neke izmjene: latinska osobna imena kao zasebna kategorija, te jidiška i mađarska osobna imena kao dodatne. Silom će se prilika pojaviti još dvije kategorije: perzijska i turkijska osobna imena, sa samo po jednim pripadnikom, redom Mirza i Boris. 
Osobna imena možemo klasificirati i prema poopćenimim odgovorima na pitanje Kako?

\begin{tabular}{|l|l|l|}
\hline \multicolumn{1}{|c|}{ Vrsta } & \multicolumn{1}{|c|}{ Opaska } & Kompatibilno s kategorijama \\
\hline pojavljuje se bez promjena & izvor i rezultat su identični & $\begin{array}{l}\text { ・ nežidovska osobna imena } \\
\text { stara osobna imena }\end{array}$ \\
\hline semantička tvorba & $\begin{array}{l}\text { izvor i rezultat su fonetski } \\
\text { identični, ali pripadaju dvama } \\
\text { različitim semantičkim } \\
\text { poljima }\end{array}$ & $\begin{array}{l}\text { opće imenice, pridjevi, glagoli } \\
\text { osobna imena suprotnog spola }\end{array}$ \\
\hline morfološka tvorba & $\begin{array}{l}\text { morfološke strukture } \\
\text { izvorišne riječi i iz nje } \\
\text { proizašlog osobnog imena } \\
\text { nisu identične }\end{array}$ & $\begin{array}{l}\text { opće imenice, pridjevi, glagoli } \\
\text { osobna imena suprotnog spola }\end{array}$ \\
\hline fonetska prilagodba & $*$ & $\begin{array}{l}\text { nežidovska osobna imena } \\
\text { stara osobna imena }\end{array}$ \\
\hline
\end{tabular}

* Kada govorni jezici Židovā i nežidova nisu isti, preuzimanje nežidovskog osobnog imena može pratiti i njegova fonetska prilagodba govornom jeziku onih prvih. Ista se stvar događa kada se pojedinac doseli u kraj u kojem je fonetski sustav lokalnog jezika drukčiji od onoga kraja iz kojeg je došao, ali i ako se osobno ime preuzme izravno iz Tanaha. Naime, lokalni se izgovor hebrejskoga može razlikovati od kraja do kraja, ali i od onoga tradicionalno prihvaćenoga ${ }^{306}$ (Beider 2001: xxxvii; Beider 2003:56-58).

Više je obrazaca po kojima se od temeljnih likova osobnih imena izvode novi likovi:

- dodavanje sufiksa

- otpadanje početnih slogova

- otpadanje dočetnih elemenata

- otpadanje elemenata unutar riječi

- ponavljanje početnog suglasnika

- promjena samoglasnika korijena

- palatalizacija suglasnika

- stvaranje akronima.

\footnotetext{
${ }^{306}$ Ovdje bi bilo dobro uvesti distinkciju izgovora hebrejskoga sličnu onoj u latinskome: (rekonstruirani) klasični hebrejski, kakav se vjerojatno govorio u biblijsko doba, te tradicionalni koji slijedi masoretska pravila.
} 
Novi se likovi mogu dobiti i kombiniranjem više navedenih obrazaca. Dok je analiza takvih obrazaca poopćeni odgovor na pitanje Kako?, odgovore na pitanje Zašto? treba tražiti u psihologiji. Određeni lik osobnog imena kojim osobe iz njegove okoline nazivaju pojedinca otkrivaju nijanse odnosā između dvije osobe, pa takvi izvedeni likovi osobnih imena, odmilice i umanjenice, postaju svojevrsnom kulturnom nužnosti. Teorijski se izvedeni likovi mogu derivirati iz svih temeljnih likova osobnih imena, no neki od ovih ne tvore izvedene likove, novi se likovi mogu izvoditi i iz odmilica, a konkretno primijenjen obrazac izvođenja može ovisiti o određenim strukturalnim značajkama izvornog lika osobnog imena poput broja slogova, položaja naglašenog sloga (koji rijetko otpada $\left.{ }^{307}\right)$ i fonema od kojih se osobno ime sastoji (neki se suglasnici ne mogu palatalizirati). Do sada se navedeno tiče samo izravnih izvođenja likova osobnih imena. $\mathrm{S}$ druge strane postoje i ona neizravna u kojima između izvora i završnog lika postoji barem jedan međulik i čije sve likove (uključujući one krajnje) rabi ista kulturna zajednica. Sva se izvođenja odvijaju u specifičnim prostornim (Gdje?) i vremenskim (Kada?) okvirima (Beider xxxvii-xxxviii; Beider 2003: 58-60).

Katkad nije lako razlikovati izvedene (derivirane) likove aškenaskih osobnih imena od njihovih inačica (varijanata). Inačice se pojavljuju i u punih likova osobnih imena, i u odmilicā, i u umanjenicā, te u njih i izvorni i krajnji lik imaju isti status. Dok na kraju procesa izvođenja i izvorni lik i izvedenica supostoje, na kraju procesa kojim nastaju inačice izvorni lik obično nestaje, inačica ga zamjenjuje, ona predstavlja njegov promijenjeni lik. Tri su glavna obrasca tvorenja inačica, tri poopćena odgovora na pitanje $\breve{S} t o$ ? Fonetske su promjene općeniti fenomen, pojavljuju se u nizu jezikā i ne zahvaćaju isključivo osobna imena. Glavni tipovi fonetskih promjena uključuju redukciju nenaglašenih samoglasnika i diftonga, asimilaciju suglasnika i fonološke pomake. Do takvih promjena često dolazi u određenim glasovnim i naglasnim okolinama. Semantičko-fonetske prilagodbe uključuju riječ koja dolazi u novu okolinu u kojoj postoji druga riječ sličnog plana izraza i sličnog plana sadržaja, te bez problema zamjenjuje prvotnu riječ. Na kraju su tu i promjene zbog pučke etimologije. Za razliku od prethodne promjene, ovdje konačni lik mijenja etimologiju u odnosu na izvornu, što je posljedica pogrešnog tumačenja riječi. Kako onda razlikovati derivaciju od varijacije? Cilj je derivacije uvijek svjesna tvorba nove odmilice ili umanjenice, dok je varijacija spontani, nesvjesni proces. Ako su stilistički status ili morfološka struktura početnog i

\footnotetext{
${ }^{307} \mathrm{U}$ talijanskome se, primjerice, jedna vrst odmilica (i to ne samo od osobnog imena, već katkad i od prezimena) tvori otpadanjem svih slogova iza naglašenoga, npr. Giusè < Giuseppe.
} 
završnog lika različiti, u pitanju je derivacija, a ako izvorni lik nestaje, u pitanju je varijacija (Beider 2001: xxxix-xlii; Beider 2003: 61-67).

Višestruka osobna imena nisu specifikum židovske antroponimije, no u ovoj možemo uspostaviti nekoliko pravila vezanja, nekoliko odgovora na pitanje $\breve{S} t o$ ?

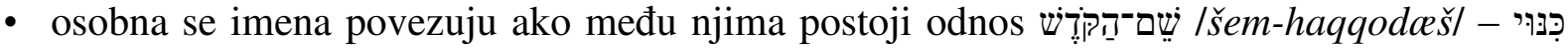
|kinnūy/

- osobna se imena povezuju ako među postoji neka druga vrsta povezanosti u kulturi

- osobna su imena međusobno neovisna, a njihova je povezanost slučajna.

Odgovor je na pitanje Zašto? u prva dva slučaja povezan sa samom klasifikacijom, a u trećem slučaju ne postoji neka vjerska ili kulturna konotativna veza među osobnim imenima. Drugi tip odgovora na ovo pitanje uključuje mogućnost točnije identifikacije pojedinca u doba prije službenog uvođenja prezimenā te mogućnost istodobnog štovanja uspomene na više preminulih srodnika. Pitanje Kako? otkriva da redoslijed osobnih imena u kombinaciji

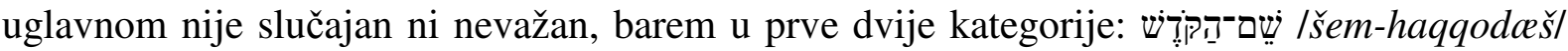

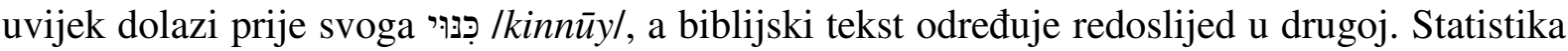
pokazuje da se čak i u trećoj neki redoslijedi pojavljuju znatno češće negoli obrnuti. Katkad se

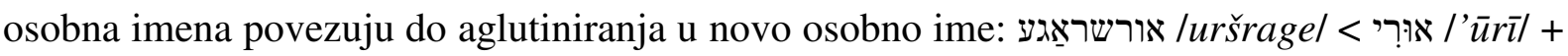

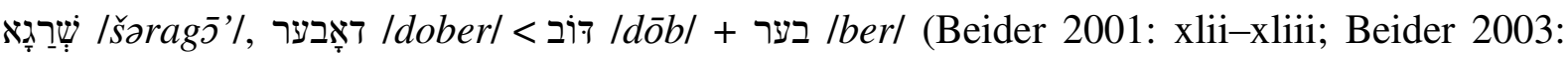
$68-69)$.

Odgovor je na pitanje zašto neko osobno ime nestaje iz antroponimskog korpusa određene

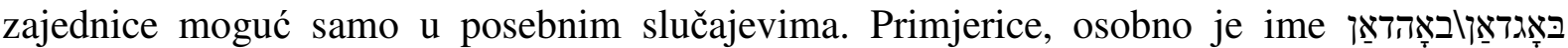
/bogdan/bohdan/ bilo uobičajeno među Židovima Velikog Vojvodstva Litve u XVI. st., a potpuno je nestalo iz uporabe nakon pogromā 1648. - 1656. g. koji su nad Židovima Ukrajine izveli Kozaci na čijem je čelu stajao ataman Sънові Богдан Хмелніцкіи (ukr. Богдан Зиновій Михайлович Хмельницький, о. 1595. - 1657.) ${ }^{308}$. Slično se dogodilo i s osobnim imenom Adolf u XX. st. (Beider 2001: 13-17; Beider 2003: 70).

\footnotetext{
${ }^{308}$ U korpusu pak nalazimo četiri Bogdana koji su rođeni 1883., 1885. (dvojica) i 1889. g. Pogromi su se o kojima je ovdje riječ vjerojatno odigrali i prostorno i vremenski dovoljno daleko da osobno ime (više) ne nosi negativne konotacije, tim više što je kao slavensko nadijevano u okruženju koje se postupno slaveniziralo.
} 
Sasvim je druga situacija s opstankom osobnog imena. Osim tradicije nadijevanja djeci osobnih imena preminulih rođaka, na nj utječu još tri čimbenika. Pojavljivanje je osobnog imena u Tanahu i važnost lika koji ga ondje nosi uvijek bilo bitnije za muška negoli za ženska osobna imena, među kojima su primjetne razlike ovisno o kraju i vremenu. Privlačna je semantika pak bila važnija pri izboru ženskog osobnog imena (ne samo u židovskoj kulturi). Među muškima se ističu ona vezana za Jakovljev blagoslov potomaka si iz 49. poglavlja

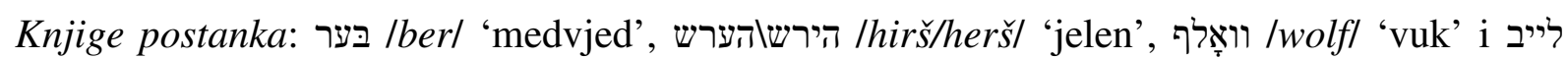

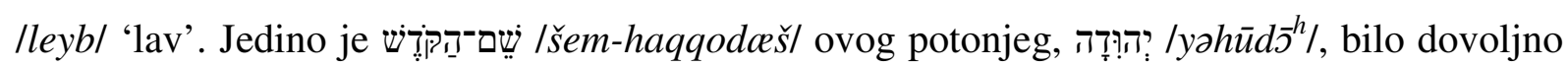

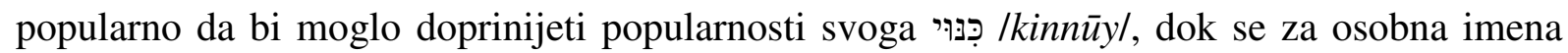

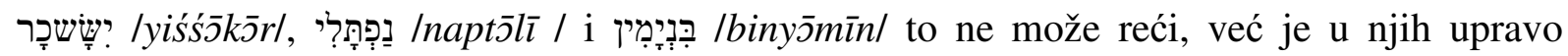

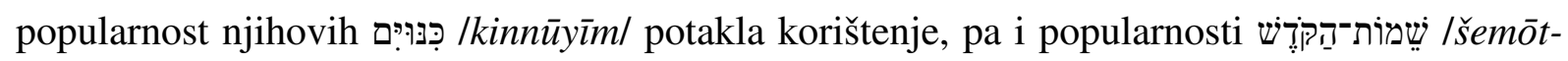
haqqodaeš/. Treći je čimbenik koji utječe na opstanak određenog osobnog imena plan izraza koji podsjeća na uobičajeno hebrejsko osobno ime. Navedeno vrijedi za osobna imena europskih Židova od srednjeg vijeka do dana današnjega (Beider 2001: xliii, 13-17; Beider 2003:70-71).

Na kraju treba napomenuti da roditelji odnosno imenodavci pri nadijevanju osobnog imena djetetu najčešće nisu bili svjesni njegove motivacije, etimologije i podrijetla, posebno u slučaju kad je ime podrijetlom iz stranoga jezika. Među izvornim govornicima često pučke etimologije nadomještaju stvarne, primjerice mnogi govornici hrvatskoga ne znaju da osobno ime Jelena nije vezano ni uz jèlena (životinju) ni uz jélu (drvo), već da potječe od grčkoga osobnog imena 'E $\lambda \varepsilon ́ v \alpha / h e l e ́ n a /$ nesigurne etimologije; da osobno ime Bojan nije povezano s turcizmom bòja, već da potječe od slavenske riječi bôj < prasl. *bojb 'bitka'; da ime zagrebačke četvrti Špansko nema nikakve veze sa Španjolskom, već da označuje područje kojega je nekada vlasnik bio špân, upravitelj, nadglednik vlastelinstva. Češće se osobno ime nadijeva po nekom srodniku bez obzira na motivaciju samoga osobnog imena. Stoga statističke analize koje se tiču motivacije, etimologije i podrijetla osobnih imena dalje u tekstu ne moraju odgovarati jezičnim odnosno etimološkim preferencijama roditelja, već samo ukazuju na popularnost određenih skupina osobnih imena u odnosu na njihovo podrijetlo, motivaciju, etimologiju i jezik iz kojih su preuzeta. 


\subsubsection{Građanska osobna imena zagrebačkih Židova}

U izvorima se navodi velik broj građanskih osobnih imena. Gavro Schwarz u svojoj knjizi navodi više od 350 različitih osobnih imena, matične knjige rođenih nešto manje od 800, a na nadgrobnim ih spomenicima na Mirogoju nalazimo više od 720. Mnoga se od njih pojavljuju samo jednom, a razmjerno je malen broj onih čija se čestoća može izraziti dvoznamenkastim brojevima. Za neka se osobna imena, malobrojna doduše, ne može točno ustanoviti pripadaju li muškarcu ili ženi (ako to nije eksplicitno navedeno). Očigledan su primjer osobna imena Bella, Bela i Béla. Bella je nesumnjivo žensko osobno ime romanskog podrijetla motivirano pridjevom značenja 'lijepa'. Béla je isto tako nesumnjivo muško osobno ime mađarskog podrijetla i nejasne motivacije, no Bela može biti i jedno i drugo, i romansko osobno ime bez naznačenog udvojenog suglasnika (onako kako bi se pisalo na mletačkom), i mađarsko osobno ime bez naznačene duljine samoglasnika ${ }^{309}$. Srećom, takvih osobnih imena nema mnogo i ne nose ih brojni pojedinci. S druge strane, postoje i mnoga osobna imena koja su podrijetlom odmilice, pa se teško može odrediti njihova motivacija. Srećom, ni ona niti su mnogobrojna niti su brojnih nositelja.

Neke su osobe u različitim izvorima navedene s različitim osobnim imenima, a neke u istom s više njih. Svako je od tih osobnih imena uzeto u obzir zasebno, ne kao dio neke imenske kombinacije.

Neka se osobna imena pojavljuju u grozdovima, okupljenima oko nekog jezgrenog osobnog imena. Sva su ona na neki način vezana uz to jezgreno osobno ime, bilo etimološki $($ Rosalia $<$ Rosa $)$, bilo semantički $(R u \check{a} a \sim R o s a)$, bilo time što je jedno iz drugoga izvedeno neizravno (Žiga $<<$ Siegmund), bilo time što je jedno osobno ime postalo odmilicom za drugo s kojim nije etimološki vezano (Reyzl $\neq$ Terezija). Ono što povezuje osobna imena unutar grozda jest činjenica da je jedna ili više osoba u različitim dokumentima zabilježena različitim osobnim imenima koja su uključena u grozd. Takva će se osobna imena u tekstu navoditi zajedno.

\footnotetext{
${ }^{309}$ Isto tako može biti i hrvatsko žensko osobno ime Bela $<$ *běla.
} 


\subsubsection{Najčešća građanska osobna imena u pojedinim izvorima}

U daljnjem će se tekstu koristiti simboli kako slijedi:

$\mathrm{X}<\mathrm{Y}$

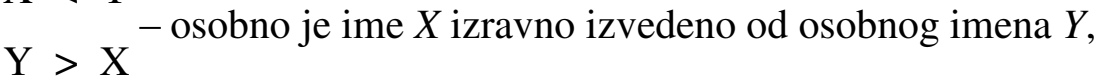

$\mathrm{X}<<\mathrm{Y}$

$\mathrm{Y} \gg \mathrm{X}$

- osobno je ime $X$ neizravno izvedeno od osobnog imena $Y$,

$\mathrm{X} \sim \mathrm{Y}$ - osobno je ime $X$ semantički ekvivalent osobnog imena $Y$ na drugom jeziku,

$\mathrm{X} \neq \mathrm{Y}$ - osobna imena $X$ i $Y$ nisu povezana ni etimološki ni semantički, već tradicijom,

$\mathrm{X} \times \mathrm{Y}$ - osobno ime $X$ dijeli plan izraza s riječju $Y$, s kojom nije nužno etimološki povezano.

\subsection{Najčešća muška građanska osobna imena u pojedinim izvorima}

U matičnim je knjigama rođenih (uključujući i osobna imena roditeljā) najčešće muško osobno ime Jacob/Jakob/Jakov/Jakel/Jacques/Jaques/Jak. sa 119 nositelja, a nešto ih manje ima Joseph/Josef/Jozef/Josif/Josip/Guseppo/Jos. sa 113. Slijede Ignatz/Ignaz/Ignac/Ignjat/Ig. s 93 nositelja, Leopold/ /Leop. s 83, Maurus/Mavro/Moritz/Moriz s 83, Heinrich/Henrik/ /Hinko/Heinr. sa 73, Alexander/Aleksander/Sándor/Sandor/Šandor sa 61, Albert/Alberto, Schmuel/Samuel/Samojlo i Siegmund/Sigmund/Sigismund/Zsigmund/Zsiga/Žiga s po 57, Adolf/Adolfo s 55, Max/Makso s 48, Carl/Karl s 47, Wilhelm/Vilmos/Wilmos/Vilim/Vilko/ /Wilh. s 46, Salamon/Salamun/Salomon/Solomon s 43, Rudolph/Rudolfo/Rudolf s 41, Robert/ /Roberto s 40, David/Dawid s 37, Hermann/Herman s 36, Ludwig/Louis/Luis/Lajos/Lajoš s 34, Bernhard/Bernhart/Bernarth/Bernard/Bernad/Bernardo/Bern. s 33, Julius/Julio s 31, Milan s 30 (prvo osobno ime motivirano općom imenicom slavenske etimologije na popisu), Oscar/Oskar s 29, Isidor/Izidor s 28, Eduard/Eduardo, Emil i Philipp/Philip/Filipp/Fillip/ /Filip s 27, Leo s 26, Arthur/Artur i Emannuel/Emanuel/Emanel/Imanuel s po 25, Paul/Pavao i Simon/Šimun s po 23, Vladimir/Vladko/Vlatko/Vlatkoj s 22 (drugo osobno motivirano općom imenicom slavenske etimologije na popisu), Otto s 21, Marcus/Markus/Mark/Marko s 20, Ferdinand/Fernando/Ferdo s 18, Alfred/Alfried sa 17, Ernest/Ernst/Ernö i Victor/Wictor/ /Viktor s po 16, Friedrich/Fritz s 15, Dragutin (treće osobno ime motivirano općom imenicom slavenske etimologije na popisu) i Richard/Rikard s po 14, Georg/Gjuro/Đuro, Gustav i Johann/Johan/Ivan/Ivo/Ivica s po 13, Anton/Antun, Lavoslav (četvrto osobno ime motivirano općom imenicom slavenske etimologije na popisu) i Michael/Michalj/Mihaly s po 12 te Hugo s 10 nositelja. Sva preostala osobna imena imaju jednoznamenkast broj nositelja. 
U knjizi je Gavre Schwarza najpopularnije muško osobno ime Josephus/Joseph/Josef/Jozefl /Josel/Josip/Jos. s 56 nositelja, a nešto manje ih, 48, ima osobno ime Jacobus/Jacob/Jakob/ /Jacques/Jakov/Jaco/Jac. Slijede Leo, Samuel/Zanvil i Sigismund/Sigismundus/Sigmund/Žiga/ /Sig. s po 29, Ignatius/Ignaz/Ignac/Ignjat s 28, Mavro/Moriz/Moric s 27, Leopold/Leopoldus s 26, Heinrich/Hinko s 22, Adolf s 21, Maks/Makso s 19, Albert i Karl/Karlo s po 18, Alexander/Aleksander/Šandor i Milan (prvo osobno ime motivirano općom imenicom slavenske etimologije na popisu) s po 16, Johann/Hanzi/Ivan/Ivo, Julius/Julio/Julijo/Jul. i Robert/Robret s po 14, Wilhelm/Vilim/Vilko s 13, Marcus/Markus/Marko s 11 te Eduard/ /Edvardus s 10 nositelja. Sva preostala osobna imena imaju jednoznamenkast broj nositelja.

Na nadgrobnim je spomenicima na Mirogoju i u bazi podataka Gradskih grobalja najčešće muško osobno ime Josef/Josip/Jožek/JOZEF/Jos. sa 108 nositelja. Slijede Jacob/Jakob/Jakov/ /JAKOG/Jaques/Jacqes/ŽAK/James sa 78 nositelja, Mauro/Mavro/Moritz/MORIZ/Moric sa 77, Ignatz/Ignacy/IGNACIJE/Ignac/Ignjat/Ig. sa 61, Julius/Julio/Julijo/Julije s 59, Lavoslav s 58 (prvo osobno ime motivirano općom imenicom slavenske etimologije na popisu), Sigmund/SIGISMUND/Žiga s 56, Adolf s 51, Dragutin s 48 (drugo osobno ime motivirano općom imenicom slavenske etimologije na popisu), Max/MAXO/Maks/Makso s 47, Hans/ /Hancika/Ivan/Ivo/Ivica s 45, Heinrich/Hinko s 43, Samuel/Samojlo/Samol s 41, Vilhelm/Vilim/Vilko s 40, Aleksander/Aleksandar/Alex/Aleksa/Sandor/Šandor s 39, Milan s 37 (treće osobno ime motivirano općom imenicom slavenske etimologije na popisu), Adalbert/Albert i Ljudevit s po 36, Isidor/Iso/Izidor/Izo s 35, Otto/Oto/Oton s 30, Salamon/ /Salomon/Solomon i Vladimir/Vlado/Vladko/Vlatko (četvrto osobno ime slavenske etimologije na popisu) s po 29, Bernhard/Bernard s 26, Leopold/Leop. i Rudolf/Rudo/Rudi s po 25, Hugo s 24, MARKUS/Marko i Miroslav (peto osobno ime motivirano općom imenicom slavenske etimologije na popisu) s 23, David i Georg/George/Gjuro/Đuro/Gjurica/Đuka/Gjukica/Đorđe s po 21, Leo i Robert s po 20, Filip s 19, Eduard/EISNY, Hermann/Herman i Theodor/Teodor/ /Feodor/Fedor/Fedja/Feđa s po 18, Oskar sa 17, Gustav/Gusti sa 16, Edmund/EDMOND, FERDINAND/Ferdo, Franz/Franjo i Vatroslav (šesto osobno ime motivirano općom imenicom slavenske etimologije na popisu) s po 15, Viktor s 14, Artur i Branko (sedmo osobno ime motivirano općom imenicom slavenske etimologije na popisu) s po 13, Emanuel/EMANUEL i Emil s po 12, Geza/Gejza i Paul/Pavel/Pavao s po 11 te Felix/Feliks, Simon/ŠIMUN i Slavo/Slavko (osmo osobno ime motivirano općom imenicom slavenske etimologije na popisu) s po 10 nositelja. Sva preostala osobna imena imaju jednoznamenkast broj nositelja. 
Isti su podaci radi lakšeg pregleda svrstani u Tablicu 4:

Tablica 4: Najpopularnija muška građanska osobna imena

\begin{tabular}{|c|c|c|c|c|c|c|}
\hline & \multicolumn{2}{|c|}{ Matične knjige rođenih } & \multicolumn{2}{|l|}{ Schwarz } & \multicolumn{2}{|l|}{ Mirogoj } \\
\hline 1. & $\begin{array}{l}\text { Jacob/Jakob/Jakov/ } \\
\text { /Jakel//Jacques/Jaques/ } \\
\text { /Jak. }\end{array}$ & 119 & $\begin{array}{l}\text { Josephus/Joseph/Josef/ } \\
\text { /Jozef/Josel/Josip/Jos. }\end{array}$ & 56 & $\begin{array}{l}\text { Josef/Josip/Jožek/ } \\
\text { /JOZEF/Jos. }\end{array}$ & 108 \\
\hline 2. & $\begin{array}{l}\text { Joseph/Josef/Jozef/Josif/ } \\
\text { /Josip/Guseppo/Jos. }\end{array}$ & 113 & $\begin{array}{l}\text { Jacobus/Jacob/Jakob/ } \\
/ \text { Jacques/Jakov/Jaco/Jac. }\end{array}$ & 48 & $\begin{array}{l}\text { Jacob/Jakob/Jakov/ } \\
\text { /Jaques/Jacqes/ŽAK/ } \\
\text { /James }\end{array}$ & 78 \\
\hline 3. & $\begin{array}{l}\text { Ignatz/Ignaz/Ignac/ } \\
\text { /Ignjat/Ig. }\end{array}$ & 93 & Leo & & $\begin{array}{l}\text { Mauro/Mavro/Moritz/ } \\
\text { /MORIZ/Moric }\end{array}$ & 77 \\
\hline 4. & Leopold/ /Leop. & 83 & Samuel/Zanvil & 29 & $\begin{array}{l}\text { Ignatz/Ignacy/ } \\
\text { /IGNACIJE/Ignac/ } \\
\text { /Ignjat/Ig. }\end{array}$ & 61 \\
\hline 5. & $\begin{array}{l}\text { Maurus/Mavro/Moritz/ } \\
\text { /Moriz }\end{array}$ & 83 & $\begin{array}{l}\text { Sigismund/ } \\
\text { /Sigismundus/Sigmund/ } \\
\text { /Žiga/Sig. }\end{array}$ & & Julius/Julio/Julijo/Julije & 59 \\
\hline 6. & $\begin{array}{l}\text { Heinrich/Henrik/Hinko/ } \\
\text { /Heinr. }\end{array}$ & 73 & $\begin{array}{l}\text { Ignatius/Ignaz/Ignac/ } \\
\text { /Ignjat }\end{array}$ & 28 & Lavoslav* & 58 \\
\hline 7. & $\begin{array}{l}\text { Alexander/Aleksander/ } \\
\text { /Sándor/Sandor/Šandor }\end{array}$ & 61 & Mavro/Moriz/Moric & 27 & $\begin{array}{l}\text { Sigmund/SIGISMUND/ } \\
\text { /Žiga }\end{array}$ & 56 \\
\hline 8. & Albert/Alberto & & Leopold/Leopoldus & 26 & Adolf & 51 \\
\hline 9. & $\begin{array}{l}\text { Schmuel/Samuel/ } \\
\text { /Samojlo }\end{array}$ & & Heinrich/Hinko & 22 & Dragutin* & 48 \\
\hline 10. & $\begin{array}{l}\text { Siegmund/Sigmund/ } \\
\text { /Sigismund/Zsigmund/ } \\
\text { /Zsiga/Žiga }\end{array}$ & & Adolf & 21 & $\begin{array}{l}\text { Max/MAXO/Maks/ } \\
\text { /Makso }\end{array}$ & 47 \\
\hline 11. & Adolf/Adolfo & 55 & Maks/Makso & 19 & $\begin{array}{l}\text { Hans/Hancika/Ivan/Ivo/ } \\
\text { /Ivica }\end{array}$ & 45 \\
\hline 12. & Max/Makso & 48 & Albert & & Heinrich/Hinko & 43 \\
\hline 13. & Carl/Karl & 47 & Karl/Karlo & & Samuel/Samojlo/Samol & 41 \\
\hline
\end{tabular}




\begin{tabular}{|c|c|c|c|c|c|c|}
\hline & Matične knjige rođel & & Schwarz & & Mirogoj & \\
\hline 14. & $\begin{array}{l}\text { Wilhelm/Vilmos/ } \\
\text { /Wilmos/Vilim/Vilko/ } \\
\text { /Wilh. }\end{array}$ & 46 & $\begin{array}{l}\text { Alexander/Aleksander/ } \\
\text { /Šandor }\end{array}$ & \multirow[b]{2}{*}{16} & \multirow[b]{2}{*}{$\begin{array}{l}\text { Aleksander/Aleksandar/ } \\
\text { /Alex/Aleksa/Sandor/ } \\
\text { /Šandor }\end{array}$} & 40 \\
\hline 15. & $\begin{array}{l}\text { Salamon/Salamun/ } \\
\text { /Salomon/Solomon }\end{array}$ & 43 & Milan* & & & 39 \\
\hline 16. & $\begin{array}{l}\text { Rudolph/Rudolfo/ } \\
\text { /Rudolf }\end{array}$ & 41 & Johann/Hanzi/Ivan/Ivo & \multirow{3}{*}{14} & Milan* & 37 \\
\hline 17. & Robert/Roberto & 40 & Julius/Julio/Julijo/Jul. & & Adalbert/Albert & \multirow{2}{*}{36} \\
\hline 18. & David/Dawid & 37 & Robert/Robret & & Ljudevit & \\
\hline 19. & Hermann/Herman & 36 & Wilhelm/Vilim/Vilko & 13 & Isidor/Iso/Izidor/Izo & 35 \\
\hline 20. & $\begin{array}{l}\text { Ludwig/Louis/Luis/ } \\
\text { /Lajos/Lajoš }\end{array}$ & 34 & Marcus/Markus/Marko & 11 & Otto/Oto/Oton & 30 \\
\hline 21. & $\begin{array}{l}\text { Bernhard/Bernhart/ } \\
\text { /Bernarth/Bernard/ } \\
\text { /Bernad/Bernardo/Bern. }\end{array}$ & 33 & Eduard/Edvardus & 10 & $\begin{array}{l}\text { Salamon/Salomon/ } \\
\text { /Solomon }\end{array}$ & \multirow[t]{2}{*}{29} \\
\hline 22. & Julius/Julio & 31 & & & $\begin{array}{l}\text { Vladimir/Vlado/Vladko/ } \\
\text { /Vlatko* }\end{array}$ & \\
\hline 23. & Milan* & 30 & & & Bernhard/Bernard & 26 \\
\hline 24. & Oscar/Oskar & 29 & & & Leopold/Leop & מר \\
\hline 25. & Isidor/Izidor & 28 & & & Rudolf/Rudo/Rudi & \\
\hline 26. & Eduard/Eduardo & \multirow{3}{*}{27} & & & Hugo & 24 \\
\hline 27. & Emil & & & & MARKUS/Marko & \multirow[b]{2}{*}{23} \\
\hline 28. & $\begin{array}{l}\text { Philipp/Philip/Filipp/ } \\
\text { /Fillip/Filip }\end{array}$ & & & & Miroslav* & \\
\hline 29. & Leo & 26 & & & David & \multirow{4}{*}{20} \\
\hline 30. & Arthur/Artur & \multirow[t]{2}{*}{25} & & & $\begin{array}{l}\text { Georg/George/Gjuro/ } \\
\text { /Đuro/Gjurica/Đuka/ } \\
\text { /Gjukica/Đorđe }\end{array}$ & \\
\hline 31. & $\begin{array}{l}\text { Emannuel/Emanuel/ } \\
\text { /Emanel/Imanuel }\end{array}$ & & & & Leo & \\
\hline 32. & Paul/Pavao & 23 & & & Robert & \\
\hline
\end{tabular}




\begin{tabular}{|c|c|c|c|c|c|}
\hline & Matične knjige rođen & & Schwarz & Mirogoj & \\
\hline 33. & Simon/ŠSimun & & & Filip & 19 \\
\hline 34. & $\begin{array}{l}\text { Vladimir/Vlado/Vladko/ } \\
\text { /Vlatko/Vlatkoj* }\end{array}$ & 22 & & Eduard/EISNY & \multirow{3}{*}{18} \\
\hline 35. & Otto & 21 & & Hermann/Herman & \\
\hline 36. & $\begin{array}{l}\text { Marcus/Markus/Mark/ } \\
\text { /Marko }\end{array}$ & 20 & & $\begin{array}{l}\text { Theodor/Teodor/ } \\
\text { /Feodor/Fedor/Fedja/ } \\
\text { /Feđa }\end{array}$ & \\
\hline 37. & $\begin{array}{l}\text { Ferdinand/Fernando/ } \\
\text { /Ferdo }\end{array}$ & 18 & & Oskar & 17 \\
\hline 38. & Alfred/Alfried & 17 & & Gustav/Gusti & 16 \\
\hline 39. & Ernest/Ernst/Ernő & \multirow{2}{*}{16} & & Edmund/EDMOND & \multirow{4}{*}{15} \\
\hline 40. & Victor/Wictor/Viktor & & & FERDINAND/Ferdo & \\
\hline 41. & Friedrich/Fritz & 15 & & Franz/Franjo & \\
\hline 42. & Dragutin* & \multirow{2}{*}{14} & & Vatroslav* & \\
\hline 43. & Richard/Rikard & & & Viktor & 14 \\
\hline 44. & Georg/Gjuro/Đuro & \multirow{3}{*}{13} & & Artur & \multirow{2}{*}{13} \\
\hline 45. & Gustav & & & Branko* & \\
\hline 46. & $\begin{array}{l}\text { Johann/Johan/Ivan/Ivo/ } \\
\text { /Ivica }\end{array}$ & & & Emanuel/EMANUEL & \multirow[t]{2}{*}{12} \\
\hline 47. & Anton/Antun & \multirow{3}{*}{12} & & Emil & \\
\hline 48. & Lavoslav* & & & Geza/Gejza & \multirow{2}{*}{11} \\
\hline 49. & Michael/Michalj/Mihaly & & & Paul/Pavel/Pavao & \\
\hline 50. & Hugo & 10 & & Felix/Feliks & \multirow{3}{*}{10} \\
\hline 51. & & & & Simon/ŠIMUN & \\
\hline 52. & & & & Slavo/Slavko* & \\
\hline & 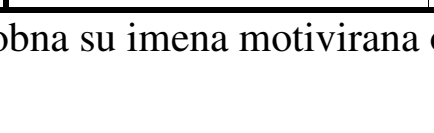 & & & ogije označena zvje & \\
\hline
\end{tabular}

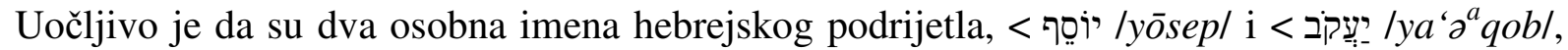
najčešća u sva tri izvora, a njihova je čestoća posebno vidljiva u Schwarzovoj knjizi gdje razlika između drugog i trećeg po redu iznosi 19 osoba, što je više od razlike između drugog i trećega najčešćeg osobnog imena. Od ostalih se osobnih imena podrijetlom iz Tanaha u 


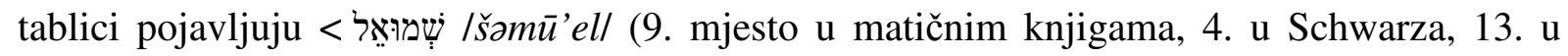

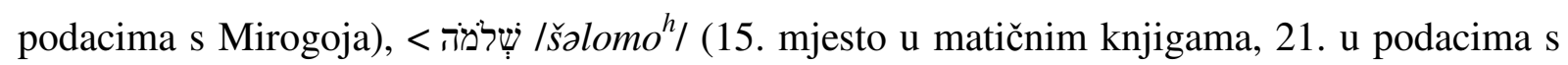

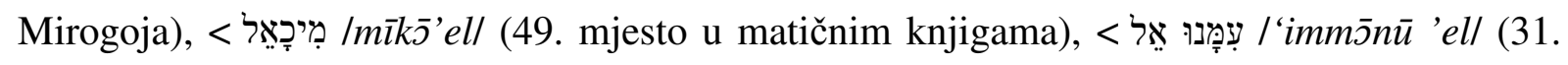
mjesto u matičnim knjigama, 46. u podacima s Mirogoja) i < שׁ̣מุ /šim ‘ōn/ (33. mjesto u matičnim knjigama, 51. u podacima s Mirogoja). Moguće objašnjenje tolike nenadmašne popularnosti upravo tih dvaju osobnih imena leži u činjenici da ona mogu podjednako uspješno funkcionirati i kao židovska i kao građanska u bilo kojoj kršćanskoj zemlji, dok su ostala (među kojima ima i onih s jednoznamenkastim brojem nositeljā) u većoj ili manjoj mjeri obilježena svojim očiglednim židovstvom (recimo < מִיכָ /mīkj̄'el/).

Od osobnih imena motiviranih općom imenicom slavenske etimologije u tablici nalazimo ova: Ljudevit (18. mjesto u podacima s Mirogoja), Miroslav (28. mjesto u podacima s Mirogoja), Vatroslav (42. mjesto u podacima s Mirogoja), Branko (45. mjesto u podacima s Mirogoja), Dragutin (42. mjesto u matičnim knjigama, 9. u podacima s Mirogoja), Lavoslav (48. mjesto u matičnim knjigama, 6. u podacima s Mirogoja), Milan (23. mjesto u matičnim knjigama, 15. u Schwarza, 16. u podacima s Mirogoja) i Vladimir/Vlado/Vladko/Vlatko/ /Vlatkoj (34. mjesto u matičnim knjigama, 22. u podacima s Mirogoja). Očigledno je da takva osobna imena najviše nalazimo među podacima s Mirogoja. Ako pretpostavimo da s vremenom slavenska osobna imena polako preuzimaju vodstvo među građanskima zagrebačkih Židova (i uz pretpostavku da su se neka osobna imena mijenjala tijekom života pojedinca, bilo službeno bilo administrativno), nije neočekivano da ovih osobnih imena u većem broju nalazimo na kraju njihovih životnih puteva.

\subsection{Najčešća ženska građanska osobna imena u pojedinim izvorima}

U matičnim je knjigama rođenih (uključujući i osobna imena roditeljā) najčešće žensko osobno ime Regina/Regine/Reginna/Regi s 85 nositeljica, a tek ih nešto manje, 83, ima osobno ime Anna / Ana / Anette / Anka / Nannette / Nanette / Nanetta / Nanetti / Nanete / /Hanni/Hani. Slijede Johanna/Johana/JeanettelIvana/Ivanna/Ivka s 81 nositeljicom, Elisabeth / Elisabetha / Elisabette / Elizabeth / Eržebet / Ella / Elise / Babette / Babete / /Babetta/Babet/Bette//Betty/Betti/Jelisava sa 72, Catharina/Katharine/Katharina/Katharin/ /Katarina/Catti/Käthe/Kathi/Katty/Kati/Katica sa 61, Fanike/Fanika/Fanny/Fany/Fanni/Fani i Rosa/Rose/Rosi/Roza/Ruža/Ružica s po 60, Gisella/Gisela/Gizella/Gizela s 59, Rosaliel /Rosalia/Rosalija/Rozalia/Rozalija s 58, Olga s 55, Maria/Marie/Marija i Theresia/Theresiel 
/Terezie/Therese/Theres/Thereze/Tereze/Terez/Resi/Resy/Terezija s po 53, Josephine/Josefinel /Josefa/Josipa/Joži s 52, Caroline/Carolina/Karoline/Karolina s 50, Charlotte/Charlottal /Šarlota/Lotty/Lotti/Loti s 48, Berthe/Bertha/Berte/Berta s 45, Julie/Julia/Julcsa/Julija/Julka s 44, Pauline/Paulina/Paola/Paula s 39, Hermine/Hermina s 38, Caecilia/Caecilie/Cäcilial /Cäcilie//Cäcilije/Cecilia/Cecilie/Cacilie/Cecilija/Cicila s 35, Helene/Helena/Elena/Jelena s 34, Ida s 33, Amalie/Amalia/AmmalialAmalija s 32, ZoralZoricalZorka s 30 (prvo osobno ime motivirano općom imenicom slavenske etimologije na popisu), Ernestine/Ernestina/Ernal /Erne/Erni s 29, Emma/Ema s 27, Malvina/Malvine/Malwine/Malvin s 26, Emilie/Emilial /Emilija s 24, Margarethe/Margaretha/Margherita/Margeta/Margrit/Margit/Margaretal /Marga/Margita i Sidonie/Sidonia/Sidonije/Sidonija/Sida s po 23, Franziska/Frany/ Franciska/Franjica/Franjka, Mathilde/Matilde/Matilda i Netty/Netti s po 21, Line/Linna/Lina i Stephanie/Stefanie/Stefanije/Stefania/Stefanija/Stiepana/Stefica s po 18 , Irene/Irena/Iren sa 17, Irma i Sophie/Sofie/Sofije/Sofia/SofijalZofi s po 16, AdellelAdella/Adéle/Adele i Wilhelmine/Wilhelmina/Wilma/Vilma s po 15, Jenny/Jenni/Jeny s 13, Clementine/Clementina/ /Klementine/Klementina, Eugenie/Eugenia/Evgenija i Ilona/Ilonka/Ilka s po 12, Elvira, Henriette/Enrichette/Enrichetta, Melanie/Melania/Melani, Minne/Minna/Mina i Vera (drugo osobno ime motivirano općom imenicom slavenske etimologije na popisu) s po 11 te Clara/Klara, Draga/Dragica (treće osobno ime motivirano općom imenicom slavenske etimologije na popisu) i Jelka s po 10 nositeljica. Sva preostala osobna imena imaju jednoznamenkast broj nositeljica.

U knjizi je Gavre Schwarza najpopularnije žensko osobno ime Roza/Rozi/Rösel/Rosina/Ruža s 37 nositeljica. Slijede Anna/Ana/Hanna/Hani/Nanette/Naneta s 32 nositeljice, Theresial /Terezija/Tereza/Rezi s 28, Charlotte/Šarlota/Loti s 24, Johanna/Johana/Ivana/Ivka i Katharina/Katerina/Katarina/Kattel/Katton/Kati s po 21, Rosalia/Rosalija/Rozalija s 19, Paulina/Paula/PavalPavica sa 17, Amalija sa 16, Elizabeta/Eliza/Ela/Babeta s 15, Franciscal /Franciška/Fany/Fani, Hermina i Julia/Julija/Julije s po 13, Regina s 12, Carolina/Karolina i Jozefina/Jozefa s po 11 te Ema i Ernestina/Erna s po 10 nositeljica. Sva preostala osobna imena imaju jednoznamenkast broj nositeljica. Zanimljivo je da među ovdje navedenima nema nijednog osobnog imena motivirano općom imenicom slavenske etimologije ${ }^{310}$.

\footnotetext{
${ }^{310}$ Ima ih, međutim, u donjem dijelu tablice popularnosti - Zora s 5 nositeljica, Jelka i Vera s po 4, Draga i Zlata s po 3, Ljuba i Mira s po 2 te Danica, Ljerka, Nada, Slava, Stanka i Zdenka s po 1 nositeljicom.
} 
Na nadgrobnim je spomenicima na Mirogoju i u bazi podataka Gradskih grobalja najčešce žensko osobno ime Rosa/Roza/Rozi/Ruža/ROZALINA/RUŽICA sa 65 nositeljica. Slijede Elisabeta/Ella/Ela/Elsa/Elza/Babette/Babeta/Betty/Betti/BETI/BETA/Betika/Jelisava sa 61 nositeljicom, AnnalAna/Annie/Anny/ANI/Hanna/Hana/AnicalAnka/Ankica s 54, Johannal /Johana/Jeannette/JEANETA/Žaneta/Ivana/Ivanka/Ivka s 49, Berta i Josefine/Josefinal /Jozefina/Josipa s po 48, Regina s 42, Charlotte/Charlotta/Charlota/Šarlota/Lotte/Lotta/Lotal /LOTI i Therese/Theresa/Tereza/Terezije/Terezia/Terezija/Terica/Tekla s po 41, Gisellal /Gisela/Gizella/Gizela/Giza s 38, Paulina/Paula/Pavla/Pavica/PAVA s 35, Rosalie/Rosalial /ROSALIJA/Rozalija s 32, Hermine/Hermina i Marie/MARIA/Mirjam/Mirjan/Marija/Marical /Mariška s po 29, Olga/Olgica s 28, Katharina/Katarina/Katica/Katinka s 27, Fany/Fanil /Fanni/Fanika i Ida s po 25, Carolina/Karolina i Cecilija/Cilika s po 23, Amalia/Amalija s 22, Nada/Nadica (prvo osobno ime motivirano općom imenicom slavenske etimologije na popisu) i Vera/Verica (drugo osobno ime motivirano općom imenicom slavenske etimologije na popisu) s po 19, Zlata/Zlatica (treće osobno ime motivirano općom imenicom slavenske etimologije na popisu) sa 17, Ernestina/Erna, Helene/Helena/Jelena, Sidonie/Sidonial /Sidonija/SIDI i Zora/Zorica (četvrto osobno ime motivirano općom imenicom slavenske etimologije na popisu) s po 16, Draga/Dragica (peto osobno ime motivirano općom imenicom slavenske etimologije na popisu), Emma/Ema, Malvina/Malva/Maluna i Mathildel IMatilda s po 15, Julie/JULIA/Julija, Mira/Mirica (šesto osobno ime motivirano općom imenicom slavenske etimologije na popisu) i Sophie/Sofie/Sofija s po 14, Irena, Laura i Martha/Marta s po 13, EMILIA/Emilija s 12, Henriette/Henrietta/Henrieta i Ilona/Ilonka/Ilka s po 11 te Grete/Greta, Julijana, Lina/LINKA i Steffy/Štefa/Štefi/Štefica s po 10 nositeljica. Sva preostala osobna imena imaju jednoznamenkast broj nositeljica. 
Isti su podaci radi lakšeg pregleda svrstani u Tablicu 5:

Tablica 5: Najpopularnija ženska građanska osobna imena

\begin{tabular}{|c|c|c|c|c|c|c|}
\hline & \multicolumn{2}{|l|}{ Matične knjige rođenih } & \multicolumn{2}{|l|}{ Schwarz } & \multicolumn{2}{|l|}{ Mirogoj } \\
\hline 1. & $\begin{array}{l}\text { Regina/Regine/Reginna/ } \\
\text { /Regi }\end{array}$ & 85 & $\begin{array}{l}\text { Roza/Rozi/Rösel/ } \\
\text { /Rosina/Ruža }\end{array}$ & 37 & $\begin{array}{l}\text { Rosa/Roza/Rozi/Ruža/ } \\
\text { /ROZALINA/RUŽICA }\end{array}$ & 65 \\
\hline 2. & $\begin{array}{l}\text { Anna/Ana/Anette/Anka/ } \\
\text { /Nannette/Nanette/ } \\
\text { /Nanetta/Nanetti/ } \\
\text { /Nanete/Hanni/Hani }\end{array}$ & 83 & $\begin{array}{l}\text { Anna/Ana/Hanna/Hani/ } \\
\text { /Nanette/Naneta }\end{array}$ & 32 & $\begin{array}{l}\text { Elisabeta/Ella/Ela/Elsa/ } \\
\text { /Elza/Babette/Babeta/ } \\
\text { /Betty/Betti/BETI/ } \\
\text { /BETA/Betika/Jelisava }\end{array}$ & 61 \\
\hline 3. & $\begin{array}{l}\text { Johanna/Johana/ } \\
\text { /Jeanette//Ivana/Ivanna/ } \\
\text { /Ivka }\end{array}$ & 81 & $\begin{array}{l}\text { Theresia/Terezija/ } \\
\text { /Tereza/Rezi }\end{array}$ & 28 & $\begin{array}{l}\text { Anna/Ana/Annie/Anny/ } \\
\text { /ANI/Hanna/Hana/ } \\
\text { /Anica/Anka/Ankica }\end{array}$ & 54 \\
\hline 4. & $\begin{array}{l}\text { Elisabeth/Elisabetha/ } \\
\text { /Elisabette/Elizabeth/ } \\
\text { /Eržebet/Ella/Elise/ } \\
\text { /Babette/Babete/ } \\
\text { /Babetta/Babet/Bette/ } \\
\text { /Betty/Betti/Jelisava }\end{array}$ & 72 & Charlotte/Šarlota/Loti & 24 & $\begin{array}{l}\text { Johanna/Johana/ } \\
\text { /Jeannette//JEANETA/ } \\
\text { /Žaneta/Ivana/Ivanka/ } \\
\text { /Ivka }\end{array}$ & 49 \\
\hline 5. & $\begin{array}{l}\text { Catharina/Katharine/ } \\
\text { /Katharina/Katharin/ } \\
\text { /Katarina/Catti/Käthe/ } \\
\text { /Kathi/Katty/Kati/Katica }\end{array}$ & 61 & $\begin{array}{l}\text { Johanna/Johana/Ivana/ } \\
\text { /Ivka }\end{array}$ & 21 & Berta & 48 \\
\hline 6. & $\begin{array}{l}\text { Fanike/Fanika/Fanny/ } \\
\text { /Fany/Fanni/Fani }\end{array}$ & & $\begin{array}{l}\text { Katharina/Katerina/ } \\
\text { /Katarina/Kattel/Katton/ } \\
\text { /Kati }\end{array}$ & & $\begin{array}{l}\text { Josefine/Josefina/ } \\
\text { /Jozefina/Josipa }\end{array}$ & \\
\hline 7. & $\begin{array}{l}\text { Rosa/Rose/Rosi/Roza/ } \\
\text { /Ruža/Ružica }\end{array}$ & & $\begin{array}{l}\text { Rosalia/Rosalija/ } \\
\text { /Rozalija }\end{array}$ & 19 & Regina & 42 \\
\hline 8. & $\begin{array}{l}\text { Gisella/Gisela/Gizella/ } \\
\text { /Gizela }\end{array}$ & 59 & $\begin{array}{l}\text { Paulina/Paula/Pava/ } \\
\text { /Pavica }\end{array}$ & 7 & $\begin{array}{l}\text { Charlotte/Charlotta/ } \\
\text { /Charlota/Šarlota/Lotte/ } \\
\text { /Lotta/Lota/LOTI }\end{array}$ & 41 \\
\hline
\end{tabular}




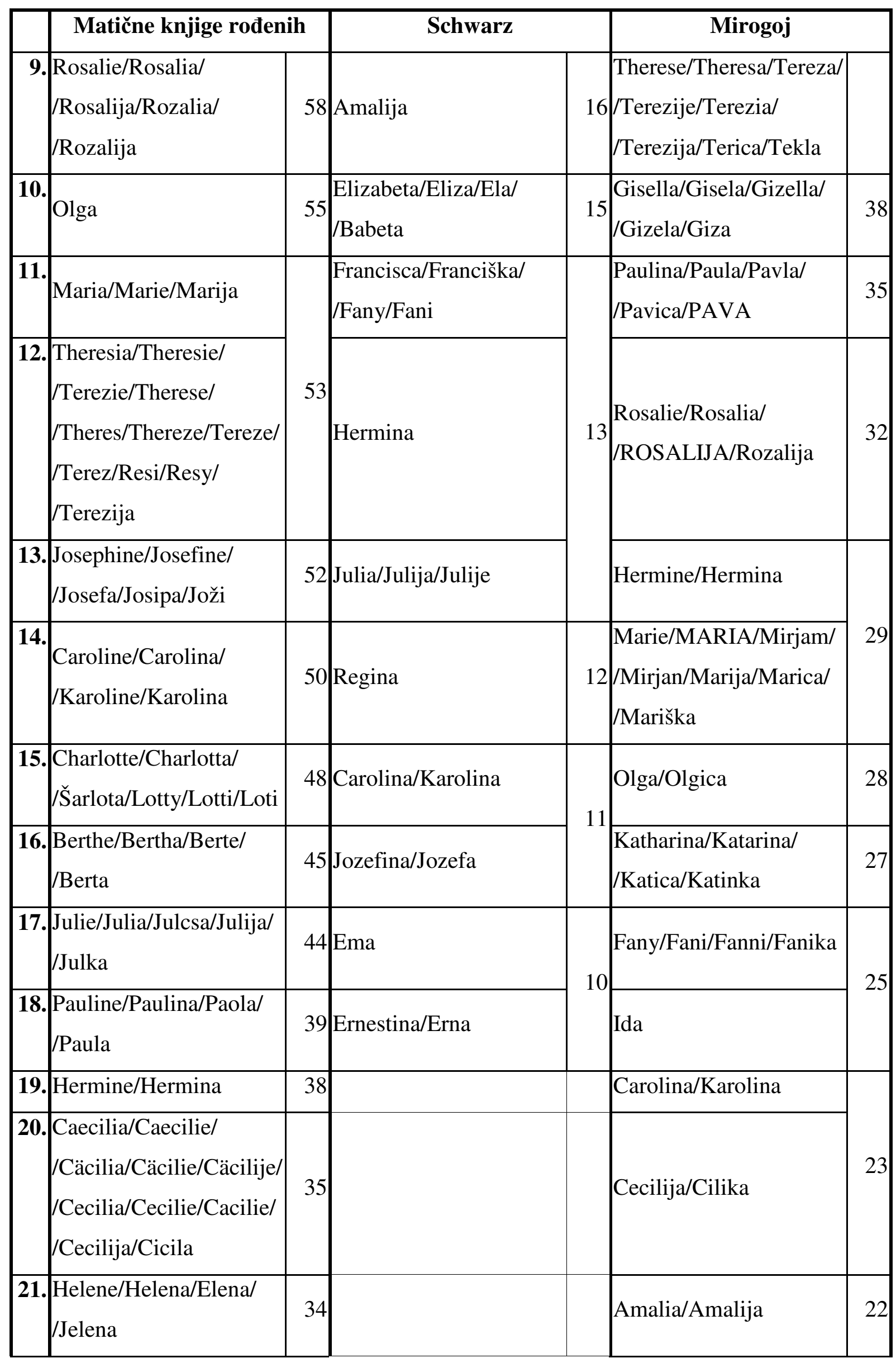




\begin{tabular}{|c|c|c|c|c|c|}
\hline & \multicolumn{2}{|c|}{ Matične knjige rođenih } & \multirow[t]{2}{*}{ Schwarz } & \multicolumn{2}{|l|}{ Mirogoj } \\
\hline 22. & Ida & 33 & & Nada/Nadica* & \multirow[b]{2}{*}{19} \\
\hline 23. & $\begin{array}{l}\text { Amalie/Amalia/ } \\
\text { /Ammalia/Amalija }\end{array}$ & 32 & & Vera/Verica* & \\
\hline 24. & Zora/Zorica/Zorka* & 30 & & Zlata/Zlatica* & 17 \\
\hline 25. & $\begin{array}{l}\text { Ernestine/Ernestina/ } \\
\text { /Erna/Erne/Erni }\end{array}$ & 29 & & Ernestina/Erna & \\
\hline 26. & Emma/Ema & 27 & & Helene/Helena/Jelena & \\
\hline 27. & $\begin{array}{l}\text { Malvina/Malvine/ } \\
\text { /Malwine/Malvin }\end{array}$ & 26 & & $\begin{array}{l}\text { Sidonie/Sidonia/ } \\
\text { /Sidonija/SIDI }\end{array}$ & 10 \\
\hline 28. & Emilie/Emilia/Emilija & 24 & & Zora/Zorica* & \\
\hline 29. & $\begin{array}{l}\text { Margarethe/Margaretha/ } \\
\text { /Margherita/Margeta/ } \\
\text { /Margrit/Margit/ } \\
\text { /Margareta/Marga/ } \\
\text { /Margita }\end{array}$ & 23 & & Draga/Dragica* & \\
\hline 30. & $\begin{array}{l}\text { Sidonie/Sidonia/ } \\
\text { /Sidonije/Sidonija/Sida }\end{array}$ & & & Emma/Ema & 15 \\
\hline 31. & $\begin{array}{l}\text { Franziska/Frany/ } \\
\text { /Franciska/Franjica/ } \\
\text { /Franjka }\end{array}$ & & & Malvina/Malva/Maluna & \\
\hline 32. & $\begin{array}{l}\text { Mathilde/Matilde/ } \\
\text { /Matilda }\end{array}$ & & & Mathilde/Matilda & \\
\hline 33. & Netty/Netti & & & Julie/JULIA/Julija & \\
\hline 34. & Line/Linna/Lina & & & Mira/Mirica* & \\
\hline 35. & $\begin{array}{l}\text { Stephanie/Stefanie/ } \\
\text { /Stefanije/Stefania/ } \\
\text { /Stefanija/Stiepana/ } \\
\text { /Stefica }\end{array}$ & 18 & & Sophie/Sofie/Sofija & 14 \\
\hline 36. & Irene/Irena/Iren & 17 & & Irena & \\
\hline 37. & Irma & & & Laura & 3 \\
\hline 38. & $\begin{array}{l}\text { Sophie/Sofie/Sofije/ } \\
\text { /Sofia/Sofija/Zofi }\end{array}$ & 16 & & Martha/Marta & \\
\hline
\end{tabular}




\begin{tabular}{|c|c|c|c|c|c|}
\hline & Matične knjige rođen & & Schwarz & Mirogoj & \\
\hline 39. & $\begin{array}{l}\text { Adelle/Adella/Adéle/ } \\
\text { /Adele }\end{array}$ & & & EMILIA/Emilija & 12 \\
\hline 40. & $\begin{array}{l}\text { Wilhelmine/ } \\
\text { /Wilhelmina/Wilma/ } \\
\text { /Vilma }\end{array}$ & 15 & & $\begin{array}{l}\text { Henriette/Henrietta/ } \\
\text { /Henrieta }\end{array}$ & 11 \\
\hline 41. & Jenny/Jenni/Jeny & 13 & & Ilona/Ilonka/Ilka & \\
\hline 42. & $\begin{array}{l}\text { Clementine/Clementina/ } \\
\text { /Klementine/Klementina }\end{array}$ & & & Grete/Greta & \\
\hline 43. & $\begin{array}{l}\text { Eugenie/Eugenia/ } \\
\text { /Evgenija }\end{array}$ & 12 & & Julijana & 10 \\
\hline 44. & Ilona/Ilonka/Ilka & & & Lina/LINKA & \\
\hline 45. & Elvira & & & 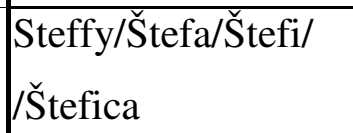 & \\
\hline 46. & $\begin{array}{l}\text { Henriette/Enrichette/ } \\
\text { /Enrichetta }\end{array}$ & & & & \\
\hline 47. & $\begin{array}{l}\text { Melanie/Melania/ } \\
\text { /Melani }\end{array}$ & 11 & & & \\
\hline 48. & Minne/Minna/Mina & & & & \\
\hline 49. & Vera* & & & & \\
\hline 50. & Clara/Klara & & & & \\
\hline 51. & Draga/Dragica* & 10 & & & \\
\hline 52. & Jelka & & & & \\
\hline
\end{tabular}

U ženskih osobnih imena od biblijskih nalazimo samo ona čiji je lik preuzet od kršćana: AnnalAnnie/Anny/Anette/AnalAnica/AnkalAnkicalANI (2. mjesto u matičnim knjigama, 3. u podacima s Mirogoja), Elisabeth/Elisabetha/Elisabette/Elizabeth/Jelisava/Eržebet/Ellal /Babette/Babetta/Babete/Babet/Bette/Betty/Betti/Betika/BETI/BETA (4. mjesto u matičnim knjigama, 10. u Schwarza, 2. u podacima s Mirogoja), Marie/Maria/Marija (11. mjesto u matičnim knjigama, 14. u podacima s Mirogoja), Martha/Marta (38. mjesto u podacima s Mirogoja), kao i ona koja su izvedena od muških osobnih imena iz Tanaha: Johanna/Johanal 
IJeanette/Ivanna/Ivana/Ivanka/Ivka (3. mjesto u matičnim knjigama, 5. u Schwarza, 4. u podacima s Mirogoja) i Josephine/Josefine/Josefina/Josefa/Jozefina/Jozefa/Josipa/Jožil IJOSFINA (13. mjesto u matičnim knjigama, 16. u Schwarza, 6. u podacima s Mirogoja).

Od osobnih imena motiviranih općom imenicom slavenske etimologije u tablici nalazimo sljedeća: Nada/Nadica (22. mjesto u podacima s Mirogoja), ZlatalZlatica (24. mjesto u podacima s Mirogoja), Mira/Mirica (35. mjesto u podacima s Mirogoja), ZoralZoricalZorka (23. mjesto u matičnim knjigama, 27. u podacima s Mirogoja), Vera/Verica (48. mjesto u matičnim knjigama, 23. mjesto u podacima s Mirogoja) i Draga/Dragica (51. mjesto u matičnim knjigama, 29. u podacima s Mirogoja). Za razliku od muških osobnih imena ženska pronalazimo podjednako i u matičnim knjigama i u podacima s Mirogoja. Indikativno je da ih među najpopularnijim osobnim imenima u Schwarza nema. Motivacija navedenih ženskih osobnih imena slavenskog podrijetla daje naslutiti da su izabrana upravo zbog privlačnog značenja općih imenica od kojih su izvedena. To kao razlog nadijevanja osobnih imena poglavito među ženama spominju autori koji su se bavili židovskim osobnim imenima (Beider 2001: xxviii; Beider 2003: 71).

\subsubsection{Najčešća građanska osobna imena u užem korpusu}

U užem korpusu, koji obuhvaća pojedince kojima znamo i osobna imena, i prezimena, i godine rođenja, osobna su imena navedena od najčešćeg, s time da su obrađena samo osobna imena s dvoznamenkastim brojem nositelja. Za svako je osobno ime prvo naveden izvorni lik, jezik iz kojeg potječe, te pojedini likovi i jezici u kojima se pojavljuju (ako ih je moguće identificirati) s brojem nositelja svake inačice navedenom u zagradama iza iste.

Germanska će se osobna imena navoditi u njihovu njemačkom liku, a njihova će etimologija biti tumačena pragermanskim korijenima ${ }^{311}$.

\subsection{Najčešća muška građanska osobna imena u užem korpusu}

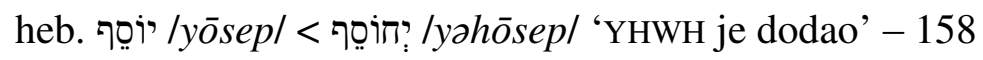

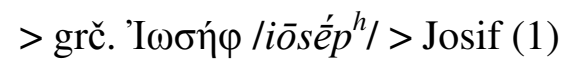

${ }^{311}$ Pragermanska je etimologija navedena prema Kroonen 2013. 
$>$ lat. Ioseph $>$ Joseph (9) $>$ Josephus (1)

$>$ njem. Josef (69) > Jozef (4)

$>$ jid. Josel (1)

$>$ hrv. Josip (68)

>> kaj. Jožek (1), Joži (1)

$>$ tal. Giuseppe $\sim$ Guseppo (2)

>> Jos. (1)

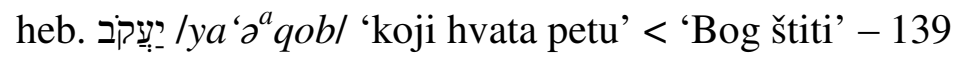

$>$ grč. ${ }^{\top} I \alpha \kappa \omega ́ \beta /$ liakó b/ > lat. Iacob > Jacob (91) > Jacobus (3) > Jaco (1)

>> jid. Jekev (1)

$>$ hrv. Jakov (22)

$>$ Jac. (2), Jak. (1)

>> fran. Jacques (3) > Jacqes (1), Jaques (13) > hrv. Žak (1)

lat. Ignatius (2) < rimska gentilicija Egnatius $\times$ lat. ignis 'oganj' - 104

$>$ njem. Ignatz (47), Ignaz (7)

$>$ polj. Ignacy (1)

$>$ hrv. Ignacije (1), Ignac (36), Ignjat (10)

lat. Maurus -98

$>$ tal. Mauro (1) > hrv. Mavro (44)

> grč. Mavpíkıৎ /mauríkios/ > lat. Mauricius >> njem. Moritz (32), Moriz (9) > hrv. Moric (12)

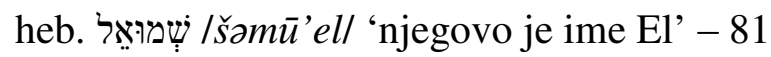

$>$ njem. Schmuel (1)

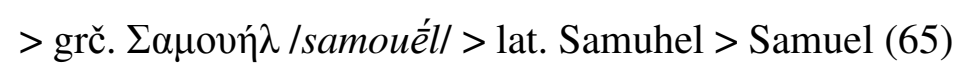

$>$ jid. Zanvil (1)

> slav. Samojlo (12)

> Samol (1), Sami (1)

lat. Maximilianus $<$ Maximus $\times$ Aemilianus -72

$>$ Maximilian (1) > hrv. Maksimilijan (3)

$\sim \operatorname{Max}(30)>\operatorname{Maks}(13)>\operatorname{Makso}(24)$

$>\operatorname{Maxo}(1)$ 
njem. Sigmund (27) < pragerm. *segiz- 'pobjeda' + *mundo- 'ruka, zaštita' - 70

$>$ Sigismund (4) $>$ lat. Sigismundus (1)

$>$ njem. Siegmund (14)

$>$ mađ. Zsigmond $>$ Zsiga $>$ hrv. Žiga (24)

njem. Leopold < pragerm. *leudi- ‘čovjek, narod' + *balp/da- 'smion' - 67

njem. Heinrich (44) < Heimirich < pragerm. *haima- 'selo, dom' + *rīk- 'vladar, kralj' - 62

$>$ Hinrich hrv. Hinko (18)

grč. 'A $\lambda \dot{\varepsilon} \xi \alpha v \delta \rho o \zeta / a l e ́ x a n d r o s /-61$

$>$ Alexander (10) > Alex (1)

>> Aleksander (13) > Aleksandar (9) > Aleksa (1)

>> mađ. Sándor (6) > Sandor (6) > Šandor (15)

lat. Iulius < gens Iulia < grč. íov內os líoulos/ 'maljave brade'?, lat. Jovilius posvećen Jupiteru'? - 61

$>$ Julius (25) > Julio (26), Julijo (4), Julije (6)

njem. Adalbert $(2)<$ pragerm. *apulja- 'plemenit' + *berhta- 'sjajan' - 59

$>$ Albert (56)

njem. Adolf (54) < pragerm. *apulja- 'plemenit' + *wulfa- 'vuk' - 55

$>$ tal. Adolfo (1)

njem. Wilhelm (32) < pragerm. *weljan- 'želja' + *helma- ‘̌lljem, kaciga' - 54

$>$ Vilhelm (1)

$>$ Wilm $>$ hrv. Vilim (16) $>$ Vilko (3)

$>$ mađ. Vilomos (1) > Wilmos (1)

njem. Rudolf (46) < pragerm. *hropi- 'slava' + *wulfa- 'vuk' - 52

$>$ Rudolph (1)

$>$ hrv. Rudo (2), Rudi (1)

$>$ tal. Rudolfo (2)

njem. Robert (45) < *hropi- 'slava' + *berhta- 'sjajan' - 47

$>$ Robert (45)

$>$ tal. Roberto (2)

hrv. Milan (46) < Mile/Milo < Miloslav < mio + -an (Čilaš Šimpraga, Ivšić Majić i Vidović 2018: 212; Skok 1974: II 426-427) - 46 


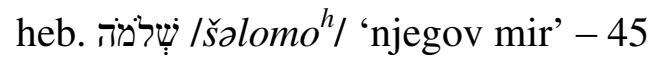

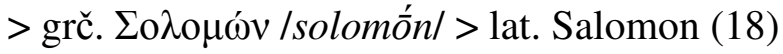

$>$ Salamon (19)

$>$ Solomon (2)

$>$ Salman (1)

$\neq$ Salom $(1)$

njem. Karl $(21)<$ pragerm. *kerla-/*karla- 'slobodan čovjek' - 43

$>$ Carl (18)

$>$ hrv. Karlo (4)

njem. Bernhard (20) < pragerm. *beran- 'medvjed' + *hardu- ‘čvrst, žestok' - 40

$>$ Bernard (16) > Bernad (3)

$>$ Bernarth (1)

hrv. Lavoslav ${ }^{312}(40)<$ lav + slava (Skok 1974: II 275-276) - 40

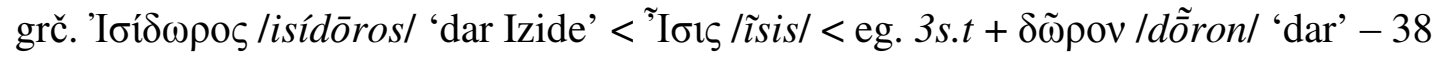

$>$ lat. Isidorus $>$ Isidor (18) > Iso (5)

$$
>\text { Izidor (14) > Izo (1) }
$$

njem Otto $(25)<$ pragerm. *auda- 'bogatstvo' - 38

$>$ Oto (12)

$>$ hrv. Oton (1)

Arthur $^{313}(20)<$ vjerojatno kelt. -37

$>\operatorname{Artur}(17)$

hrv. Dragutin $(37)<$ Dragut $(a)<$ Drago $<$ Dragomir/Dragoslav $+-u t+$-in (Čilaš Šimpraga, Ivšić Majić i Vidović 2018: 124-125; Skok 1974: I 428-429, I 721) - 37

lat. Leo (36) 'lav' - 36

lat. Aemilius < gens Aemilia < lat. aemulus 'suparnik' - 35

$>$ Emil (35)

\footnotetext{
${ }^{312}$ Prema Petru Skoku pogrešan prijevod njem. Leopold (v.) (Skok 1974: II 276).

${ }^{313}$ Prema osobnom imenu kralja Artura (lat. Rex Art(h)urius), možda povezano s vel. arth 'medvjed'.
} 


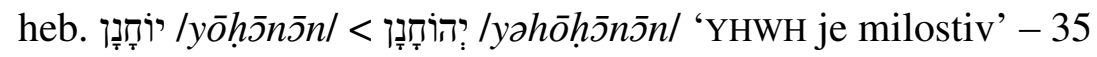

$>$ grč. 'I $\omega \alpha v \alpha v / i \bar{o} a n a n />$ lat. Iohanan

>> njem. Johann (2) > Hans (3)

>> hrv. Ivan (15) > Ivo (9), Ivica (6)

njem. Ludwig (20) < pragerm. *hlüda- 'glasan' + *w⿳̆冖han- 'boriti se' - 34

$>$ Ludvig (6)

$>$ fran. Louis (1)

> španj. Luis (1)

> mađ. Lajos (4) > hrv. Lajoš (2)

lat. Marcus (7) - 33

$>$ Markus (13)

> hrv. Marko (13)

kelt. Oscar (3) < ir. os 'jelen' + car 'koji voli' - 33

$>$ Oskar (30)

hrv. Vladimir (20) < vladati + prasl. *mirb (Čilaš Šimpraga, Ivšić Majić i Vidović 2018: 279;

Skok 1974: III 604-605, II 427-428) - 33

$>$ Vlado (2) > Vladko (7) > Vlatko (3)

$>$ Vlatkoj (1)

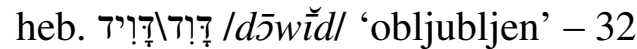

$>$ grč. $\Delta \alpha v i ́ \delta$ /dauíd/ > lat. David (25)

$>$ njem. Dawid (7)

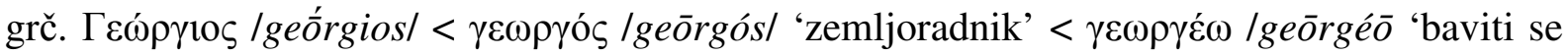
zemljoradnjom' - 32

$>$ lat. Georgius

$>$ njem. Georg (11)

$>>$ hrv. Gjuro (7), Giuro (2) > Gjurica (1) > Gjukica (1)

> hrv. Đuro (8)

$>$ hrv. Juraj > Jura > Jurica (1)

> Đorđe (1) 
angs. Ēadweard < pragerm. *auda- 'bogatstvo' + *warjan- ‘čuvati' - 31

$>$ lat. Eduardus $>$ Edvardus (1)

$>$ Eduard (28)

$>$ tal. Eduardo (2)

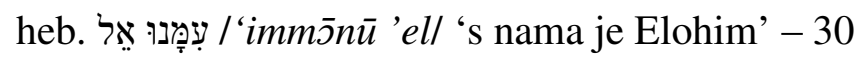

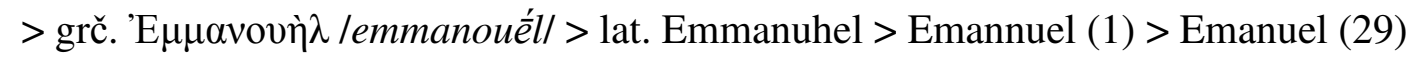

lat. Paulus 'malen, skroman' - 27

$>$ Paul (19)

>> hrv. Pavao (7), Pavel (1)

njem. Hermann $(10)$ < pragerm. *harja- 'četa, vojska' + *mannan- 'čovjek' - 26

$>$ Herman (16)

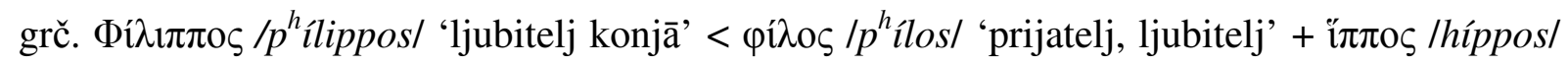
'konj' -25

$>$ lat. Philippus (1) > Philipp (2) > Philip (4)

$>$ Filipp (5)

$>$ Fillip (1)

$>$ hrv. Filip (12)

njem. Hugo (25) < pragerm. *hugi- 'razum, um' - 25

hrv. Ljudevit ${ }^{314}(23)$ < prasl. *ljud- + *vit- 'gospodar' (Čilaš Šimpraga, Ivšić Majić i Vidović 2018: 193; Skok 1974: III 599) - 23

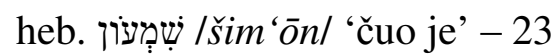

$>$ grč. $\Sigma v \mu \varepsilon \omega ́ v /$ sumeón/ > lat. Symeon > Simeon (2)

> Simon (19)

$>$ hrv. Šimun (2)

njem. Ernst (13) < pragerm. *arnja- 'ozbiljan' - 23

$>$ njem. Ernest (5)

$>$ tal. Ernesto (1)

$>$ mađ. Ernő (1)> Erne (1)

$>$ Erni (1)

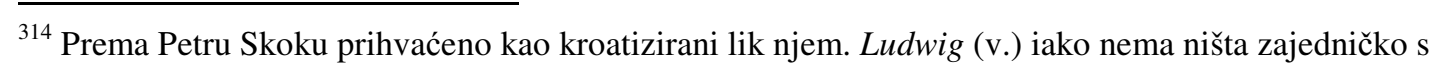
njemačkim osobnim imenom (Skok 1974: II 313). 
steng. Ælfræd < pragerm. *albi- 'vilenjak' + *rēdan- 'odlučiti' - 20

$>$ Alfred (20)

njem. Richard (14) < pragerm. *rīk- 'vladar, kralj’ + *hardu- 'čvrst, žestok'

$>$ hrv. Rikard (6)

lat. Victor (10) 'pobjednik' - 20

$>$ Wictor $(1)$

$>$ Viktor (9)

španj. Ferdinando < pragerm. *fardi- 'putovanje' + *nanpjan- 'usuditi se' - 18

$>$ Ferdinand $(10)>$ ib. Fernando (1)

$>$ hrv. Ferdo (6)

$>$ Feri (1)

njem. Friedrich $(11)<$ pragerm. *fripu- 'prijateljstvo, mir' + *rīk- 'vladar, kralj' - 17

$>$ Fridrich (1)

$>$ Fritz (5)

lat. Franciscus 'Francuz'315 - 16

$>>$ njem. Franz (7)

$>$ hrv. Franjo (8)

$>$ Frany (1)

hrv. Miroslav (16) < prasl. *mirb + *slava (Čilaš Šimpraga, Ivšić Majić i Vidović 2018: 217;

Skok 1974: II 427-428) - 16

njem. Gustav (13) < pragerm. *gautaz 'Get' + stafr < pragerm. *staba- ‘štap'?; slav. Gostislav< prasl. *gostb- + *slav- (Skok 1974: I 595) - 14

$>$ Gusti (1)

lat. Antonius < ?etr. -12

$>$ Anton (7)

$>$ hrv. Antun (4) >> Ante (1)

lat. Felix (6) ‘sretan, uspješan’ - 12

$>$ Feliks (6)

\footnotetext{
${ }^{315}$ Po osobnom imenu sv. Franje Asiškoga (tal. Francesco d'Assisi, 1181./1182. - 1226.), prve osobe za koju se zna da ga je nosila.
} 


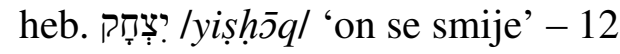

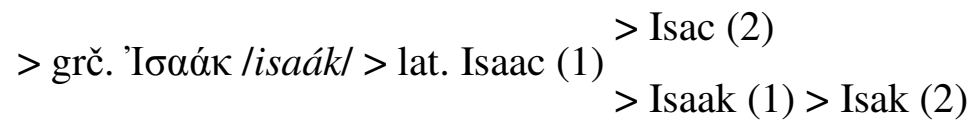

$>$ hrv. Izak (2)

$>>$ jid. Jic-hok (1), Icig (1)

angs. Ėadmund < pragerm. *auda- 'bogatstvo' + *mundo- 'ruka' > 'zaštita' - 10

$>$ Edmund (10)

hrv. Slavo $(1)<$ Slavoljub/Vjekoslav/... < slav- + slava (Čilaš Šimpraga, Ivšić Majić i Vidović 2018: 254$)-10$

$>$ Slavko (9)

hrv. Vatroslav ${ }^{316}(10)<$ vatra + prasl. *slava (Čilaš Šimpraga, Ivšić Majić i Vidović 2018: 273) -10

Najpopularnija su osobna imena i opet ona izvedena od hebrejskih יעְקָב /yōsep/ lya'a $q$ ob/.

\subsection{Najčešća ženska građanska osobna imena u užem korpusu}

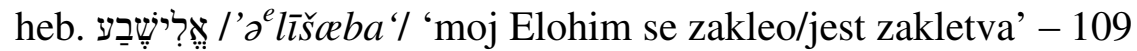

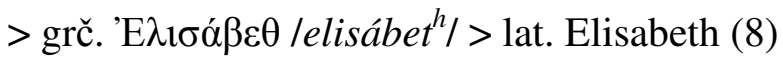

$>$ Elisabetha (1)

$>$ Elizabeth (1)

$>$ Elisabette (1)

> Elise (3), Eliza (2)

$>$ Elsa (25) > Elza (12)

$>$ Ella (15) > Ela (3)

>> Betty (4), Betti (12), Beti (2), Beta (1)

>> Betika (3)

>> Jelisava (3)

>> Babette (6) > Babete (1)

\footnotetext{
${ }^{316}$ Ilirska prevedenica lat. Ignatius (Skok 1974: I 710)
} 
$>$ Babetta (1) > Babeta (5)

$>$ Babet (1)

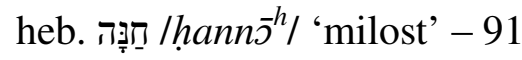

$>$ grč. 'Avvo lánnal > lat. Anna (21)

$>$ Hanna (5) > Hana (1) > Hanni (3)

> Anny (1), Ani (1)

$>$ Ana (22) > Anica (2), Anka (7)

>> Nanette (11), Nanetti (2), Naneta (15)

lat. Rosa (26) 'ruža' - 85

>> njem. Rose > Rosel (1)

>> mađ. Rozsika (1) > Rožika (1) > Rozika (1)

>> hrv. Ruža (16) > Ružica (4)

$>$ Rosi (6)

$>$ Rosina (3)

$>\operatorname{Roza}(25)>\operatorname{Rozi}(1)$

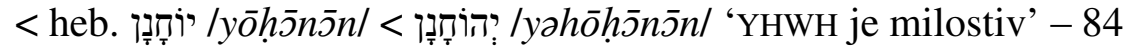

>> njem. Johanna (33) > Johana (21)

$>$ fran. Jeannette (2) > Jeanette (2) > Jeaneta (2) > Žaneta (2)

$>>$ hrv. Ivana (18) > Ivka (4)

ib. Teresa ${ }^{317}$, etimološki nerazjašnjeno - 75

$>$ Theresie $(1)>$ Theresia (11)

$>$ Therese (13) $>$ Thereze (1) > Theresa (1) > Theres (2) $>$ Terez (1)

$>$ Terezia $(1)>$ Terezija $(27)$

$>$ Tereza (14)

$>$ Resy (1) > Resi (1) > Rezi (1)

fran. Giselle < pragerm. *gisla- 'talac, zalog' - 72

$>$ Gisella (32) > Gisela (9)

$>$ Gizella (6) > Gizela (23) > Giza (2)

\footnotetext{
${ }^{317}$ Osobno se ime proširilo zahvaljujući sv. Tereziji Avilskoj (španj. Teresa de Ávila; 1515 - 1582.).
} 
fran. Charlotte $(20)<$ Charlot < Charles < pragerm. *kerla-/*karla- 'slobodan čovjek' - 68

$>$ Charlotta (7) $>$ Charlota (10) > Šarlota (24)

$>>$ Lotta > Lota (1), Lotti (4), Loti (2)

> heb. יחוֹסֵף > /yohōsep/ 'YHWH je dodao' - 65

$>$ > Josephine (2) > Josefine (23)> Josefina (5) $\begin{aligned} & >\text { Josefa }(1) \\ & >\text { Jozefina }(10)>\text { Jozefa }(1)\end{aligned}$

lat. Rosalia (26) < rosa 'ruža' - 62

$>$ Rosalie (6)

$>$ Rosalija (2) > Rozalija (28)

nor. Helga $<$ Helge < Helgi < pranor. *heilagr 'svet' - 59

$>$ rus. Ольга > Olga (59)

lat./tal. Regina (52) 'kraljica' - 58

$>$ Reginna (1)

$>$ Regine (4)

$>>$ Regi (1)

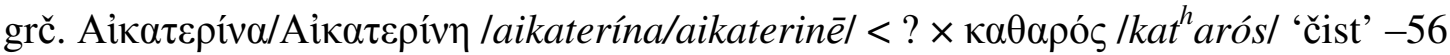

$>$ Catharina (2)

>> Katharine (1) > Katharina (15)

$>$ Käthe (1)

$>>$ Kathi (1) > Kati (3)

$>$ Katty (1)

$>$ Katerina (1)

$>>$ Katarina $(23)>$ Katica $(7)$

> Katton (1)

heb. מִרְִ /mirȳ̄m/ - 56

> grč. Mapió $\mu$ /mariám/, Mapía /maría/ > lat. Maria (10)

> Mirjam (2), Mirjan (1), Marjem (1)

>> Marie (16)

> Mari (1)

$>>$ hrv. Marija (23) > Marica (1), Maritza (1) 
vjerojatno odmilica za Francisca/Franziska/Franciska/Franciška/Franka/Franjka/Franjica 54

Fanny (4) > Fany (13)

Fanni (11) > Fani (13)

Fanike (1)

Fanika (12)

lat. Paula (17) < Paulus 'malen, skroman' - 51

$>$ Pauline (15) > Paulina (15)

$>$ tal. Paola (1)

$>$ hrv. Pavla (1) > Pava (2)

njem. Bertha (19) < pragerm. *berhta- 'sjajan' - 48

$>\operatorname{Berta}(29)$

njem. Amalia (16) < pragerm. *amal 'bodrost, hrabrost' - 43

$>$ Amalie (6)

$>$ Amalija (21)

njem. Hermine (17) < Hermann < pragerm. *harja- 'četa, vojska' + *manna- 'čovjek' - 40 $>$ hrv. Hermina (23)

lat. Iulia < Iulius < gens Iulia < ? grč. íovios /íoulos/ 'maljave brade' ili lat. Jovilius posvećen Jupiteru'? - 39

$>$ Julia (2)

$>$ Julie (20)

$>$ Juli (1)

$>$ hrv. Julija (14)

$>>$ Julka (2)

$>$ Julcsa $(1)$

hrv. Zora (31) < zora < prasl. *zorja (Čilaš Šimpraga, Ivšić Majić i Vidović 2018: 284) - 38

$>$ Zorica (6)

$>$ Zorka (1)

njem. Karoline (9) < Karl < pragerm. *kerla-/*karla- 'slobodan čovjek' - 36

$>$ Karolina (1)

$>$ Caroline (6) > Carolina (4) 
njem. Ida (36) < pragerm. *id- 'rad', nor. boginja Iðunn 'vječno mlada, pomlađujuća'? - 36 njem. Emma (16) < pragerm. *ermun- 'cio ', možda odmilica za Emmanuele (v. Emanuel) 31

$>$ Ema (15)

lat. Margarita < grč. $\mu \alpha \rho \gamma \alpha \rho ı \eta\rceil$ /margaritēs/ 'biser' - 31

$>$ tal. Margherita (1)

$>$ Margarethe (4) > Margaretha (4)

$>$ hrv. Margareta (3)

$>$ Margeta (1)

$>>$ mađ. Margit (9) > Margita (3)

$>$ Margrit (1)

$>>$ Marga (2)

$>$ Greta (3)

grč. 'E $\lambda \dot{\varepsilon} v \alpha / \mathrm{E} \lambda \dot{v} v \eta$ /eléna/elénēl $<?-30$

$>$ Helene (15) > Helena (13)

$>$ slav. Jelena (2)

lat. Caecilia (1) < Caecilius < caecus 'slijep' - 28

$>$ Caecilie (2), Cäcilie (8)

$>$ Cecilia (1)

$>$ hrv. Cecilija (13)

>> Cilly (1), Cilliy (1), Cili (1)

njem. Ernestine (10) < Ernest < Ernst < pragerm. *arnja- 'ozbiljan' - 28

$>$ Ernestina (11)

$>$ Erna (7)

njem. Mathilde (9) < pragerm. *mahti- 'snaga' + *hild- 'boj' - 25

$>$ Matilde (2)

$>$ Matilda (13)

$>$ Tilda (1)

lat. Aemilia < lat. Aemilius < gens Aemilia < lat. aemulus 'suparnik' - 24

$>$ Emilie (13)

$>$ Emilia (1)

$>$ hrv. Emilija (10) 
lat. Sidonia (5) < Sidonius 'iz Sidona, sidonski' - 23

$>$ Sidonie (7) $>$ Sidonije (1)

$>$ Sidonija (10)

Malvina (12) < šk. gel. 'glatka čela'; osobno je ime u svojim osijanskim pjesmama stvorio škotski pjesnik James MacPherson (1736. - 1796.) - 22

$>$ Malvine (8)

>> Malvin (1)

> Maluna (1)

< grč. $\Sigma \tau \varepsilon \dot{\varepsilon} \varphi \alpha v o \varsigma /$ stép ${ }^{h}$ anos/ 'kruna' - 21

$>>$ Stephanie (1) $>$ Stefanie (10) $>$ Stefanije (1)

$>$ Stefania (2) > Stefanija (2)

$>>$ Štefa (2), Štefi (1)

$>$ Stefica (1)

$>$ Stiepana

njem. Henriette $(8)<$ Heinrich $(44)<$ Heimirich < pragerm. *haima- 'selo, dom' + *rīk- ' vladar, kralj' - 20

$>$ Henriete (1)

$>$ Henrietta (2) $>$ Henrieta (7) $>$ Henrijeta (2)

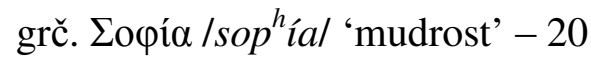

$>$ Sophie (3)

$>$ Sofie (5)

$>$ Sofia (1) > Sofija (10)

> Zofi (1)

hrv. Vera (15) < prasl. *věra (Čilaš Šimpraga, Ivšić Majić i Vidović 2018: 279) - 19

$>$ Vjera (1)

$>$ Verica (1)

$>$ Wera $(2)>$ Werica $(1)$

lat. Francisca (1) < lat. Franciscus 'Francuz' (v.) - 17

$>$ Franziska (3)

$>$ Franciska (7)

$>$ Franciška (3)

$>$ Franka (1) 
> Franjka (1)

> Franjica (3)

lat. Melania (2) < grč. $\mu \varepsilon \lambda \alpha v i ́ \alpha$ /melaníal 'crna, tamna' - 16

$>$ Melanie (6)

$>$ Melanija (4)

$>$ Melani (4)

grč. Eịñvๆ leirềnēl 'mir' - 15

$>$ Irene (5)

$>$ Irena (8)

$>$ mađ. Irén $>$ Iren (2)

njem. Irma $(15)<$ pragerm. *ermina-/*ermena-/*ermuna- 'jak, cio' - 15

njem. Adele (8) < pragerm. *apulja- 'plemenit' - 14

$>$ Adelle (1)

$>$ fran. Adéle [sic] (1)

$>$ Adella (1) > Adela (3)

hrv. Draga (4) < Dragomila/Dragomira/Dragoslava $<$ drag < prasl. *dorgz- (Čilaš Šimpraga, Ivšić Majić i Vidović 2018: 123) - 14

$>$ Dragica (10)

hrv. Zlata (10) < zlato (Čilaš Šimpraga, Ivšić Majić i Vidović 2018: 283) - 14

$>$ Zlatica (3)

$>$ Zlatka (3)

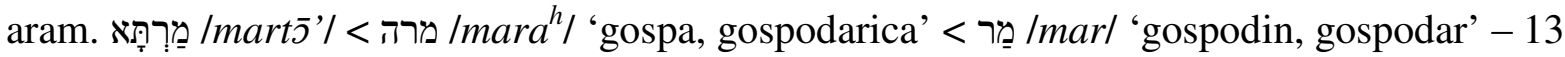
$>$ grč. Má $\theta \alpha$ /márt ${ }^{h} a />$ lat. Martha (6)

$>$ Marta (7)

španj. Elvira (12) < pragerm. *alla- 'sve' + *wēr- 'istinit'? - 12

hrv. Jela $<$ jela; vjerojatnije odmilica za osobno ime Jelena $<$ grč. E E $\lambda \varepsilon ́ v \alpha$ /helénal (Čilaš Šimpraga, Ivšić Majić i Vidović 2018: 164; Skok 1974: I 663) - 12

$>$ Jelka (12) 
odmilica za osobna imena čiji je drugi dio -lina - 12

Linna (3)

Lina (8)

Linka (1)

lat. Clara ${ }^{318}(4)<$ Clarus 'jasan, sjajan, slavan’ - 11

$>$ Klara (7)

lat. Clementina (1) < Clementius < Clemens 'milosrdan, nježan' - 11

$>$ Clementine (2)

$>$ Clementin (1)

$>$ Klementine (3)

$>$ Klementina (4)

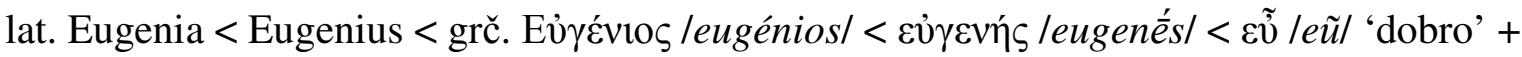

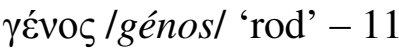

$>$ Eugenie (6)

$>$ Eugenija (5)

$?-11$

Milka (11)

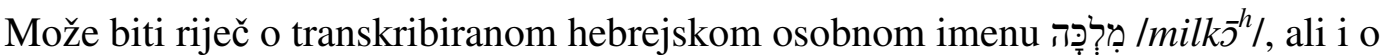
slavenskome Milka < Mila + -ka (Čilaš Šimpraga, Ivšić Majić i Vidović 2018: 213; Skok 1974: II 426-427).

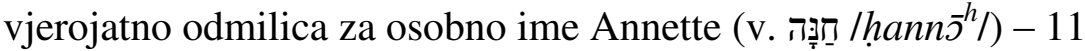

Netti (7)

Neti (3)

Netika (1)

njem. Frieda (2) < pragerm. *fripu- 'prijateljstvo, mir' - 10

$>$ Frida (8)

lat. Laura $(10)<$ Laurus 'lovor' - 10

hrv. Ljuba (4) < Ljubomira/Ljuboslava < prasl. *ljubiti (Skok 1974: II 337) - 10

$>$ Ljubica (6)

${ }^{318}$ Osobno se ime proširilo zahvaljujući sv. Klari Asiškoj (tal. Chiara d'Assisi, 1194. - 1253.), sljedbenici Franje Asiškoga i osnivačici reda klarisa. 


\subsubsection{Etymologia remota građanskih osobnih imena u užem korpusu}

\subsection{Etimološka struktura građanskih osobnih imena u užem korpusu}

\subsection{Etimološka struktura muških građanskih osobnih imena u užem korpusu}

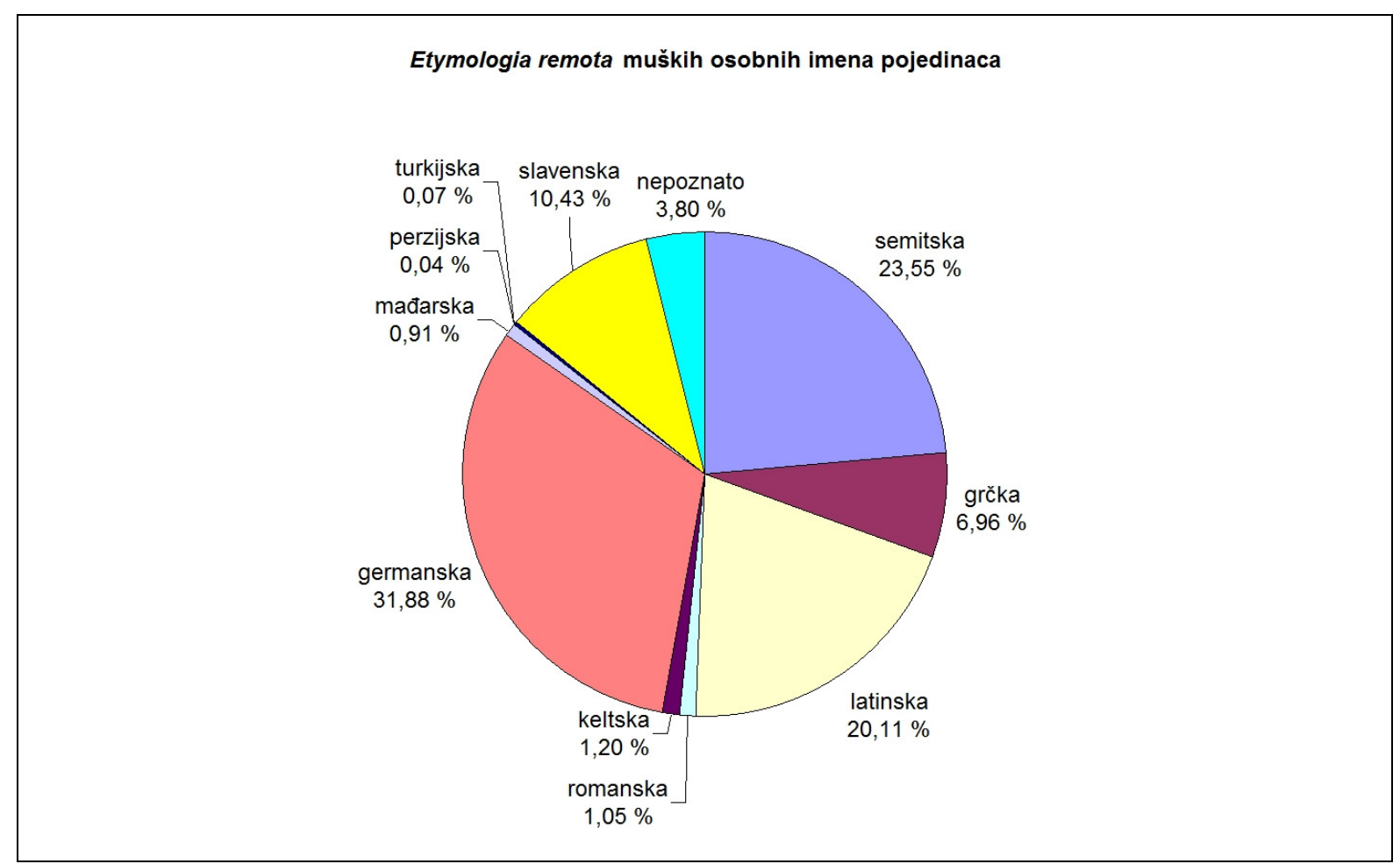

Slika 1: Etymologia remota muških osobnih imena pojedinaca

Najveći postotak zagrebačkih Židova nosi osobna imena motivirana općom imenicom germanske etimologije, najvećim dijelom njemačke, a tek u pojedinim slučajevima anglosaske ili nordijske. To je u skladu sa spoznajama koje imamo o zagrebačkoj židovskoj općini, čiji su članovi bili germanofoni ${ }^{319}$ : i sâm Gavro Schwarz piše kako »moderna njemačka propovijed [modernoga rabina Mavra Goldmana 1840. g.] bijaše za Zagrepčane novost, svjetski naobraženi rabin bijaše za njih pojava, o kojoj su čuli i čitali te za njom čeznuli« (Schwarz 1939: 32). Slijede pojedinci s osobnim imenima semitskog (hebrejskog ili aramejskog) podrijetla, kojih ima oko tri četvrtine onih s osobnim imenima germanskog

\footnotetext{
${ }^{319}$ I hungarofoni (Brandl 2015 : 56; Goldstein 2004: 61). V. i tablicu 1. Jezična asimilacija hrvatskih Židova, 1880-1931. (Goldstein 2004, 18) i tablicu 2. Jezična asimilacija hrvatskih Židova, 1900-1971. (Goldstein 2004: 19).
} 
podrijetla, te latinskoga, da bi se oni s osobnim imenima slavenskog podrijetla našli već na četvrtome mjestu, a grčkoga na petom (slika 1).

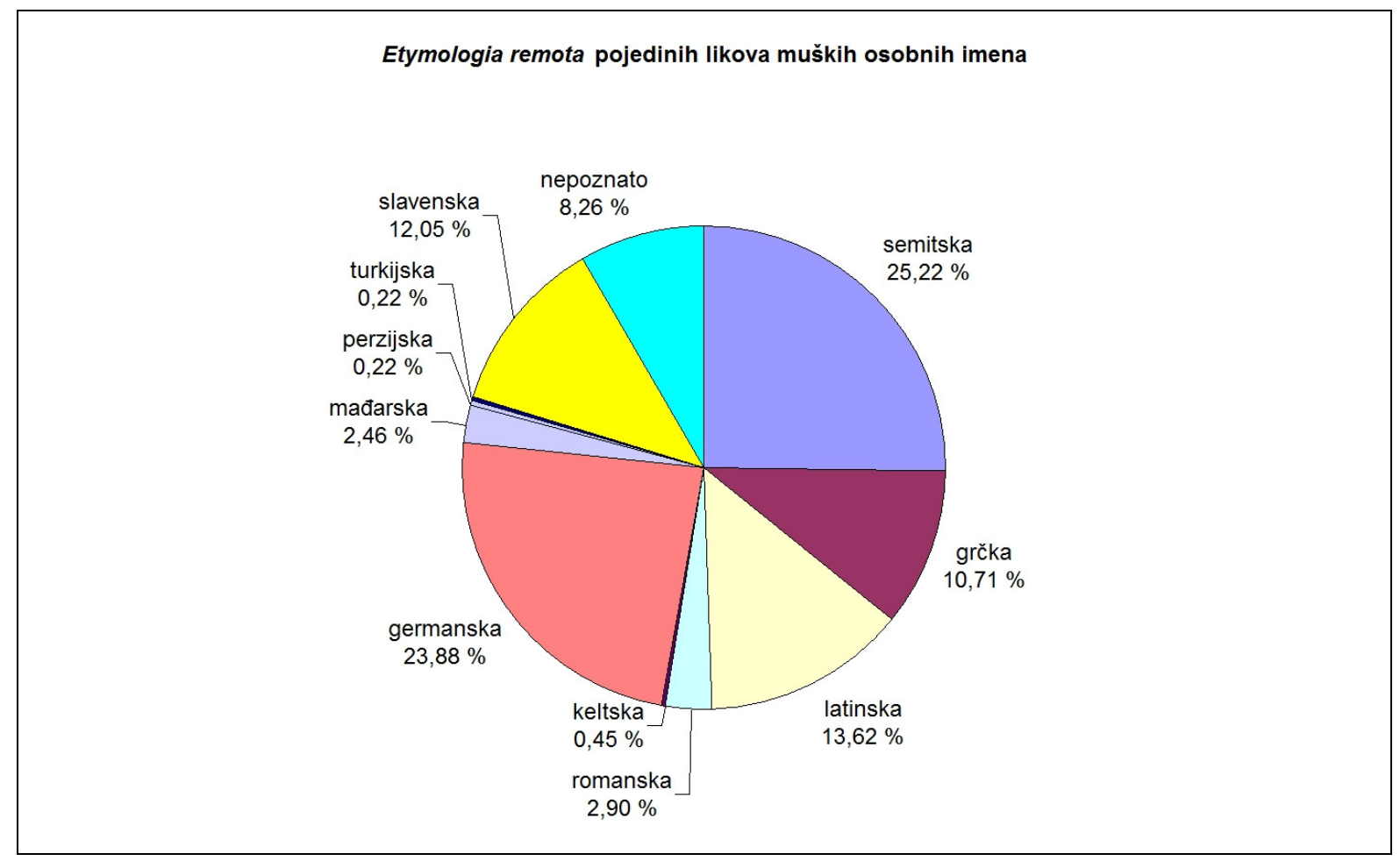

Slika 2: Etymologia remota pojedinih likova muških osobnih imena

Ako pozornost obratimo na likove samih osobnih imena ne obazirući se na broj pojedinaca koji ih nose, situacija se donekle mijenja, ali ne bitno. Na prvo mjesto dolaze osobna imena semitskog podrijetla, dok ih slijede osobna imena germanskog podrijetla. Daljnji je redoslijed isti kao i u prethodnom slučaju: osobna imena latinskog, pa slavenskog te grčkog podrijetla (slika 2).

\subsection{Etimološka struktura ženskih građanskih osobnih imena u užem korpusu}

Ono što odmah upada u oči jest relativno velik postotak osobnih imena kojima nije moguće jednoznačno odrediti podrijetlo, gotovo trostruko veći negoli u muških. To je posljedica relativno velikog broja odmilica uzdignutih na razinu punih (službenih) osobnih imena, većeg negoli je to slučaj u muškaraca. 


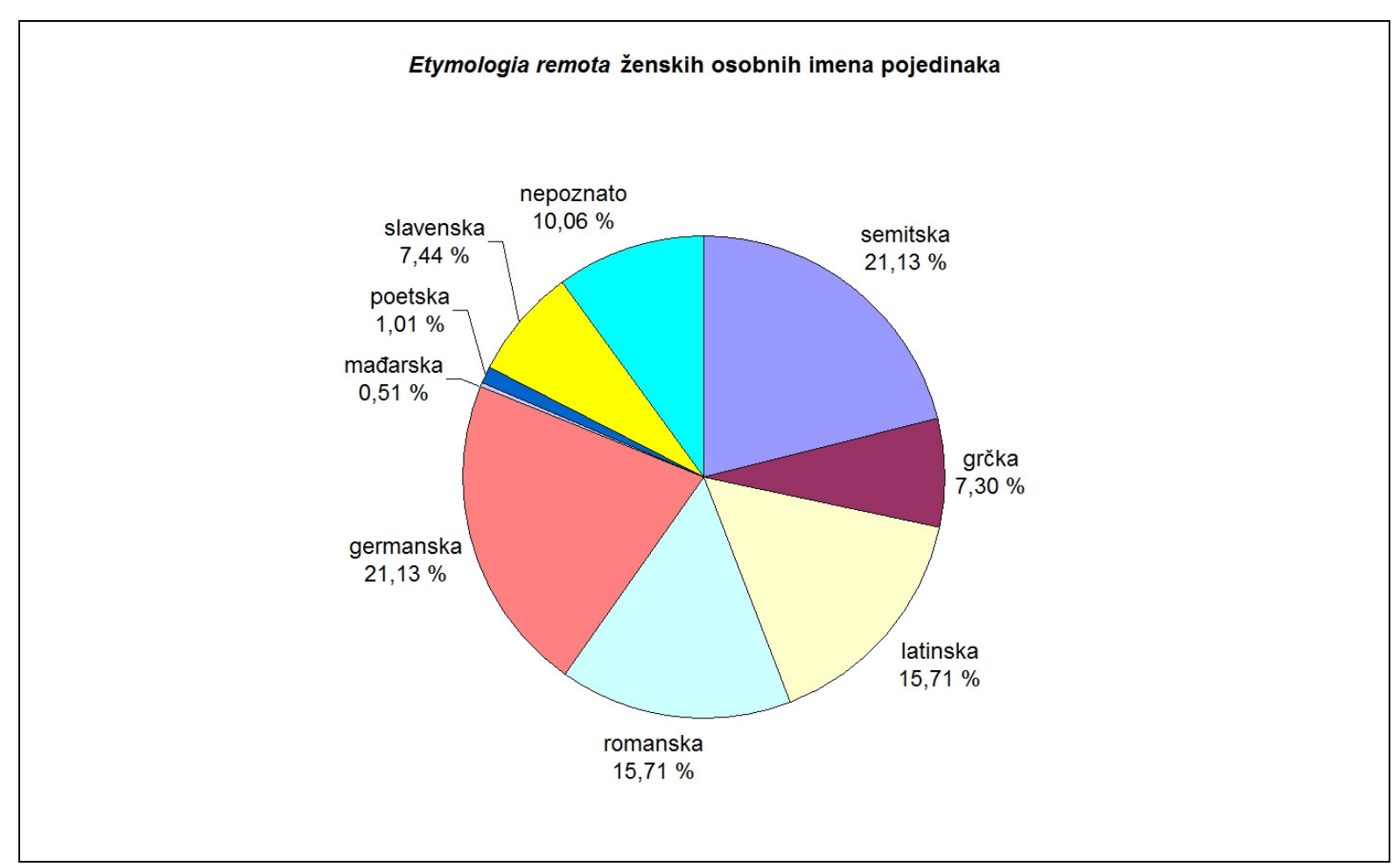

Slika 3: Etymologia remota ženskih osobnih imena pojedinaka

Postotak pojedinaka s osobnim imenima semitskog (hebrejskog i aramejskog) podrijetla, provučenih kroz filtre različitih europskih jezika, jednak je broju onih germanskog podrijetla. Postoci su pojedinaka s osobnim imenima latinskoga te romanskoga podrijetla izjednačeni, a slijede ih pojedinke s osobnim imenima slavenskog podrijetla, već na petome mjestu, dok je postotak pojedinaka s osobnim imenima grčkoga podrijetla na šestome (slika 3).

Ako se usredotočimo na likove samih osobnih imena ne obazirući se na broj pojedinaka koji ih nose, situacija se donekle mijenja, ali ne bitno. Na prvom su mjestu i dalje osobna imena semitskog podrijetla, da bi ih slijedila ona germanskoga, latinskoga, romanskoga, grčkoga, pa tek onda slavenskog podrijetla. Razlike su u postocima, međutim, minimalne (slika 4). 


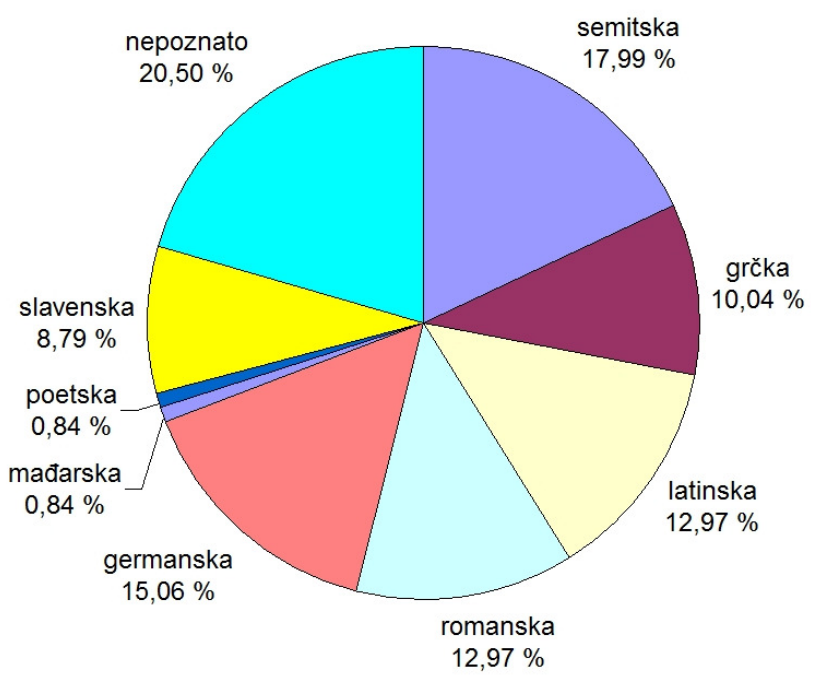

Slika 4: Etymologia remota pojedinih likova ženskih osobnih imena

\subsection{Usporedba etimoloških strukturā muških i ženskih građanskih osobnih imena u užem korpusu}

Ovdje su u obzir uzeta samo osobna imena kojima je moguće jednoznačno uspostaviti etimologiju odnosno utvrditi jezik iz kojeg potječu.

\begin{tabular}{|c|c|}
\hline $\begin{array}{c}\text { Poznata etymologia remota } \\
\text { muških osobnih imena pojedinaca }\end{array}$ & $\begin{array}{c}\text { Poznata etymologia remota } \\
\text { ženskih osobnih imena pojedinaka }\end{array}$ \\
\hline 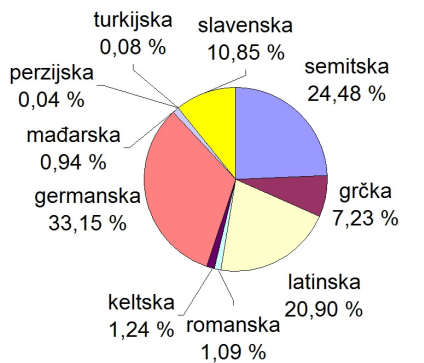 & 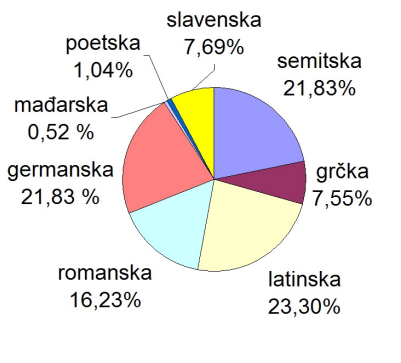 \\
\hline
\end{tabular}

Slika 5: Usporedba poznatih etymologia remota muških $i$ ženskih osobnih imena pojedinaca/ka

Postotak je žena koje nose osobna imena semitskog podrijetla neznatno manji od onoga muškaraca, no postotak žena koje nose germanska osobna imena predstavlja nešto manje od 
dvije trećine postotka muškaraca. I dok ženā s osobnim imenima grčkog podrijetla u postocima ima približno koliko i muškaraca, onih s osobnim imenima slavenskog podrijetla oma tek nešto više od dvije trećine postotka muškaraca, a onih s osobnim imenima romanskog podrijetla trinaest puta više, dok su ostali postoci približno isti (slika 5).

Uočljivo je da su postoci pojedinih likova osobnih imena semitskog i germanskog podrijetla znatno manji u ženā negoli u muškaraca, a u korist onih latinskog i romanskog podrijetla. Postoci se ženskih osobnih imena semitskog odnosno germanskog podrijetla kreću oko dvije trećine u usporedbi s onima muških. Postotak je osobnih imena latinskog podrijetla u ženā

\begin{tabular}{|c|c|}
\hline 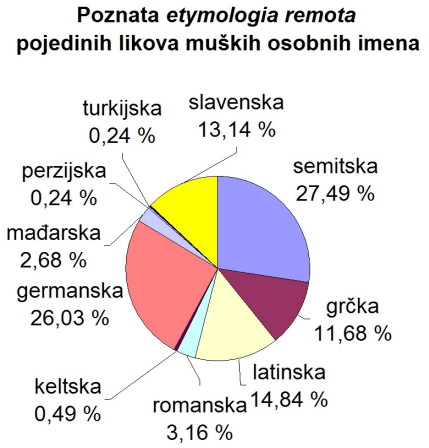 & 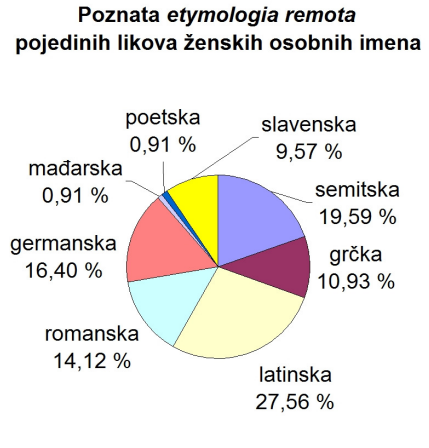 \\
\hline
\end{tabular}

Slika 6: Usporedba poznatih etymologia remota

pojedinih likova muških $i$ ženskih osobnih imena

nešto manje od dvaput veći od onog u muškaraca, dok je u slučaju onih romanskog podrijetla taj postotak više negoli četverostruk. Zanimljivo je da je postotak osobnih imena slavenskog podrijetla u žena (nešto) manji od onoga u muškaraca. Ovakav rezultat iznenađuje jer bismo očekivali da za žene postoji veća vjerojatnost antroponimske adaptacije okolini, odnosno da usvajaju više osobnih imena iz jezikā koji ih okružuju. Moguće je da bi ovi statistički podaci izgledali drukčije da imamo pristup većem broju izvora za XX. st., posebno za doba Kraljevine Srba, Hrvata i Slovenaca odnosno Kraljevine Jugoslavije, kad je slavenofonost, ali i animozitet spram »neprijatelja iz Prvog svjetskog rata, potisnula germanofonost (slika 6). 


\subsection{Dijakronijska analiza građanskih osobnih imena zagrebačkih Židova}

\subsection{Dijakronijska analiza muških građanskih osobnih imena zagrebačkih Židova}

Prvo se osobno ime slavenskog podrijetla (Lavoslav kao vjerojatni pandan germanskome Leopold, iako drukčije motivacije) među muškarcima pojavljuje 1859. g. Broj dječaka kojima je nadjenuto osobno ime slavenskog podrijetla dosiže maksimum 1897. g. s 14 pojedinaca i 9 različitih osobnih imena - Božidar (2), Dragutin, Lavoslav (2), Ljudevit, Milan (4), Radivoj, Srećko, Stanko i Vladimir (slika 7).

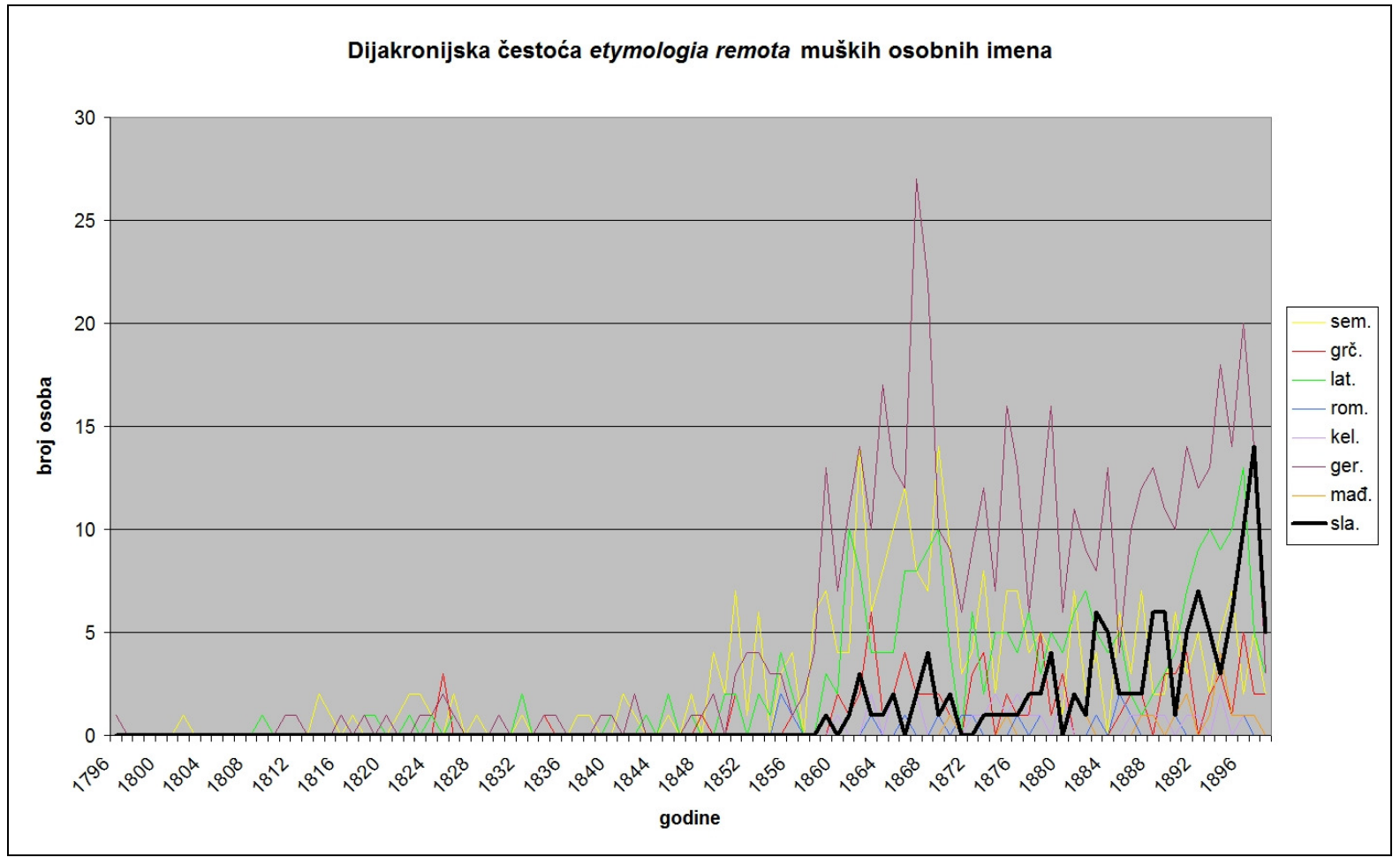

Slika 7: Dijakronijska čestoća etymologia remota muških osobnih imena

Kako ne raspolažemo istom količinom podataka za sve godine rođenja iz užeg korpusa, prikaz istih podataka u postocima daje drukčiju sliku porasta broja slavenskih osobnih imena među zagrebačkim Židovima. Vidljivo je da su na kraju razdoblja za koje raspolažemo podacima o godinama rođenja pojedinaca osobna imena slavenskog podrijetla s 33,33 \% najčešća među onima koja su se nadijevala dječacima, slijede osobna imena latinskog i germanskog podrijetla s po $20 \%$ te ona semitskog i grčkog podrijetla s po $13,33 \%$ (slika 8). 


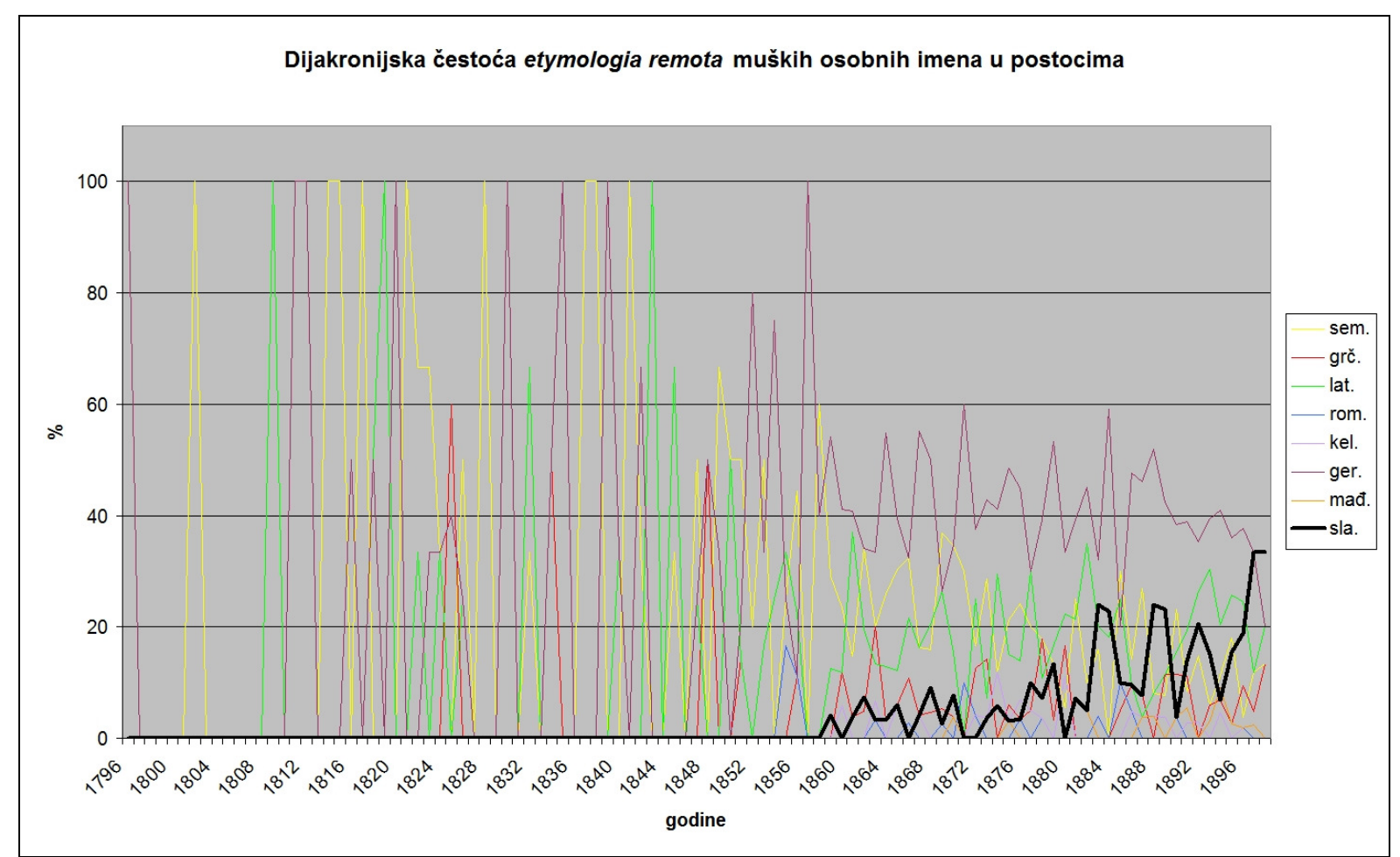

Slika 8: Dijakronijska čestoća etymologia remota muških osobnih imena u postocima

\subsection{Dijakronijska analiza ženskih građanskih osobnih imena zagrebačkih Židova}

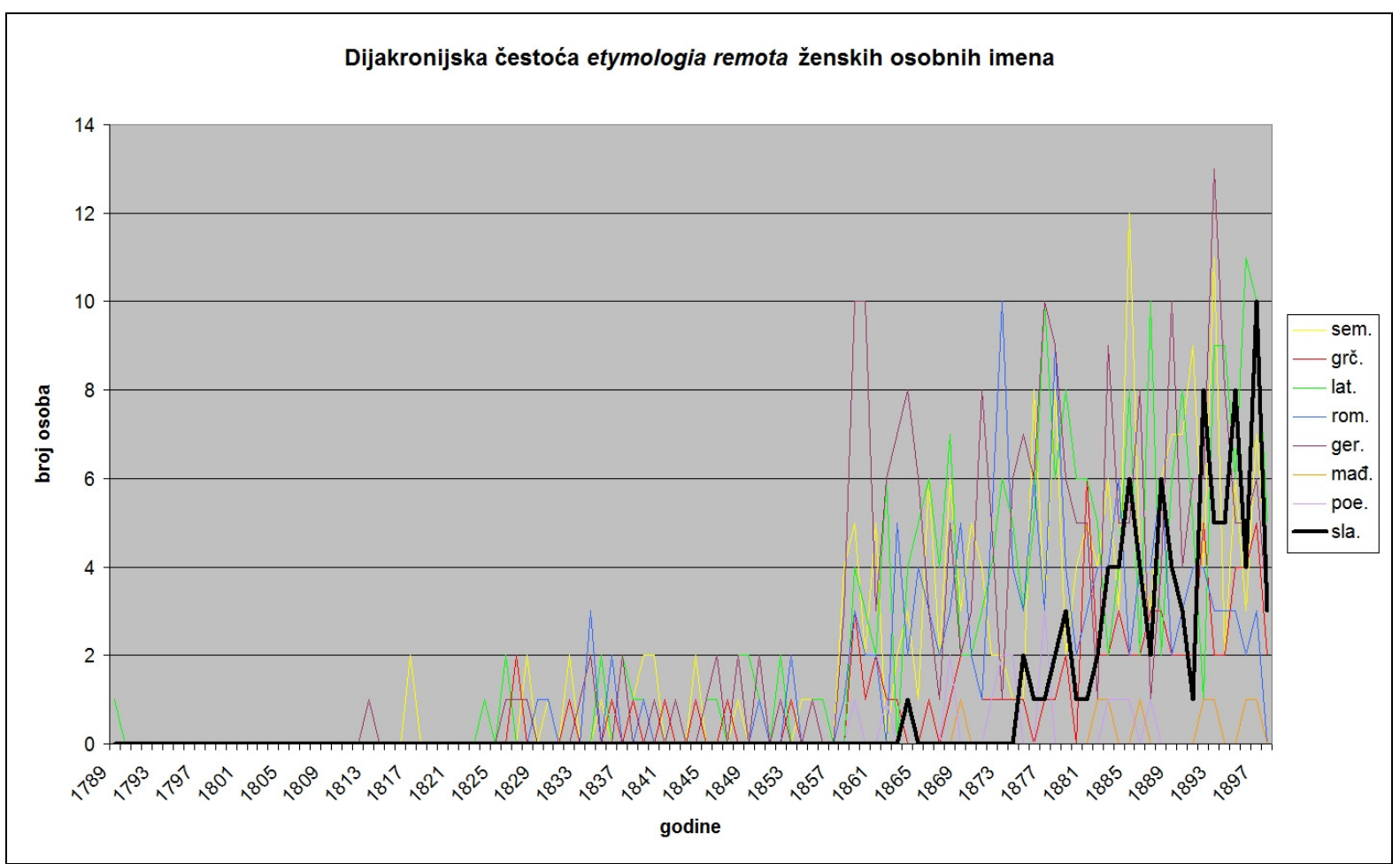

Slika 9: Dijakronijska čestoća etymologia remota ženskih osobnih imena 
Prvo se osobno ime slavenskog podrijetla (Ljuba) među ženama pojavljuje 1864. g., pet godina kasnije nego u muškaraca. Broj djevojčica kojima je nadjenuto osobno ime slavenskog podrijetla dosiže maksimum 1897. g. s 10 pojedinaka, tri manje negoli je to bio slučaj s dječacima, i 7 različitih osobnih imena - Darinka, Dragica (2), Ljudevita, Nada, Vera (3), Zdenka i Zora (slika 9).

Uočljivo je da su na kraju promatranog razdoblja ženska osobna imena slavenskog podrijetla s $17,65 \%$ treća po čestoći, poslije osobnih imena latinskog podrijetla s $29,41 \%$ i onih semitskoga s $23,53 \%$. Isti postotak kao osobna imena slavenskog porijekla imaju ona germanskoga, a slijede osobna imena grčkog podrijetla s 5,88 \% (slika 10).

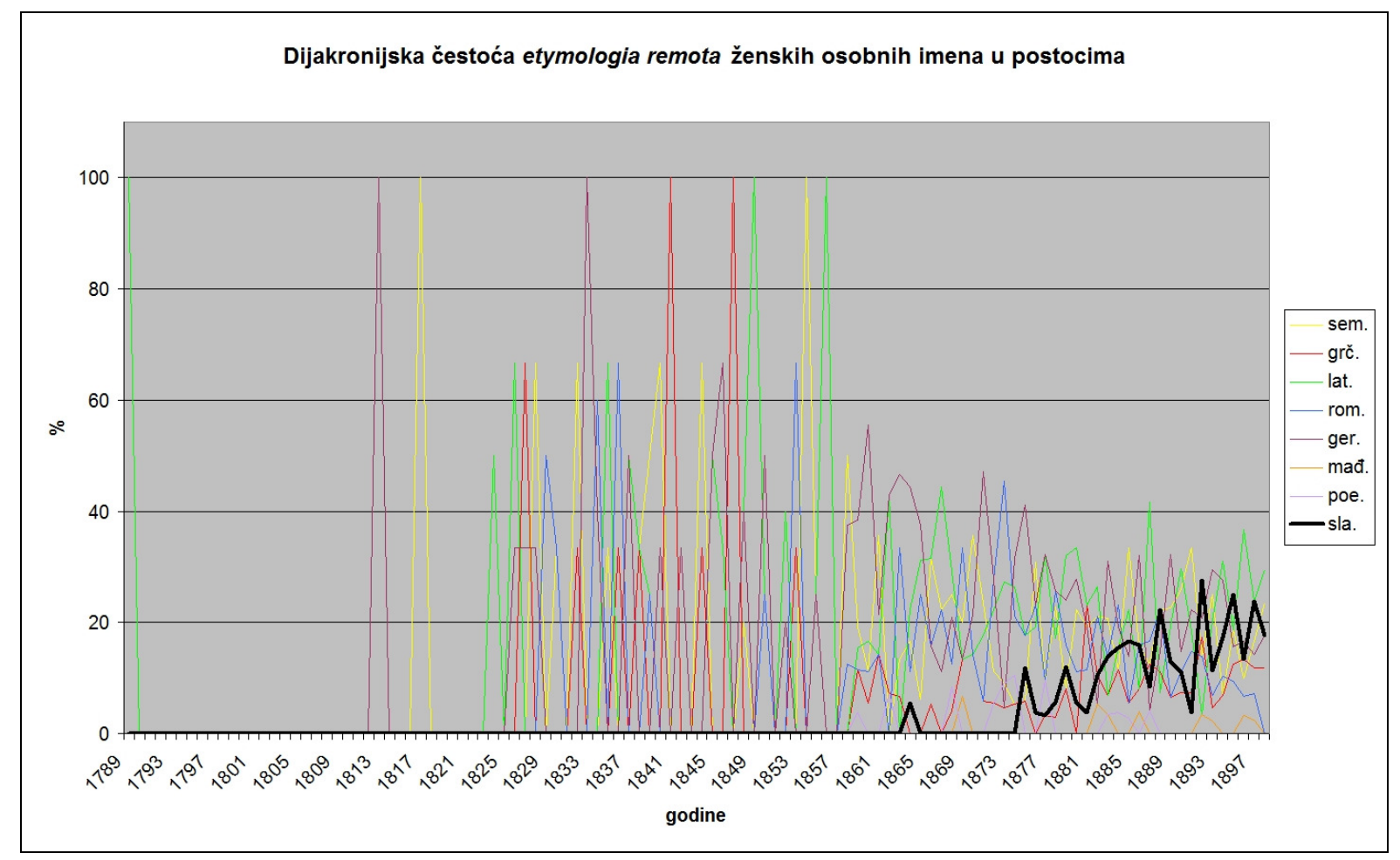

Slika 10: Dijakronijska čestoća etymologia remota ženskih osobnih imena u postocima

Nadijevanje je slavenskih osobnih imena dječacima počelo nešto ranije nego djevojčicama te u oba slučaja slijedi usporedni porast broja (i postotka) tih osobnih imena da bi na kraju promatranog razdoblja postala najbrojnijima među dječacima, a treća po brojnosti među djevojčicama. Možemo pretpostaviti da se taj porast nastavlja i u idućem razdoblju povijesti zagrebačkih Židova. 


\subsubsection{Etymologia proxima građanskih osobnih imena u užem korpusu}

Kod određivanja jezika iz kojeg je neko osobno ime izravno preuzeto nailazimo na veće poteškoće negoli pri onome iz kojeg jezika isto potječe (Beider 2001: xxxv-xxxvii; Beider 2003: 53-56).

Uzmimo kao primjer žensko osobno ime Anna. Ono se u takvu liku pojavljuje i u germanskim jezicima (osim njemačkog i u engleskom, nizozemskom i sjevernogermanskim jezicima danskom, farskom, islandskom, norveškom i švedskom), i u romanskim jezicima (talijanskom, katalonskom i okcitanskom), i u zapadnoslavenskim jezicima (češkom, poljskom i slovačkom), i u istočnoslavenskima (bjeloruskom, ruskom i ukrajinskom), i u bugarskom, i u mađarskom i cijelom nizu drugih jezika (latvijskom, bretonskom, estonskom i finskom). Čak i ako zanemarimo »nemoguće« jezike neposredne posudbe, ostaje nam dovoljno onih mogućih - jezici Austro-Ugarske (njemački, mađarski, češki, poljski, slovački, ukrajinski, talijanski) - da ne možemo sa sigurnošću utvrditi iz kojeg je jezika osobno ime preuzeto.

$\mathrm{S}$ druge je strane (i iz same grafije) relativno lako utvrditi da su osobna imena poput Adéle (u francuskom, doduše, pisano Adèle, no preciznost u pisanju dijakritika nije osobina koja je krasila autore zapisa iz korpusa), $J a(c) q(u)$ es i Jeanette morala biti preuzeta iz francuskog (iako ne smijemo u potpunosti odbaciti posredovanje njemačkoga), osobna imena poput Aladar, Aranka, Béla, Deszö, Ernö, Eszter, Geza, Ilona, Istvan, Jenö, Julcsa, Lajos, Margit, Sándor, Szeline, Szerene, Vilmos, Zoltan i Žiga preuzeta iz mađarskoga, a osobna imena Achille, Adolfo, Aliče (grafiji unatoč), Camillo, Eduardo, Egidio, Girolamo, Giudita, Guido, Grazietta, Margherita, Paola, Roberto i Stefano iz talijanskoga, no to je samo šačica u moru raznovrsnih osobnih imena našega korpusa.

S obzirom na pretežnu germanofonost zagrebačke zajednice, mogli bismo paušalno zaključiti da su sva ona osobna imena koja likom mogu biti i njemačka preuzeta iz njemačkoga, to bi međutim bila spekulacija bez prave osnove. Zato će njemačkima biti označena samo ona osobna imena za koja ne postoji nikakav alternativni (a vjerojatan!) jezik iz kojeg su mogla biti preuzeta. Primjerice, osobno ime Johanna može, osim njemačkog, biti i nordijsko (dansko, finsko, norveško, švedsko), estonsko i nizozemsko, no vjerojatnost je da je došlo iz nekog od potonjih jezika praktički nikakva. 
Rezultat je takve odluke nesumnjivo manji broj podataka, ali točnih, koji će stoga ipak dati neku sliku kretanja etymologiae proximae osobnih imena zagrebačkih Židova iz užeg korpusa.

\subsection{Etimološka struktura građanskih osobnih imena u užem korpusu}

\subsection{Etimološka struktura muških građanskih osobnih imena u užem korpusu}

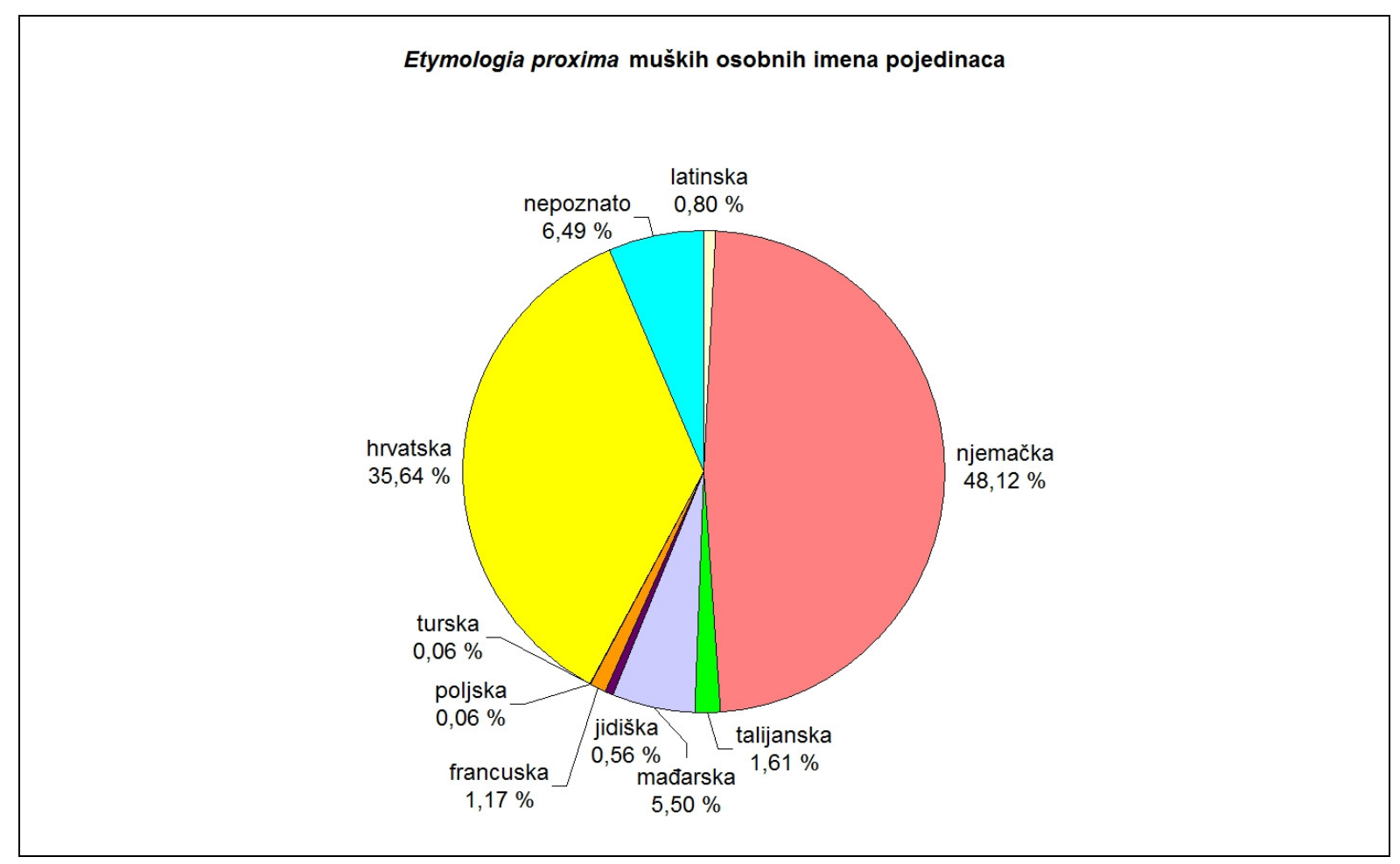

Slika 11: Etymologia proxima muških osobnih imena pojedinaca

Pojedinaca s muškim građanskim osobnim imenima preuzetima iz njemačkog ima nešto manje od polovine, a onih s osobnim imenima preuzetima iz hrvatskoga nešto više od trećine njihova ukupnog broja. Pojedinaca sa mađarskim građanskim osobim imenima ima tek nešto manje od onih s osobnim imenom kojega se jezik iz kojega su potekli ne može odrediti. U usporedbi su s navedenima ostali brojčano beznačajni, ukupno ne čine ni $5 \%$ svih pojedinaca (slika 11).

Kad s pojedinaca prijeđemo na likove osobnih imena, situacija se bitno mijenja. Broj likova osobnih imena poteklih iz nepoznatog jezika preuzimanja raste na više od polovine. Tih je $55,8 \%$ likova raspoređeno na $6,49 \%$ nositelja, što znači da u prosjeku nema mnogo nositelja 
pojedinog lika osobnog imena nepoznatog jezika preuzimanja. S druge strane, hrvatskih likova osobnih imena ima više nego dva puta više od onih njemačkih, što opet znači da manji broj njemačkih osobnih imena nosi veći broj pojedinaca, odnosno da veći broj hrvatskih nosi manji broj pojedinaca. Samo još mađarskih i talijanskih osobnih imena ima više od $2 \%$ (slika 12).

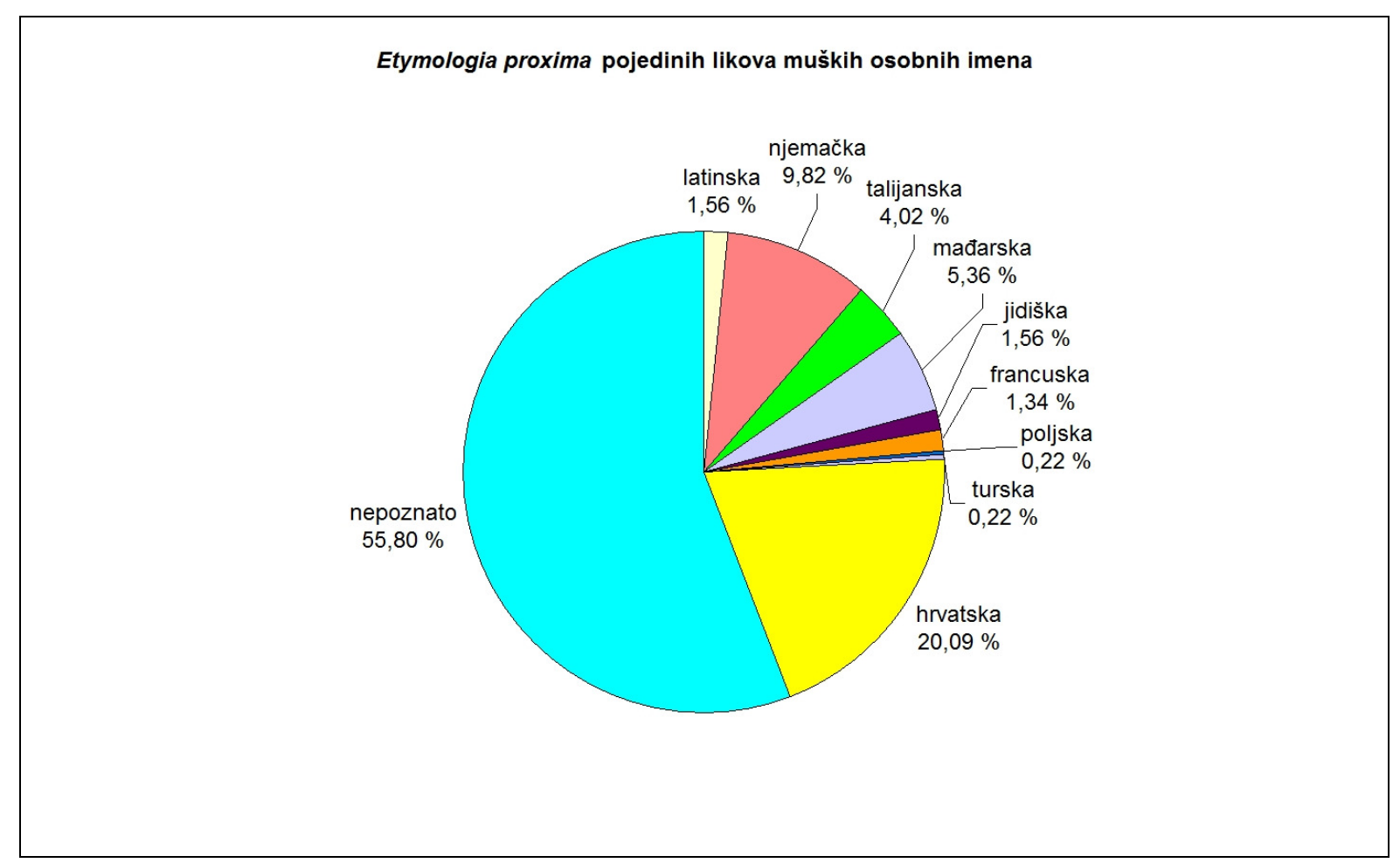

Slika 12: Etymologia proxima pojedinih likova muških osobnih imena

\subsection{Etimološka struktura ženskih građanskih osobnih imena u užem korpusu}

Broj je žena u korpusu koje nose osobno ime nepoznate etymologiae remotae prilično velik $62,89 \%$. Žene s osobnim imenima preuzetima iz njemačkog i hrvatskog, dvije najveće skupine koje slijede, zajedno čine tek oko trećine ukupnog broja žena, dok sva ostala osobna imena nosi tek nešto više od 20 \% žena (slika 13). 


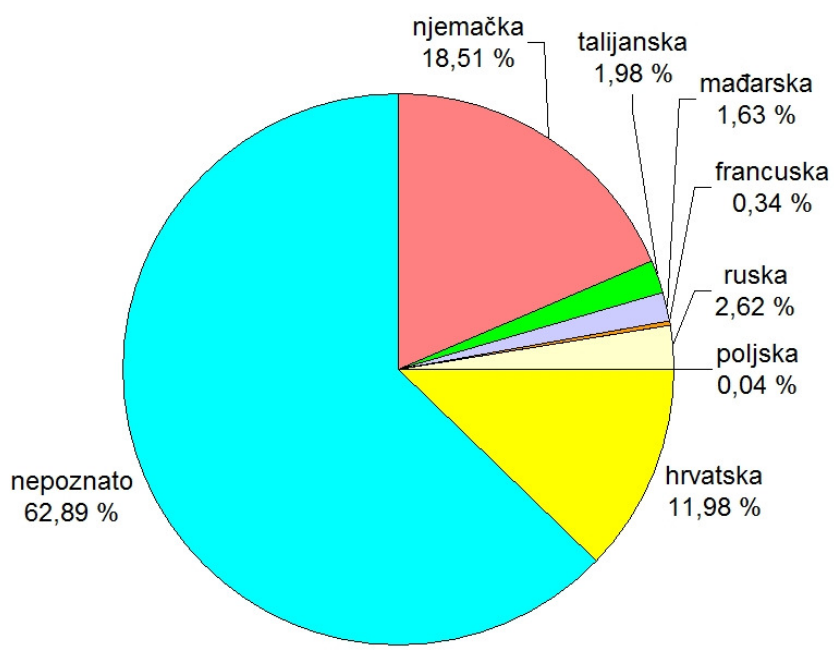

Slika 13: Etymologia proxima ženskih osobnih imena pojedinaka

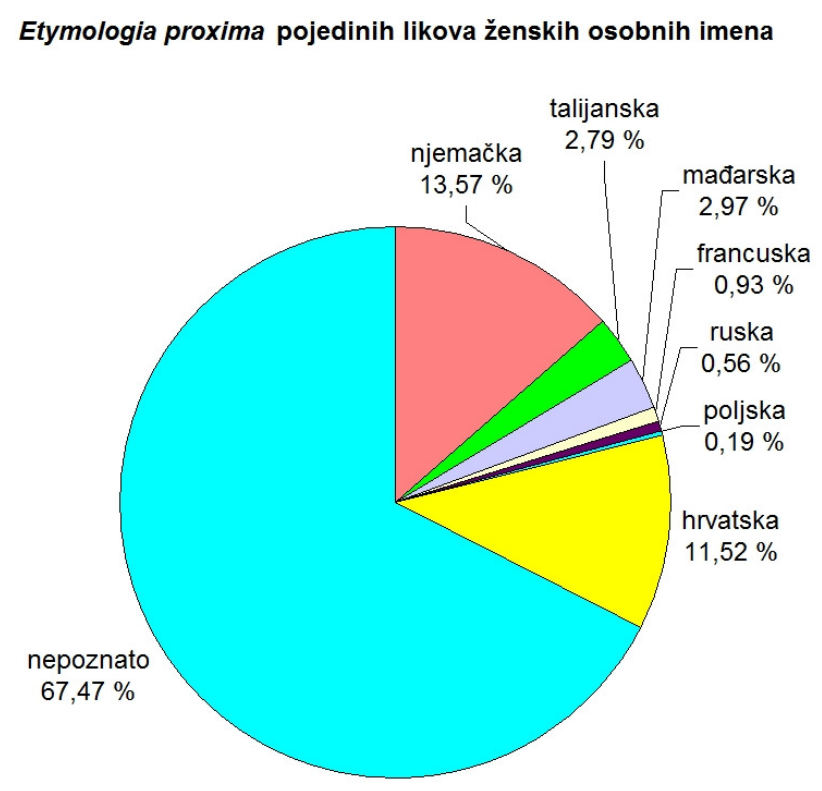

Slika 14: Etymologia proxima pojedinih likova ženskih osobnih imena

Kad pogledamo broj različitih likova ženskih osobnih imena, najviše je onih kojima je jezik iz kojeg su neposredno posuđena nepoznat, 67,47\%. Njemačkih i hrvatskih likova osobnih 
imena zajedno ima tek malo više od četvrtine ukupnog broja. Svi preostali likovi osobnih imena čine tek 7,26\% ukupnih (slika 14).

\subsection{Usporedba etimoloških strukturā muških i ženskih građanskih osobnih imena u užem korpusu}

Kad usporedimo broj muškaraca i žena koji nose njemačka osobna imena, oba se broja kreću oko polovine svih uz minimalnu razliku - muških ima 51,45 \%, a ženskih 49,88 \%. Slično vrijedi i za hrvatska osobna imena: muških ima 38,11\%, a ženskih 32,29\%. Znatnije su

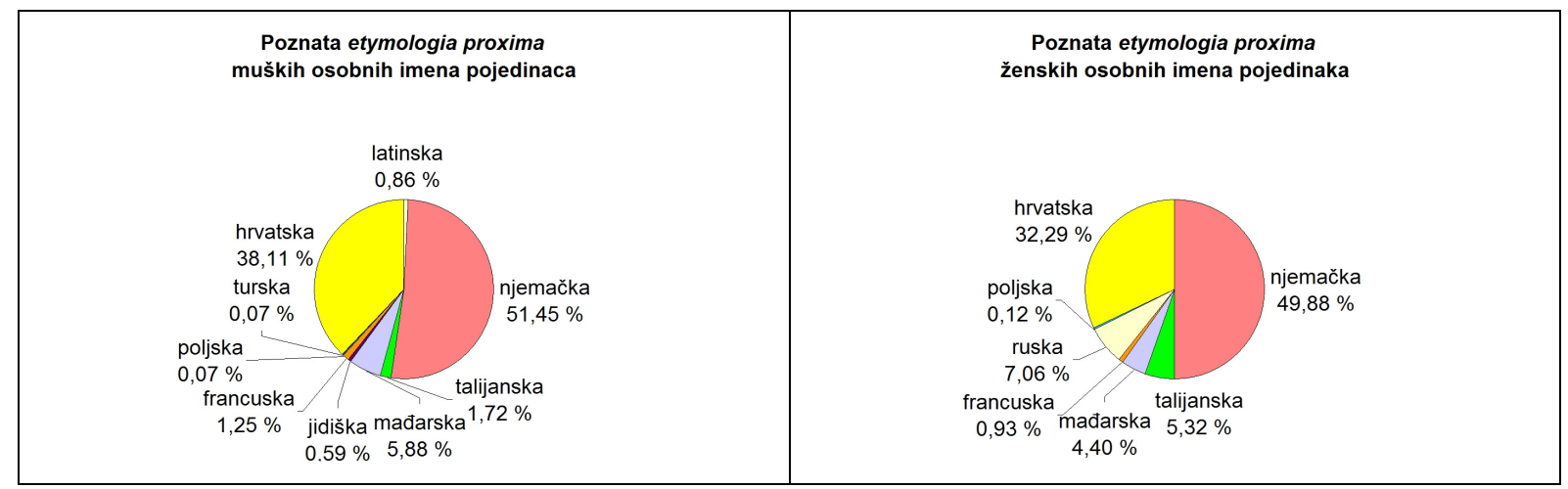

Slika 15: Usporedba etymologia proxima muških $i$ ženskih osobnih imena pojedinaca/ka

razlike vidljive u broju talijanskih osobnih imena, kojih u žena ima više negoli u muškaraca: $5,32 \%$ spram $1,72 \%$. Isto tako, nemali broj žena $(7,06 \%)$ nosi ruska osobna imena, dok ih u muškaraca nema (slika 15).

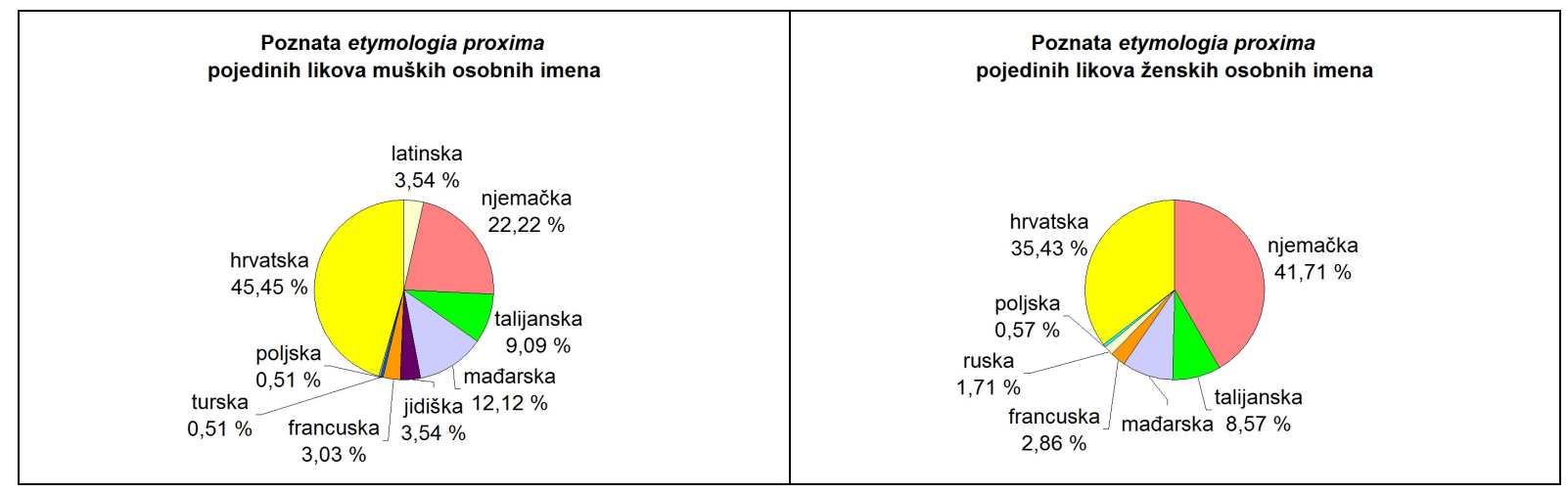

Slika 16: Usporedba poznatih etymologia proxima

pojedinih likova muških $i$ ženskih osobnih imena 
Pri usporedbi samih imenskih likova, uočljivo je da njemačkih muških ima gotovo upola manje od ženskih, a da hrvatskih muških ima više negoli ženskih - 45,45 \% spram 35,43 \% (slika 16).

Ni brojem nositeljica ni brojem likova osobnih imena hrvatska ne nadmašuju njemačka.

\subsection{Dijakronijska analiza građanskih osobnih imena zagrebačkih Židova}

\subsection{Dijakronijska analiza muških građanskih osobnih imena zagrebačkih Židova}

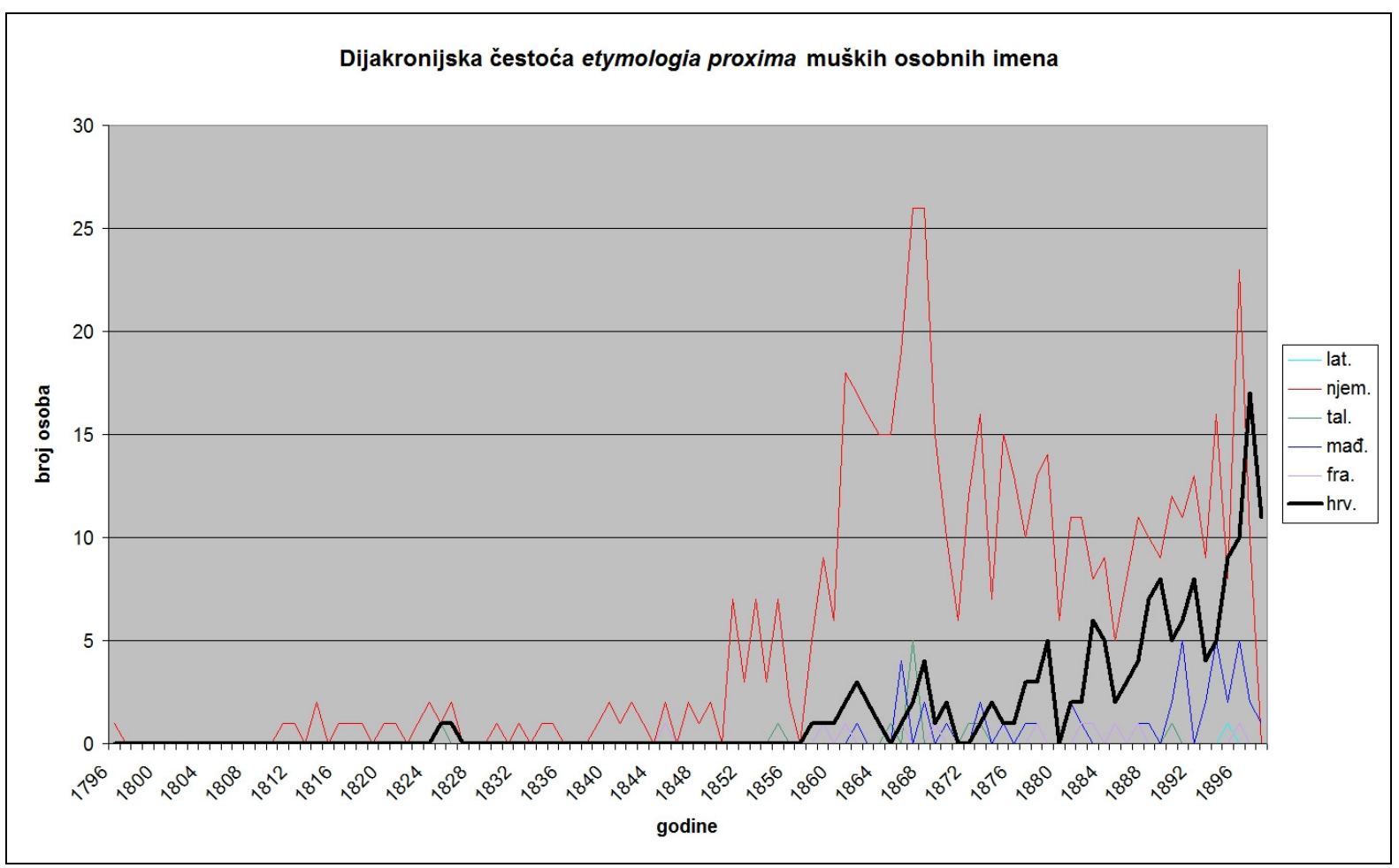

Slika 17: Dijakronijska čestoća etymologia proxima muških osobnih imena

Kao što je i očekivano, dijagram prikazuje dominaciju njemačkih osobnih imena sve do 1896. g. Iduće godine hrvatska osobna imena preuzimaju vodstvo sa 17 nositelja spram 10 njemačkih da bi već 1898. g. njemačka osobna imena u potpunosti izostala. Presudnom se godinom čini 1879. kada su hrvatska osobna imena dosegla brojku od 5 nositelja - dotadašnji rekord nenjemačkih osobnih imena, koji su 1867. g. postigla talijanska. Od tada do 1896. g. hrvatska osobna imena nadmašuju sva ostala osim njemačkih (slika 17). 
Apsolutnu dominaciju njemačkih osobnih imena do 1856. g. još bolje prikazuje dijagram izražen u postocima. Godine 1880. ona zadnji put dosižu $100 \%$ nositeljā te je nakon toga njihov postotak u postupnom opadanju, koje prati porast nositelja hrvatskih osobnih imena. U zadnjoj godini za koju imamo sigurne podatke, 1898., hrvatska osobna imena čine 91,67\% svih nadjenutih muških osobnih imena, a preostalih se $8,33 \%$ odnosi na talijanska osobna imena (slika 18).

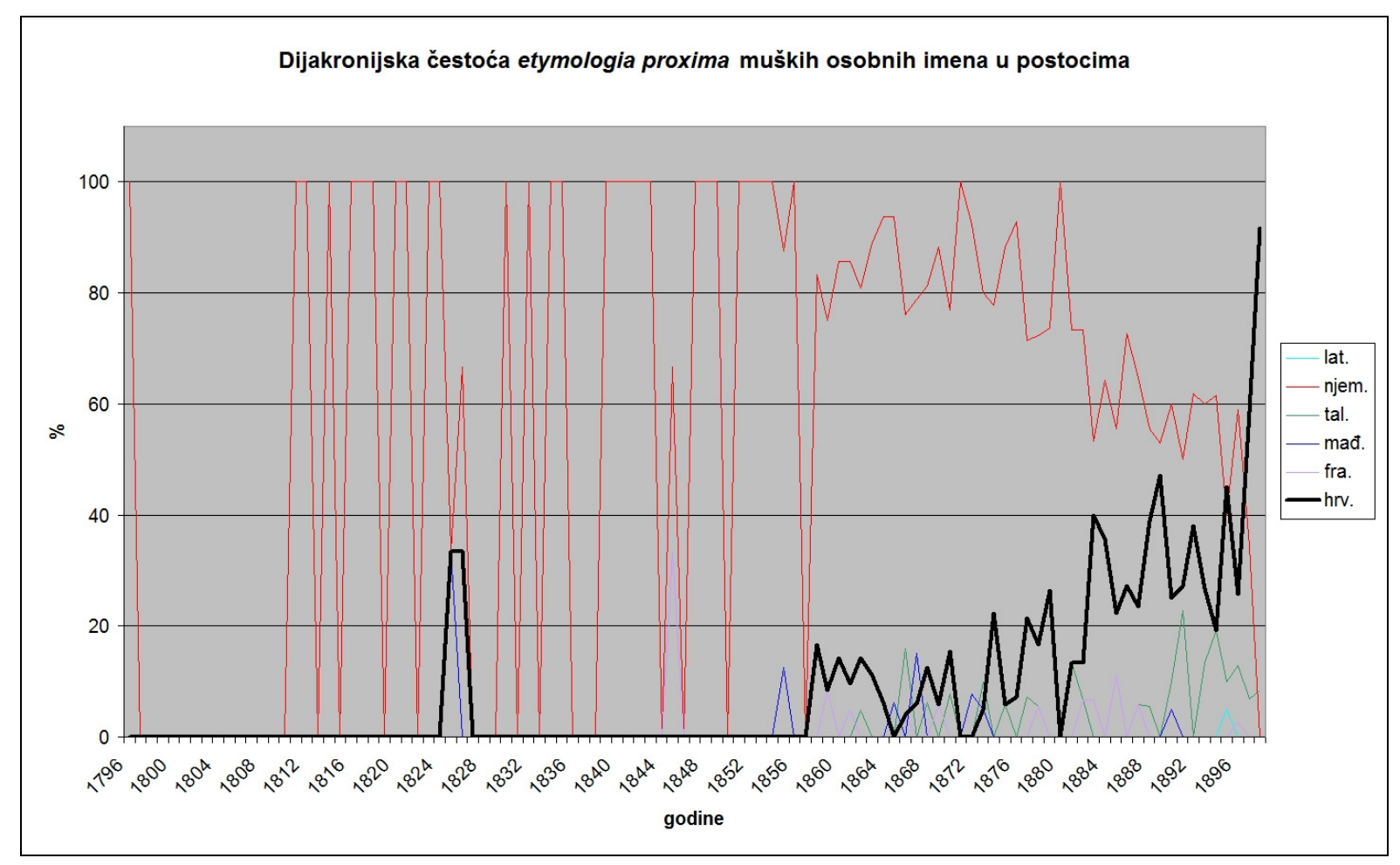

Slika 18: Dijakronijska čestoća etymologia proxima muških osobnih imena u postocima

\subsection{Dijakronijska analiza ženskih građanskih osobnih imena zagrebačkih Židova}

I kod žena osobna imena preuzeta iz njemačkoga dominiraju do 1894. g. da bi 1895. g. prevladala hrvatska. Zanimljivo je da su točno desetljeće prije toga hrvatska osobna imena već jednom preuzela primat od njemačkih, samo na godinu dana. Hrvatska su se osobna imena ponešto uzdigla iznad nenjemačkih još 1879. g. kad su zabilježene 4 nositeljice, broj koji osobna imena iz drugih jezika, osim njemačkoga, nisu dostigla. Hrvatska ženska osobna imena rekord dosižu 1897. g. s 19 nositeljica, da bi iduće godine, zadnje za koju raspolažemo točnim podacima, pala na 11 (slika 19). 


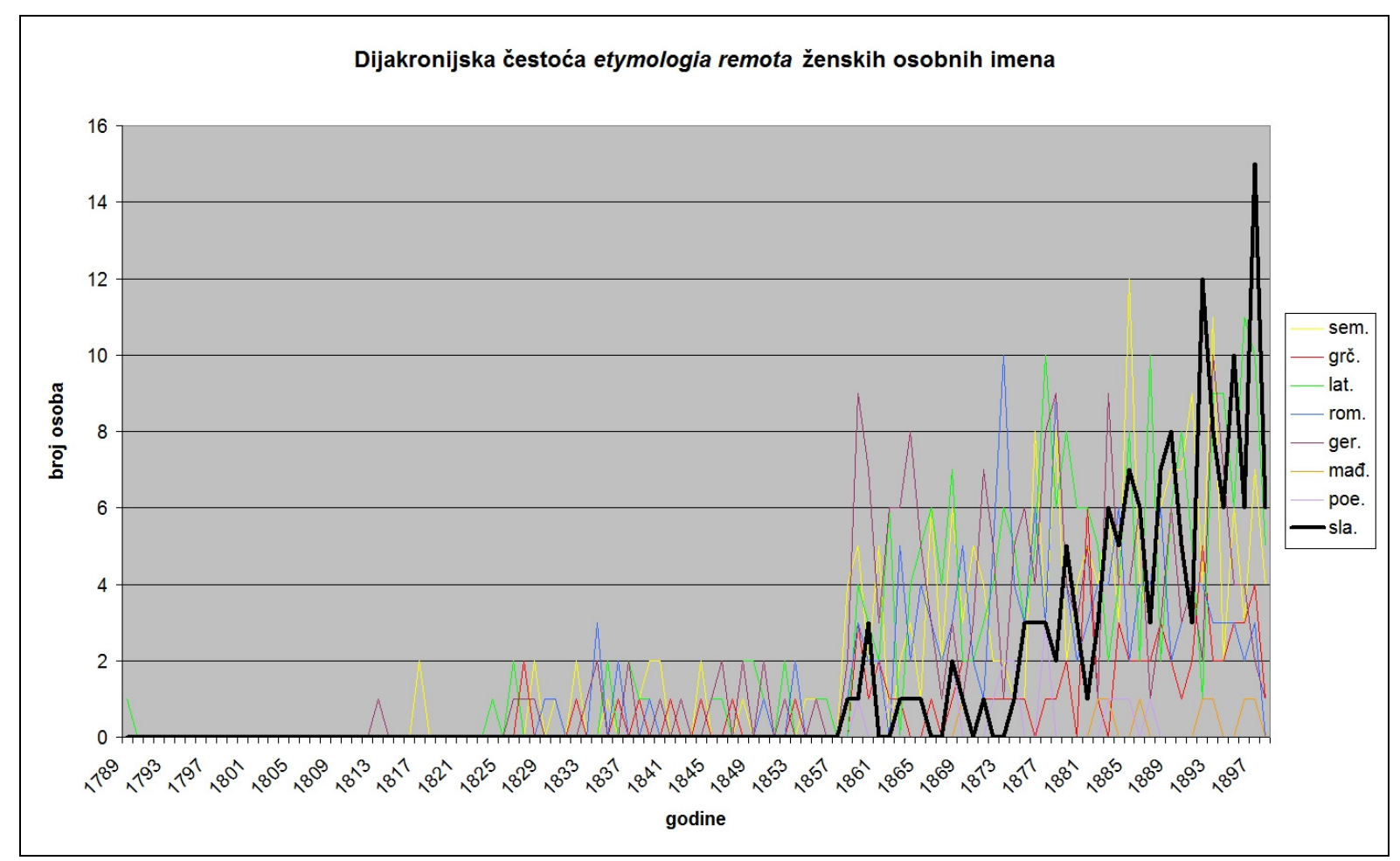

Slika 19: Dijakronijska čestoća etymologia proxima ženskih osobnih imena

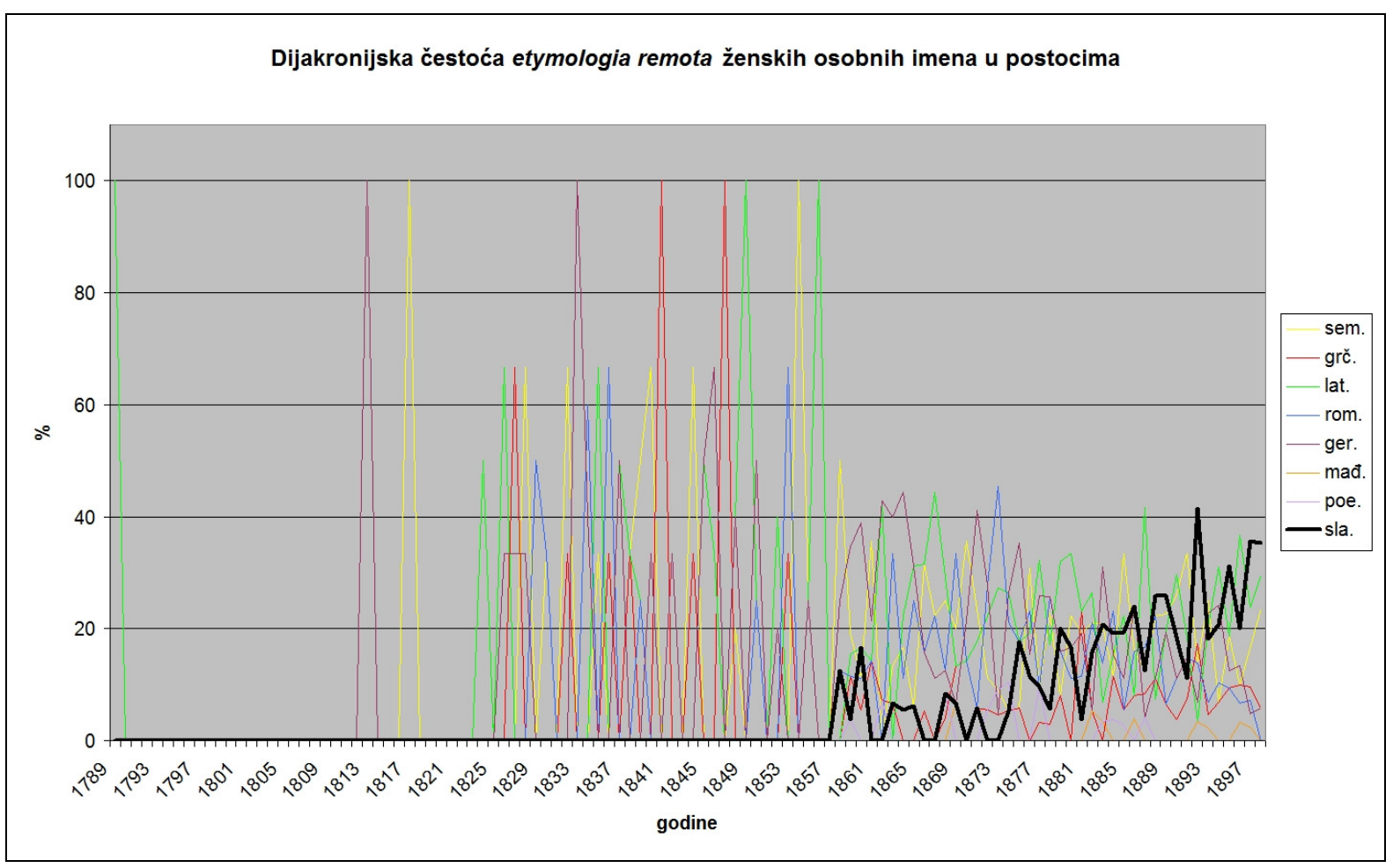

Slika 20: Dijakronijska čestoća etymologia proxima ženskih osobnih imena u postocima

Prikaz nam u postocima pak pokazuje da taj pad u broju nije i pad u udjelu, naprotiv, 1897. je g. hrvatska osobna imena nosilo 63,33\% nositeljica, a 1898. g. čak 78,57\%. Za razliku od 
muških osobnih imena, ta je zadnja godina na primjerima ženskih osobnih imena nešto šarolikija, uz hrvatska i 7,14 \% talijanskih, tu je još i 14,29 \% ruskih osobnih imena (slika 20).

\subsection{3 Židovska osobna imena zagrebačkih Židova}

U ovom se poglavlju obrađuju ona osobna imena zagrebačkih Židova koja nisu građanska.

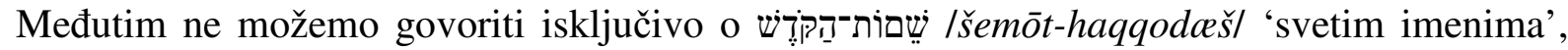
jer ona pripadaju samo muškarcima, a ovdje ima i ženskih osobnih imena. Ne možemo govoriti ni o osobnim imenima pisanim hebrejskim pismom jer su neka od njih pisana latinicom. Na kraju ne možemo govoriti ni o hebrejskim/aramejskim osobnim imenima jer među njima ima i onih jidiških. Zato je odabran pomalo nezgrapan termin »židovska osobna imena «.

U židovskim matičnim knjigama rođenih uz neku su novorođenčad zabilježena i njihova osobna imena na hebrejskom (837, za troje su zabilježena latinicom), kao i osobna imena njihovih otaca (66) - ili majki (2), ako su očevi bili nepoznati - te datum rođenja prema židovskom kalendaru. Nažalost nisu svi ti podaci čitljivi jer se ruke koje su ih bilježile čine nemarnijima od onih koje su pisale latinicom ili Sütterlinom (rukopisnom goticom). Pritom su ženska osobna imena gore prošla od muških jer dobar dio njih pripada govornom jeziku (uglavnom jidišu), s više umanjeničkih i odmiličkih likova, zbog čega je nečitljivija teže rekonstruirati. Uključena su samo ona osobna imena koja se sa sigurnošću mogu pročitati.

Gavro Schwarz u svojoj knjizi za neke od patres familias navodi više osobnih imena, pa i patronim, iz čega bi se moglo zaključiti da su neka od tih osobnih imena ustvari שِם /šemōt-haqqodaš̆, no kako ih on piše latinicom, a često nije očigledno koji dio imenske formule pripada građanskom registru, a koji židovskome, podaci iz njegove knjige neće biti uključeni u ovu analizu.

Na Mirogoju se na 51 grobu nalaze natpisi na hebrejskom jeziku, od kojih su neki, srećom malobrojni, nažalost nečitljivi odnosno teško čitljivi, bilo zbog istrošenosti bilo zbog zaraslosti. Među čitljivima su na 44 zabilježena osobna imena što muškaraca, što žena.

Hebrejskima su (odnosno aramejskima) u idućim popisima označena samo ona osobna imena koja su identična izvornom liku. Ako je osobno ime doživjelo preinaku u lokalnom jeziku, 
smatrat će se da pripada dotičnom jeziku. Hebrejska su i aramejska osobna imena transkribirana u skladu s izvornim jezikom, iako je moguće da su ih zagrebački Židovi izgovarali na jidiški način: אברהם /avrom/, a ne /'abrs̄hs̄m/, אהרן /orn/, a ne /'ahəa ron/, אליהו

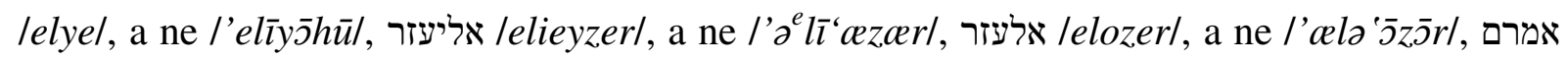

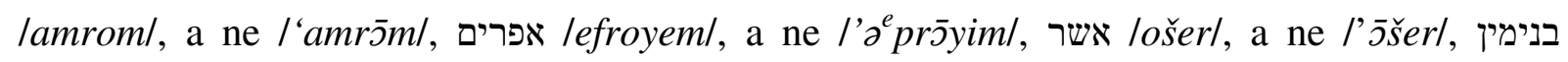

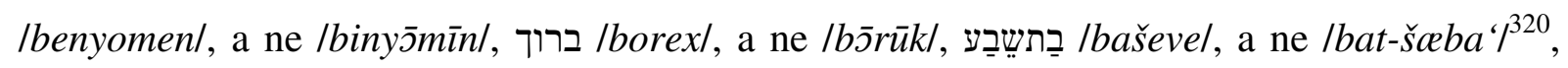

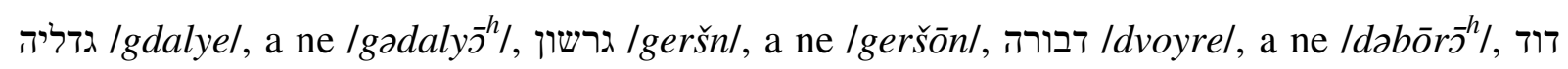

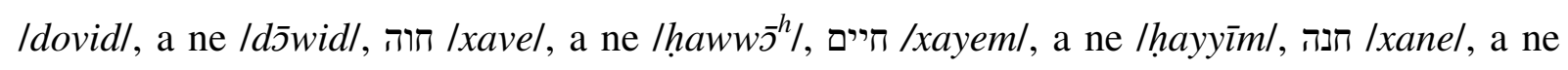

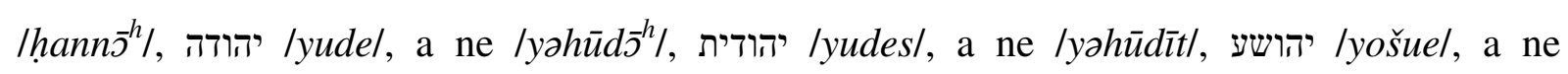
/yəhōšua\%, יוכבד /yoxved/, a ne /yōkaebaed/, יום טוב /yontefl, a ne /yōm țōb/, יונה /yoynel, a ne

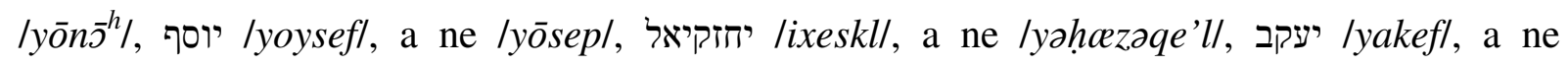

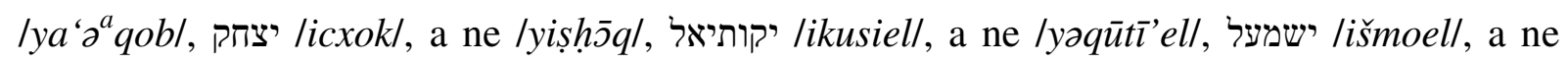

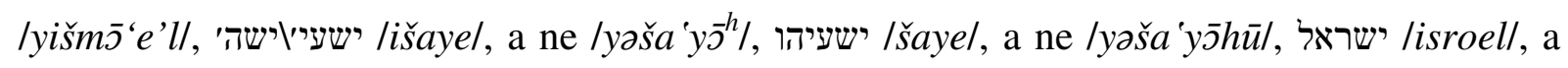

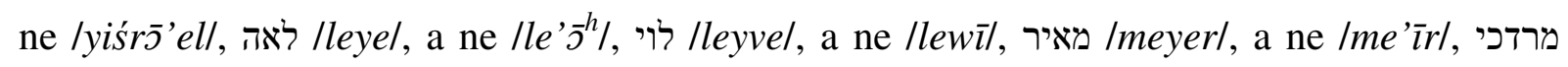

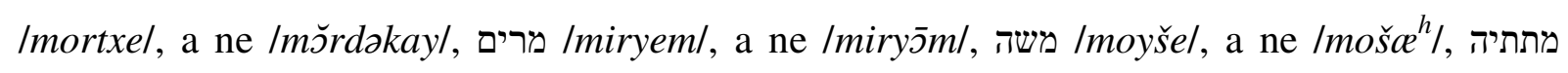

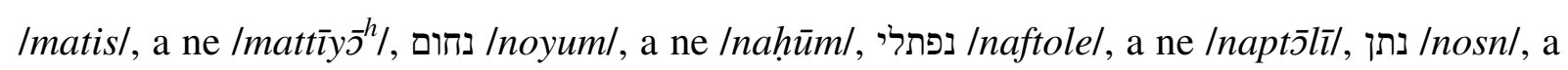

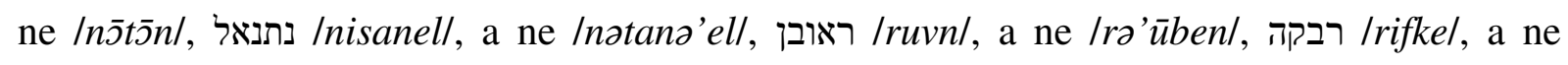

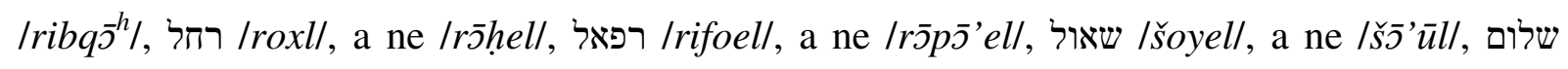
/šolem/, a ne /šalom/, שמשמון /šloyme/, a ne /šimen/, a ne /šim /šimšn/, a ne /šimšon/, שרה /sorel, a ne /ś̄̄ $r \bar{s}^{h} /$.

Osobna su imena poredana po broju nositeljā. Unutar istog broja nositeljā prvo su, poredana prema alef-betu, navedena osobna imena hebrejskog ili aramejskog podrijetla, a potom ona jidiškoga uključujući i jidiške izvedenice hebrejskih osobnih imena, da bi se na kraju našle dvoimene i troimene kombinacije.

\subsubsection{Muška židovska osobna imena zagrebačkih Židova}

Među muškim su se osobnim imenima u različitim razdobljima i na različitim prostorima

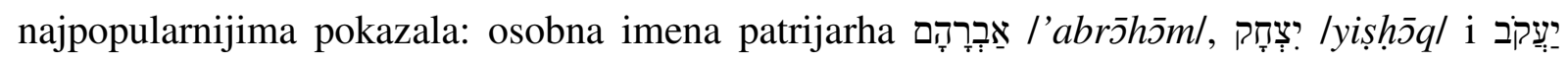

\footnotetext{
${ }^{320}$ Poznati je židovski književnik Isaak Baševis Singer (1902.-1991.), rođen kao יצחק הירש זינגער /yiṣh̄̄q herš זינגער זinger/, svoj pseudonim באשעוויס /zinger/!) stvorio prema osobnom imenu svoje majke בַתשַבַע.
} 


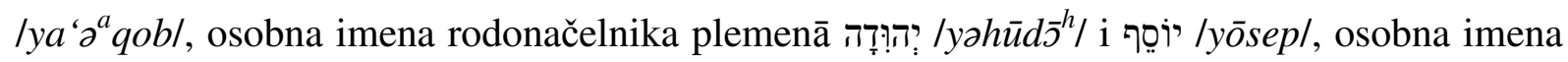

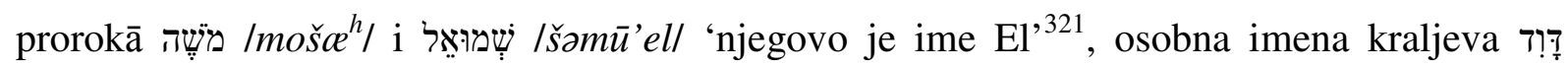

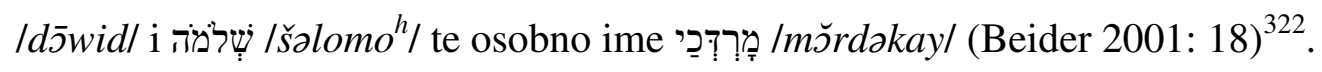

(אָבְרָהָםם) אברהם /'abrōhōm/ 'otac mnoštva' - heb. - 34

Abraham $^{323}-1$

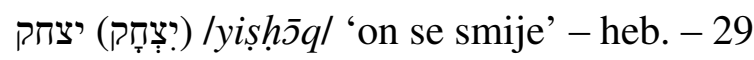

יעקב (יעיעקב) /ya'a 'qob/ 'koji hvata petu' - heb. - 21

יעקוב - heb. - 1

יאקב /yakev/ - jid. - 2

Kao što će biti slučaj i s drugim osobnim imenima hebrejskog ili aramejskog podrijetla, i ovdje nalazimo nesigurnost u njihovu pisanju. Stapanje izgovora fonema ע[ $[\mathrm{C}] \mathrm{s}$ onim fonema $\mathrm{N}$ [?] rezultiralo je i izmjenjivanjem slova $\langle\boldsymbol{y}\rangle \mathrm{i}\langle\boldsymbol{\alpha}\rangle$ u pisanju osobnih imena.

יוסף (יוֹסֵף) /yōsep/ 'YHWH je dodao' - heb. - 22

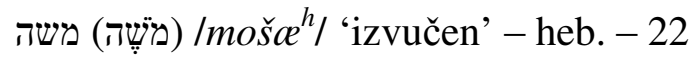

(نש⿱⺌למה) שלמה /Šalomo / 'njegov mir' - heb. - 19

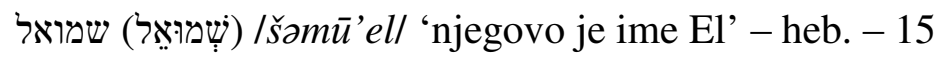

(ראוּבֵן) ראובן /ro'ūben/ 'vidite sina!' - heb. - 13

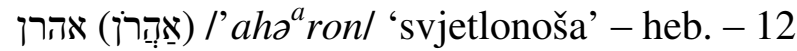

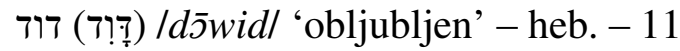

ליב /leyb/-jid. - 11

Prvo nehebrejsko osobno ime na popisu. Mnoge su židovske zajednice koristile riječ 'lav'

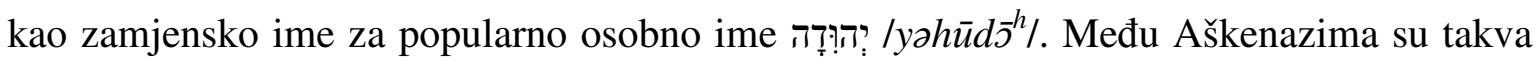
osobna imena Leve, Lebe i Leb, izvedena od srednjovisokonjemačkih lëwe, löwe, lebe i leb (: njem. Löwe), ali nije sigurno jesu li ih sami stvorili ili preuzeli od kršćana u kojih su također zabilježena. Kasniji je glasovni razvoj jidiških osobnih imena, međutim, tekao neovisno od onih nežidovskih: Lebe > (apokopa) Leb > Leyb (Beider 2001: 358-362).

\footnotetext{
${ }^{321} 1$ Sam 1,20. U transkripciji Antuna Sovića: Samuel.

${ }^{322}$ Alexander Beider u Dodatku C svoje knjige donosi popise najpopularnijih ženskih i muških osobnih imena u različitim vremenima i na različitim područjima srednje i istočne Europe (Beider 2001: 233-236).

${ }^{323}$ Jedno od rijetkih hebrejskih osobnih imena zabilježenih nehebrejskim pismom u maticama rođenih (45/1892).
} 
(גֶרְשוֹן) גרשון /geršōn/ 'progonstvo',324 - heb. - 10

(מֵאִיר) מאיר /me'̌rr/ 'koji osvjetljava' - heb. - 10

Poslijebiblijsko osobno ime, koje se pojavljuje u Talmudu (Eruvin 13). Bijaše to nadimak rabina Meira zvanog Čudotvorac (139. - 163.), jednog od najvažnijih učenika rabina Akive. Nadimak je navodno stekao jer je (pr)osvijetlio oči učenjaka i učenika Tore, a njegova je slava doprinijela popularnosti osobnog imena u različitim židovskim zajednicama (Beider 2001: 15, 377-379).

חיים (חַיים) /hayyim/ 'život' - heb. - 9

Još jedno poslijebiblijsko osobno ime, stvoreno kao apotropsko. Nalazimo ga u mnogim zajednicama od Bliskog istoka preko Bizanta i Francuske sve do Iberskog poluotoka, ali ne i u samoj Njemačkoj prije XIII. st. Osobno je ime bilo izrazito popularno u Austriji i slavenskim zemljama (Beider 2001: 348-351).

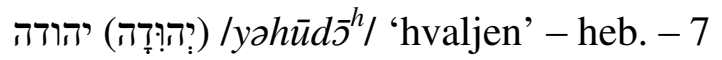

יהודא - heb. - 1

יהודא|יהודה - heb. - 1

Još jedan primjer nesigurnosti pisanja hebrejskih osobnih imena. Ovaj se put nedoumica pojavljuje oko zadnjeg slova, treba li ono biti $\langle\pi>$ (kao u izvornom liku osobnog imena) ili pak $<\aleph>$ koje u jidišu uglavnom označava samoglasnik /a/ (ili /o/)?

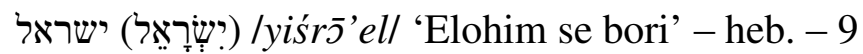

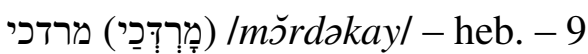

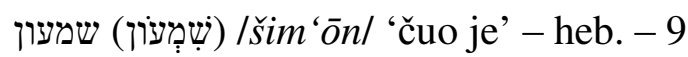

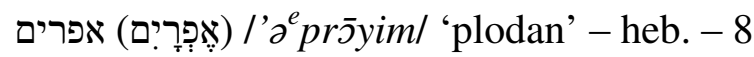

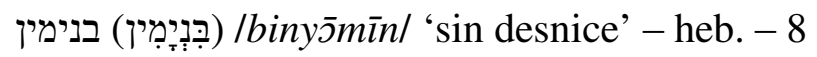

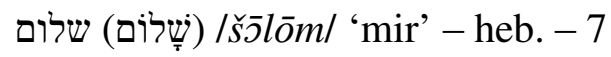

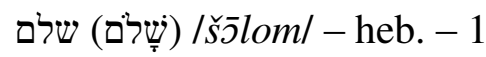

Poslijebiblijsko osobno ime koje se pojavljuje u jeruzalemskom Talmudu (Demai 12,4).

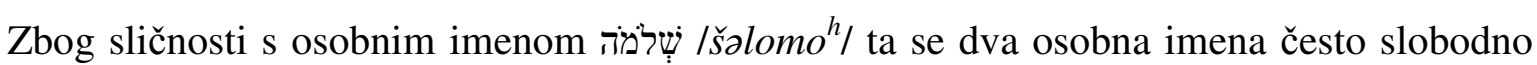
izmjenjuju. U srednjem se vijeku pojavljuje u Bizantu, sjevernoj i južnoj Francuskoj i Italiji. Nije bilo uobičajeno u Njemačkoj, ali je bilo iznimno popularno u zapadnom

\footnotetext{
${ }^{324}$ Post 46,11. U transkripciji Silvija Grubišića: Geršon.
} 
(srednjoeuropskom) Kanaanu, kamo su ga vjerojatno donijeli doseljenici s istoka (Beider 2001: 423-424).

(מְנְֵַם) מנחם /manahem/ 'tješitelj' - heb. - 6

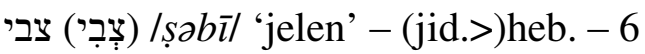

Prema Alexanderu Beideru osobno je ime nastalo kao prijevodno osobno ime jidiškoga

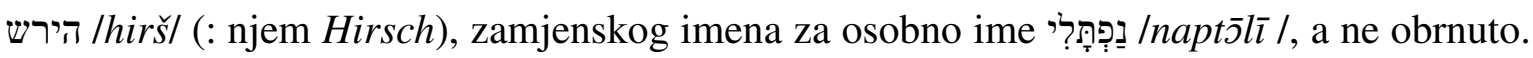
Ne pojavljuje se prije XVI. st., ne pojavljuje se u nežidovskim spisima i iz njega nije izvedena nijedna odmilica. Beider stoga zaključuje da osobno ime nije bilo u uporabi u svakodnevnom govoru, te da su u svakodnevnom životu nositelji toga osobnog imena koristili njegovo zamjensko ime (prijevodno osobno ime) na lokalnom jeziku (Beider 2001: 434).

ףווארז /wolfl - jid. - 3

וואלף - jid. - 3

Još jedno osobno ime koje je, kao i prethodno, nastalo na temelju Jakovljevih blagoslova sinova si iz 49. poglavlja Knjige postanka. Inačice su osobnog imena Wolf bile nazočne među njemačkim nežidovima još od V. st., najčešće kao odmilice složenih osobnih imena koja su počinjala tim segmentom. Među Židovima je ovo osobno ime prihvaćeno kao

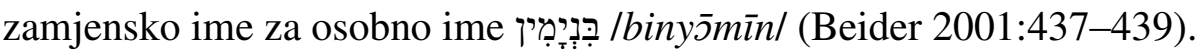

יוסף ליב /yōsep leyb/ - heb.-jid. - 6

Dvoimena kombinacija sastavljena od hebrejskog osobnog imena יוֹסף /yōsep/ (v. יוֹסף) (יוסף) /yōsep/) i jidiškoga osobnog imena ליב /leyb/ (v.)

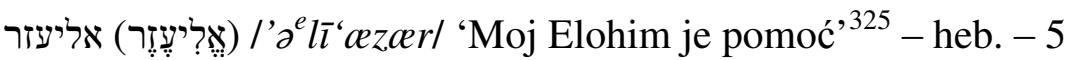
מענדל /mendl/ - jid. - 5

Među nežidovima se u Njemačkoj osobna imena izvedena od korijena man 'čovjek' (: njem. Mann) pojavljuju već u VIII. st. Najčešće je od njih bilo Manno, ali su često u pitanju bile i odmilice izvedene od složenih osobnih imena čiji je dočetni segment bio -man. Židovi su osobno ime posudili od nežidova, između ostalog i zbog zvučne sličnosti s popularnim hebrejskim osobnim imenom p̣נִ /manahem/, posebno ako uzmemo u obzir njemačku nežidovsku odmilicu Mennechen (Mennechin, Mennikin) koja se pojavljuje već u X. st. Njemački su Židovi prenijeli osobno ime u slavenske zemlje.

\footnotetext{
${ }^{325}$ Post 15,2. U transkripciji Silvija Grubišića: Eliezer.
} 
Glasovni razvoj: Mano/Mana > (redukcija zanaglasnog samoglasnika) Mane > Man > (umanjenica s prijeglasom) Mendl (Beider 367-371)

בנימין זאב /binȳ̄mīn za'eb/ - heb.-(jid.>)heb. - 5

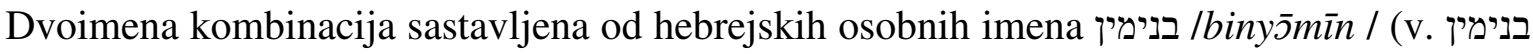

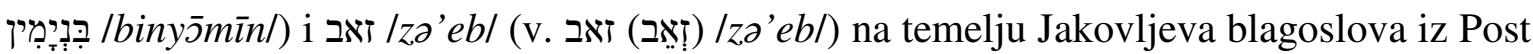
49,27

(אליְ:הוּ) אליהו /'elīyshhūl 'moj Elohim je YHWH' - heb. - 1

אליו - heb. - 1

אליה - heb. - 1

אליה - heb. - 1

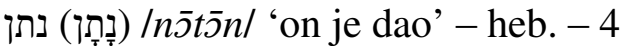

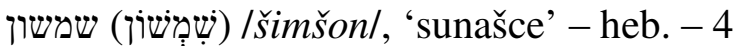

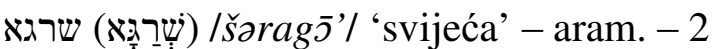

- שרגא' - aram. - 1

- aram. - 1

Osobno ime stvoreno od aramejske riječi i povezano s osobnim imenom /'ūrì 'oganj ${ }^{326}$ kao njegovo zamjensko ime. Kasnije je kao samostalno osobno ime dobilo svoje zamjensko ime - פיפבוש /feyvuš/ (v. פייבל /feyvl/) - pučkom etimologijom koja je zamjensko ime povezala s grčkim Фoĩßos /phoĩbos/ 'svijetao, ${ }^{327}$, pridjevkom boga Apolona u ulozi boga Sunca (Beider 2001: 425).

בערל /berl/ - jid. - 4

Umanjenica od osobnog imena בער /ber/ (v.) (Beider 2001: 287).

יהודה ליב /yzh $\bar{u} d \bar{\nu}^{h}$ leyb/ - heb.-jid. - 4

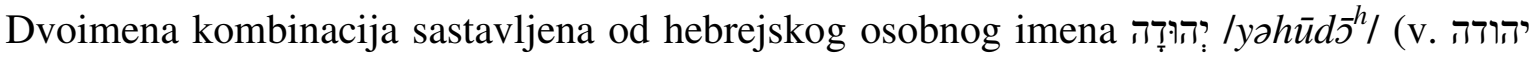

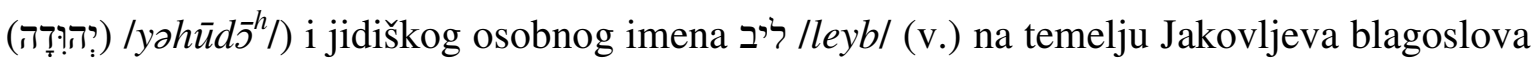
iz Post 49,9

\footnotetext{
${ }^{326}$ Izl 31,2. U transkripciji Silvija Grubišića: Uri.

${ }^{327}$ Iako je ustvari potekao od lat. Vivus, v. פייבל /feyvl/i פיישל /feyšl/ (Beider 2001, xxv)
} 


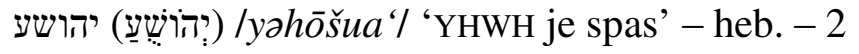

יהשוא - heb. - 1

U suvremenom se hebrejskom samoglasnička oznaka /u/ više ne koristi, već ju je svuda (osim u religioznim tekstovima) zamijenila mater lectionis,$/ w /$. U jidišu je s vremenom slovo ו /w/, prvotno korišteno i za samoglasnik /u/ i za samoglasnik /o/, postalo grafički znak isključivo samoglasnika /u/. (Samoglasnik se /o/ bilježi kao < אָ>.) Otud nesigurnost pisanja u ovom slučaju.

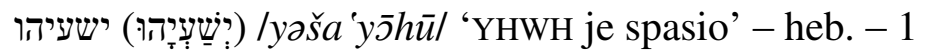

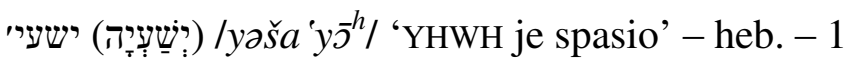

ישיא' - heb. - 1

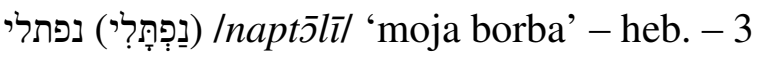

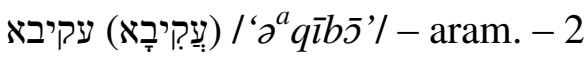

- aram. - 1

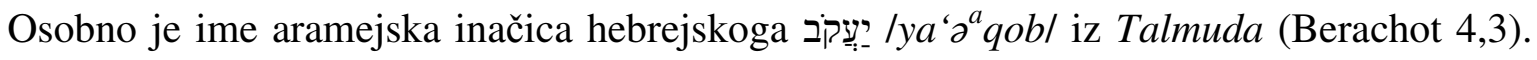

Popularnost može zahvaliti talmudskom učenjaku Akivi ben Josef (o. 50. - 132.). Nije bilo uobičajeno u srednjovjekovnoj Njemačkoj, bilo je rijetko u Češkoj, a uobičajilo se u istočnoj Europi zadnjih stoljeća (Beider 2001: 15, 440-444).

פייבל /feyvl/ - jid. - 3

Osobno je ime izvedeno od latinskog pridjeva vivus 'živ' stvoreno kao prijevodno osobno

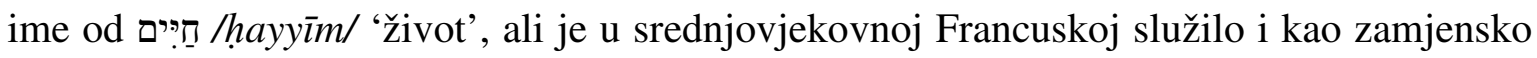

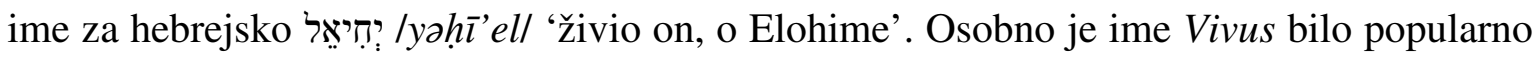
i u Francuskoj i u Španjolskoj, vjerojatno zbog kretanja židovskog stanovništva između te dvije zemlje. Iz Francuske je došlo u Njemačku. Rabinska je tradicija osobno ime Fayvuš pučkom etimologijom povezala s grčkim Фoĩßos /phoîbos/ 'svijetao', pridjevkom boga Apolona u ulozi boga Sunca, a ono se pojavljuje i kao zamjensko ime za hebrejsko osobno ime אוּרִ /'ūrī/. Iz Porajnja je, gdje se početno /v/ obezvučilo u $/ f /$, osobno ime prešlo u Bavarsku i Franačku, gdje je /i/ diftongizirano u /ay/, a odande u slavenske zemlje gdje je dočetak /Vs/ zamijenjen u tim krajevima uobičajenijim /Vš/.

Glasovni razvoj: Vivis/Vives/Vivus > Fivis/Fives/Fivus > Fayvis/Fayves/Fayvus [> Fayviš/Fayveš/Fayvuš] > (umanjenica) Feyvl (Beider 2001: 308-312, Beider 2003: 72-73) 
פיישל Ifeyšll - jid. - 3

Ovo je osobno ime u jidišku antroponimiju već ušlo kao umanjenica germanskoga korijena fiš 'riba' (: njem. Fisch). Neumanjeni je lik Fiš po svemu sudeći nastao tek kasnije hiperkorekcijom. U srednjem se vijeku ovo osobno ime držalo zamjenskim imenom za

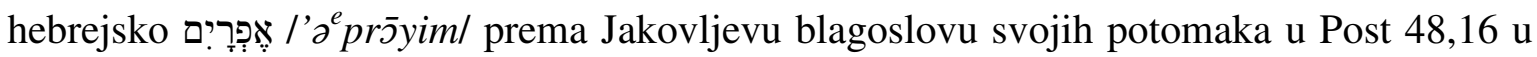
kojem se, doduše, ne spominju ribe, ali je korišten glagolski oblik namnožit će se' izveden od korijena T.ג/d-g-h/, nalik onomu iz kojeg je izvedena imenica גד̣ /dag/ 'riba' (Beider 2001: 6, 313-314).

/'abrōhōm he/iršs / - heb.-jid. - 3

Dvoimena kombinacija sastavljena od hebrejskog osobnog imena אָבְרָהָם /'abrs̄hs̄m/ (v. הרש /he/iršl (v.)

/ moš $e^{h}$ yəhūd $\bar{\nu}^{h} /$ - heb.-heb. - 3

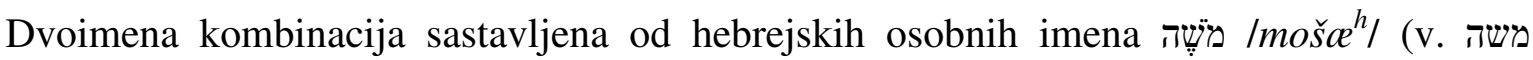

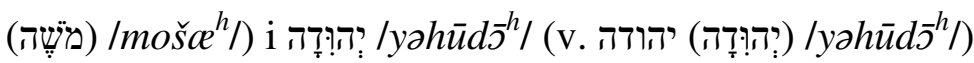

(אֶלְעָזָר) אלעזר /'alo 'כ̄zōr/ 'Elohim je pomogao' - heb. - 1

Elasar $^{328}-1$

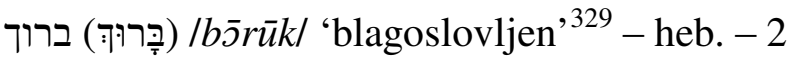

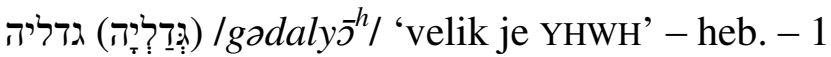

דגליי - heb. - 1

יונה (יוֹנָה) /yōns̄ / 'golub' - heb. - 2

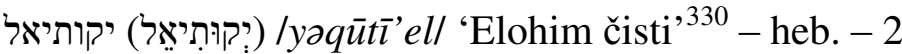

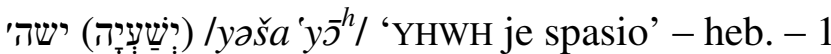

י - heb. - 1

לויר) /lewīl 'pridružen' - heb. - 2

בער /berl - jid. - 2

Korijen je osobnih imena ber- 'medvjed' (: njem. Bär), uz već spomenut wolf- 'vuk' i eber- 'vepar', bio jedan od tri najpopularnija u njemačkoj antroponimiji srednjeg vijeka.

\footnotetext{
${ }^{328}$ Jedno od rijetkih hebrejskih osobnih imena zabilježenih nehebrejskim pismom u maticama rođenih (1066/1884).

${ }^{329}$ Jer 32,12. U transkripciji Antuna Sovića: Baruh.

${ }^{330} 1$ Ljet 4,18. U transkripciji Antuna Sovića: Jekutiel.
} 
Židovi su od kršćana posudili i samostalno osobno ime Ber(o) i složeno בערמאָ /berman/

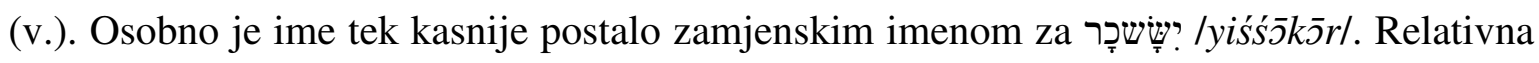
kronologija oba osobna imena, naime, pokazuje da se hebrejsko proširilo nakon germanskoga. Osobno je ime seobom preneseno iz zapadne Njemačke u istočnu Njemačku i Češku, a potom iz srednje Europe u istočnu Europu (Beider 2001: 287-288).

הירש /hiršl-jid. - 2

הרש /he/iršl-jid. - 2

Ovo osobno ime vuče podrijetlo iz srednjovisokonjemačkoga hirz 'jelen' (njem. Hirsch), da bi u visokonjemačkom dočetni postdentalni frikativ prešao u dentalni, a potom u nekim riječima u palatalni. U prajidiškome je imenica izvorno glasila hirš da bi u dijalektima istočne Ukrajine, Besarabije, Rumunjske i nekih zemalja sjeverno od njih prešlo u herš, dok je u onima Litve, Latvije, Bjelorusije i dijela sjeveroistočne Poljske postalo hirs. Od XIV. se st. pojavljuju još dvije inačice osobnog imena: Hirc u Frankfurtu, Alzasu i Švicarskoj i Herc u samom Frankfurtu. Osobno je ime u različitim inačicama postalo uobičajeno u mnogim aškenaskim zajednicama, a kao zamjensko je ime na temelju

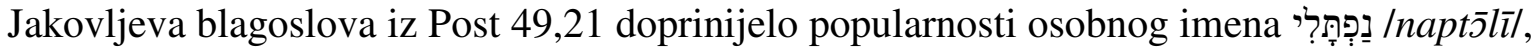
što je pak potaknulo stvaranje hebrejskog prijevodnog osobnog imena צִבְ̣ /ṣabī/ od jidiškoga הרש /he/iršl i njegovo širenje.

Glasovni razvoj: Hirse > (ispadanje dočetnog samoglasnika) Hirš > Herš (Beider 2001: $329-331)$

זעליג /zelig/ - jid. - 2

Osobno je ime nastalo među Židovima Porajnja iz judeonjemačkog izraza 'blagoslovljen čovjek' (srednjovisokonjemački saelecman, saelicman : njem. Seligmann). Iz Porajnja je seobom preneseno u južnu Njemačku, a potom u slavenske zemlje. Pojavljuje se kao

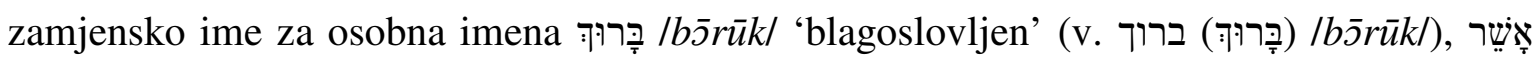

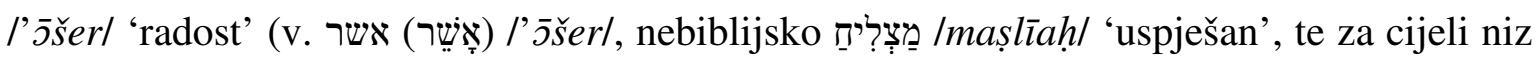
biblijskih osobnih imena (Alexander Beider ih navodi 16!).

Glasovni razvoj: Zelikman > (regresivna asimilacija po zvučnosti) Zeligman > (apokopa) Zelig (Beider 2001: 461-463)

מייער /ma/eyer/ - jid. - 2

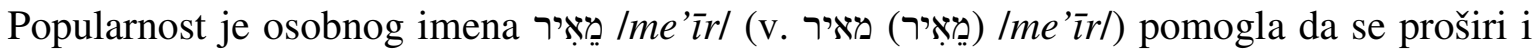
ova njegova inačica. U srednjem se vijeku u srednjoj Europi (Češkoj, Moravskoj i Austriji) pojavljuje i lik Mayer, moguće nastao križanjem s njemačkom imenicom Meier 'seoski 
starješina', ali i s istočnoslavenskim osobnim imenom Майop < lat. maior 'veći'. Potvrde iz XIX. st. pak pokazuju da je raspodjela likova Meyer i Mayer komplementarna: prvi nalazimo u Litvi, Latviji, Bjelorusiji i dijelu sjeveroistočne Poljske te u istočnoj Ukrajini, Besarabiji i Rumunjskoj, a drugi u Poljskoj, Galiciji i dijelovima Slovačke i Mađarske, prvi, dakle, na rubovima istočnojidiškog područja, a drugi u njegovu središtu, u skladu s raspodjelom ostalih jidiških riječi u kojima se nalazio prasamoglasnik $\bar{e}$.

Glasovni razvoj: Meir > Meyer > Mayer (Beider 2001: 377-379)

אברהם בעער /'abrōhōm beerl - heb.-jid. - 2

Dvoimena kombinacija sastavljena od hebrejskog osobnog imena אַבְרָרָם /'abrōhs̄m/ (v.

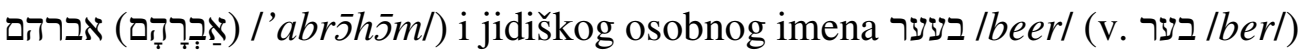

אברהם צבי /'abrōhōm șab̄̄l - heb.-(jid.>)heb. - 2

Dvoimena kombinacija sastavljena od hebrejskih osobnih imena אַבְרָהָם /'abrs̄hs̄m/ (v.

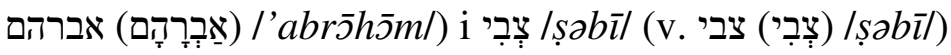

/'arye $e^{h}$ yhūd $\bar{j}^{h} /$ - heb.-(jid.>)heb. - 2

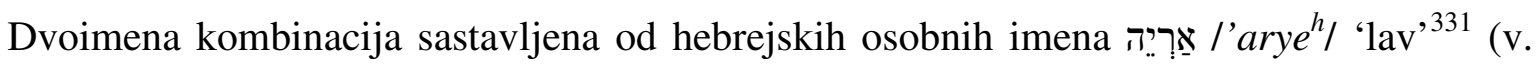

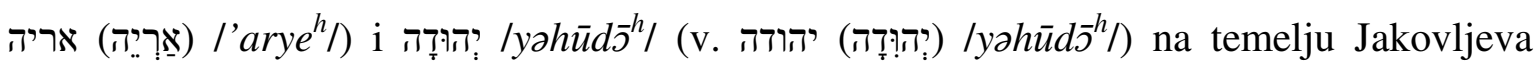
blagoslova iz Post 49,9

/'aryeh leyb / - (jid.>)heb.-jid. - 2

Hibridna, tautološka, dvojezična dvoimena kombinacija sastavljena od hebrejskog osobnog

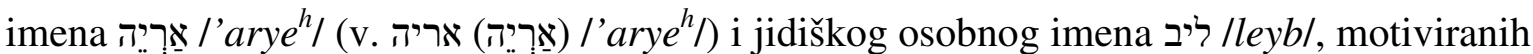
imenicama istog značenja 'lav'

יצחק ליב /yiṣhhōq leyb / - heb.-jid. - 2

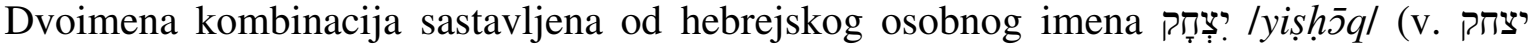

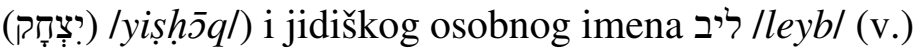

שמואל חיים/šəmū'el hayyìm/ - heb.-heb. - 2

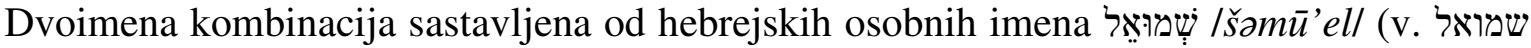

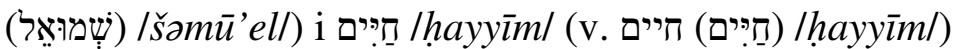

שמואל ליב /šamū'el leyb/ - heb.-jid. - 2

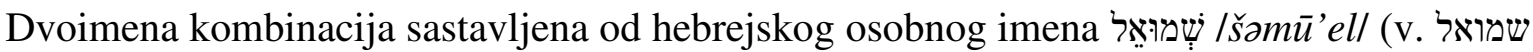
(שְׁמוּאֵל) / ליב /leyb/ (vomūel/) i jidiškog osobnog imena

\footnotetext{
${ }^{331} 2 \mathrm{Kr} 15,25$. U transkripciji Antuna Sovića: Arje.
} 


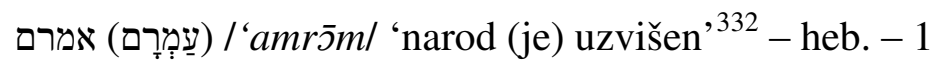

Još jedan primjer osobnog imena u kojem dolazi do miješanja

(אַרי.יה) אריה /'arye / 'lav' - (jid.>)heb. - 1

Korištenje je ove hebrejske riječi kao osobnog imena među Židovima najranije potvrđeno

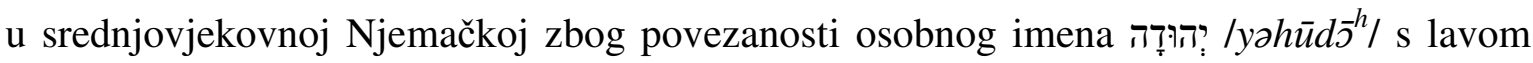
(ustvari s lavljim mladunčetom, lavićem) u Jakovljevu blagoslovu u Post 49,9. Osobno se ime redovitije pojavljuje od XVII. st. kao hebrejsko prijevodno osobno ime jidiškoga ליב /leyb/ (v.) (Beider 2001: 277-278).

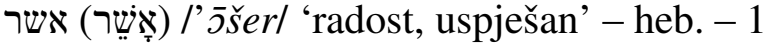

(הָלִל) הילל /hillel/ 'zahvala' - heb. - 1

Osobno je ime bilo popularno vjerojatno zahvaljujući slavi talmudskog učenjaka Hilela Velikog (o. 110. g. pr. n. e. - 10. g. n. e.) (Beider 2001: 15).

זאב (זָאב) /zo'eb/ 'vuk' - (jid.>)heb. - 1

Osobno je ime stvoreno u aškenaskim zajednicama kao prijevodno osobno ime jidiškoga

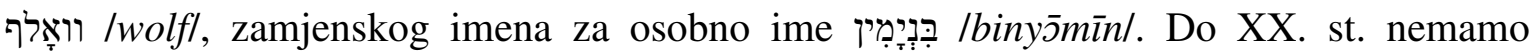
potvrde o uporabi ovog osobnog imena u svakodnevnom životu, nema njegovih izvedenica, te je vjerojatno da je uglavnom funkcionirao kao zamjensko ime bilo za jidiško bilo za hebrejsko osobno ime (Beider 2001:463).

(יוֹם טוֹב) יום טוב /yōm tōob/ - heb. - 1

Hebrejski frazem יוֹ טוֹב /yōm țōb/ (doslovno'dobar dan') znači 'blagdan', te je kao osobno ime nadijevano dječaku rođenom na koji blagdan. Osobno je ime u srednjem vijeku bilo popularno u jugozapadnoj Europi, na Iberskom poluotoku i u južnoj Francuskoj, a potvrđeno je i u Italiji, dok u Njemačkoj nije bilo uobičajeno. Seobama je osobno ime preneseno u Njemačku, a potom dalje na istok (Beider 2001: 449).

Nažalost, za ovu nam osobu datum rođenja nije poznat, te nije moguće potvrditi je li doista rođena na blagdan.

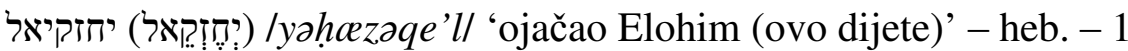

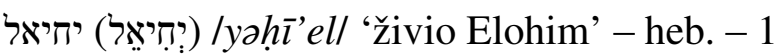

\footnotetext{
${ }^{332}$ Izl 6,18. U transkripciji Silvija Grubišića: Amram.
} 


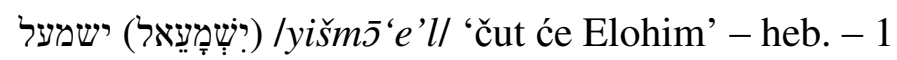

Išmael kao praotac Arapā nosi prilično negativne konotacije u popularnoj židovskoj književnosti, no ipak je samo osobno ime bilo uobičajeno u talmudsko doba, iako se u samom Talmudu (Gen. R. 71,3) Jišmael navodi kao primjer lika iz Tanaha čije je osobno ime bilo lijepo, ali su mu djela bila ružna. Među Aškenazima se osobno ime pojavljuje tek u nekoliko slučajeva u srednjoj Europi, dok iz istočne Europe nema potvrdā (Beider 2001: 14, 336-337; Rabinowitz : 767).

מהרם /maharam/ - heb. - 1

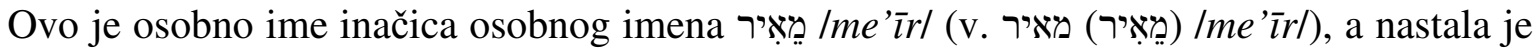

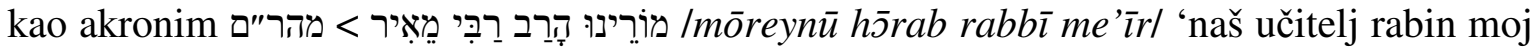
rabin Meir' koji se pripisivao nekolicini slavnih rabina osobnim imenom מֵאִיר /me'îr/, od kojih je najvažniji bio Meir iz Rothenburga (o. 1215. - 1293.) (Beider 2001: 377-379).

מכל /mixll - jid. - 1

Činjenica da je osobno ime מִיכָ /mīks̄'el/ nosio jedan arkanđeo doprinijela je njegovoj raširenosti kako među kršćanima tako i među Židovima. U njemačkih se kršćana kontaminiralo s njemačkim osobnim imenom Michel<srednjovisokonjemački michel 'velik'. To su osobno ime od kršćana posudili Židovi, a od njega je (a ne od hebrejskog osobnog imena) nastao lik מיכל /mixl/. Dodatnu potporu ovoj tvrdnji daje i činjenica da su

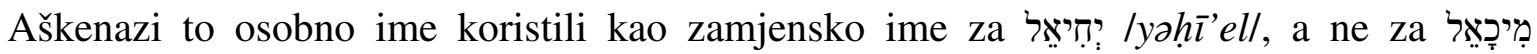
Imīkj̄'ell (Beider 2001: 380-381).

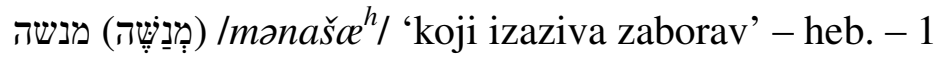

משה = מאזיס /mošce $e^{h}=$ moze/is/ - heb.-jid. - 1

Zanimljiva jednadžba koja »objašnjava« identičnost jidiške inačice osobnog imena Imoze/is/ s hebrejskim משֶָׁ /moš $e^{h} /(\mathrm{v}$.

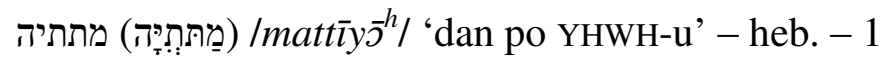

ננחוּם) נחםם /nahūm/ 'tješitelj' - heb. - 1

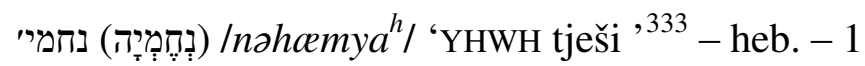

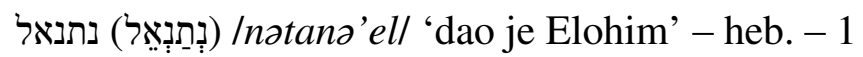

(עַזְריאֵל) עזריאל / azrì'ell 'moja pomoć je Elohim,334 - heb. - 1

\footnotetext{
${ }^{333}$ Ezr 2,2. U transkripciji Antuna Sovića: Nehemija.
} 


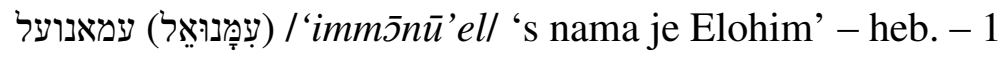

(רפָָאלל) רפאלל /rōps'el/ ‘iscijelio je Elohim' - heb. - 1

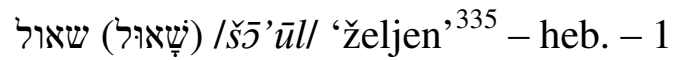

שבתא /šabsel - jid. - 1

U zapadnoeuropskih i srednjoeuropskih kršćana u srednjem vijeku osobno ime /šabbətay/ 'subotnji odmor' 336 nije potvrđeno, ali je bilo često u Bizantu, uobičajeno na Bliskom istoku i popularno u Italiji. Predaškenaske su likove osobnog imena, Šabtay/ /Šaptay u (srednjoeuropski) Kanaan vjerojatno donijeli doseljeni istočnjački Židovi, a slični su likovi ( ̌̌abday, Šabdey, Sabday, Scabdey) bili popularni u srednjovjekovnoj Šleskoj, dok je u Porajnju i Franačkoj osobno ime bilo nepoznato. Svi su ti predaškenaski likovi odumrli, ali su se jidiški dalje razvijali u skladu s fonološkim promjenama u jeziku (u jidišu se ת izgovara [s]; samo bi se slovo ת čitalo [t]).

Glasovni razvoj: Šabsay > (redukcija nenaglašenog diftonga) Šabse (Beider 2001: 409-411)

איציק/icik/ - jid. - 1

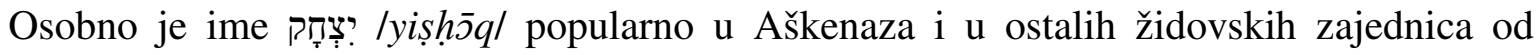
talmudskog doba nadalje. Ispadanje se fonema $/ x /$ unutar riječ s jedne strane može objasniti preseljenjem osobnog imena u Njemačku iz Francuske, u čijem jeziku ne postoji ekvivalentan glas, ali i kontaminacijom s kršćanskim likom toga osobnog imena, $I z a(a) k$, u kojem se $/ x /$ ne pojavljuje. U slavenskim su zemljama popularni bili likovi koji su dočinjali na -ek i -ik, koji u slavenskim jezicima funkcioniraju kao deminutivni sufiksi.

Glasovni razvoj: Icxak > Icak > (redukcija nenaglašenog samoglasnika) Icek > (progresivna asimilacija samoglasnika) Icik (Beider 2001: 339-343)

אַנשֶר /anšl/ - jid. - 1

Staro su germansko osobno ime Anselm < pragerm. *ansu- 'bog' + *helma- 'šljem, zaštita' porajnjski Židovi posudili od svojih nežidovskih zemljaka, u kojih je bilo popularno još od

\footnotetext{
${ }^{334} 1$ Ljet 5,24. U transkripciji Antuna Sovića: Azriel.

${ }^{335}$ Post 36,37. U transkripciji Silvija Grubišića: Šaul.

U prijevodu Novog zavjeta Ljudevita Rupčića ovo je osobno ime preoblikovano u Savao (Dj 8,3), kako bi se postigla rima s imenom Pavao (Dj 13,9) analogna onoj iz grčkog izvornika $\Sigma \alpha \tilde{v} \lambda o \varsigma / s a u ̃ l o s /-~ П \alpha \tilde{\lambda}{ }_{0} \varsigma$ Ipaũlos/.

${ }^{336}$ Ezr 10,15. U transkripciji Antuna Sovića: Šabetaj.
} 


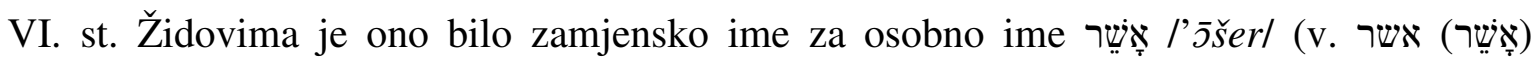
('כ̌šer/), što mu je osiguralo postojanost u židovskim zajednicama.

Glasovni razvoj: Anselm > (njemački kolokvijalni lik) Anšel > (ispadanje zanaglasnog samoglasnika) Anšl (Beider 2001: 279-277)

/berman/ - jid. - 1

Korijen je osobnih imena ber- 'medvjed' (: njem. Bär; v. בער /ber/), uz već spomenut wolf'vuk' i eber- 'vepar', bio jedan od tri najpopularnija u njemačkoj srednjovjekovnoj antroponimiji. Židovi su od kršćana posudili više osobnih imena korijena ber- 'medvjed' (v. בער /ber/), među njima i složeno osobno ime בערמאַן /berman/ (Beider 2001: 287-288).

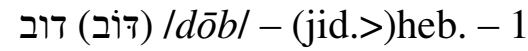

Još jedna »Životinjsko《 prijevodno osobno ime, ovaj put jidiškoga בער /ber/ (v.). Kao i ostala osobna imena iz te skupine, ni za nj se ne čini da je bilo u svakodnevnoj uporabi, ne pojavljuje se u kršćanskim izvorima niti je dalo kakvih izvedenica ni odmilica. I ono je,

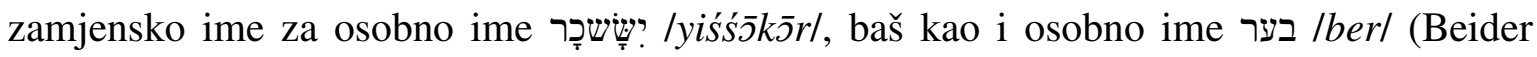
2001: 296).

דליה /dalye/ - jid. - 1

Po svemu sudeći inačica osobnog imena

Glasovni razvoj: Gedalya > (redukcija nenaglašenog samoglasnika) Gedalye > (ispadanje nenaglašenog samoglasnika) Gdalye > Dalye (Beider 2001: 318-319)

הערצל /hercl/ - jid. - 1

Inačica osobnog imena הירש /hirš/ (v. הרש /hiršl, הירש /he/irš/: njem. Hirsch). Lik se Herc pojavljuje u Frankfurtu. Podrijetlo dočetnog /c/ nije sasvim razjašnjeno, možda je riječ o pravilnoj promjeni $/ s />/ c /$ u lokalnom židovskom idiomu, a možda potječe i od nekog nama danas nepoznatog njemačkog dijalekta. Promjena je $/ i />/ e /$ potvrđena u lokalnom njemačkom dijalektu.

Glasovni razvoj: Hirse $>$ (ispadanje dočetnog samoglasnika) Hirc $>$ Herc $>$ (umanjenica) Hercl (Beider 2001: 329-331)

/hi/eršll - jid. - 1

Još jedna inačica osobnog imena הירש /hirš/ (הירש /hiršl, הרש /he/irš/: njem. Hirsch). Glasovni razvoj: Hirse > (ispadanje dočetnog samoglasnika) Hirš > (umanjenica) Hiršl Alternativni glasovni razvoj: Hirse > (ispadanje dočetnog samoglasnika) Hirš $>$ Herš > (umanjenica) Heršl (Beider 2001: 329-331) 
זיסל /zisl/ - jid. - 1

Osobno su ime kreirali sami Židovi iz judeonjemačkoga 'sladak čovjek' (srednjovisokonjemački süezeman, suozeman : njem. süßer Mann). Motivacija je sintagmom privlačne etimologije utjecala na širenje osobnog imena. Lik se Zusman sačuvao u Litvi, Latviji, Bjelorusiji i dijelu sjeveroistočne Poljske, dok je u ostalim nenjemačkim zemljama prevladao lik Zisman, što može biti posljedica pravilne fonološke promjene, ali i prilagodbe osobnog imena jidiškoj riječi zisl 'sladak' (: njem. süß).

Glasovni razvoj: Zusman [> Zisman] > (umanjenica [s prijeglasom]) Zisl (Beider 2001: 458-460)

זלמין /zalmen/ - jid. - 1

Osobno je ime שֶׁלמה /Šalomo $/$ zahvaljujući istoimenom kralju iz Tanaha bilo popularno i među Aškenazima i u ostalim židovskim zajednicama, ali i među kršćanima. U srednjem su vijeku njemački Židovi od nežidova preuzeli osobno ime Salman kao inačicu osobnog imena שִׁלמלז biblijskom osobnom imenu da ga i kršćani prihvate kao njegovu varijantu.

Glasovni razvoj: Zalman > (redukcija nenaglašenog samoglasnika) Zalmen (Beider 414-417)

טעבעלע Itevelel - jid. - 1

Ovo se osobno ime može izvesti iz dva različita hebrejska osobna imena (v. טעבי ליב Itevi leyb/).

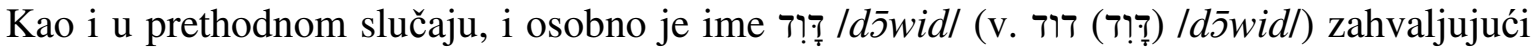
istoimenom kralju iz Tanaha bilo popularno i među Aškenazima i u ostalih židovskih zajednica. Jidiške su inačice osobnog imena glasile Dovid i Duvid, no zabilježeni su i likovi s početnim $D a$-. Inačica se Tavit pojavljuje kao kršćansko osobno ime i u srednjovjekovnoj Bavarskoj.

Glasovni razvoj: David > Tavit > (umanjenica s prijeglasom) Tevele (Beider 2001: 296-298)

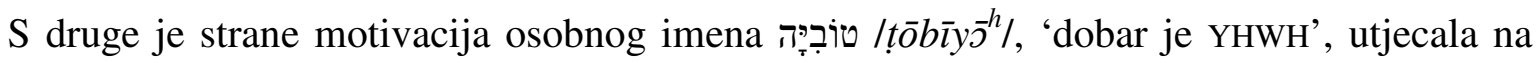
njegovu rasprostranjenost kako među Židovima (u srednjem vijeku na Bliskom istoku, $\mathrm{u}$ Bizantu, Italiji i južnoj Francuskoj) tako i među kršćanima. U židovskoj se predaji ovo osobno ime drži jednim od nadimaka Mojsijevih.

Glasovni razvoj: Tovye $>$ (umanjenica) Tovl $>$ (umanjenica s prijeglasom) Tevele (Beider 2001: 434-434) 
יהוד /ihud/ - jid. - 1

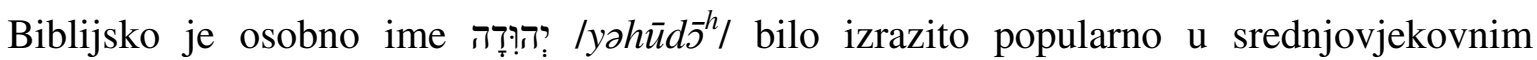
njemačkim zemljama. Inačica je Ihuda potvrđena u Ruteniji ili Volinju te u Bjelorusiji.

Glasovni razvoj: Ihuda > (redukcija nenaglašenog samoglasnika) Ihude > Ihud (Beider 2001: 458-460)

יוקבה /yokevel - jid. - 1

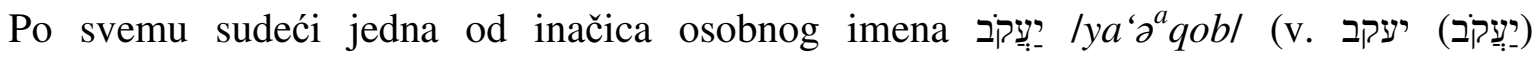
/ya' $\left.\partial^{a} q o b /\right)$, koje bijaše izrazito popularno i među Židovima i među kršćanima. Lik se Yokov razvio iz starijega Yakov, no likovi se s početnim Yo- mogu naći i u poljskih i njemačkih kršćana.

Glasovni razvoj: Yaakov > Yakov > Yokov > (redukcija nenaglašenog samoglasnika) Yokev > Yokeve (Beider 2001: 440-444)

ליזר /leyzerl-jid. - 1

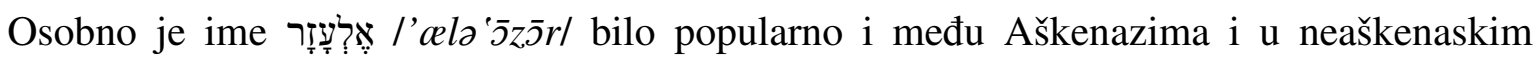
zajednicama, vjerojatno i zbog svoje motivacije, rečenice značenja 'Elohim je pomogao', ali i zbog činjenice da je nositelj toga osobnog imena u Tanahu bio sluga patrijarha Abrahama, važnog lika Knjige postanka.

Glasovni razvoj: Elieyzer > Leyzer (Beider 2001: 299-300)

ליפמן /lipman/ - jid. - 1

Privlačna je motivacija svezom značenja 'voljen čovjek' vjerojatan razlog preuzimanja ovog osobnog imena od njemačkih kršćana, među kojima se pojavljuje od IX. st. (srednjovisokonjemački liepman, sjevernonjemački liefman : njem. Liebmann). Aškenazi

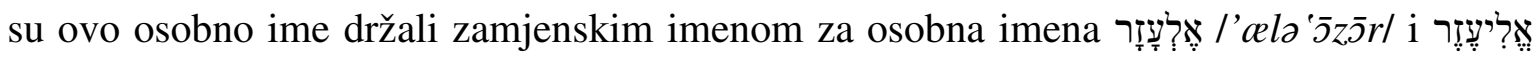
/'a lì 'cezarl (zbog /l/ kao prvog suglasnika u osobnom imenu), ביוֹ /yōmtōv/ 'blagdan (dosl. dobar dan)' te אוּרִ /'ūrī/ (veza nije jasna, ali se pojavljuje u istočnoj Europi od XVI. st.) (Beider 2001: 364-365).

סלונימניח /kalmen/ - jid. - 1

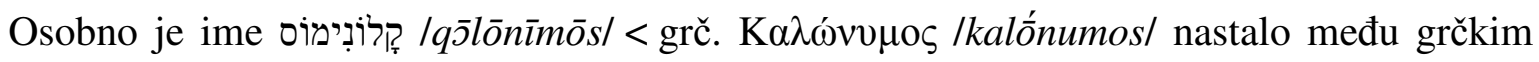
Židovima iz judeogrčke sintagme 'lijepo ime'. Ova nije predstavljala prijevod nekog hebrejskog (ili aramejskog) osobnog imena, jer je hebrejski ekvivalent, نשָם /šem tōb/, kasnijeg postanja i vjerojatno nastao njezinim prijevodom (Colorni 1983: 77). Iako

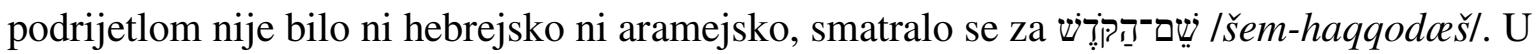


srednjem je vijeku osobno ime bilo popularno u Italiji. Prema predaji se nositelj tog osobnog imena negdje u X. st. iselio iz talijanske pokrajine Lucca u Porajnje, a njegovi su potomci postali važnom porodicom u kulturnom životu te regije. Upravo je popularnost te porodice izazvala širenje osobnog imena u Njemačkoj. Seobama je preneseno u južnu Njemačku, ali i u južnu Francusku. Njemački su iseljenici donijeli izvedenice Kalman i Kalmen u slavenske zemlje. Inačica je Kolman mogla nastati kontaminacijom $\mathrm{s}$ germanskim osobnim imenom Koloman $<<$ lat. Columbanus, koje među kršćanima nalazimo već u IX. st.

Glasovni razvoj: Kalonimos/Kalonimus/Kalonimes $>$ Kaloman $>$ (redukcija nenaglašenog samoglasnika) Kaleman > (ispadanje nenaglašenog samoglasnika) Kalman > (redukcija nenaglašenog samoglasnika) Kalmen (Beider 2001: 343-344)

שמחה /simxe/ - jid. - 1

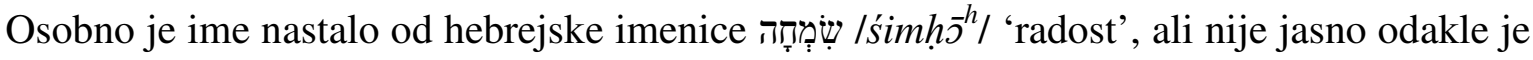
uvezeno u njemačke i slavenske zemlje. U srednjem ga vijeku nalazimo na Bliskom istoku i u sjevernoj Francuskoj.

Glasovni razvoj: Simxa > (redukcija nenaglašenog samoglasnika) Simxe (Beider 2001: 426-427)

יצחק כהן /yișḩ̄q kohen/ - heb. - 1

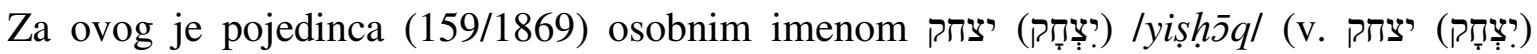

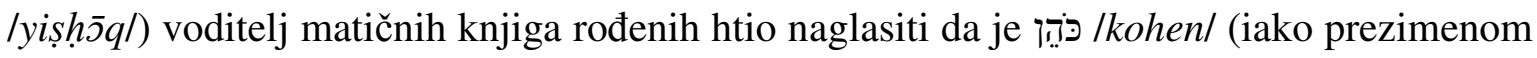
Stern), da pripada svećeničkoj porodici, potomcima Arona iz Tanaha.

אברהם (כהן) /'abrōhs̄m (kohen)/ - heb. - 1

I za ovog je pojedinca (145/1868) osobnim imenom אַבְרָהָם /'abrh̄hōm/ (v. אַבְרָהָם) אברהם

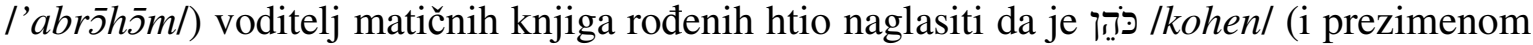
jest Kohn), da pripada svećeničkoj porodici, potomcima Arona iz Tanaha.

אברהם (לוי)/הלוי /'abrōhōm (lewī)/hallewī / - heb. - 1

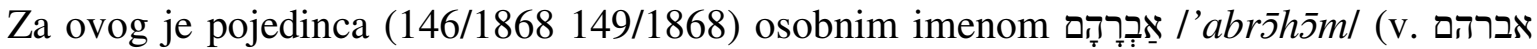

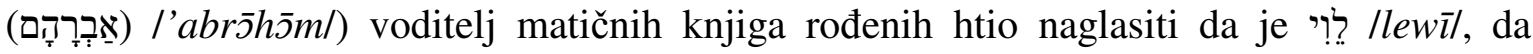
pripada levitskoj porodici (ali prezimenom Schwarz/Schwartz), potomcima Levija (ali ne iz Aronove loze) iz Tanaha. 
וואלף (בנימין זאב) /wolf (binȳ̄mīn zo'eb)/ - jid. (heb. (jid.>)heb.) - 1

Matičar je u ovom slučaju jasno naznačio da je zamjensko ime koji će pojedinac koristiti u svakodnevnom životu, וואָלף/wolf / (v.) povezano s hebrejskim osobnim imenima בנימין זאב

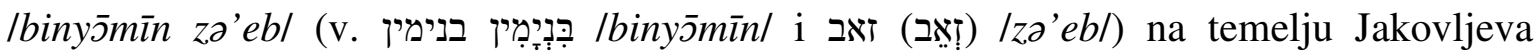
blagoslova iz Post 49,27.

מאיר/מרדכי /me'̌̄r/mכ̌rdəkay/ - heb.-heb. - 1

Za ovog pojedinca različite zabilješke u matičnim knjigama rođenih donose dva različita

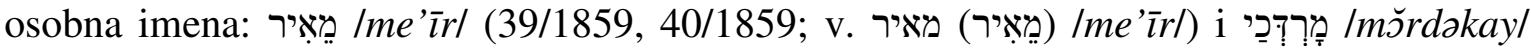

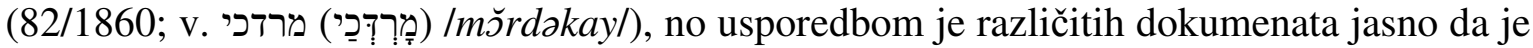
riječ o istoj osobi.

יעקבויחזקאל /ya'a'qob/yahcezaqe'll - heb./heb. - 1

Za ovog pojedinca različite zabilješke u matičnim knjigama rođenih donose dva različita

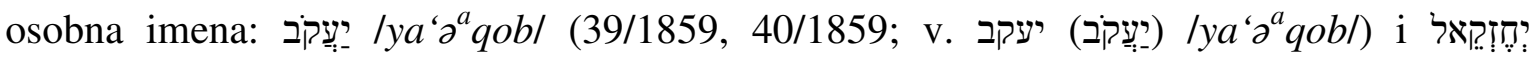

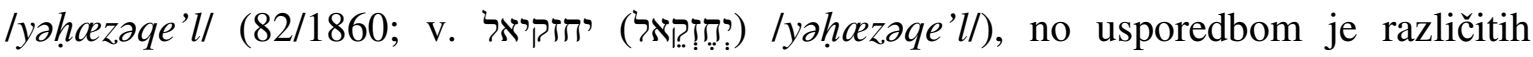
dokumenata jasno da je riječ o istoj osobi.

יצחק|יעקב/yiṣḩ̄q/ya'a a qob/ - heb./heb. - 1

Za ovog pojedinca različite zabilješke u matičnim knjigama rođenih donose dva različita

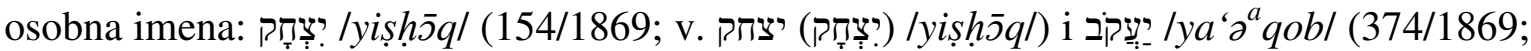

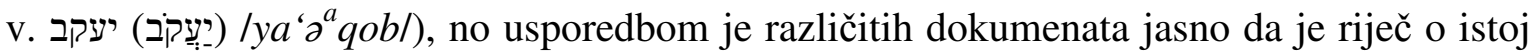
osobi.

שמואלוזנוויל / šamū'el/zanwell - heb./jid. - 1

Za ovog pojedinca različite zabilješke u matičnim knjigama rođenih donose dva različita

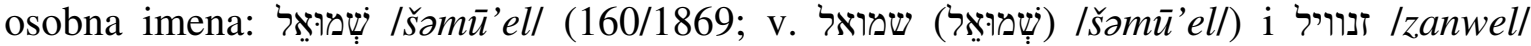
(388/1869). Ovo je drugo osobno ime ustvari tek jidiška inačica onog prvoga, koja je očigledno posuđena u germanofonim zemljama.

Glasovni razvoj: Zamuel > Zanuel > Zanvel (Beider 2001: 419-422)

/berl/ber/ - jid./jid. - 1

Za ovog pojedinca različite zabilješke u matičnim knjigama rođenih donose dva različita lika istog osobnog imena: בער /berl (342/1868; v.) i njegovu umanjenicu בערל /berl/ (144/1868; v.). 
ישוע = זעליג - heb.-jid. - 1

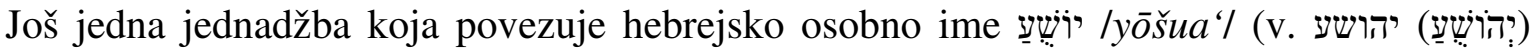

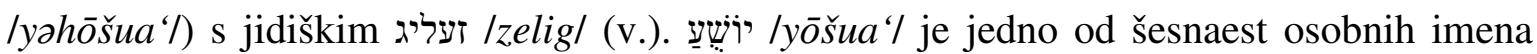

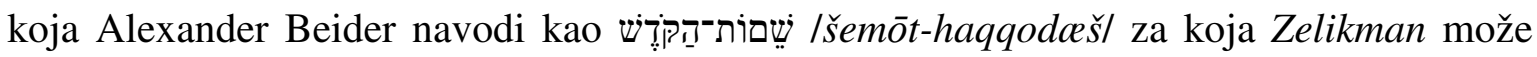
biti כִִּּּוּ /kinnūy/ (Beider 2001: 461).

אברהם אהרן /'abrōh̄̄m 'ahə'ron / - heb.-heb. - 1

Dvoimena kombinacija koja se sastoji od hebrejskih osobnih imena אַבְרָָהָם /'abrōhsm/ (v.

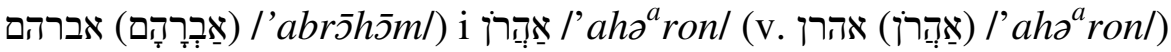

/'abrōhōm zo'eb/ - heb.-(jid.>)heb. - 1

Dvoimena kombinacija koja se sastoji od hebrejskih osobnih imena אַבְרָָהָם /'abrōhs̄m/ (v.

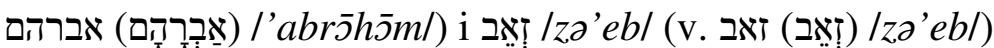

אברהם חיים /'abrōhōm hayyı̄m/ - heb.-heb. - 1

Dvoimena kombinacija koja se sastoji od hebrejskih osobnih imena אַבְרָָה /'abrōhs̄m/ (v.

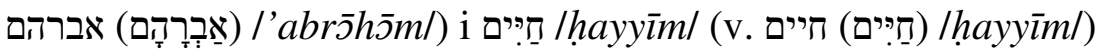

אברהם הרש מאיר /'abrōhs̄m he/irš me'̄̌rr/ - heb.-jid.-heb. - 1

Troimena kombinacija koja se sastoji od dva hebrejska osobna imena אָבְרָהָם /'abrōh $\bar{s} /$ /v.

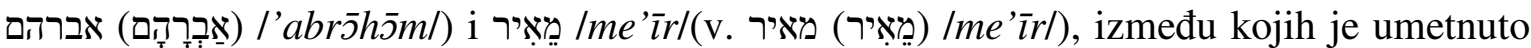
jidiško osobno ime הרש /he/iršl (v.)

אברהם יוסף /'abrōhōm yōsep/ - heb.-heb. - 1

Dvoimena kombinacija koja se sastoji od hebrejskih osobnih imena אָבְרָָהָם /'abrōhs̄m/ (v.

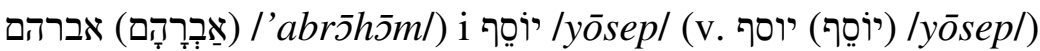

/'abrōhōm me'̄̄r/ - heb.-heb. - 1

Dvoimena kombinacija koja se sastoji od hebrejskih osobnih imena אָבְרָָהָם /'abrōhs̄m/ (v.

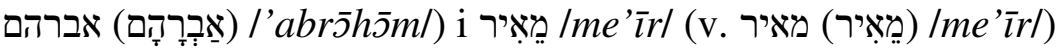

אברהם פנחס /'abrōhs̄m pīnh̄̄s/ - heb.-heb. - 1

Dvoimena kombinacija koja se sastoji od hebrejskih osobnih imena אַבְרָָהָם /'abrōhs̄m/ (v.

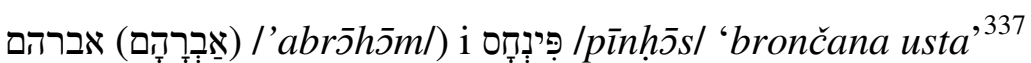

\footnotetext{
${ }^{337}$ Izl 6,35. U transkripciji Silvija Grubišića: Pinhas.
}

U drugim izvorima (Metzger i Coogan 1993: 11; Brown, Rolles Driver i Briggs 1906; Archer, Harris i Waltke 2003) ovo osobno ime predstavlja inačicu egipatskog osobnog imena Pa-nehasi, Panehesy. Prefiks p' 
/'abrōhōm šamū'ell - heb.-heb. - 1

Dvoimena kombinacija koja se sastoji od hebrejskih osobnih imena אַבְרָָהָם /'abrōhs̄m/ (v.

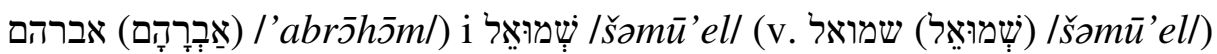

איצק ליב /icik leyb/ - jid.-jid. - 1

Dvoimena kombinacija koja se sastoji od jidiških osobnih imena איציק /icik/ (v. איק /icik/) i ליב /leyb/ ( ליב /leyb/)

בן ציון יוסף מאיר /ban șīyōn yōsep me'īr/ - heb.-heb.-heb. - 1

Troimena kombinacija koja se sastoji od hebrejskih osobnih imena יוֹסֵף ,

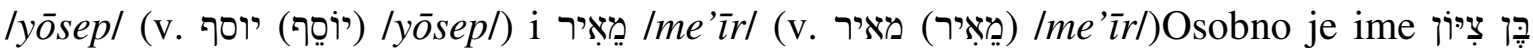
Ibaen șìyōn/ 'sin Ciona' poslijebiblijsko, pojavljuje se u Talmudu (Edduyyot 8,7). Nepoznato je u njemačkim zemljama, ali od XVII. st. zastupljeno u istočnoj Europi (Beider 2001: 285).

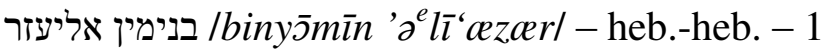

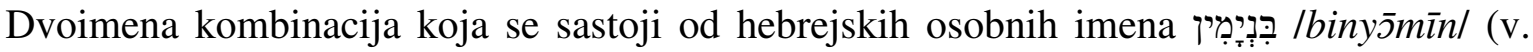

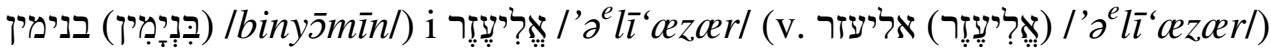
בנימין הרש /binȳ̄min he/irš / - heb.-jid. - 1

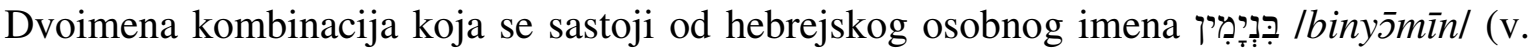

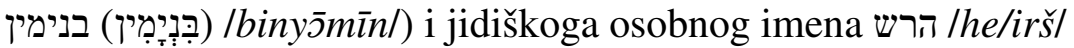
בנימין וואָלף /binȳ̄minn wolf / - heb.-jid. - 1

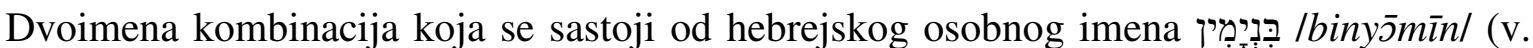

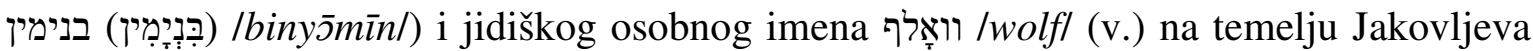
blagoslova iz Post 49,27

גרשון יהודה /geršōn yəhūd $\bar{s}^{h} /$ - heb.-heb. - 1

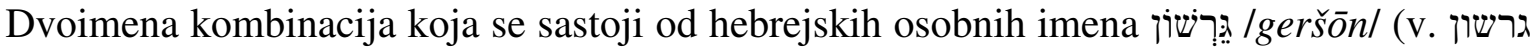

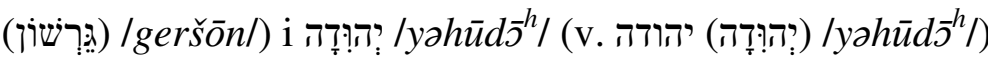
/geršōn leyb/ - heb.-jid. - 1

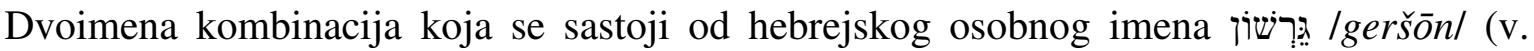
(גֶרטשוֹן) גרשון /leyeršōn/) i jidiškog osobnog imena (v.)

označava određeni član, a riječ je Neḥesi (korijena $\left.n h{ }^{\prime} s y\right)$ 'južnjak’ s vremenom poprimila značenje 'crn' odnosno 'Nubijac'. Ako je tako, osobno bi ime moglo značiti ‘čovjek brončane boje kože'. 
/d̄̄wid he/iršs / - heb.-jid. - 1

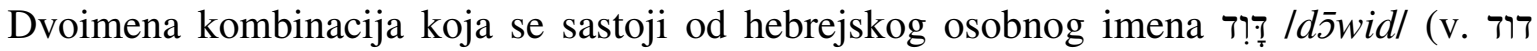

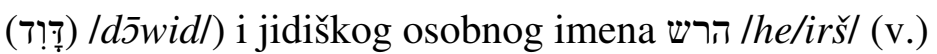

דוד ליב /d̄̄wid leyb/- heb.-jid. - 1

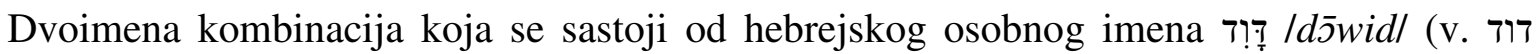
(דיב / ליב /leyb/ (v.)

דוד צבי /d̄̄wid șabī / - heb.-(jid.>)heb. - 1

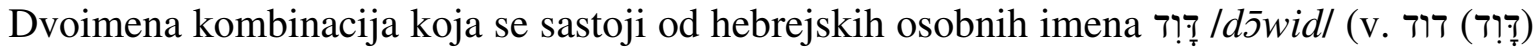

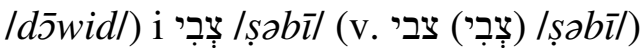

הלל ליב /hillel leyb/ - heb.-jid. - 1

Dvoimena kombinacija koja se sastoji od hebrejskog osobnog imena הִִּל /hillell (v. הילל

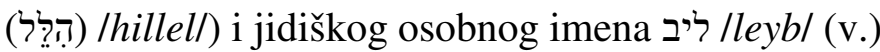

זלמן ליב /zalmen leyb/ - jid.-jid. - 1

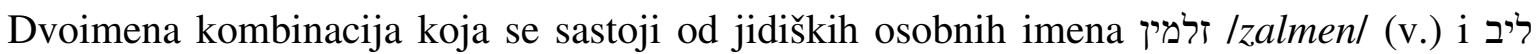
/leyb/ (v.)

זעליג הרש /zelig he/irš/ - jid.-jid. - 1

Dvoimena kombinacija koja se sastoji od jidiških imena זעליג /zelig/ (v.) i הרש /he/iršl (v.) חיים שלמה - heb.-heb. - 1

Dvoimena kombinacija koja se sastoji od hebrejskih osobnih imena חַייים /hayyim/ (v. חיים

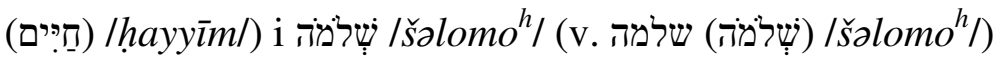

חנזה אליא /xone elya/e / - jid.-heb. - 1

Dvoimena kombinacija koja se sastoji od jidiških osobnih imena חליא ixone/

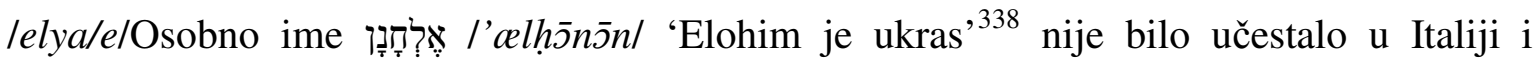
Njemačkoj, ali jest na Bliskom istoku.

Glasovni razvoj: Elxonon/Elxonen > Xonon/Xonen > Xone (Beider 2001: 300-301)

Osobno je ime אָלדיָהוּ /'elīyshhū/, kao i njegove izvedenice, bilo popularno i među kršćanima (zahvaljujući nekolicini svetaca toga osobnog imena) i među Židovima.

Glasovni razvoj: Elyahu > (ispadanje dočetnog sloga) Elya > (redukcija nenaglašenog samoglasnika) Elye (Beider 2001: 303-304)

\footnotetext{
${ }^{338} 2$ Sam 23,24. U transkripciji Silvija Grubišića: Elhanan.
} 
טעבי ליב /tevi leyb/ - jid.-jid. - 1

Dvoimena kombinacija koja se sastoji od jidiških osobnih imena טעבי /tevi/ i ליב /leyb/ (v.).

Prvo se od njih može izvesti iz dva različita hebrejska osobna imena (v. טעבעלע /tevele/).

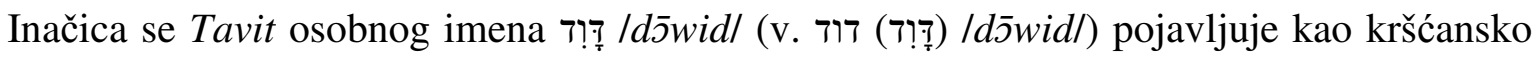
osobno ime i u srednjovjekovnoj Bavarskoj.

Glasovni razvoj: David > Tavit > (umanjenica s prijeglasom) Tevl > Tevi (Beider 2001: 296-298)

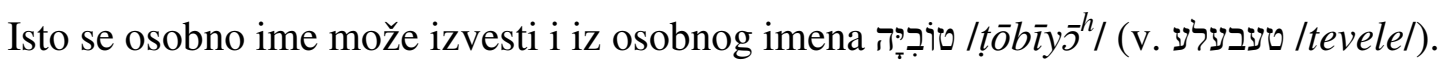

Glasovni razvoj: Tovye $>$ (umanjenica) Tovl $>$ (umanjenica s prijeglasom) Tevl $>$ Tevi (Beider 2001: 434-434)

יהודא ליבואליעזר /yahūd $\bar{y}^{h}$ leyb/'əolī'azzarl - heb.-jid./heb. - 1

Za ovog pojedinca različite zabilješke u matičnim knjigama rođenih donose dva različita osobna imena: dvoimenu kombinaciju יהודא ליב /yahūd $\bar{D}^{h}$ leyb/ sastavljenu na temelju Jakovljeva blagoslova iz Post 49,9 (v. יהודה ליב ליב /yahūd $\bar{\nu}^{h}$ leyb/; v. 56/1859) te hebrejsko

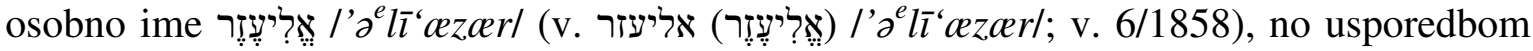
je različitih dokumenata jasno da je riječ o istoj osobi.

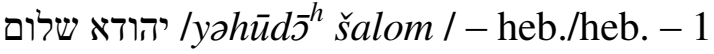

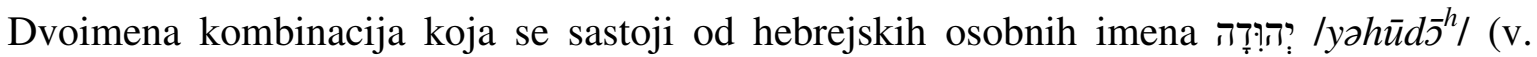

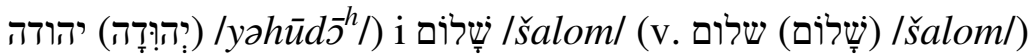

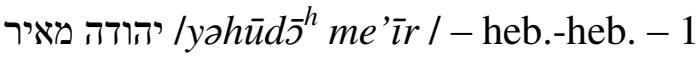

Dvoimena kombinacija koja se sastoji od hebrejskih osobnih imena יה:ְְ: /yzh $/ \bar{u} d \bar{\nu}^{h} /$ (v.

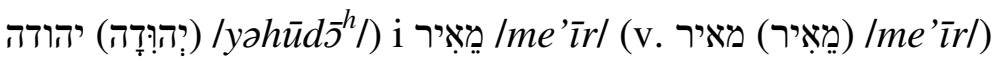

יודא ליב /yudah leyb/ - jid.-jid. - 1

Dvoimena kombinacija koja se sastoji od jidiških osobnih imena ויא /yuda/ i ליב /leyb/ (v.) na temelju Jakovljeva blagoslova iz Post 49,9Glasovni razvoj: Yehuda > (ispadanje nenaglašenog samoglasnika i /h/ unutar riječi) Yuda (Beider 2001: 458-460)

יום טוב ליפמאָן /yōm tōōb lipman/ - heb.-jid. - 1

Dvoimena kombinacija koja se sastoji od hebrejskog osobnog imena יום טוב /yōm țōb/i jidiškoga osobnog imena ליפמן /lipman/ (v.)Iako se osobno ime tyōōb/ 'blagdan'

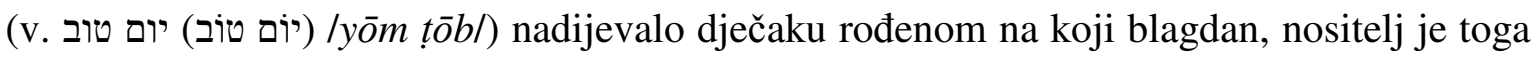
osobnog imena rođen 15. svibnja 1886. g., odnosno 7. ijara 5646., na datum na koji nije padao nijedan veliki židovski blagdan, tek 22. dan brojanja Omera. 
יונה ליב /yōns̄h leyb / - heb.-jid. - 1

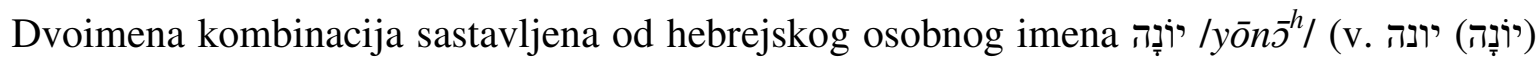

/yōns $\bar{s}^{h} /$ 'golub') i jidiškog osobnog imena ליב /leyb/

יוסף חיים /yōsep hayyȳm/ - heb.-heb. - 1

Dvoimena kombinacija koja se sastoji od hebrejskih osobnih imena יוסף /yōsep/ (v. יוסף

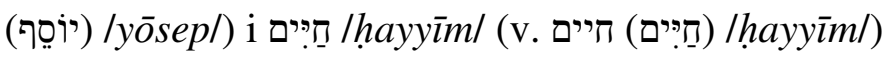

יוסף מיכאל /yōsep mīkj̄'el / - heb.-heb. - 1

Dvoimena kombinacija koja se sastoji od hebrejskih osobnih imena יוסף /yōsep/ (v. יוֹסף

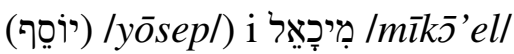

יוסף משה /yōsep moš $\alpha^{h} /-$ heb.-heb. - 1

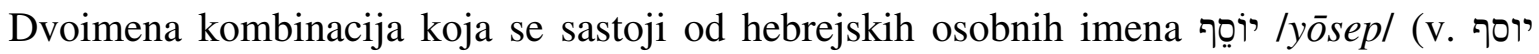

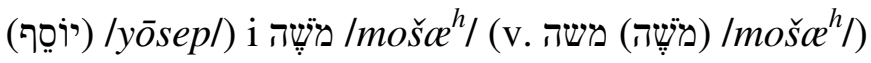

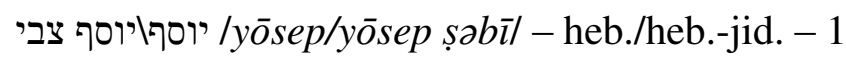

Za ovog pojedinca različite zabilješke u matičnim knjigama rođenih donose dva različita osobna imena: hebrejsko osobno ime יוֹסֵסף /yōsep/ (v. יוֹסֵף) /yōsep/; 104/1861) te

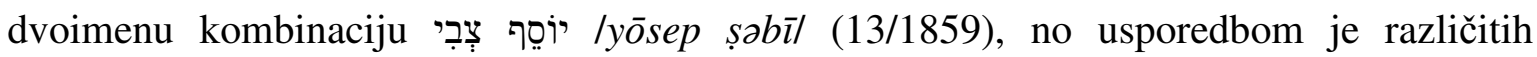
dokumenata jasno da je riječ o istoj osobi.

יעקב בער /ya'a a qob ber/ - heb.-jid. - 1

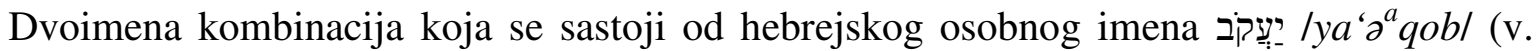

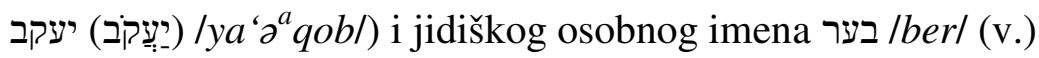

יעקב הרץ /ya'a 'qob hercl - heb.-jid. - 1

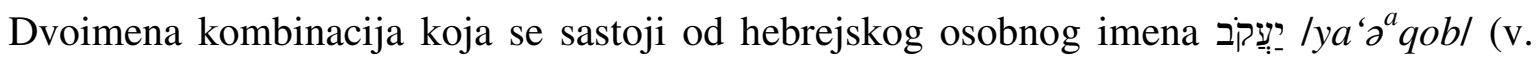

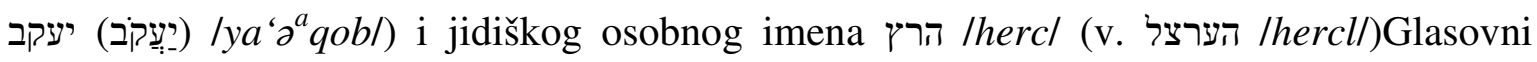
razvoj: Hirse > (ispadanje dočetnog samoglasnika) Hirc > Herc (Beider 2001: 329-331)

יעקב ליב /ya'a a qob leyb / - heb.-jid. - 1

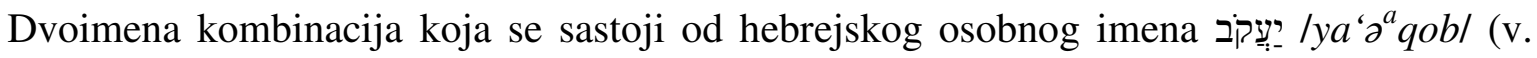

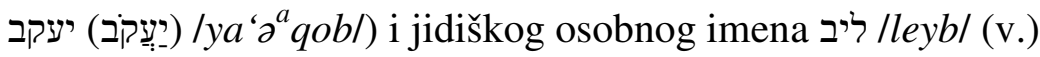

יעקב משה /ya' a'aob moš $e^{h} /$ - heb.-heb. - 1

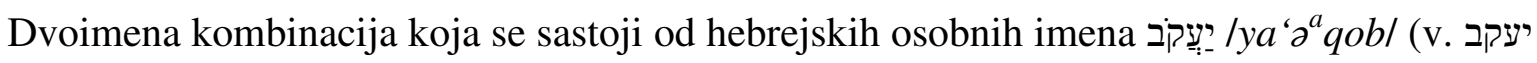

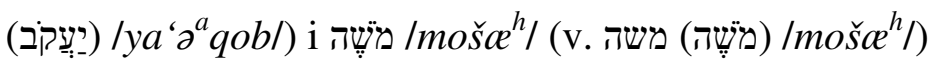


יעקבויאקב שלום /ya'sa qob/ya'əa qob šalom/ - heb./heb.-heb. - 1

Za ovog pojedinca različite zabilješke u matičnim knjigama rođenih donose dva različita

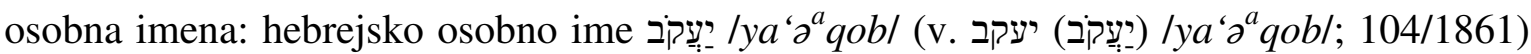

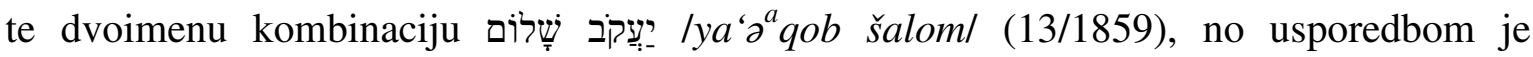
različitih dokumenata jasno da je riječ o istoj osobi.

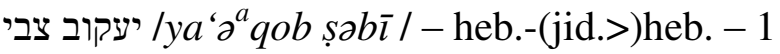

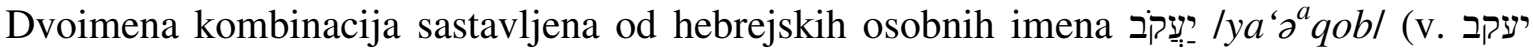

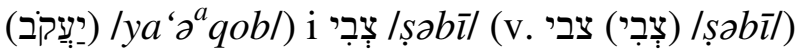

יצחק יהודא /yișḩ̄q yahūd $\bar{\nu}^{h} /$ - heb.-heb. - 1

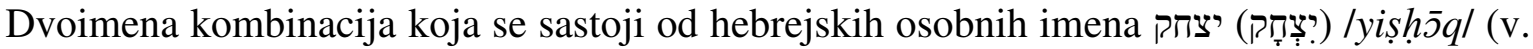

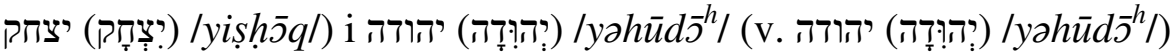

יצחק יוסף /yiṣḩ̄q yōsep / - heb.-heb. - 1

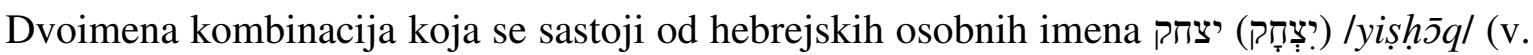

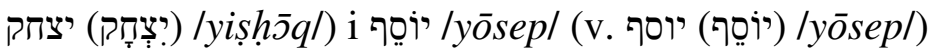

יצחק נפתלי Inapt̄̄lī yiṣhhōql - heb.-heb. - 1

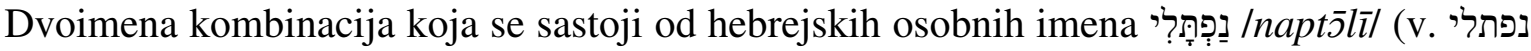

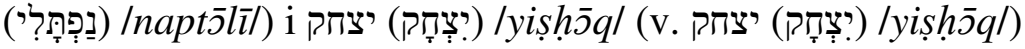

יצחק צבי /yiṣḩ̄o șabīl - heb.-(jid.>)heb. - 1

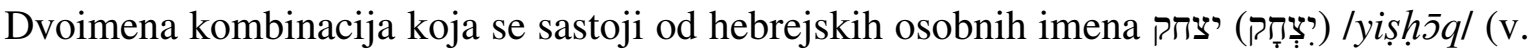

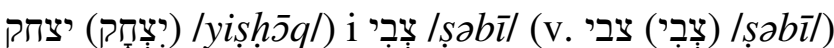

ישוע שמואל /yahōšua ‘̌somù'ell - heb.-heb. - 1

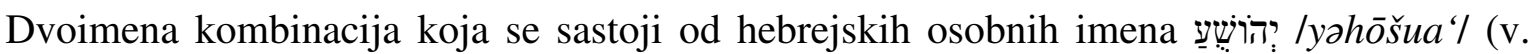

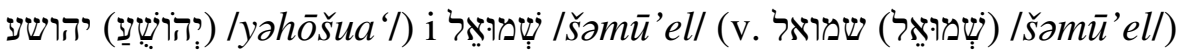

ליזר הרש /leyzer he/iršl - jid.-jid. - 1

הרש isoimena kombinacija koja se sastoji od jidiških osobnih imena ליזר /leyzer/ (v.) /he/iršl (v.)

מאיר הרש /me'îr he/iršl - heb.-jid. - 1

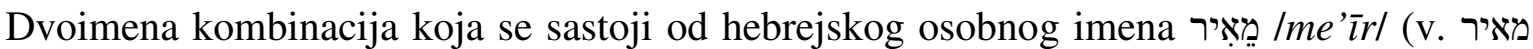
(מֵאיר) (מאיר /me'irr/) i jidiškog osobnog imena (v.) 
מאיר משה /me'ı̀r moš $\alpha^{h} /$ - heb.-heb. - 1

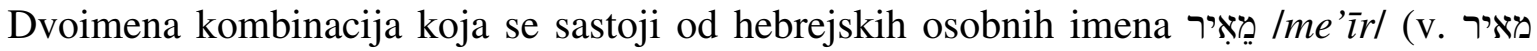

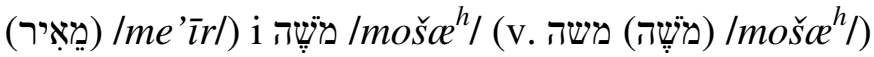

מיכאל בער /mīkō'el berl - heb.-jid. - 1

Dvoimena kombinacija koja se sastoji od hebrejskog osobnog imena מִיכָאהל /mīks̄ell i jidiškog osobnog imena בער/ber/ (v.)

/manahem ya'a ${ }^{a}$ qob/ - heb.-heb. - 1

Dvoimena kombinacija koja se sastoji od hebrejskih osobnih imena מִנְֵַח /mənahem/ (v.

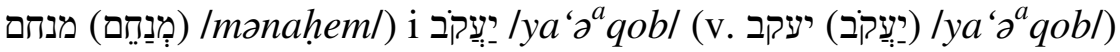

/manahem mencl/ - heb.-jid. - 1

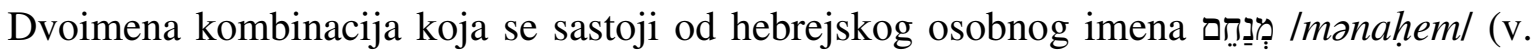
מענצל /mencl/Židovi su od njemačkih kršćana posudili nekoliko odmilica popularnog njemačkog osobnog imena Hermann < pragerm. *harja- 'četa, vojska' + *mannan- 'čovjek'. Jedna je od njih Mentz(e)l. Osobno je ime bilo nepoznato u slavenskim zemljama (Beider 2001: 375).

/manahem šalomo ${ }^{h} /$ - heb.-heb. - 1

Dvoimena kombinacija koja se sastoji od hebrejskih osobnih imena מִֵַּ /mənahem/ (v.

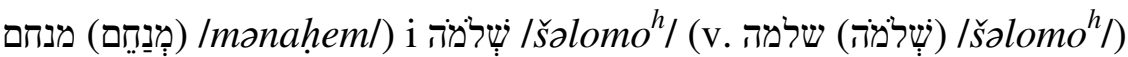

/mənahem 'abrōhs̄m/ - heb.-heb. - 1

Dvoimena kombinacija koja se sastoji od hebrejskih osobnih imena מְנִֵַח /mənahem/ (v.

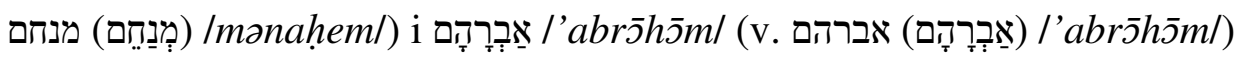

משה אברהם נתן /moš $e^{h}{ }^{h}$ 'abrōhōm n̄̄tว̄n/ - heb.-heb.-heb. - 1

Troimena kombinacija koja se sastoji od hebrejskih osobnih imena משה משֶׁה /moša

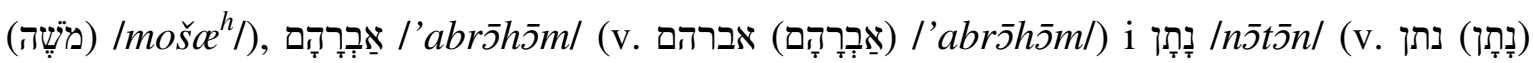
$\ln \bar{\jmath} \operatorname{s} n /)$

Imoša $e^{h}$ 'abrōhōm ṣabīl - heb.-heb.-(jid.>)heb. - 1

Troimena kombinacija koja se sastoji od hebrejskih osobnih imena משֶֶֶ/moš ${ }^{h} e^{h} /$ (v. משה

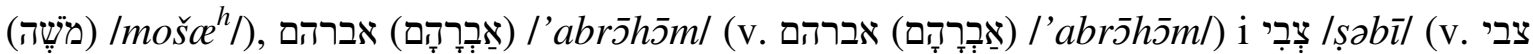

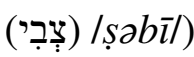


משה אליי - heb.-heb. - 1

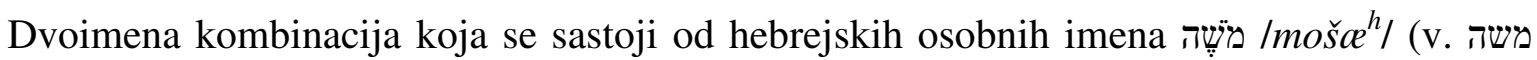

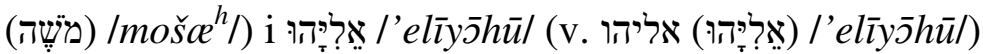

משה דוד /moš $e^{h} d \bar{w} w i d /$ - heb.-heb. - 1

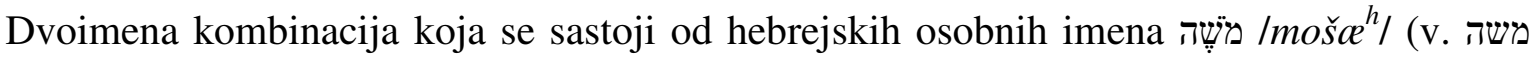

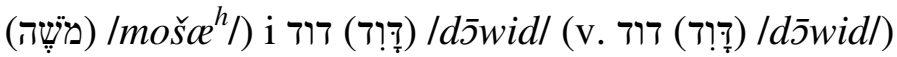

/moš $e^{h} y i s ̣ h \bar{q} q /$ - heb.-heb. - 1

Dvoimena kombinacija koja se sastoji od hebrejskih osobnih imena משֶֶ, משה /moš

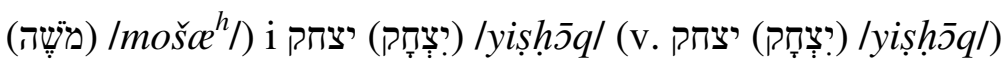

משה צבי /moš $e^{h} s ̦ a b \bar{l} /$ - heb.-(jid.>)heb. - 1

Dvoimena kombinacija koja se sastoji od hebrejskih osobnih imena משה משֶׁה /moš

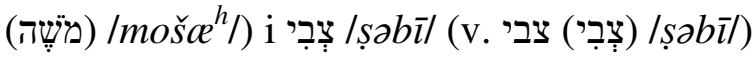

נתן דוד /n̄̄t̄̄n d̄̄wid/ - heb.-heb. - 1

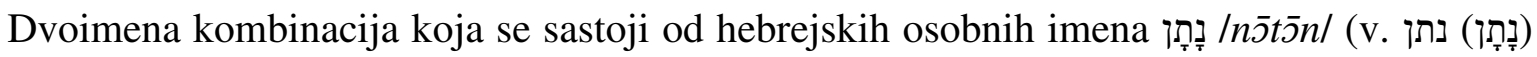

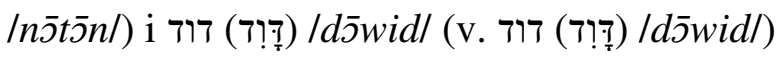

נתן צבי In̄̄t̄̄n șabīl - heb.-(jid.>)heb. - 1

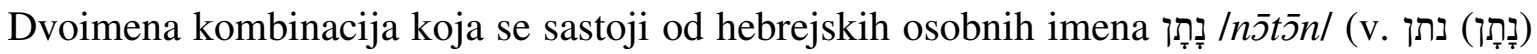

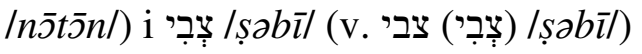

פַיישל ליב /feyšl leyb/ - jid.-jid. - 1

ליב i Dvoimena kombinacija koja se sastoji od jidiških osobnih imena (פיישל (v. /leyb/ (v.)

פיישל שרגא /feyšl šaraḡ’’ - jid.-aram. - 1

Dvoimena kombinacija koja se sastoji od jidiškog osobnog imena פיישל /feyšl/ (v.)i

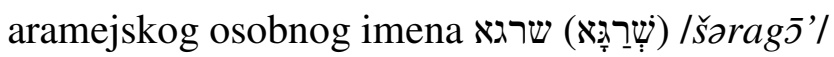

פרץ חיים /paraes hayyìm/ - heb.-heb. - 1

Dvoimena kombinacija koja se sastoji od hebrejskih imena פָּ /paraeș/ 'lom, prekid'339

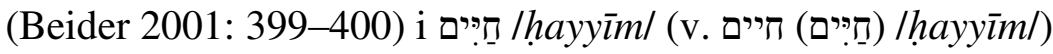

צבי הירש /şabī hiršs/ - heb.-jid. - 1

Hibridna, tautološka, dvojezična dvoimena kombinacija sastavljena od hebrejskog osobnog

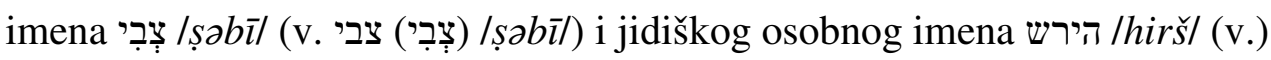

\footnotetext{
${ }^{339}$ Post 38,29. U transkripciji Silvija Grubišića: Peres.
} 
צבי נתן /ṣabī n̄̄t̄̄n/ - heb.-heb. - 1

Dvoimena kombinacija sastavljena od hebrejskih osobnih imena צִִבְב צִִבִי)

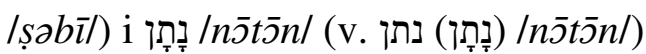

שלום יהודה /šalom yəhūd $\bar{\jmath}^{h} /$ - heb.-heb. - 1

Dvoimena kombinacija sastavljane od hebrejskih osobnih imena שלום . שָלוֹם (išalom/

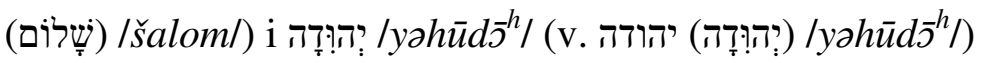

שלמה יהודה /šalomo ${ }^{h}$ yahūd $\bar{\partial}^{h} /-$ heb.-heb. - 1

Dvoimena kombinacija sastavljena od hebrejskih osobnih imena שלמה . שִ שִלמהז

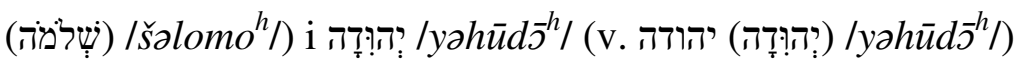

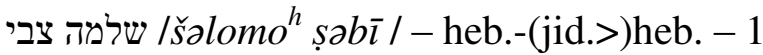

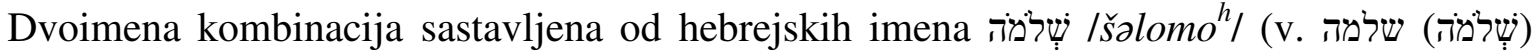

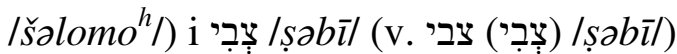

שמואל אברהם /šamū'el'abrōhōm/ - heb.-heb. - 1

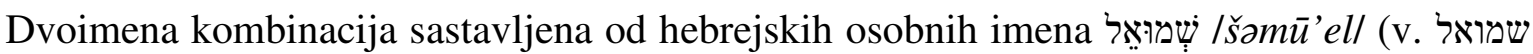

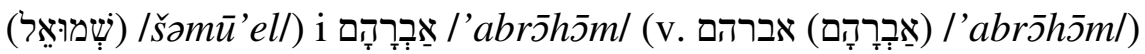

שמואל שלום/šamū'el šalom/ - heb.-heb. - 1

Dvoimena kombinacija sastavljena od hebrejskih osobnih imena שמואל

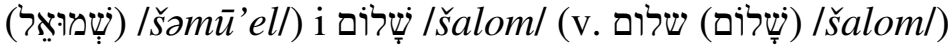
שמיה יהודה /šama 'y $\bar{\nu}^{h} y \partial h \bar{u} d \bar{\nu}^{h} /$ - heb.-heb. - 1

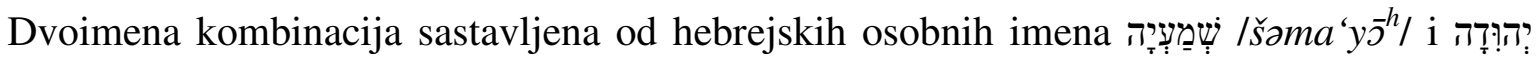

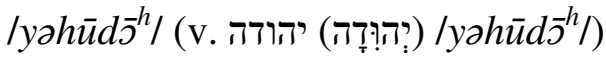

שמיהו ליב /šama'ȳ̄hū leyb/ - heb.-jid. - 1

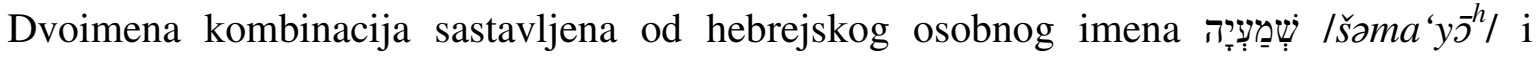
jidiškog osobnog imena ליב /leyb/

Među muškim je židovskim osobnim imenima najviše hebrejskih, njih 68 , dok je jidiških više nego upola manje - samo 31. Usto ovdje imamo i četiri hebrejska osobna imena koja su, iako poznata i u drugim židovskim zajednicama, među Aškenazima nastala kao prijevodi jidiških osobnih imena. Sva su ta četiri osobna imena nastala od naziva životinja s kojima je Jakov u oporuci iz 49. poglavlja Knjige postanka usporedio pojedine svoje potomke: Judu s lavićem ליב /leyb/, Jisakara s magarcem, kasnije zamijenjenim drugim simbolom 


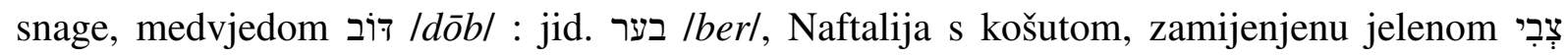
/șabī/ : jid. הירש /hirš/, a Benjamina s vukom וזאב /woleb/ : jid. U pet slučajeva pojedinci nose aramejsko osobno ime. Što se dvoimenih kombinacija tiče, u 36 su muškaraca obje sastavnice hebrejske, a samo su u sedmorice obje sastavnice jidiške. Od 25 dvoimenih kombinacija koje se sastoje od po jedne hebrejske i jidiške sastavnice, čak 24 ih ima hebrejsko osobno ime na prvom mjestu, dok je samo u jedne na prvom mjestu jidiško osobno ime, uz još jednu kombinaciju kojoj je na prvom mjestu jidiško, a na drugom aramejsko osobno ime. (Kod ženskih osobnih imena kombinacija prvog tipa ima dvije, a onih drugih

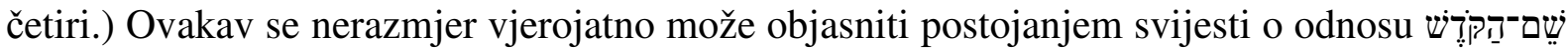

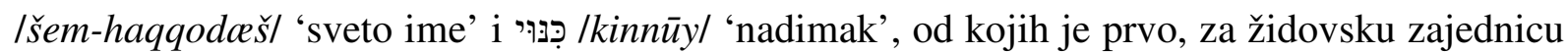
važnije, redovito hebrejsko, eventualno aramejsko. Potvrđene su i dvije kombinacije po triju hebrejskih osobnih imena te jedna hebrejsko-jidiško-hebrejska kombinacija.

Broj je muškaraca koji nose hebrejsko osobno ime 354, uz još 11 njih koji nose već spomenute hebrejske prijevode jidiških osobnih imena, sedam pojedinaca $\mathrm{s}$ aramejskim osobnim imenom i 107 nositelja višeimenske kombinacije od kojih je barem jedno osobno ime hebrejsko ili aramejsko (za ovo potonje samo jedna osoba). Nasuprot tome, samo 62 pojedinca nose jidiško osobno ime, a pedesetorica ih imaju dvoimenu kombinaciju barem $\mathrm{s}$ jednim jidiškim osobnim imenom u njoj. (Naravno, nositelji dvoimenih kombinacija barem $\mathrm{s}$ jednim hebrejskim osobnim imenom $\mathrm{i}$ oni barem $\mathrm{s}$ jednim jidiškim u određenoj se mjeri poklapaju.)

Deset je najpopularnijih muških osobnih imena hebrejsko - אַבְרָָָָם /'abrōhōm/ (35),

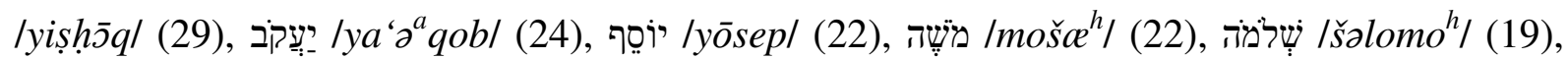

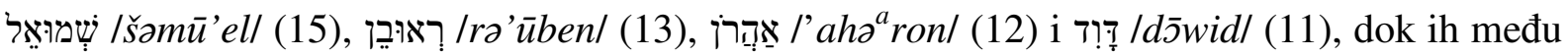

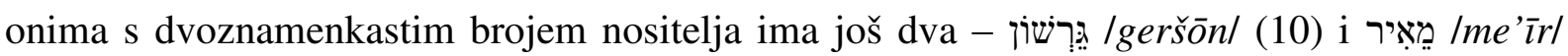
(10). Od jidiških se osobnih imena položajem među deset najpopularnijih može pohvaliti samo ליב /leyb/ (11). Ovaj se popis donekle poklapa s onim Alexandera Beidera; od osobnih

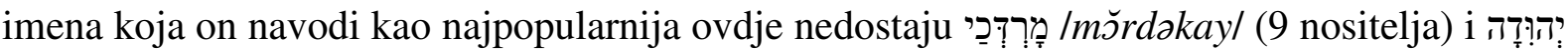

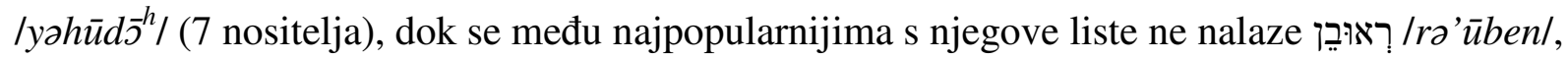

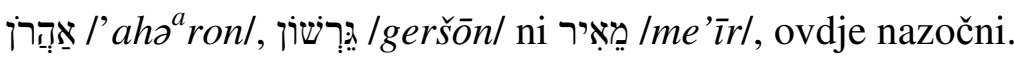

I dok je među ženskim osobnim imenima 30 od 64 jidiška osobna imena tvoreno deminutivnim sufiksom $/ l /$, tipičnim za južne njemačke jezike: bavarsko-austrijski i 
alemanski, među muškima takvih osobnih imena ima tek osam (od 31), a njihovih nositelja 20.

\subsubsection{2 Ženska židovska osobna imena zagrebačkih Židova}

Među ženskim su se osobnim imenima u Aškenazā u različitim razdobljima i na različitim prostorima najpopularnijima pokazala: osobna imena pramajki רֵאָה

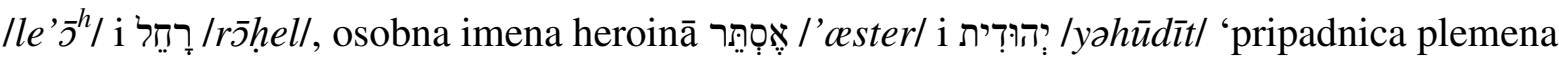

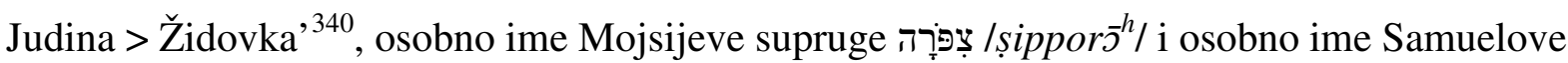

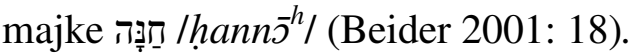

(רחחל) רחל (rōhell 'ovca' - heb. - 24

רחלה /raxelal - jid. - 1

Lik je /raxela/ preuzet od kršćana u slavenskim zemljama (npr. polj. Rachela) (Beider 2001: 560-562).

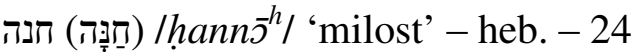

(לֵאָה) לאה (לִ /le' $\bar{\jmath}^{h} /$ 'brižna' - heb. - 17

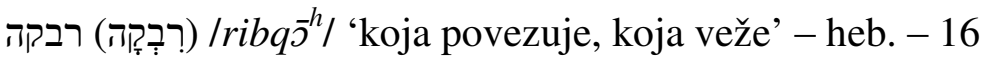

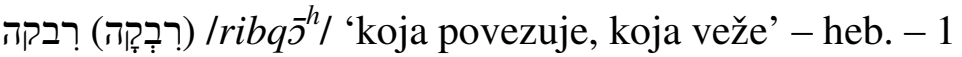

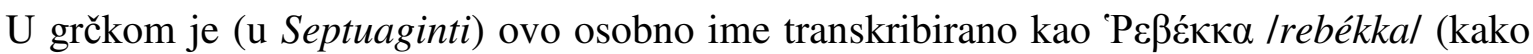
je i preuzeto u kršćanskom svijetu), no u suvremenom hebrejskom ono glasi ['rivka] ${ }^{341}$.

Grčka bi transkripcija mogla odgovarati hebrejskome רְ רְקָה /rabəq $\bar{\jmath}^{h} /$ što bi u novohebrejskom pravilno dalo današnji izgovor osobnog imena (Beider 2001: 557-558).

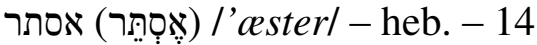

Eszter $^{342}-$ heb. -1

(מִרְיםם) מרים /mirȳ̄m/ - heb. - 14

מריים /miryem/ - jid. - 1

Glasovni razvoj: Miryam > (redukcija zanaglasnog samoglasnika) Miryem (Beider 2001: $544-548)$

\footnotetext{
${ }^{340}$ Post 26,34. U transkripciji Silvija Grubišića: Judita

${ }^{341} \mathrm{Na}$ Mirogoju je, na jednom nadgrobnom spomeniku (4 I 47), zabilježeno osobno ime Rifka.

${ }^{342}$ Jedno od rijetkih hebrejskih osobnih imena zabilježenih nehebrejskim pismom u maticama rođenih (45/1892).
} 
גיטל /gitll - jid. - 15

Prvo nehebrejsko osobno ime na popisu. Pridjev iz kojeg je izvedeno jest srednjovisokonjemački guot 'dobar' (: njem. gut), a među Židovima je postalo popularno više zahvaljujući motivaciji pridjevom privlačnog značenja negoli činjenici da je bilo vrlo popularno i među kršćanima.

Glasovni razvoj: Guta > (redukcija zanaglasnog samoglasnika) Gute [> Gite] > (umanjenica) Gitl (Beider 2001: 512-515)

בילה /beylel - jid. - 14

Osobno je ime Bel(l)a došlo u Njemačku s useljenicima iz Francuske. U Francuskoj su pak osobno ime Židovi preuzeli od nežidova, među kojima je bilo popularno u XIV. i XV. st. Osobno je ime ili izvedeno od francuskog pridjeva 'lijepa' ili predstavlja odmilicu od osobnog imena Isabella, što je pak španjolski lik osobnog imena Elizabeta < grč. 'E $\lambda ı$ øá $\beta \varepsilon \tau$

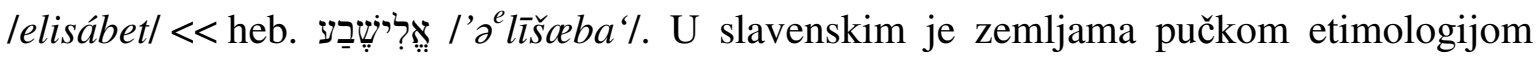
ovo osobno ime kontaminirano sa slavenskim pridjevom běla (Beider 2001: 16).

Glasovni razvoj: Bela > (redukcija zanaglasnog samoglasnika) Bele $>$ Beyle (Beider 2001: 480-482)

- heb. - 12

U nedostatku samoglasnika ovo se osobno ime može čitati na dva načina.

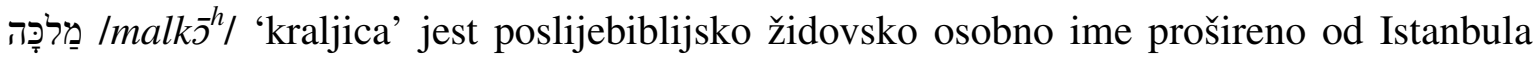
preko slavenskih i njemačkih zemalja do Francuske. Pojavilo se u srednjoj Europi, u Austriji i Češkoj, odakle se proširilo. Popularnost u Češkoj vjerojatno zahvaljuje i kontaminacijom s odmilicama Malka i Mala izvedenima od osobnih imena Amálie < germ. Amalia << pragerm. *amal 'rad' (Beider 2001: 536-37).

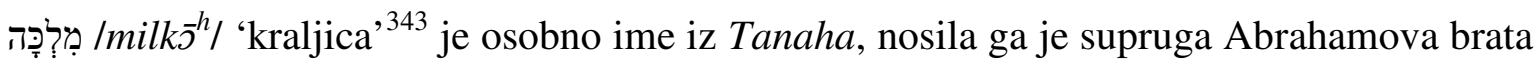
Nahora. Popularnost ovog osobnog imena među Židovima iz slavenskih zemalja vjerojatnije ipak treba tražiti u slavenskom osobnom imenu izvedenom od korijena mildeminutivnim sufiksom $-k a$, jer je osobno ime bilo neuobičajeno među njemačkim Židovima u srednjem vijeku. Naknadno je moglo doći do pučkog povezivanja slavenskog osobnog imena s onim biblijskim (Beider 2001: 542-43).

\footnotetext{
${ }^{343}$ Post 11,29. U transkripciji Silvija Grubišića: Milka.
} 
חיילה /heylel - jid. - 10

Osobno ime preuzeto od njemačkih kršćana, izvedeno od imenice Heile 'blagostanje'.

Osobno ime ne nalazimo među istočnoeuropskim Židovima (Beider 2001: 515-516).

שרל /serl/ - jid. - 10

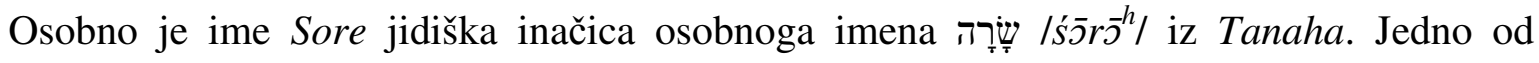
najpopularnijih osobnih imena kako u srednjoj tako i u istočnoj Europi. Širilo se kako seobama tako i izravnim preuzimanjem iz Tanaha.

Glasovni razvoj: Sara > (redukcija zanaglasnog samoglasnika) Sare [> Sore] > (umanjenica s prijeglasom) Serl (Beider 2001: 574-578)

דבורה (דָברוֹרָה) /dabōr $r \bar{s}^{h} /$ 'pčela' - heb. - 7

דבורא /dvoral - heb. - 1

דברה /dvora/ - heb. - 1

פיראדל /

פראדל /fradll - jid. - 3

פראגל /fradll - jid. - 1

I פַראָדל (fradl/ - jid. - 1

פַּרָדל /frodll - jid. - 1

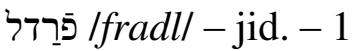

Frad je bio uobičajen lik osobnog imena Freyde (v. פריידה /fra/eyde/ : njem. Freude) u zemljama zapadno i južno od Poljske.

Glasovni razvoj: Frode/Fröude/Freude $>$ Freyde $>$ Frayde $>$ Frade $>$ (umanjenica) Fradl (Beider 2001: 503-505)

צירל /ce/irll - jid. - 8

צרל /ce/irl/ - jid. - 1

Osobno ime izvedeno od osobnog imena Sore (v. שרל /serl/), pučkom etimologijom kontaminirano s jidiškom imenicom ציר/cirl 'ukras' (× njem. Zier 'dragocjen(a), lijep(a), prekrasan(-na)') (Beider 2001: 16).

Glasovni razvoj: Sara $>$ (redukcija zanaglasnog samoglasnika) Sare $>$ Sore $>$ Care $>$ Core > (umanjenica s prijeglasom) Cerl > Cirl (Beider 2001: 574-578) 
/reyzll - jid. - 7
רייזל/reyzl/ - jid. - 2

Osobno je ime Rosa/Rose posuđeno od kršćana kojima je ono bilo predstavljalo odmilicu za osobna imena kojima je prvi dio glasio rosa-, motivirano imenicom osnovnog značenja 'ruža'. Osobno je ime postalo popularno među Židovima, ali se u kršćanskim dokumentima često prevodilo na lokalni jezik.

Glasovni razvoj: Roze $>$ Rouze $>$ Royze $>$ (umanjenica s prijeglasom) Reyzl (Beider 2001: $563-565)$

הינדל /hindll - jid. - 8

Osobno ime Hinde potječe iz srednjovisokonjemačke imenice hinde 'košuta' (: njem. Hindin). Osobno je ime vjerojatno nastalo u Njemačkoj kao prijevodno osobno ime

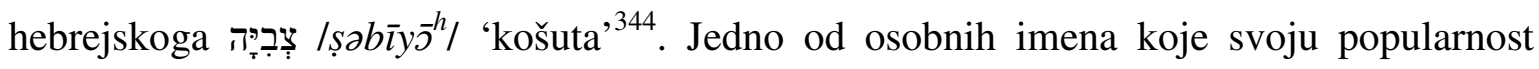
zahvaljuje motivaciji općom imenicom privlačnog značenja.

Glasovni razvoj: Hinde > (umanjenica) Hindl (Beider 2001: 516-517)

$$
\begin{aligned}
& \text { יטל /yitl/ - jid. - } 5 \\
& \text { יטל /yitl/ - jid. - 1 } 1 \\
& \text { ייטל /yitll - jid. - } 1
\end{aligned}
$$

Yudes je jidiška inačica hebrejskog osobnog imena יִּוּדִיר /yahūdìt/, koje svoju popularnost može više zahvaliti junakinji istoimene knjige koja nije ušla u Tanah, ali preko Septuaginte jest u katolički Stari zavjet, negoli činjenici da se tako zvala supruga Ezavova. U južnonjemačkim je zemljama i među kršćanima, a potom i među Židovima, popularna bila inačica Jutta iz koje je moglo biti izvedeno ovo osobno ime.

Glasovni razvoj: Yehudis > (ispadanje /h/ unutar riječi i zanaglasnog samoglasnika uz redukciju samoglasnika) Yudes $>$ Yude $>$ Yute $>$ (umanjenica s prijeglasom) Yitl (Beider 2001: 601-603)

${ }^{344} 2 \mathrm{Kr} 12,2$. U transkripciji Antuna Sovića: Sibja.

Osobno se ime može shvatiti i kao ženski parnjak muškog osobnog imena צְִ̣ /ṣəbīl 'jelen', zamjenskog

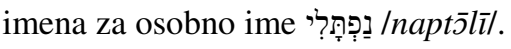




$$
\begin{aligned}
& \text { גאלדה /goldel - jid. - } 2 \\
& \text { גאָלדע /goldel - jid. - 2 } \\
& \text { גאלדע /goldel - jid. - 1 } \\
& \text { גלדה /goldel - jid. - 1 }
\end{aligned}
$$

Osobno je ime Golda posuđeno od njemačkih kršćana, među kojima je vjerojatno predstavljalo odmilicu od složenih osobnih imena kojih bi prvi dio bila riječ 'zlato' (srednjovisokonjemački golt : njem. Gold). Motivacijom se privlačno osobno ime proširilo među Židovima u njemačkim zemljama te je potom seobama prihvaćeno i u slavenskima. Glasovni razvoj: Golda > (redukcija zanaglasnog samoglasnika) Golde (Beider 2001: $510-511)$

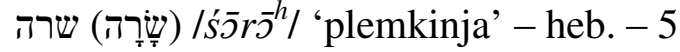

יענטל /yentl/ - jid. - 4

יענט /yent/ - jid. - 1

Ovo je osobno ime jedno od više židovskih izvedenih iz romanske riječi gentil 'plemenit'. Alexander Beider navodi da je do promjene početnog suglasnika u [j] svakako došlo u Njemačkoj, vjerojatno od početnoga [g] kako se izgovaralo u vrijeme kad je iz francuskoga posuđeno među njemačke kršćane (XI. st.). Ipak, ovo je tumačenje malo vjerojatno $s$ obzirom na to da je palatalizacija fonema $/ g / \mathrm{u}$ romanskim jezicima vrlo rana pojava. Iz ovog je osobnog imena izveden hiperkorektni lik Yente uz pogrešnu pretpostavku da je dočetno $-l$ deminutivni sufiks.

Glasovni razvoj: Gentil > Yentil $^{345}>$ (ispadanje zanaglasnog samoglasnika) Yentl > (hiperkorekcijom) Yente > (ispadanje zanaglasnog samoglasnika) Yent (Beider 2001: 596-597, Beider 2003: 74) $)^{346}$

בלימלה /blim(e)le/ - jid. - 2

בלימעלע /blimelel - jid. - 2

Nije sasvim jasno je li ovo osobno ime posuđeno od njemačkih kršćana (najstariji בלומ zabilježeni likovi su Pluoma/Pluma) ili je pak samostalno izvedeno od jidiške riječi Iblum/ 'cvijet' (srednjovisokonjemački bluome : njem. Blume). S juga se Njemačke širilo

\footnotetext{
${ }^{345}$ Vjerojatniji glasovni razvoj: Gentil > rom. Žentil $>$ Đentil > njem. Yentil

${ }^{346}$ Među samim Židovima postoji pogrešno uvjerenje da je yenta ili yente riječ kojom se označuje židovska

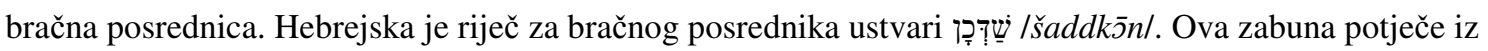
filma Fiddler on the Roof (Guslač na krovu) iz 1964. g., u kojem lik osobnim imenom Yente vrši ulogu bračne posrednice u štetlu Anatevka.
} 
na sjever i u slavenske zemlje. Još jedno osobno ime popularno zbog motivacije općom imenicom privlačnoga značenja.

Glasovni razvoj: Blume > (umanjenica s prijeglasom) Blim(e)le (Beider 2001: 482-483)

זעלדע /zeldel - jid. - 3

זעלדה Izeldel - jid. - 1

Osobno ime posuđeno od njemačkih kršćana u srednjem vijeku, otkud je preneseno $u$ slavenske zemlje, popularnost je vjerojatno steklo zbog motivacije općom imenicom privlačnog značenja. Osobno je ime izvedeno od srednjovisokonjemačke imenice saelde 'radost, blaženost, blagostanje' (Beider 2001: 604).

נוחה /nuxel - jid. - 4

Osobno je ime Menuxa hebrejskog podrijetla, ali ga nema u Tanahu. Potječe iz hebrejske

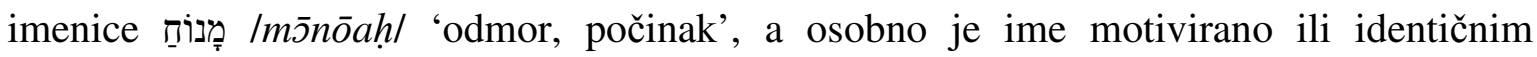
jidiškim osobnim imenom muškog roda ili pak kao ženski parnjak muškog osobnog imena ถַijuָ /mōnōaḥ/. Popularno u srednjoeuropskim slavenskim zemljama, odakle se proširilo na istok i na zapad.

Glasovni razvoj: Menuxa > (redukcija zanaglasnog samoglasnika) Menuxe [> (redukcija nenaglašenog samoglasnika) Mnuxe] > Nuxe (Beider 2001: 539-540)

נחמה /nexama/el - jid. - 4

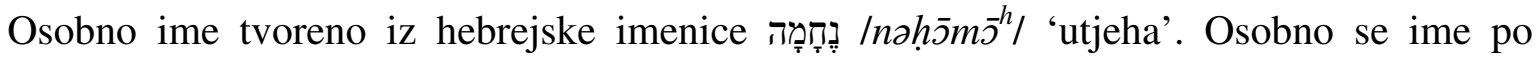
svemu sudeći pojavilo u predaškenasko doba, jer bi inače samoglasnik naglašenog drugog sloga bio $/ o /$, a ne $/ a /$.

Glasovni razvoj: Nexama > (redukcija zanaglasnog samoglasnika) Nexame (Beider 2001: $549-550)$

פערל /perl/ - jid. - 4

Osobno ime nesumnjivo potječe od vulgarnolatinske imenice perla 'biser'. Dvije su mogućnosti njezina usvajanja kao osobnog imena među njemačkim Židovima. Na sjever su je mogli prenijeti doseljenici iz Italije, gdje je Perla bilo uobičajeno žensko osobno ime i među kršćanima i među Židovima. S druge strane, moguće je i da je riječ i o neovisnoj tvorbi iz judeogermanske riječi iste motivacije (srednjovisokonjemački përle/bërle : njem. Perle), Bilo kako bilo, u Aškenaza je prvo potvrđeno u Bavarskoj i Franačkoj, odakle se dalje širilo (Beider 2001: 552-553). 
פ פרוממעט /frommet/frummet/ - jid. - 2

פרומט /fromet/frumet/ - jid. - 1

פרומעט /fromet/frumet/ - jid. - 1

Osobno je ime povezano sa srednjovisokonjemačkom sintagmom vrô mиot 'dobro raspoloženje'. Pojavilo se u Porajnju, a do XIII. je st. bilo popularno i među tamošnjim kršćanima. Pučkom je etimologijom osobno ime povezano s jidiškim pridjevom 'pobožna' (Beider 2001: 16).

Glasovni razvoj: Fromut $>$ (regresivna asimilacija samoglasnika) Frumut $>$ (redukcija zanaglasnog samoglasnika) Frumet (Beider 2001: 505-506)

רייצל /raycll - jid. - 4

Židovi su osobno ime Richenza/Richinza posudili od njemačkih kršćana. Osobno je ime tvoreno od srednjovisokonjemačkog pridjeva rîche 'bogat' (: njem. reich) sufiksom -in i deminutivnim dometkom $-z a$. Osobno je ime u Njemačkoj odumrlo u XIV. st., a u seobama je Židova osnovni lik zaboravljen, pa se osobno ime širilo u dva osnovna lika, kao Rayce i kao Reyxe.

Glasovni razvoj: Rixenca $>$ (redukcija zanaglasnog samoglasnika) Rixence $>$ Rixe $(n)$ ce $>$ (ispadanje zanaglasnog samoglasnika) Rixce $>$ Rihce $>$ (ispadanje /h/ unutar riječi) Rice $>$ Rayce > (umanjenica) Raycl (Beider 201: 554-556)

שינדל /šeyndl/ - jid. - 4

Njemačko je osobno ime Sconea/Sconna izvedeno od starovisokonjemačkog pridjeva scöni 'lijep' (: njem. schön) još u IX. st. Židovi su osobno ime preuzeli od kršćana ili su ga pak sami stvorili od jidiškog pridjeva istog značenja (: srednjovisokonjemački schoene). Još jedno osobno ime koje svoju popularnost može zahvaliti motivaciji općom imenicom privlačnog značenja.

Glasovni razvoj: Šene > Šeyne > (umanjenica) Šeyndl (Beider 2001: 567-569)

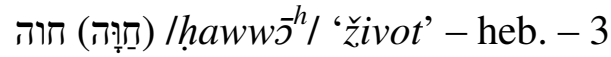

בריינדל /brayndl/ - jid. - 2

ברענדל /brendl/ - jid. - 1

Pridjev 'smeđ' kao osobno ime nalazimo i u romanskim zemljama i u njemačkim. Kako ga ne nalazimo među francuskim Židovima, već među onima u Porajnju, vjerojatno je izvedeno od srednjovisokonjemačkoga brûn (njem. braun). Otud se proširilo na jug i u slavenske zemlje. 
Glasovni razvoj: Bruna > (redukcija zanaglasnog samoglasnika) Brune > Broyne > (umanjenica s prijeglasom) Brayndl (Beider 2001: 484-486)

Inačica Brone nije potvrđena u Beiderovim izvorima, već je vjerojatno riječ o dijalektnom liku osobnoga imena.

Glasovni razvoj: Brone > (umanjenica s prijeglasom) Brendl (Beider 2001: 484-486)

הדד /hodes/ - jid. - 2

האָָדעס /hodes/ - jid. - 1

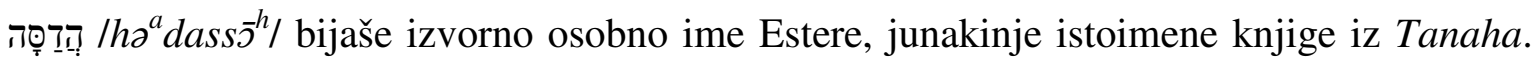

Osobno je ime bilo uobičajeno u srednjoj Europi, a rijetko u zapadnonjemačkim zemljama.

Proširilo se među Židovima ne samo zbog seoba, već i izravnim preuzimanjem iz Tanaha.

Glasovni razvoj: Hadasa > (apokopa zanaglasnog samoglasnika) Hadas > (redukcija zanaglasnog samoglasnika) Hodes (Beider 2001: 518-519)

הענדל /hendl/ - jid. - 3

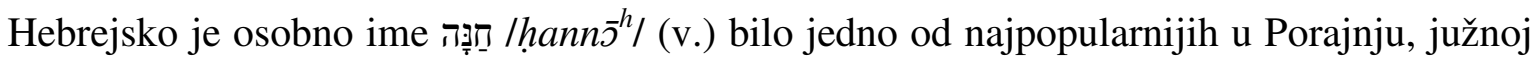
Njemačkoj i slavenskim zemljama, ne nužno u isto vrijeme. $S$ jedne je strane tomu tako zbog poštovanja spram junakinje iz Tanaha, majke proroka Samuela, s druge zbog privlačne motivacije imenicom značenja 'milost', a s treće zbog popularnosti kršćanske inačice osobnog imena, Anna. U njemačkome bi pak osobno ime Anna moglo biti i ženski parnjak muškoga Anno.

Glasovni razvoj: Xana > Xane > Hane > (umanjenica s prijeglasom) Hendl (Beider 2001: $520-524)$

חיי /xayel - jid. - 2

חי /xaye/ - jid. - 1

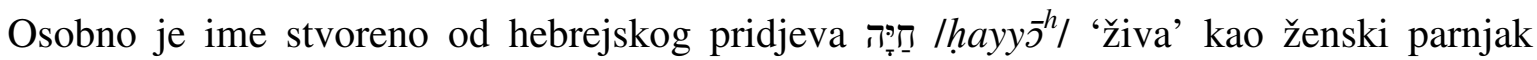
muškog osobnog imena חַיִ /hayyīm/. Po svemu se sudeći pojavilo u srednjoj Europi (Austriji ili Češkoj) odakle se proširilo na istok da bi u u XIX. st. u Ruskom Carstvu postalo jednim od najpopularnijih osobnih imena (Beider 2001: 525-526).

חי' שרה /xaye ś $\bar{\partial} \bar{y}^{h} /$ - jid.-heb. - 1

חיי שרה /xaye śs̄ $r \bar{\supset}^{h} /$ - jid.-heb. - 1

חיי' שרה /xaye śs̄ $r \bar{\partial}^{h} /$ - jid.-heb. - 1

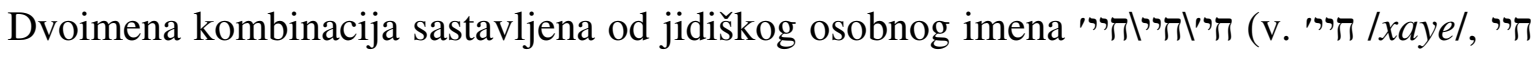
/xaye/) i hebrejskog osobnog imena שָ /śว̄r $\bar{s}^{h} /$ (v.) 


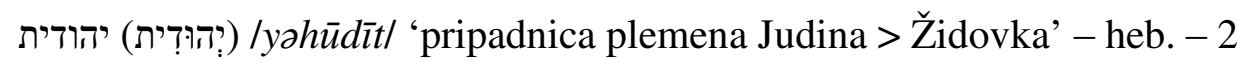

בינה /binel - jid. - 1

בינע /binel - jid. - 1

Romansko je osobno ime Bona/Bone 'dobra' poznato iz židovskih zajednica i sa sjevera is juga Francuske, gdje je bilo posuđeno od kršćana. Židovi su osobno ime prenijeli u Porajnje i na jug Njemačke. Osobno je ime Bona bilo poznato i Sefardima. Osobno je ime Bine poteklo od navedenoga bilo pravilnom promjenom $/ u />/ i / \mathrm{u}$ srednjoistočnim dijalektima jidiša (Poljska, Galicija, dijelovi Slovačke i Mađarske), bilo promjenom $|u|>|\ddot{u}|>|i|$ u samoj Njemačkoj, no moguće je i da je izvedeno od umanjenica koje su zbog sufiksa doživjele prijeglas samoglasnika osnove. Pučkom je etimologijom osobno ime Bine povezano s jidiškom imenicom בין /bin/ 'pčela' (: njem. Biene), te je tako postalo

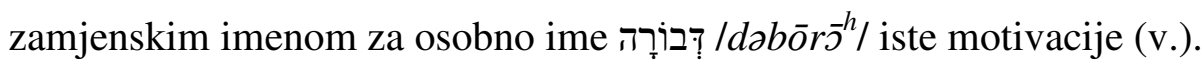

Glasovni razvoj: Bone [> Büne] > Bine (Beider 2001: 487-488)

טשארנה /tša/orna/el - jid. - 1

טשארנע /ť̌a/ornel - jid. - 1

Osobno ime preuzeto od čeških kršćana, motivirano pridjevom osnovnog značenja 'crna'. Kako se osobno ime širilo slavenskim zemljama, tako se i prilagođavalo lokalnoj inačici dotičnog pridjeva.

Glasovni razvoj: Tšarna > (redukcija nenaglašenog samoglasnika) Tšarne

Alternativni glasovni razvoj: Tร̌orna > (redukcija nenaglašenog samoglasnika) Tšorne (Beider 2001: 588-589)

ליבה /libel - jid. - 1

ליבע /libel - jid. - 1

Njemački su kršćani osobno ime motivirano imenicom značenja 'ljubav' koristili još od VI. st. u različitim likovima: Leuba, Lieba, Lioba, Liuba i Luba (: njem. Liebe). Među Židovima se u Češkoj i Moravskoj to osobno ime pojavilo zbog seoba njemačkih Židova (kao i u drugim slavenskim zemljama) i kontaminacije s češkim osobnim imenom Libuše/Libuša (Beider 2001: 532-534).

מערל /merl/ - jid. - 2

Među Aškenazima su osobna imena Merlin, Merl i Merle predstavljala inačice osobnog imena בִרְִ /miryj̄m/ (v.) u svakodnevnom govoru. Likovi su preuzeti od njemačkih kršćana (Beider 2001: 544-548). 
משל /mašll - jid. - 2

U istočnoj je Europi došlo do kontaminacije aškenaskih osobnih imena izvedenih iz /mirȳ̄m/ (v.) i odmilicā za isto osobno ime u ruskome. Jedna je od tih odmilica i Maшa.

Glasovni razvoj: Maša > (redukcija zanaglasnog samoglasnika) Maše $>$ (umanjenica) Mašl (Beider 2001: 544-548)

סאשא /sošel - jid. - 1

סאשי /sošel - jid. - 1

Još jedna izvedenica iz osobnog imena Sore (v. שרל /serl/).

Glasovni razvoj: Sara $>$ (redukcija zanaglasnog samoglasnika) Sare $>$ Sore $>$ Soše (Beider 2001: 574-578)

פיגלה /fa/eygle/ - jid. - 1

Ifaleygelel - jid. - 1

Osobno ime izvedeno od judeonjemačke riječi 'ptica' (: njem. Vogel), kao prijevodno osobno ime hebrejskoga צִ̣ /ṣippor $\overline{5}^{h} /$ iste motivacije, popularno i zbog motivacije općom imenicom privlačnog značenja i zbog činjenice da je to bilo osobno ime Mojsijeve supruge u Tanahu.

Glasovni razvoj: Fogel $>$ (ispadanje zanaglasnog samoglasnika) Fogl $>$ Fougl $>$ Foygl $>$ (umanjenica) $>$ Feygle $>$ Feyge $>$ Fayge $>$ (umanjenica) Faygele (Beider 2001: 500-501)

פייערל /payerl/ - jid. - 2

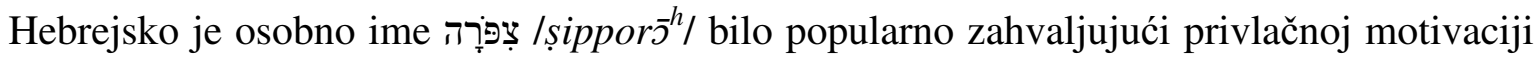
imenicom značenja 'ptica' kao i činjenici da je u Tanahu pripadalo Mojsijevoj supruzi.

Glasovni razvoj: Cipora > (redukcija zanaglasnog samoglasnika) Cipore $>$ Cipure > (ispadanje prednaglasnog sloga) Pure > (umanjenica s prijeglasom) Payerl (Beider 2001: 590-593)

פיסל /pesl/ - jid. - 1

פס /pesl/ - jid. - 1

Supruga je kralja Davida i majka kralja Salomona svojom popularnošću utjecala na

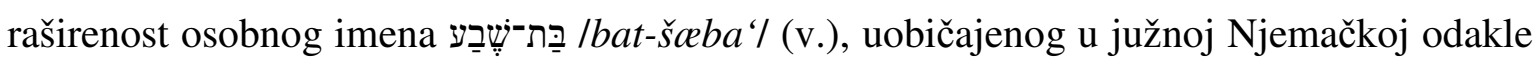
se proširilo. Inačica je Betseline stvorena u Porajnju deminutivnim sufiksom -lin.

Glasovni razvoj: Betseline > Beselin > Peselin > Peslin > Pesl (Beider 2001: 477-480) 


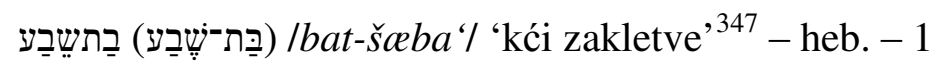

אדל /adll - jid. - 1

Ovo osobno ime podrijetlo vuče iz germanskog osobnog imena Adelheid $(a)<$ pragerm.

*apala- 'plemenit' + *haidu- 'rod'. Njemački su ga Židovi preuzeli od njemačkih kršćana i iz njega razvili veći broj izvedenica i odmilica. Jedna je od njih i Adel(e/a) koju nalazimo i u Njemačkoj, Češkoj, Moravskoj i Poljskoj. Druga je mogućnost da je osobno ime izravno izvedeno od pridjeva značenja 'plemenit'.

Glasovni razvoj: Adelxeyt $>$ (ispadanje zanaglasnog sloga) Adel > Adl (Beider 2001: 497-499)

אלקל /alekll - jid. - 1

Još jedna izvedenica iz osobnog imena Adelheid(a) (v. אדל /adel/). Odmilica je prvotno izvedena sjevernonjemačkim deminutivnim sufiksom - $k e$. Proširila se na jug Njemačke i u slavenske zemlje. Alexander Beider navodi da je osobno ime odumrlo u XV. st. Osobno ime אלקל /alekl/ pak djeluje kao da je na (već postojeću umanjenicu) Aleke dodan još jedan, južnonjemački deminutivni sufiks - $l$ (Beider 2001: 497-499).

בלימה /blimel - jid. - 1

Još jedno osobno ime izvedeno od imenice značenja 'cvijet' (v. בלימעלע /blimle/, בלימלה /blimelel : njem. Blume).

Glasovni razvoj: Blume [> Blüme] > Blime (Beider 2001: 482-483)

גנענדל / $/ g(e) n e n d l /-j i d .-1$

Likovi su osobnog imena Genanna i Gnani među kršćanima u Porajnju potvrđeni u XI. st. Židovi su ih ondje preuzeli kao Genana i Gnane. Osobno je ime izvedeno od srednjovisokonjemačke imenice $g(e) n a n n e$ 'imenjak, drug'. Pri njegovom je širenju među

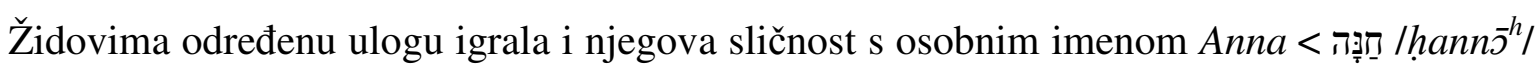
iz Tanaha.

Glasovni razvoj: Gnane > (umanjenica s prijeglasom) Gnendl > (dodan anaptički samoglasnik) Genendl (Beider 2001: 508-510)

געלע /gelel - jid. - 1

Njemačkim su kršćanima Gele i Gela predstavljali odmilice za njemačko osobno ime Gertrude < pragerm. *gaiza- 'koplje' + *brupi- 'snaga'. Židovi su preuzeli osobno ime od njih i prenijeli ga u slavenske krajeve (Beider 2001: 507).

\footnotetext{
${ }^{347} 2$ Sam 11,3. U transkripciji Antuna Sovića: Bat-Šeba
} 
גרונט/grunet/ - jid. - 1

Osobno ime nejasne motivacije. Dva su najstarija potvrđena lika Grunet i Grune za koje nije jasno jesu li povezani (recimo da je jedan odmilica za drugoga) ili neovisni jedan o drugom. Komplementarna distribucija likova Grune i Grine u jidiškim dijalektima XIX. st. pokazuje da je drugi nastao od prvoga. Pučkom je etimologijom osobno ime povezano s jidiškim pridjevom גרינע/grinel 'zelena' (: njem. grüne).

Glasovni razvoj: Grunet > Grune (Beider 2001: 511-512)

זיסל /zisl/ - jid. - 1

Podrijetlo je temeljnog lika osobnog imena Zuse u jidiškom pridjevu זיסע /zisel 'slatka' (: njem. süße). Bezvučnost drugog suglasnika upućuje na to da nije riječ o izvedenici iz

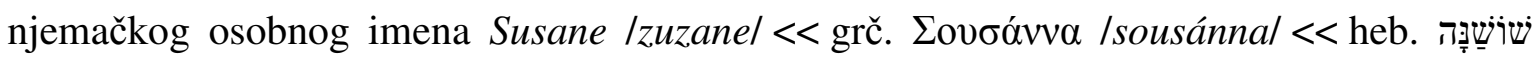
/šōšann $\bar{D}^{h} /$ 'ljiljan'. Moguće je da je riječ o prijevodnom osobnom imenu jidiškoga טָאלצע Itolce/ iste motivacije, a romanskog podrijetla.

Glasovni razvoj: Zuse > (umanjenica s prijeglasom) Zisl (Beider 2001: 605-606)

זיסלע/zisle/ - jid. - 1

Osobno ime istog podrijetla kao i זיסל /zisl/ (v.).

Glasovni razvoj: Zuse > (umanjenica s prijeglasom) Zisle (Beider 2001: 605-606) חאָנעלע /xanelel - jid. - 1

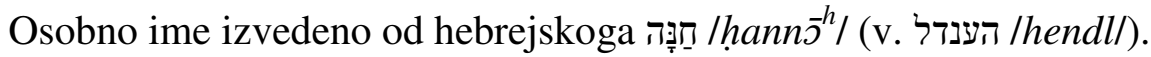

Glasovni razvoj: Xane > (umanjenica) Xanele (Beider 2001: 520-524)

טויבע /toybel - jid. - 1

Jedno od mnogih osobnih imena koja su njemački kršćani izveli iz imenica 'golub' i 'grlica' (: njem. Taube), a Židovi od njih posudili. Standardna jidiška imenica toga značenja glasi טויב /toyb/.

Glasovni razvoj: Tube > Toube > Toybe (Beider 2001: 584-585)

(יוֹכֶבֶד) יוכבד /yōkacbaed/ - heb. - 1

יחו /ya/oxed/ - jid. - 1

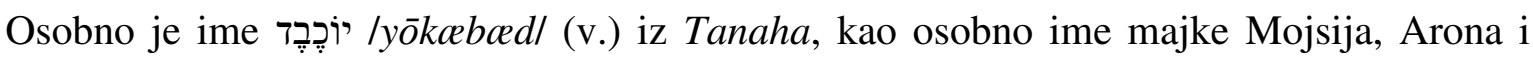
Mirjam, bilo izrazito popularno među Židovima, no ne i među kršćanima u njemačkim i slavenskim zemljama.

Glasovni razvoj: Yoxeved > (ispadanje zanaglasnog samoglasnika) Yoxved > (pojednostavljenje suglasničke skupine) Yoxed > Yaxed (Beider 2001: 598-600) 
ליפעט /lipet/ - jid. - 1

Osobno ime izvedeno od riječi za ljubav (v. ליבה /libel, ליבע /libel : njem. Liebe), odnosno iz osobnog imena Liebheit.

Glasovni razvoj: Libheyt > (regresivna asimilacija suglasnika) Lipheyt > (pojednostavljenje zanaglasnog diftonga uz ispadanje / $h$ / unutar riječi) Lipet (Beider 2001: 532-534)

משל /metl/ - jid. - 1

Iz srednjovisokonjemačkoga je magetîn, megetîn, maitîn, meitîn, umanjenice od 'djevojka' (: njem. Mädchen, jnjem. i aust. Mäd(e)l), izvedeno osobno ime Meytin, iz kojeg se pak razvilo Meyte.

Glasovni razvoj: Meytin $>$ Meyte $>$ (monoftongizacija) Mete $>$ (umanjenica) Metl

Alternativni glasovni razvoj: Meytin > Meyte > Mayte $>$ (monoftongizacija) Mate > (umanjenica s prijeglasom) Metl (Beider 2001: 540-541)

מינדל /mindll - jid. - 1

Osobno je ime Mine 'ljubav' (njem. Minne) bilo popularno među njemačkim kršćanima, a osobito u južnim njemačkim zemljama u liku Mina. Raširenost se osobnog imena među Židovima poklapa s njegovom popularnošću među nežidovima. S juga se Njemačke proširilo u slavenske zemlje.

Glasovni razvoj: Mina > (redukcija zanaglasnog samoglasnika) Mine > (umanjenica) Mindl (Beider 2001: 543-544)

משהה /moše/ha?/ - jid. - 1

Žensko je osobno ime Moyše stvoreno kao ženski parnjak identičnog muškog osobnog imena (Beider 2001: 548).

פיילע /payle/ - jid. - 1

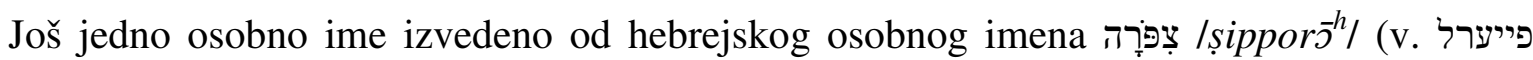
/payerl/).

Glasovni razvoj: Cipora $>$ (redukcija zanaglasnog samoglasnika) Cipore $>$ Cipure $>$ (ispadanje nenaglašenog sloga) Pure > (prijeglas i ubacivanje samoglasnika /e/) Payerl(e) > Payle (Beider 2001: 590-593)

פינקל /finkll - jid. - 1

Osobno ime nesigurne motivacije, možda izvedeno od jidiške imenice פَינקל/finkl/ 'iskrica' (: njem. Funke 'iskra'). Zabilježeno isključivo u slavenskim zemljama (Beider 2001: 501). 
פריווע /priwel - jid. - 1

Osobno se ime pojavilo u zapadnom (srednjoeuropskom) Kanaanu (Češka). Češki su ga Židovi seobama prenijeli u Njemačku i istočnu Europu. Moguće je da je početni lik Priba preuzet od čeških kršćana, kojima Přiba i Přyba bijahu odmilice za složeno osobno ime

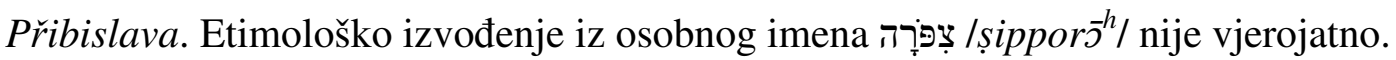

Glasovni razvoj: Priba > (redukcija zanaglasnog samoglasnika) Pribe > Prive (Beider 2001: 554)

פריידה /fraleydel - jid. - 1

Dva su moguća izvorišta osobnog imena Freyde: srednjovisokonjemačko vröude i srednjosrednjonjemačko vrôde, obje riječi istog značenja 'radost' (: njem. Freude). U srednjem je vijeku osobno ime glasilo Vreuda, dok je na jugu njemačkog govornog područja bio uobičajen lik Fröude. Židovi su ovo osobno ime vjerojatno preuzeli kao

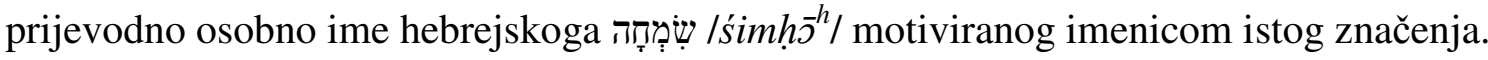

Glasovni razvoj: Fröude/Freude > Freyde > Frayde (Beider 2001: 503-505)

פ/p/fre/il/ ili פריל /p/frl./ - - - 1

Osobno se ime pojavljuje na jednom nadgrobnom spomeniku (3 II 44). Na istome osobno ime napisano latinicom glasi Pavla.

פרעדל /fredll - jid. - 1

Izvedenica iz osobnog imena Freyde (v. פריידה /fra/eydel : njem. Freude).

Glasovni razvoj: Fröude/Freude $>$ Freyde $>$ Frayde $>$ Frade $>$ (umanjenica s prijeglasom)

Fredl (Beider 2001: 503-505)

פרענדל /frendl/ - jid. - 1

Još jedna izvedenica iz osobnog imena Freyde (v. פריידה /fra/eydel : njem. Freude).

Glasovni razvoj: Fröude/Freude $>$ Freyde $>$ Frayde $>$ Frade $>$ (umanjenica s prijeglasom)

Frendl (Beider 2001: 503-505)

צאָרטל /cortl/ - jid. - 1

Izvedenica iz osobnog imena Sore < שרָרָה /serl/).

Glasovni razvoj: Sara $>$ (francuski sufiks) Saret $>$ Caret $>$ Coret $>$ (umanjenica) Cortl (Beider 2001: 574-578)

ציפרל /ciperl/ - jid. - 1

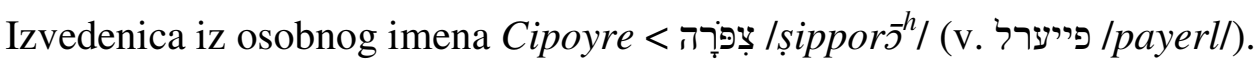


Glasovni razvoj: Cipora $>$ Cipore [> Cipoyre] $>$ Cipor $>$ (umanjenica) Ciperl (Beider 2001: 590-593)

קיענדל / / $(i ?)$ endll - jid. - 1

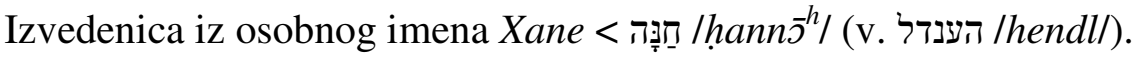

Glasovni razvoj: Xana > (redukcija zanaglasnog samoglasnika) Xane > Kane > (umanjenica) Kendl (Beider 2001: 520-524)

קלערל /klerl/ - jid. - 1

Osobno je ime Klara/Clara 'jasna' bilo popularno i među kršćanima i među Židovima. Potonji su ga preuzeli od kršćana. Potvrđeno je i među francuskim Židovima i među iberskima, no njemački ga zasigurno nisu preuzeli od njih, već od lokalnih kršćana jer se među njima pojavljuje relativno kasno.

Glasovni razvoj: Klare [> Klore] > (umanjenica s prijeglasom) Klerl (Beider 2001: 527)

/rozil - jid. - 1

Osobno je ime vjerojatno izvedeno od Rosa (v. רייזל /reyzl/) iako Alexander Beider ne spominje taj lik među izvedenicama osobnog imena Royze (Beider 2001: 563-565).

שיפרה /šifre/ - jid. - 1

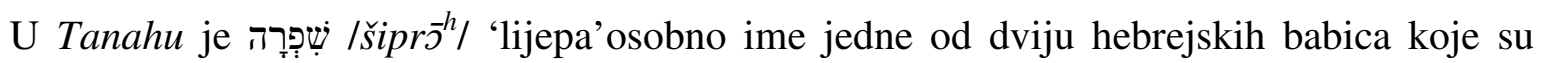
odbile ubijati mušku djecu židovskih robova faraonovu naređenju unatoč ${ }^{348}$. Bilo je neuobičajeno u Njemačkoj, a iznimno popularno u istočnoj Europi.

Glasovni razvoj: Šifra > (redukcija zanaglasnog samoglasnika) Šifre (Beider 2001: 569)

שענדל /šendl/ - jid. - 1

Osobno ime izvedeno od Šeyne (v. שינדל /Šeyndl/ : njem. Schöne).

Glasovni razvoj: Šone > Šene > (umanjenica) Šendl (Beider 2001: 567-569) שפרינין /šprincl - jid. - 1

Više je hipoteza o podrijetlu ovog osobnog imena. Moguća je izvedba iz srednjovisokonjemačke imenice sprinze 'ženka kopca'. Moguće je i da je riječ o osobnom imenu izvedenom od talijanske imenica speranza 'nada', no u tom slučaju lik Šprince ne bi se mogao izvesti unutar židovske zajednice. Možda je došlo i do križanja tih dviju etimologija. Osobno se ime povezuje i s onim sv. Esperentije ${ }^{349}$. Vjerojatno su Židovi od

\footnotetext{
${ }^{348}$ Izl 1,15. U transkripciji Silvija Grubišića: Šifra

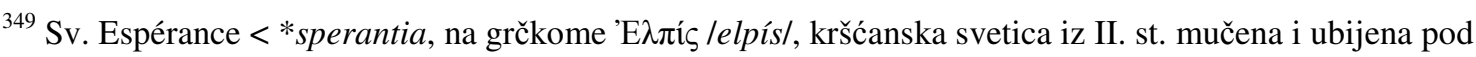
rimskim carem Hadrijanom (76.-138.).
} 
kršćana preuzeli već gotovo osobno ime. U slučaju je lika bez dočetnog samoglasnika možda došlo do kontaminacije sa srednjovisokonjemačkim sprinz 'iskra'.

Glasovni razvoj: Šprince > Šprinc (Beider 2001: 570-71)

בילה חוה /beyle haww $\bar{\nu}^{h} /$ - jid.-heb. - 1

Dvoimena kombinacija sastavljena od jidiškog osobnog imena בילה /beyle/ (v.) i

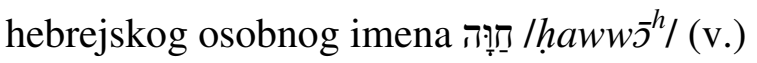

בלאנקה דוד /blanka d5wid?/ - ?-heb. - 1

Neobična kombinacija osobnih imena koju nalazimo samo na jednom mjestu, na nadgrobnom spomeniku (13 I 2). Osobno ime ispisano latinicom glasi Blanka D. Prvo je osobno ime u kombinaciji, dakle, nesumnjivo Blanka. Drugo pak izgleda kao דִִ̣ /d̄̄wid/, muško osobno ime. Je li takva kombinacija muškog i ženskog osobnog imena bila uobičajena u Židovā? Nijedan je izvor ne potvrđuje. Među kršćanima je, s druge strane, slična kombinacija moguća, ali u muškaraca, npr. Rainer Maria (Rilke), Gian Maria (Volontè).

/golde le $\bar{\partial}^{h} /$ - jid.-heb. - 1

Dvoimena kombinacija sastavljena od jidiškog osobnog imena גלדזה /goldel (v. גאלדה

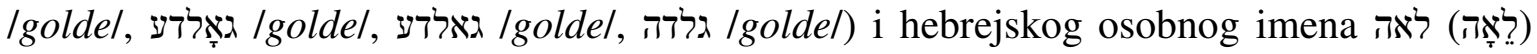
/le $\bar{\nu}^{h} /(\mathrm{v}$.)

חוה שרה /hawws $\bar{s}^{h} s \dot{\partial} r \bar{\partial}^{h} /$ - heb.-heb. - 1

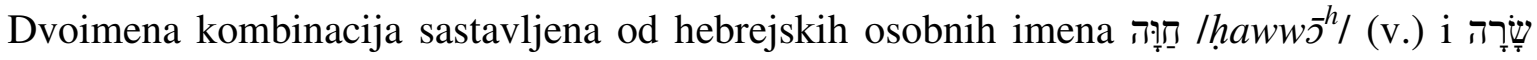
Iśs̄ $r \bar{\supset}^{h} /(\mathrm{v}$.

יענטל יודעם /yentl yudes/ - jid.-jid. - 1

Dvoimena kombinacija sastavljena od jidiških osobnih imena יענטל /yentl/ (v. יענטל /yentl/,

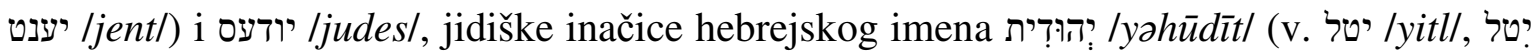
/yitll, ייטל /yitl/)

יענטע פיגא /yente feyga/el - jid.-jid. - 1

Dvoimena kombinacija sastavljena od jidiških osobnih imena יענטע פיגא /yentel (v. יענט /yentl/, פיענט Iyent/) i פיגא /feyga/el (v. פיגלה /fa/eygle/, פיגעלע /fa/eygele/)

Postoji i druga svetica toga osobnog imena, Espérance odnosno Exupérance (u. 380), koja se štuje u francuskoj pokrajini Champagne. 
לאה חנה /le' $\bar{\jmath}^{h}$ hann ${ }^{h} /$ - heb.-heb. - 1

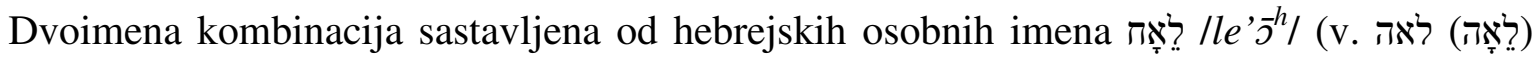

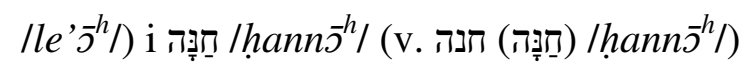

ליבה יטל /libe yitll - jid.-jid. - 1

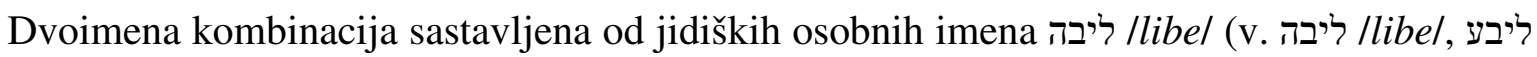

/libel) i יטל /yitl/ (v. יטל /yitl/, /yitl/, ייטל /yitl/)

ליבה לאה /libe le $\bar{\jmath}^{h} /$-jid.-heb. - 1

Dvoimena kombinacija sastavljena od jidiškog osobnog imena ליבה /libe/ (v. ליבה /libel,

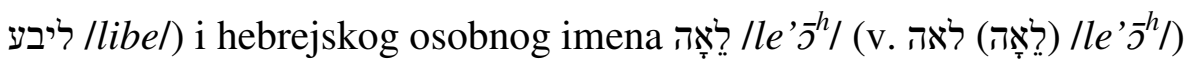

/mirȳ̄m binel - heb.-jid. - 1

Dvoimena kombinacija sastavljena od hebrejskog osobnog imena מִריָם /mirȳ̄m/ (v. מרים בינע /mirȳ̄m/, מריים /mryem/) i jidiškog osobnog imena בינה /binel (v. בינה /bine/, בינה (bine/)

מרים חיילה /mirȳ̄m heyle/ - heb.-jid. - 1

Dvoimena kombinacija sastavljena od hebrejskog osobnog imena מרים . מרים . (מִרְים) /mirȳm/, מריים /mrym/) i jidiškog osobnog imena חיילה /heyle/ (v.)

עדל שארנע ledl ša/ornel - jid.-jid. - 1

Dvoimena kombinacija sastavljena od jidiških osobnih imena עדל / אדל /adl/) i טארנע /trša/orna/el, טשארנה /tša/orne/)

פַראדל שרל /fradl serl/ - jid.-jid. - 1

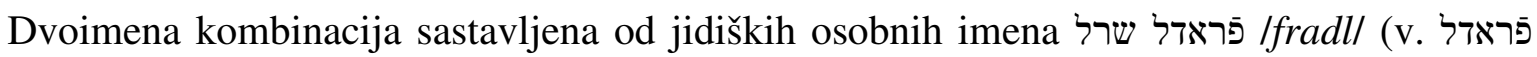

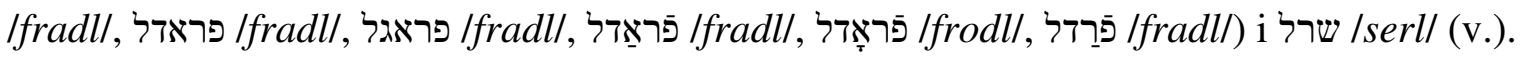
/ribq $\bar{\partial}^{h} h a w w \bar{\partial}^{h} /$ - heb.-heb. - 1

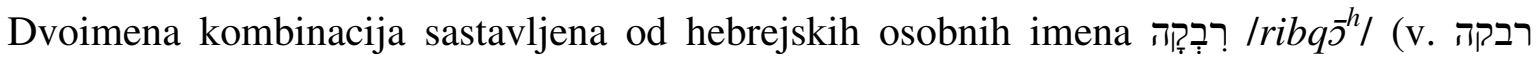

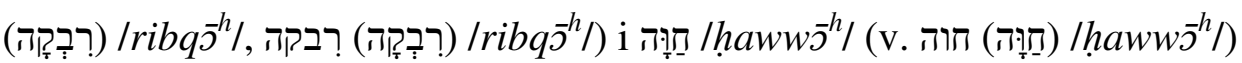

ריינה יאודה /reyna yauda/ - sef.-sef. - 1

יאודה i ריינה Ireynal lyaudal

Nalazimo je na nadgrobnom spomeniku (13 II 12) Sefardkinje. 
Osobno je ime Reyne izvedeno od romanske imenice 'kraljica' (šp. Reina, fran. Reyne) kao

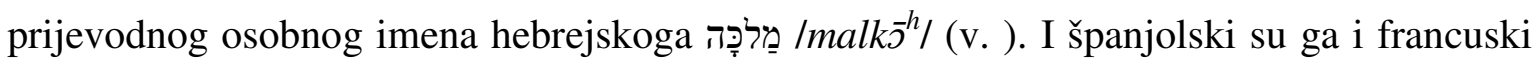
Židovi nadijevali kćerima.

Osobno ime Yauda vjerojatno potječe od arapske riječi يَهُودَ čime je istovrijedno hebrejskome יִיְוּדִית /yahūditt/ (v. יטל /yitl/, /yitl/, ייטל /yitl/). - שרה רחל - heb.-heb. - 1

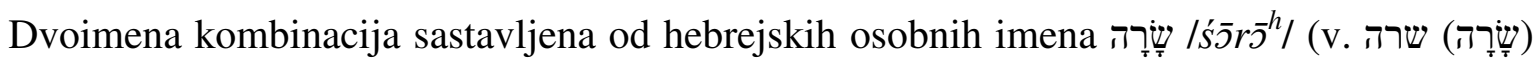

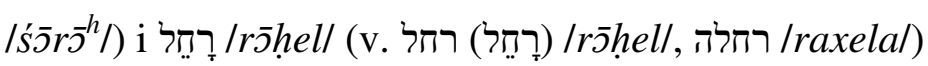

Među ženskim je osobnim imenima najviše jidiških, 64, dok je hebrejskih znatno manje samo 12. Za jedno osobno ime nije sigurno ni kako točno zvuči ni koja mu je motivacija פריל פר/f/fre/frl./ (3 II 44). Među dvoimenim je kombinacijama najviše hibridnih, onih u kojima je jedna sastavnica hebrejska, a druga jidiška, 6, dok je onih u kojima su obje sastavnice jidiške 5, a onih u kojima su obje sastavnice hebrejske 4. Od hibridnih dvoimenih kombinacija 2 imaju hebrejsko osobno ime na prvom mjestu, dok je u 4 njih na prvom mjestu jidiško osobno ime. Na jednom nadgrobnom spomeniku (13 II 12) imamo sefardsku dvoimenu kombinaciju - ריינה יאודה /reyna yauda/, a na drugom (13 I 2) dvoimenu kombinaciju בלאנקה דוד/blanka d̄̄wid?/ koja bi isto tako mogla biti sefardska, ali nemamo podataka o osobi koja je ta osobna imena nosila.

Od svih žena za koje imamo podatak o njihovu židovskom osobnom imenu, 194 njih nosi jidiška osobna imena, a 145 hebrejska. Što se dvoimenih kombinacija tiče, u 5 su žena obje sastavnice jidiške, u 4 su obje sastavnice hebrejske, dok u 9 žena nalazimo po jednu jidišku i jednu hebrejsku sastavnicu.

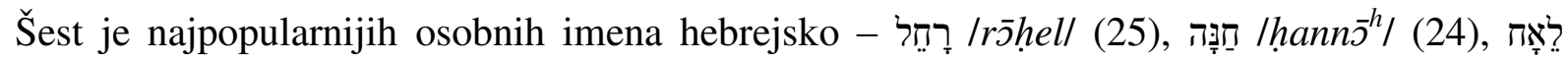

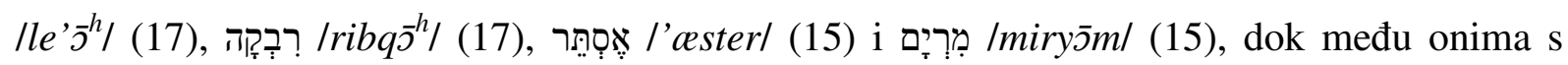
dvoznamenkastim brojem nositeljica ima još jedno - מלכה /malks $\bar{s}^{h} /$ ili /milks $\bar{s}^{h} /$ (12). Od

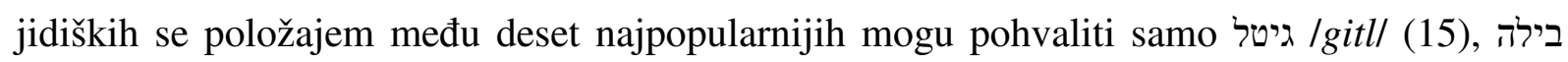
Ibeyle/ (14), חיילה /heyle/ (10) i שרל /serl/ (10). Popis se donekle poklapa s Beiderovim; od

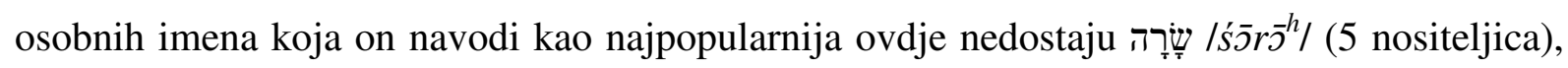




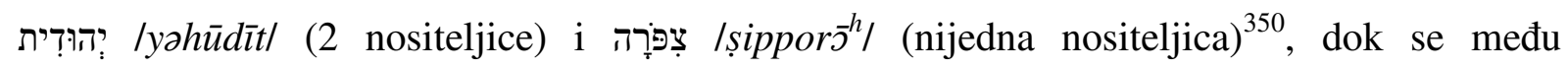

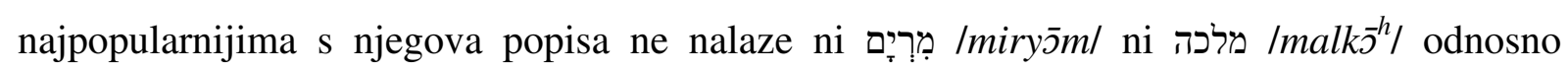
$/ m i l k \bar{s}^{h} /$, ovdje nazočne.

Među jidiškim osobnim imenima dominiraju umanjenice izvedene deminutivnim sufiksom koji sadržava segment /l/, tipičnim za južne njemačke idiome: bavarsko-austrijski i alemanski. Takvih osobnih imena ima 30, a nositeljicā takvih osobnih imena 100. Samo u jednom osobnom imenu (אלקל/alekl/) možda nalazimo sjevernonjemački deminutivni sufiks -ke, ali je i tako dobivena umanjenica dodatno deminutivizirana južnonjemačkim sufiksom - $l$.

\subsubsection{Suodnos građanskih i židovskih osobnih imena zagrebačkih Židova}

Židovi, dakle, nose dva osobna imena. Jedno je proizašlo iz vjerske tradicije, najčešće je podrijetlom hebrejsko ili eventualno aramejsko, iako u ovu skupinu mogu ući i osobna imena druge provenijencije (v. קלמין/kalmen/), a koristi se unutar same židovske zajednice, pogotovo $\mathrm{u}$ dokumentima pisanima hebrejskim pismom i jezikom. $\mathrm{S}$ druge strane, $\mathrm{u}$ komunikaciji se s vanjskim, nežidovskim svijetom oni služe drugim osobnim imenom, uglavnom odabranim iz antroponimskog fonda većinskog stanovništva (Colorni 1983: 68). Općenito govoreći nije moguće uspostaviti odnos 1:1 između židovskog i građanskog osobnog imena, ni prostorno ni vremenski. Neka se židovska osobna imena u jednih zajednica povezuju s jednim građanskim osobnim imenom, a u drugih s nekim drugim. S druge strane, veze koje su u jednom razdoblju postojale između dva osobna imena nestaju da bi se u sljedećem stvarale druge, nove. Vittore Colorni navodi kako je i na istom prostoru i u istom vremenu moguće naći više židovskih osobnih imena koja bi odgovarala jednome građanskom (Colorni 1983: 69-70). Stoga, iako je proučavani korpus u ovom istraživanju i prostorno i vremenski relativno uzak (Zagreb tijekom stoljeća i pol) i u nas možemo očekivati slične brojčane odnose, no ne nužno i ista osobna imena s jedne i druge strane.

Pri brojanju nositelja pojedinih osobnih imena u obzir su se uzimali i pojedinci kojima je dotično jedino osobno ime, kao i oni kojima je ono jedno od dvaju ili triju osobnih imena.

\footnotetext{
${ }^{350}$ Ovdje su uračunate samo osobe čija su osobna imena izvorna hebrejska, ne i one s jidiškim inačicama tih osobnih imena.
} 


\subsubsection{Suodnos muškog građanskog i židovskog osobnog imena}

U proučavanom je korpusu najčešća kombinacija muškog građanskog i židovskog osobnog imena ona koja s jedne strane uključuje osobna imena Joseph/Josef/Josip, a s druge יוֹסֵף /yōsep/. Pojedinaca s tim osobnim imenima ima 31. Kako je osobno ime Joseph/Josef/Josip i inače najčešće među Židovima, njegova visoka pozicija i u ovom slučaju ne iznenađuje. Ovdje ustvari imamo slučaj kombinacije »europeizirane«, kršćanske, i izvorne, hebrejske inačice istog osobnog imena. Takvih slučajeva ima još nekoliko. Devetnaest pojedinaca nose

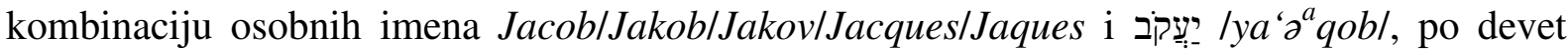
pojedinaca nose kombinaciju osobnih imena Salamon/Salomon i שָׁלמלה /šalomo / te Samuel/Samojlo i שִׁמוּאָל /šmū'ell, šest pojedinaca nose kombinaciju osobnih imena David/Dawid i שִׁמְעוֹן /šim 'ōn/, tri pojedinca nose kombinaciju osobnih imena Moses/Mosé i מקשֶה /moša $e^{h} /$, a dva

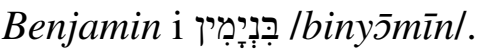

Sedamnaestorica uz građansko osobno ime Leopold nose i osobno ime ליב /leyb/ (povezano pučkom etimologijom germanskog osobnog imena, čiji se početak tumači kao latinska imenica značenja 'lav'), po šesnaestorica spajaju osobna imena Albert i אַבְרָָהָם /'abrōhs̄m/ i Moritz/Moriz/Moric/Mavro i משֶֶ /moš $e^{h} /$, a u petnaestorice nalazimo osobna imena Ignatz/

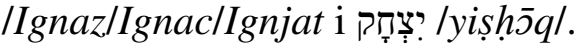

Devet ArthuralArtura nosi hebrejsko osobno ime אַבְרָרָָ /'abrōhs̄m/, u osmorice se spajaju

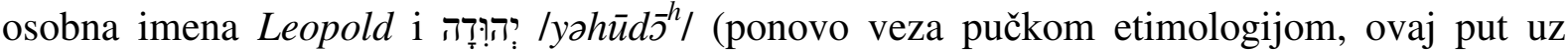
posredovanje Jakovljeva blagoslova iz Post 49,9), u po šestorice nalazimo osobna imena

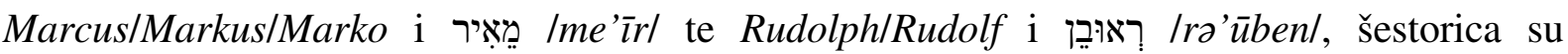
pojedinaca građanskim osobnim imenom Wilhelm ujedno i וואלף /wolf/, po petorica imaju

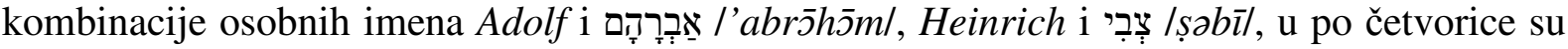

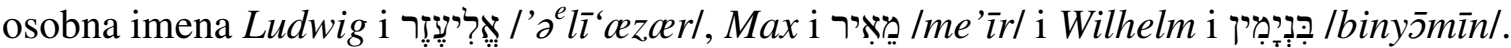

Mnogo je tročlanih skupina osobnih imena kojima se poklapaju građanska i židovska osobna

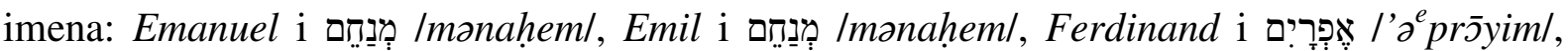

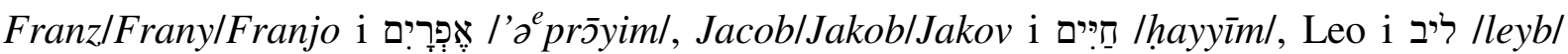
(povezano motivacijom po imenicama značenja 'lav'), Leopold א ארי.יה /'arye / (još jedna veza zbog pučke etimologije germanskoga osobnog imena), Maksimilijan/Max/Makso i מקשֶה 


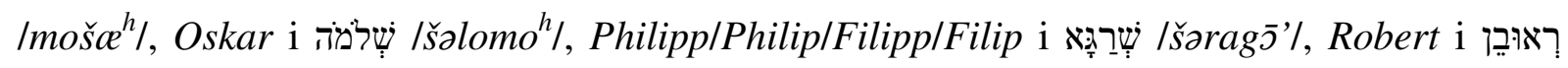

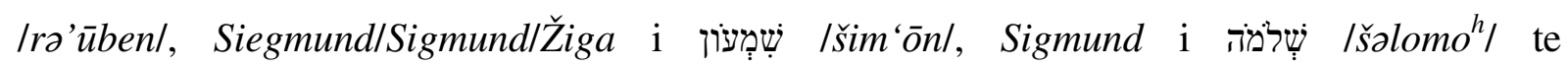
Sigismund/Siegmund/Sigmund/Žiga i שְִׁ̣išimšon/.

Pitanje je kako treba tretirati kombinacije građanskih i židovskih osobnih imena koje nalazimo samo u dvojice pojedinaca. Je li riječ o slučajnosti, koincidenciji ili o uobičajenoj pojavi koja, eto, ima tek mali broj potvrda u dokumentima? Takve su kombinacije: Alfred i

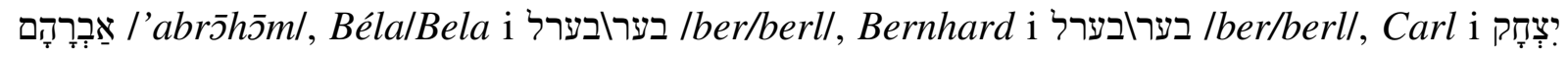

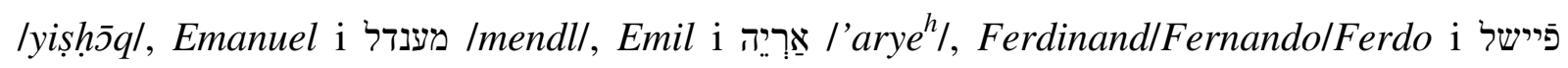

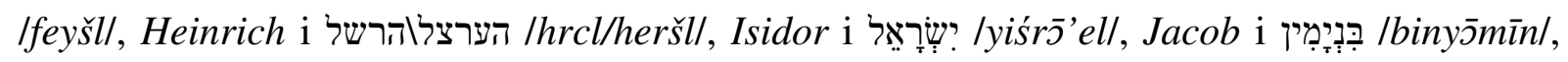

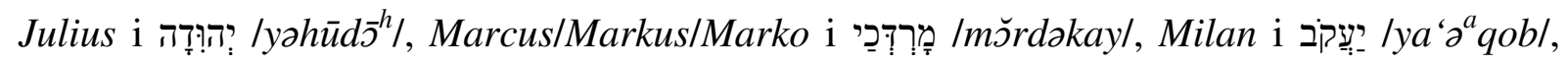

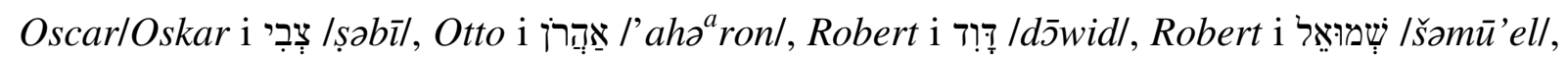

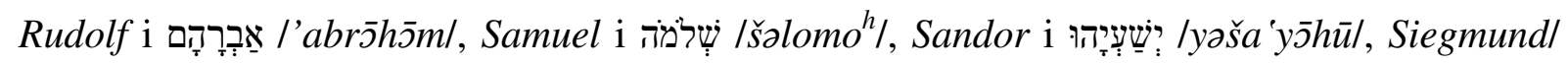

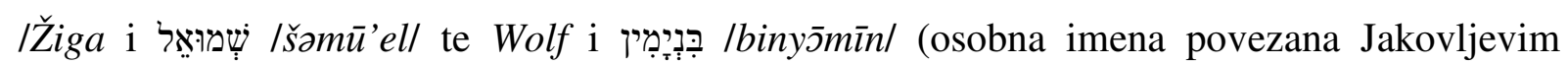
blagoslovom iz Post 49, 27).

Najčešće kombinacije građanskog i osobnog imena (Leopold i ליב /leyb/, Moritzl

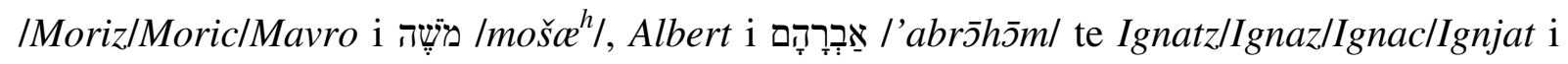

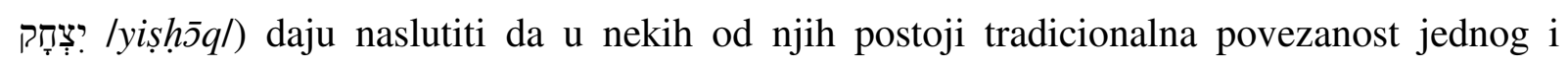
drugog osobnog imena, da nije riječ tek o pukoj slučajnosti.

Veza se između židovskog osobnog imena i onog građanskog u pravilu temelji na jednom od tri načela:

1. prijevodu

2. sličnosti plana izraza, često približnoj i uz slobodnu izmjenu homolognih suglasnika

3. vezi logičke ili homiletičke naravi proizašloj iz teksta Tanaha, poput već spomenutih Jakovljeve oporuke iz 49. poglavlja Knjige postanka i Mojsijeva blagoslova izraelskih plemena iz 33. poglavlja Ponovljenog zakona (Colorni 1983: 71).

Što se prijevoda tiče, vidjeli smo da se on temelji na pučkoj etimologiji koja prvi dio germanskih osobnih imena, pragermansko *leudi- 'čovjek, narod' tumači kao lat. leo i time ih

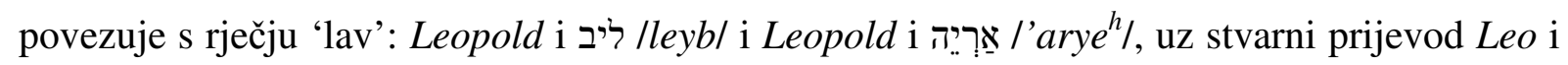
ליב /leyb/, te Bernhard, čiji je prvi dio tvoren od pragermanskoga *beran- 'medvjed', i I בער|בערל /ber/berl/. 
Znatno je više primjera spajanja osobnih imena na temelju sličnosti plana izraza, a posebice osobnih imena istog početnog slova/glasa, poput tradicionalnih parova Albert i

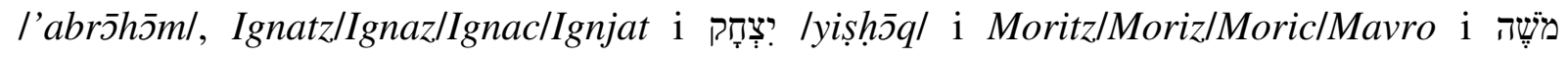

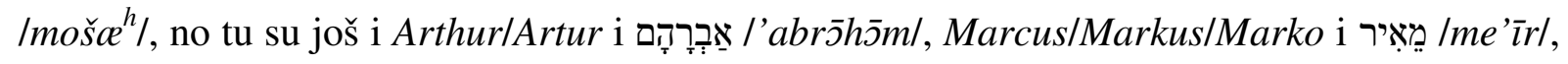

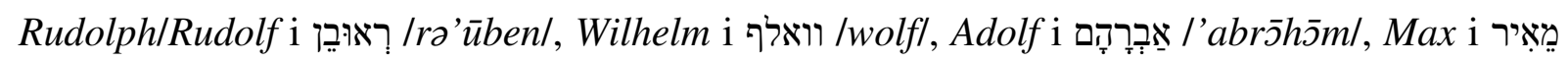

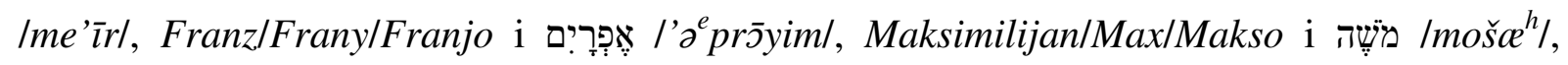

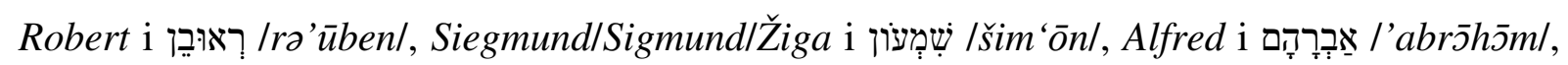
Béla/Bela i בערובערל/ber/berl/, Bernhard i בערובערל/ber/berl/, Emanuel i מענדל/mendl/,

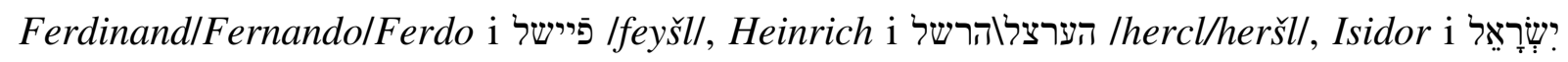

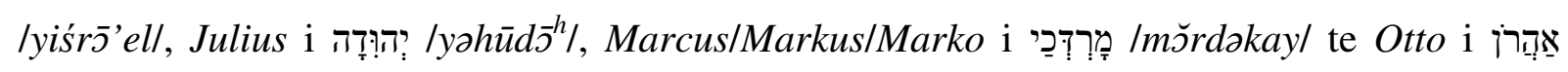

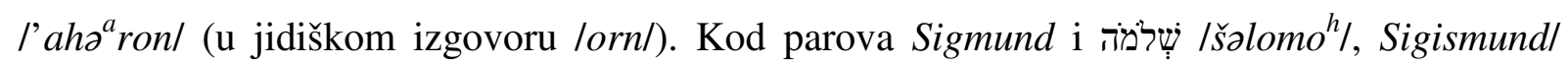

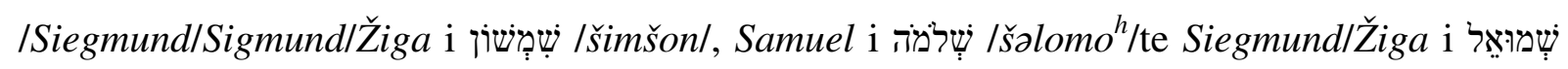
/šวmū'el/ možemo uzeti u obzir da sva navedena hebrejska osobna imena u kršćana počinju sa |s/ - Salomon, Samson i Samuel - baš kao i građanska. Slučaj para osobnih imena Heinrich i צִ̣ /ṣabīl kao da isto tako spada u ovu kategoriju, ako uzmemo u obzir da i Heinrich i jidiška inačica osobnog imena motiviranog jelenom - הירש /hirš/ - također počinju istim slovom.

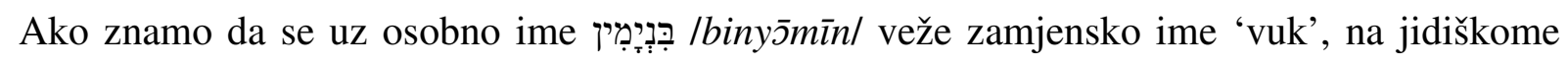
וואָָלף /wolfl, možda i tu možemo uspostaviti vezu istog početnog slova s osobnim imenom Wilhelm ${ }^{351}$.

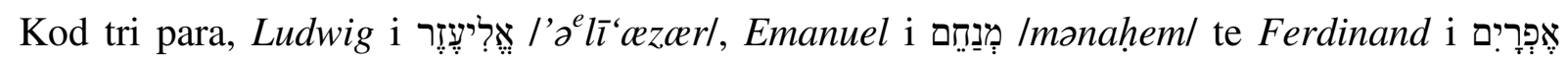
/’a prōyim/ nalazimo sličnost u planovima izraza, ali ne i u početnim glasovima: u prvom je slučaju /l/ prvi suglasnik u oba osobna imena, u drugom oba osobna imena dijele suglasnike $/ m /$ i $/ n /$, a u trećem $/ f /$ i $/ r /$.

Među parovima spojenima logikom iz navedenih dijelova Tore, Jakovljeve oporuke iz 49. poglavlja Knjige postanka i Mojsijeva blagoslova izraelskih plemena iz 33. poglavlja Ponovljenog zakona, dominiraju osobna imena vezana uz pojam 'lav', najčešće uz pučku

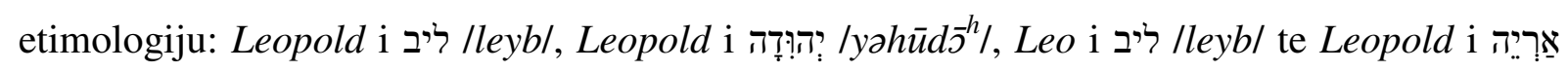

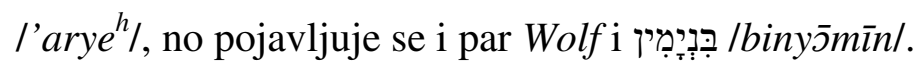

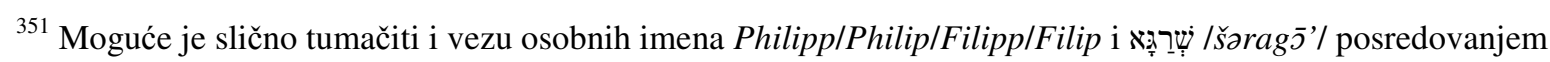
osobnog imena Feyvuš.
} 


\subsection{Dijakronijska analiza suodnosa čestih parova muških osobnih imena}

Pitanje koje se postavlja jest: je li suodnos određenog židovskog i određenog građanskog osobnog imena postojan u vremenu? Je li moguće dokazati da u relativno kratkom razdoblju kojim se bavi ovaj rad prvotno stabilne veze između dva osobna imena sve više slabe?

Odgovore ćemo potražiti na četiri najčešća para koji ujedno nisu i dvije različite inačice istog osobnog imena: Leopold i ליב אַבְרָהָם /leyb/, Albert /'abrh̄̄m/, Ignatz/Ignaz/Ignacl

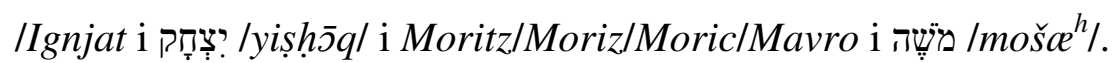

Kod osobnog imena ליב /leyb/ nalazimo zanimljivu situaciju u kojoj je popularnost osobnog imena dosegla vrhunac 1875. g. s drugim vrhuncem 1882. g. Kombinacija s osobnim imenom Leopold unutar razdoblja 1872. - 1882. g. u četiri navrata dostiže brojku od dva pojedinca godišnje (1872. g., 1875. g., 1879. g. i 1882. g.) dok je izvan tog razdoblja potvrđen najviše

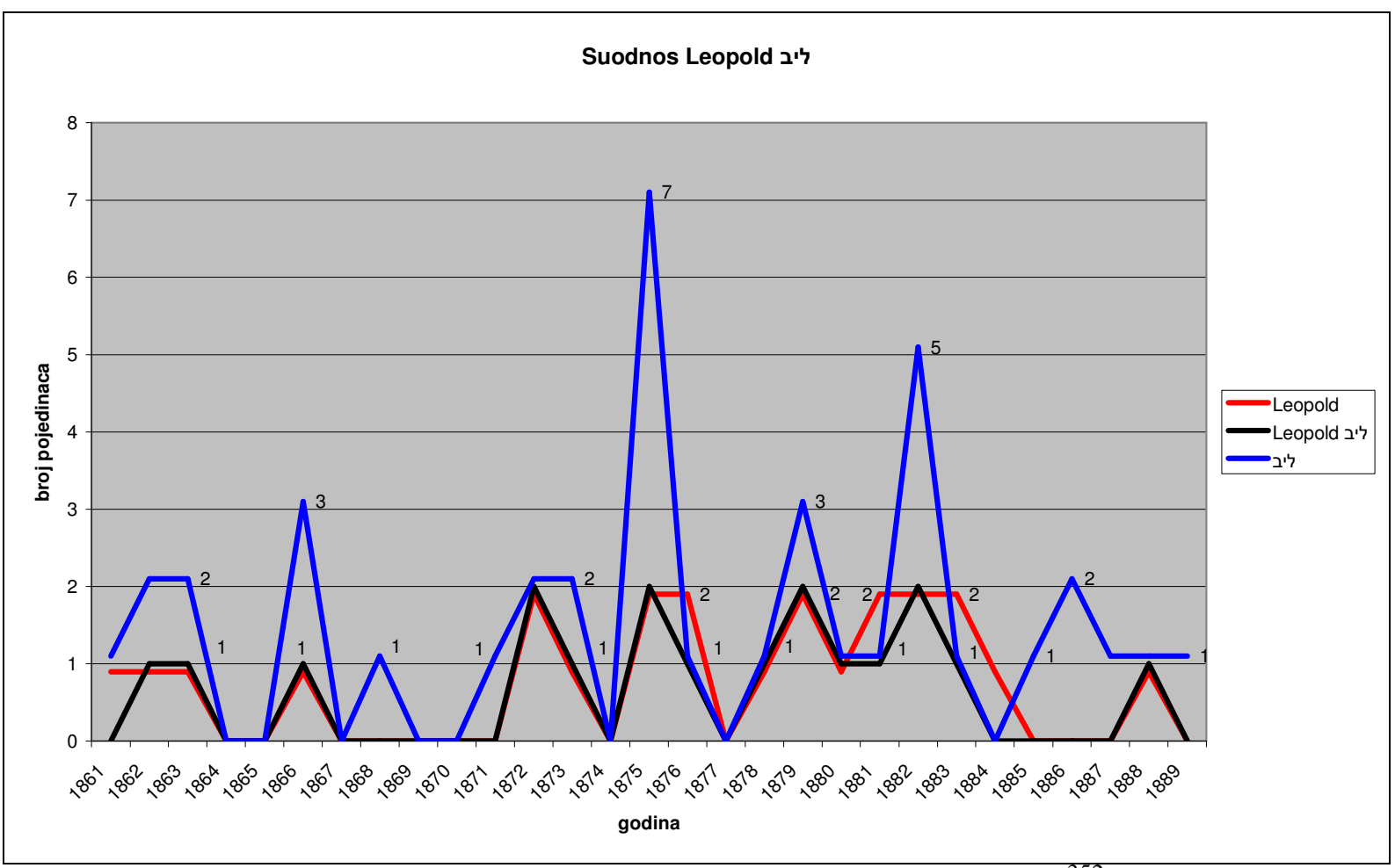

Slika 21: Suodnos osobnih imena Leopold $i$ ליב /eyb/ ${ }^{352}$

jedan pojedinac s tim parom osobnih imena. Samo se osobno ime Leopold tek u nekoliko godina pojavljuje bez židovskoga parnjaka ליב /leyb/ (1861. g., 1876. g., 1881. g., 1883. g. i

\footnotetext{
${ }^{352}$ Svi su grafikoni napravljeni s malim pomakom linija kako se one ne bi međusobno prekrivale.
} 
1884. g.). Nesumnjivo je jidiško osobno ime ליב /leyb/ bilo popularno tijekom cijelog promatranog razdoblja, znatno popularnije negoli bilo osobno ime Leopold samo bilo spoj ta dva osobna imena (slika 21).

U slučaju osobnog imena Albert, u korpusu ne nalazimo nijednog pojedinca toga osobnog

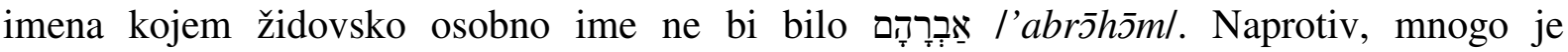
pojedinaca sa židovskim osobnim imenom אַבְרָָהָם /'abrōhs̄m/, čak 52, od kojih 36 ne nose građansko ime Albert. Iz podataka se stječe dojam da spoj osobnih imena Albert i אַבְרָָָם l'abrōhs̄m/ s vremenom slabi, jer više od jednog takvog para godišnje nalazimo samo 1859. i 1869. g., dok u 23 godine koje slijede nalazimo najviše jedan takav par godišnje. Ujedno je vidljivo da se u godinama 1882. - 1891. ne pojavljuje nijedan takav par. Kao i u prethodnom slučaju, i ovdje je židovsko osobno ime u cijelom promatranom razdoblju popularnije od građanskoga (slika 22).

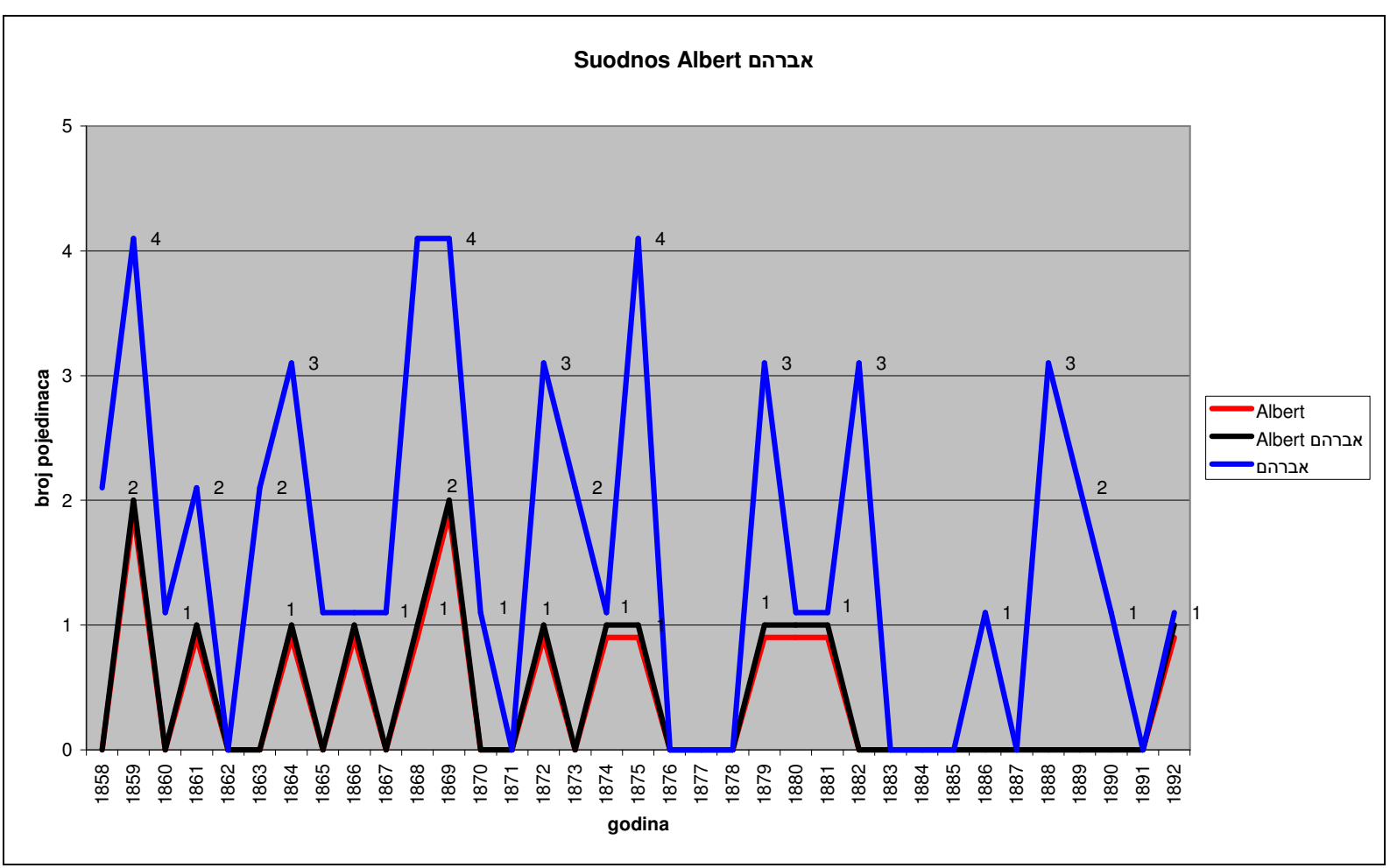

Slika 22: Suodnos osobnih imena Albert $i$ אבָרְ / abrōhōm/

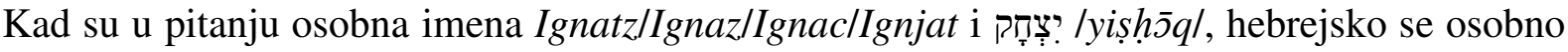
ime pokazuje učestalijim i od građanskoga i od njihova spoja. Godine 1872. zabilježena su

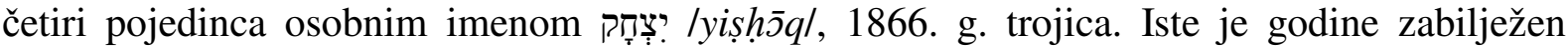


najveći broj pojedinaca nositelja obaju osobnih imena - dvije osobe. Poslije 1881. se g. ova kombinacija osobnih imena više ne pojavljuje (slika 23).

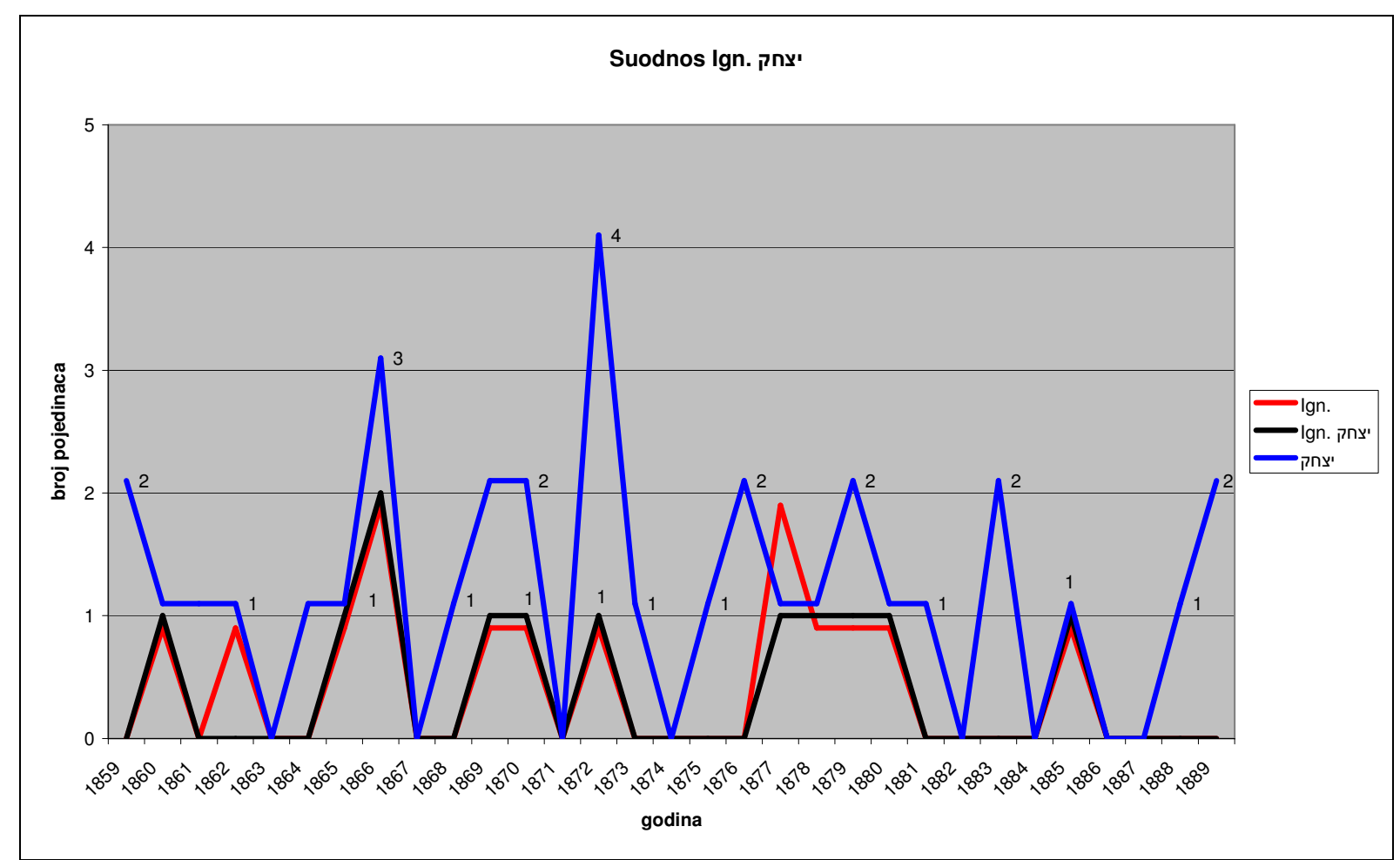

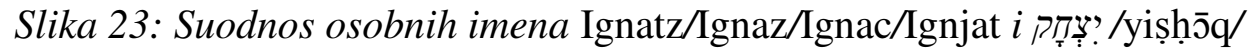

Četvrti par osobnih imena, Moritz/Moriz/Moric/Mavro i משֶֶ /moš $\mathfrak{c}^{h} /$, pokazuje dva relativna vrhunca u nadijevanju tog para, 1861. g. i 1882. g., no od 1884. g. ne nalazimo više nijednu takvu kombinaciju u korpusu. Hebrejsko je osobno ime popularnije od građanskoga, istih tih godina bilježimo po četiri pojedinca osobnog imena משֶֶ /mošce $e^{h} /$ (1861. su g. svi spareni s nekim od istraživanih građanskih osobnih imena.). Hebrejsko osobno ime doživljava još jedan manji vrhunac popularnosti 1878. g. Građanska se pak osobna imena, osim maksimuma od 4 pojedinca dosegnutog 1861. g., nikada ne pojavljuju više od jednom godišnje, osim 1882. g. kada su takvo osobno ime dobila dva pojedinca da bi od 1884. g. i samo nestalo iz korpusa (slika 24). 


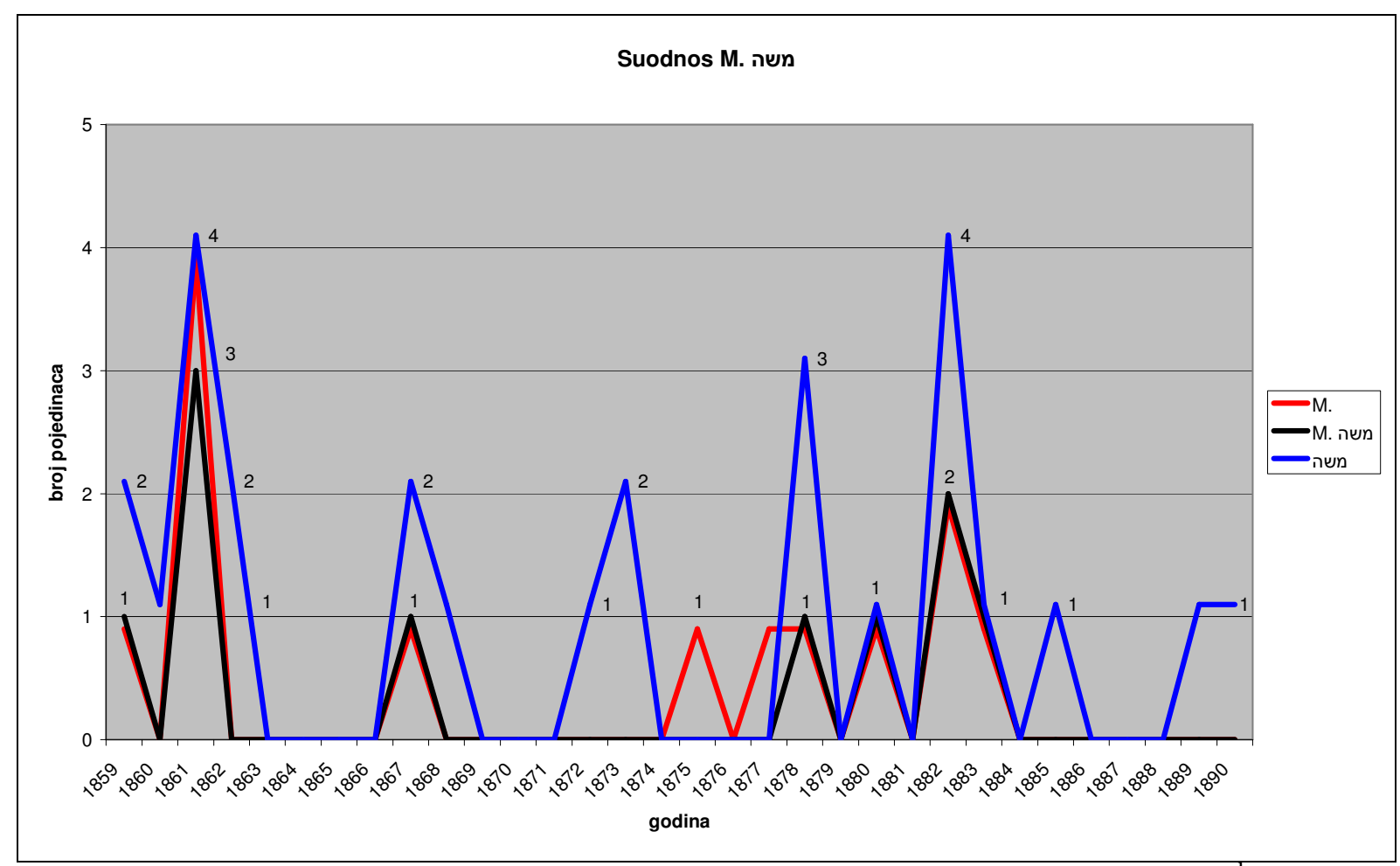

Slika 24: Suodnos osobnih imena Moritz/Moriz/Moric/Mavro $i$, מעׁ /mošæh/

Iz navedena četiri primjera možemo zaključiti da su obrasci spajanja građanskog i židovskog osobnog imena, ako su i postojali prije godina za koje imamo sigurne podatke, u promatranom razdoblju počeli slabjeti. Određeno se građansko osobno ime, doduše, skoro redovito veže s određenim židovskim, ali ne i obrnuto. U sva je četiri slučaja broj nositelja određenog židovskog osobnog imena uvijek bio veći od broja nositelja određenog građanskog osobnog imena. Moguće bi objašnjenje ove pojave moglo biti da je broj pogodnih židovskih osobnih imena uvijek bio manji od broja građanskih, da imamo suprotstavljene relativno zatvoreni skup prvih osobnih imena s jedne strane i otvoreni skup drugih, podložan vanjskim utjecajima, s druge. Nijedno osobno ime, bilo građansko, bilo židovsko, ne ostavlja dojam da izlazi iz mode.

I za kraj, primjer grafa koji prikazuje dijakronijsku čestoću svih osobnih imena povezanih s nazivom 'lav', bilo doslovnim značenjem, bilo pučkom etimologijom, uključujući i sve moguće kombinacije građanskog i židovskog osobnog imena (crnom bojom). Kao i na prethodnim dijagramima, i ovdje je vidljivo da su židovska osobna imena uglavnom popularnija i od građanskih, i od kombinacija jednih i drugih ili barem isto toliko popularna. Jedina je iznimka građansko osobno ime Leon, koje se 1875. g. nadijeva petorici pojedinaca, 
iste godine kad i židovsko osobno ime ליב /leyb/ dosiže svoj vrhunac od sedam nositelja (slika 25).

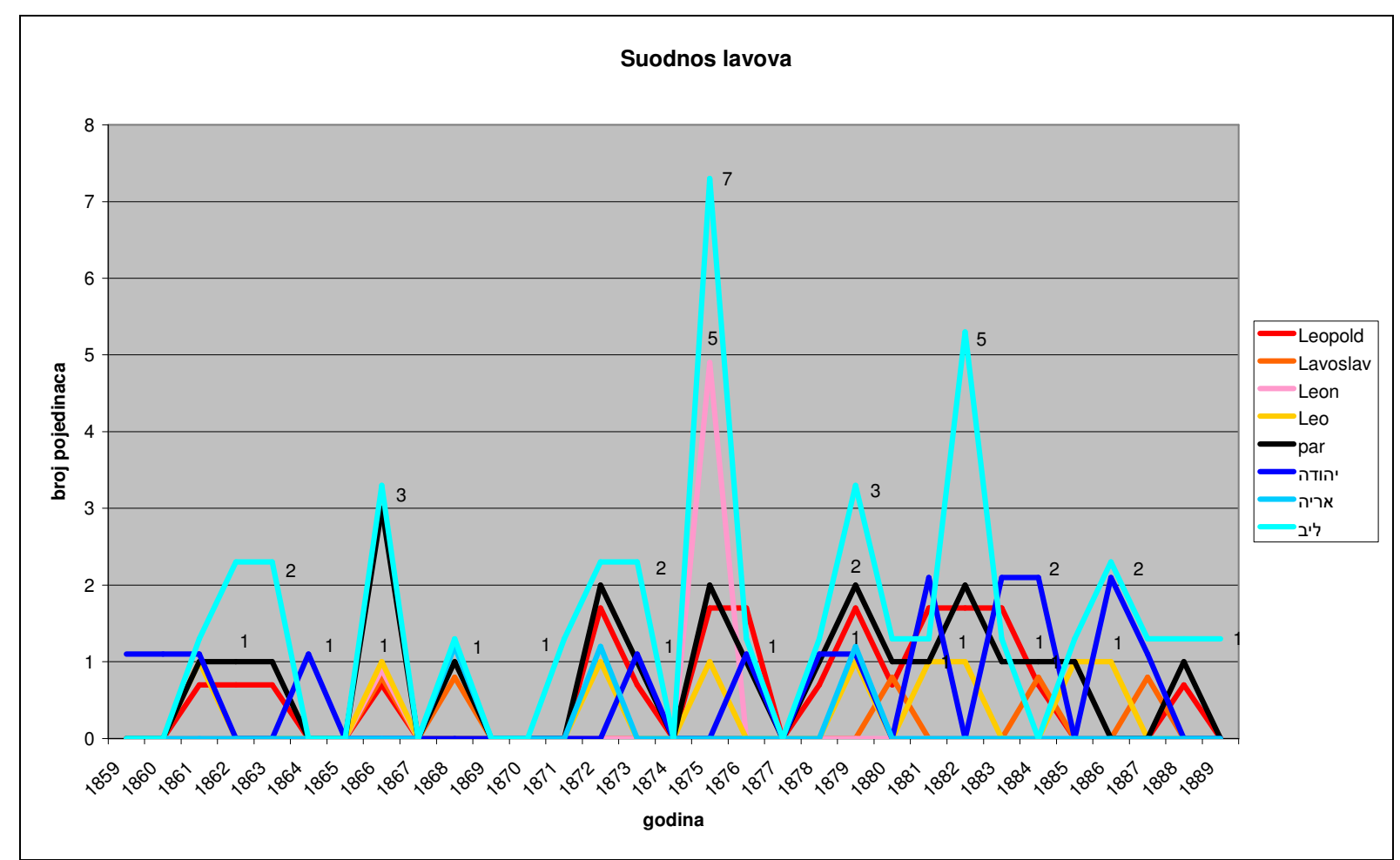

Slika 25: Suodnos osobnih imena povezanih motivacijom 'lav'

\subsubsection{Suodnos ženskog građanskog i židovskog osobnog imena}

I u ženā nalazimo parove osobnih imena koji se pojavljuju češće od drugih. Njihovi su brojevi, doduše, manji negoli u onih muških osobnih imena.

Jedini je par osobnih imena s dvoznamenkastim brojem nositeljica, njih 10, Marie/Marial /Marija i מִרְִ /miryj̄m/. I ovdje je riječ o dvjema inačicama istog osobnog imena, kršćanskoj i

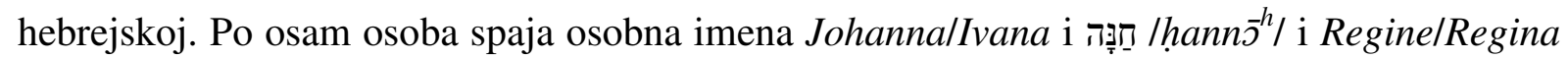

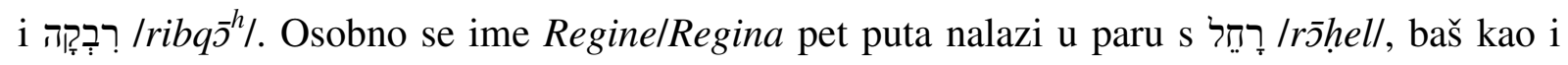
osobna imena Rosalia/Rosi/Ruža i רָָ /rōhell. Po četiri osobe nose osobna imena Johannal /Johana i הינדל /hindl/, Paola/Paula/Pauline i פערל /perl/ i Theres/Therese/Theresa/Theresiel /Terezija i רייזלוריזל/reyzl/. Tri osobe nose osobna imena Rosalia/Rosa i שרל /serl/. Preostaju

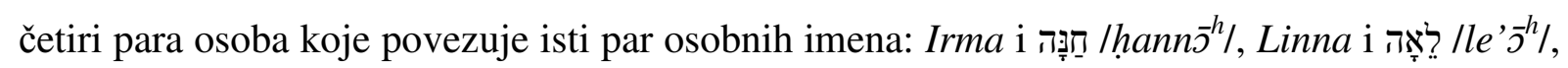

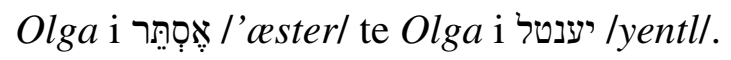


Od tri gorenavedena načela povezivanja određenog građanskog i određenog židovskog osobnog imena u ženskih nalazimo samo sličnosti plana izraza. Regine/Regina s jedne strane i

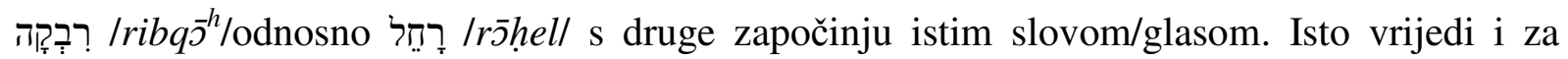

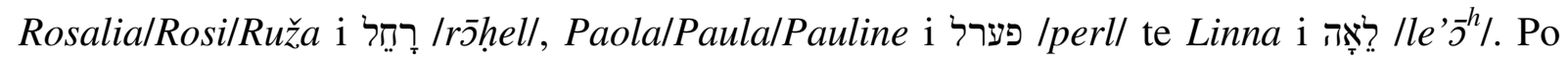

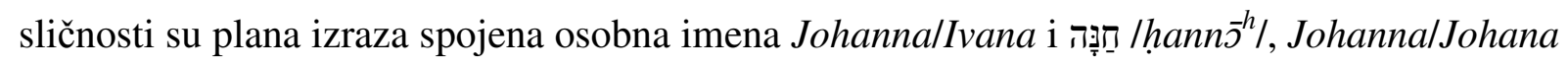
i הינדל /hindl/ (u oba slučaja suglasnici /h/ i /n/), Theres/Therese/Theresa/Theresie/Terezija i רייזלוריזל /reyzl/ (suglasnici /r/ i /z/ između kojih se nalazi bilo samoglasnik /e/ bilo dvoglas iste boje /ey/). Na taj bi se način čak mogla povezati i osobna imena Rosalia/Rosa i שרל /serl/ (oba imaju suglasnike /s/ i /r/, ali obrnutim redoslijedom, dok Rosalia ima i suglasnik /l/).

\subsection{Prezimena zagrebačkih Židova}

Za razliku od osobnih imena, koja su pojedinačna, prezimena su kolektivna. Prezimena ne identificiraju pojedinca kao jedinku, već kao dio kolektiva okarakteriziranog istim prezimenom (barem pri rođenju). Dok promjenom osobnog imena možebitno utječemo samo na percepciju sebe kao individuuma, promjenom se prezimena ograđujemo, otuđujemo od skupine kojoj smo njime pripadali. Osobna su imena pomodna, ulaze u modu i izlaze iz nje brzinom naraštaja, prezimena opstaju, uz eventualne pravopisne promjene koje donose nove epohe i nove vlasti.

Prezimena imaju tri važne značajke (Šimunović 2009: 167-168):

1. Stalna su, stabilna u vremenu, pa čak i u prostoru uz odgovarajuće fonetske i pravopisne prilagodbe novoj okolini.

2. Nasljedna su, predaju se $\mathrm{s}$ pokoljenja na pokoljenje u obiteljima, u porodicama te označavaju pripadnost pojedinca porodici.

3. Nepromjenjiva su i nezamjenjiva, nemaju značenja te se zbog buke u komunikacijskom kanalu ne mogu rekonstruirati iz konteksta.

Naravno, sve su tri navedene karakteristike uvjetne. Prezime je moguće zakonski promijeniti u neko drugo, nahočad nemaju od koga naslijediti prezime, a neka su prezimena dovoljno učestala i općepoznata da ih se teško može zamijeniti kojim drugim. To su tek ekstremne situacije dok za veliku većinu prezimena vrijede tri gorenavedene karakteristike. 
Prezimena su postanjem, a pogotovo svojom fiksiranošću u vremenu, mlađa od osobnih imena. Etiologija se prezimena dijeli u četiri moguća motiva.

1. genetsko podrijetlo (čiji si?), a prezimena koja daju odgovor na to najčešće su patronimna (izvedena od osobnog imena oca, rodonačelnika), rjeđe metronimna (izvedena od osobnog imena majke, rodonačelnice)

2. opis (kakav si?), podrijetlom najčešće nadimak koji ukazuje na neku osobinu rodonačelnika

3. zemljopisno podrijetlo (odakle si?). Ono nastaje kao posljedica seoba poslije kojih je novog naseljenika bilo najlakše prepoznati i opisati po mjestu odakle je došao

4. zanimanje (čime se baviš?), obrt kojim se bavio rodonačelnik, a koji se u pravilu nasljeđivao s oca na sina.

Kod svih je tih motivacija najvažnije bilo pojedinca nečim izdvojiti iz okoline (Šimunović 2009: 170-171).

Kad skrenemo pogled s hrvatskih prezimena na ona židovska, poglavito aškenaska, jidiška, s jedne strane vidimo da je najveći broj židovskih prezimena izveden od osobnih imena i njihovih izvedenica, da su ona izvedena od toponima rjeđa, a da su još rjeđa ona izvedena od naziva zanimanja ili biblijskih odnosno rabinskih hebrejskih sintagama, dok s druge strane nalazimo i neke druge njihove izvore (Guggenheimer H. W. i Guggenheimer E. H. 1992: xi).

Edwin D. Lawson izvore židovskih prezimena dijeli u sedam kategorija (Lawson 2005):

1. osobna imena iz Tanaha

2. patronimi

3. prezimena izvedena od zanimanja

4. prezimena izvedena od zemljopisnog podrijetla

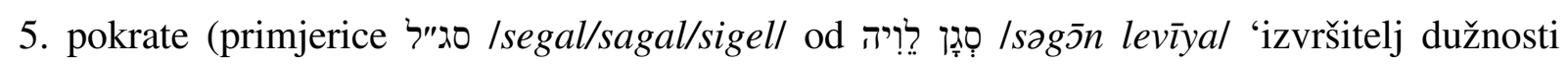

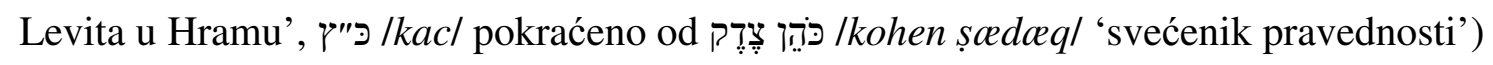

6. prezimena koja su nametnule vlasti

7. ostala prezimena (simbolična, bogonosna, metronimi,...)

Mnoga su židovska osobna imena postala prezimenima bez oznake da je riječ o patronimu ili metronimu. Takva prezimena nalazimo i u našem korpusu. Druga su pak podrijetlom zamjensko ime u smislu osobnog imena (ili više njih) pod kojim je pojedinac poznat izvan uobičajene formule $X$ sin/kći $Y$ - $a$. I ona se uglavnom pojavljuju bez afikasa kojima se tvore patronimi/metronimi. 
Uz zamjenska je imena u smislu onih iz Jakovljeve oporuke i Mojsijeva blagoslova vezana i kategorija prezimena nastalih konverzijom od naziva za životinje, tipična za Aškenaze.

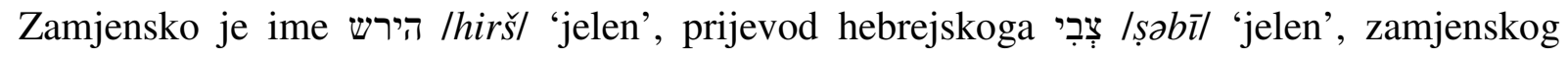

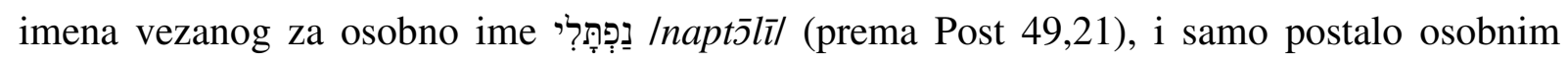
imenom (te je moguće da i ono ima svoje zamjensko ime), da bi na kraju, često transkribirano njemačkom grafijom kao Hirsch, postalo prezimenom. Osim njega su takav razvojni put prošli i već navedeni Loeb, Leib 'lav' (njem. Löwe) za osobno ime יה:? /yahūd $\bar{\nu}^{h} /$, Drach

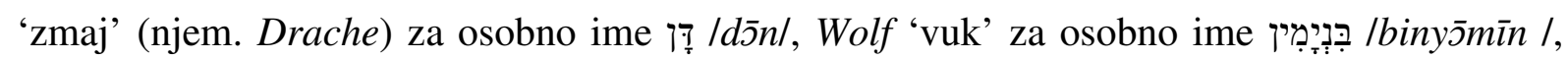

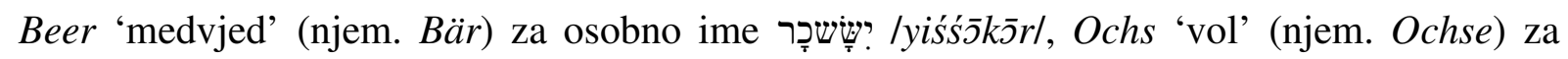

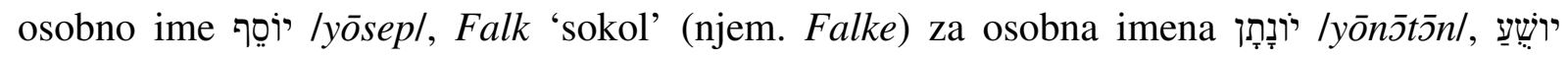

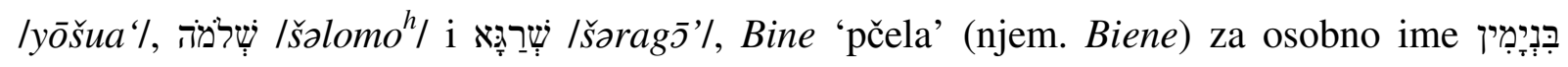

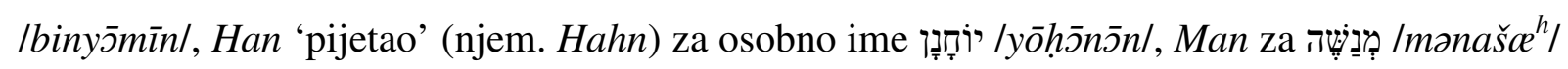

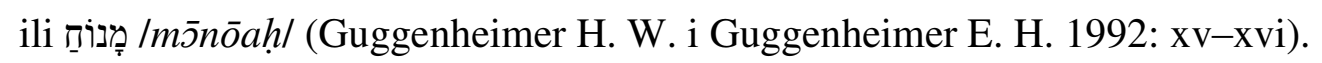

Kad je riječ o aškenaskim prezimenima nastalima iz naziva zanimanja rodonačelnika ili njegova zemljopisnog podrijetla, valja biti vrlo oprezan. U korpusu prezimena s toga područja ima dosta njih koja sliče prezimenima takvog podrijetla, ali sama nužno ne moraju biti takvima. U srednjovjekovnoj je Europi polje zanimanja dostupno Židovima bilo vrlo skučeno, a izvan države Jagelovića židovski cehovi nisu postojali. Već je spomenuto da je nadimak Schreiber 'pisar' bio pripisan Mojsiju, te je i prezime vjerojatnije izvedeno od toga nadimka negoli iz činjenice da je rodonačelnik bio pisar po zanimanju. Heinrich W. i Eva $\mathrm{H}$. Guggenheimer navode kako je sličan slučaj i s prezimenima Becker 'pekar', Kassirer 'blagajnik' i Wagner 'izrađivač kočija, kočijaš', čije podrijetlo treba tražiti u pokraćenim likovima osobnih imena Bak, Kas i Vaag, dok prezimena poput Kupferschmidt 'kotlar' i Goldschmidt 'zlatar' vjerojatno ipak predstavljaju izvedenice iz Kupper, zamjenskog imena

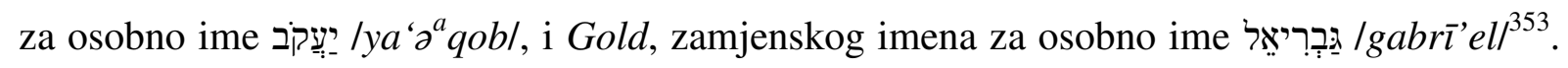
Kad su u pitanju toponimi i iz njih moguće izvedena prezimena, prvo treba dokumentima dokazati da je u mjestu dotičnoga imena uopće postojala židovska zajednica. I prezimena koja izgledaju kao da su nadjenuta prema mjestu podrijetla mogu biti izvedena od pojedinih osobnih imena. Tako Heinrich W. i Eva H. Guggenheimer smatraju da je vjerojatnije da

\footnotetext{
${ }^{353}$ Kao što zlatna boja simbolizira arhanđela osobnim imenom הַבְרִיאֵל /gabrīe el/, srebrna simbolizira onoga

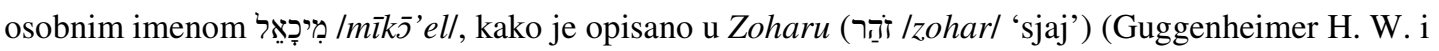
Guggenheimer E. H. 1992: xvii).
} 
prezime Frankfurter upućuje na osobno ime Frank, zamjensko ime za osobno ime /'œeprȳyim/, negoli na grad na Majni u kojem je bila smještena vodeća židovska zajednica toga doba, a još manje na drugi grad na Odri u kojem je Židovima bilo zabranjeno zadržavati se noću ${ }^{354}$. Oni navode još primjera: Engländer od Engel, zamjensko ime za osobno ime Imal' ’kkil 'moj poslanik' /lappīdōt/ 'baklje' ${ }^{356}$, Berlin, umanjenica od Berl 'medvjed', zamjenskog imena za osobno

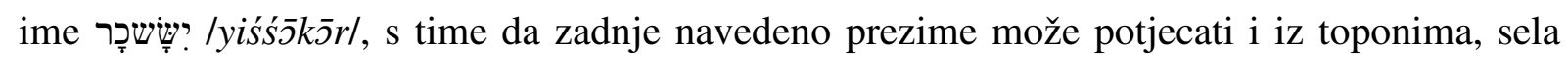
Barlin pored Broda u Galiciji. S druge strane, pišu dalje oni, pouzdano znamo da su u Schottlandu, predgrađu Gdanjska, i u Preussisch-Hollandu u istočnoj Pruskoj krajem XVII. st. obitavale zajednice Židova, te bi prezimena Schottländer i Holländer mogla biti zemljopisnog podrijetla, ali ne i odnositi se na Škotsku odnosno Holandiju. Prezimena izvedena od imena naselja s malim židovskim zajednicama doista jesu zemljopisnog podrijetla. Ako toponim pritom uz »službeno« ima i znano ime na jidišu, sumnje praktički nema. Za primjer možemo uzeti ojkonim Sachsenhausen u Hessenu nedaleko Frankfurta na Majni, čije jidiško ime glasi

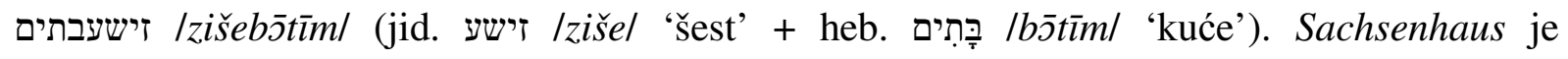
potvrđeno židovsko prezime. Prezimena s osnovom Kis(s)- (Kisinger, Kiser, Kisin, Kisler, Kislin, Kisslinger, Kisman, Kisner) mogu potjecati iz grada Bad Kissingen, ali samo ako se može dokumentirati da dotična porodica potječe iz toga mjesta. U svim drugim slučajevima moguće je i izvođenje iz zamjenskog imena Kisl za osobno ime יחזֶ? /yahazzaqe'll ili iz

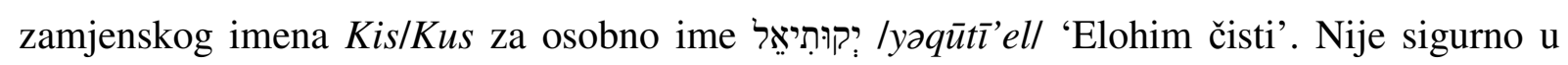
kojem smjeru teku veze između naziva kuća (iz doba kad kuće još nisu imale brojeve) i prezimenā, jesu li prvo nastali prvi ili druga (Guggenheimer H. W. i Guggenheimer E. H. 1992: xviii-xxi). Na području prezimena izvedenih iz toponima ostaje još dosta nedovoljno istraženih prezimena koje motivaciju vuku iz zemljopisnih lokacija iz antike (Lawson 2005).

Međutim kao što i sami autori navode dalje u tekstu (Guggenheimer H. W. i Guggenheimer E. H. 1992: xxvi-xxvii), postoji uobičajen skup većinom poetskih sufikasa kojima se tvore patronimi i metronimi: -baum 'drvo', -bein 'kost' ${ }^{357}$, -berg 'brdo', -blatt 'list', -er, -feld

\footnotetext{
${ }^{354}$ Ovakvo je tumačenje malo vjerojatno s obzirom na to da -furter ne predstavlja nikakav produktivan patronimski sufiks.

${ }^{355}$ Mal 1,1. U transkripciji Antuna Sovića: Malahija.

${ }^{356}$ Suci 4,4. U transkripciji Antuna Sovića: Lapidot.

${ }^{357}$ Ovaj sufiks planom izraza nalikuje hebrejskoj riječi takvu vezu između dvije riječi.
} 
'polje', -heim 'dom', -kin(d) 'dijete', -man(n) 'čovjek', -so(h)n 'sin', -stam(m) 'stabljika, deblo, soj', -stein 'kamen',358, -stern 'zvijezda', -tal 'dolina', -zweig 'grana'. Svi su oni produktivni sufiksi koje je moguće naći u više različitih prezimena. $S$ druge strane, sufikse -furter (iz Frankfurter) ili pak -inger (iz Kissinger) ne nalazimo među njima. Čak su i sufiksi -schild 'štit' i -schmidt 'kovač, obrađivač kovina' sumnjivi jer je prvi uglavnom vezan za pojedine boje (primjerice Rotschild), a drugi za metale (npr. Kupferschmidt, Goldschmidt) te je moguće da su se prvim označavale obitelji koje žive u pojedinoj kući (onoj obilježenoj crvenim znakom), a drugim potomci obrtnika koji su obrađivali kovine (bakar odnosno zlato). Problem je s nekima od navedenih sufikasa i u tome što među njima i onih koji označavaju i toponime (npr. -berg 'brdo', -stein 'kamen', -tal 'dolina'), dok se sufiks -er koristi i u tvorbi etnika.

Vittorio Colorni, pišući o vremenima koja prethode onom iz ovog istraživanja, navodi primjere dvojnosti židovskih prezimena, koja zrcale dvojnost njihovih osobnih imena - uz građansko prezime supostoji i židovsko, pri čemu je ono prvo često prijevod drugoga (Colorni 1983: 83-86). U korpusu se obrađenom u okviru ovog rada, međutim, takva dvojna prezimena ne pojavljuju.

U domeni proučavanja židovskih prezimena nema toliko radova koliko ih je kad su u pitanju židovska osobna imena.

\subsubsection{Statistička analiza prezimenā}

Nije tako jednostavno odrediti čestoću prezimena kao što je to bio slučaj s osobnim imenima. Nije teško uvidjeti zašto je tomu tako. Osobna imena nose pojedinci, a njih nije teško izbrojati. S druge strane, prezimena nose obitelji i cijele porodice ${ }^{359}$, a njih je teško pobrojati, već i stoga što nije lako odrediti granicu gdje prestaje obitelj, a počinje porodica, jer se članovi pojedinih obitelji osamostaljuju i zasnivaju svoje obitelji, neke zadržavajući prvotno prezime, a druge s novim prezimenom. Ništa lakše nije niti odrediti gdje prestaje jedna porodica, a počinje druga istog prezimena.

\footnotetext{
${ }^{358}$ Heb. צוּ / צִ̣̄r/ 'kamen' je jedna od riječi kojom se označava Boga.

${ }^{359}$ Riječju obitelj smatram sve one koji obitavaju u jednom domaćinstvu, dok riječju porodica držim sve osobe koje su vezane rodbinskim vezama. Porodica se tako najčešće sastoji od više obitelji.
} 
Idealno bi bilo prebrojiti porodice istog prezimena, no njihov je točan broj iz dostupnih nam podataka teško ako ne i nemoguće utvrditi. Stoga ćemo čestoću pojave prezimenā istražiti po pojedinim izvorima.

\subsubsection{Knjiga Povijest zagrebačke židovske općine od osnutka do 50-tih godina 19. vijeka Gavre Schwarza}

Gavro Schwarz u svojoj knjizi navodi 9 obitelji popisanih 1808. g. u gradskoj jurisdikciji, 8 obitelji popisanih 1812. u biskupskoj jurisdikciji, 57 obitelji popisanih 1840. - 43. g. te 59 obitelji popisanih prema konskripciji 1858. g., ukupno, dakle 133 obitelji.

U svim je tim popisima najviše obitelji s prezimenom Stern, 15 njih (od njih jedno s dva prezimena, Stern i Zvijezdić), dok prezime Schwarz nosi 14 njih. Slijedi prezime Weiss s 8 obitelji (njima se vjerojatno može dodati i obitelj Weihs ${ }^{360}$ ). Prezimena Epstein i Spitzer nosi po 6 obitelji. Četiri je obitelji Deutsch, a ako se zbroje obitelji s prezimenom Fischer (3) i Fisher (1), također dobivamo 4 obitelji. Po 3 obitelji nosi prezimena Bresslauer, Hirsch, Palotta, Dachs i Stiegler. Slijedi niz prezimena s po 2 obitelji-nositeljice: Fürst, Hertmann, Klein, Löbl, Müller, Ornstein, Pick, Prister i Schlesinger, dok su sva ostala prezimena zastupljena u po jednoj obitelji: Aleksander, Angelus, Bauer, Baumgärtner, Betlheim, Blum, Braun, Brill, Cohen, Ehrenreich, Eichner, Eiland, Eisen, Erlih, Figatner, Fisher, Fleischmann, Frankl, Friedländer, Goldzieher, Granitz, Guthardt, Hartmann, Heimbach, Heksch, Herschl, Hirschler, Hochstätter, Hofmann, Holzmann, Hönigsberg, Kahn, Kaufmann, Khon, Khroh, Kohn, Kolmar, Krakauer, Kremsir, Langraf, Löffler, Löwy, Maceljski, Moses, Naschitz, Neuberger, Neufeld, Oswald, Pulzer, Rosenberg, Rosenfeld, Rosenzweig, Rotter, Sauerbrunn, Schönstein, Schuller, Schweizer, Segen, Siebenschein, Singer, Sisman, Spirer, Stegler, Steiner, Sternberg, Sulcbach, Veiszer, Weihs, Wellisch, Wolf i Zaghaft $^{361}$.

\footnotetext{
${ }^{360}$ Moguće da je riječ o omašci i da prezime ustvari glasi Weiss jer u pismu Sütterlin (rukopisna gotica) dočetna kombinacija $s s<f \circ>$ sliči onoj $h s<g \circ>$.

${ }^{361}$ Za jednog pojedinca (1) nije poznato prezime, već samo osobno ime Samson.
} 


\subsubsection{Matične knjige rođenih}

U matičnim knjigama rođenih Židova za godine 1849. - 1898. (osim 1857. g.) pojedine obitelji možemo prepoznati po osobnim imenima i prezimenima oca i majke pojedinaca. Tako dobivamo 803 obitelji. Prezimena, međutim, nisu dosljedno bilježena te nalazimo dublete, pa i triplete. Tomu treba dodati i raznoliko navođenje nekih prezimenskih sufikasa poput -berg/ /-berger ili pak njihovo potpuno odbacivanje u pojedinim slučajevima te nedoumice oko pisanja geminata uobičajenih u njemačkom jeziku, ali ne i u jidišu, a isto vrijedi i za prijeglašene samoglasnike i slogotvorne sonante. Različita su pisanja istog prezimena $u$ popisu koji slijedi zanemarena.

Najviše obitelji, 31, nosi prezime Weis/Weiß/Weiss/Weisz, slijede prezimena Schwarc/ /Schwartz/Schwarz/Svarz s 26 obitelji, Stern s 25 obitelji, Kohn s 20 obitelji, Deutsch i Hirschl/Hiršl s po 18 obitelji, prezime Spicer/Spitzer s 14 obitelji, prezime Rosenberg/ /Rosenberger s 13 obitelji, prezimena Neuman/Neumann i Steiner s po 12 obitelji te prezimena Alexander i Miller/Müller s po 10 obitelji. Po 9 obitelji nosi prezimena Berger, Fischer, Klein i Singer, po 8 obitelji prezimena Eisenstädter i Fürst, po 7 obitelji prezimena Loev/Löw/Löwi/Löwy, Pollak, Rendeli/Rendely i Weinberger, po 6 obitelji prezimena Friedman/Friedmann, Heinrich i Schlesinger, po 5 obitelji prezimena Braun, Fried, Hoenigsberg/Hönig/Hönigsberg, Kraus/Krauss/Krausz, Priester/Prister, Sachs i Steinhardt/ /Steinhart, po 4 obitelji prezimena Abeles, Betlheim/Bettelheim, Büchler, Friedländer, Hochstädter/Hochstaedter, Hoffman/Hofman/Hofmann, Langraf, Majer/Mayer, Moskovićl IMoskovitz, Rechnitzer, Rückländer/Rükländer, Schwabenitz, Stärk/Sterk i Weiser, po 3 obitelji prezimena Adler, Altstädter, Bacharach/Bachrach, Beck, Blum, Frankel/Frankl, Freund, Fröhlich, Graf, Grünwald, Haas, Herlinger, Herrenstein/Herrnstein, Hertmann, Heumer, Hirschler/Hiršler, Karpeles, Kauders, Kaufman/Kaufmann, Kornfein, Kornitzer, Kronfeld, Leitner, Lineberg/Lineberger/Linenberg/Linneberger, Mautner, Neuberg, Pick/Pik, Salamon/Sallomon/Salomon/Solomon, Schön, Schwarzenberg i Wohlmuth, po 2 obitelji prezimena Berndorfer, Bernstein, Biller, Blau, Brodjovin/Brodjowin, Bruckner/Brücknerl /Brükner, Brumlik, Budlovski/Budlovsky/Budlowsky, Diamandstein/Diamantstein, Donner, Ehrlich, Eisner, Freiberger, Fritz, Goldman/Goldmann, Goldschmied, Granitz, Grünbaum, Grünfeld, Haberfeld, Hacker, Herman/Hermann, Herzer, Hirschman/Hirschmann, Hoenigsfeld/Hönigsfeld, Kastel/Kastl, Kell, Kremsir, Lausch, Lazansky/Lažansky, Lederer, Lustig, Mailänder, Mandler, Moises/Moses, Oswald/Osvald, Palota/Palotta, Pulzer, Reich, 
Reicher, Reichl, Rosenfeld, Schweitzer/Schweizer, Segen, Siebenschein, Slovak, Spiegler, Spiller/Spieller, Stöger, Straus/Strausz, Taußig/Taussig, Weiler/Weiller, Wolkenfeld i Wortmann, dok sva preostala prezimena nosi po jedna obitelj: Alt, Altmann, Amslberg, Angelus, Apller, Armuth, Ausch, Ausländer, Ausspitz, Baar, Baneth, Basch, Batjani, Bayer, Behrmann, Benedek, Benedikt, Benjamin, Bergel, Bichler, Bondy, Bornstein, Boskovitz, Breslauer, Breyer, Broch, Buchbinder, Buschitzki, Chalof, Daniberg, Deucht, Deutschberger, Dobrin, Drucker, Dub, Dukesz, Ehrmann, Eichner, Engländer, Englesrath, Erdinger, Feder, Fein, Feldmann, Fiedelhaar, Figatner, Fischbein, Fischl, Flesch, Fonfeder, Freistädtler, Friedrich, Friem, Frieß, Fuchs, Geiger, Gelb, Gewöll, Glesinger, Glück, Glücks, Goldhammer, Goldzieher, Gottfried, Gottlieb, Grillo, GroskopflGrosskopf, Grubić, Grünhüt, Guthard/Guthardt, Gutmann, Hafner, Hahn, Hamburger, Hecht, Heidenfeld, Heim, Heiman/Heimann, Heimbach, Helfer, Heller, Hertz, Herzel, Herzfeld, Heßel/Hessel, Hirth, Hochsinger, Hohenberg, Holzmann, Horšetzky, Hübscher, Israel, Jacobi, Jeck, Jungwirth, Kahn, Kantor, Kaufer, Keiser, Kemeny, Kern, Khan, Kikinis, Kollmann, Košarak, Kovač, Kozitschek, Kraut, Kron, Kun, Kunić, Lakenbach, Lang, Löbl, Luka, Lušicki, Luzzatto, Markus, Mattersdorfer, Metzl, Milhofer, Mosinger, Münz, Naschitz, Neuberger, Neufeld, Novak, Oblat/Oblatt, Oesterreicher/Österreicher, Ornstein, Peerlfaster, Pessek?, Polaček, Rabenstein, Rákosi/Rákoši/Rakoši, Redlich, Reichenthal, Reiner, Reisner, Reiss, Richtmann, Rosenbaum, Rosner, Rosskorn, Rothschild/Rotschild, Rothstein/Rotstein, Roubiček, Saltzer/Salzer, Salzberger, Sattler, Satz, Sauerbrun/Sauerbrunn, Scheiber, Scheibner, Scherpner, Schlomm, Schmerz, Scholler, Schönstein, Schulz, Silberstein, Sitzer, Sohr, Sommer, Somogyi, Sonnenberg, Spielmann, Spira, Spitz, Stedri/Stedry, Stein, Steindler, Stiegler, Straßberger, Strümpfter, Süsmann/Sißmann/Süssmann/Süßmann, Sussmann, Szattler,

Szende, Szender, Szeniczei, Šorš, Tänzer, Tauber, Tausk, Veith, Waldhauser, Waltersdorfer, Wasserlauf/Wasserlauf, Wasserthal, Weintraub, Wellisch, Weltner, Werner, Wertheimer, Wiener, Wittler, Wolf, Wollak, Zaloscer, Zierer i Zirner.

\subsubsection{Izraelitski odjel zagrebačkog groblja Mirogoj}

Na izraelitskom se odjelu groblja Mirogoj grobnice mogu grubo podijeliti u dvije skupine: obiteljske grobnice, koje katkad zauzimaju više od jednog grobnog mjesta, i grobnice u kojima su pokopani pojedinci koji nisu nužno povezani obiteljskim ili rodbinskim odnosima. Stoga će analiza čestoće prezimena u ovom slučaju biti podijeljena u dvije odvojene analize: 
analiza čestoće prezimena na obiteljskim grobnicama te analiza čestoće prezimena na grobnicama drugog navedenog tipa.

Među obiteljskim grobnicama najviše je onih obitelji prezimena Schwartz/Schwarz/Švarc, njih 22, a slijede Weiss s 18 grobnica, Dajč/Deutsch/Maceljski/Njemčić sa 17 grobnica, Neuman/Neumann s 11 grobnica te Kohn, Müller/Mueller i Spitzer/Špicer s po 10. Na 9 obiteljskih grobnica se nalazi prezime Hirschl/Hiršl, na po 7 prezimena Fischer/Fišer, na po 6 prezimena Mayer, Pick, Steiner i Stern/Štern, na po 5 Aleksander/Alexander/Alexander Sesvetski, Bauer, Grünwald/Grunwald, Hirschler/Hiršler, Kronfeld, Lederer, Polak/Pollak/ /Poljak, Prister i Schlesinger, na po 4 prezimena Berger, Herman/Hermann/Herrmann, Kardoš, Klein, Kraus, Rechnitzer, Singer i Weinberger, na po 3 prezimena Breyer, Ebenspanger/Ebenšpanger, Eisner, Frank, Freund, Friedman/Friedmann/Fridman, Haas, Hoenigsberg/Hönigsberg, Jelinek/Jellinek, Jungwirth/Jungvirt, Katz, Kolmar, Lustig, Rosenberg, Schrenger/Šrenger, Schwabenitz i Ungar, na po 2 prezimena Adler, Bachrach, Basch/Bǎ̌, Baumgartner, Blau, Blitz, Bornstein, Bresslauer, Brichta/Brihta, Brodman/ /Brodmann, Bruckner/Brukner, Büchler/Bihler, Deucht, Dresner, Eisenstädter/Eisenstaedter/ IAjzenšteter, Epstein, Fischel/Fischl, Fodor, Fröhlich/Frelić, Fuchs, Fürst, Goldberger, Goldstein, Gorjan, Gostl, Gross, Guttmann, Hafner, Hahn, Herlinger, Kabiljo, Kaiser, Kastl, Kaufman, Kaufmann, Kis/Kiš, Koranić, Kornfein, Kuh, Lausch/Lauš, Leitner, Licht, Lieberman/Liebermann, Lövy/Löwy, Moster, Oswald/Osvald, Podvinetz/Podvinec, Pressburger, Reich, Rendeli, Richter, Roman, Sachs, Salzer, Schmidt/Šmit, Schön i Schuster, dok se sva ostala prezimena mogu naći samo na po jednoj obiteljskoj grobnici: Abramović, Ackermann, Aksebrad, Albahari, Altschul, Angelus, Arnstein, Ašner, Ausch/Auš, Auspitz, Ausuebel, Axelrad, Baraksandić, Baran, Baum, Bayer, Beck, Beer, Behr, Behrmann, Benedik, Berkovits/Berkovitz, Bernstein, Betlheim, Biermann, Blivajs, Bondi, Bonyhadi, Braun, Brodjovin, Buhvald, Cegledi, Donner, Dragoner, Drucker, Ehrenfreund, Ehrlich, Eichhorn, Engel, Ernst, Eškenazi, Fajgenbaum, Färber, Farkaš, Fein, Feldbauer, Feldman, Figatner, Fischbach/Fišbah, Fischbein, Fischler, Fišter, Fleischman, Flesch, Friedfeld, Friedrich, Frisch, Frommer, Fussman, Gaon, Gavrin, Geiger, Geyduschek, Glaser, Glesinger, Glück, Goldfinger, Goldscheider, Goldschmidt, Gradečak, Graf, Graner, Granitz, Granski, Grossmann, Grünfeld, Grünhut, Haberfeld, Hajon, Heisler, Heršković, Hertmann, Herzer, Herzl, Herzog, Heumer, Hirsch, Hochsinger, Hochstädter, Hoffmann, Huber, Jacobi, Karpati, Kassowitz, Kaufner, Kell, Kern, Keršner, Kirschner, Klingenberg, Knežić, Koen, Kollman, Kortin, Krasso, Kremzir, Kreutzer, Kuffler, Kunetz, Kunić, Lakenbacher, Laufer, 
Lehner, Lemberger, Lichtenberger, Lichtenfeld, Lisičar, Livadić, Lobl, Löw, Löwenstein, Maks, Mandić, Marberger, Marić, Markus, Mautner, Mayländer, Menzer/Mencer, Montilija, Moses, Mosinger, Mosković, Muth, Naschitz, Neuberger, Nović, Nyitrai, Oblatt, Oppenheim, Ornstein, Oštrić, Pajtaš, Panzer, Pavlinović, Pichler, Pisk-Sitzer, Plachte, Preisz/Preis, Pulzer, Radan, Reichsmann, Rendi/Rendić, Rodanić, Romano, Rosenbaum, Rosenberger, Rosenfeld, Rosenwasser, Rosinger, Rosner, Saltzberger, Samujlović, Sattler, Sauerbrun, Schaffer, Schatteles, Scheiber, Scherpner, Schillinger, Schlenger, Schnitlinger, Scholler, Schönbaum, Schönstein/Schoenstein, Schreiner, Segen, Selinger, Sever, Sidon, Siebenschein, Sommer, Sonnenmark, Spiegler, Spiller, Spitzstein, Spreiregen, Stein, STERK/Šterk, Stiegler, Stockhammer, Stöger, Strassberger, Strauss, Süssmann, Szarvasy, Šalamon, Šoten, Špančić, Štajminger, T. Levi, Tkalčić, Tomograd, Trautman, Vajda, Vranić, Wachtel, Walder, Waltersdorfer, Wasserlauf, Wasserthal, Weber, Weiner, Weiser, Weiss Polnaiski, Wiesmeyer, Wilczek, Winter, Wolkenfeld, Zierer i Zirner.

Među pojedincima ima najviše onih s prezimenom Weiss/Weis, njih 19, a slijede prezime Schwartz/Schwarz/Švarc sa 17 pojedinaca, prezime Neuman/Neumann s 15 pojedinaca, prezimena Koen/Kohn/Kon, Singer i Spitzer s po 13 pojedinaca, prezime Hirschl s 12 pojedinaca, Büchler/Buchler/Buechler i Stern/Štern/Zvijezdić s po 11 pojedinaca te prezime Fischer s 10 pojedinaca. Po 9 pojedinaca nosi prezimena Krauss/Krausz/Kraus i Pollak/ /Polak, po 7 pojedinaca prezime Eisenstädter/Eisenstaedter/Eisenstadter, po 6 pojedinaca prezimena Beck, Deutsch/Njemčić, Fürst/Fuerst, Hahn, Herzog/Hercog, Hiršl, Klein i Steinhardt/Steinhart, po 5 pojedinaca prezimena Fuchs, Lausch/Lauš i Müller/Mueller, po 4 pojedinca prezimena Altstädter/Altstaedter/Aldšteter, Bachrach, Berger, Goldstein, Grünwald, Herman/Hermann, Hirschler/Hiršler, Hoffmann/Hoffman/Hofman, Kauders, Lederer, Lewy/Levi/Loevy/Löwy, Rosenberg, Spiegel/Špigel i Spiller, po 3 pojedinca prezimena Betlheim, Eichhorn/Eichorn, Finzi/Finci, Hertman/Hertmann, Oblat/Oblath, Rechnitzer, Rosenberger, Schönwald/Schoenwald, Schwabenitz/Švabenic, Steiner, Schick/Šik i Wohlmuth, po 2 pojedinca prezimena Abeles, Berkeš, Blau, Danon, Ebenspangerl /Ebenšpanger, Engel, Fein, Feldman, Fried, Fussman/Fussmann, Gerber, Glück/Glick, Goldman/Goldmann, Goldner, Gross, Haas, Hafner, Hajon, Heinrich, Herlinger, Hiršberger, Hochsinger, Horn, Jellinek, Juhn, Kerkai/Kerkaj, Kern, König/Koenig, Kornfein, Kramerl /Krämer, Ledecki, Leitner, Mayer, Maylander/Majlaender/Majlender, Metzger, Moses, Rendeli/Rendely, Rothstein, Schmutzer, Schulhof, Segen, Spiegler, Sussmann, Šterk, Švarcenberg, Taussig/Tausig, Teich, Ungar, Weinberger i Wolf, dok sva ostala prezimena 
nalazimo u po jednom pojedincu: Abraham, Ackermann, Adler, Ajzenštajn-Stojić, Alt, Altaras, Alter, Ambruš, Amodaj, Andaran, Apfel, Armuth, Arnold, Ascher, Atias, Auferber, Baar, Bacher, Bäder, Basch, Bauer, Benčić, Benedik, Bijelić, Blatt, Bleicher, Bloch, Blum, Blumschein, Böhm, Borković, Bornstein, Borunski, Božan, Brammer, Brock, Bruck, Bruckner, Büchner, Buergner, Čermak, Davidson, Dick, Dobida, Donner, Dorner, Dreisinger, Drožanski, Dub, Egri, Ehrenfreund, Eisner, Eliau, Endrenyi, Engelsmann, Engelsrath, Epstein, Eskenazi, Feigalstock, Feiner, Felikx, Feni, Ferber, Feuereisen, Fišler, Flesch, Flick, Fodor, Frankl, Freiberger, Frenkl, Fröhlich, Fuhrman/Furman, Gardoš, Geiger, Gemünder, Glesinger, Glücks, Gold, Goldschmidt, Grin, Gruenbaum, Grünberger, Guttman, Hacker, Haim, Haiman, Halwachs, Hamburger, Hanapel, Hauser, Heim, Heimler, Herrnstein, Hersfeld, Hessel, Heumer, Hochstädter, Hoff, Hohman, Holland, Holzer, Hönigsberg, Horetzky, Horvatić, Hubert, Huzjak, Izrael, Jelenić, Jelenska, John, Junker/Juenker, Kac, Kalai, Kamenić, Kandl, Kanižai, Kaposi-Schnitzler, Karan, Kastl, Katić, Keele, Kell, Kerpner, Keszler, Klaber, Koch, Konrid, Kopelman, Koritschan, Kornitzer, Korvin Kohn, Kössler, Krautblatt, Kremsir, Kuh, Lachmann, Lang, Langraf, Latzko, Lazar, Ledić, Leeb, Lesić, Licht, Lieberman, Lithemberger, Loevenstein, Loewinger, Lukač, Mandolfo, Marić, Mautner, Mazel, Meiler, Merkler, Miljević, Miškolzy, Molnar, Mosner, Moster, Mošansky, Neuberg, Neufeld, Neustadt, Nonveiller, Njemirovski, Ofner, Oswald, Papić, Pauli, Peči, Peičić Freiberger, Perok, Picher, Pichler, Pick, Pisk, Plachte, Preisz, Pressburger, Prister, Pseherhof, Pulaš, Pulzer, Rabinović, Radan, Radinger, Radulović, Recanati, Rehberger, Reich, Reicher, Reichman, Reiner, Reiss, Reves, Richter, Ripner, Rochlitz, Romano, Rosner, Roth, Rothmüller, Rotković, Rotter, Ruhig, Russ, Sachs, Salaj, Sasson, Sattler, Schaffer, Schapringer, Scheier, Schey, Schiller, Schlesinger, Schon, Schönbaum, Schönberg, Schreiber, Schreibner, Schrenzel, Schulmann, Schuster, Schweinburg, Sekač, Seligmann, Skopal, Sonenšajn/Sonenschein, Sorger, Städtler, Stein, Sternberg, Stöger, Strasser, Szabadi, Szaner, Szekler, Szőke, Szomjas, Šandor, Ščrbašić, Šorš, Šrenger, Tandler, Teller, Tencer, Thune, Tolentino, Tolnauer, Tomi, Trautman, Trinki, Ullmann, Vajda-Rausnic, Verboy, Vinski, Vojković, Volner, Weiler, Weiner, Weiser, Weisser, Weissmann, Weiszmayer, Weitzner, Wertheiner, Wessél, Wilczek, Winter, Wirnik, Zafuta, Zeriali, Zirner i Zuckerman Fleischacker. 


\subsubsection{Najčešća prezimena u sva tri izvora}

Ako se usporede najčešća prezimena iz svih triju izvora (ona s dvoznamenkastim brojem nositelja), dobivamo tablicu:

Tablica 6: Najčešća prezimena u pojedinim izvorima

\begin{tabular}{|c|c|c|c|c|c|c|c|c|}
\hline & \multirow{2}{*}{\multicolumn{2}{|c|}{ Schwarz }} & \multirow{2}{*}{\multicolumn{2}{|c|}{ Matične knjige }} & \multicolumn{4}{|c|}{ Mirogoj } \\
\hline & & & & & \multicolumn{2}{|l|}{ obitelji } & \multicolumn{2}{|l|}{ pojedinci } \\
\hline 1. & Stern/Zvijezdić & 15 & $\begin{array}{l}\text { Weis/Weiß/ } \\
\text { /Weiss/Weisz }\end{array}$ & 31 & $\begin{array}{l}\text { Schwartz/ } \\
\text { /Schwarz/Švarc }\end{array}$ & 22 & Weiss/Weis & 19 \\
\hline 2. & Schwarz & 14 & $\begin{array}{l}\text { Schwarc/ } \\
\text { /Schwartz/ } \\
\text { /Schwarz/Svarz }\end{array}$ & 26 & Weiss & 18 & $\begin{array}{l}\text { Schwartz/ } \\
\text { /Schwarz/Švarc }\end{array}$ & 17 \\
\hline 3. & & & Stern & 25 & $\begin{array}{l}\text { Dajč/Deutsch/ } \\
\text { /Maceljski/ } \\
\text { /Njemčić }\end{array}$ & 17 & $\begin{array}{l}\text { Neuman/ } \\
\text { /Neumann }\end{array}$ & 15 \\
\hline 4. & & & Kohn & 20 & $\begin{array}{l}\text { Neuman/ } \\
\text { /Neumann }\end{array}$ & 11 & Koen/Kohn/Kon & \\
\hline 5. & & & Deutsch & & Kohn & & Singer & \\
\hline 6. & & & Hirschl/Hiršl & & Müller/Mueller & 10 & Spitzer & \\
\hline 7. & & & Spicer/Spitzer & 14 & Spitzer/Špicer & & Hirschl & 12 \\
\hline 8. & & & $\begin{array}{l}\text { Rosenberg/ } \\
\text { /Rosenberger }\end{array}$ & 13 & & & $\begin{array}{l}\text { Büchler/Buchler/ } \\
\text { /Buechler }\end{array}$ & \\
\hline 9. & & & $\begin{array}{l}\text { Neuman/ } \\
\text { /Neumann }\end{array}$ & 12 & & & $\begin{array}{l}\text { Stern/Štern/ } \\
\text { /Zvijezdić }\end{array}$ & \\
\hline 10. & & & Steiner & & & & Fischer & 10 \\
\hline 11. & & & Alexander & & & & & \\
\hline 12. & & & Miller/Müller & & & & & \\
\hline
\end{tabular}

Vidljivo je da se prezime Schwarz sa svojim inačicama i prijevodnim likovima nalazi među najčešćima u svim izvorima. Prezime se Stern ne pojavljuje među najpopularnijima samo među obiteljskim grobnicama na Mirogoju (7 obitelji). Prezimena se Koen/Kohn/Kon, Neuman/Neumann, Spitzer/Špicer i Weis/Weiß/Weiss/Weisz pojavljuju među najčešćima u 
svim izvorima osim Schwarza (ondje ih nose redom jedna, nijedna, šest i osam obitelji). Prezimena DajčlDeutsch/Maceljski/Njemčić, Hirschl/Hiršl i Miller/Müller/Mueller pojavljuju se među najpopularnijima u po dva izvora.

\subsubsection{Etimološka analiza prezimenā}

U jidišu, za razliku od standardnog njemačkoga, nema udvojenih suglasnika. Otud različite mogućnosti transkripcije jidiških prezimena na latinicu, npr. za sufiks מאן-/-man/ bilo kao -man ili pak njemačkom transkripcijom kao -mann. S druge strane, jidiš čuva starije čitanje dvoglasa, pa se primjerice prezime koje se najčešće transkribira kao Eisenstein ustvari izgovaralo Ejznštejn (kao u sovjetskog filmskog redatelja imenom Сергей Михайлович Эйзенштейн), a Deutsch Dajč (promjena koju je moguće naći na nadgrobnim spomenicima na Mirogoju). Varijacije istog prezimena u popisu koji slijedi uglavnom proizlaze iz tih razlika između njemačkog i jidiša. (Ne treba smetnuti s uma i pogreške nastale prepisivanjem rukom pisanih dokumenata u bazu podataka Gradskih grobalja.) Iako je jidiš, kao što je već spomenuto, neko vrijeme uživao status jednog od službenih jezika Ukrajinske Narodne Republike, Bjeloruske Sovjetske Socijalističke Republike, Galicijske Sovjetske Socijalističke Republike i Židovske autonomne oblasti u SSSR-u, većim dijelom njegove povijesti jezik se pisalo i različitim pravopisima temeljenima na hebrejskom pismu.

Česti su slučajevi kad se etimološko izvođenje prezimena iz neke opće imenice križa s postojećom, a s njim nepovezanom njemačkom riječi. Prema autorima (Guggenheimer H. W. i Guggenheimer E. H. 1992) to ne znači da je osobno ime ili prezime izvedeno baš iz te njemačke riječi, već može imati i drukčije podrijetlo.

Abeles/ABELES - jid. - Jidiški Pַבעלעם. Prezime nije nastalo konverzijom od osobnog imena iz Post 4,2 koje u izvorniku glasi דָָָ /habael/ 'dah'362, već od zamjenskog imena za

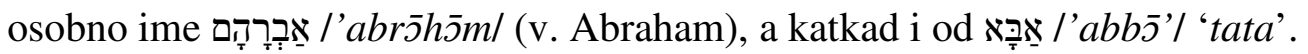

${ }^{362}$ Post 4,2. U transkripciji Silvija Grubišića: Abel

Odgovarajuće arapsko osobno ime: هَابِيل /hābīll, bez tumačenja (Agić 1996: 45).

Robert Graves i Raphael Patai o etimologiji ovog osobnog imena pišu (Graves i Patai 1969: 89):

»Abelovo ime, Hebel, ostaje neobjašnjeno možda zbog toga što je bilo dobro poznato da riječ hebel znači

»dah«, »ništavilo«, »prolaznost«, u vezi s ljudskim životom (Psalam 144: 4; Job 7: 16). Međutim u prijevodu u Septuaginti napisano je hevel kao »Abel« što, transkribirano na hebrejski, postaje avel ili evel: »korota« ili 
Abraham - heb. - Prezime nastalo konverzijom od osobnog imena אַבְרָָדָם /'abrōhs̄m/ prvog patrijarha u Tanahu.

Abramović - heb.-hrv. - Prezime nastalo konverzijom od patronima od osobnog imena אַבְרָם l'abr亏̄m/ tvorenog slavenskim patronimskim sufiksom -ović. Inačice su toga sufiksa u transkripcijama na druge jezike -ovicz, -ovitz, -owicz, -owitz ${ }^{363}$.

Ackermann/ACKERMAN - jid. - Jidiški אַקערמאָאו, Prezime nastalo konverzijom od patronima od prezimena /aker/ ( $\times$ njem. Acker 'polje'), a koje je nastalo od osobnog imena אָ /ako/,

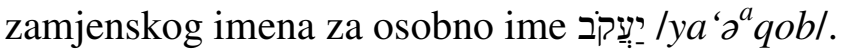

Adler/ADLER - jid. - Prezime nastalo konverzijom izvornog srednjovjekovnog jidiškog (ali i nežidovskog) osobnog imena אַדללער 'orao' (njem. Adler). Moguće je da je riječ i o prezimenu nastalom od אַדע /ade/ ili pak konverzijom od patronima/metronima izvedenog od osobnog imena אַדל /adl/ (× njem. adel 'plemenit'), u jidiškim inačicama i אָדל /odl/ i אודל /udll.

Ajzenštajn - jid. - Jidiški אייזנשטיין, prezime nastalo konverzijom od patronima od osobnog imena אייזן /eyzn/ (× njem. Eisen 'željezo', v. Eisen). Drugo je tumačenje da je prezime nastalo konverzijom od toponima Eisenstein, danas Železná Rudá u Češkoj.

AKSEBRAD - jid.? - Ovo se prezime nalazi jedino u bazi podataka Gradskih grobalja, koji su nerijetko upitni zbog pogrešnog prepisivanja iz rukom pisanih dokumenata. Kad nam nisu dostupni podaci iz drugih izvora, ne možemo sa sigurnošću utvrditi je li riječ o pogrešci ili nije. Što se ovog prezimena tiče, možemo samo spekulirati da bi prezime

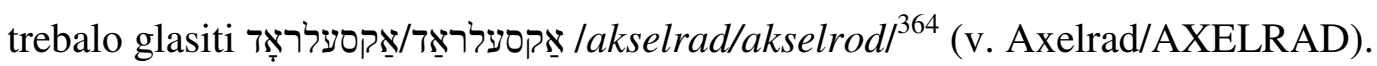

»tuga «.«

Isaac Asimov o ovom osobnom imenu kaže (Asimov 1969: 34):

"The name Abel may also be related to the Babylonian aplu meaning "son." This would indicate a possible Sumerian origin for the tale."

[Ime Abel može biti povezano is babilonskim aplu što znači 'sin'. To bi ukazivalo na moguće sumersko podrijetlo priče.]

${ }^{363}$ Sličan primjer navodi i Petar Šimunović, naime prezimena Salamunić i Salamunović uz napomenu da je osobno ime iz kojeg su izvedena gotovo postalo opća imenica: »on je pravi salamun« (= mudrac, ali i mudrijaš) (Šimunović 2006: 169).

${ }^{364}$ Ako je slovo $l<\ell>$ pisano pismom Sütterlin (rukopisna gotica) pogrešno pročitano kao slično mu slovo $b$ $<b>$. 
Albahari/ALBAHARI - sef. - Prezime arapskog podrijetla, nastalo od آلَبَحَّارِ /al-baḥhārīl 'mornarski, pomorski' 365 .

Alexander/Aleksander/ALEXANDER/ALEKSANDER/ALEKSANDAR - grč.-jid. - Jidiški

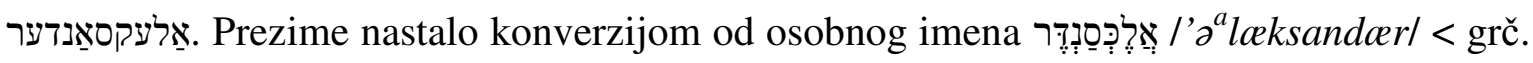
'A $\lambda \dot{\varepsilon} \xi \alpha v \delta \rho \circ \varsigma$ 'koji brani čovjeka', koje su Židovi usvojili još u doba Aleksandra Velikoga (356. - 323. g. pr. n. e.) (Beider 2001 273-274; Colorni 1983: 76). Osobno je ime postalo rašireno kao prezime u različitim likovima, uključujući mađarsko Sándor (v. Šandor).

Alexander-Sesvetska / Alexander-Sesvetski / Aleksander »Sesvetski« - Trgovac je, industrijalac, bankar i filantrop Šandor Aleksander (1866. - 1829.) za svoj zaslužan rad 1918. g. od cara i kralja Karla I. Austrijskoga (1887. - 1922.) dobio plemstvo s pridjevkom »Sesvetski« u znak zahvalnosti što je početkom rata donirao milijun zlatnih austrijskih kruna kao nepovratni zajam državi.

Alt/ALT - jid. - Jidiški אַל 'star' (: njem. alt), prezime nastalo konverzijom od osobnog imena (češće אַלטער /alterl 'starost' : njem. Alter, v. ALTER) koje je davano djetetu čiji su stariji brat ili sestra umrli, ali i posmrčetu, kako bi ga se sačuvalo od anđela smrti. Alexander Beider ovo osobno ime izvodi od osobnog imena אַלטער /alter/ (Beider 2001: 274-275; v. ALTER).

Altaras - sef. - Prezime אלטרס arapskog podrijetla. Heinrich W. i Eva H. Guggenheimer kao izvorni lik navode آلْطَرَّاس /al-tarrās/ i tumače ga kao 'restaurator, urednik rukopisa' (Guggenheimer H. W. i Guggenheimer E. H. 1992:24). U privatnoj mi je komunikaciji dr. sc. Tatjana Paić-Vukić sugerirala izvorni lik آلطَرَّاز /al-tarrāz/ 'muška vezilja'. Na takvo bi rješenje mogao upućivati u zemljama bivše Jugoslavije uobičajeni lik ovog prezimena Altarac.

Altenberg - jid. - Jidiški Pִלטנבערג. Prezime je nastalo ili konverzijom od patronima od osobnog imena אַלט (v. Alt/ALT), ili konverzijom od toponima Altenberg u Porajnju ili Gornjoj Šleskoj.

ALTER - jid. - Jidiški אַלטער /alterl 'starost' (: njem. Alter), prezime nastalo od osobnog imena koje je davano djetetu čiji su stariji brat ili sestra umrli, ali i posmrčetu, kako bi se prevarilo anđela smrti. Osobno ime nije poznato u zemljama njemačkog govornog

\footnotetext{
${ }^{365}$ Heinrich W. i Eva H. Guggenheimer kao izvorni lik navode آلَبَحْرِي /al-bahrīl i tumače ga kao 'mornar'
} (Guggenheimer H. W. i Guggenheimer E. H. 1992:18). Gore je navedeno tumačenje predložila dr. sc. Tatjana Paić-Vukić u privatnoj komunikaciji. 
područja, već je vjerojatno poniklo u XVIII. st. u slavenskima (Beider 2001: 274-275; Guggenheimer H. W. i Guggenheimer E. H. 1992: 22).

Altmann/Altman - jid. - Jidiški Pַלטמאָאו Prezime nastalo konverzijom od patronima od osobnog imena Alt (v. Alt/ALT).

Altschul/ALTSCHUL/ALTUCHUL - jid. - Prezime po svemu sudeći nastalo od jidiškoga 'stara sinagoga', usp. sinagogu Altneuschul u Pragu (češ. Staronová synagoga), čije

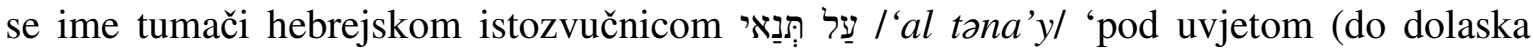
Mesije)'. Manje je vjerojatno da je prezime nastalo od zanimanja 'postolar', onaj koji popravlja staru obuću (njem. alter Schuh), kako to tumače Heinrich W. i Eva H. Guggenheimer (Guggenheimer H. W. i Guggenheimer E. H. 1992: 25).

Altstädter/Alstädter/Aldšteter/ALTSTAEDTER/ALTSTADTER - jid. - Jidiški אַלטשטעטער, prezime nastalo od osobnog imena אַלטער /alter/ (v. ALTER) ili konverzijom od etnika od toponima u Švapskoj (Altenstadt), Češkoj, Moravskoj i istočnoj Galiciji (danas Старий Самбір u zapadnoj Ukrajini).

AMBRUŠ - mađ./jid. - Prezime nastalo konverzijom od mađarskog osobnog imena Ambrus

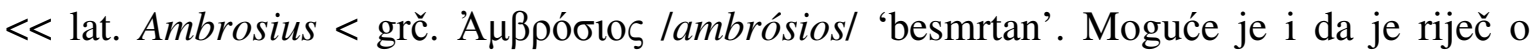
ponešto iskrivljenom prezimenu אַמברוך /ambrux/, nastalom konverzijom od produžene inačice osobnog imena אֵברוך /abrux/, umanjenice od osobnog imena אַבער /aber/, zamjenskog imena za osobno ime אָבְרָרָָ /'abrōhs̄m/. Među deminutivnim sufiksima kojima se tvore neka židovska osobna imena (ali i ona kršćanā) u slavenskim zemljama (Češka, Moravska, Šleska) u srednjem vijeku nalazimo i dometak -uš (uz -eř i -ǐs), pa je moguće da i ovo prezime predstavlja tvorbu s takvim dometkom.

AMODAJ - sef. - Prezime nמודי nastalo od tal. Amadeo 'koji voli boga'.

Amslberg - jid. - Jidiški pֵמסלבערג, prezime nastalo konverzijom od patronima od jidiške imenice אַמסללואַמזל /amsl/amzll (× njem. Amsel 'kos'). Sama imenica funkcionira kao

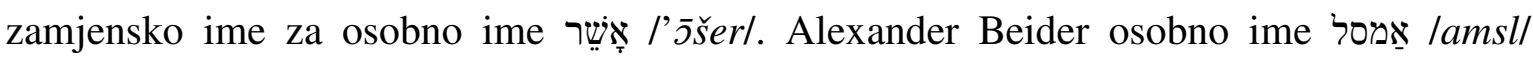
izvodi iz njemačkog osobnog imena Anselm < pragerm. *ansu- 'bog' + *helma- 'šljem, kaciga': Anselm > (kolokvijalno) Ansel > (ispadanje zanaglasnog samoglasnika) Ansl > Amsl (Beider 2001: 276-277).

Andaran.

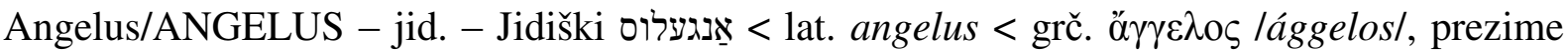

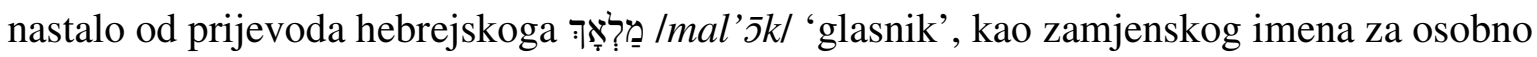
ime 
APFEL - jid. - Jidiški אַפע lapel/ (× nnjem. 'jabuka' : njem. Apfel), prezime nastalo konverzijom od pokraćenog lika njemačkog osobnog imena Albrecht $<$ pragerm. *apala'narav > plemenit' + *berhta- 'sjajan', zamjenskog imena za osobno ime l'abrs̄hs̄m/.

Appler/Apller - jid. - Jidiški אַפַּל prezime nastalo od prezimena Apfel (v.).

Armuth/ARMUTH - jid. - אַרמוט (× njem. Armut 'siromaštvo'), prezime nastalo od osobnog imena אַרם /arm/ (× njem. arm 'siromašan'), pokraćenog lika osobnih imena Armand < njem. Herman (v. Hermann/Herman/HERMANN/HERMAN) i Armin,

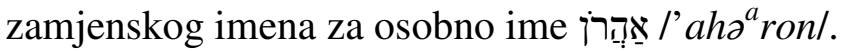

Arnold - jid. - Jidiški אַרנזָלד njem. Arnold < pragerm. *aran- 'orao' + *waldan- 'vladati', prezime nastalo konverzijom od osobnog imena koje se katkad pojavljuje i kao zamjensko ime za osobno ime אַבְרָרָּ /'abrōh̄̄m/.

Arnstein/ARNSTEIN - jid. - Jidiški ארֵשטיין, prezime nastalo konverzijom od patronima od njemačkih osobnih imena čiji prvi dio glasi Arn- < pragerm. *aran- 'orao', ili pak konverzijom od toponima, imena grada u Donjoj Franačkoj.

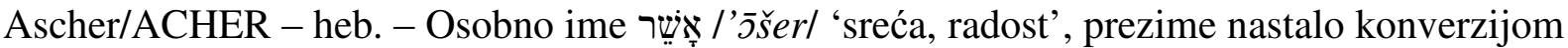
od osobnog imena iz Tanaha.

Ašner - jid. - Jidiški pַשנער, prezime nastalo konverzijom od patronima od osobnog imena אַ /aš/. Možda je riječ i o prezimenu nastalom od osobnog imena wָָָ /'כॅšer/ (v. Ascher/ /ACHER).

Atias/ATIJAS - sef. - Prezime עטיאס arapskog podrijetla, nastalo od arapskoga عَطَاء /'ațā'/

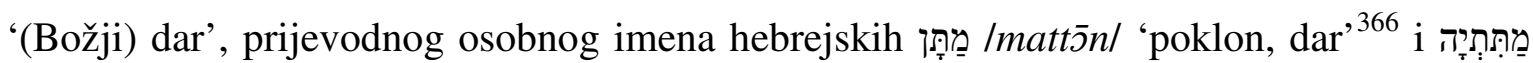
Imattity $\bar{s}^{h}$ / 'dan po YHWH-u' iz Talmuda.

Auferber - jid. - Jidiški Prezime nastalo od srvnjem. ûferber 'nasljednik'. Moguće da je riječ o jednom od profilaktičkih osobnih imena.

Ausch/Auš/AUSCH - jid. - Jidiški אַ. Prezime je nastalo ili od pokraćenog lika osobnog

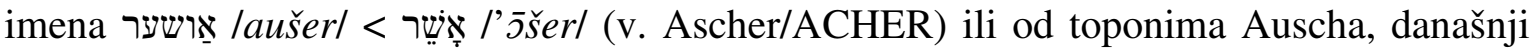
Úštěk u Češkoj.

Ausländer - jid. - Jidiški (× njem. Ausländer 'stranac'), prezime vjerojatno nastalo od יאַוזל /yauzl/, zamjenskog imena za osobno ime יוֹסֵף/yōsep/. Alexander Beider ne navodi, doduše, ovaj lik osobnog imena, ali bilježi više njih njemu nalik (iz nekog od kojih

\footnotetext{
${ }^{366} 2 \mathrm{Kr} 11,18$. U transkripciji Antuna Sovića: Matan.
} 
je možda izveden): Yesl, Yeyzl, Yosl, Yoysl, Yoyzl i Yozl (Beider 2001: 455-458). Moguće je i da je riječ o obitelji doseljenoj iz nekog drugog kraja.

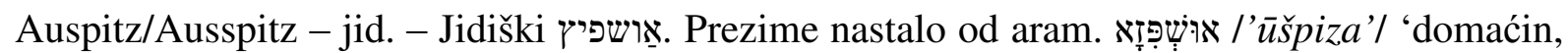
gost $^{367}$, no moguće je i da je nastalo i konverzijom od toponima Auspitz, današnje Hustopeče u Moravskoj.

Ausuebel/AUSüBEL - jid. - Jַוזיבל prezime nastalo od zamjenskog imena יאוזיבל /yauzibl/ za osobno ime יוֹסֵס /yōsep/.

AVRAM - heb. - Prezime nastalo konverzijom od hebrejskog osobnog imena אברְרָם /'abrōm/ iz Tanaha.

Axelrad/AXELRAD - jid. - Jidiško prezime אַקסעלראַד, nastalo konverzijom od osobnog

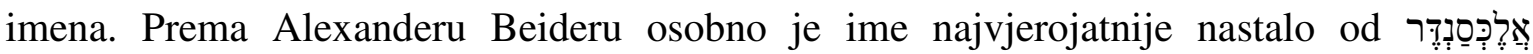

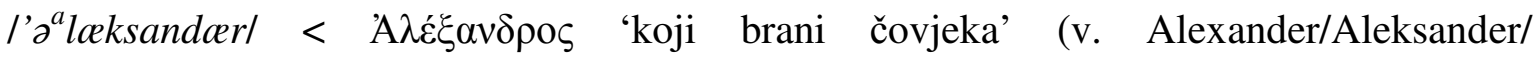
/ALEXANDER/ALEKSANDER/ALEKSANDAR) višestrukim suglasničkim metatezama. Ono se pojavljuje isključivo u židovskim izvorima, a židovsko je osobno je ime Acseldar potvrđeno 1605. g. u Pijemontu. Osobno je ime vjerojatno nastalo u srednjem vijeku u Porajnju dok na jugu Njemačke nije bilo uobičajeno. Rabinska ga tradicija drži za שָם־הָקדָש /šem-haqqodaš/. Izvorno je zamjensko ime vezano uz ovo osobno ime bilo בענדיט/bendit/ $<$ Benedikt < lat. Benedictus 'blagoslovljen' (v. Benedikt/Benedik/Benedek/ /BENEDIK/BENDEIK), no u istočnu se Europu vjerojatno proširilo kao njegovo zamjensko ime (Beider 2001: 273-274).

Baar/BAAR - jid. - Jidiški באַר, inačica osobnog imena בער /ber/ 'medvjed' (: njem. Bär), prezime nastalo prijevodom hebrejskog osobnog imena דi /dōb/, zamjenskog imena za osobno ime

Bacharach/Bachrach - jid. - Jidiški באַכ(אַ)ראַר, prezime nastalo od toponima Bacharach na Rajni.

BACHER - jid. - Jidiški באַכער /baxer/, prezime nastalo od באָכ /bax/. U suvremenom njemačkom Bach znači 'potok', što je i često ime naseljenog mjesta ${ }^{368}$.

Bader - jid. - Jidiški בַּער (× srvnjem. 'liječnik', ne nužno akademski školovan).

\footnotetext{
${ }^{367}$ Možda i od latinskog hospitem.

${ }^{368}$ Heinrich W. i Eva H. Guggenheimer navode etimologiju prema kojoj jidiški באַך/bax/ znači 'divlja krmača', što bi mogla biti ženska analogija osobnog imena עבער /eber/, pokraćenog lika njemačkog osobnog imena Eberhard < pragerm. *ebura- 'vepar' + *hardu- ‘čvrst, žestok', zamjenskog imena za osobno ime אֶבְרָּם l'abrs̄hs̄m/ (Guggenheimer H. W. i Guggenheimer E. H. 1992: 50-51). S obzirom na židovsku religioznu averziju prema svinjama, ova je etimologija malo vjerojatna.
} 
Bahl - jid. - Jidiški באֵַ prezime nastalo od pokraćenog lika osobnog imena /balțšașar/.

Baneth - jid. - Jidiški באֵנעט, prezime nastalo od pokraćenog lika osobnih imena Bonwit,

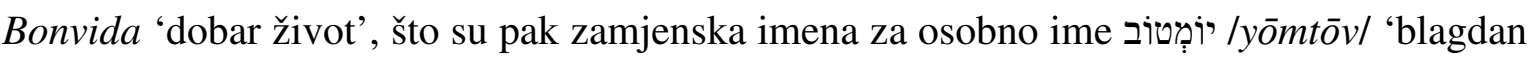
(dosl. dobar dan)', koje se obično nadijeva djetetu rođenom na neki židovski blagdan. Iako je prezime motivirano romanskom sintagmom, u Zagrebu ga nosi aškenaska obitelj.

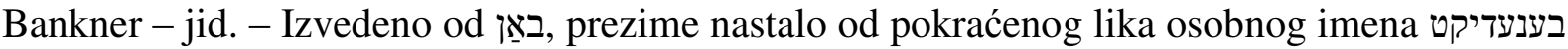
/benedikt/ (v. Benedikt/Benedik/Benedek/BENEDIK/BENDEIK).

Baraksandić - hrv.

Baran/BARAN - jid. - Jidiški prezime nastalo od polj. baran ili rus. баран 'ovan'.

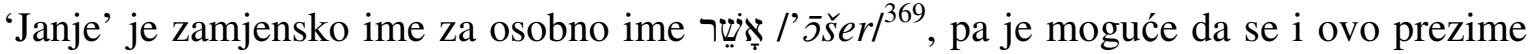
nadovezuje na to.

Barany/Baranji - mađ. - Jidiški באַראַני, prezime nastalo od mađarskoga bárány 'janje' >< rus. баран 'ovan' (v. Baran/BARAN), zamjenskog imena za osobno ime

Bartos - jid. - Jidiški באַרטָָס, prezime nastalo od inačice osobnog imena באַרטש /barteš/, slavenskog pokraćenog lika osobnog imena Bartolomej < lat. Bartholomaeus < grč.

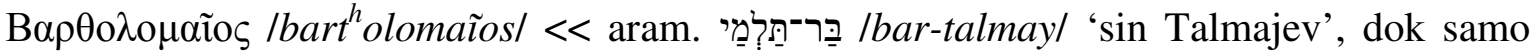

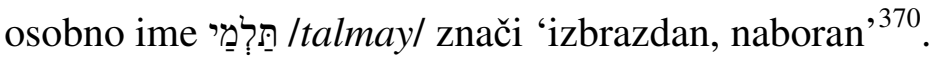

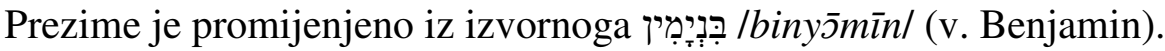

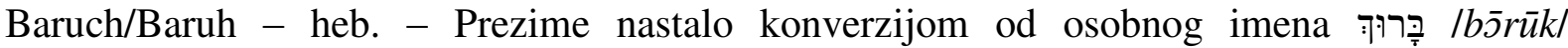
‘blagoslovljen' iz Tanaha.

Basch/Baš/BASCH - jid. - Jidiški באָש, prezime nastalo od zamjenskog imena za osobna

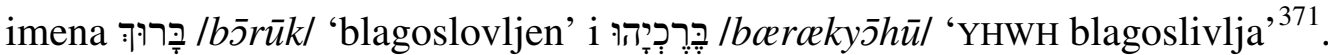

Bašić - hrv. - Prezime nastalo od baš < tur. baş 'glava' > 'poglavar, starješina, zapovjednik' + -ić (Skok 1974: I 117-118).

Prezime je promijenjeno iz izvornoga באַכראַך/baxrax/ (v. Bacharach/Bachrach).

Batjani - mađ. - Fonetski zapis mađarskog prezimena Batthyány, jednog od mađarskih praplemena pri doseljavanju na današnje prostore. Prezime nastalo od imena grada Battyán (današnji Szabadbattyán) koji je Žigmund Luksemburški (1368. - 1437.) s okolicom 1398. g. dao jednom pripadniku obitelji.

\footnotetext{
${ }^{369}$ Ova antroponimska veza nema svog utemeljenja u Tanahu.

${ }^{370} \mathrm{Br} 13,22$. U transkripciji Silvija Grubišića: Talmaj.

${ }^{371} 1$ Ljet 6,39, u hrvatskom prijevodu 1 Ljet 6,24. U transkripciji Antuna Sovića: Berekja.
} 
Bauer/BAUER - jid. - Jidiški באוער (× njem Bauer 'zemljoradnik').

BAUM - jid. - Jאוּ (× njem. Baum 'drvo'), prezime nastalo od zamjenskog imena za osobno ime אָבְרָרָּ /'abrōhōm/.

באֵַומגאַרטן > באַומגאַרטנער באֵֵום /baum/ (v. BAUM ).

Bayer/BAYER - jid. - Jidiški בייער, prezime nastalo od jidiškoga בייע /baye/ > njemačko osobno ime Baye.

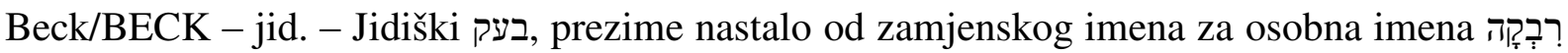
/ribq $\bar{\nu}^{h} /$ i

Beer/Behr/BEER/BEHR - jid. - Jidiški בער 'medvjed', prezime nastalo prijevodom

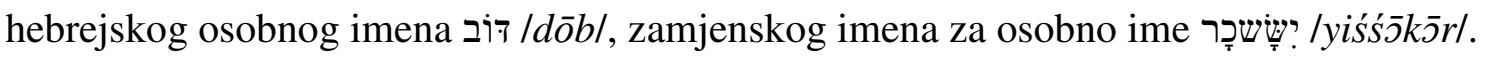

Behrmann/BEHRMANN - jid. - Jidiški בערמאָן, prezime nastalo konverzijom od patronima od prezimena בער/ber/ (v. Beer/Behr/BEER/BEHR). Može biti riječ i o prezimenu nastalom konverzijom od složenog osobnog imena koje su Židovi preuzeli od kršćana.

BELIN - jid./hrv.? - Kao jidiško prezime, בעלין je nastalo od jidiškog ženskog osobnog imena ביילע /beylel 'lijepa'. Osobno je ime u njemačke krajeve došlo iz Francuske gdje su ga Židovi bili preuzeli od kršćana. U srednjem je vijeku bilo popularno u židovskim zajednicama Porajnja, izvorno govornicima romanskih jezika. Ondje ga kršćani nisu koristili. U južnu je Njemačku dospjelo s doseljenicima iz Porajnja i Francuske, a odatle se proširilo u slavenske zemlje (Beider 2001: 480-482).

Kao slavensko prezime, nastalo je konverzijom od metronima od osobnog imena Bela $<$ prasl. *bělb- (Čilaš Šimpraga, Ivšić Majić i Vidović 2018: 95).

Benčić/BENČIĆ - hrv. - Prezime nastalo konverzijom patronima od imena Benko $<<$ Benedikt < lat. Benedictus 'blagoslovljen' (v. Benedikt/Benedik/Benedek/BENEDIK/ /BENDEIK) + -ić (Čilaš Šimpraga, Ivšić Majić i Vidović 2018: 95; Skok 1974: I 400).

Benedikt/Benedik/Benedek/BENEDIK/BENDEIK - jid. - Jidiški בענעדיקט /benedikt/ > lat. benedictus 'blagoslovljen', prezime nastalo konverzijom od osobnog imena, zamjenskog

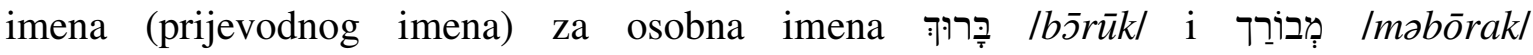
'blagoslovljen',373.

\footnotetext{
3721 Ljet 12,3. U transkripciji Antuna Sovića: Beraka. Kao muško osobno ime najčešće davano svećenicima.

${ }^{373}$ Osobno se ime Benedikt proširilo zahvaljujući popularnosti sv. Benedikta iz Nursije (480. - 543./547.).
} 
Benjamin - heb. - Prezime nastalo konverzijom od osobnog imena בִּנְיָמִין /binȳmin/ iz Tanaha.

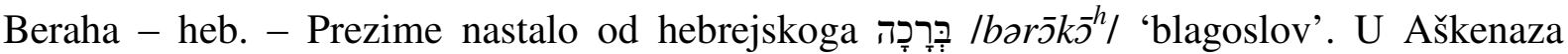
žensko osobno ime.

Bergel/Bergl - jid. - Jidiški בערגל. Prezime nastalo od umanjenice od רברֶר /barx/, zamjenskog

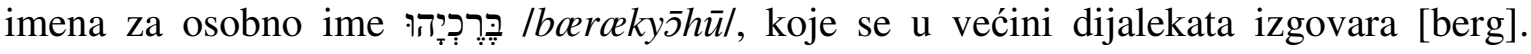
Moguće je i da je prezime nastalo od toponima Berg, imena više mjesta u Njemačkoj.

Berger/BERGER - jid. - Jidiški בערגער, prezime nastalo konverzijom od patronima od

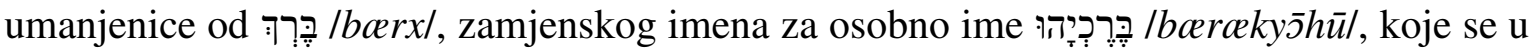
većini dijalekata izgovara [berg]. Moguće je i da je prezime nastalo konverzijom od etnika od toponima Berg, imena više mjesta u Njemačkoj.

Berkeš/BERKEŠ - mađ. - Jidiški בערקעש, prezime nastalo konverzijom od toponima u Sedmogradskoj, današnje selo Borzești (do 1922. g. Berchiș) u Rumunjskoj.

Berkovits/BERKOVITZ/NEBERKOVITZ - jid. - Jidiški בערקאָביץ, prezime nastalo konverzijom od patronima od osobnog imena בערקָ /berko/, umanjenice osobnog imena בער /ber/ (v. Beer/Behr).

Berndorfer - jid. - Jidiški בערנדאָרפער /bern/, patronima od osobnog imena בער /ber/ (v. Beer/Behr), a možda i konverzijom od etnika od toponima Berndorf u Njemačkoj i Austriji.

Bernfest - jid. - Jidiški בערנפעסט, prezime vjerojatno nastalo od prezimena בערן /bern/, patronima od osobnog imena בער /ber/ (v. Beer/Behr).

BERNHARD - jid. - Jidiški בערנהאַר, prezime nastalo konverzijom od njemačkog osobnog imena Bernhard < pragerm. *beran- 'medvjed' + *hardu- 'čvrst, žestok', zamjenskog imena od osobnog imena בער /ber/ (v. Beer/Behr).

Bernstein/BERNSTEIN - jid. - Jidiški בערנשטיין, prezime nastalo konverzijom od patronima od osobnog imena Ber (v. Beer/Behr). Prezime je moglo nastali i od imenice izvornog

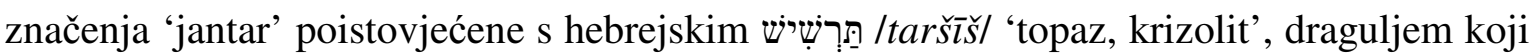

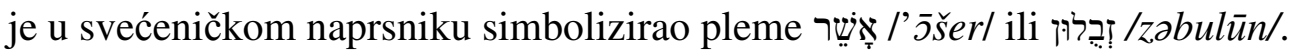

Bettelheim/Betlheim/BETLHEIM/BETHEIM - jid. - Jidiški בעטלהיים, prezime nastalo konverzijom od toponima u Donjoj Austriji.

Bienenfeld - jid. - Jidiški בינענפעלד (× njem. Bienenfeld 'polje pčelā'), prezime nastalo konverzijom od patronima od jidiškoga בין /bin/ (× srvnjem. bîn 'pčela'), zamjenskog

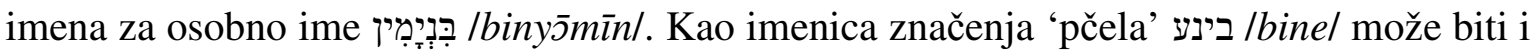

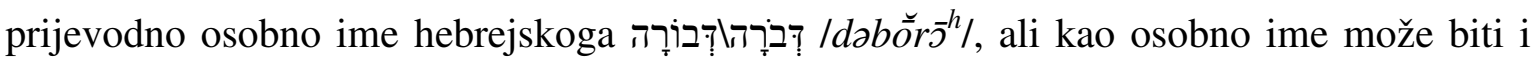


izvedenica od romanskog osobnog imena motiviranog pridjevom značenja 'dobra' (: fran. bonne, tal. buona) (Beider 2001: 487-488). U tim je slučajevima riječ o prezimenu nastalom konverzijom od metronima.

Bier - jid. - Jidiški ביר, prezime nastalo konverzijom od zamjenskog osobnog imena za španjolsko osobno ime i prezime $\operatorname{Duran}(d)$ < španj. durar 'ustrajati', što je zamjensko ime

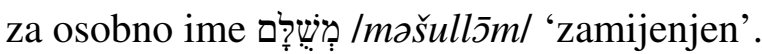

Biermann/BIRMANN - jid. - Jidiški בירמאָן, prezime nastalo konverzijom od patronima od prezimena ביר /bir/ (v. Bier).

Bijelić/BIJELIĆ - hrv. - Prezime nastalo od prijevodnog lika prezimena ווייס /weys/ (v. Weiß/ /Weiss/Weisz/Weis/Weihs/WEISS/WEIS). Prezime se uklapa u hrvatska prezimena nastala iz kakvog karakterističnog obilježja rodonačelnika, u ovom slučaju boje pûti ili kose (Skok 1874: I 152-155, 706-707; Šimunović 2006: 21).

ביל Biller - jid. - Jidiški בילער, prezime nastalo konverzijom od metronima od osobnog imena

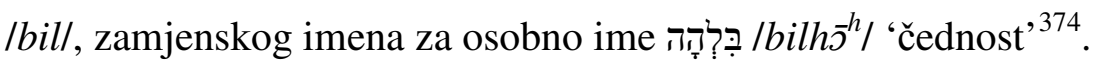

Bišicky - jid. - Jidiški בישיצקי, prezime nastalo konverzijom od patronima izvedenog od jidiškoga בישיץ/buššl ( בוש /bricl, što je i samo patronim od jidiškogasch 'grm').

Bjelinski - hrv. - Prezime je promijenjeno prijevodom izvornoga ווייס /weys/ (v. Weiß/Weiss/ /Weisz/Weis/Weihs/WEISS/WEIS) (Šimunović 2006: 274-275).

Blatt/BLATT - jid. - Jidiški בלאַט (× njem. Blatt 'list'). Čest patronimski/metronimski sufiks $\mathrm{u}$ aškenaskim prezimenima.

Blau/BLAU/BLAN - jid. - Jidiški בלאֵו 'modar', prezime nastalo od boja zastava plemenā

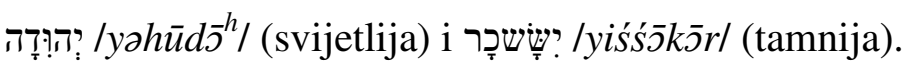

Bleicher/BLEISHER - jid. - Jidiški בלייכע, prezime nastalo konverzijom od patronima od jidiškoga בלייך/bleyx/ (× njem. bleich 'blijed').

Blitz/BLITZ - jid. - Jליץ (× njem. Blitz 'munja'), prezime nastalo konverzijom od patronima od osobnog imena בליט /blit/ (× njem. Blute 'cvijet').

BLOCH - jid. - Jidiški בלָאך 'govornik nekog romanskog jezika', usp. polj. Włoch 'Talijan'.

Blüh - jid. - Jidiški בלי 'cvijet'.

Blühweiss/Blivajs - jid. - Jidiški בליווייס|בליביים 'bijel poput cvijeta', prezime nastalo spajanjem prezimena ווייס /bli/ (veys/ (v. Beiß/Weiss/Weisz/ /Weis/Weihs/WEISS/WEIS).

\footnotetext{
${ }^{374}$ Post 29,29. U transkripciji Silvija Grubišića: Bilha.
} 
Blum/BLUM - jid. - Jidiški בלום 'cvijet'. Čest patronimski/metronimski sufiks u aškenaskim prezimenima.

בלומנשיין|בלימנשיין|בלומנשיין Blumenschein/Blümschein/Blumschein/Blumstein - jid. - Jidiški בלומנשטיין, prezime nastalo od prezimena בלום /blum/ (v. Blum/BLUM).

Bodanecky - jid. - Jidiški prezime nastalo konverzijom od patronima od

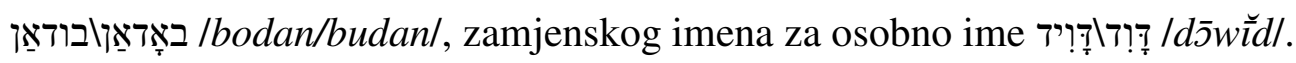

Böhm/BöHN - jid. - Jidiški בעם (× njem. Böhme ‘Čeh'). Moguće je da je riječ o novom prezimenu obitelji doseljene iz Češke.

Bondy/Bondi/BONDI - tal. - בונדי, prezime nastalo iz prijevoda osobnog imena יוֹמְטוֹב /yōmtōv/ 'blagdan (dosl. dobar dan)'.

Bonyhád/Bonyhady/Bonyhadi/BONYKADI/BANYKADI - mađ. - Mađarsko prezime nastalo konverzijom od toponima, imena grada Bonyháda u mađarskoj Tolnanskoj Županiji.

Borković/BORKOVIĆ - hrv. - Prezime nastalo konverzijom od patronima od osobnog imena Borko < Bore/Boro + -ko < Borislav/Borimir (Čilaš Šimpraga, Ivšić Majić i Vidović 2018: 101).

Prezime je promijenjeno iz izvornih בערגער /berger/ (v. Berger/BERGER) i lberndorfer/ (v. Berndorfer).

Bornstein/BORNSTEIN - jid. - Jidiški באָרנשטיין, prezime nastalo konverzijom od patronima od osobnog imena באָרן|באָרנע|בערנע/born/borne/berne/, zamjenskog imena za osobno ime 习习习习ำ $/ b \bar{s} r \bar{u} k /$.

BOROŠ - mađ. - Jidiško prezime באָרָָ > mađ. bor 'vino'. Moguće je da je riječ o adaptaciji nekog od aškenaskih prezimena koja počinju s Wein-.

Borovitz - jid. - Jidiški באָראָביץ, prezime nastalo konverzijom od patronima od osobnog imena באָָראב /borov/ > rus. боров 'vepar', prijevod njemačkoga Eber < pragerm. *ebura-

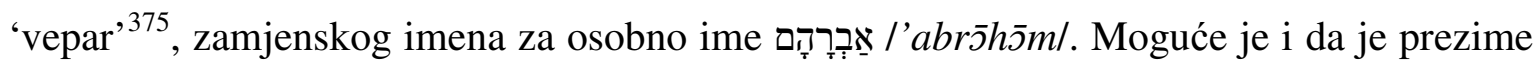
nastalo od češkoga borovice 'bor'.

Borunski - jid. - Jidiški באָרונסקי polj. prezime Boruński, vjerojatno nastalo od toponima Borun.

Boskovitz - jid. - Jidiški באָסקאָביץ, prezime nastalo konverzijom od toponima, danas Blansko u Moravskoj.

\footnotetext{
${ }^{375}$ S obzirom na židovsku religioznu averziju prema svinjama, jesu li Židovi pri preuzimanju ovog osobnog imena od kršćana bili svjesni njegove etimologije?
} 
BOŽAN - hrv. - Prezime nastalo konverzijom od osobnog imena Božan < Božo < Božidar (Čilaš Šimpraga, Ivšić Majić i Vidović 2018: 103; Skok 1974: I 178-181).

Brammer - jid. - Jidiški prezime nastalo konverzijom patronima od osobnog imena

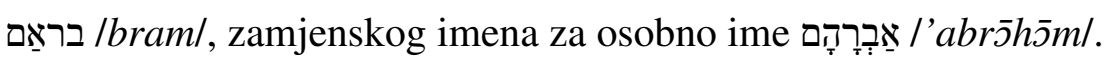

Braun/BRAUN - jid. - Jראון (× njem. 'smeđ'). Smeđa je jedna od mnogih boja

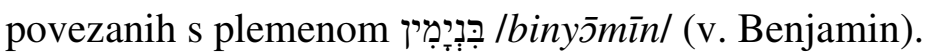

BRAUNER - jid. - Jidiški pראונער, prezime nastalo konverzijom od patronima od prezimena ברֵֵון /braun/ (v. Braun/BRAUN).

Bresslauer/Breslauer/BRESLAUER/BRESLUER/BRSSLAUER - jid. - Jidiški ברעסלַוער, prezime nastalo od etnika od nekog od toponimā Bresslau (danas Wrocław u Poljskoj), Bresław/Brèslauja (danas Браслаў и Bjelorusiji) ili Bracław (danas Брацлав u Ukrajini). Heinrich W. i Eva H. Guggenheimer prezime izvode iz osobnog imena Bres < slav. 'breza' (Guggenheimer H. W. i Guggenheimer E. H. 1992: 129), što je malo vjerojatno, jer -lauer ne spada u skupinu patronimskih sufikasa.

Bret - jid. - Jidiški ברעט slav. 'brat', prezime nastalo od prijevodnog osobnog imena njemačkoga Bruder, zaštitničkog osobnog imena koje se davalo posmrčetu.

Breyer/Breüer/BREYER - jid. - Jidiški ברייער (× srvnjem. 'pivovar').

Brichta/Brihta/BRICHTA - češ. - Jidiški בריכטראר Češko prezime njemačkog podrijetla.

Brief - jid. - Jidiški בריף (× njem. Brief 'pismo').

Brill/Brühl/Brüll - jid. - Jidiški בריל, prezime nastalo od toponima, imena više mjesta u Njemačkoj: Briel, Brill ili Brüel. Ovo su prezime nosili i potomci Joela ben Jošua Lajb

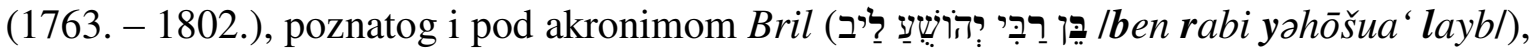
učitelja u Bresslauu (današnjem Wrocławu) u Šleskoj.

Broch/Brok/Bruck/BROCK/BRUCK - jid. - Jidiški בראָך|בראָקוברוק, prezime nastalo od

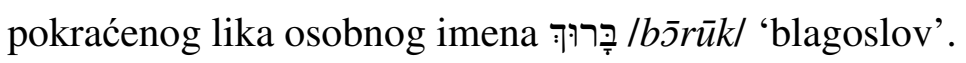

Brodjowin/Brodjovin/BRODJOVIN - jid. - Jidiški ברָָדיאָבין|ברָָדָָָווין, prezime nastalo konverzijom od patronima od osobnog imena בראזד/brod/ > slav. 'gaz, brod', toponima čestog u slavenskom svijetu.

BRODMANN/BRODMAN - jid. - Jidiški בראָדמאָן, prezime nastalo konverzijom od patronima od osobnog imena בראָד/brod/ > slav. 'gaz, brod', toponima čestog u slavenskom svijetu.

Brückner/Brükner/Bruckner/Brukner/BRUCKNER/BRUKNER - jid. - Jidiški ברוקנער ובריקנער, prezime nastalo konverzijom od patronima od osobnog imena ברוק /bruk/ (v. Broch/Brok/Bruck/BROCK/BRUCK). 
Brumlik - jid. - Jidiški ברומליק, prezime nastalo konverzijom od patronima od jidiškog osobnog imena ארבְרָהָם /brum/, zamjenskog imena za osobno imēhm/.

Buchbinder - jid. - Jidiški בוכבינדער (× njem. Buchbinder 'knjigoveža'), prezime nastalo od naziva zanimanja.

Heinrich W. i Eva H. Guggenheimer, doduše, navode da je u pitanju patronim od osobnog imena בוך /bux/ (× njem. Buch 'knjiga') (Guggenheimer H. W. i Guggenheimer E. H. 1992: 136), no -binder ne spada među sufikse kojima se tvore patronimi.

Büchler/Bichler/BUECHLER/BUCHLER/BIHLER - jid. - Jidiški ביכלער, prezime nastalo ili od srvnjem. umanjenice Büechel 'knjižica' ili pak od 'bukovica (plod bukve)'.

Budlowsky/Budlovsky/Budlovski - jid. - Jidiški בודלאָבסקיובודלָאווסקי, prezime nastalo od toponima Būdelè nedaleko od Vilniusa u Litvi.

Budschowitz - בודשאָוויץ Mid. - Jidiški toponima, danas Bučovice u Češkoj.

BUERGNER - jid. - Jidiški בירגנער, prezime nastalo od osobnog imena רירג/בורק/בירך

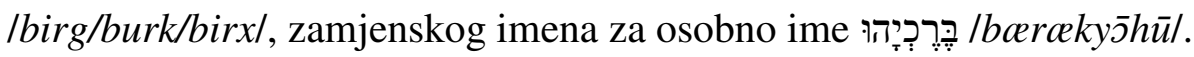

Buhvald - jid. - Jidiški בוכוואַלד (× njem. Buchwald 'bukvik'), prezime nastalo od toponima, čestog imena naselja u Njemačkoj i Poljskoj.

Bunzl - jid. - Jidiški בונצל, prezime nastalo od slavenskog osobnog imena Boleslav.

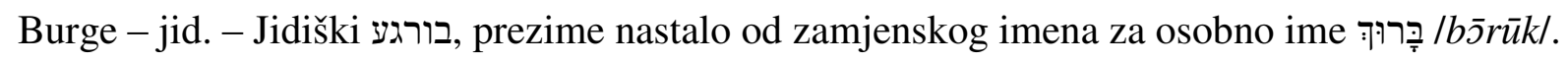

Buschitzki - jid. - Jidiški בושיצקי, prezime nastalo konverzijom od patronima od jidiškog osobnog imena בוש /bušl (× njem. Busch 'grm').

Cajhner - jid. - Jidiški צייכנער (× srvnjem. zeichener 'čudotvorac'; njem. Zeichner 'crtač’).

Camis - sef. - Prezime nastalo konverzijom od judeošpanjolskog osobnog imena כאמס.

Cegledi/CEGLEDI - mađ. - Jidiški pעגלעד, prezime nastalo od etnika izvedenog od toponima Cegléd u Mađarskoj.

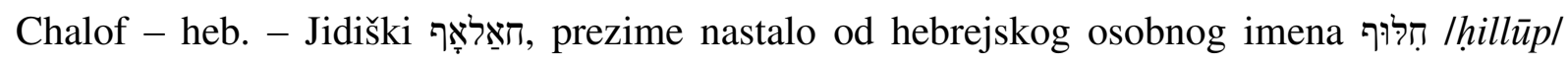
'zamjena' koje se nadijevalo djetetu rođenom nakon smrti brata si.

Cohen/Koen/Kohn/Kohen/Khon/Kahn/Khan/KOEN/KOHN/KHON/KON/KOLIN - heb. Prezime nastalo od hebrejske riječi ${ }^{376}$ /kohen/ 'svećenik (u Hramu)'.

Colin - jid. - Jidiški קָָלין, prezime nastalo od osobnog imena קָָ /kol/, slavenskog

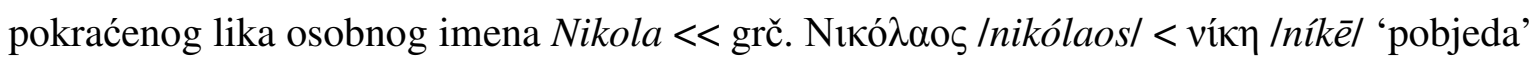
$+\lambda \alpha$ ós /laós/ 'narod'.

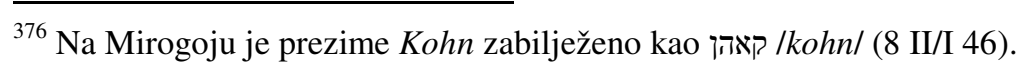


Cuzzi - tal. - Talijansko prezime.

Czierer/Czirer/Zierer/ZIERER - ašk. - Jidiški צירער, prezime nastalo konverzijom od metronima od osobnog imena צירוצירלין ציר צirlcirl/cirlin/, umanjenice od njem. Zier 'dragocjen(a), lijep(a), prekrasan(-na)').

Moguće je i da je prezime nastalo od ženskog osobnog imena Sore (Beider 2001: 16, 574-578).

Czirner/Zirner/ZIRNER - jid. - Jidiški צירנער, prezime nastalo od patronima od metronima

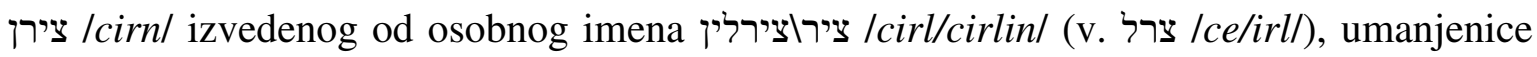
od ציר /cir/ (× njem. Zier 'dragocjen(a), lijep(a), prekrasan(-na)').

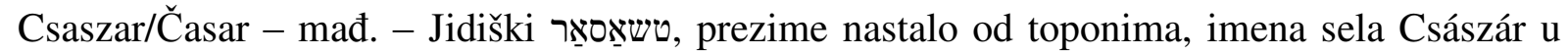
Mađarskoj.

Prezime je promijenjeno iz izvornoga ווייס/weys/ (v. Weiß/Weiss/Weisz/Weis/Weihs/ /WEISS/WEIS).

ČERMAK - češ. - Jidiški טשערמאַק, prezime nastalo od češkoga čermák 'crvendać'.

Daniberg - jid. - Jidiški דאניבערג, prezime nastalo konverzijom od patronima od osobnog

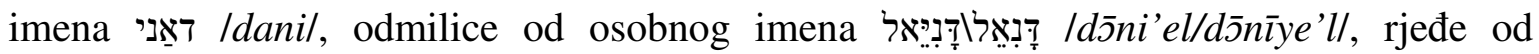
osobnog imena דָָ̣ /d5n/.

Daničić - hrv. - Prezime nastalo konverzijom od metronima od osobnog imena i od astronima Danica < prasl. *dbnbnica, praslavenskog imena Venere koja se vidi ujutro neposredno prije izlaska Sunca (Čilaš Šimpraga, Ivšić Majić i Vidović 2018: 113; Skok 1974: I 379-381).

Prezime je promijenjeno iz izvornoga שוואַרץ/šwarc/ (v. Schwartz/Schwarz/Schwarc/ / Shwarz / Svarz / Šwarz / Švarc / SCHWARTZ / SCHVARTZ / SCHWARZ / /SCHVARZ/SCHWARZZ/SCHWATZ/ŠVARC).

Dannenberg/Danneberg/Daneberg - jid. - Jidiški pַנענבערג, prezime nastalo konverzijom od

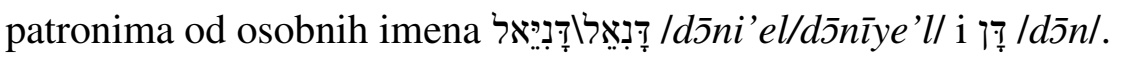

Danon/DANON - sef. - Judeošpanjolski דאנון, prezime nastalo od zamjenskog imena za

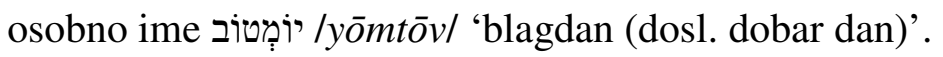

Darvas - mađ. - Jidiški prezime nastalo od toponima u Mađarskoj.

Prezime je promijenjeno iz izvornoga דייטשהערגער /daytšbergerl (v. Deutschberger/ /Dautschberger).

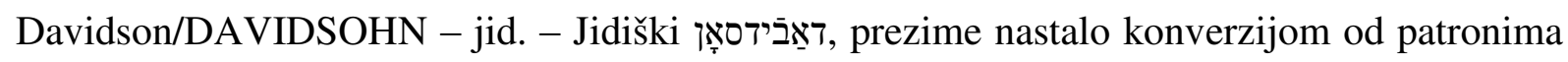
od osobnog imena

de Grič - v. Sachs »de Grič«. 
Deissiger - jid.? - Možda pogrešno napisano Dreissiger. Dreißiger 'tridesetaši' su bili liberalni intelektualci koji su tridesetih godina XIX. st. napustili Njemačku i preselili se u SAD kako bi pobjegli političkoj represiji, no u širem smislu pojam obuhvaća sve one koji su se tih godina doselili u SAD iz Njemačke. Ako je to prezime zaista povezano s navedenim pojmom, ostaje pitanje kako su njegovi nositelji dospjeli u Zagreb.

Deucht/Dajht/DEUCHT - jid. - Jidiški דייכט. Možda prezime nastalo od njemačke riječi Deich 'nasip'.

Deutsch/Dajč/DEUTSCH/DAUTSCH - jid. - Jidiški דייטש, prezime nastalo od njemačkoga 'govornik njemačkoga/jidiša'.

Deutsch »Maceljska «/Deutsch »Maceljski «/DEUTSCH-MACELJSKI - pl. - Godine je 1910. car i kralj Franjo Josip I. (1830. - 1916.) drvotršcu, veletrgovcu i veleposjedniku Filipu Feivelu Šrageu b. Benjamin Deutschu (u. 1919. g. u dobi od 96 g.), njegovoj supruzi Franjici r. Hertman i sinovima Vilimu (1853. - 1926.), Benku (1863. - 1923.) i Albertu (r. 1867.) te njihovim zakonitim potomcima dodijelio plemstvo s predikatom Maceljski, prema maceljskoj šumi, te su Vilim, Albert i Benko dotični plemićki naslov preuzeli kao prezime.

Ovo su prezime preuzeli i neki pripadnici obiteljī Granitz i Hochsinger, koji su pripadali istoj porodici kao i gorenavedeni.

Deutschberger/Dautschberger - jid. - Jidiški דייטשבערגער, prezime nastalo konverzijom od patronima od prezimena דייטש/daytš/ (v. Deutsch/Dajč/DEUTSCH/DAUTSCH).

Diamand/Diamant - jid. - Jיאַמאַנד/דיאַמאַנט 'dijamant', prezime nastalo od naziva dragulja koji je u svećeničkom naprsniku simbolizirao pleme זְבְּלוּן /zabulūn/.

Diamandstein/Diamantstein - jid. - Jidiški דיאַמאַנדשטייןודיאַמאַנטשטיין, prezime nastalo od patronima od prezimena דיאַמאַנד/דיאַמאַנט /diamand/diamant/ (v. Diamand/Diamant).

Dick/DICK - jid. - Jidiški דיק (× njem. dick 'debeo').

d'Italia - tal. - Prezime talijanske obitelji iz XVIII. st. iz južne Italije (: heb. מֵאִיטֵליָיה Ime' 'italiy $\bar{s}^{h} /$ 'iz Italije').

Dobida - jid. - Jidiški דֵָָבידאי, prezime iz Štajerske.

Dobo - mađ. - Jidiški אָָָָ, mađarsko prezime Dobó, ali je isto tako moguće da je prezime nastalo od toponimā u Slovačkoj (danas Dubové, do 1886. g. Dubovó), Székelydobó u Rumunjskoj (danas Dobeni, do 1889. g. Dobó) i Tarcadobó u Slovačkoj (danas Dubovica). Prezime je promijenjeno iz izvornoga שייבער/šeyber/ (v. Scheiber).

Dobrin - jid. - Jidiški prezime nastalo od toponima, današnji Dobrzyń u Poljskoj. 
Donat/Donath - jid. - דונאַט/דונאַת prezime nastalo od latinskog osobnog imena Donatus 'dan (po Bogu)', odgovara hebrejskom osobnom imenu נָָָ /n̄̄t̄̄n/ 'dao je'.

Donner/DONNER - jid. - Jאזנער ( $\times$ njem. Donner 'grom'). Prezime nastalo od osobnog imena /don/, jidiškog izgovora osobnog imena

Dorner/DORNER - jid. - Jidiški דאָרנער, prezime nastalo od osobnog imena דאָרן /dorn/ ( njem. Dorn 'trn'), zamjenskog imena za osobno ime

Dragoner - jid. - Jidiški דראַגָאנער (× njem. Dragoner 'dragun'), vjerojatno je riječ o prezimenu nastalom od slavenskog osobnog imena Draga.

Drechsler/Drexler/Dreschler - jid. - Jidiški דרעכסלער, prezime nastalo od osobnog imena

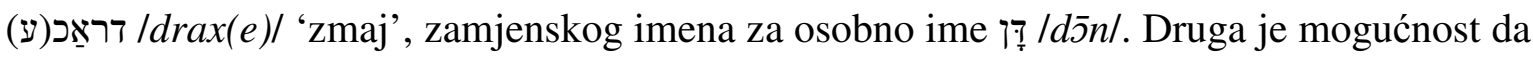
je riječ o prezimenu nastalom od naziva zanimanja, njemačke riječi Drechsler 'tokar', ali samo ako je Židovima bilo dopušteno baviti se tim obrtom. S treće je strane moguće i da je židovska obitelj preuzela prezime od neke njemačke obitelji, a da sama nije morala imati nikakve veze s navedenom profesijom.

DREISINGER - jid. - דרייסינגער Možda prezime nastalo kombinacijom imenice דריי Idrey/ 'tri' i prezimena זינגער/zinger/ (v. Singer/SINGER). V. i Deissiger.

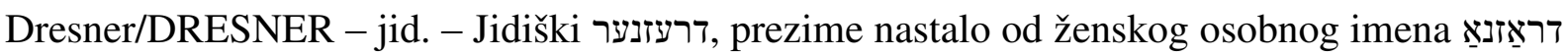
Idraznal. Osobno je ime u zapadnom (srednjoeuropskom) Kanaanu preuzeto od čeških kršćana, među kojima je u srednjem vijeku bilo uobičajeno. Vjerojatno se izgovaralo ['drazna], a moguće je da je izvedeno od korijena drz- 'hrabar, smion' (Beider 2001: 491-492).

Drill - jid. - Jidiški דריל (× srvnjem. 'okretati').

DROŽANSKI - jid. - Jidiški דראָזשאַנסקי, prezime nastalo od ženskog osobnog imena דרייזין /dreyzin/ (v. Dresner/DRESNER).

Drucker/DRUCKER - jid. - Jרוקער מרוק מiški, prezime nastalo od jidiškog osobnog imena /druk/ < rus. друг, prijevodnog osobnog imena jidiškoga פרוינד /froynd/ 'prijatelj'.

Dub - jid. - Kako je riječ o aškenaskoj obitelji, prezime je nastalo od jidiškoga דוב > rus. дуб.

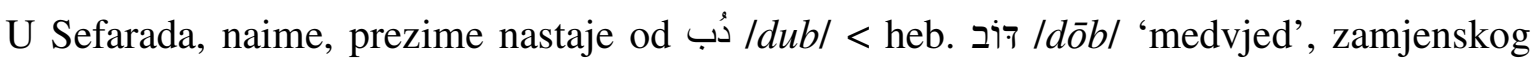

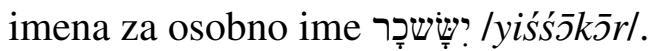

Duić - hrv. - Prezime je promijenjeno iz izvornoga Deutsch (v·Deutsch/Dajč/DEUTSCH/ /DAUTSCH) fonetizacijom i prilagodbom hrvatskoj prezimenskoj tradiciji.

Dukesz - jid. - Jidiški דוקעסודוקעש, prezime nastalo od osobnog imena דאָק /dok/, zamjenskog imena za osobno ime רָָ /rōhell.

Ebenspanger/Ebenšpanger/EBENSPANGER - jid. - Jidiški עבענשפאַנגער. 
Eckfeld - jid. - Jidiški עקפעלד, prezime nastalo od toponima u Njemačkoj.

Eckstein/Ekstein - jid. - Jקשטיין, Didiški, prezime nastalo konverzijom od patronima od jidiškog osobnog imena עק lekl (× njem. Ecke 'oštrica (mača)'). Prema drugim tumačenjima prezime je nastalo od niskonjemačkoga eek 'hrast', ili iz hebrejskoga

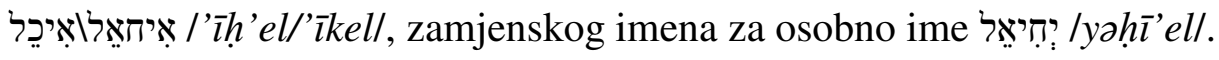

Egri/EGRI - mađ. - Jidiški עגרי

Ehrenfest - jid. - Jidiški ערנפעטט, prezime nastalo od jidiškoga ערע /erel (× njem. Ehre 'čast'),

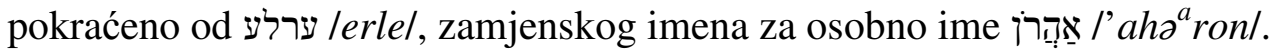

Ehrenfreund/ERENFREUND - jid. - Jidiški ערענפריינד, prezime nastalo od jidiškoga ערע /ere/ (× njem. Ehre 'čast'), pokraćeno od ערכְר lerlel, zamjenskog imena za osobno ime l'aha ${ }^{a}$ ron/.

Ehrenreich - jid. - Jidiški ערענרייך, prezime nastalo od jidiškoga ערע lerel (× njem. Ehre

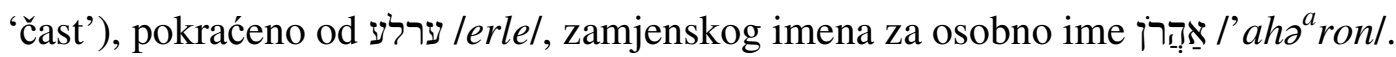

Ehrlich/Erlih/EHRLICH/ERLICH - jid. - Jidiški ערליך (× njem. Ehrlich 'častan'), prezime

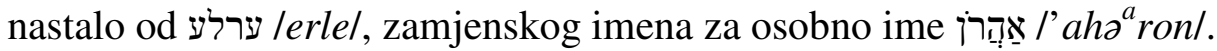

Ehrmann - jid. - Jidiški prezime nastalo konverzijom od zamjenskog imena za osobno

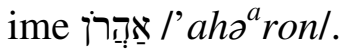

Eichhorn/Eichorn/EICHHORN/EICHORN - jid. - Jidiški אייכהורן (× njem. Eichhörnchen 'vjeverica'), prezime nastalo od אייכל leyxl/, jidiške inačice hebrejskog osobnog imena

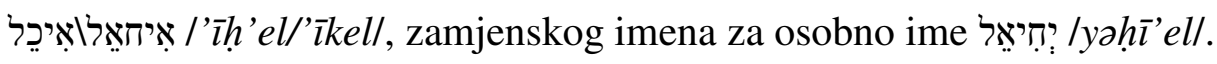

Eiland - איילנד (

Eilner - jid. - Jidiški איילנער, prezime nastalo od osobnog imena Eile, pokraćenog lika starog njemačkog osobnog imena Eilhart < pragerm. *agjo- 'oštrica' + *hardu- 'čvrst, žestok'.

Eisen - jid. - Jייזן (× njem. Eisen 'željezo'), prezime nastalo konverzijom od

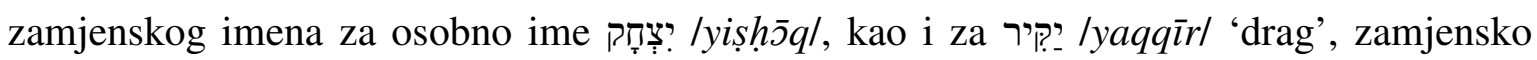

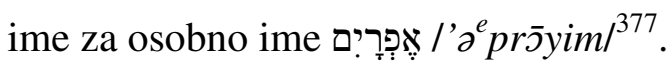

Eisenmann - jid. - Jidiški pייזנמאַן prezime nastalo konverzijom od patronima od zamjenskog

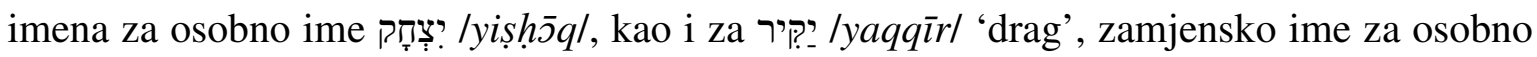

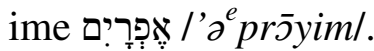

${ }^{377}$ Prema Jer. 30,20. U prijevodu Antuna Sovića:

${ }^{20}$ Zar mi je Efrajim sin toliko drag, dijete najmilije? Jer koliko god mu prijetim, bez prestanka živo na njega mislim i srce mi dršće za njega od nježne samilosti« - riječ je YHWH-ova. 
Eisenstädter / Eisenstaedter / Eisenstadter / EISENSTäDTER / EISENSTAEDTER / / EISENSTEADTER / ERSENSTAEDTER / EISENSTADTER / EISENSTAEDTLER/ /Ajzenšteter - jid. - Jidiški אייזנשטעטער ${ }^{378}$. U mađarskih Židova prezime nastalo od etnika od toponima Eisenstadt u Gradišću (hrv. Željezni Grad, Željezno).

Eisner/EISNER - jid. - Jidiški אייזנער, prezime nastalo od osobnih imena אייזן /eyzn/ (v. Eisen) ili אייז/אייזלואייזן /eyzl/eyzh/, zamjenskih imena za osobna

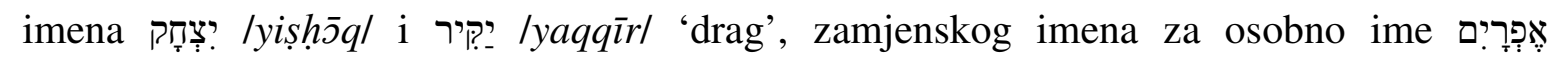
/’a prōyim/.

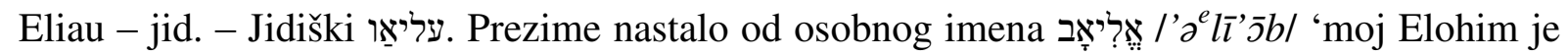

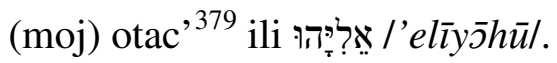

Endrenyi/ENDRENJI - mađ. - Jidiški ענדרעני.

Engel/ENGEL/ENGL - jid. - Jidiški ענגל > njem. 'anđeo' (v. Angelus/ANGELUS). Prezime nastalo tako što ga je preuzelo ogranak porodice Kahn koja je živjela u kući Engel. Moguće je i da je riječ o prezimenu nastalom konverzijom od osobnog imena Engel,

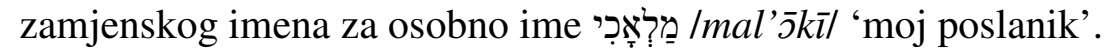

ENGELSMANN - ענגלסמאָן - jid. - Jidiški, prezime nastalo konverzijom od patronima od prezimena ענגל /engl/ (v. Engel/ENGEL/ENGL).

Engelsrath/Englesrath/Engelsratha/ENGELSRATH - jid. - Jidiški ענגלסראט (× njem. 'anđeo savjetnik'), prezime nastalo kao složenica od osobnih imena ענגל /engl/ 'anđeo' (v. Engel/ENGEL/ENGL) i ראַ / $/ \mathrm{rad} /$ 'savjet' (: polj. rada, njem. Rat).

Engelstadt - jid. - Jidiški ענלשטאט, prezime nastalo od osobnog imena ענגל /engl/ (v. Engel/ /ENGEL/ENGL).

Engländer - jid. - ענגלענדער ענגלאֵנד /england/ prezime nastalo od osobnog imena pak od osobnog imena ענגל /engl/ (v. Engel/ENGEL/ENGL), zamjenskog imena za osobno

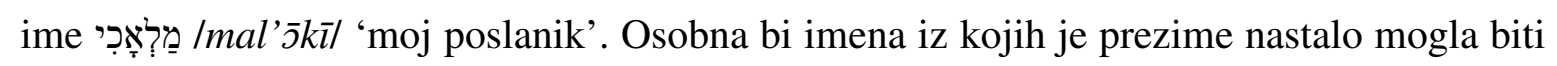
izvedena ili iz toponima Enger u Zapadnoj Falačkoj ili iz osobnog imena ענג /eng/.

Enzinger - jid. - Jidiški ענצינגער, prezime nastalo od osobnog imena אנזה/ענזיל /enze/enzil/, zamjenskog imena za osobno ime

Epstein/EPSTEIN/EPŠTEIN - jid. - Jidiški עפשטיין, što može biti prezime nastalo konverzijom od patronima izvedenog od osobnog imena כפ /ep/, pokraćenog lika

\footnotetext{
${ }^{378} \mathrm{Na}$ Mirogoju zabilježeno kao אייזענשטעדטער /eyzenštedterl (2 I 56).

${ }^{379} \mathrm{Br} 16,1$. U transkripciji Silvija Grubišića: Eliab.

${ }^{380} \mathrm{Na}$ Mirogoju zabilježeno kao ענגעלסראטה /engelsrath/ (13A II/I 10).
} 
njemačkog osobnog imena Eberhard < pragerm. *ebura- "vepar' ${ }^{381}+$ *hardu- 'čvrst, žestok', što je zamjensko ime za osobno ime אַבְרָָָָם /'abrs̄hs̄m/. Prezime je isto tako moglo עבער nastati od toponima Epstein u Falačkoj i Eppstein u Hessenu. Samo osobno ime leber/, uz osnovnu motivaciju njemačkom imenicom značenja 'vepar', može biti i hebrejsko osobno ime צֵּק /'ebarl 'udaljeno područje (možda Asirija?) ${ }^{382}$, eponim Hebrejā (Izraelićana, Edomaca, Moabljana, Amonaca, Midjanaca i dr.), no pisano אבר može biti i zamjensko ime za osobno ime אַבְרָרָהם /'abrōhs̄m/.

Erdinger - jid. - Jidiški ערדינגער, prezime nastalo od etnika od toponima Erding u Bavarskoj.

Ernst - jid. - Jidiški ערנסט, prezime nastalo konverzijom od njemačkog osobnog imena Ernst $<$ pragerm. *arnja- 'ozbiljan'.

Eskenazi/Eškenazi - heb.-jid. - Prezime nastalo od hebrejskog osobnog imena I'aška ${ }^{a} n a z /$ 'raspršen oganj' ${ }^{383}$. Ime je kasnije povezano sa sjevernjačkim zemljama, da bi se na kraju preko Porajnja i Falačke i dijelova sjeverne Francuske ustalilo kao ime za Njemačku te za Židove koji govore germanskim jezikom - jidišem.

Fajgenbaum - jid. - Jidiški פייגנבאַום, prezime nastalo konverzijom od metronima od osobnog imena פַייגע /feygel (× njem. Feige 'smokva'), pokraćenog lika ženskog osobnog imena פיייגלופָָגלל /feygl/fogl/ 'ptica', prijevodnog osobnog imena i zamjenskog imena za hebrejsko

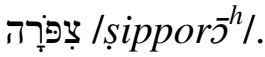

Glasovni razvoj: Fogel $>$ (ispadanje zanaglasnog samoglasnika) Fogl $>$ Fougl $>$ Foygl $>$ (umanjenica s prijeglasom) Feygl > Feyge (Beider 2001: 500-501)

Moguće je i da je samo osobno ime motivirano imenicom značenja 'smokva', jednim od sedam plodova Zemlje Obećane.

Färber/Ferber/FERBER - jid. - Jidiški פערבע 'bojadisar'. Prezime nastalo od naziva zanimanja ako su se Židovi smjeli baviti tim obrtom. S druge je strane moguće i da je židovska obitelj preuzela prezime od neke njemačke obitelji, a da sama nije morala imati nikakve veze s navedenom profesijom.

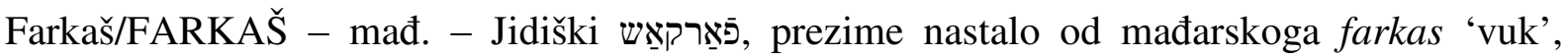

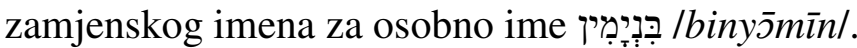

\footnotetext{
${ }^{381}$ Pri preuzimanju ovog osobnog imena Židovi vjerojatno nisu bili svjesni njegove etimologije, jer je teško povjerovati da bi s osobnim imenom svoga praoca povezali išta što ima ikakve veze sa svinjom, obredno nečistom životinjom.

${ }^{382}$ Post 10,21. U transkripciji Silvija Grubišića: Eber.

${ }^{383}$ Post 10,3. U transkripciji Silvija Grubišića: Aškenaz.
} 
Feder - jid. - Jidiški פעדער 'bratić, rođak', ujedno može biti i prezime nastalo od osobnog imena.

FEIGAPESLA - jid. - Ovo se prezime nalazi jedino u bazi podataka Gradskih grobalja, koji su nerijetko upitni zbog pogrešnog prepisivanja iz rukom pisanih dokumenata. Ako je prijepis točan, riječ je o prezimenu sastavljenom od dva jidiška ženska osobna imena, prvo je ujedno i prezime פייגע /feyge/fayge/ (v. Fajgenbaum), a drugo פיסלופל . פיגל /pesl/ /pesl/ פסל /pesl/).

Feigelstock/Feiglstock/FEIGALSTOCK - jid. - Jidiški פייגלשטָָָ, prezime nastalo konverzijom od metronima od osobnog imena פַייגע /feyge/ (v. Fajgenbaum).

Fein/FEIN - jid. - Jidiški פיין 'fina, nježna', prezime nastalo od ženskog osobnog imena.

Feiner/FEINER - jid. - Prezime nastalo od prezimena פיין /feyn/ (v. Fein/FEIN).

Feldbauer/FELDBAUER/FELDBANER - jid. - Jidiški פעלדבאַוער konverzijom od patronima od jidiškog osobnog imena פעלד (× njem. Feld 'polje'), odnosno od פעלדבהַו Ifeldbau/ (× njem. Feldbau 'poljoprivreda').

Feldheim - jid. - Jidiški פעלדהיים, prezime nastalo konverzijom od patronima od osobnog imena פעלד (× njem. Feld 'polje').

Feldmann/Feldman/FELDMAN - jעלדמאָן - jid. - Jidiški, prezime nastalo konverzijom od patronima od osobnog imena פעלד (× njem. Feld 'polje').

Felikx/FELIKS - jid. - Jidiški פעליקס, prezime nastalo od latinskog osobnog imena Felix 'sretan', zamjenskog imena za osobno ime

Fellner - jid. - Jidiški פעלנער, prezime nastalo od jidiškog osobnog imena פעל /fell ( $\times$ njem. Fell 'krzno, runo'). Samo je osobno ime pokraćeni lik slavenskih osobnih imena čiji je prvi dio veli-.

Fellstein - jid. - Jidiški פעלשטיין, prezime nastalo konverzijom od patronima od jidiškog osobnog imena פעל (אel/ (× njem. Fell 'krzno, runo'). Samo je osobno ime pokraćeni lik slavenskih osobnih imena čiji je prvi dio veli-.

FENI - ? - Ovo se prezime pojavljuje jedino u bazi podataka Gradskih grobalja. Moguće je da je riječ o omašci i da bi ispravno prezime trebalo glasiti Fein. U tom slučaju v. Fein/FEIN.

Feuereisen/FEUEREISEN - jid. - Jidiški פירייזן (× njem. Feuereisen 'kresivo'), prezime nastalo konverzijom od metronima od jidiškog osobnog imena פיר /foyer/ ( $\times$ njem. Feuer

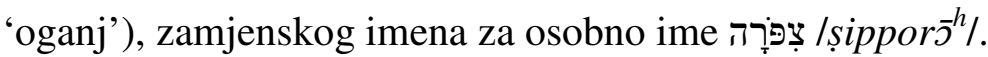

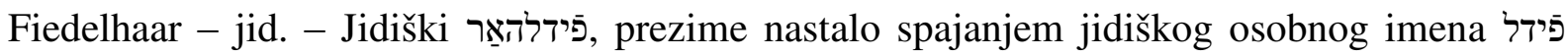
/fidl/ (× njem. Fiedel 'violina') izvedenog od פיידל /ffeydl/, umanjenice od פייט Ifeyt/ < njem. 
Veit < pragerm. *walpu- 'šuma' ili *wīda- ‘širok, dalek', što je pak zamjensko ime za

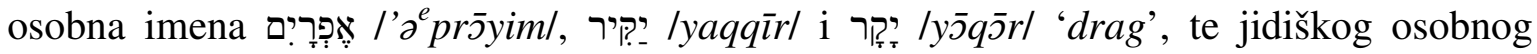
imena האַר /harl (× njem. Haar 'kosa, lan') ili pak / הער /her/ (× njem. Herr 'gospodar').

Figatner/FIGATNER - jid. - Jidiški פַיגאַטנער današnje mjesto Figaty u Poljskoj.

Finzi/Finci/FINZI/FINCI - tal. - Prezime nastalo konverzijom od patronima od osobnog imena פינץ /finc/, zamjenskog imena zạ̄ș/ 'brončana usta'. Talijanska je porodica Finzi poznata još iz XII. st.

Fischbein/FISCHBEIN - jid. - Jidiški פישביין, prezime nastalo konverzijom od patronima od

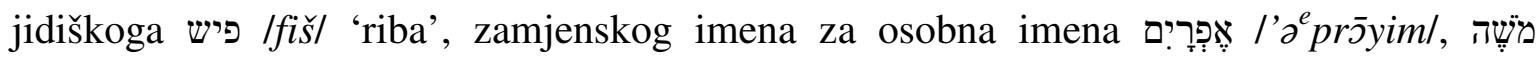

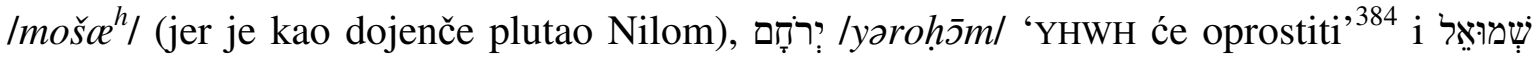
/šamū'ell.

Fischel/Fischl/FISCHEL/FISCHL - jid. - Jidiški פישל, prezime nastalo od umanjenice od

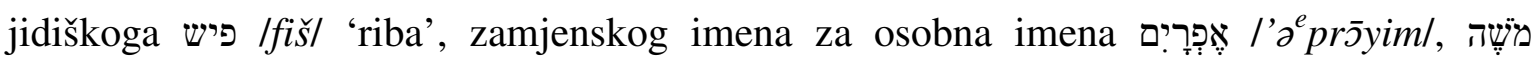

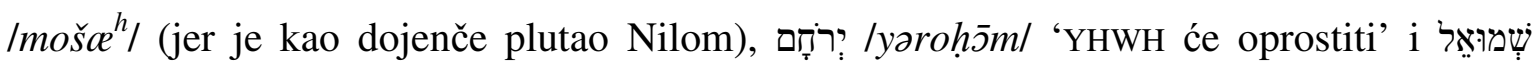
/šวmū'el/.

Fischer/Fisher/Fišer/FISCHER/FISHER/FIŠER - jid. - Jidiški פישע, prezime nastalo konverzijom od patronima od jidiškoga פיש /fiš/ 'riba', zamjenskog imena za osobna imena

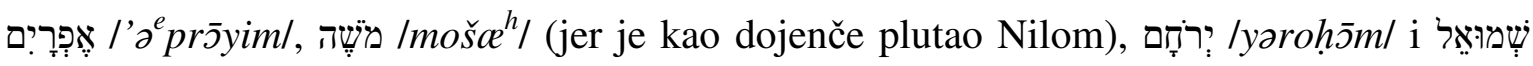
/šวmū'ell.

Fischler/Fišler - jid. - Jidiški פישלער, prezime nastalo konverzijom od patronima od osobnog imena פַישל /fišl// (v. Fischel/Fischl/FISCHEL/FISCHL).

Fišar - Prezime je promijenjeno iz izvornoga פישביין/fišbeyn/ (v. Fischbein/Fischbein/ /FISCHBEIN), dolazi i u dvoprezimenskom liku Fišbein Fišar. Je li u pitanju inačica prezimena Fišer (v. Fischer/Fisher/Fišer/FISCHER/FISHER/FIŠER)?

Fišbah/FISCHBACH/FISCHBAH - jid. - Jישבאַך, prezime nastalo konverzijom od patronima od osobnog imena פיש /fiš/ (v. Fischbein/FISCHBEIN).

Fišter - jid. - Jidiški פישטער. Možda prezime nastalo od osobnog imena פישר /fiš/ (v. Fischbein/ /FISCHBEIN).

Flamm - jid. - Jidiški פַלאם 'plamen', prezime nastalo prijevodom aramejskih osobnih imena

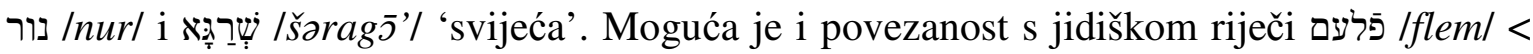
polj. plama 'mrlja'.

\footnotetext{
${ }^{384} 1$ Sam 1,1. U transkripciji Antuna Sovića: Jeroham.
} 
Fleischacker - jid. - Jidiški פַיישהאָקער 'mesar', inačica prezimena פַליישער /fleyšer/ 'mesar', prezime nastalo od naziva zanimanja. U židovskim je zajednicama mesar koji meso

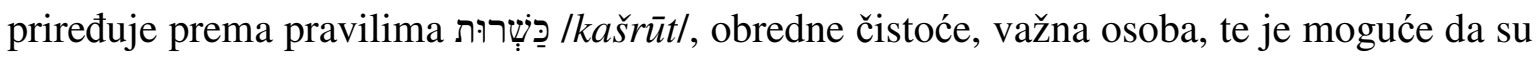
prezimena dotične motivacije doista izvedena od naziva tog zanimanja.

Fleischmann/FLEISCHMAN/FLEISHMAN - jid. - Jidiški פליישמאַ 'mesar', prezime nastalo od naziva zanimanja.

Flesch/FLESCH - jid. - Jidiški פלעש 'meso'.

Flesih - jid. - Jidiški פלעסיך, prezime (× njem. fleißig 'marljiv' < njem. Fleiß 'marljivost').

FLICK - jid. - Jidiški פَדיק (× njem. Flick 'zakrpa').

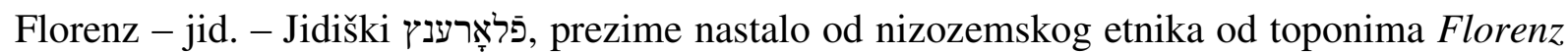
'Firenca'.

Prezime dolazi samo u dvoprezimenskom liku Figatner-Florenz, u što je promijenjeno izvorno prezime פַיגאטטנער /figatner/ (v. Figatner/FIGATNER).

Fodor/FODOR - jid. - Jidiški פָָָָר, prezime nastalo od ruskog osobnog imena Фёдор <<

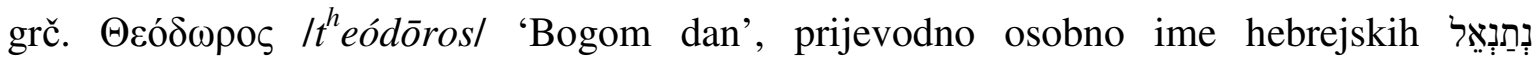

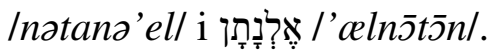

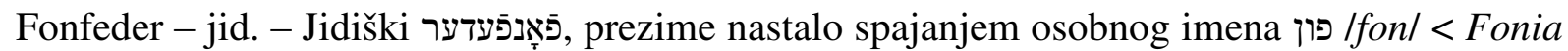
i osobnog imena פעדער /feder/ (v. Feder).

Forschner - jid. - Jidiški פَאָרשנער (njem. Forschner 'istraživač'), prezime nastalo konverzijom od patronima od osobnih imena Fora i Pora.

Frank/FRANK - jid. - Jidiški פַּאָק, prezime nastalo konverzijom od zamjenskog imena za

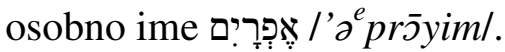

Frankel/Frank1/FRANKL - jid. - Jidiški פَראנקל, prezime nastalo od osobnog imena פַראנק (v.

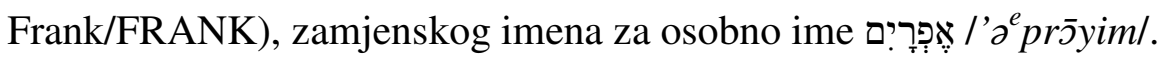

Frei - jid. - Jidiški פריי (× njem. Frei 'slobodan, plemenit, radostan, bezbrižan').

Ujedno i prezime koje je promijenjeno iz već promijenjenog prezimena Polak (v. Pollak/ /Polak/Poljak/POLLAK/POLAK).

Freiberger/FREIBERGER - jid. - Jidiški פרייבערגער, prezime nastalo konverzijom od patronima od jidiškoga פריי /frey/ (v. Frei).

Freida - jid. - Jidiški פריידא, prezime nastalo konverzijom od zamjenskog imena za osobno

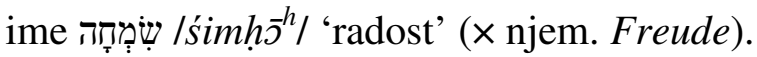

Freistädtler - jid. - Jidiški פריישטעטלער, prezime nastalo od etnika od toponima Freistadt.

Frelić/FRELIĆ - hrv. - Prezime je promijenjeno iz izvornoga פרעליך/frelix/ (v. Fröhlich/ /FROELICH) fonetizacijom i adaptacijom hrvatskoj prezimenskoj tradiciji. 
Frenkl - jid. - Jidiški פַרעקל, prezime nastalo od osobnog imena פֵֵַנק /frank/ (v. Frank/ /FRANK).

Freund/FREUND - jid. - Jidiški פרינינד 'prijatelj'.

Fried/Früed/FRIED - jid. - Osobno ime פَריד (: njem. Friede 'mir'), prezime nastalo od pokraćenog lika njemačkog osobnog imena Friedrich (v. Friedrich/Fridrich/FRIEDRICH).

Friedfeld/FRIEDFELD - jid. - Jidiški פרידפיעלד, prezime nastalo konverzijom od patronima od osobnog imena פריד /frid/ (v. Fried/Früed/FRIED).

Friedl - jid. - Jidiški פَרידל 'omiljen', prezime nastalo konverzijom od osobnog imena.

Friedländer/Friedlander - jid. - Jidiški פרידלאַנדער|פַּידלענדער, prezime nastalo konverzijom od patronima od osobnog imena פ̄ פריד /frid/ (v. Fried/Früed/FRIED).

Friedlfeld - jid. - Jidiški פַרידלפעלד, prezime nastalo konverzijom od patronima od osobnog imena פ̄ פרידל /fridll/ (v. Friedl).

Friedmann/Friedman/Fridman/FRIEDMAN/FRIDMAN - jid. - Jidiški prezime nastalo konverzijom od patronima od osobnog imena פריד/frid/ (v. Fried/Früed/FRIED).

Friedrich/Fridrich/FRIEDRICH - jid. - Jפרידריך, Jidiški prezime nastalo konverzijom od njemačkog osobnog imena Friedrich < pragerm. *fripu- 'mir' + *rīk- 'vladar, kralj'.

Friem - jid. - Jidiški פרים, prezime nastalo ili od osobnog imena, ili od pokraćenog lika

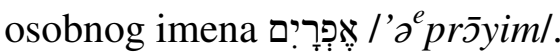

Frieß/Fries - jid. - Jidiški פ̄, prezime nastalo konverzijom od osobnog imena.

Frisch/FRISCH - jid. - Jidiški פריש (× njem. Frisch 'svjež, mlad, poduzetan'), prezime nastalo od čestog pokraćenog lika osobnog imena Friedrich (v. Friedrich/Fridrich/ /FRIEDRICH).

Frischmann - jid. - Jidiški פרישמאָן, prezime nastalo konverzijom od patronima od prezimena פּריש /frišl (v. Frisch/FRISCH).

Fritz - jid. - Osobno ime פריץ, prezime nastalo konverzijom od pokraćenog lika osobnog imena Friedrich (v. Friedrich/Fridrich/FRIEDRICH).

Fritzi/Frizzi - tal. - Prezime vjerojatno nastalo od njemačkog osobnog imena Fritz (v.).

Heinrich W. i Eva H. Guggenheimer ovo prezime tumače kao nastalo od talijanske riječi frizzo 'dosjetljivost' (Guggenheimer H. W. i Guggenheimer E. H. 1992: 255).

Fröhlich/FROELICH - jid. - Jidiški פרעליך (× njem. Fröhlich 'radostan, veseo').

פָראָם /from/ (× njem. fromm 'pobožan'), što može biti lik osobnih imena אֶפְרָים /’a prōyim/ i

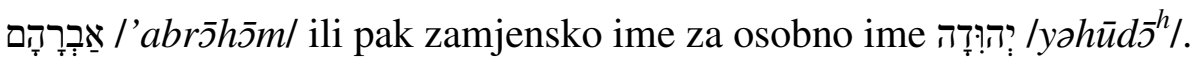

Frühzeitig - jid. - Jidiški פריצייטיג. 
Fuchs/FUCHS/FUKS - jid. - Jidiški פוקס 'lisica', prezime nastalo od zamjenskog imena za

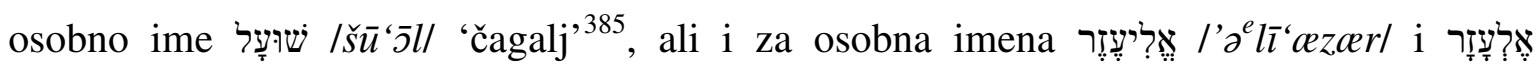
l'ala's̄z̄̄ol.

Furman/FUHRMAN - jid. - Jidiški פַורמָָ (× njem. Fuhrmann 'kočijaš'), prezime nastalo konverzijom od patronima od osobnog imena פורער /furer/ (× 'opskrbljivač').

Fürst/Furst/FUERST/FURST - jid. - Jidiški פורסט|פירסט (× njem. Fürst 'prvi, najplemenitiji, knez').

Fussmann/Fussman/FUSSMAN - jid. - Jidiški prezime nastalo konverzijom od patronima od imenice פוס /fus/ (× njem. Fuß 'stopa(lo)').

Gajić - hrv. - Prezime nastalo konverzijom od patronima od osobnog imena Gajo.

Prezime je promijenjeno iz već promijenjenoga prezimena גאֵרדזָׁש /gardoš/ (v. Gárdos/ /Gardoš), prijevodom njegova etimona, osobnog imena גרדי/garde/gardi/ 'vrt, grad'.

Gál - mađ. - Jidiški גאֵ, često mađarsko prezime.

Prezime je promijenjeno iz izvornoga גליק/glik/ (v. Glück/Glick/GLüCK/GLUECK/ /GLUCK).

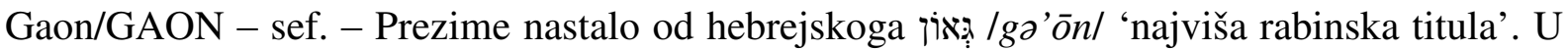
Sefarada i osobno ime.

Gárdos/Gardoš - mađ. - Jidiški גארזדָש, prezime nastalo konverzijom od mađarskog patronima od osobnog imena גאַרדע|גאַרדי/garde/gardi/ (× njem. Garten 'vrt'), zamjenskog imena za osobno ime גaר /geršōn/.

Prezime je promijenjeno iz izvornoga גאָלדהאַמער /goldhamer/ (v. Goldhammer).

Gavrin - hrv. - Prezime nastalo od osobnog imena Gavro > גבּבְרִיאַל /gabrīell (Skok 1974: I 541). Nije nemoguće da je prezime nastalo prilično slobodnim prijevodom prezimena שוואַרץ ש̌swarc/ (v. Schwartz/Schwarz/Schwarc/Shwarz//Svarz/Šwarz/Švarc/SCHWARTZ/ / SCHVARTZ / SCHWARZ / SCHVARZ / SCHWARZZ / SCHWATZ / ŠVARC), uzevši u obzir boju gavrana (v. Vranić).

Ovo se prezime pojavljuje jedino u dvoprezimenskom liku Gavrin-Schwarz.

Geiger/GEIGER - jid. - Jidiški גייגער 'violinist'.

Geiringer - jid. - Jidiški גיירינגע, prezime nastalo od etnika od toponima Geiring u Gradišću.

Geisler - jid. - Jidiški גייזלער, prezime nastalo od imenice (× srvnjem. geiz, 'koza').

Prezime je promijenjeno iz izvornoga שענוואַלד/šenwald/ (v. Schönwald/SCHOENWALD/ /SCHONWALD).

\footnotetext{
${ }^{385} 1$ Sam 13,17. U transkripciji Antuna Sovića: Šual.
} 
Gelb - jid. - Jidiški געלב 'žut’, prezime nastalo od boje zastave plemena

Gemünder/GENUENDER - jid. - Jidiški געמינדער 'veseo', no prezime je moglo nastati i od etnika od nekog od toponimā Gamünd, Gamünden, Gmünd u Njemačkoj i Austriji.

Gentilli - tal. - Talijanski 'plemeniti', prezime nastalo od nadimka furlanske porodice Hefetz (heb. חֶֶָ /hefaṣ/ 'užitak, želja').

Gerber/GERBER - jid. - Jidiški גערבע (× njem. Gerber 'štavitelj'). Moguće je da je riječ o prezimenu nastalom od naziva zanimanja ako su se Židovi smjeli baviti ovim obrtom. $\mathrm{S}$ druge je strane moguće i da je židovska obitelj preuzela prezime od neke njemačke obitelji, a da sama nije morala imati nikakve veze s navedenom profesijom.

Gewöll - jid. - Jidiški געוועל (× njem. Gewöll 'gvalja').

Geyduschek/GEYDNSCHEK/GEYDNSECHEK - גִeš. - Jajdušek i Gajdi̊šek su češka prezimena.

Glaser/GLASER - jid. - נלאָזזר (× njem. Glaser 'staklar'), prezime nastalo od osobnog imena גלסס /glas/ (× njem. Glas 'staklo'). Moguće je da je riječ o prezimenu nastalom od naziva zanimanja ako su se Židovi smjeli baviti ovim obrtom. S druge je strane moguće i da je židovska obitelj preuzela prezime od neke njemačke obitelji, a da sama nije morala imati nikakve veze s navedenom profesijom.

Glauber - jid. - Jidiški גלאובער, prezime nastalo od imenice Glaube 'vjera, povjerenje'.

הlesinger/GLESINGER - jid. - Jלעזינגער גלאַס גidiški, prezime nastalo od osobnog imena Iglas/ (v. Glaser/GLASER) ili pak < polj. głaz 'kamen' odnosno < rus. глаз 'oko'.

Globnik - Prezime je promijenjeno iz izvornoga שטערן/štern/ (v. Stern/Štern/STERN/ /ŠTERN). Moguće da je u pitanju slovensko prezime.

Glück/Glick/GLüCK/GLUECK/GLUCK - jid. - Jidiški גליק (× njem. Glück 'sreća'), prezime nastalo od ženskog osobnog imena.

Glücks/GLICKS - jid. - Jidiški גליקס, prezime nastalo od prezimena גליק/glik/ (v. Glück/ /Glick/GLüCK/GLUECK/GLUCK).

Gold/GOLD - jid. - Jidiški גָָזלד 'zlato', prezime nastalo od riječi 'zlato' kao ekvivalenta

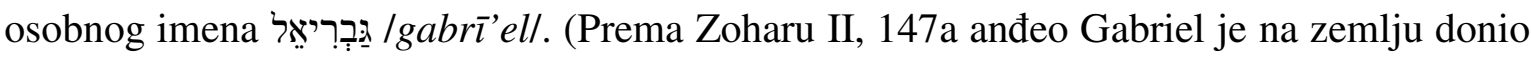
nebesko zlato.)

Goldberger/GOLDBERGER/GODBERGER - jid. - Jidiški גאזדבערג > גאָלדבערגע /goldberg/ ( $\times$ njem. Goldberg 'rudnik zlata'), prezime nastalo konverzijom od patronima od osobnog imena גאָלד /gold/ (v. Gold/GOLD), ali i je moguće da je nastalo i od toponima, imena grada u Šleskoj, danas Złotoryja u Poljskoj. 
Goldenberg - jid. - Jidiški גאלדענבערג, prezime nastalo konverzijom od patronima od osobnog imena גָזָלד /gold/ (v. Gold/GOLD).

GOLDFINGER/GODFINGER - jid. - Jidiški גאלדפינגנר (njem. Goldfinger 'prstenjak'), prezime nastalo od osobnog imena גָָלד /gold/ (v. Gold/GOLD).

Goldhammer - jid. - Jidiški njem (njem. Goldhammer 'zlatni čekić', Goldammer 'žuta strnadica'), prezime nastalo od osobnog imena גאָלד /gold/ (v. Gold/GOLD).

Goldmann/Goldman/GOLDMANN/GOLDMAN - jid. - Jאָלדמאַן prezime nastalo konverzijom od patronima od osobnog imena גאָלד /gold/ (v. Gold/GOLD).

Goldner/GOLDNER - jid. - Jidiški גאָלדנער, prezime nastalo od osobnog imena גאזלד /gold/ (v. Gold/GOLD).

Goldscheider/GOLDSCHEIDER - jid. - Jidiški גאָלדשיידער, prezime nastalo od osobnog imena גאזלד /gold/ (v. Gold/GOLD).

Goldschein - jid. - Jidiški גאלדשיין (× njem. Goldschein 'zlatni sjaj'), prezime nastalo od osobnog imena גאזרל /gold/ (v. Gold/GOLD).

גאָלדשמידו Goldschmidt/Goldschmied/GOLDSCHMIDT/GOLDSCHMIED - jid. - Jidiški גארדדשמיט| (× njem. Goldschmied 'zlatar'), u Šleskoj u XVIII. st. zamjensko ime za osobno

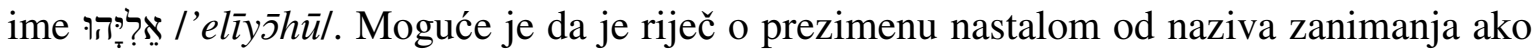
su se Židovi smjeli baviti ovim obrtom. S druge je strane moguće i da je židovska obitelj preuzela prezime od neke njemačke obitelji, a da sama nije morala imati nikakve veze $s$ navedenom profesijom.

Goldstein/GOLDSTEIN - jid. - Jidiški גאלדשטיין 'krizolit, olivin', prezime nastalo konverzijom od patronima od osobnog imena גָָלדז /gold/ (v. Gold/GOLD) ili od naziva jednog od dragulja iz naprsnika velikog svećenika, simbola plemena זְבְלוּן /zabulūn/.

Goldzieher - jid. - Jאָלדציער prezime nastalo od osobnog imena גאָלד /gold/ (v. Gold/GOLD).

Goran - hrv. - Prezime nastalo konverzijom od osobnog imena nastalog konverzijom od mjesnog lika 'stanovnik gore' < gora + -an (Čilaš Šimpraga, Ivšić Majić i Vidović 2018: 148).

Prezime je promijenjeno odbacivanjem dočetnog sufiksa već promijenjenoga prezimena Goranin (v.).

Goranin - hrv. - Prezime nastalo konverzijom od osobnog imena nastalog konverzijom od standardnojezičnog lika 'stanovnik gore'.

Prezime je promijenjeno prijevodom izvornoga בערגער /berger/ (v. Berger/BERGER). 
Gorjan/GORJAN - hrv. - Prezime nastalo od nekadašnjeg mjesta boravka rodonačelnika, u ovom slučaju gore.

Prezime je promijenjeno iz izvornoga שוואַבעניץ/Šwabenic/ (v. Schwabenitz/Schwabeniz/ /Shwabenitz/Švabenitz/Švabenic/SCHWABENITZ/SCHVABENITZ/ŠVABINIC).

GORSKI - hrv./jid. - Prezime nastalo od imenice gora (Skok 1974: I 289-591), kao i tri prethodna.

Druga je mogućnost da je riječ o jidiškome גָארסקי, prezimenu nastalom konverzijom od patronima od osobnog imena גוּר /goral, sefardske aramejske inačice osobnog imena

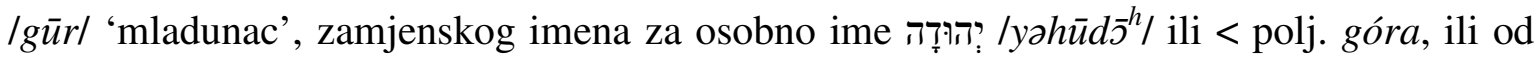

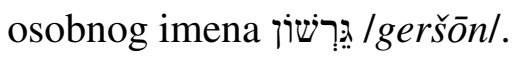

Gostl/GOSTL - jid. - Jidiški גָזָטל / גוסט /gost/ prezime nastalo od osobnog imena гость 'trgovac, gost'.

Gottfried - jid. - Jidiško גוטפ̄ריד, prezime nastalo konverzijom od njemačkog osobnog imena < pragerm. *guda- 'bog' + *fribu- 'mir'.

Gottlieb - jid. - Jidiški גָאטליב 'ljubljen po Bogu', prezime nastalo konverzijom od njemačkog osobnog imena < pragerm. *guda- 'bog' + *leuba- 'drag, voljen', prijevoda osobnog

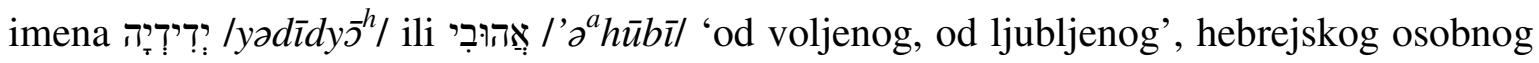
imena koje se ne pojavljuje ni u Tanahu ni u Talmudu, a koje je izvedeno od אָּוּב /'万̄hūb/ 'voljen, ljubljen', jednog od pridjevaka Tore.

Gradečak - hrv. - Prezime nastalo od toponima Gradec.

Graff/Graf - jid. - Jidiški גראר (× njem. Graf'grof').

Graner - jid. - Jidiški גראנער / גראנעם /granes/ prezime nastalo od osobnog imena svnjem. grân 'crven, grimizan', boje zastave plemena רְוּרן /ro'ūben/. Alternativnim je tumačenjem prezime nastalo od ruskoga гран 'zrno'.

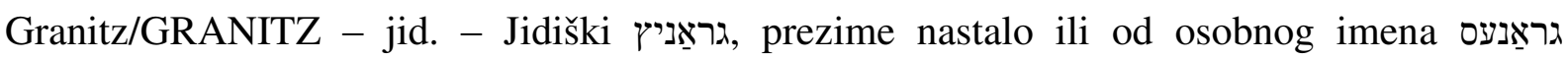

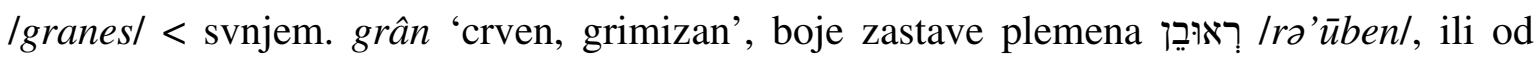
ruskoga гран 'zrno'.

Granski/GRANSKI - jid. - Jidiški גראנסקאי /granes/ < svnjem. grân 'crven, grimizan', boje zastave plemena רִּאוּבן /rə'ūben/, ili od ruskoga гран 'zrno'.

Grič - v. Sachs »de Grič«.

Grillo - tal. - Prezime nastalo od talijanskoga 'zrikavac'. Porodica je Grillo bila drevna nežidovska konzularna porodica iz Genove. 


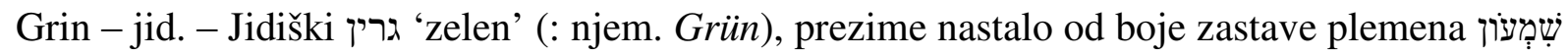

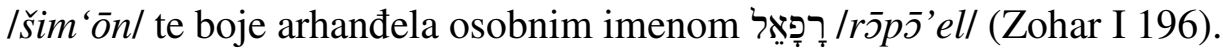

Gross/Groß/Grosz/GROSS - jid. - Jראָס Jidiški njem. Groß 'velik, debeo, krupan, osobit, važan, jak, čuven, plemenit'), prezime nastalo konverzijom od zamjenskog imena za osobno ime

Grosskopf/Groskopf - jid. - Jidiški גראָסקָָ (× njem. Großkopf 'koji je velike glave').

Heinrich W. i Eva H. Guggenheimer prezime tumače kao prezime nastalo konverzijom od patronima od prezimena גראָס/gros/ (v. Gross/Groß/Grosz/GROSS) (Guggenheimer H. W. i Guggenheimer E. H. 1992: 303), iako -kopf nije jedan od sufikasa kojim se tvore patronimi.

Grossmann/GROSSMAN - jid. - Jidiški ${ }^{386}$, prezime nastalo konverzijom od patronima od prezimena גראָס/gros//v. Gross/Groß/Grosz/GROSS), zamjenskog imena za

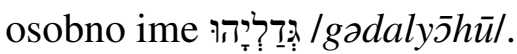

Gruber - jid. - Jidiški גרובער, prezime nastalo od osobnog imena גרוב /grub/, iako je moglo nastati i od njemačkoga Grube 'jama'.

Grubić - hrv. - Prezime nastalo konverzijom od patronima ili metronima od osobnih imena izvedenih iz pridjeva grub (Grubo, Gruba, Grube) (Skok 1974: I 626).

Grünbaum/Grinbaum/GRUENBAUM - jid. - Jidiški גרינבאוּום, prezime nastalo konverzijom od patronima od osobnog imena גרין /grin/ (v. Grin).

Grünberger/GRUENBERGER - jid. - Jidiški גרינבערגער, prezime nastalo ili konverzijom od patronima od osobnog imena גרין /grin/ (v. Grin) ili od etnika od toponima Grünberg, imena više mjesta u Njemačkoj.

Grünfeld/GRUENFELD - jid. - Jidiški גרינפעלד (: njem. Grünfeld 'zeleno polje'), prezime nastalo konverzijom od patronima od osobnog imena גרין /grin/ (v. Grin).

Grünhütt/GRUENHUT - jid. - Jidiški גרינהוט (: njem. grüne Hütte 'zelena koliba'), prezime nastalo od osobnog imena גרין /grin/ (v. Grin).

Grünwald / Grunwald / GRÜNWALD / GRüNWALD / GRUENWALD / GRüNNVALD / /GRüVALD - jid. - Jidiški גרינוואַלד, prezime nastalo od osobnog imena גרין /grin/ (v. Grin).

Gulgas - Prezime je promijenjeno iz izvornoga גרינוואַלד/grinwald/ (v. Grünwald/Grunwald/ GRÜNWALD/GRüNWALD/GRUENWALD/GRüNNVALD/GRüVALD).

\footnotetext{
${ }^{386}$ Na Mirogoju zabilježeno kao גראססמאן /grossman/ (5 I 27).
} 
Günser - jid. - Jidiški גינסער, prezime nastalo konverzijom od etnika od toponima, imena grada Güns u Gradišću, danas Köszeg (gradišćanskohrvatski Kiseg) u Mađarskoj.

Gütermann/Guttermann - jid. - Jidiški prezime nastalo konverzijom od

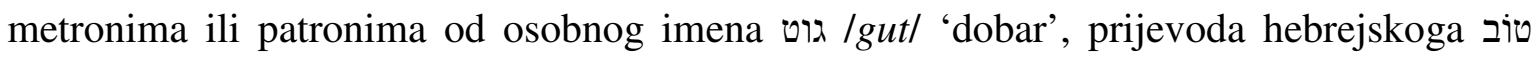
Itōb/, što može biti osobno ime i jedan od pridjevaka Tore, a u liku Guthiel i zamjensko

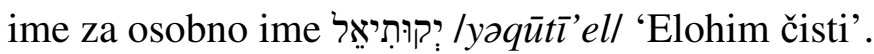

Gutfreund - jid. - Jidiški גוטפרוינד (: njem. guter Freund 'dobar prijatelj'), prezime nastalo od osobnog imena גוט /gut/ (v. Gütermann/Guttermann).

Guthard/Guthardt/Guthart - jid. - Jidiški גוטהאַרדוגוטהאַרט, prezime nastalo od osobnog imena גוט/gut/ (v. Gütermann/Guttermann) ili pak od njemačkoga osobnog imena Gotthard < pragerm. *guda- 'bog' + *hardu- 'čvrst, žestok'.

Guttentag - jid. - Jidiški גוטנטאו /gut/ (v. Gütermann/ /Guttermann), ali i uobičajeni pozdrav na njemačkome 'dobar dan, ${ }^{387}$, kao i prijevod hebrejskog osobnog imena יוֹטוֹ /yōmtōv/ 'blagdan (dosl. dobar dan)'.

Guttmann/Gutmann/Gutman/GUTTMANN/GUTTMAN - jid. - Jidiški prezime nastalo od metronima ili patronima od osobnog imena גוט /gut/ (v. Gütermann/

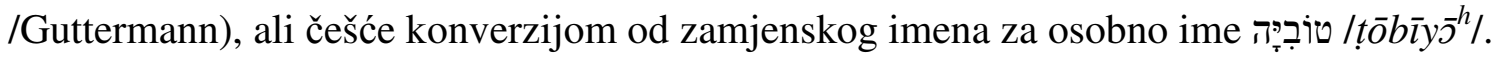

Gvozdan - hrv. - Prezime nastalo konverzijom od osobnog imena Gvozdan < gvozd- 'željezo' (Skok 1974: I 643).

Prezime je promijenjeno djelomičnim prijevodom izvornoga אייזנשטעטער /eyznšteter/ (v. Eisenstädter / Eisenstaedter / Eisenstadter / EISENSTäDTER / EISENSTAEDTER / / EISENSTEADTER / ERSENSTAEDTER / EISENSTADTER / EISENSTAEDTLER / /Ajzenšteter).

Gvozdanović - hrv. - Prezime nastalo konverzijom od patronima od osobnog imena Gvozdan (v.) < gvozd- 'željezo’ (Skok 1974: I 643).

Prezime je promijenjeno djelomičnim prijevodom izvornoga אייזנשטעטער leyznšteter/ (v. Eisenstädter / Eisenstaedter / Eisenstadter / EISENSTäDTER / EISENSTAEDTER / / EISENSTEADTER / ERSENSTAEDTER / EISENSTADTER / EISENSTAEDTLER / /Ajzenšteter).

Haas/HAAS - jid. - Jאַ (× njem. Hase 'zec'), prezime nastalo od zamjenskog imena

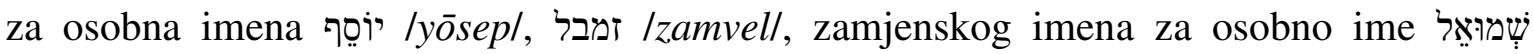

\footnotetext{
${ }^{387}$ U hrvatskome je zabilježeno prezime Dobrojutrović (Leksik prezimena... 1976: 133).
} 


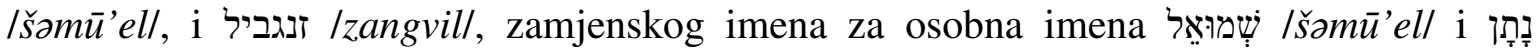
In̄̄t̄̄n/.

Habermann - jid. - Jאֵַערמאַן האבר /haber/ (: njem. Hafer 'zob'), zamjenskog imena za osobno ime אַבְרָרָם /'abrร̄hร̄m/. Moguće je i da je izvor prezimena u hebrejskoj riječi חָָ /ḥ̄ber/ 'prijatelj, član' > 'učen, pobožan čovjek', tituli koja se u Europi pridavala proučavatelju Tore koji nije bio i rabin, no iz tog se prezimena uglavnom nisu izvodili patronimi ove vrste.

Habersfeld/Haberfeld/HABERFELD - jid. - האבער)(ספעלד (: njem. Hafersfeld 'polje raži'), prezime nastalo konverzijom od patronima od jidiškoga האָבר /haber/ (v. Habermann).

Hacker - jid. - Jidiški האֵַקער, האַקאָקן /hak/hakn/ (: njem. Hacke 'peta'),

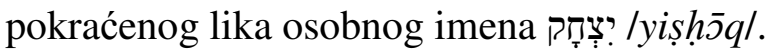

Hafner/HAFNER - jid. - Jidiški האָפַנער, prezime nastalo od osobnog imena /hofl (v. Hoff/ /HOFF).

Hahn/HAHN - jid. - Jאֵאן 'kokot, pijetao', prezime nastalo od zamjenskog imena za

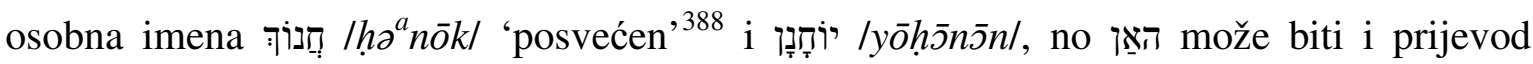
hebrejskoga גֶֶּ /gaebarl, što ujedno znači i ‘čovjek', njemački Mann, te je kao takvo

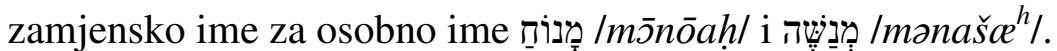

Hajduška - jid. - Jיידושקאֵ prezime nastalo od imena nekadašnje mađarske županije Hajdúság, danas dijela Hajdu-biharske županije.

Hajon/HAJON - sef. - Jיון החיים /hayyīm/. Izvorno je značenje hebrejske imenice često kontaminirano španjolskim i portugalskim osobnim imenom Jaime $<<$ heb. /ya' $\partial^{a} q o b /$.

Halter - jid. - Jidiški האַלטער.

Halwachs/HALVACHS - האָלוואַכס - jid. - Jidiški. židovskoga prezimena Halbwachs, vjerojatno nastalog od nežidovskog osobnog imena Halber 'napoličar koji radi za pola uroda polja'. Kao židovsko je osobno ime ono inačica

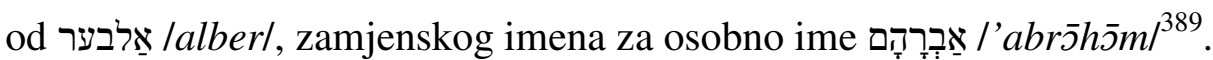

\footnotetext{
${ }^{388}$ Br 26,5. U transkripciji Silvija Grubišića: Henok

${ }^{389}$ Ako je אַלבער /alber/ inačica njemačkog osobnog imena Albert < pragerm. *apulja- 'plemenit' + *berhta‘sjajan', njegova je veza s osobnim imenom אַבְרָָָם /'abrōhōm/ potvrđena i u našem korpusu, u kojem nalazimo 16 pojedinaca s dotičnom kombinacijom građanskog i židovskog osobnog imena.
} 
Hamburger - jid. - Jidiški האמבורגער, prezime nastalo od etnika, vjerojatnije izvedeno od imena grada Homburga u pokrajini Hessen-Nassau Kraljevine Pruske negoli od imena luke Hamburga na rijeci Labi.

Hanapel - jid. - Jidiški האַנאפפעל

Häring/Hering - jid. - הערינג (x njem. Hering 'sleđ'), prezime nastalo od osobnog imena הער /her/ (× njem. Herr 'gospodar') ili od toponima, imena grada u Hessenu.

Hartman/Hertmann/Hertman/HERTMAN - jid. - Jערטמאָן (x njem. Hartmann 'snažan čovjek', jnjem. 'čovjek iz šume'), prezime nastalo konverzijom od starog osobnog imena, ali i patronima od osobnog imena האֵרט /hart/, aškenaskog zamjenskog imena za osobna imena הירש /hiršl/sạabī/, zamjenskog

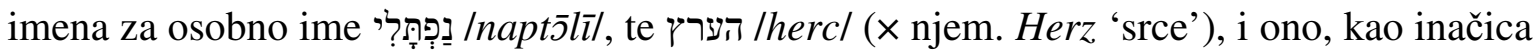

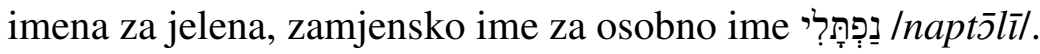

Hauser - jid. - Jidiški האוזער, prezime nastalo od osobnog imena האוש /hauš/, zamjenskog

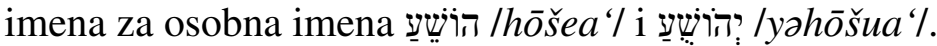

Havas - jid. - Jidiški (× mađ. havas 'snježan'), prezime nastalo od metronima od osobnog imena חַוֹ $/$ haw $w \bar{s}^{h} /$.

Prezime je promijenjeno iz izvornoga האס /has/ (v. Haas/HAAS).

העכט (× njem. Hecht - jid. - Jidiški

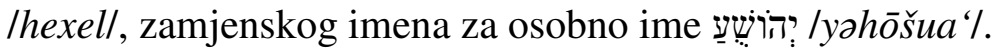

Heidenfeld - jid. - Jidiški היידנפעלד, prezime nastalo od toponima, imena mjesta Heidingsfeld pokraj Würzburga u Franačkoj.

Heim/HEIM/HAIM - jid. - Hebrejski חַיִים /hayyim/ 'život' ( $\times$ njem. Heim 'dom'). Prezime nastalo konverzijom od osobnog imena koje ne nalazimo u Tanahu, već se pojavljuje tek u srednjem vijeku. Izvorno je značenje hebrejske imenice često kontaminirano španjolskim i portugalskim osobnim imenom Jaime << heb. /ya' 'a qob/.

Heimann/Heiman/Haiman/HAIMAN - jid. - היימאָן - Jidiški, prezime nastalo konverzijom od patronima od osobnog imena חַיִיִ /hayyim/ (v. Heim/HEIM/HAIM), ali i od zamjenskog imena za osobno ime הֶֶ, /heymōn/ 'uništenje ${ }^{, 390}$, koji se poistovjećuje s Mojsijem.

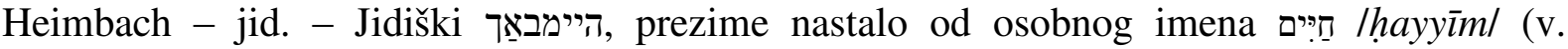
Heim/HEIM/HAIM).

Heimer/Heumer/HEUMER/HENMER - jid. - Jidiški היימער, prezime nastalo od osobnog imena חָיִ /hayyim/ (v. Heim/HEIM/HAIM), ali može značiti i ‘čuven u svojoj zemlji’.

\footnotetext{
${ }^{390} 1 \mathrm{Kr} 5,11$, u Tanahu $1 \mathrm{Kr}$ 4,31. U transkripciji Antuna Sovića: Heman.
} 
Heimler/HEIMLER - jid. - Jidiški היימלער, prezime nastalo od osobnog imena היימל /heyml, umanjenice od osobnog imena חַיִיִ /hayyim/ (v. Heim/HEIM/HAIM) ili zamjenskog imena za osobno ime שִׁמוּאָל /šamū'ell.

Heinrich/HEINRICH - jid. - Jidiški היינריך, prezime nastalo konverzijom od njemačkog osobnog imena < pragerm. *haima- 'selo, dom' + *rīk- 'vladar', zamjenskog imena za

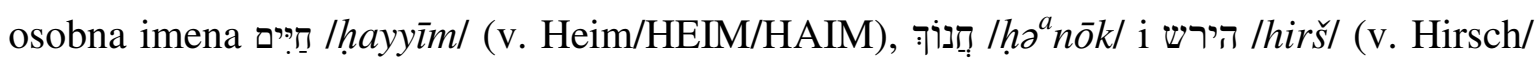
/HIRSCH).

Heischhauer - jid. - Jidiški היישהאַוער. Njemačko prezime.

Heisler - jid. - Jidiški הייסלער, prezime nastalo od osobnog imena היים /heys/ (× njem. heiße 'vruć').

Heksch - mađ. - Jidiški העקש. Mađarsko prezime.

Helfer - jid. - Jidiški העלפער 'pomagač', prezime nastalo od osobnog imena העשלף /helfl, koje se nadijevalo djetetu rođenom poslije smrti brata ili sestre mu.

Heller - jid. - Jidiški העלער, prezime nastalo od toponima, imena mjesta Schwäbisch Hall u saveznoj njemačkoj državi Baden-Württemberg. U njemu su se kovali novčići od pola Pfenniga zvani Häller, koje se ime proširilo za novčiće u mnogim njemačkim zemljama, pa tako i u Austro-Ugarskoj (u mađarskom je dijelu carstva naziv adaptiran u fillér; hrv. filir). $\mathrm{S}$ druge je strane prezime nosila znamenita rabinska porodica podrijetlom iz toga grada.

Herak - hrv. - Prezime nastalo konverzijom od osobnog imena nastalog (neizravno) od njem. Herzog 'vojvoda' < pragerm. *harja- 'vojska' + *teuhan- 'vući, voditi' (Skok 1974: III 612-613).

Prezime se pojavljuje u dvoprezimenskoj kombinaciji Hirschl-Herak.

Herlinger/HERLINGER - jid. - Jidiški הערלינגער, prezime nastalo od osobnog imena הער /her/ ( $\times$ njem. Herr 'gospodar'). Herling pak na njemačkom znači 'grožđe od drugog cvata na sporednim ograncima loze'.

Hermann/Herman/HERMANN/HERMAN - jid. - Jidiški הערמאָן, prezime nastalo konverzijom od njemačkog osobnog imena < pragerm. *harja- 'vojska' + *mannan‘čovjek', zamjenskog imena za osobno ime צִבְ̣ /ṣabī/ pučkom etimologijom preko osobnih imena motiviranih imenicama značenja ‘jelen'.

Herrnstein - jid. - Jidiški הערנשטיין, prezime nastalo konverzijom od patronima od osobnog imena הער/herl (× njem. Herr 'gospodar'). 
Herschl - jid. - Jidiški הערשל, prezime nastalo od umanjenice od jidiškoga הערש /herš/ 'jelen',

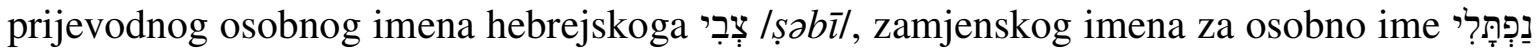
Inapts̄līl.

Hersfeld/HERSFELD - jid. - Jidiški הערספעלד, prezime nastalo konverzijom od patronima od osobnog imena הערש /heřs/ ‘jelen', prijevodnog osobnog imena hebrejskoga צִ /șabī/,

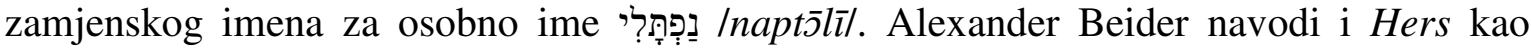
jednu od inačica/izvedenica osobnog imena Hirš: Hirse > (otpadanje dočetnog samoglasnika) Hirš > Herš > Hers (Beider 2001: 329-331).

HERŠKOVIĆ - jid. - Jidiški הערשקאָביטש, prezime nastalo konverzijom od patronima od osobnog imena הערש /herš/ 'jelen', prijevodnog osobnog imena hebrejskoga צִבְבי /ṣabī/,

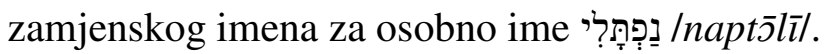

Hertz - jid. - Jidiški הערץ/herc/ (× njem. Herz 'srce'), prezime nastalo od inačice naziva za jelena, zamjenskog imena za osobno ime צִבְִ /ṣabī/, što je pak zamjensko ime za osobno

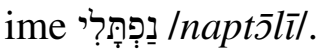

Herzel/Herzl/HERZL - jid. - Jidiški הערצל, prezime nastalo od umanjenice od osobnog imena נַפְתָָרִי Inapt̄̄lil/.

Herzer/HERZER - jid. - Jidiški הערצע, prezime nastalo od osobnog imena הערץ /herc/ (v. Hertz).

Herzfeld - jid. - Jidiški הערצפעלד, prezime nastalo konverzijom od patronima od osobnog imena הערץ /herc/ (v. Hertz) ili od toponima u Zapadnoj Falačkoj.

Herzog/Herzeg/Hercog/HERZOG/HERCOG/HERCEG - jid. - Jidiški הערצאָגוהערצעג (× njem. Herzog 'vojvoda').

Heßel/Hessel/HESSEL - jid. - Jidiški העסל ${ }^{391}$, prezime nastalo od umanjenice od osobnog

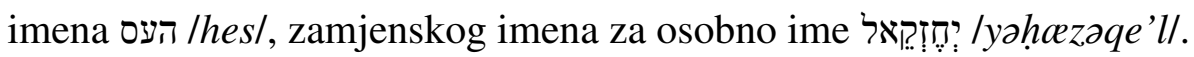

Hilfreich - jid. - Jילפ̄רייך (× njem. hilfreich 'od pomoći'), prezime nastalo od osobnog

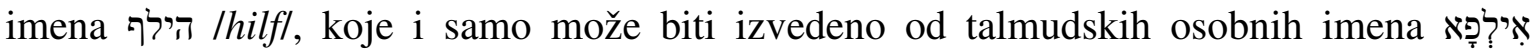

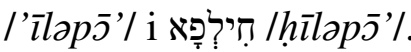

Hirsch/HIRSCH - jid. - Jidiški הירש /hirš/ 'jelen' ${ }^{392}$, prezime nastalo od zamjenskog imena za

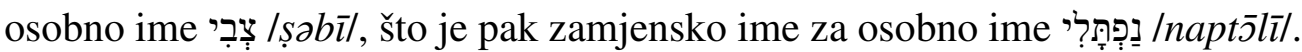

\footnotetext{
${ }^{391} \mathrm{Na}$ Mirogoju zabilježeno kao העססעל /hessel/ (13A II/I 9).

392 Oba (prez)imena, הערש /herš/ znače isto - ‘jelen'. Alexander Beider navodi glasovni razvoj osobnog imena: Hirse > (otpadanje završnog samoglasnika) Hirš > (pravilna promjena u nekim istočnim dijalektima jidiša) Herš (Beider 2001: 329).
} 
Hirschel/Hirschl/Hiršl/HIRSCHL/HEIRSCHL/HIRSEHL/HIRŠL - jid. - Jidiški הערשלוהירשל, prezime nastalo od umanjenice od osobnog imena הירש /hiršl (v. Hirsch/HIRSCH).

Hirschler/Hiršler/HIRSCHLER/HIRCSHLER/HIRŠLER - jid. - Jidiški הירשלער, prezime nastalo od osobnog imena הירשל /hiršl/ (v. Hirschel/Hirschl/Hiršl/HIRSCHL/HEIRSCHL/ /HIRSEHL/HIRŠL).

Hirschmann/Hirschman - jid. - Jidiški הירשמאַן, prezime nastalo konverzijom od patronima od osobnog imena הירש /hiršl (v. Hirsch/HIRSCH).

Hiršberger - jid. - Jidiški הירשבערגע, prezime nastalo konverzijom od patronima od osobnog imena הירש/hirš/ (v. Hirsch/HIRSCH) ili od etnika od toponima, imena više mjesta u Njemačkoj, Poljskoj i Češkoj.

Hirth - jid. - Jidiški הירט (× njem Hirt 'pastir').

Hoch - jid. - Jidiški האָך ( $\times$ njem. hoch 'visok, jak, plemenit, ponosan').

Hochsinger/HOCHSINGER - jid. - Jidiški האָכזינגע, prezime nastalo od prezimena האָר /hox/ (v. Hoch).

Hochstädter/Hochstaedter/HOCHSTAEDTER - jid. - Jidiški האָשטטעטער, prezime nastalo od toponima, nekog od mjesta imena Hochstadt u Njemačkoj i Češkoj (Vysoké).

Hoff/HOFF - jid. - Jidiški האָ /hofl (× njem. Hof 'dvor(ište)'), prezime nastalo od toponima, imena više mjesta u Franačkoj i Moravskoj (Dvorce).

Hoffman/Hofmann/Hofman/HOFFMAN/HOFMAN - jid. - Jidiški האָפסמאַן (× njem. Hoffmann 'zakupac feudalnog zemljišta'), prezime nastalo konverzijom od patronima od prezimena האָ /hofl (v. Hoff/HOFF).

Hohenberg - jid. - Jאָענבערג Tidiški, prezime nastalo od toponima, imena grada u Donjoj Austriji.

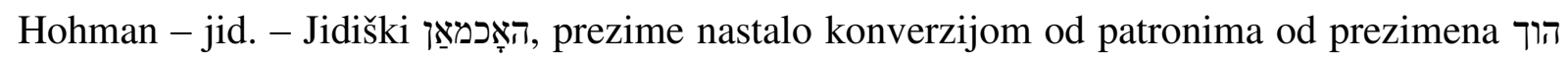
/hox/ (v. Hoch).

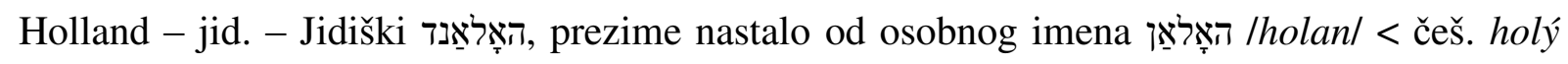
'gol', Inačica je הוליק/hulik/ istog osobnog imena zamjensko ime za osobno ime lyəh $\bar{u} d \bar{\nu}^{h} \%$.

Kako je dokumentirano da su u Preussisch-Hollandu u istočnoj Pruskoj (današnji Pasłęk u Poljskoj) krajem XVII. st. obitavale zajednice Židova, moguće je da je riječ i o prezimenu nastalom od toponima (Guggenheimer H. W. i Guggenheimer E. H. 1992: xix-xx).

HOLZER - jid. - Jארזצער הולר /hold, prezime nastalo od osobnog imena 'drvo, šuma'.

Holzmann - jid. - Jidiški האָָלצמאָ prezime nastalo konverzijom od patronima od osobnog imena הולץ/holcl 'drvo, šuma'. 
Hönig - jid. - Jidiški העניג 'med', prezime nastalo od naziva za med od datulje, jednog od הedam plodova Zemlje Obećane, no moguće je i da je prezime nastalo od inačice האָניך

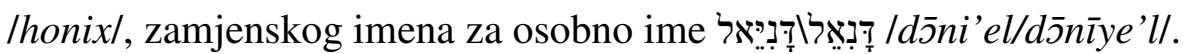

Hönigsberg/Hoenigsberg/Honigsberg/HOENIGSBERG - jid. - Jidiški העניגזבערג (× njem. Hönigsberg 'brdo, brijeg meda'), prezime nastalo konverzijom od patronima od prezimena העניג /henig/ (v. Hönig).

Hönigsfeld/Hoenigsfeld - jid. - Jidiški הענידספעלד (× njem. Hönigsfeld 'polje meda'), prezime nastalo konverzijom od patronima od prezimena העניג /henig/ (v. Hönig).

Horetzky - češ. - Jidiški Čs eško prezime, nastalo od imenice hora 'gora'.

Horn/HORN - jid. - Jidiški (× njem. Horn 'rog').

Horovitz - jid. - Jidiški האָראביץץהאָרָָוויץ, prezime nastalo konverzijom od patronima od osobnog imena הָָרא /horal < češ. 'gora', prijevoda osobnog imena Berg. Osim motivacije imenicom značenja 'brdo, brijeg', ovo je osobno ime uglavnom izvedeno od רְִִּ /bark/,

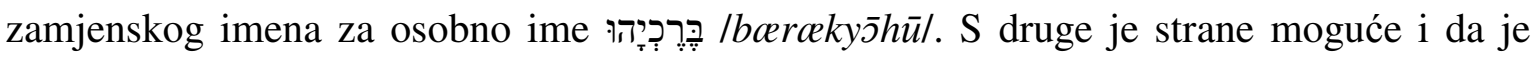
prezime nastalo od toponima, imena grada Hořovice u Češkoj. Znamenita levitska porodica Horovitz potječe iz Praga. Sufiks je -berg čest u tvorbi patronima i metronima.

Horvat - hrv. - Prezime nastalo od etnonima 'Hrvat (iz Kraljevine Hrvatske)'. Prezime je vrlo često u Hrvatskoj, Mađarskoj (Horváth), Slovačkoj i Sloveniji (Skok 1974: I 690-692). Prezime je promijenjeno iz izvornoga שטארֵ /šterk/ (v. Stärk/Sterk/Steerk/Sterk/Šterk/ /STERK/ŠTERK).

HORVATIĆ - hrv. - Prezime nastalo od etnonima Horvat (v.) (Skok 1974: I 690-692).

Horzecky/Horšetzky/HORTENZKY - jid. - Jארָרצעצי Moguće je da je prezime nastalo od toponima Chorzów, imena mjesta pokraj Königshütte, danas Królewske Hute u Šleskoj u Poljskoj.

Hranilović - hrv. - Prezime nastalo konverzijom od patronima od osobnog imena koji u sebi ima korijen hran- 'čuvati, braniti', primjerice Hranimir ili Hranislav (Skok 1974: I 684). Prezime je promijenjeno iz izvornoga הערנשטיין /hernšteyn/ (v. Herrnstein).

Hrlić - hrv. - Prezime je promijenjeno iz izvornoga הערמאַן /herman/ (v. Hermann/Herman/ /HERMANN/HERMAN).

Huber/HUBER - jid. - Jidiški הובער, הובל prezime nastalo od osobnog imena /hubl/ (× njem. Hobel 'blanja'), umanjenice od osobnog imena הובזָ/hubo/, zamjenskog imena za osobno ime משֶֶֶ/mošch ${ }^{h} /$. 
HUBERT - jid. - Jidiški הובערט, prezime nastalo konverzijom od njemačkog osobnog imena < pragerm. *hugi- 'um' + *berhta- 'sjajan', proširenog lika osobnog imena הובז /hubo/, zamjenskog imena za osobno ime מעשֶׁ /moš $\mathfrak{c}^{h} \%$

Hübscher - jid. - Jidiški היבשע, היבש/הובש /hibš/hubš/, zamjenskog imena za osobno ime יוֹאָש $/ y \bar{o}$ '̄̌s/, što je i samo zamjensko ime za osobno ime

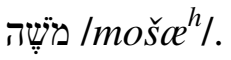

Huzjak - hrv.

Ilić - hrv. - Stegnuti lik prezimena Ilijić, nastalog konverzijom od patronima od osobnog imena Ilija < grč. 'H Vidović 2018: 155; Skok 1974: I 663-664).

Prezime je promijenjeno iz izvornoga ישָָׁרָאל /yiśrōell (v. Israel).

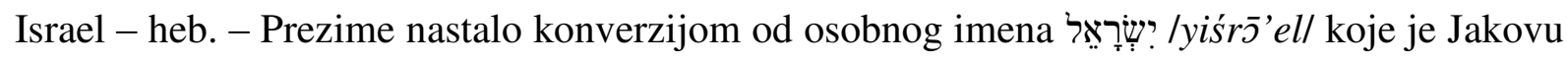
nadjenuo onaj s kojim se hrvao cijelu noć u Knjizi postanka 32,29.

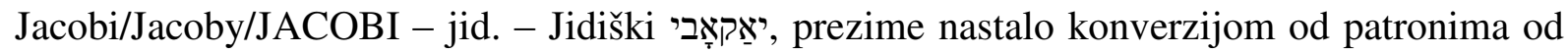

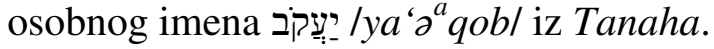

Jagić - hrv. - Prezime nastalo konverzijom od metronima od osobnog imena Jaga $<<$ Agata $<$ grč. 'A $\gamma \alpha \dot{\theta} \theta \eta$ lagát ${ }^{h} e$ l 'dobra' (Čilaš Šimpraga, Ivšić Majić i Vidović 2018: 161; Skok 1974: I 745).

Prezime je promijenjeno iz izvornoga שטערק/Šterk/ (v. Stärk/Sterk/Steerk/Sterk/Šterk/ /STERK/ŠTERK).

Jeck - jid. - Jidiški יעק. Ovo je prezime moglo nastati od jednog od zamjenskih imena i

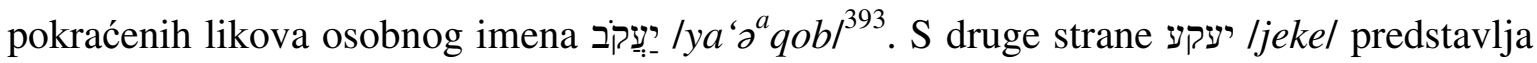
posprdan izraz za njemačkog Židova, preciznog i točnog ${ }^{394}$, koji navodno potječe od kraćih kaputa koje su nosili vanjštinom asimilirani njemački Židovi u usporedbi s dugim kaftanima Židova iz istočnijih dijelova Europe. Nadimak se proširio i na Židove Austrije, Češke i Slovačke.

\footnotetext{
${ }^{393}$ Alexander Beider prikazuje glasovni razvoj osobnog imena kako slijedi: Yakov/Yakob > (umanjenica s prijeglasom) Yekelin > Yeke (Beider 2001: 440-444).

${ }^{394}$ Ta se pedantnost obično projicira i na striktno pridržavanje židovskih vjerskih običaja. Salcia Landmann pak u svojoj knjizi, opisujući stereotipove Židova iz različitih krajeva u vicevima, o Jekima kaže: »Najveći podsmeh prati nemačke Jevreje, tzv. Jeke. Naziv za njih potiče od reči „Jacke” - jakna i prvobitno je označavao Jevreje, koji su sa istočnjačke, kaftanske nošnje prešli na zapadnjački način odevanja. Oni su pronemački orijentisani, nemaju mnogo znanja iz Talmuda, znanja hebrejskog su im isto tako oskudna i nisu bogzna kako poslovni«(Landmann 1987: 165).
} 
Jelenić/JELENČIĆ - hrv. - Prema Petru Skoku prezime nastalo konverzijom od metronima od osobnog imena Jelena < grč. 'E $\lambda \varepsilon ́ v \alpha$ /helénal (Skok 1974: I 663), iako on dopušta i mogućnost da je u pitanju i prezime nastalo konverzijom od patronima od imenice jelen (Skok 1974: I 771), što je manje vjerojatno

Jelenska - hrv. - Prezime za koje je najvjerojatnije da je nastalo etnika (primjerice od toponima Jelenje ili sl.), iako je moguće i da je nastalo konverzijom od ženskog pridjeva

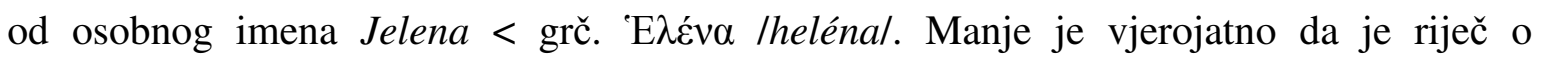
prezimena nastalom konverzijom od patronima od imenice jelen.

Jellinek/Jelinek/JELINEK - jid. - Jidiški עלינעק', prezime nastalo od umanjenice od slavenske riječi jelen, prijevodnog osobnog imena od jidiškoga הירש /hirš/ 'jelen', zamjenskog imena

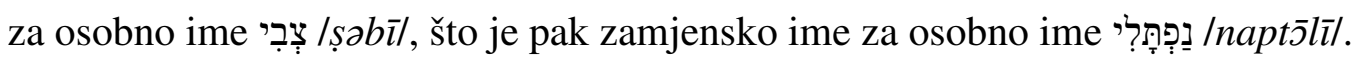

John/JOHN - eng. - Prezime nastalo konverzijom od engleskog osobnog imena

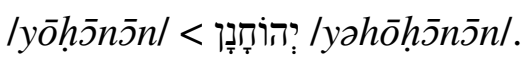

Juhn - jid. - Jidiški יון, prezime nastalo od inačice osobnog imena יוֹנָה $/ y \bar{o} n \overline{5}^{h} /$.

יונג יונגווירט Jungwirth/Jungvirt/JUNGWIRTH - prezime nastalo od jidiškoga - Jidiški

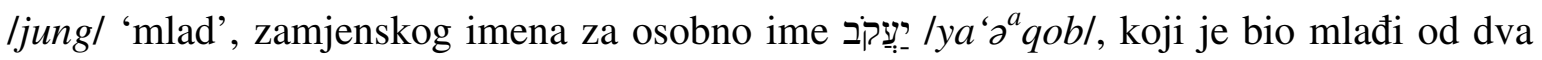
blizanca Izaka i Rebeke.

Junker/JUENKER - jid. - Jidiški יונקער (× njem. plemićki naslov 'mladi plemić').

Justus - lat. - Prezime nastalo konverzijom od latinskog osobnog imena Iustus 'ispravan,

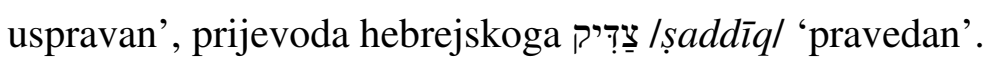

Kabili - sef. - Judeošpanjolski קבילי , קבَبِل prezime nastalo od arapskoga /qail/ 'babica, jamac, zavjet, supružnik'.

Kabiljo/KABILJO - tal. - prezime nastalo od prethodnoga.

Kaiser/Keiser/KAISER - jid. - Jidiški קייזער (× njem. Kaiser 'car'), često njemačko prezime.

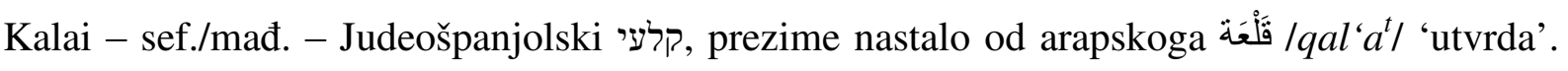
Od lika s određenim članom أَلَقَلْعَة /'alqal'a/ > Alcalá, prezime i toponim. Vjerojatnije je pak da je prezime nastalo od toponima Kal u Mađarskoj (usp. mađarsko prezime Kallay).

Kamenić - hrv. - Prezime nastalo od imenice kamen.

Kandel/Kandl - jid. - Jidiški קאָנדל (× 'vrč, cijev, lula, svijeća').

Kanitz - jid. - Jidiški prezime nastalo od toponima, imena više mjesta u Saskoj, Češkoj (Dolní Kounice) i Poljskoj (Olszewo Węgorzewskie).

Kanižai - mađ. - Prezime nastalo od etnika od toponima Kanizsa u Mađarskoj (Nagykanizsa) i susjednim zemljama. 


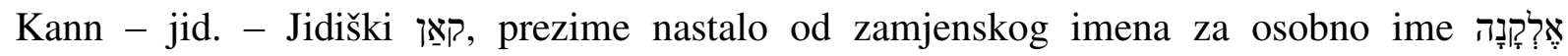
l'alq $\bar{\jmath} n \bar{\nu}^{h} /$ 'Elohim ga je opskrbio',395.

Prezime je promijenjeno iz izvornoga כּנּן /kohen/ (v. Cohen/Koen/Kohn/Kohen/Khon/ /Kahn//Khan/KOEN/KOHN/KHON/KON/KOLIN).

Kantor - jid. - Jidiški קאַנטאָר (kantor', no katkad i prezime nastalo od prezimena קאָט /kant/, koje se i samo može izvesti iz osobnog imena קאַן /kan/ (v. Kann).

Kaposi-Schnitzler/KAPOŠI-SCHNITZLER - mađ.-jid. - Jidiški קאָפָָש /kapoši/ < mađ. Kaposi, prezime nastalo od hidronima Kapos, rijeke na jugozapadu Mađarske.

Prezime שניצלער/šnicler/ pripada austrijsko-židovskoj porodici koja se u XIX. st. u Austriju doselila iz Mađarske.

Karan - Moguće je da je riječ o prezimenu nastalom od korijena kar- (usp. karati), no vjerojatnije je da je nastalo od tur. kara 'crn'.

Kardiš - jid. - Jidiški prezime nastalo od mađarskoga kardos 'borben' < mađ. kard 'mač' (v. Kardos/KARDOŠ).

Kardos/KARDOŠ - jid. - Jidiški pאָרדאָש, prezime nastalo od mađarskoga kardos 'borben' < mađ. kard 'mač'.

Karlsberg - jid. - Jidiški קארלסבערג, prezime nastalo konverzijom od patronima od njemačkog i jidiškog osobnog imena Karl < pragerm. *kerla-/*karla- ‘čovjek, slobodnjak'.

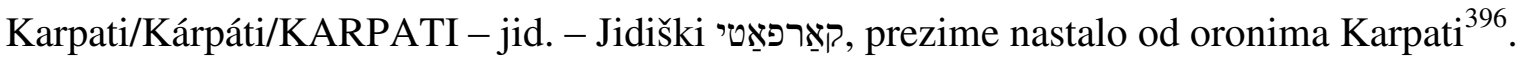
Prezime je promijenjeno iz izvornoga Kárpeles/Karpeles (v.).

Kárpeles/Karpeles - jid. - Jארפעלעס קאַרפ /karp/ prezime nastalo od prezimena (: njem. Karpfen 'šaran').

Kassowitz/KASSOVITZ - jid. - Jidiški prezime nastalo od patronima od

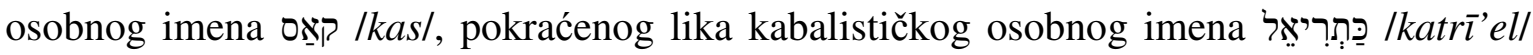

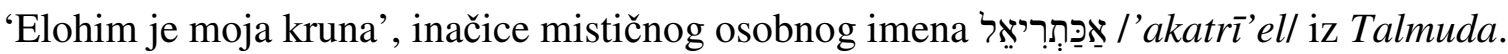

Kastel/Kastl/KASTL/KASLL - jid. - Jidiški קאַס, prezime nastalo od osobnog imena קאָָטטاקוסט/kost/kust/ (× njem. Kost 'jelo, uzdržavanje'), zamjenskog imena za osobno ime

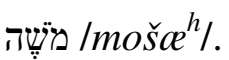

Katić/KATIĆ - hrv. - Prezime nastalo konverzijom od metronima od pokraćenoga osobnog

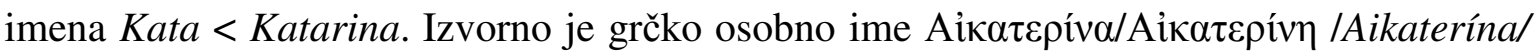

\footnotetext{
${ }^{395}$ Izl 6,24. U transkripciji Silvija Grubišića: Elkana

${ }^{396} \mathrm{Ne}$ može se sa sigurnošću utvrditi je li oronim preuzet iz češ./slov./polj. Кarpaty, ukr. Карпати, ili rus. Карпаты.
} 


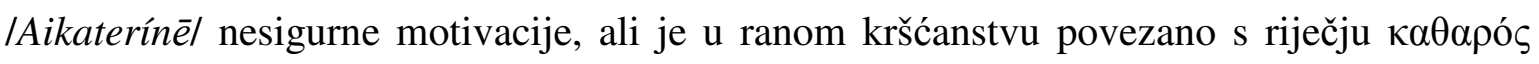
|kat ${ }^{h}$ arós/ 'čist' (Čilaš Šimpraga, Ivšić Majić i Vidović 2018: 174-175; Skok 1974: II $61-62)$.

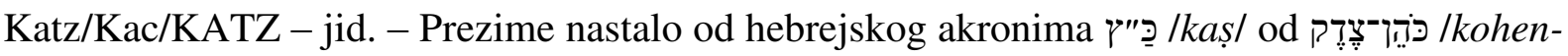
șaedaeq/ '(hramski) svećenik pravednosti'. U nesvećeničkih porodica pokraćeni lik za zamjensko ime קאַצעב /kacev/, spomenut u XIII. - XIV. st. (: njem. Katze 'mačka').

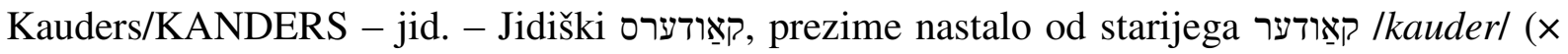
njem. Kauder 'kudjelja'), što opet može biti pokraćeni lik od קאוגערער /kauderer/ (× 'lutajući prosjak iz Italije'). Do 1945. se g. današnje selo Klaczyna u Donjoj Šleskoj zvalo Kauder.

Kaudes - jid. - Jidiški קאַודעם.

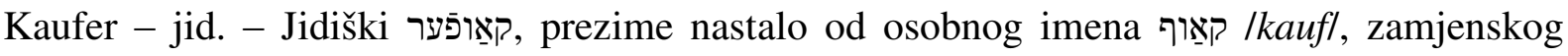

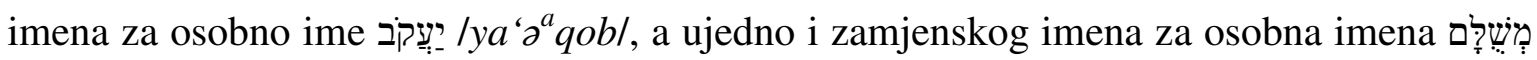

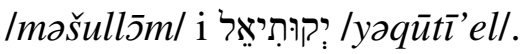

Kaufmann/Kaufman/KAUFMANN/KAUFMAN - jid. - Jidiški קאַופמאַן (× njem. Kaufmann 'trgovac'), prezime nastalo konverzijom od patronima od osobnog imena /kauf/,

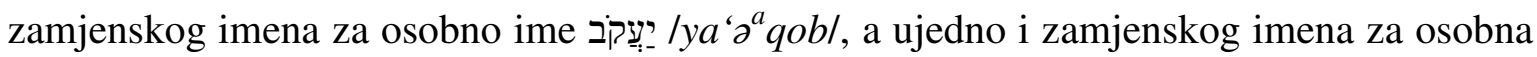

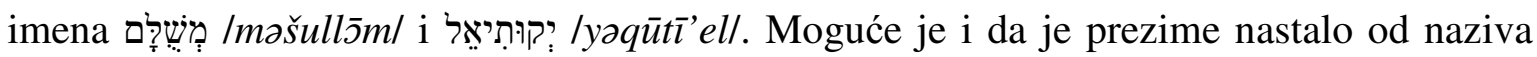
zanimanja. Isto je tako moguće da je riječ o izvorno njemačkome prezimenu, koje je potom preuzela židovska obitelj koja nije nužno morala biti povezana s tom profesijom.

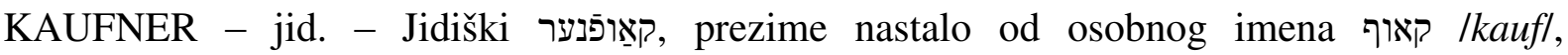

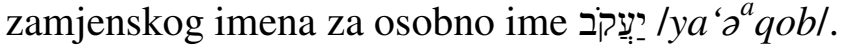

Kavić - hrv. - Prezime se pojavljuje u dvoprezimenskoj kombinaciji Kardoš-Kavić.

Kaszás - mađ. - Jidiški prezime nastalo od mađarskoga 'kosac'.

Prezime je promijenjeno iz izvornoga כּנה /kohen/ (v. Cohen/Koen/Kohn/Kohen/Khon/ Kahn/Khan/KOEN/KOHN/KHON/KON/KOLIN).

Keele.

אקאלמאַן /kalman/, što je i samo pokraćeni lik osobnog imena קלונימוס/kalonimos/ < grč.

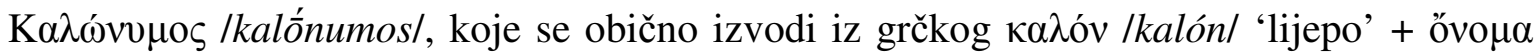

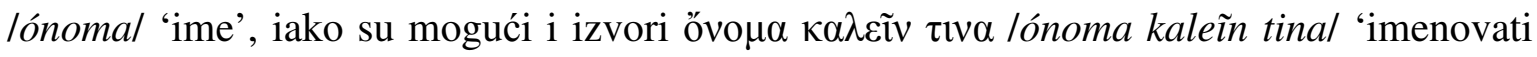

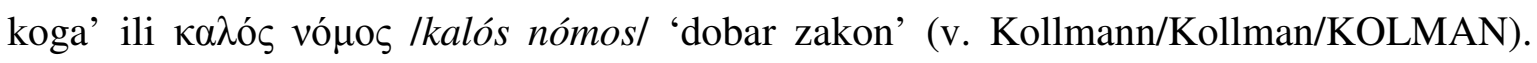
Osobno je ime proslavio Kalonymus iz talijanske pokrajine Lucca, koga je 787. g. Karlo 
Veliki imenovao osobom koja će donijeti židovski nauk na sjever Europe. S druge strane קַ /qal/ u suvremenom hebrejskom znači 'lagan (ne u fizičkom smislu), jednostavan)'.

Kellner - jid. - Jעלנער (× srvnjem. kelnaere 'upravitelj vinograda'). Moguće je da je prezime nastalo od prezimena קעל /kel/ (v. Kell/KELL).

Kemeny - jid. - Jidiški קעמעני, prezime nastalo od mađarskoga kemény 'jak'.

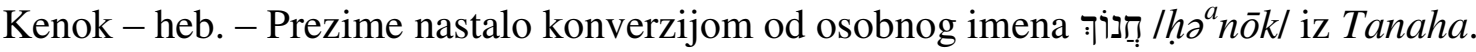

Prezime je promijenjeno iz izvornoga Kárpeles/Karpeles (v.).

Kerkai/Kerkaj/KERKAY/KERKAI - mערקאי - mađ. - Jidiški prezime nastalo od etnika od hidronima Kerka 'Krka'. U Mađarskoj postoje dvije rijeke toga imena, Kerka ili NagyKerka ili Kerkás (slovenski Velika Krka) i Kerca ili Kis-Kerka (slovenski Mala Krka), koje se južno od sela Bajánsenye spajaju u jedinstvenu rijeku imenom Kerka (slovenski Krka). Prezime je promijenjeno iz izvornoga עסטערייכער lestereyxerl (v. Österreicher/ /Oesterreicher).

Kern/KERN - jid. - Jidiški קערן (× njem. Kern 'zrno').

Kerpner/KERPNER - jid. - Jidiški קערפנער, prezime nastalo od osobnog imena קארפ /karp/ (:

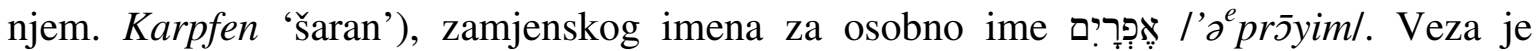
uspostavljena pogrešnom etimologijom koja u Jakovljevu blagoslovu Efrajima nalazi korijen riječi 'riba'.

Keszler/KESLER/KESALER - mađ. - Jidiški קעסלער, prezime nastalo od toponima Keszlér, danas Chesler u Rumunjskoj.

Khroh - jid. - Jidiški (הרזָ) (: njem. Krähe 'vrana').

Kikinis - jid. - Jיקינים, prezime nastalo od osobnog imena קיקין/kikin/, navodnog potomka proroka Jone, zabilježenog u Lublinu u Poljskoj.

קין Kinsberg - קid. - Jidiški קינסבערג. Možda prezime nastalo od metronima od osobnog imena /kin/.

Kirschner/Kürschner/Keršner/KIRSCHNER - jid. - Jidiški קירשנער|קערשנע, prezime nastalo od osobnog imena קירש/קערש/kirš/kerš/ (× njem. Kirsche 'trešnja'), koje se obično

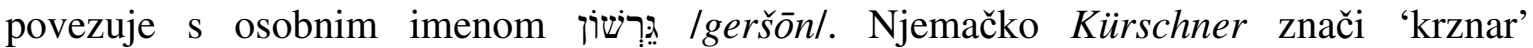
(posuđenica iz slavenskoga), međutim da bismo pretpostavili da je prezime nastalo od naziva zanimanja, morali bismo prvo dobiti potvrdu da su se Židovi smjeli baviti tim obrtom. Isto je tako moguće da je riječ o izvorno njemačkome prezimenu, koje je potom preuzela židovska obitelj koja nije nužno morala biti povezana s tom profesijom. 
Kis/Kiš - mađ. - Jidiški קיש, prezime nastalo od mađarskoga kis 'malen', zamjenskog imena

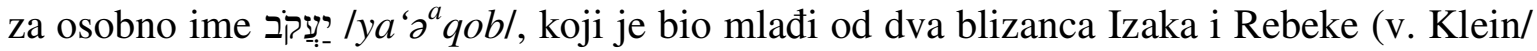
/KLEIN).

Klaber/KLABER - jid. - Jidiški קלאֵבער (: njem. Klaue 'čaporak').

Klaić - hrv. - Prezime nastalo od nadimka Klajo < kljast (Skok 1974: II 104).

Klait - jid. - Jidiški קלייט (× njem. Kleid 'haljina, komad odjeće').

Klein/KLEIN - jid. - Jidiški קליין 'malen', prezime nastalo od zamjenskog imena za osobno

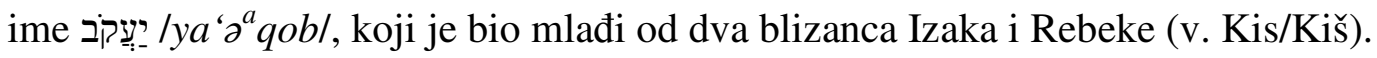

Klingenberg - jid. - Jidiški קלינגנבערג, prezime nastalo od osobnog imena קלינג /kling/ (: njem. Klang 'glazba, zvuk').

Knežić - hrv. - Prezime nastalo od vladarskog naslova knez (Skok 1974: II 108-109).

KOCH - jid. - Jidiški קָָ (× njem. Koch 'kuhar, kuhano jelo'), prezime nastalo od

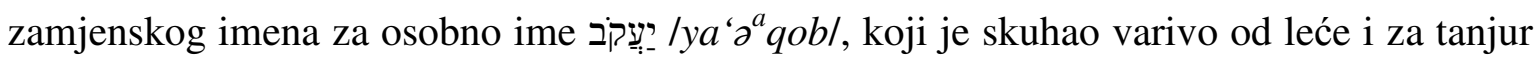
istoga kupio prvorodstvo od brata si.

Kollmann/Kollman/KOLMAN - jid. - Jidiški prezime nastalo od pokraćenog lika

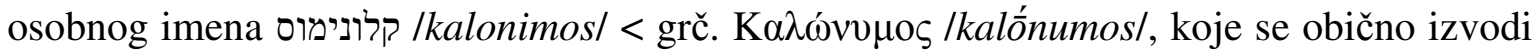

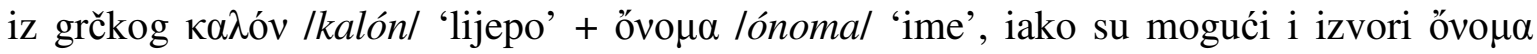

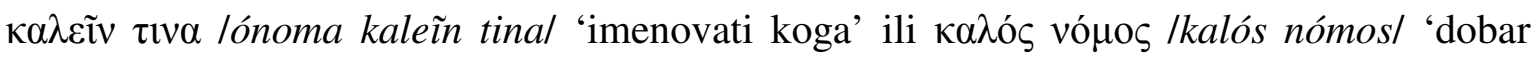
zakon'. Osobno je ime proslavio Kalonymus iz talijanske pokrajine Lucca, koga je 787. g. Karlo Veliki imenovao osobom koja će donijeti židovski nauk na sjever Europe. (v. Kell/KELL).

Köllo/Kóllo/Kollo - mađ. - Možda prezime Köllö.

Prezime je promijenjeno iz izvornoga קראוס /kraus/ (v. Krauss/Krauß/Krausz/Kraus/ /KRAUS).

Kolmar/KOLMAR - jid. - Jidiški Prezime nastalo od toponima, imena više mjesta, grada Kolmar, danas Chodzież u Velikopoljskom Vojvodstvu, grada Kollmar u Šleskoj, oba u Poljskoj, te Colmar pokraj Oldenburga u Holsteinu u Njemačkoj.

Prezime je promijenjeno iz izvornoga כּּה /kohen/ (v. Cohen/Koen/Kohn/Kohen/Khon/ /Kahn/Khan/KOEN/KOHN/KHON/KON/KOLIN).

König/Koenig/KOENIG - jid. - Jidiški קעניג (× njem. König 'kralj').

Königfriedenfeld - jid. - Jidiški קעניגפרידנפעלד, prezime nastalo od prezimena קעניג /kenig/ (v. König/Koenig/KOENIG) i patronima od osobnog imena פَרידל /fridl/ (v. Friedl).

KONRID - jid. - Prezime vjerojatno nastalo od njemačkog osobnog imena Konrad < pragerm. *kōni-'sposoban > smion' + *redan- 'odlučiti > savjet'. 
Kopelman - jid. - Jidiški prezime nastalo konverzijom od patronima od osobnog imena קאָּ /kopl/ (v. Koppel).

Koppel - jid. - Jidiški קאָָ /kopl/, prezime nastalo od umanjenice od osobnog imena

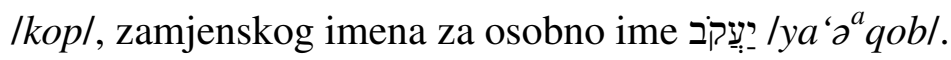

Kopstein - jid. - Prezime nastalo konverzijom od patronima od osobnog imena/,

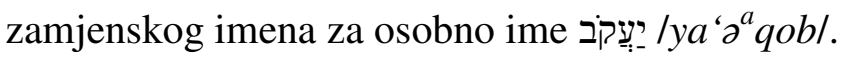

Koranić - hrv. - Prezime možda nastalo od hidronima (i osobnog imena) Korana (Čilaš Šimpraga, Ivšić Majić i Vidović 2018: 177).

Koritschan/Koritstein/KORITSCHAN - jid. - Jidiški prezime nastalo od etnika od toponima, imena grada Koryczany u Šleskoj te imena grada Koryčany u Moravskoj.

Kormend - mađ. - Jidiški prezime nastalo od toponima Körmend u zapadnoj Mađarskoj.

Prezime je promijenjeno iz izvornoga כּּה /kohen/ (v. Cohen/Koen/Kohn/Kohen/Khon/ /Kahn/Khan/KOEN/KOHN/KHON/KON/KOLIN).

Körner - jid. - Jidiški קערנער (× njem. Körner 'trgovac zrnjem'), prezime nastalo od osobnog imena קאָר (× njem. Korn 'zrno').

Kornfein/KORNFEIN - jid. - Jidiški קאָרנפייין, prezime nastalo od osobnog imena קאָרן ( njem. Korn 'zrno').

Kornitzer/KORNITZER - jid. - Jidiški קארניצער, prezime nastalo od etnika od imena sela Kornitz, danas Chornice u Češkoj.

Kortin - jid. - Jidiški קָָרטין, prezime vjerojatno nastalo od osobnog imena קאָרט /kort/, inačice njemačkog osobnog imena Kurt, pokraćenog lika njemačkog osobnog imena Konrad < pragerm. *kōni-'sposoban > smion' + *redan- 'odlučiti > savjet'.

Korvin - jid. - Jidiški Pארבבין. Prezime nastalo od latinske umanjenice corvinus od latinskoga corvus 'gavran'. Kao nadimak se pojavljuje u Rimu u I. st. pr. n. e. u imenskoj formuli generala, pisca i mecene Marka Valerija Mesale Korvina (64. g. pr. n. e. - 8. g. n. e.). Kasnije je isto prezime ponio ugarski i hrvatski kralj Matijaš Korvin (1443. - 1490.), a nalazimo ga i u latinskoj inačici imena njegova oca, Janka Hunyadija (oko 1406. - 1456.) Ioannes Corvinus. Njihova je obitelj podrijetlom bila iz dvorca Hunyad u Sedmogradskoj, nedaleko od današnjeg grada Hunedoara u Rumunjskoj.

Prezime je promijenjeno od izvornoga כּּה /kohen/ (v. Cohen/Koen/Kohn/Kohen/Khon/ /Kahn/Khan/KOEN/KOHN/KHON/KON/KOLIN).

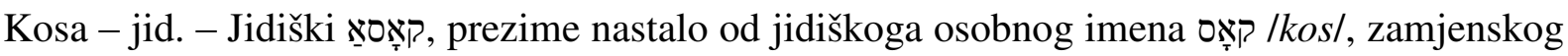

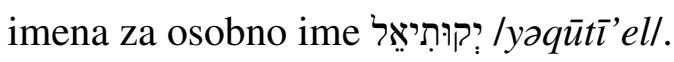


Kössler - jid. - Jidiški קעסלער. Moguće da je i ovo prezime nastalo od osobnog imena קאָס /kos/, zamjenskog imena za osobno ime יקוִִּיארל: /yaqūtī'ell.

Köstler/Kestler - jid. - Jidiški קעסטלער, prezime nastalo od umanjenice od קאָט /kost/ (× njem. 'kuhar, jelo, uzdržavanje'), zamjenskog imena za osobno ime משֶֶ /moš $a^{h} /$.

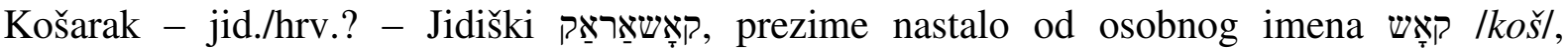

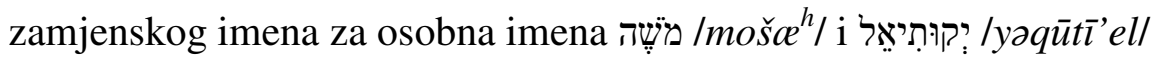

S druge strane, moguće je da je riječ o prezimenu nastalom od naziva zanimanja košarar.

Kovač - hrv. - Prezime nastalo od naziva zanimanja (Skok 1974: II 171-172).

Kovačić - hrv. - Prezime nastalo od prezimena Kovač (v.) ili od umanjenice izvedene od toga prezimena ili od naziva zanimanja.

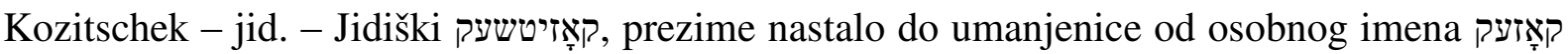
/kozek/, koje je i samo umanjenica od slavenske riječi koza.

Krakauer - jid. - Jidiški prezime nastalo od toponima, imena više mjesta, Krakówa u Galiciji, Krakaua kod Gdańska, oba danas u Poljskoj, i Krakowa u njemačkoj regiji Mecklenburgu.

Krämer/Kramer - jid. - Jidiški קראמער/קרעמער (× njem. Krämer 'torbar, pokućarac'). U ovom je slučaju moguće da je riječ o prezimenu nastalom od naziva zanimanja, jer iz dostupnih podataka znamo da su se i prvi doseljeni Židovi u Zagrebu bavili trgovinom na malo i pokućarenjem (Schwarz 1939: 10-11).

Krasso/KRASSO.

Krauss/Krauß/Krausz/Kraus/KRAUS - jid. - Jidiški קרַוס (× njem. kraus 'kovrčav'), prezime nastalo od čestog njemačkog nadimka.

Kraut - jid. - Jidiški (× njem. Kraut 'zelje'), moguće je da je prezime nastalo od rumunjskoga croitor 'krojač'.

Krautblatt/KRAUTBHATT - jid. - Jidiški קראוטבלאַט (× njem. Krautblatt 'list zelja'), prezime nastalo od prezimena קראַוט /kraut/ (v. Kraut).

Kreč - jid. - Jidiški קרעטש, prezime nastalo kao inačica jidiškoga prezimena קרעץ /krec/ (× jnjem. Krätze 'košara'). Moguće je i da je riječ o prezimenu nastalom od toponima, imena sela Křeč u Češkoj ili pak imena mjesta Kretz u Falačkoj.

Kremen - jid. - Jidiški קרעמען, prezime nastalo od slavenskoga kremen.

Dio dvoprezimenskog lika Kardoš-Kremen.

Kremsier/Kremsir/Kremzir/KREMSIR - jid. - Jidiški קרעמזיר, prezime nastalo od toponima, danas Kroměříž u Moravskoj. 
Kreutzer/KREUTZER - jid. - Jidiški pרייצער, prezime nastalo od njemačkog naziva srebrnog novca Kreuzer iz južnih njemačkih država i Austrije, kasnije bakrenjaka. U AustroUgarskoj je Monarhiji bio poznat pod lokalnim nazivima: creiţar/crăiţar na rumunjskom, grajcar na poljskom, grajciar na Slovačkom, krajcar na hrvatskom i slovenskom, krajczár na mađarskom i krejcar na češkom.

Kriegler - jid. - Jidiški קריגלער, prezime nastalo od umanjenice קריגל /krigl/ od riječi /krig/ ( $\times$ njem. Krieg 'rat'). Na jidišu je moguće da je riječ o prezimenu nastalom od imenice קרוג/krug/ (× njem. Krug 'vrč, gostionica') ili pak od srvnjem. pridjeva kriege 'hrabar, grub'.

Krivanek - češ. - Jidiški קריבַאנעק, češko prezime Křivánek.

קראָן Rron - jid. - Jidiški קרָן (: njem. Kranich 'ždral'). Prezime je možda nastalo od imenice Ikron/ 'kruna' (: njem. Krone).

Kronfeld/KRONFELD - jid. - Jidiški קראָנפָעלד, prezime nastalo konverzijom od patronima od prezimena קרָָן/kron/ (v. Kron).

Kruh - jid. - Jidiški קרוך|קרוה, prezime vjerojatno nastalo konverzijom od inačice osobnog

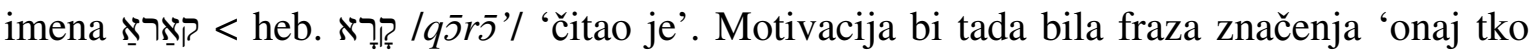
čita (Tanah)'.

Kudelka - jid. - Jidiški češko prezime Koudelka 'pređa od kudjelje'. Možda prijevodni lik prezimena Kauder (v. Kauders/KANDERS).

Kuffler/KUFFLER/KUFLER - jid. - קופלער קאָפ

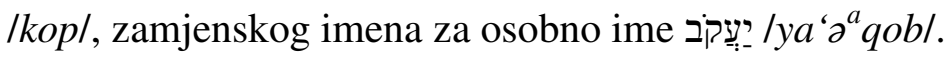

Kugler - jid. - Jidiški קוגלער, prezime nastalo od osobnog imena קוגל /kugl/ (× njem. Kugel 'lopta, kugla').

Kuh/KUH - jid. - Jidiški קוה (× njem. Kuh 'krava').

Kuhn/Kún/Kun - jid. - Jidiški קון, ili prezime nastalo od pokraćenog lika njemačkog osobnog imena Konrad < pragerm. *kōni-'sposoban > smion' + *redan- 'odlučiti > savjet' ili prezime nastalo konverzijom od osobnog imena motiviranog imenicom značenja 'suprug'. Kun je i mađarsko prezime nastalo od etnika 'Kuman, Polovac'.

Prezime je promijenjeno iz izvornoga כּּה /kohen/ (v. Cohen/Koen/Kohn/Kohen/Khon/ /Kahn/Khan/KOEN/KOHN/KHON/KON/KOLIN).

קון Kunetz/KUNETZ - jid. - Jidiški prezime nastalo od umanjenice od osobnog imena /kun/ (v. Kuhn/Kún/Kun). 
Kunić - hrv. - Prezime nastalo od naziva životinje kuna.

Prezime je promijenjeno iz izvornoga כּּה /kohen/ (v. Cohen/Koen/Kohn/Kohen/Khon/ /Kahn/Khan/KOEN/KOHN/KHON/KON/KOLIN).

Lachenbacher / Lakenbacher / LACKENBACHER / LACKENBACKER - jid. - Jidiški

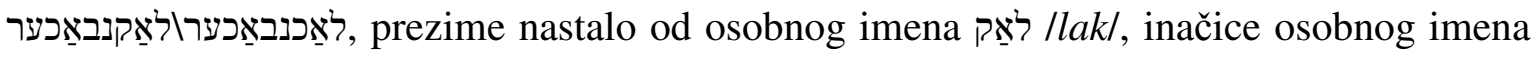
לאַך/lax/, slavenske odmilice za osobno ime Ladislav, a možda i zamjenskog imena za

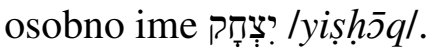

Lachmann/LACHMAN - jid. - Jidiški לאַָכמאַן, prezime nastalo konverzijom od patronima od osobnog imena לאַָך/lax/, slavenske odmilice za osobno ime Ladislav, a možda i zamjenskog imena za osobno ime

Lakenbach - jid. - Jidiški לאַקנבאָ, prezime nastalo od osobnog imena לאַק /lak/, inačice osobnog imena לאֵך/lax/, slavenske odmilice za osobno ime Ladislav, a možda i

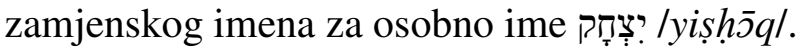

Landauer - jid. - Jאַנדאַוער prezime nastalo od etnika od toponima Landau, imena više mjesta u Njemačkoj. Manje je vjerojatno da je riječ o prezimenu nastalom od imenice לאַנד /land/ 'zemlja'.

Landesmann - jid. - Jidiški (x njem. Landesmann 'sunarodnjak'), prezime nastalo konverzijom od patronima od osobnog imena לאֵֵנד/land/ (× njem. Land 'zemlja').

Lang - jid. - Jidiški לאֵנג 'düg', prezime nastalo od nadimka kojim se razlikovalo pojedince istog osobnog imena i patronima. Prijevodno osobno ime hebrejskog nadimka אָר /'万̃rok/, motiviranog pridjevom istog značenja, koji je zabilježen još u talmudsko doba.

Langraf/LANGRAF - jid. - Jidiški לאַנגראַף (× njem. Landgraf, plemenitaški naslov u Svetom Rimskom Carstvu iste razine kao i vojvoda, a iznad naslova grof).

Latzko/LATZKO - jid. - Jidiški prezime nastalo od umanjenice od osobnog imena לָָּץָ /lac/, odmilice od slavenskog osobnog imena Ladislav. Možda je riječ i o prezimenu nastalom od umanjenice od osobnog imena לאֵ /lak/, inačice osobnog imena לאַך/, slavenske odmilice za osobno ime Ladislav, a možda i zamjenskog imena za osobno ime

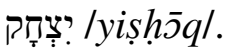

Laufer/LAUFER - jid. - Jidiški לאַופעער (× njem. Laufer 'trkač, glasnik').

Lausch/Lauš/LAUSCH/LANSCH/LAUŠ - jid. - Jidiški לאַוש, prezime nastalo od inačice osobnog imena לָָ /lošl < polj. toś 'los'.

Lavrić - hrv. - Prezime nastalo konverzijom od patronima/metronima od osobnog imena Lavro/Lavra << lat. laurus 'lovor' (Čilaš Šimpraga, Ivšić Majić i Vidović 2018: 182). 
Prezime je promijenjeno iz izvornoga לעבי|לעווי /levi/lewi/ (v. Löwy/Lövy/Löwi/Löwi/ /LöVY/LOEWY/LOEVY/LOWY).

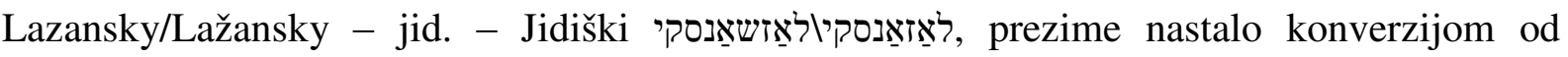

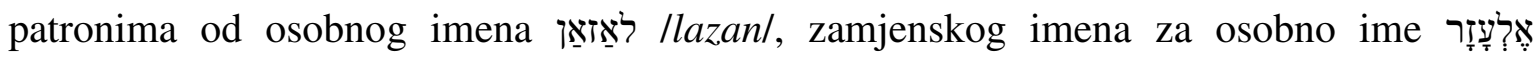
l'ala's̄z̄̄rl.

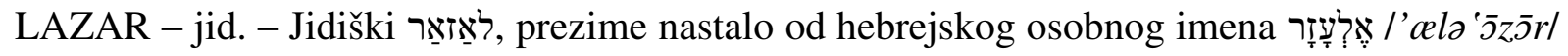

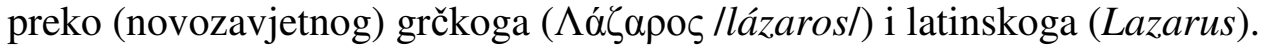

Lebović - hrv. - Prezime nastalo od imenice leb 'hljeb, kruh'.

Lebrecht - jid. - Jidiški לעברעט ‘živi ispravno’, prezime nastalo prijevodom od zamjenskog imena za osobno ime חַיים טוֹבִים /hayyìm tōbìm/ 'dobar život'.

Lederer/LEDERER - jid. - Jidiški לעדערער (× njem. Lederer 'štavitelj'), prezime nastalo od jidiškoga לעדער /leder/ (× njem. Leder 'koža'). Moguće je da je riječ o prezimenu nastalom od naziva zanimanja, ali samo ako je Židovima bilo dopušteno baviti se ovim obrtom. S druge je strane isto tako moguće da je riječ o njemačkom prezimenu koje je preuzela židovska obitelj koja sama nije morala imati veze s tom profesijom.

Ledicki/LEDECKI - češ. - Jidiški לעדיצקיולעדעצי, češko prezime Ledecký.

Ledić - hrv. - Prezime nastalo od imenice led.

LEEB - jid. - Jidiški לעב, prezime nastalo od inačice osobnog imenā ליבולאָב /leyb/lob/ 'lav', zamjenskog imena za osobno ime

Lehner/LEHNER - jid. - Jidiški לענער (× njem. Lehner 'posjednik (feudalnog) dobra').

LEHöN - jid. - Jidiški לעהען.

Leitner/LEITNER/LETNER - jid. - Jidiški 'x 'onaj koji živi na padini'), prezime nastalo od toponima, ime više mjestā u Njemačkoj.

Lemberger/Lamberger/LEMBERGER - jid. - Jidiški לאֵמבערגערולעמבערגער, prezime nastalo od etnika od toponima Lemberg u Gornjoj Falačkoj, Lotaringiji i istočnoj Galiciji (današnji Львів и Ukrajini) ili Löwenberg u Šleskoj (današnji Lwówek Śląski u Poljskoj).

Lengsfelder - jid. - Jidiški לענגספעלדער, prezime nastalo od etnika od toponima, imena sela Kalten-Lengsfeld ili grada Stadtlengsfeld, oba u Tirinškoj.

Lesić/LESIĆ - hrv. - Petar Skok za ovo prezime navodi da je nastalo konverzijom od

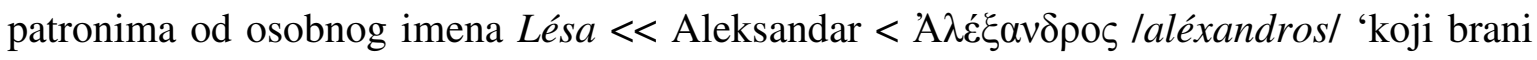
čovjeka' (v. Alexander/Aleksander/ALEXANDER/ALEKSANDER/ALEKSANDAR) (Skok 1974: I 26-27). Druga je mogućnost da je prezime nastalo od imenice les 'šuma'.

Lewinger - jid. - Jidiški לעבינגערולעווינגער, prezime nastalo od osobnog imena לוני /lewī/. 
Lewy/Levi - heb. - Prezime nastalo konverzijom od osobnog imena לִ̣ /lewī/ iz Tanaha. Može značiti i 'ljevak', iz prasl. *lěvъ.

Licht/LICHT - jid. - Jidiški ליכט (× njem. Licht 'svjetlo'). Malo je vjerojatno da je prezime nastalo od poljskoga lichta 'siromah'.

Lichtenberger / Lihtemberger / LICHTENBERG / LICHTENBERGER - jid. - Jidiški ליכטנבערג(ער), prezime nastalo konverzijom od toponima odnosno etnika od imena mjesta Lichtenberg u Saskoj.

Lichtenfeld/LICHTENFELD - jid. - Jidiški ליכטנפעלדד, prezime nastalo konverzijom od patronima od prezimena ליכט /lixt/ (v. Licht/LICHT).

Lichtenstein - jid. - Jidiški ליכטנשטיין (× 'svijećnjak'), prezime nastalo konverzijom od patronima od prezimena ליכט/lixt/ (v. Licht/LICHT).

Liebermann/LIEBERMAN - jid. - Jidiški ליבערמאַן, prezime nastalo konverzijom od patronima od osobnog imena ליפמן /lib/ 'voljeni' ilipman/ 'voljeni čovjek' (v.),

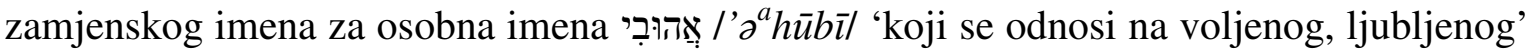
(hebrejsko osobno ime koje se ne pojavljuje ni u Tanahu ni u Talmudu, a koje je izvedeno

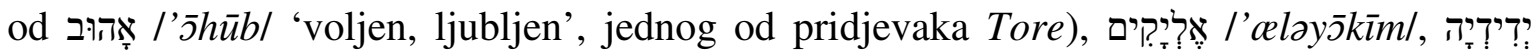

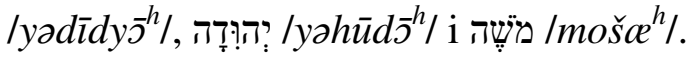

Lindenberg - jid. - Jidiški לינדענבערג, prezime nastalo od toponima Lindenberg, imena više gradova u Njemačkoj.

Links - jid. - Jidiški לינקס, prezime nastalo od osobnog imena לינק /link/ (: njem. linke 'lijevi').

Linnenberg/Linnenberger/Linneberg/Linneberger/Lineberg/Lineberger/Linenberg - jid. Jidiški לינע(נ)בערג). Uz tolike različite zabilježene likove istog prezimena teško je iznaći koji je bio izvorni, no vjerojatno je u pitanju prezime nastalo od kakvog toponima. Druga je mogućnost da je prezime nastalo od patronima od osobnog imena לין /lin/, zamjenskog imena za osobno ime

Linski - Prezime je promijenjeno iz izvornoga לעדערער /lederer/ (v. Lederer/LEDERER).

Lisičar/LISIČAR - slav. - Prezime nastalo prijevodom prezimena פَקס /fuks/ (v. Fuchs/ /FUCHS/FUKS).

Livadić - hrv. - Prezime nastalo prijevodom prezimena וויזנער /vizner/ (: njem. Wiesner) nastalog od imenice וויזן/wizn/ (: njem. Wiese 'livada')

\footnotetext{
${ }^{397}$ Primjerice ilirac Ferdo Livadić, koji je rođen kao Ferdinand Wiesner (1799. - 1879.).
} 
Löbel/Löbl/Lobl/LOBL - jid. - Jidiški לעבל, prezime nastalo od umanjenice od osobnog imena אערייה /leb/ 'lav', prijevodnog osobnog imena od hebrejskoga 'lav',

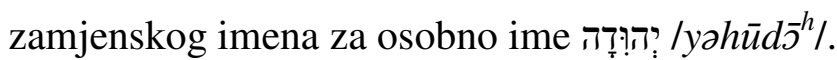

Löffler - jid. - Jidiški לעפכלער, prezime nastalo od osobnog imena לעפכל /lefl/ (× njem. Löffel 'Žlica'), umanjenice od osobnog imena לער /lefl, inačice imena לעבל /lebl/ (v. Löbel/Löbl/ /Lobl/LOBL).

Lörnitz - jid. - Jidiški לערניץ.

Prezime je promijenjeno iz izvornoga היימער, /heymer/ (v. Heimer/Heumer/HEUMER/ /HENMER).

Löw/Loew/Loev/LOW - jid. - לעב /lev/ 'lav', prezime nastalo prijevodom hebrejskog

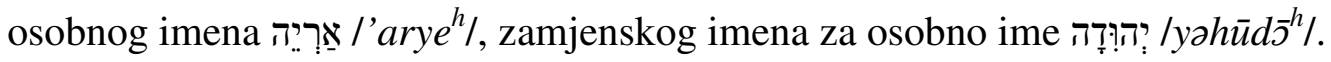

Ovo je prezime dobar primjer kako jidiška prezimena, kad se pišu latinicom, slijede (barem donekle) grafiju njemačkog jezika.

Löwensohn - jid. - Jidiški לעבנסָאן, prezime nastalo konverzijom od patronima od osobnog imena לעב /lev/ (v. Löw/Loew/Loev/LOW).

Löwenstein/LOEVENSTEIN - jid. - Jidiški לעבנשטיין, prezime nastalo konverzijom od patronima od osobnog imena לעב /lev/ (v. Löw/Loew/Loev/LOW).

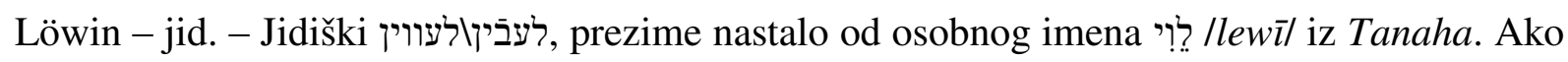
je preuzeto iz ruskoga лев 'lav', mоže biti i prezime nastalo od zamjenskog imena za

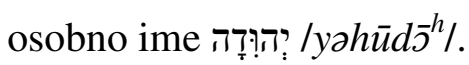

Katkad je teško razlučiti prezimena izvedena od hebrejskog osobnog imena לִ̣ /lewī/ i ona izvedena od jidiškog osobnog imena ליב /leyb/.

Löwinger/Loewinger/LOWINGER - jid. - Jidiški לעבינגער|לעווינגער, prezime nastalo od osobnog imena לעב /lev/ (v. Löw/Loew/Loev/LOW).

Löwy/Lövy/Löwi/Löwi/LöVY/LOEWY/LOEVY/LOWY - jid. - Jidiški לעביולעווי , prezime nastalo od osobnog imena לעב/lev/ (v. Löw/Loew/Loev/LOW).

Lubynski/Lubinsky - jid. - Jidiški לובינסקי, prezime vjerojatno nastalo od toponima Lubin u Donjoj Šleskoj.

Prezime je promijenjeno iz izvornoga לעביולעווי /levi/lewi/ (v. Löwy/Lövy/Löwi/Löwi/ /LöVY/LOEWY/LOEVY/LOWY).

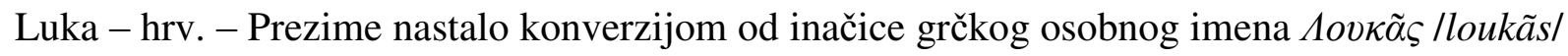
'iz Lukanije (pokrajine u južnoj Italiji)', latinski Lūcas (Čilaš Šimpraga, Ivšić Majić i Vidović 2018: 189; Skok 1974: II 328). 
LUKAČ - mađ. - Jidiški לוקאָט, mađarsko prezime Lukács, nastalo od osobnog imena Luka (v.).

Lustig/LUSTIG - jid. - Jidiški לוסטיג (× njem. lustig 'veseo').

Lušicki - jid. - Jidiški לושיצקי.

Luzzatto/Luzzato - tal. - U liku לוצאטו 'iz Lužica (prema obiteljskoj predaji)'. Prezime nastalo od etnika. Lužice su bile svojevrsno središte židovskih naseobina u slavenskim zemljama, u židovskom tradicionalnom zemljopisu nazvanima egzonimom Kanaan, a u predaji ujedno i polazište odakle su se Židovi naseljavali u slavenske zemlje.

Maceljska / Maceljski - v. Deutsch »Maceljska« / Deutsch »Maceljski« / DEUTSCHMACELJSKI.

Maider - jid. - Jidiški מיבידע, prezime nastalo od njemačke zastarjelice Maid 'djevojka' (: njem. Mädchen, jnjem. i aust. Mäd(e)l)< pragerm. *magapi- 'djevojka'

Maks - jid. - Jidiški osobno ime. Prezime u svakom slučaju nastalo od latinskoga osobnog imena Maximus 'najveći', samo nije sigurno je li posredničko osobno ime bilo Maximilian < lat. Maximilianus ili pak rusko i ukrajinsko Максим odnosno bjelorusko Максім.

Mandić/MANDIĆ - hrv. - Prezime nastalo od metronima od osobnog imena Manda < Mandaljena < Magdalena 'žena iz Magdale' < Magdala (toponim) > aram. מגדלא

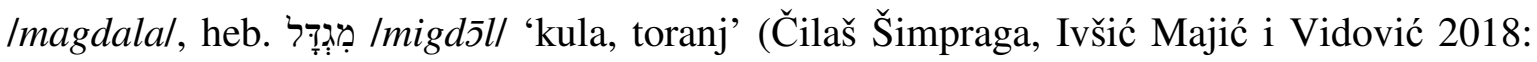
196; Skok 1974: II 352-353).

Mandler - jid. - Jidiški מאנדלער, prezime nastalo od osobnog imena מאֵנדל /mandl/ (× njem. Mandel 'mandula, badem'), što je umanjenica od osobnog imena מאַן /man/ (v. Mann). Ovo

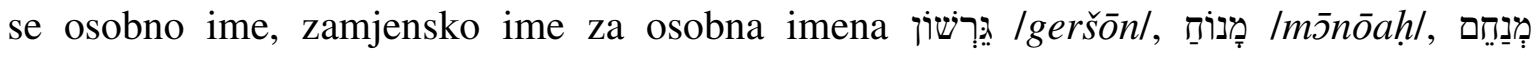

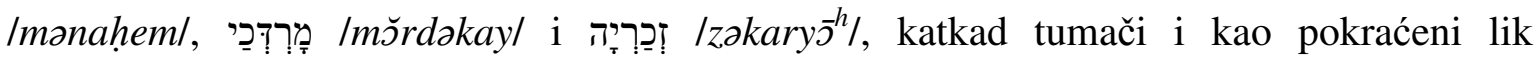
njemačkog osobnog imena Meinhart < pragerm. *mainjan- 'misliti' + *hardu- 'čvrst, žestok'.

Mandolfo/MANDOLFO - tal. - Talijansko prezime ${ }^{398}$ nastalo konverzijom od osobnog imena germanskog podrijetla.

Mann - jid. - Jidiški מאַ /man/ (× njem. Mann 'čovjek, ratnik, muž'), prezime nastalo od zamjenskog imena za osobna imena מִָּ

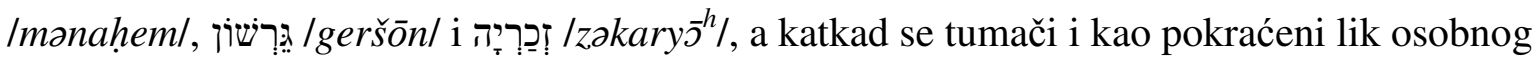
imena Meinhart < pragerm. *mahti- 'snaga' + *hardu- 'čvrst, žestok'.

\footnotetext{
${ }^{398}$ Na Mirogoju zabilježeno kao מאנדולפו /mandōlfō/ (12 II 12).
} 
Marberger/MARBERGER - jid. - Jidiški מאַרבערגע, prezime nastalo od etnika od toponima Marburg u Hessenu ili pak Marburg u Štajerskoj, današnji Maribor u Sloveniji.

Marco - jid. - Prezime nastalo konverzijom od latinskog osobnog imena (praenomen) Marcus < *Marticos, vjerojatno izvedeno od osobnog imena boga Marsa, ne samo boga rata, nego i poljoprivrede (Čilaš Šimpraga, Ivšić Majić i Vidović 2018: 202). Osobno je

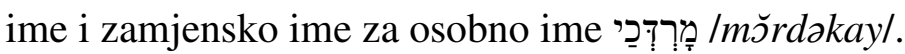

Marić/MARIĆ - hrv. - Prezime nastalo konverzijom od metronima od osobnog imena Marija < heb. מִריָּ /mirȳ̄m/ (Skok 1974: II 377-378).

Prezime je promijenjeno iz izvornoga מייער /mayer/ (v. Meyer/Mayer/Maier/Majer/ /MAYER/MAJER).

Prezime dolazi i u dvoprezimenskoj kombinaciji Mayer-Marić.

Markenstein - jid. - Jidiški מארקענשטיין (× njem. Markenstein 'granični kamen'), prezime nastalo konverzijom od patronima od osobnog imena מאַרק /mark/ (v. Marco).

MARKOVIĆ - hrv. - Prezime nastalo konverzijom od patronima od osobnog imena Marko (v. Marco) (Skok 1974: II 376).

Markus/MARKUS - jid. - Jidiški מאר מוס, prezime nastalo konverzijom od njemačke verzije osobnog imena Marcus (v. Marco).

Martin - ? - Prezime nastalo konverzijom od latinskog osobnog imena Martinus izvedenog od genitiva Martis teonima Mars nesigurne motivacije.

Mathersdorfer/Mattersdorfer - jid. - Jidiški prezime nastalo od etnika od toponima Mattersdorf u Gradišću (mađarski Nagymarton, gradišćanskohrvatski Materštof), današnji Mattersburg u Austriji.

Mautner/MAUTNER - jid. - Jidiški מאוטנער (× njem. Mautner 'skupljač poreza, poreznik'). Moguće je da je prezime nastalo od toponima Mauthern u Austriji. Ako je riječ o prezimenu nastalom od naziva zanimanja, treba prvo ustanoviti da su se Židovi smjeli baviti tim poslom. Isto je tako moguće da je riječ o izvorno njemačkome prezimenu, koje je potom preuzela židovska obitelj koja nije nužno morala biti povezana s tom profesijom.

Mayländer/Mailänder/Maylander/MAJLAENDER/MAJLENDER - jid. - Jidiški מיליענדער, prezime nastalo od etnika od toponima Mailand, njemačkog imena grada Milana u Italiji.

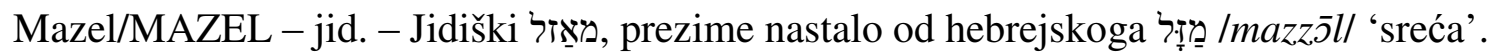

Meiler - jid. - Jidiški מיילע, prezime nastalo od ženskog osobnog imena Meile.

Mendelsohn - jid. - Jidiški מענדלסאָן, prezime nastalo od patronima od osobnog imena מענדל מעי מער Imendl/ ( $\times$ njem. Mandel 'mandula, badem'), što je umanjenica od osobnog imena

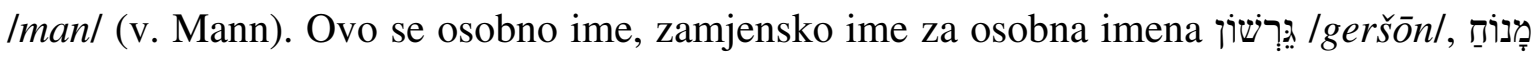




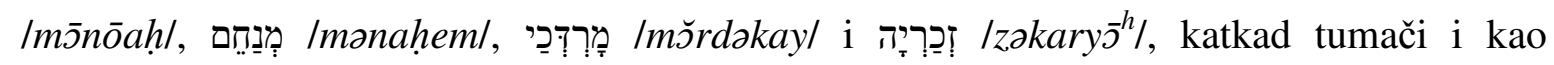
pokraćeni lik osobnog imena Meinhart < pragerm. *mahti- 'snaga' + *hardu- 'čvrst, žestok'.

Menzer/Mencer/MENZER/MENCER - jid. - Jidiški מענצער, prezime nastalo od osobnog

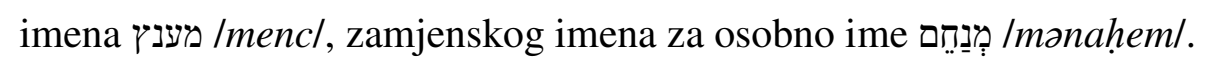

Merkadić - hrv./sef? - Možda prezime nastalo od judeošpanjolskoga מרקדו /merkado/ 'kupljen', osobnog imena koje nadijevalo djetetu rođenom pošto mu je umro brat, + -ić; »kupljen« kako bi se zavaralo urokljivo oko.

Merkler - jid. - Jidiški מערקלער, prezime nastalo od osobnog imena מערק /merk/, zamjenskog

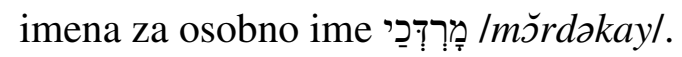

Metzger/METZGER - jid. - Jidiški מעצגער (× njem. Metzger 'mesar'), prezime nastalo od

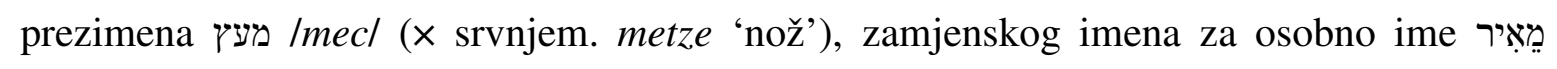
/me'`̄rl. Moguće je i da je prezime nastalo od naziva zanimanja. U židovskim je zajednicama mesar koji meso priređuje prema pravilima važna osoba, te je moguće da su prezimena dotične motivacije doista izvedena od riječi za to zanimanje.

Metzl - jid. - Jidiški מעצל, prezime nastalo od umanjenice od מעיץ /mec/ (× srvnjem. metze 'nož'), zamjenskog imena za osobno ime מֵֵאיר /me'̄ir/.

Meyer/Mayer/Maier/Majer/MAYER/MAJER - jid. - Jidiški מייער (× njem. 'upravnik, nadzornik, izvršitelj, mljekar'), prezime nastalo od zamjenskog imena za talmudsko osobno ime מֵאִיר /me'irr/.

Milić - hrv. - Prezime nastalo od patronima od osobnog imena Milan < Mile/Milo < Miloslav < mio + -an (Čilaš Šimpraga, Ivšić Majić i Vidović 2018: 212; Skok 1974: II 426-428).

Prezime je promijenjeno iz izvornoga Moses < משֶׁה /moš $\mathfrak{c}^{h} /$ (v. Moises/Moses/Mozes/ /MOSES).

Prezime se pojavljuje i u dvoprezimenskoj kombinaciji Moses-Milić.

Miljević - hrv. - Prezime nastalo od patronima od osobnog imena Milj, pokraćenog oblika osobnih imena Milivoj, Milorad, Milovan + -ić (Čilaš Šimpraga, Ivšić Majić i Vidović 2018: 214).

Mirjević - hrv. - Prezime nastalo konverzijom od metronima od osobnog imena Mirja.

Prezime je promijenjeno prijevodom izvornoga פَרידמאָן / fridman/ (v. Friedmann/Friedman/ /Fridman/FRIEDMAN/FRIDMAN).

Mirski - hrv. - Prezime nastalo prijevodom izvornoga פריץ /fric/ (v. Fritz). 
Miskolczy/Miškolcy/MIŠKOLZY - mađ. - Jidiški מישקָָלצי, prezime nastalo od etnika izvedenog od toponima Miskolcz (jidiški מישקאָלץ /miškolc/), grada na sjeveroistoku današnje Mađarske.

Misković - hrv. - Moguće je da je riječ o omašci, te da prezime izvorno glasi Mišković, što je prezime nastalo konverzijom od patronima od odmilice Miško < Miše/Mišo < Mihovil << מִיכָאָר /mīkj̄ell + -ko (Čilaš Šimpraga, Ivšić Majić i Vidović 2018: 218; Skok 1974: II 420-421).

Mitter - jid. - Jidiški מיטער, prezime nastalo od ruskog osobnog imena Митя, odmilice za

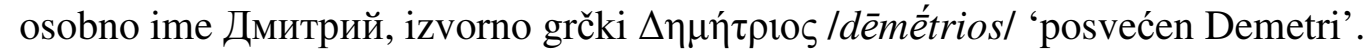

Mogan.

משֶֶָה Moises/Moses/Mozes/MOSES - jid. - Prezime nastalo od hebrejskog osobnog imena

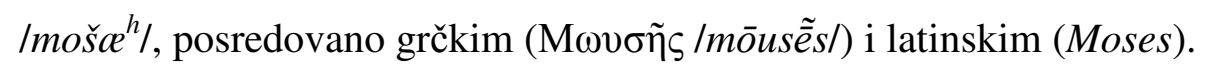

Molnar/MOLNAR - jid. - Jidiški מאָלָאָר > mađ. molnár 'mlinar'. Moguće je da je riječ o prezimenu nastalom od naziva zanimanja, ali samo ako je Židovima bilo dopušteno baviti se ovim obrtom. S druge strane, moguće je i da je riječ o mađarskom prezimenu koje je preuzela židovska obitelj koja nije imala veze s tom profesijom.

Mondschein - jid. - Jidiški מאנדשיין (× njem. Mondschein 'mjesečina'), prezime nastalo od imenice מאזָט /mont/ (njem. Mond 'Mjesec', Monat 'mjesec ').

Montag - jid. - Jidiški (× njem. Montag 'ponedjeljak (dan Mjeseca)'), prezime nastalo od imenice מאזָנ /mont/ (njem. Mond 'Mjesec', Monat 'mjesec').

Montilija - sef. - Prezime nastalo od toponima Montilla, grada u španjolskoj pokrajini Córdoba.

Morpurgo - tal. - Prezime za koje se tradicionalno navodi da je nastalo od toponima Marburg u Hessenu ili pak Marburg u Štajerskoj, današnji Maribor u Sloveniji.

Mosinger/MOSINGER - jid. - Jidiški מאָזינגער, prezime vjerojatno nastalo od osobnog imena משֶֶה /moš $\mathfrak{c}^{h} /$ (v. Moises/Moses/Mozes/MOSES).

Moskowitz/Moskovitz/Moscović/Mosković - jid. - Jidiški מאָסקאביץומאָסקאָביטש, prezime nastalo od patronima od osobnog imena Moses (v. Moises/Moses/Mozes/MOSES).

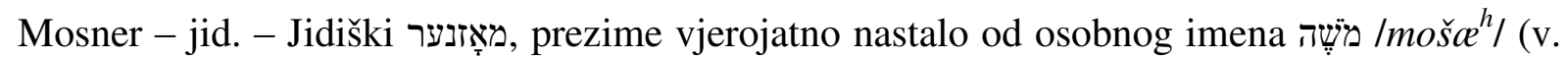
Moises/Moses/Mozes/MOSES).

Moster/MOSTER - jid. - Jidiški מאָסטער, patronim od prezimena מָָסט /most/, što je i samo patronim od osobnog imena מָָס משֶָׁה /mos/, zamjenskog imena za osobno ime / (v. Moises/Moses/Mozes/MOSES). 
Mošansky/MOŠANSKI - jid. - Jidiški מאָשאָנסקי, prezime nastalo konverzijom od patronima od osobnog imena משֶֶ, מmoš $e^{h} /$ (v. Moises/Moses/Mozes/MOSES).

Mozović - hrv. - Prezime je promijenjeno iz izvornoga Moises (v. Moises/Moses/Mozes/ /MOSES), prilagođeno hrvatskoj prezimenskoj tradiciji.

Mühlhofer/Mülhofer/Milhofer - jid. - Jidiški מילהאָפפע. Možda nastalo od toponima Mühlhof ili Mühlhofen.

Müller/Miller/Miler/MÜLLER/MüLLER/MUELLER/MURLLER - jid. - Jidiški מילער ( njem. Müller 'mlinar'), prezime nastalo od osobnog imena מועל /muel/, zamjenskog imena za osobno ime שָׁמוּאָל /šamū'ell. Moguće je da je riječ o prezimenu nastalom od naziva zanimanja, ali samo ako je Židovima bilo dopušteno baviti se ovim obrtom. Isto je tako moguće da je riječ o izvorno njemačkome prezimenu, koje je potom preuzela židovska obitelj koja nije nužno morala biti povezana s tom profesijom.

Munk - jid. - Jidiški מונק, prezime nastalo od umanjenice od osobnog imena מאָן > מאָן /mon /man/, što je zamjensko ime za osobno ime יוֹסֵ /yōsep/.

Münz - jid. - Jidiški מינץ (× njem. Münze 'novčić, kovnica novaca'), prezime nastalo od zamjenskog imena za osobno ime מְִֵּ /mənahem/.

Muth/MUTH - jid. - Jidiški מוטاמות. Njemačko prezime.

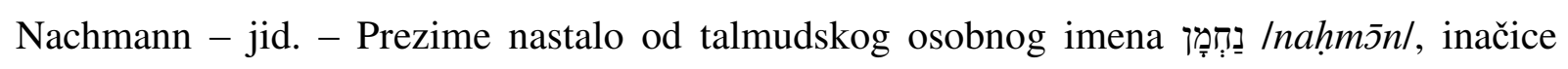
imena נֵָ /noah/ 'počinak, odmor' ${ }^{399}$.

Naschitz/Našić/NASCHITZ/NASEHITZ - jid. - Jidiški נאֵשיץ, prezime nastalo od umanjenice

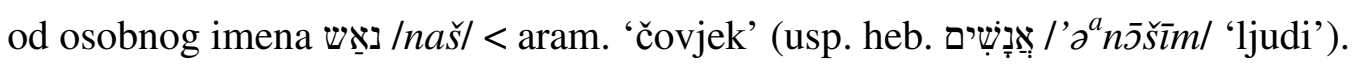

Nemes - jid. - Jidiški נעמעש, prezime nastalo od mađarskoga nemes 'plemenit'.

Prezime je promijenjeno iz izvornoga ניימאָן /nayman/ (v. Neumann/Neuman/Naumann/ /Nauman/NEUMAN/NAJMAN).

Neuberg/Neuberger/NEUBERGER - jid. - Jidiški נייבערג), prezime nastalo od toponima Neuberg, ime više mjesta u Njemačkoj i Austriji te od etnika izvedenog od njega.

Neufeld/NUFELD - jid. - Jidiški נייפיפלדר, toponim, prezime nastalo od njemačkog toponima, danas mjesto Konielspol pokraj Łódźa u Poljskoj.

Neuhäusel/Neuhäusl/Neuhäusler/Neuheusel - jid. - Jidiški (עייהויזל(ר, prezime nastalo od umanjenice od toponima Neuhaus, imena više mjesta u Franačkoj, Tirinškoj, Hannoveru,

${ }^{399}$ Post 5,29. U transkripciji Silvija Grubišića: Noa.

Odgovarajuće arapsko osobno ime: نُوح ح/nūḥ/ 'tješitelj, pravednik, zahvalnik, mir, odmor, počinak, utjeha' (Agić 1996: 85). 
Zapadnoj Falačkoj u Njemačkoj te današnjih gradova Jindřichův Hradec u Češkoj i Nové Zámky u Slovačkoj.

Neumann/Neuman/Naumann/Nauman/NEUMAN/NAJMAN - jיפמאָן pid. prezime nastalo konverzijom od patronima od osobnog imena נאֵום /naum/, inačice hebrejskog osobnog imena נֵַַוּם /naḥ̂̄m/. Može biti riječ i o novom prezimenu nakon promjene starog - novo prezime = novi čovjek (: njem. neuer Mann 'nov čovjek').

Neustadt/NEUSTADT - jid. - Jidiški prezime nastalo od toponima, imena više gradova u Njemačkoj, Austriji (Wiener Neustadt), Češkoj (Nové Město, više njih), Poljskoj (Nowe Miasto, više njih) i Sedmogradskoj (danas Baia Mare u Rumunjskoj).

Neuwirth - jid. - Jidiški נייבירט|ניביווירט (× njem. Neuwirt 'novi domaćin, novi gostioničar'), prezime nastalo od pridjeva נייר /nay/ 'nov'.

Nonveiller - jid. - Jidiški prezime vjerojatno nastalo od toponima Nonnweiler u Saaru.

Novak - hrv. - Prezime nastalo prijevodom prezimena ניפמאָן /nayman/ (v. Neumann/Neuman/ /Naumann/Nauman/NEUMAN/NAJMAN) (Skok 1974: II 525-526).

Nović - hrv. - Prezime nastalo prijevodom prezimena ניפמֵאן /nayman/ (v. Neumann/Neuman/ /Naumann/Nauman/NEUMAN/NAJMAN).

Nyitrai/NJITRAYI - mađ. - Prezime nastalo od mađarskog toponima i hidronima Nyitra, danas Nitra u Slovačkoj.

Njemčić/NJEMČIĆ - hrv. - Prezime nastalo prijevodom izvornoga דייאש/dayčl (v. Deutsch/ /Dajč/DEUTSCH/DAUTSCH) i njegovom prilagodbom hrvatskoj prezimenskoj tradiciji (Skok 1974: II 516-517).

Njemirovski/NJEMROVSKY - rus. - Jidiški ניעמיראָבסקי. Rusko prezime Немировский.

Oberson - jid. - Jidiški prezime nastalo konverzijom od patronima od osobnog imena אַבער /aber/, pokraćenog lika osobnog imena אָבְרָרָּם /'abrōhōm/.

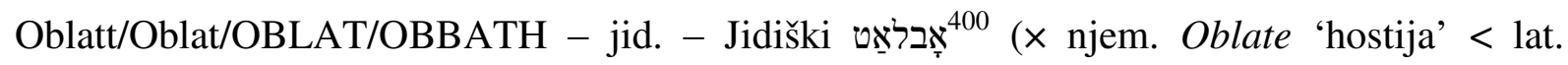
oblatio 'žrtva'; riječ se pojavljuje i u židovskim izvorima).

Offner/Ofner/OFNER - jid. - Jidiški אָפָּנע, prezime nastalo od osobnog imena אָָ /ofn/, što je ujedno i njemačko ime mađarskog grada Budima.

Oppenheim/OPPENHEIM - jid. - Jidiški אָננהיים, prezime nastalo od toponima, imena grada u Falačkoj.

\footnotetext{
${ }^{400} \mathrm{Na}$ Mirogoju zabilježeno kao אבדלאטט /oblatt/ (10 I 121).
} 
Ornstein/ORUSTEIN - jid. - Jidiški pרָשרנטיין, prezime nastalo od patronima od osobnog

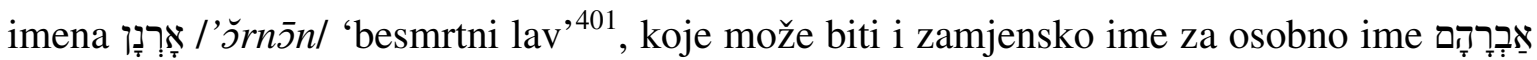
l'abrs̄h̄̄m/.

Österreicher/Oesterreicher - jid. - Jidiški עסטערייכער 'Austrijanac, austrijski'. Prezime nastalo konverzijom od etnika.

Oswald/Osvald/Oschwald/OSWALD/OSVALD - jid. - Jidiški prezime nastalo konverzijom od osobnog imena Oswald $<$ steng. $\bar{o} s<$ pragerm. *ansu- 'bog' + steng. wealdan < pragerm. *waldan- 'vladati', pojavljuje se i kao novo prezime u slučaju promjene, primjerice prezimena אכָס /oxs/ 'vol, bik', nastalog od zamjenskog imena za osobno ime יוֹס /yōsep/.

Oštrić - hrv. - Prezime nastalo od pridjeva oštar.

Prezime je promijenjeno iz izvornoga אָרנשטיין /ornšteyn/(v. Ornstein/ORUSTEIN).

Pajtaš/PAJTAŠ - jid. - Jidiški prezime nastalo od mađarskoga pajtás < tur. padaş < perz. pāydā̌s 'drug, suputnik'.

Palotta/Palota - jid. - Prezime nesigurne motivacije. Postoji selo Palota u Slovačkoj, no

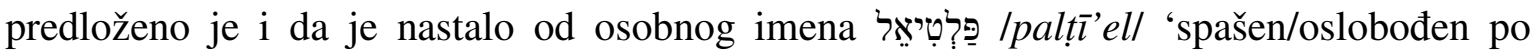
Elohimu' ${ }^{402}$ iz Tanaha.

Pander - jid. - Jאַנדער Didiški, prezime nastalo od osobnog imena פנדו /pando/, navodno iz Talmuda.

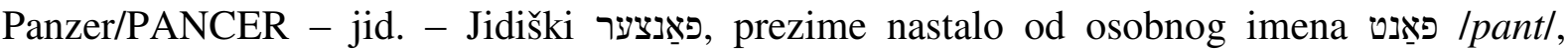

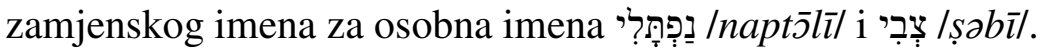

Papić/PAPIĆ - hrv. - Prezime zacijelo nastalo od regionalne riječi pape 'otac' + -ić.

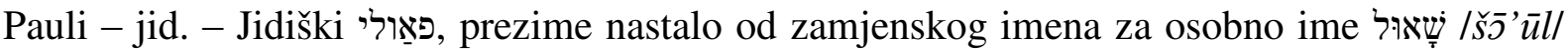
‘željen', no isto tako može biti i od zamjenskog imena za osobnog imena יוֹסֵ /yōsep/ i יִזיִ Iyahī'ell. Možda postoji i veza s latinskim osobnim imenom Paul(l)us < 'malen, ponizan'.

Pavlinović/PAVLINOVIĆ - hrv. - Prezime nastalo konverzijom od patronima/metronima od osobnog imena Pavlina $<$ Pavo $<$ Pavao $<<$ lat. Paul(l)us < ‘malen, ponizan' + -ina (Čilaš Šimpraga, Ivšić Majić i Vidović 2018: 234; Skok 1974: II 624-625).

Peči/PEĆI - mađ. - פעאשי, prezime nastalo od etnika od toponima Pécs (hrvatski Pečuh) u Mađarskoj.

\footnotetext{
${ }^{401} 1$ Ljet 21,28. U transkripciji Antuna Sovića: Ornan.

${ }^{402}$ Br 34,26. U transkripciji Silvija Grubišića: Paltiel.
} 
Peičić - hrv. - Petar Skok za prezime Pejčić navodi da je nastalo od osobnog imena Pejčo <

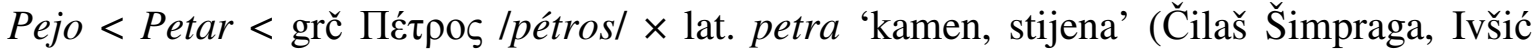
Majić i Vidović 2018: 234; Skok 1974: II 649-650).

Prezime se pojavljuje jedino u dvoprezimenskoj kombinaciji Peičić Freiberger (v. Freiberger/FREIBERGER).

Pelzing - jid. - Jidiški פעלצינג, prezime nastalo od prezimena פעלץ/pelc/ ( $\times$ njem. Pelz 'krzno'), patronima osobnog imena פעלטאה /peltal, zamjenskog imena za osobna imena

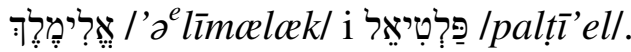

פערל Perlfaster/Peerlfaster - jid. - Jidiški פערלפֵַסטער, prezime nastalo od osobnog imena בער /perl/, umanjenice od osobnog imena בערל /berla, biser', inačice osobnog imena

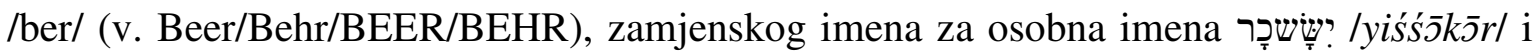

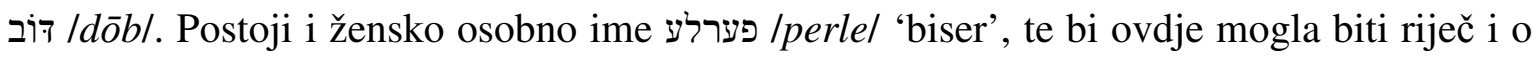
prezimenu nastalom od njega.

Perok/PEROK - Možda dijalektalan lik prezimena Perak za koje Petar Skok navodi da je nastalo od osobnog imena Petar (v. Peičić) (Skok 1974: II 649-650).

Pessek - Možda izvedeno od prezimena פעסל /pesl/ (v. Pessl).

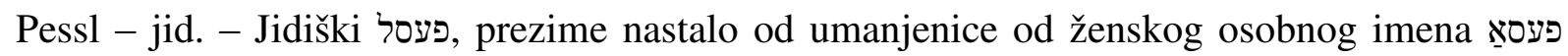

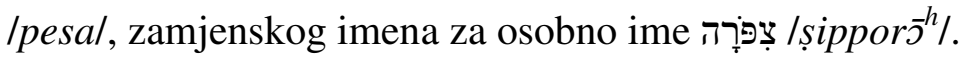

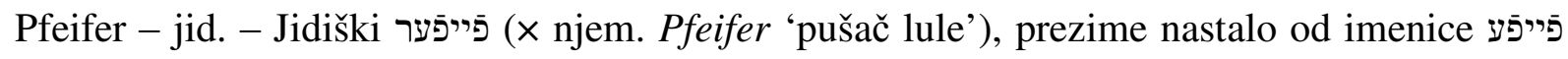
Ifeyfel ( $\times$ njem. Pfeife 'lula').

Pichler/PICHER/PISCHLER - jid. - Jidiški פיכלער, prezime nastalo od etnik od toponima Pichl, imena više mjesta u današnjoj Austriji.

Pick/Pik/PICK - jid. - Jidiški פיק (× njem. Pick 'trnokop'), prezime nastalo od inačice osobnog imena ביק/bik/ 'bik'; ako dolazi iz slavenskih jezika, zamjensko ime za osobno ime יוֹסֵōsep/.

Pilcz - jid. - Jidiški פילץ (× njem. Pilz 'gljiva'), prezime nastalo od patronima od osobnog

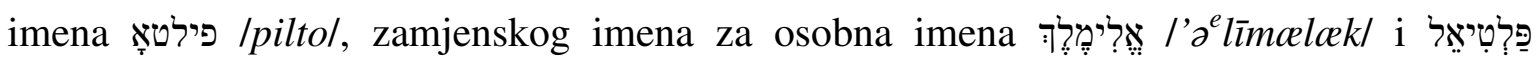
Ipalțī'ell.

Piozk - Možda inačica prezimena פיסק /pisk/ (v. PISK).

PISK - jid. - Jidiški פיסק, prezime nastalo od polj. pisk, rus. писк 'vriska'.

Pisker - jid. - Jidiški פיסקער, prezime nastalo od prezimena פיסק /pisk/ (v. PISK).

Plachte/PLACHTE - jid. - Jidiški prezime nastalo od češ. plachta 'jedro', polj. płachta 'platno'. 
Plamenak - hrv. - Prezime nastalo od imenice plam(en).

Prezime je promijenjeno iz izvornoga זיבנשיין /zibnšeyn/ (v. Siebenschein/ /SIEBENSCHEIN).

Podvinetz/Podvinec/PODVINEC - jid. - Jidiški prezime nastalo od etnika od jednog od mjesta imenom Podwinie (jedno od njih nedaleko od Vilniusa u današnjoj Litvi, a drugo današnji Рогатин u Ukrajini).

Politzer - jid. - Jאָליצער Jidiški, prezime nastalo od etnika od toponima, današnje Police u Češkoj.

Pollacsek/Polaček - jid. - Jאָָאַטשעק 'Poljak'.

Pollak/Polak/Poljak/POLLAK/POLAK - jid. - Jאָלאָק 'Poljak'. Prezime nastalo od etnika.

Polak je ujedno i Prezime je promijenjeno iz izvornoga וויים /weys/ (v. Weiß/Weiss/Weisz/ /Weis/Weihs/WEISS/WEIS).

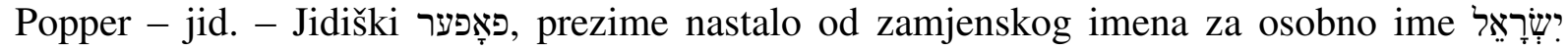
lyiśrō'ell.

Prager - jid. - Jidiški פראגֵער, prezime nastalo od etnika od imena češke prijestolnice Praga.

Preisz/Preis/Prajs/PREISZ - jid. - Jidiški פרייס (× njem. Preis 'cijena').

Pressburger/PRESSBURGER/PRESBURGER - jid. - Jidiški פרעסבורגער, prezime nastalo od etnika od grada Pressburg, današnja Bratislava u Slovačkoj. Moguće je i da je riječ o prezimenu nastalom od imenice פרעס /pres/ 'tijesak'.

Priester/Prister/PRISTER - tal. - Iako je podrijetlo ovog prezimena nesumnjivo germansko, nastalo od jidiškoga פריסטער / פּהן 'svećenik', u Zagrebu ga nose porodice talijanskih Židova doseljene iz Gorice.

PSEHERHOF - jid. - Još jedno prezime koje nalazimo samo u bazi podataka Gradskih grobalja, vjerojatno pogrešno prepisano. S obzirom na sličnost slova $f\langle f\rangle$ sa slovima $s$ $<>>$ i $h<f>$ u pismu Sütterlin (rukopisna gotica), moguće je da prezime glasi Pfeferhof, jidiški פעפפערהאָּ. U tom je slučaju riječ o prezimenu nastalom od imenice פעפעפר /fefer/ 'papar'.

PULAŠ - jid. - Jidiški פולאַש, prezime nastalo od osobnog imena פולאַ/pula/ > polj. pula 'iznos u koji se karta'. 
Pullay/Pulay - mađ. - Jidiški פולאי, mađarsko prezime ${ }^{403}$.

Pulzer/PULZER - jid. - Jidiški פולצע, austrijsko prezime.

Rabenstein - jid. - Jidiški ראַבנשטיין, prezime nastalo od imenice ראָבן /rabn/, inačice osobnog imena ראֵ / $/ \mathrm{rab} /$. Za ovo potonje postoji više mogućih tumačenja. Jedno je toponim Raab, današnji Győr u Mađarskoj, drugo imenica 'gavran', treće češko rab i rusko paб 'sluga, rob', četvrto talmudska titula רַ / $\mathrm{rab}$ / 'rabin'. S druge je strane Rabenstein i toponim, ime grada u Saskoj.

Rabinović/RABINAIĆ - jid. - Jidiško ראבינאָביטש, prezime nastalo konverzijom od patronima ראוּרֵ |ro'ūben/.

Radan/RADAN - hrv. - Prezime nastalo od osobnog imena Rade/Rado < Radimir/Radislav/ /Radivoj(e)/Radomir/Radoslav/Radovan. (Čilaš Šimpraga, Ivšić Majić i Vidović 2018: 237, 238; Skok 1974: III 94-95; Šimunović 2006: 132).

Prezime je promijenjeno iz izvornoga רעכניצער/rexnicer/ (v. Rechnitzer/RECHNITZER/ /RECCHMITZER).

Radinger/RADINGER - jid. - Jidiški ראָדינדער, prezime vjerojatno nastalo od etnika od toponima Rading u Bavarskoj.

Radó/Rado - mađ. - Jidiški אָדאר, mađarsko prezime nastalo od osobnog imena Radisló, mađarske inačice slavenskog osobnog imena Radislav < prasl. *radb 'veseo, voljan' + *slava (Čilaš Šimpraga, Ivšić Majić i Vidović 2018: 237).

Prezime je promijenjeno iz izvornoga ראזָנבערגער /roznberger/ (v. Rosenberg/Rosenberger/ /Rozenberg/ROSENBERG/ROSENBERGER).

Radulović - hrv. - Prezime nastalo konverzijom od patronima od osobnog imena Radul < Rade/Rado < Radimir/Radislav/Radivoj(e)/Radomir/Radoslav/Radovan (Čilaš Šimpraga, Ivšić Majić i Vidović 2018: 237, 238; Skok 1974: III 94-95).

Raić - hrv. - Inačica prezimena Rajić, prezimena nastalog konverzijom patronima od osobnog imena Rajo < Radomir/Radoslav < prasl. *radb + -ić (Čilaš Šimpraga, Ivšić Majić i Vidović 2018: 238; Skok 1974: III 100).

Prezime je promijenjeno iz izvornoga רייכל (v. Reichl).

Rákosi/Rakosi/Rákoši/Rakoši - mađ. - Jidiški ראָ, prezime od etnika od toponima Rákos, imena mjesta u Mađarskoj te više njih u Slovačkoj (danas Rákoš).

\footnotetext{
${ }^{403}$ Nose ga primjerice kemičar i mikrobiolog Pulay Gábor István (1927. - 1975.), kemičar Pulay Peter (r. 1941.) i ekonomist i političar Pulay Gyula (r. 1956.).
} 
Prezime je promijenjeno iz izvornoga Kahn (v. Cohen/Koen/Kohn/Kohen/Khon/Kahn/ /Khan/KOEN/KOHN/KHON/KON/KOLIN).

Rapaport - jid. - Jidiški ראַפֵַפָָרט. Pretpostavlja se da je prezime talijanskog podrijetla, nastalo od sintagme rapà di Porto Mantovano 'gavran iz grada Porto Mantovano', pripadalo je svećeničkoj porodici Rapà-Cohen, znanoj i kao Porto haKohen Aškenazi.

Ratz - jid. - Jidiški ראֵ, prezime nastalo od ראֵ /rat/ (× njem. Rat 'savjet'). Moguće je i da je prezime nastalo od toponima Rath pokraj Düsseldorfa u Njemačkoj.

Raudnitz - jid. - Jidiški prezime nastalo od toponima, današnje selo Roudnice u Češkoj.

Rausnic - jid. - Jidiški ראוסניץ, prezime nastalo od toponima.

Recanati/REKANATY - tal. - Prezime nastalo od toponima, imena grada u talijanskoj pokrajini Marche.

Rechnitzer/RECHNITZER/RECCHMITZER - jid. - Jidiški רעכניצער, prezime nastalo od etnika od imena mjesta Rechnitz (gradišćanskohrvatski Rohonc) u Gradišću.

Redlich - jid. - Jidiški רעדליך (× njem. redlich 'pošten, razuman, važan, prikladan'). Moguće je da je prezime nastalo od osobnog imena רעד/red/.

Rehberger - jid. - Jidiški רעבערגע, prezime nastalo od etnika od imena mjesta Rehberg u Češkoj.

Reich/REICH - jid. - Jidiški רייך (× njem. reich 'bogat, plemenit', Reich 'vlast, kraljevina, carstvo').

Reichenthal - jid. - Jidiški רייכנטאָל, prezime nastalo od toponima, a možda i od prezimena רייך/reyx/ (v. Reich/REICH).

Reicher/REICHER - jid. - Jidiški רייכער, prezime nastalo od prezimena רייך/reyx/ (v. Reich/ /REICH).

Reichl - jid. - Jidiški רייכל, prezime nastalo od umanjenice od prezimena רייך /reyx/ (v. Reich/ /REICH) ili od umanjenice od zamjenskog imena za osobno ime רִ̣ /rọhell.

Reichsmann/Reichman/REICHSMANN - jid. - Jidiški prezime nastalo od patronima od prezimena רייך/reyx/ (v. Reich/REICH).

Rein - jid. - Jidiški ריין (× njem. rein 'čist'), prezime nastalo od ženskog osobnog imena izvedenog od romanskih riječi za kraljicu i kao takvog prijevod hebrejskoga osobnog

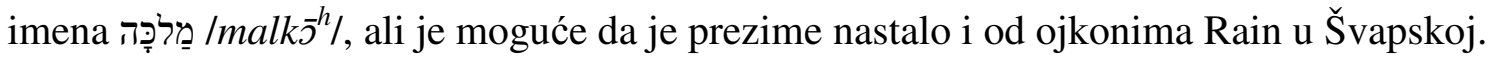

Reiner/REINER - jid. - Jidiški ריינע, prezime nastalo konverzijom od njemačkog muškog osobnog imena Rainer < pragerm. *ragina- 'odluka' + *harja- 'vojska', ali i od metronima od osobnog imena ריין/reyn/ (v. Rein). 
Reisner - jid. - Jidiški רייסנער, prezime nastalo od osobnog imena רייס /reys/ (v. Reiß/Reiss/ /REISS), ali može biti i od etnika od toponima Reisen, danas grad Rydzyna u Poljskoj.

Reiß/Reiss/REISS - jid. - Jidiški ריים/reys/, prezime koje je moglo nastati konverzijom od ženskog osobnog imena (nadimka od osobnog imena Theresa), od ruskog ženskog osobnog imena Pauca, ili od jidiškog ženskog osobnog imena רויזע/royzel 'ruža'.

Rendely/Rendeli/Rendele/RENDELY/RENDELI - tal. - Prezime je vjerojatno nastalo od prezimena רענדעל /rendel/ > 'krupica', no može biti i od imenice רֵֵנד /rand/ 'rub'.

Rendi/RENDI - jid. - Jidiški רענדי, prezime vjerojatno nastalo od imenice ראנד /rand/ 'rub'.

RENDIĆ - hrv. - Prezime nastalo konverzijom od patronima od osobnog imena Rendo.

Renner - jid. - Jidiški רענער (× njem. Renner 'trkač, glasnik na konju'), prezime nastalo konverzijom od židovskog osobnog imena koje se pojavljuje od 1400. g.

REVES - jid. - Jidiški רעבעם, prezime nastalo od mađarskoga révész 'splavar'.

Richter/RICHTER - jid. - Jidiški ריכטער (× njem. Richter 'sudac'), prezime nastalo od osobnog imena רעכט /rext/ (× njem. Recht 'pravo, pravda').

Richtmann - jid. - Jidiški ריכטמאָן, prezime nastalo konverzijom od patronima od osobnog imena רעכ /rext/ (njem. Recht 'pravo, pravda').

Riegler - jid. - Jidiški ריגלער, prezime nastalo od osobnog imena ריגל /rigl/ (× njem. Riegel 'zasun').

RIPNER - jid. - Jidiški ריפנער, prezime nastalo od osobnog imena ריפ /rip/, zamjenskog

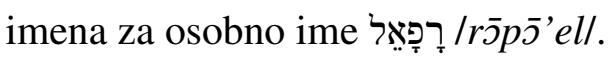

ROCHLITZ - jid. - Jidiški ראָכליץ, prezime nastalo od toponima u Saskoj (gluž. Rochlica).

Rodanić/RODANIĆ/RADONIĆ - hrv. - Zbog različitosti zapisa prezimena motivacija nije sigurna, vjerojatno prezime nastalo konverzijom patronima od osobnog imena Radan < rad-.

Rodić - hrv. - Prezime je promijenjeno iz izvornoga ראזָנבערגער /roznberger/ (v. Rosenberg/ /Rosenberger/Rozenberg/ROSENBERG/ROSENBERGER).

Roguljić - hrv. - Prezime nastalo konverzijom od patronima od Rogulja, čestog zoonima. Prezime se pojavljuje samo u dvoprezimenskoj kombinaciji Oblat Roguljić.

Rojan - Prezime je promijenjeno iz izvornoga פריסטער/prister/ (v. Priester/Prister/PRISTER). Rokonstein/Rockenstein/Rokenstein/Rakonstein - jid. - Jidiški ראָקא(אָנשטיין, prezime nastalo konverzijom od patronima od imenice רזָ /rok/ (× srvnjem. 'suknja, kora drveta, preslica').

Roman/ROMAN - jid. - Jidiški ראָמאָן, prezime nastalo ili od osobnog imena ראָם /rom/, zamjenskog imena za osobno ime אַבְרָָָם /'abrōhs̄m/, ili od etnika 'Rimljanin' ili 'Rumunj'. 
Romano/ROMANO - tal. - Prezime nastalo od etnika 'Rimljanin'.

Romanović - hrv. - Prezime nastalo konverzijom od patronima od osobnog imena Roman(o) (v.).

Prezime je promijenjeno iz izvornoga רעכניצער /rexnicer/ (v. Rechnitzer/RECHNITZER/ /RECCHMITZER).

Rosenbaum/ROSENBAUM - jid. - Jidiški ראָזנבאָום (× njem. Rosenbaum 'ružino drvo'), prezime nastalo konverzijom od metronima od ženskog osobnog imena ראָזע/rozel motiviranog imenicom značenja 'ruža', koja u pridjevskom značenju 'ružičast' može biti i

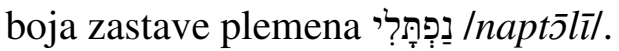

Rosenberg / Rosenberger / Rozenberg / ROSENBERG / ROSENBERGER - jid. - Jidiški ראָזע ראזָזָנבערג(ער), prezime nastalo konverzijom od metronima od ženskog osobnog imena /roze/ motiviranog imenicom značenja 'ruža', koja u pridjevskom značenju 'ružičast' može biti i boja zastave plemena נַפְָּתרלי /napts̄lī/. Druga je mogućnost da je prezime nastalo od toponima Rosenberg, imena više mjesta u Pruskoj (danas Susz u Poljskoj), Šleskoj (danas Olesno u Poljskoj), Češkoj (danas Rožmberk) i Slovačkoj (danas Ružomberok).

Rosendorfer/Rogendorfer/Ragendorfer - jid. - Prezime se iste osobe (10/1891 18/1892 4/1894 ראגָנדָארפער , 10/1895 90/1896) pojavljuje u tri različita lika, jidiški ראַגנדָארפעער Prozo je očigledno nastalo od jidiškog ženskog osobnog imena motiviranog imenicom značenja 'ruža', koja u pridjevskom značenju 'ružičast' može biti i

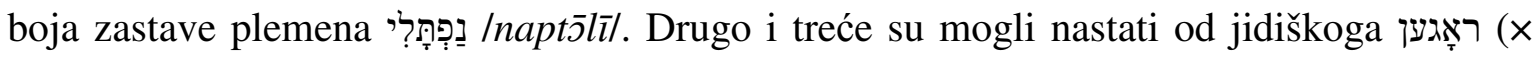
njem. Rogen 'ikra', Roggen 'raž'). Nije nevjerojatno ni da su u pitanju prezimena nastala od etnika od toponimā Rosendorf i $\operatorname{Rog}(\mathrm{g})$ endorf.

Rosenfeld/Rosenthal/ROSENFELD - jid. - Još jedan slučaj kad se u iste osobe (ovaj put dvije: 86/1865 226/1865 275/1866 349/1868 414/1870 481/1872 $624 / 1875 \quad 747 / 1878$ 935/1881 1081/1884 i 456/1871 511/1873 583/1875 679/1876 $\quad$ 962/1882 1350/1889) pojavljuju različita prezimena: ראָזנטאַל i רָזזנפּעלד. Oba su nastala konverzijama metronima od ženskog osobnog imena ראָזע/roze/ motiviranog imenicom značenja 'ruža',

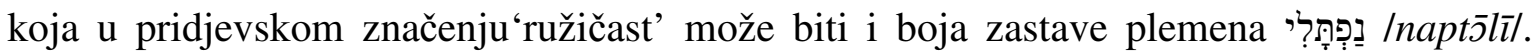
Rosenthal je ujedno i toponim, ime više sela u Hessenu, Hannoveru, Šleskoj i Pruskoj.

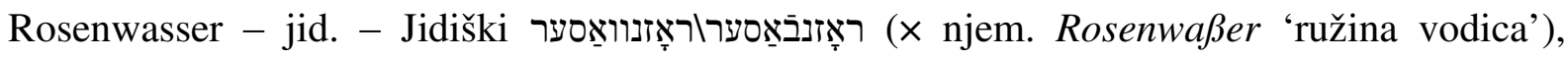
prezime nastalo od ženskog osobnog imena ראזָ /roze/ motiviranog imenicom značenja 'ruža', koja u pridjevskom značenju 'ružičast' može biti i boja zastave plemena נַפְתָּר? Inapts̄līl. 
Rosenzweig - jid. - Jidiški ראָזנצבייגוראָזנצווייג (× njem. Rosenzweig 'grančica ruže'), prezime nastalo konverzijom od metronima od ženskog osobnog imena ראָזע /roze/ motiviranog imenicom značenja 'ruža', koja u pridjevskom značenju 'ružičast' može biti i boja zastave

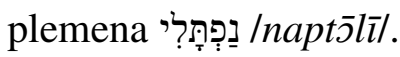

Rosinger/ROSINGER - jid. - Jidiški ראָזינגער, prezime nastalo od ženskog osobnog imena ראָזע /roze/ motiviranog imenicom značenja 'ruža', koja u pridjevskom značenju 'ružičast'

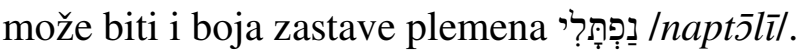

Rosner/Rozner/ROSNER - jid. - Jidiški ראזָנער, prezime nastalo od ženskog osobnog imena ראזָ /roze/ motiviranog imenicom značenja 'ruža', koja u pridjevskom značenju 'ružičast'

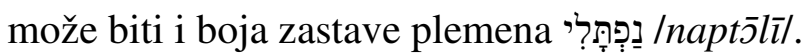

Rosskorn - jid. - Jidiški ראָסָָר (× njem. Ross 'konj’ + Korn ‘žito’).

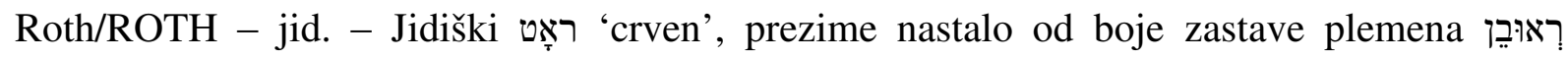
|ro'ūben/.

Roth Müller/ROTHMÜLLER - jid. - Jidiški ראָט מילערוראָטמילער, prezime nastalo kombinacijom dvaju prezimena, ראָט/rot/ (v. Roth/ROTH) מילער /miler/ (v. Müller/Miller/ /Miler/MÜLLER/MüLLER/MUELLER/MURLLER).

Rothschild/Rotschild - jid. - Jidiški ראָטשילד, prezime nastalo od prezimena ראָט /rot/ (v. Roth/ROTH).

Rothstein/Rotstein/ROTHSTEIN - jid. - Jidiški ראירטטשיין ${ }^{404}$, prezime nastalo konverzijom od patronima od prezimena ראָ /rot/ (v. Roth/ROTH).

Rotković/ROTKOVIĆ - hrv. - Prezime nastalo konverzijom patronima od Rotko < Rode < Rodimir/Rodoslav.

Rotter/ROTTER - jid. - Jidiški ראָטער, prezime nastalo od prezimena ראָט /rot/ (v. Roth/ /ROTH).

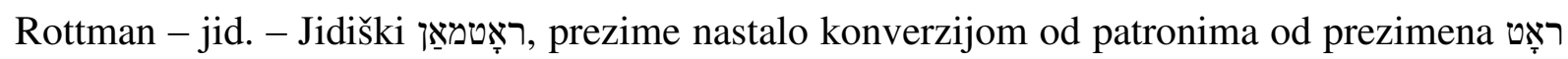
/rot/ (v. Roth/ROTH).

Roubiček - jid. - Jidiški ראוביטשע, prezime nastalo od češkog roubík 'batina, povez za usta'.

Rožić - hrv. - Prezime nastalo od nestandardne imenice roža 'ruža' ili konverzijom metronima od osobnog imena Roža.

Prezime je promijenjeno prijevodom izvornoga רזָזנבערג /roznberg/ (v. Rosenberg/ /Rosenberger/Rozenberg/ROSENBERG/ROSENBERGER).

\footnotetext{
${ }^{404}$ Na Mirogoju zabilježeno kao ראטהשטיין/rothšteyn/ (13A II/I 3).
} 
Rückländer/Rükländer - jid. - Jidiški ריקלענדער, prezime možda nastalo od osobnog imena ריק Irik/, pokraćenog lika osobnog imena Rickert < Richard < pragerm. *rīk- 'vladar, kralj' + *hardu- 'čvrst, žestok'.

Rudolf - jid. - Jidiški רודאָלף, prezime nastalo konverzijom od njemačkog osobnog imena < *hrōpi- 'slava' + *wulfa- 'vuk'.

Ruhig - jid. - Jidiški רואיג (× njem. ruhig 'tih').

Russ - jid. - Jidiški רוס (× njem. Russ 'čađa' ili Russe 'Rus').

Ružić - hrv. - Prezime nastalo konverzijom od metronima od osobnog imena Ruža.

Prezime je promijenjeno prijevodom izvornoga רזָזנבערג /roznberg/ (v. Rosenberg/ /Rosenberger/Rozenberg/ROSENBERG/ROSENBERGER).

Sachs/SACHS - jid. - Jidiški זאַקס/זאַכס, prezime koje se može tumačiti na mnoge načine. Prezime je moglo nastati od etnika 'Sas', zatim može biti riječ o prezimenu nastalom konverzijom od osobnog imena izvedenog od osobnog imena זעקל /zekl/, zamjenskog

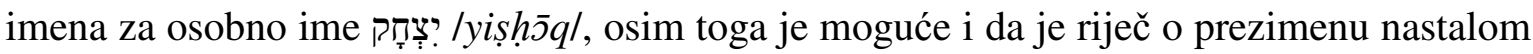

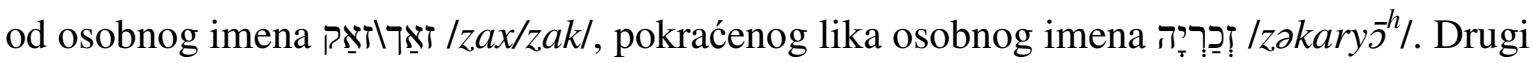
je lik prezimena, זק"ש, nastao od akronima za koji opet postoji više tumačenja: ili je puni

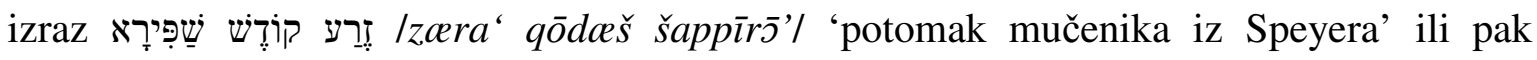
patronim od osobnog imena ז ז ז זֶר /zak/, i samog akronima mogućih značenja

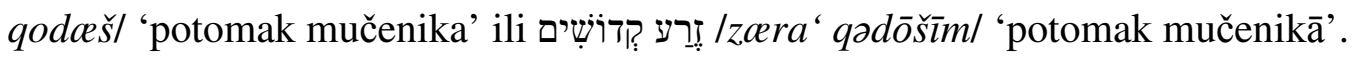

Sachs »de Grič« - pl. - Riječki je odvjetnik dr. Hinko Sachs za svoje zasluge dobio plemstvo »de Grič«. Njegovi su potomci naslijedili naslov.

Sahlikover.

Salaj/SALAJ. - Moguće su dvije motivacije ovog prezimena. Prema jednoj je nastalo od etnika od mađarske pokrajine Szala uz hrvatsku granicu (Šimunović 2006: 315$)^{405}$. Ovo prezime ima i motivaciju iz hebrejskog jezika, u tom je slučaju nastalo od novohebrejskoga סִ

Salamon / Sallamon / Sallomon / Salomon / Solomon / Šalamon - heb. - Prezime nastalo

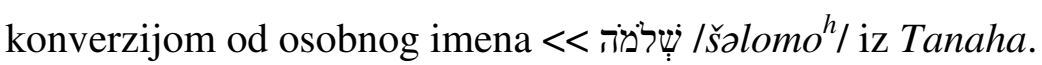

\footnotetext{
${ }^{405}$ Nažalost, nigdje nisam uspio naći toponim Szala na koji se referira Petar Šimunović, osim kao jedno od zaselaka čijim je udruživanjem nastalo selo Szalaszend. Dotično se selo, međutim, nalazi na sjeveru Mađarske, daleko od hrvatske granice.

S druge strane, uz hrvatsku se granicu nalazila županija Zala, za koju, međutim, nisam nigdje našao da se ikada zvala Szala.
} 
Saltzberger/Salzberger/SALZBERGER - jid. - Jאוֹלצערגער prezime nastalo konverzijom od patronima prezimena זָאֵלץ /zalc/ (v. Salz).

Saltzer/Salzer/Salcer/SALZER - jid. - Jidiški (× njem. Salzer 'solar'), prezime nastalo od prezimena זאָלרץ /zalc/ (v. Salz). Moguće je i da je riječ o prezimenu nastalom od naziva zanimanja. S druge je strane moguće i da je židovska obitelj preuzela prezime od neke njemačke obitelji, a da sama nije morala imati nikakve veze s navedenom profesijom.

Salz - ašk. - Jidiški זֵָלץ (× njem. Salz 'sol, rasol').

Salzmann/Salzman - jid (x njem. Salzmann 'solar'), prezime nastalo konverzijom od patronima od prezimena זאָלץ /zalc/ (v. Salz). Moguće je i da je riječ o prezimenu nastalom od naziva zanimanja. S druge je strane moguće i da je židovska obitelj preuzela prezime od neke njemačke obitelji, a da sama nije morala imati nikakve veze $s$ navedenom profesijom.

Samujlović/SAMUJLOVIĆ - hrv. - Prezime nastalo konverzijom patronima od osobnog

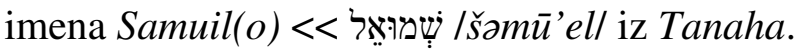

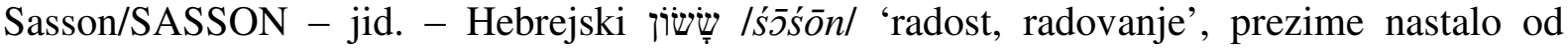

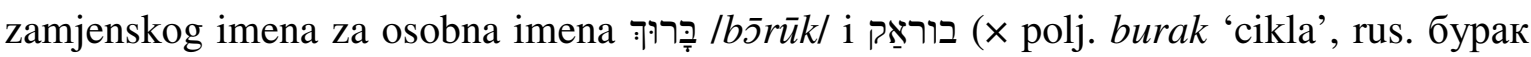
'cikla, posuda izrađena od brezine kore').

Sattler/Szattler/SATTLER - jid. - Jidiški סאטטלער (× njem. Sattler 'sedlar'), no prezime je po svemu sudeći ipak nastalo od pridjeva סאַ 'sit'.

Satz - jid. - Jidiški זֵָ, toponim, mjesto Čatec u Češkoj.

Sauerbrunn/Sauerbrun/SAUERBRUN/SANERBRUN - jid. - Jאוערברון prezime nastalo od pridjeva זאַוער /zauer/ 'kiseo', no moguće je i da je nastalo od toponima Sauerbrunn, danas Bad Sauerbrunn (gradišćanskohrvatski Kisela voda), grada s toplicama u Gradišću.

Savić - hrv. - Prezime nastalo konverzijom od patronima od osobnog imena Savo.

Prezime je promijenjeno iz izvornoga שוואַרץ/šwarc/ (v. Schwartz/Schwarz/Schwarc/ / Shwarz / Svarz / Šwarz / Švarc / SCHWARTZ / SCHVARTZ / SCHWARZ / SCHVARZ / /SCHWARZZ/SCHWATZ/ŠVARC).

Schaffer/SCHAFFER - jid. - Jאָָעָר Ridiški. Prezime nastalo od osobnog imena שפיר koje

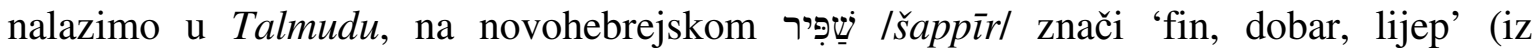

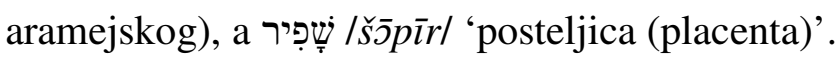

Schamburg - jid. - Jidiški שֵמבורג, prezime nastalo od toponima (također i Schaumburg i Schamberg i Schaunberg). 


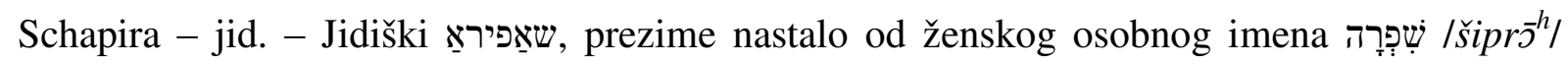
'lijepa', no moguće je i da je nastalo od toponima Speyer u Porajnju. Treća je mogućnost

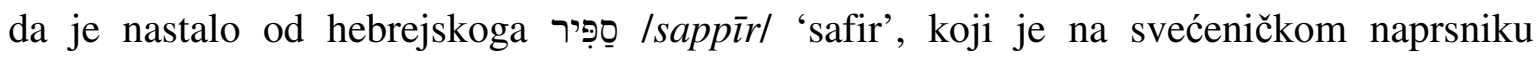

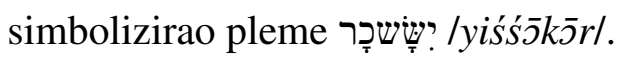

Schapringer/SCHAPRINGER - jid. - Jidiški שאפרינגער, prezime nastalo od osobnog imena

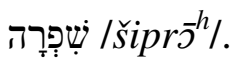

Scharf - jid. - Jidiški 'oštar, ljut (okus), oštrouman', prezime nastalo prijevodom hebrejskoga חָָרִ /ḥ̄rip/ 'ljut (okus), oštrouman', počasne titule proučavatelja Talmuda.

Schatteles/SCHATELES - jid. - שאטטעלעם /šatner/ (× češ. šat 'odjeća').

Scheiber - jid. - Jidiški שייבע, prezime nastalo od osobnog imena שייב /šeyb/.

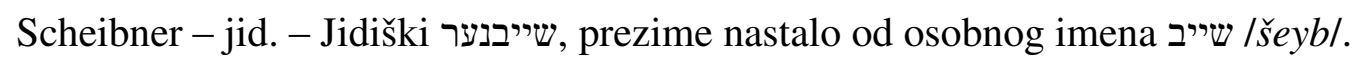

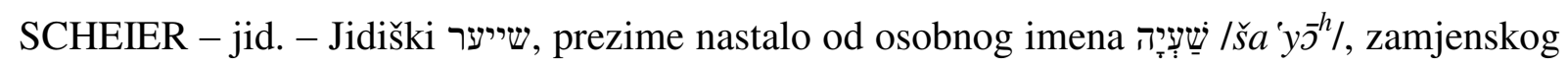

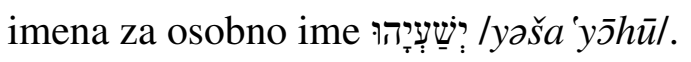

Schenberg - jid. - Jidiški שענבערג, prezime nastalo od osobnog imena שען/šen/ (v. Schön/

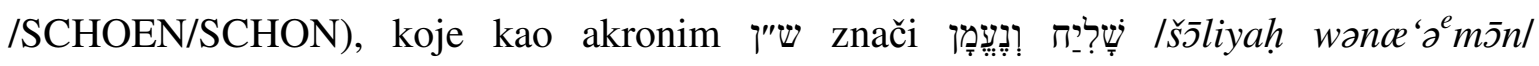
'izaslanik (dvora) i povjerenik', a inačice osobnog imena שיין /šeyn/ (: njem. schön 'lijep').

Scherpner/SCHERPER/SCHERPNER - jid. - Jidiški שערפנע, njemačko prezime.

Scherz - jid. - Jidiški שערץ (× njem. Scherz 'šala'), prezime koje je možda nastalo od

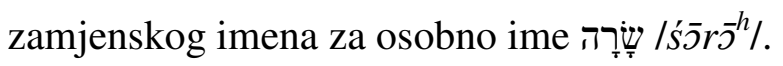

Schey - jid. - Jidiški שיי, prezime nastalo od pokraćenog lika osobnog imena שִׁעִיזה

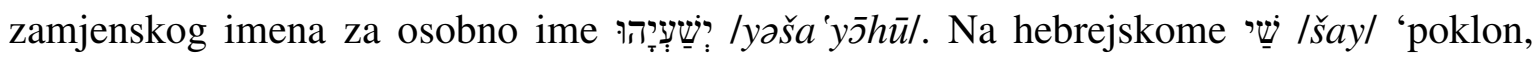
dar'.

Scheyer - jid. - Jidiški שייער, prezime izvedeno od prezimena שיי/šey/ (v. Schey).

Schienger - jid. - Jidiški שינגער.

Schiller/SCHILLER - jid. - Jidiški שילער, prezime nastalo od patronima od osobnog imena

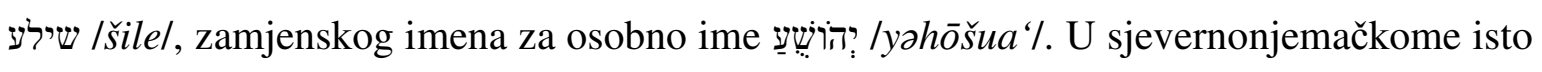
osobno ime biti motivirano imenicom značenja 'grgeč, štuka'.

Schillinger/SCHILLINGER/SCHILINGER - jid. - Jidiški prezime nastalo od prezimena שילינג ( $\times$ njem. Schilling 'srebrnjak vrijedan 1/20 srebrne marke'), koje je pak

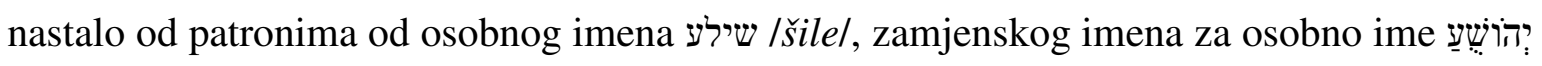
/yəhōšua \% U sjevernonjemačkome isto osobno ime biti motivirano imenicom značenja 'grgeč, štuka'.

Schlenger - jid. - Jidiški שלענגע, njemačko prezime. 
Schlesinger/SCHLESINGER/SCHLEZINGER - jid. - Jidiški שלעזינגער, prezime nastalo od etnika, ili ‘osoba iz Šleske' ili od toponima Ślesin u Poljskoj.

Schlöhinger - jid. - Jidiški שלעאינגע.

Schlomm - jid. - Jidiški שלאָם, prezime nastalo od zamjenskog imena za osobna imena שָלוֹם

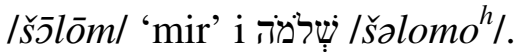

Schmerz - jid. - Jidiški שמערץ (× njem. Schmerz 'bol'), prezime nastalo od osobnog imena שמער /šmer/.

Schmidek - jid. - Jidiški שמידעק, prezime nastalo od umanjenice od prezimena שמיד /šmid/ (v. Schmidt/Šmit/SCHMIDT).

Schmidl - jid. - Jidiški שמידל, prezime nastalo od umanjenice od prezimena שמיד /šmid/ (v. Schmidt/Šmit/SCHMIDT).

Schmidt/Šmit/SCHMIDT - jid. - Jמידושמיט (× njem. Schmied 'kovač'). Prezime nastalo od zanimanja.

Schmutzer/SCHMUTZER - jid. - Jidiški שמוצער, prezime nastalo od pridjeva שמוץ /šmuc/ (× njem. Schmusen 'poljubac', Schmutz 'prljavština').

Schneider - jid. - Jidiški שניידער 'krojač', prezime nastalo od zanimanja, ali i prezime nastalo od osobnog imena שנייד/šneyd/ 'oštrica'.

Schnitlinger/SCHNITTLINGER - jid. - Jidiški שניטלינגער, prezime nastalo od prezimena שניט /šnit/ (× njem. Schnitt 'rez').

Schnitzer - jid. - Jניצער שניט /šnit/ (× njem. Schnitt 'rez').

Scholler/SCHOLLER - jid. - Jidiški שָאלער 'Školarac, učenjak’.

Schön/SCHOEN/SCHON - jid. - שען Jidiškep'. Moguće je i da je prezime nastalo od

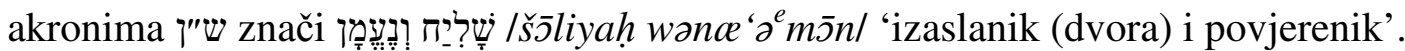

Schönbaum/SCHOENBAUM/SCHöNBAUMM - jid. - Jidiški שענבאַום , prezime nastalo konverzijom od patronima od prezimena שען/šen/ (v. Schön/SCHOEN/SCHON).

Schönberg/SCHOENBERG - jid. - Jidiški שענבערג, prezime nastalo konverzijom od patronima od prezimena שען/šen/ (v. Schön/SCHOEN/SCHON), ali i od toponima u Donjoj Bavarskoj, Mecklenburgu, Schleswig-Holsteinu i Latviji (danas Skaistkalne).

Schönfeld - jid. - Jidiški שענפעלד, prezime nastalo konverzijom od patronima od prezimena שען /šen/ (v. Schön/SCHOEN/SCHON), ali i od toponima u Saskoj i Češkoj (Krásno).

Schönheit - jid. - Jidiški שענהייט (× njem. Schönheit 'ljepota'), prezime nastalo od prezimena שען /šen/ (v. Schön/SCHOEN/SCHON). 
Schönstein/Schoenstein/SCHOENSTEIN - jid. - Jidiški prezime nastalo konverzijom od patronima od prezimena שען/šen/ (v. Schön/SCHOEN/SCHON).

Schönwald/SCHOENWALD/SCHONWALD - jid. - Jidiški prezime nastalo od prezimena שען/šen/ (v. Schön/SCHOEN/SCHON), ali i od toponima.

Schreiber/SCHREIBER - jid. - Jidiški שרייבער 'pisar', prezime nastalo od zamjenskog imena za osobno ime משֶֶ, מmoš $e^{h} /$.

SCHREIBNER - jid. - Jidiški שרייבנער 'pisar', prezime nastalo kao inačica prezimena שרייבער /šreyber/ (v. Schreiber/SCHREIBER).

Schreiner/SCHREINER/ŠREINER - jid. - Jidiški שריינער 'stolar'.

Schrenger/Šrenger/SCHRENGAR/ŠRENGER - jid. - Jidiški שרענגע, prezime nastalo od prezimena שראֵֵק /šrank/ (× njem. Schrank 'kovčeg, škrinja').

Schrenzel/SCHRENZEL - jid. - Jidiški שרענצל (× 'mladić u odijelu'). Schrenzel je bio nadimak znamenitog talmudista iz Lemberga (danas Львів и Ukrajini) imenom Abraham Rapoport (1584. - 1651).

Schulhof/SCHULHOF - jid. - Jidiški שולהאָף (× njem. Schulhof 'školsko dvorište'), prezime nastalo od osobnog imena שול /šull, zamjenskog imena za osobno ime שָׁאוּל /šs̄üll.

Schuller - jid. - Jidiški שולער, prezime nastalo od osobnog imena שול /šul/, zamjenskog imena

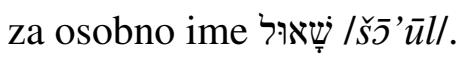

Schulmann/SCHULMANN - jid. - Jidiški שולמאַן, prezime nastalo konverzijom od patronima

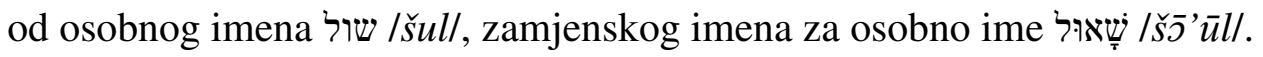

Schulz - jid. - Jidiški שולץ. U Saskoj je i Češkoj, u (srednjoeuropskom) Kanaanu, prezime nastalo od osobnog imena motiviranog imenicom 'sudac', a u drugim krajevima od imenice 'onaj koji nameće obaveze'.

Schuster/SCHUSTER - jid. - Jidiški שוסטער 'postolar', prezime nastalo od naziva zanimanja, a možda i prezime nastalo od osobnog imena שוס /šus/.

Schwabenitz / Schwabeniz / Shwabenitz / Švabenitz / Švabenic / SCHWABENITZ / /SCHVABENITZ//ŠVABINIC - jid. - Jidiški prezime nastalo od etnika שוואַבושוואַבע / ש̌xvab/švabel 'Švabo'.

Schwartz / Schwarz / Schwarc / Shwarz / Svarz / Šwarz / Švarc / SCHWARTZ / SCHVARTZ / /SCHWARZ/SCHVARZ/SCHWARZZ/SCHWATZ/ŠVARC - jid. - Jidiški שוואַרץ 'crn'.

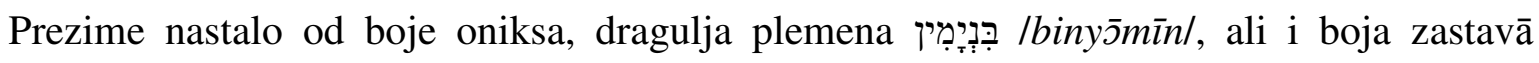
plemenā יוֹסֵף /yōsep/.

Schwarzenberg/Švarcenberg - jid. - Jidiški prezime nastalo konverzijom od patronima od prezimena שוואַרץ/šwarcl (v. Schwartz/Schwarz/Schwarc/Shwarz/Svarz/ 


\section{/ Šwarz / Švarc / SCHWARTZ / SCHVARTZ / SCHWARZ / SCHVARZ / SCHWARZZ /}

/SCHWATZ/ŠVARC), ali i od toponima u Saskoj i Mađarskoj (Feketehegy).

SCHWEINBURG - jid. - Jidiški שוויינבורג, prezime vjerojatno nastalo od toponima.

Schweitzer/Schweizer - jid. - Jidiški שווייצע 'Švicarac’. Prezime nastalo od etnika.

Segen/SEGEN - jid. - Jidiški זעגן 'blagoslov'.

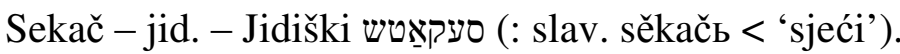

SEKAS - mađ. - Jidiški סעקאָ prezime vjerojatno nastalo od toponima Székás (danas Colibi u Rumunjskoj) ili od etnika od toponima Szék (danas Sic u Rumunjskoj). Szék 'stolac' je bio i naziv za administrativne teritorijalne jedinice kraljevine Mađarske.

Seligmann/SELIGMAN - jid. - Jidiški זעליגמאֵן, prezime nastalo konverzijom od patronima od osobnog imena זעליג /zelig/ 'sretan, blagoslovljen' (: njem. selig), zamjenskog imena za

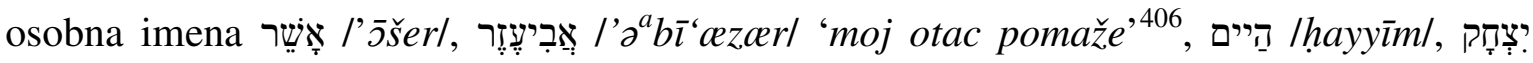

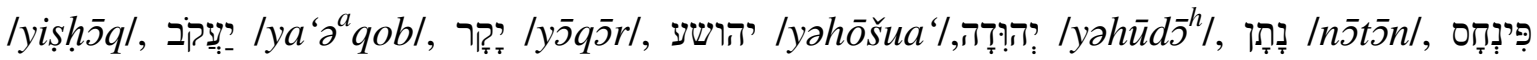

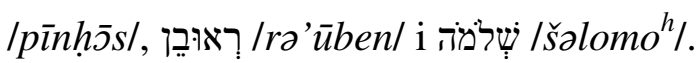

Selinger/SELINGER - jid. - Jidiški סעלינגער, prezime nastalo od osobnog imena ספרי /sali/,

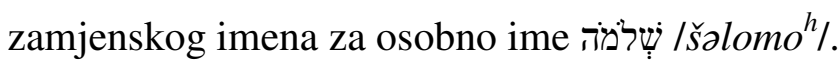

Senigaglia - tal. - Talijanska židovska porodica nesigurnog podrijetla čije se stablo može pratiti unatrag gotovo 800 godina, u doba između razvijenog srednjeg vijeka i renesanse. Prezime je vjerojatno nastalo od toponima Senigallia (starije: Sinigaglia), imena mjesta pored Ancone (hrvatski: Jakin) gdje su se bili naselili.

Sesvetska/Sesvetski - v. Alexander-Sesvetska/Alexander-Sesvetski/Aleksander »Sesvetski «.

Sever/SEVER - jid. - Jidiški סעבער. Prezime nastalo konverzijom od osobnog imena. Talmud spominje Severa, oca jednog od Rimskih careva, koji je konvertirao na zidovstvo. U Poljskoj zamjensko ime za osobno ime שִׁלִ 'sjever'.

Sidon/SIDON - sef. - Hibridno, tautološko, dvojezično osobno ime nastalo spajanjem

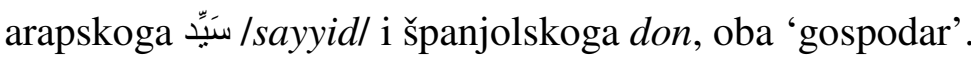

Siebenschein/SIEBENSCHEIN - jid. - Jidiški זיבנשיין, prezime nastalo od jidiškoga זיבנער (: njem Sieb 'sito').

Sief - jid. - Jidiški זיף. Aramejska riječ 'sjaj', no prezime je vjerojatnije nastalo od osobnog imena זער /zefl, pokraćenog lika osobnog imena יסָר /yōsep/.

\footnotetext{
${ }^{406}$ Jš 17,2. . U transkripciji Antuna Sovića: Abiezer.
} 
Silberberg - jid. - Jidiški ז ז njem. Silberberg 'rudnik srebra'), prezime nastalo konverzijom od patronima od osobnog imena זילבער /zilber/ 'srebro', atributa arhanđela osobnim imenom מִָָ̣ /mīks̄ell (Zohar II 67). S druge je strane Silberberg i toponim u Šleskoj, današnja Srebrna Góra u Poljskoj.

Silberstein - jid. - Jidiški זילבערשטיין (× njem. Silberstein 'srebrni uteg, srebrna caklina'), prezime nastalo konverzijom od patronima od osobnog imena זילבער /zilberl 'srebro', atributa arhanđela osobnim imenom מִיכָ /mịkj̄el/ (Zohar II 67).

Simmonsfeld/Simonsfeld/Simonfeld - jid. - Jidiški סימאָנ(ס)פעלד, prezime nastalo konverzijom od patronima od osobnog imena סימזָאו /simon/ (v. Simon).

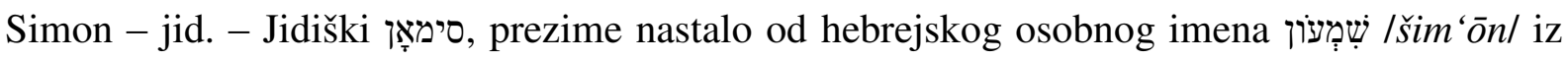
Tanaha.

Simonfai - mađ. - Jidiški prezime vjerojatno nastalo od etnika od toponima Simonfa u Mađarskoj.

Prezime je promijenjeno iz izvornoga שווארֵצנבערג /šwarcnberg/ (v. Schwarzenberg/ /Švarcenberg).

Singer/SINGER - jid. - Jidiški זינגער 'kantor, pjevač, pjesnik'.

Sitzer/SITZER - jid. - Jidiški זיצע. Heinrich W. i Eva H. Guggenheimer ga tumače kao nastalo od pokraćenog lika slavenskoga osobnog imena Sitslav < praslav. *sytb 'sit' + *slava (Guggenheimer H. W. i Guggenheimer E. H. 1992: 723). Vjerojatnije je ipak da je nastalo od njemačke imenice Sitz 'sjedalo'.

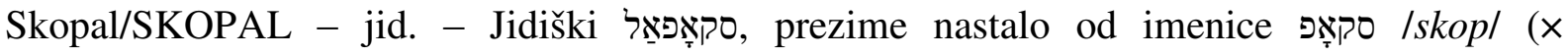
'uškopljeni ovan'). Možda nastalo i od toponima Skopje (Šimunović 2006: 130).

Prezime je promijenjeno iz već promijenjenog prezimena Slavoljub (v.).

SLAVIĆ - hrv. - Prezime nastalo konverzijom od patronima ili metronima od osobnih imena koja počinju morfemom slav- 'slava' ili prezime nastalo od imena ptice (slavuja) (Šimunović 2006: 17).

Prezime je promijenjeno iz izvornoga שוואַרץ /šwarcl (v. Schwartz/Schwarz/Schwarc/ / Shwarz / Svarz / Šwarz / Švarc / SCHWARTZ / SCHVARTZ / SCHWARZ / SCHVARZ / /SCHWARZZ/SCHWATZ/ŠVARC).

Slavoljub - hrv. - Prezime nastalo konverzijom od osobnog imena Slavoljub < slava + ljubiti (Čilaš Šimpraga, Ivšić Majić i Vidović 2018: 254).

Prezime je promijenjeno iz izvornoga זָאנענבערג /zonenberg/ (v. Sonnenberg). 
Slovak - jid. - Jidiški סלָָבָאָק 'Slovak', prezime najvjerojatnije nastalo od etnonima, a možda i nastalo od osobnog imena Slova, pokraćenog lika osobnog imena Tislova ili od slavenske imenice slovo 'riječ'.

Smeđić - hrv. - Prezime nastalo prijevodom izvornoga בראון /braun/ (v. Braun/BRAUN).

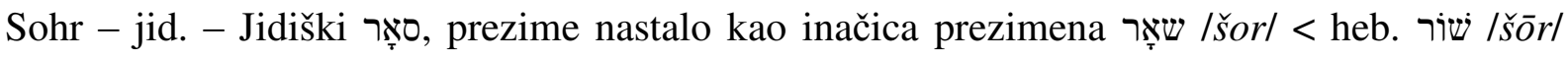

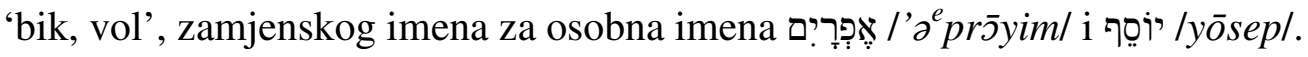

Sommer - jid. - Jidiški ז זמָער (× njem. Sommer 'ljeto'), prezime nastalo od osobnih imena Soma i Zoma.

Somogyi - jid. - Jidiški סאָמאָדזשי, prezime nastalo od etnika od toponima, imena Šomođske županije (mađ. Somogy vármegye, stariji hrvatski naziv: Šimeška županija) u Mađarskoj.

Sonenšajn/SONENSCHEIN - jid. - Jidiški זָאנענשיין (× njem. Sonnenschein 'sunčani sjaj'), prezime nastalo od imenice זָאנע/zonel ( $\times$ njem. Sonne 'Sunce').

Sonnenberg - jid. - Jidiški pris prezime nastalo konverzijom od patronima od imenice זאָזע /zone/ (× njem. Sonne 'Sunce'). moguće je i da je nastalo od toponima iz Tirinške.

Sonnenfeld - jid. - Jidiški pris prezime nastalo konverzijom od patronima od imenice זָזנ /zonel (× njem. Sonne 'Sunce').

Sonnenmark - jid. - Jidiški זָנענממארק, prezime nastalo od imenice / 'Sunce').

Sorger/SORGER - jid. - Jidiški זָָרגער (× srvnjem. 'čuvar, odvjetnik, jadnik, nesretnik').

Spiegel/Špigel/SPIEGEL/SPIEGL - jid. - Jidiški שפיגל (× njem. Spiegel 'ogledalo, naočale').

Spiegler/Spigler/SPIEGLER/ŠPIEGLER - jid. - Jidiški שפיגלער, prezime nastalo od prezimena שפיגל /špigl/ (v. Spiegel/Šspigel/SPIEGEL/SPIEGL).

Spieller/Spiller/SPILLER - jid. - Jidiški שפילער ( $\times$ njem. Spieler 'igrač, glumac' $\left.{ }^{407}\right)$, prezime nastalo od imenice שפיל (× njem. Spiel 'zabava').

Spielmann/Speilmann - jid. - Jidiški (× njem. 'glumac, putujući glazbenik, žongler'), prezime nastalo konverzijom od patronima od imenice שפיל (× njem. Spiel 'zabava').

Spierer/Spirer - jid. - Jidiški שפירער (× 'lastavica'), prezime nastalo od jidiške imenice שפיר /špir/ (× 'vršak vlati trave').

Spira - jid. - Jidiški שפירא, prezime nastalo od jidiške imenice שפיר /špir/ (× 'vršak vlati trave').

Spitz - jid. - Jidiški שפיץ (× njem. Spitze 'vrh').

\footnotetext{
${ }^{407}$ S obzirom na to da glumački poziv među Židovima nije bio cijenjen (Landmann 1987: 130), malo je vjerojatno da su ovo i iduće prezime izvedeni od naziva zanimanja.
} 
Spitzer/Spizer/Spitzeer/Spicer/Špicer/SPITZER - jid. - Jidiški שפיצער, prezime nastalo od prezimena שפיץ/špic/ (v. Spitz).

Spitzstein - jid. - Jidiški שפיצשטיין, prezime nastalo konverzijom od patronima od prezimena שפיץ/špic/ (v. Spitz).

Spreiregen/SPREIREGEN - jid. - Jidiški שפריירעגן, prezime nastalo spajanjem dvaju prezimena, שפריי/šprey/ (× 'pokrivač') i רעגן /regn/ (× njem. Regen 'kiša'), ali je moguće da je nastalo i od toponima, imena grada i rijeke u Gornjoj Falačkoj.

Städtler/STATLER - jid. - Jidiški שטעטלער/שטאַטלער (× 'vlasnik prenoćišta').

Stärk/Sterk/Steerk/Sterk/Šterk/STERK/ŠTERK - jid. - Jidiški שטאַרקטשטעק ( $\times$ njem. stark (jak').

Stedry/Stedri - jid. - Jטעדרי, Jidiški, prezime možda nastalo od toponima Štědrá u Češkoj (njem. Stiedra).

Stein/STEIN - jid. - Jidiški שטיין, prezime nastalo od zamjenskog imena za osobno ime /yiṣḩ̄q/ (možda povezano s izrazom steinalt 'vrlo star'). Osim je toga moguće i da je nastalo od toponima u Šleskoj, Limburgu, Franačkoj i Badenu. Švapska je plemićka porodica von Stein bila poznata po zaštiti Židovā.

Steindler - jid. - Jidiški שטיינדלער, prezime nastalo od imenice שטיינדל /šteyndl/, umanjenice osobnog imena שטיינהאַרד/שטיינהאַרט /šteynhard/šteynhart/ (v. Steinhardt/Steinhart/ /STEINHARDT/STEINHART).

Steiner/STEINER/STENINER/ŠTEINER - jid. - Jidiški שטיינע, prezime nastalo od prezimena שטיין/Šteyn/ (v. Stein/STEIN).

Steinhardt/Steinhart/STEINHARDT/STEINHART - jid. - Jidiški שטיינהאַרד/שטיינהאַרט /šteynhard/šteynhart/ (× njem. steinhart 'čvrst kao stijena'), prezime nastalo od prezimena שטיין /šteyn/ (v. Stein/STEIN). S druge je strane Steinhard i njemačko osobno ime < *staina- 'kamen' + *hardu- 'čvrst, žestok'.

Stella - ? - Prezime nastalo od latinskoga i talijanskoga 'zvijezda'.

Prezime se pojavljuje isključivo u dvoprezimenskoj kombinaciji Frank Stella.

U korpusu ništa ne upućuje na mogućnost da je riječ o prijevodu prezimena שטערן/štern/ (v. Stern/Štern/STERN/ŠTERN).

Stern/Štern/STERN/ŠTERN - jid. - Jidiški שטערן (× njem. Stern 'zvijezda').

Sternberg/ŠTERNBERG - jid. - Jidiški שטרנבערג, prezime nastalo od patronima od prezimena שטערן/Štern/ (v. Stern/Štern/STERN/ŠTERN), ali i od toponima u Češkoj i Moravskoj (Šternberk) i u istočnom Brandenburgu (danas dijelu Poljske). 
Stiegler/STIEGLER - jid. - Jidiški שטיגלער, prezime vjerojatno nastalo od toponima Stiegel ili Stiegl.

Stockhammer - שטאָקהאממער (× jid. - Jidiški Stockhammer 'vrsta čekića'), prezime nastalo od prezimena שטָז /štok/ (× njem. Stock 'štap, kolac, motka'), koje može, a i ne mora biti pokraćeni lik nekog prezimena koje ima taj dočetak.

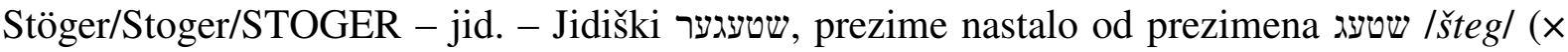
njem. Steig 'strm put').

Stojić - hrv. - Prezime nastalo konverzijom od patronima od osobnog imena Stojo < Stojislav (Skok 1974: III 324-325).

Stranić - hrv. - Prezime je promijenjeno iz izvornoga שטיינהאַרד|שטיינהאַרט /šteynhard/ /šteynhart/ (v. Steinhardt/Steinhart/STEINHARDT/STEINHART).

Straßberger/Strassberger/STRASSBERGER - jid. - Jidiški שטראַבערגע, prezime nastalo od patronima od prezimena שטראַ /stras/ (× njem. Straße 'ulica').

Strasser - jid. - Jidiški שטראַסער, prezime nastalo od prezimena שטראַס /štras/ (× njem. Straße 'ulica').

Strauss/Strausz/Straus/STRAUSS - jid. - Jidiški שטראוס (× njem. Strauß 'svežanj, kitica (cvijeća)'), prezime nastalo prijevodom osobnog imena צ̦ /ṣวrōor/ iz Tanaha.

Strümpfter - jid. - Jidiški שטרימפער, prezime možda nastalo od njemačkoga Strumpf ‘čarapa'.

Sulcbach - jid. - Jidiški prezime nastalo od toponima sela pokraj Frankfurta na Majni te selā u Gornjoj Falačkoj i Saaru.

Süssmann/Süßmann/Süsmann/Süssman/Sißmann/Sussmann/Sismann/SUESMAN - jid. Jidiški זיסמאָן prezime nastalo od patronima odnosno metronima izvedenih iz osobnog

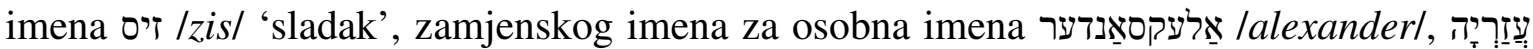

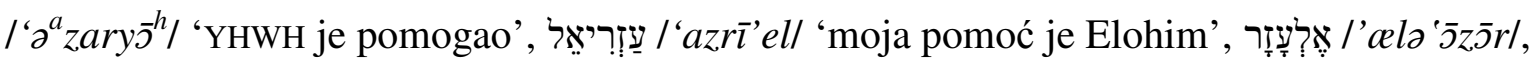

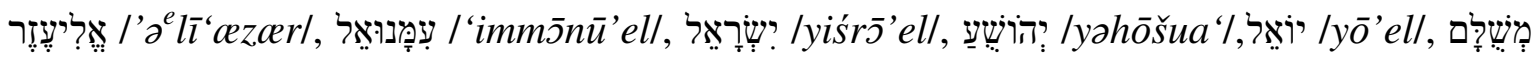

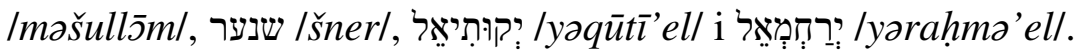

SZABADI - mađ. - Jidiški סאֵַַָד, prezime nastalo od toponima u Mađarskoj.

SZANER - mađ. - Jidiški סאֵנער, mađarsko prezime, vjerojatno nastalo od szán 'posvetiti se, zavjetovati se'.

Szarvas - jid. - Jidiški סארבַַאש, prezime nastalo od mađarskoga szarvas 'jelen', prijevoda

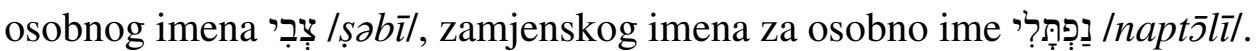

Szarvasy/SZARVASY - jid. - Jidiški סאַרבֵַַאַש /sarvašl (v. Szarvas). 
Szegő - mađ. - Jidiški mađarsko prezime. Možda je riječ o prezimenu nastalom od kakve odmilice za etnik Szegedy, prema imenu grada Szegeda u Mađarskoj.

Prezime je promijenjeno iz izvornoga שפיץ/špic/ (v. Spitz).

Szeidl - jid. - Jidiški סיידל, prezime nastalo od umanjenice od osobnog imena סיידע /seydel 'djed'. Osobno se ime djetetu nadijevalo sa željom za dug život.

Szekely - mađ. - Prezime nastalo od imena etničke skupine, koja se smatra različitom od Mađarā (iako govore mađarski), a koja živi u Székelyföldu, današnjem Ținutul Secuiesc ili Secuimea u Rumunjskoj.

Prezime je promijenjeno iz izvornih שלָאם /šlom/ (v. Schlomm) i שווארץ /šwarc/ (v. Schwartz / Schwarz / Schwarc / Shwarz / Svarz / Šwarz / Švarc / SCHWARTZ / /SCHVARTZ/SCHWARZ/SCHVARZ/SCHWARZZ/SCHWATZ/ŠVARC).

Szekler/SZEKLER - jid. - Jidiški סעקלער, prezime nastalo od osobnog imena סעקל /sekl/,

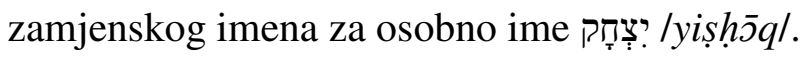

Szekulesz - jid. - Jidiški סעקולעם, prezime nastalo od osobnog imena סעקל /sekl/, zamjenskog imena za osobno ime

Szende - mađ. - Prezime je promijenjeno iz izvornoga סענדער/sender/ (v. Szender) odbacivanjem dočetnog suglasa.

Szender - jid. - Jidiški סענדער, prezime nastalo od zamjenskog imena za osobna imena

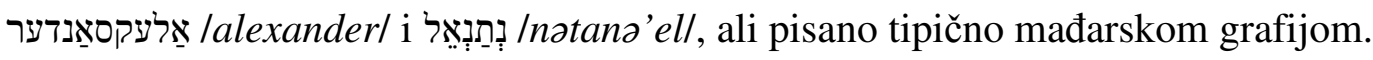

Szeniczei - mađ. - Prezime nastalo od etnika od toponima, imena pokrajine Szenicei járás, danas Okres Senica u Slovačkoj.

Szőke/SZOHE - jid. - jidiški סעקע, prezime nastalo od mađarskoga szőke 'plavokos'.

Szomjas/SZOMJAS - mađ. - Jidiški סאָמיאָש, prezime nastalo od mađarskoga 'žedan'.

Šandor - jid. - Jidiški שֵאנדָר, prezime nastalo od mađarskog osobnog imena Sándor < grč.

A $\lambda \hat{\varepsilon} \xi \alpha v \delta \rho \circ$ /aléxandros/ (v. Alexander/Aleksander/ALEXANDER/ALEKSANDER/ /ALEKSANDAR).

Ščrbašić - hrv. - Prezime vjerojatno nastalo od nadimka nastalog od osobine rodonačelnika (škrbav, krezub).

Šik/SCHICK - jid. - Jidiški שיק, prezime nastalo od zamjenskog imena za osobno ime lyəhōšua \%

Šilović - hrv. - Prezime nastalo prijevodom izvornoga שפיצער/špicer/ (v. Spitzer/Spizer/ /Spitzeer/Spicer/Špicer/SPITZER).

Šorš/ŠOR ̌̌ - mađ. - Prezime možda nastalo od mađarskog izgovora latinske imenice sors 'sudbina'. 
Šoten - jid. - Jidiški שאָטען, prezime nastalo od osobnog imena שָאט /šot/ (× 'torbar, pokućarac' $)^{408}$. U slučaju $\times$ njem. Schotte 'Škot' moguće je osobno ime povezati $\mathrm{s}$ Schottlandom, predgrađem Gdanjska, gdje je krajem XVII. st. obitavala zajednica Židova. Schotten je i grad u Nassauu.

Špančić/ŠPANČIĆ - hrv. - Prezime nastalo od zanimanja ̌̌pân 'upravitelj, nadglednik vlastelinstva'.

Španić - hrv. - Prezime nastalo od zanimanja špân 'upravitelj, nadglednik vlastelinstva'.

Prezime je promijenjeno iz izvornoga שפיצער /špicer/ (v. Spitzer/Spizer/Spitzeer/Spicer/ /Špicer/SPITZER).

Štajminger - jid. - Jidiški שטיימינגער. Moguće je da je riječ o omašci, te da bi prezime trebalo biti zapisano kao שטיינינגער /šteyninger/. U tom slučaju je riječ o prezimenu nastalom od prezimena שטיין/Šteyn/ (v. Stein/STEIN).

Šumanović - hrv. - Moguće da je riječ o prezimenu nastalom od prezimena Šuman < njem. Schuhmann (Schuhhandler) 'trgovac obućom' (Šimunović 2006: 314).

Prezime je promijenjeno iz izvornoga שווארֵ /šwarc/ (v. Schwartz/Schwarz/Schwarc/ / Shwarz / Svarz / Šwarz / Švarc / SCHWARTZ / SCHVARTZ / SCHWARZ / SCHVARZ / /SCHWARZZ/SCHWATZ/ŠVARC).

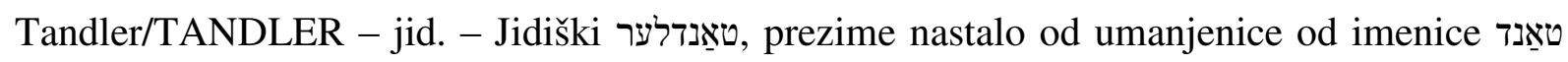
Itand/ ( $\times$ njem. Tand 'rabljene stvari').

Tänzer/Tenzer/Tencer/TAENZER - jid. - Jidiški טענצער (× njem. Tänzer 'plesač'), prezime nastalo od osobnog imena טאָנ (× njem. Tanz 'ples'), koje može biti i patronim od osobnog imena טאֵַ /tan/, pokraćenog lika osobnog imena /tamjenskog imena za

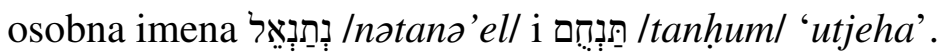

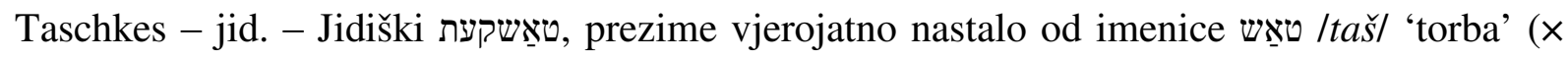
njem. Tasche 'torba').

Tauber - jid. - Jidiški טאובובער 'mužjak goluba/grlice', prezime nastalo od muškog ili ženskog osobnog imena טאוב /taub/ 'golub/grlica', koje kao muško osobno ime predstavlja prijevod hebrejskog osobnog imena יוֹנָּ / $/ y \bar{o} n \bar{\nu}^{h} /$ iz Tanaha.

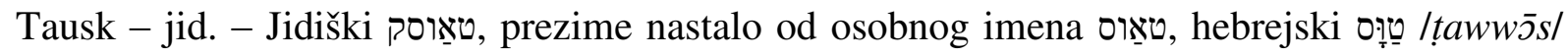

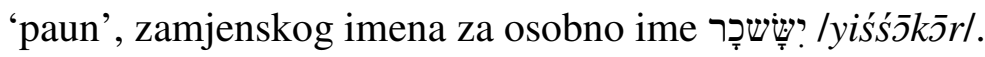

Taußig/Taussig/TAUSIG/TANSIG - jid. - Jidiški prezime nastalo od osobnog imena

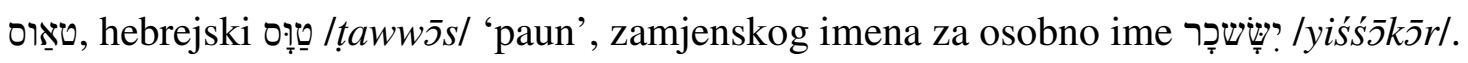

\footnotetext{
${ }^{408}$ Prvi Židovi koji su se naselili u Zagrebu uglavnom su se bavili pokućarenjem i sitnom trgovinom.
} 
TEICH/TELCH - jid. - Jidiški טייך (× njem. Teich 'jezerce, ribnjak'), prezime nastalo od

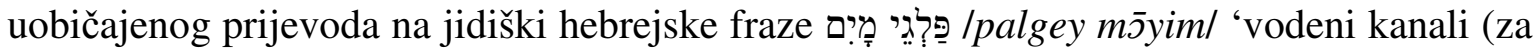
navodnjavanje) ${ }^{409}$.

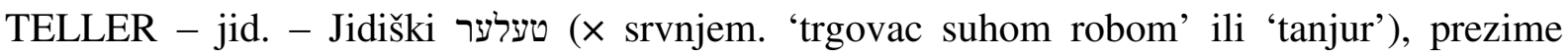
nastalo od osobnog imena טעל /tell, u suvremenom hebrejskom טַל /țal/ 'rosa', a u Aškenaza

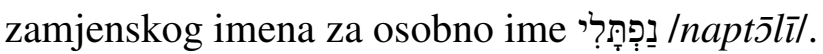

Temar - Prezime je promijenjeno iz izvornoga לוסטיג /lustig/ (v. Lustig/LUSTIG).

Teveles - jid. - Jidiški טעבעלעס, prezime nastalo od hebrejske imenice תֵברל /tebel/ 'svemir, univerzum', ali i od osobnog imena טעבעלע /tevelel (v.), koje se pak može izvesti iz dva

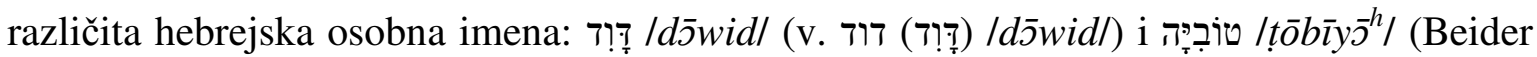
2001: 296-298, 434-434).

Thune/THUNE - jid. - Jidiški טונע, prezime nastalo konverzijom od ženskog i muškog

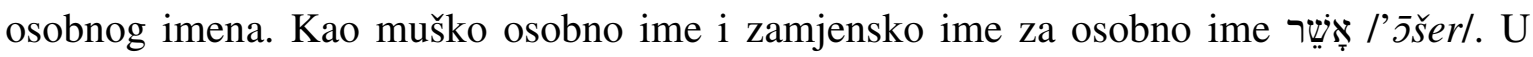
hebrejskom je zemljopisu טונַ /tuna/, inačica ovog osobnog imena, hidronim rijeke Dunav.

Tkalčić - hrv. - Prezime nastalo konverzijom od patronima od zanimanja tkalac (Skok 1974: III 477). Moguće je da je riječ o prijevodu prezimena וועבער /weber/ (v. Weber/ (WEBER $)^{410}$.

Tolentino/TOBENTINO - tal. - Prezime nastalo od toponima u talijanskoj pokrajini Marche.

Tolnai - mađ. - Prezime nastalo od etnika od toponima Tolna, imena županije u Mađarskoj. Prezime je promijenjeno iz izvornoga ווערטהיימער /wertheymerl (v. Wertheimer/ /WERTHEINER).

Tolnauer/TOLNAUER - jid. - Jidiški prezime nastalo od toponima Tolna, imena županije u Mađarskoj.

Tomi.

TOMOGRAD/TARMOGRAD.

Trautmann/Trautman/TRAUTMANN - jid. - Jidiški טראַוטמאָן, prezime nastalo preoblikom patronima od osobnog imena טראוט /traut/ ( $\times$ njem. traut 'ugodan, poznat, blizak'), odnosno metronima od טראֵוטא /trauta/ (× njem. traute 'ugodna, poznata, bliska').

Trinki.

Tritsch - jid. - Jidiški טריטש, austrijsko prezime.

\footnotetext{
${ }^{409}$ Ps 1,3. U prijevodu Filiberta Gassa: (pokraj) vódâ tekućica.

${ }^{410}$ Npr. filolog i književnik Adolfo Veber Tkalčević (1825. - 1889.).
} 
Turnauer - jid. - Jidiški prezime nastalo od etnika od toponimā Turna (danas Turňa nad Bodvou u Slovačkoj) ili Tyrnau (danas Trnava u Slovačkoj).

Ullmann/Ullman/ULLMAN - אולמאָן - jid. - Jidiškime nastalo od pokraćenog lika osobnog imena Ulrich < pragerm. *auda- 'bogatstvo' + *rīk- 'vladar, kralj', ali i konverzijom od patronima od osobnog imena אולע lulel (× srvnjem. ûle 'sova'), zamjenskog imena za osobno ime יוֹאيל /yō'ell.

Ungar/UNGAR - jid. - Jidiški אונגאֵר 'Mađar'. Prezime nastalo od etnika.

Unghvár/Unghvari - mađ. - Jidiški אונגבֵַר, prezime nastalo od mađarskog toponima Ungvár (danas Ужгород u zapadnoj Ukrajini).

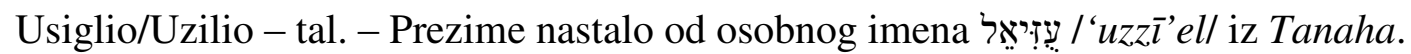

Vajda/VAJDA - jid. - Jidiški ווידָאו, prezime nastalo konverzijom od osobnog imena (× srvnjem. wîde 'vrba').

Vanić - Prezime je promijenjeno iz izvornoga ווייס/weys/ (v. Weiß/Weiss/Weisz/Weis/Weihs/ /WEISS/WEIS).

Veith - jid. - Jidiški פיית, prezime nastalo od njemačkog osobnog imena Veit < pragerm. *walpu- 'šuma' ili *wīda- 'širok, dalek', što je pak zamjensko ime za osobna imena אֶפְרָיִם

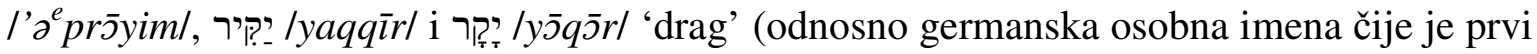
dio < pragerm. *walpu- 'šuma' ili *wīda- 'širok, dalek'), × latinsko osobno ime Vitus < vita 'život'.

Venezian - tal. - Prezime nastalo od etnika od toponima Venezia.

VERBOY - ? - Prezime koje se nalazi samo u bazi podataka Gradskih grobalja. Vjerojatno je u pitanju mađarsko prezime Verbőczy.

Vinski - hrv. - Prezime nastalo prijevodom aškenaskih prezimena čiji je prvi dio וויין /weyn/ 'vino'.

Vojković/VOJKOVIĆ - hrv. - Prezime nastalo konverzijom od patronima od osobnog imena Vojko < Vojo < Voj(i)mir/Vojislav + -ko (Čilaš Šimpraga, Ivšić Majić i Vidović 2018: 281). Vojtitz/Wotik - ? - Ako je riječ o prezimenu ווויטיץ/wojtic/, ono je nastalo od umanjenice od slavenskih osobnih imena Vojtek i Vitoslav.

Volner - jid. - Jidiški וואָלמער, prezime nastalo od osobnog imena וואָל /voll, uglavnom pokraćenog lika njemačkog osobnog imena Walter < pragerm. *waldan- 'vladati' + *harja- 'vojska', ali i srvnjem. wôl/wûl/wuol 'prijestolje, zapovjedništvo'.

Vranić/VRANIĆ - hrv. - Prezime nastalo prijevodom izvornoga שווארץ /šwarc/ (v. Schwartz/ /Schwarz / Schwarc / Shwarz / Svarz / Šwarz / Švarc / SCHWARTZ / SCHVARTZ / SCHWARZ/SCHVARZ/SCHWARZZ/SCHWATZ/ŠVARC) (Skok 1974: III 617-618). 
Vujić - hrv. - Prezime nastalo konverzijom od patronima od osobnog imena Vujo < Vuk (Skok 1974: 635-636; Šimunović 2006: 212).

Prezime je promijenjeno iz izvornoga וויים /weys/ (v. Weiß/Weiss/Weisz/Weis/Weihs/ /WEISS/WEIS).

Wachsmann - jid. - Jidiški וואַכסמאָא וואַכס /vaxs/ (× njem. Wachs 'vosak', srvnjem. 'vosak, porast'). Moguće je da je riječ i o prezimenu nastalom od naziva zanimanja. S druge je strane moguće i da je židovska obitelj preuzela prezime od neke njemačke obitelji, a da sama nije morala imati nikakve veze $s$ navedenom profesijom.

Wachtel/WACHTEL - jid. - Jidiški וואַכטל (× njem. Wachtel 'prepelica'), moguće da je riječ o prezimenu nastalom od umanjenice od prezimena וואַכט /vaxt/ (: njem. Wache 'straža'), patronimu od osobnog imena וואַך/wax/, pokraćenom liku slavenskog osobnog imena *Věnceslav.

Walder/WALDER - jid. - Jidiški וואַלדערז /wald/, prezime nastalo od prezimena njem. Wald 'šuma').

Waldhauser - jid. - Jidiški וואַלדהאַוזער /wald/ prezime nastalo od prezimena Wald 'šuma').

Waltersdorfer/WALTERSDORFER - jid. - Jidiški וואַלטערסדאָרפער, prezime nastalo od etnika.

Wamoser - jid. - Jidiški prezime vjerojatno nastalo od mađarskoga vám 'carina'.

Wasserlauf/WASSERHAUF - jid. - Jidiški וואַסערלאַוף njem. Waßerlauf 'tok vode, odvod'), prezime nastalo od prezimena וואַסער /waser/ (× njem. Waßer 'voda'), koje katkad može biti pokraćeni lik od וואַסערמאֵַ /waserman/ (× njem. Waßermann 'vodenjak, vodar').

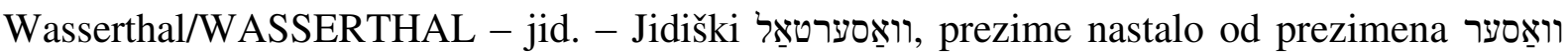
Iwaserl (× njem. Waßer 'voda'), koje katkad može biti pokraćeni lik od /waserman/ 'vodenjak, vodar' ( $\times$ njem. Waßermann 'vodenjak, vodar').

Weber/WEBER - jid. - Jidiški tkalac', prezime nastalo od zanimanja ili od

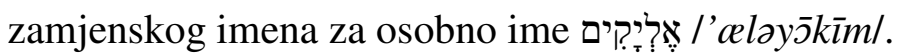

Wehli - jid. - Jidiški וועלי /well, prezime nastalo od prezimena וועל / וועל / imena וועדל /wedll.

Wehlin - jid. - Jidiški וועלין ועל /well, prezime nastalo od prezimenacenog lika osobnog imena וועדל /wedll.

Weiller/Weiler/WEILER - jid. - Jidiški וויילער, prezime nastalo od osobnog imena ווייל /veyl/, inačice osobnog imena וואָלף /wolfl 'vuk', prijevoda hebrejskog osobnog imena זָָאב /zכ'eb/, 


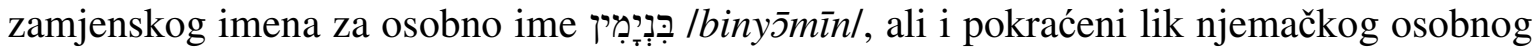
imena Weigand < pragerm. * wĭhan- 'rat'.

Weinberg - jid. - Jidiški וויינבערג (× njem. Weinberg 'vinograd'), prezime nastalo konverzijom od patronima od osobnog imena וויין /weyn/ (× njem. Wein 'vino'),

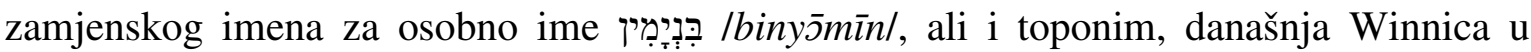
Poljskoj.

Weinberger/WEINBERGER - jid. - Jidiški וויינבערגער, prezime nastalo konverzijom od patronima od osobnog imena וויין /weyn/ (× njem. Wein 'vino'), zamjenskog imena za osobno ime

Weiner/Veiner - jid. - Jidiški וויינע, prezime nastalo od osobnog imena (× njem. Wein 'vino'), zamjenskog imena za osobno ime

Weintraub - jid. - Jidiški וויינטראַוב (× njem. Weintraube 'grozd'), prezime nastalo od osobnog imena וויין Iweyn/ ( |binȳ̄mīn/.

Weiser/Veiszer/WEISSER/WEISER - jid. - Jidiški ווייסער (× njem. weiser 'mudar'), prezime nastalo od prezimena ווייס/weys/ (v. Weiß/Weiss/Weisz/Weis/Weihs/WEISS/WEIS).

Weiß/Weiss/Weisz/Weis/Weihs/Vajs/WEISS/WEIS - jid. - Jidiški ווייס 'bijel', prezime na זִבְלוּן Izabulūn/. Ostale imenice koje su mogle poslužiti kao motivacija prezimena: njemački weise 'mudar', a i srednjovisokonjemačko wise 'tratina'.

Weiss »de Polna«/Weiss Polnaiski/WEISS-POLNA - pl. - Zagrebački veletrgovac Jakob Weiss odnosno Jehuda b. Šelomo Weiss (u. 1866.) bio je prvi Židov u Hrvatskoj koji je 19. siječnja 1874. g. (ili 1872. g.) dobio plemićku titulu od cara Franje Josipa I. (1830. 1916.), s pridjevkom »de Polna«.

Weisshaus/Weishaus - jid. - Jidiški ווייסהאַוס, prezime nastalo od prezimena וויים /weys/ (v. Weiß/Weiss/Weisz/Weis/Weihs/WEISS/WEIS).

Weissmann/WEISSMAN - jid. - Jidiški ווייסמאָן prezime nastalo konverzijom od patronima od prezimena וויים/weys/ (v. Weiß/Weiss/Weisz/Weis/Weihs/WEISS/WEIS).

Weiszmayer/Wiesmeyer/WEISMAYER/WEIZMAYER - jid. - Jidiški ווייסמייער, prezime nastalo spajanjem prezimenā ווייס/weys/ (v. Weiß/Weiss/Weisz/Weis/Weihs/WEISS/ /WEIS) i מייער /meyer/ (v. Meyer/Mayer/Maier/Majer/MAYER/MAJER).

Weitzner/WEITZNER - jid. - Jidiški ווייצנער, prezime nastalo od prezimena (x njem. Weizen 'pšenica'). 
Welemin - jid. - Jidiški וועלעמין, prezime nastalo od toponima Wołomin pokraj Varšave u Poljskoj.

Welleminsky - jid. - Jidiški prezime nastalo od toponima Wołomin pokraj Varšave u Poljskoj.

Wellisch - jid. - Jidiški וועליש, prezime nastalo od jidiškoga 'govornik romanskog jezika'.

Weltner - jid. - Jidiški וועלטנער, prezime nastalo od osobnog imena וועלט /welt/ $\times$ njem. Welt 'svijet'), pokraćeni lik njemačkog osobnog imena Walter < pragerm. *waldan- 'vladati' + *harja- 'vojska', ali i prijevod hebrejske imenice תֵֵֵ) /tebell 'svemir, univerzum', koja se

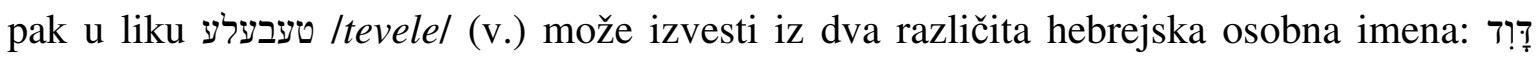

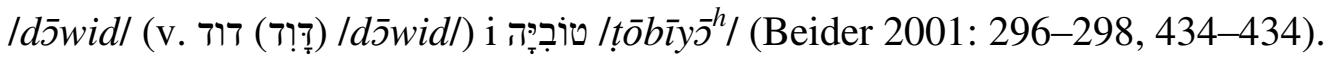

Werfel - jid. - Jidiški ווערפל (× srvnjem. wërvel, umanjenica od wërve 'riječna ustava'), prezime nastalo od zamjenskog imena (: njemački Damm) od osobnog imena אָדָ /'万̄ 'čovjek' ${ }^{411}$. Na njemačkome pak prezime može biti motivirano i imenicom značenja 'vir'.

${ }^{411}$ Post 4,25. U transkripciji Silvija Grubišića: Adam.

Odgovarajuće arapsko osobno ime: أَدَّ /'adam/ 'zemlja, zemni prag' (Agić 1996: 16).

Robert Graves i Raphael Patai o značenju ovog osobnog imena pišu (Graves i Patai 1969: 62):

»Nije sigurno da su riječ muškog roda adam (»čovjek«) i riječ ženskog roda adama (»zemlja«) etimološki srodne. Ta se srodnost međutim podrazumijeva u Postanku, gl. 2, a prihvaćaju je komentatori midraša i Talmuda. Sigurnija veza, na što prvi ukazuje Kvintilijan, postoji između latinskih riječi homo (»čovjek «) i humиs (»zemlja«): suvremeni lingvisti izvode podrijetlo obje riječi iz drevnog indoevropskog korijena koji je u grčkom dao hthon [sic] (»zemlja«), hamai (»na zemlji«) i epihthonios (»ljudski«).« Isaac Asimov u svojem vodiču kroz Bibliju kaže (Asimov 1969: 21-22):

"The word "man" [in Genesis 2:7] is a translation of the Hebrew word adam, which is a general expression rather akin to what we mean when we say "mankind." (The Hebrew word for an individual man is ish.) The word adam, used in reference to this first created man, came to be a proper name, Adam. The King James version slips into this usage later in the chapter:

Genesis 2:19.... the Lord God formed every beast... and every fowl ... and brought them unto Adam ... Actually, the Hebrew does not seem to make use of Adam as a proper name until the beginning of the fifth chapter:

Genesis 5:1. This is the book of the generations of Adam ... and the Jerusalem Bible, for instance, is careful to translate adam as "man" up to that very point." [Riječ je »čovjek« (u Knjizi postanka 2,7) prijevod hebrejske riječi adam, što je općenit izraz prilično nalik onome što mislimo kad kažemo »čovječanstvo« (hebrejska riječ za čovjeka pojedinca je iš.) Riječ je adam, korištena kao referenca na tog prvog stvorenog čovjeka, postala pravim imenom, Adam. Prijevod se Biblije kralja Jamesa uklapa u takvu uporabu kasnije u poglavlju:

Postanak 2,19. ... Tada Jahve, Bog, načini od zemlje sve životinje ... i sve ptice ... i predvede ih Adaти ... Ustvari, čini se da hebrejski ne koristi Adam kao pravo ime sve do početka petog poglavlja: 
Werner - jid. - Jidiški ווערנער, prezime nastalo konverzijom od njemačkog osobnog imena < pragerm. *wara- 'svjestan' + *harja- 'vojska', no može biti i prezime nastalo od prezimena ווערנע /werne/ < rus. верный 'vjeran'.

ווערט ווערטהיימער אertheimer/WERTHEINER - jid. - Jidiški /wert/ ( $\times$ njem. Wert 'vrijednost'), ali i od etnika od toponima Wertheim u zapadnoj Pruskoj, današnje Dobrzewino u Poljskoj.

Wessél - jid. - Jidiški prezime nastalo od toponima Wesel u Porajnju, Wessel u Zapadnoj Falačkoj, ali i od pokraćenog lika prezimena ווערנער /werner/ (v. Werner).

Wiener - jid. - Jidiški ווינער 'Bečanin', prezime nastalo od etnika. Na srednjovisokonjemačkome wînern 'berba grožđa'.

Wilczek/WILCZEK - jid. - Jidiški ווילטשעק, prezime nastalo od poljskoga 'vučić'. S tom je

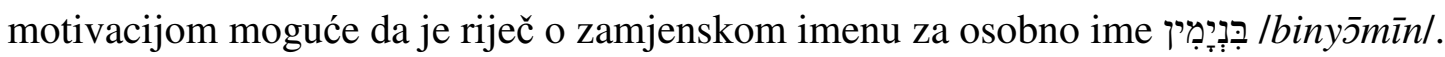

Willner - jid. - ווילנער ווילנע /widiške/, jidiškog imena grada Vilniusa u Litvi, ali je moguće i da je nastalo od osobnog imena ווילע /wilel.

Winter/WINTER - jid. - Jidiški ווינטער (× njem. Winter 'zima', srvnjem. winter 'vino').

Wirnik/WIRNIK.

Wirt/Wirth - jid. - Jidiški ווירט 'gostioničar', prezime nastalo od zanimanja, ali je moguće i da je riječ o inačici prezimena ווערט /wertl (× njem. Wert 'vrijednost'). Na srednjovisokonjemačkome 'riječni otok'.

Witte - jid. - Jidiški וויטע, prezime nastalo od osobnog imena Vital < lat. vitalis 'koji se odnosi na život, životan' (u liku יטֵ! /wittal/ postalo i hebrejskim osobnim imenom) $\times$ njemačko osobno ime Veit < pragerm. *walpu- 'šuma' ili *widda- 'širok, dalek', što je pak

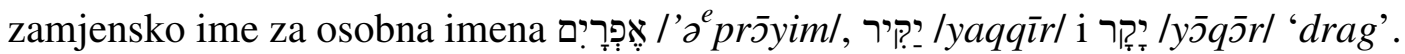

Wittler - jid. - Jidiški prezime nastalo od osobnog imena Vital < lat. vitalis 'koji se odnosi na život, životan' (u liku יטֵ! /wittal/ postalo i hebrejskim osobnim imenom) $\times$ njemačko osobno ime Veit < pragerm. *walpu- 'šuma' ili *wīda- 'širok, dalek', što je pak

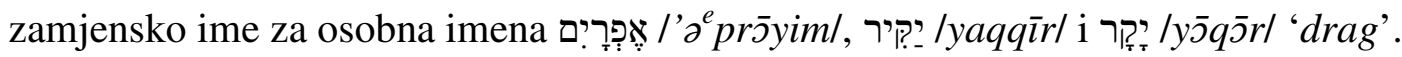

Wohlmuth/WOHLMUTH - jid. - Jidiški וואזָאל /woll, uglavnom pokraćenog lika njemačkog osobnog imena Walter < pragerm. *waldan'vladati' + *harja- 'vojska', ali na srednjovisokonjemačkome wôl/wûl/wuol 'prijestolje,

Postanak 5,1. Ovo je povijest Adamova roda ...

i Jeruzalemska Biblija, na primjer, pomno prevodi adam kao »čovjek« sve do tog poglavlja.] 
'zapovjednički stav', a na slavenskim jezicima 'vol', zamjensko ime za osobno ime /yōsep/.

Wojtitz - ašk- Jidiški וואָיטיץ, prezime vjerojatno nastalo od toponima Woititz/Wojtitz.

Wolf/WOLF - jid. - Jidiški וואזלף 'vuk', prezime nastalo od prijevoda hebrejskoga osobnog

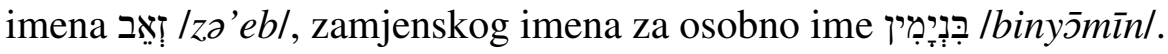

Woliko.

Wolkenfeld/WOLKENFELD - jid. - Jidiški וואָלקנפَעלד (× njem. Wolkenfeld 'oblačni pokrov'), prezime nastalo konverzijom od patronima od osobnog imena וואָלק/wolk/ (× njem. Wolke 'oblak'), ali na ruskome волк 'vuk', prijevod hebrejskoga osobnog imena

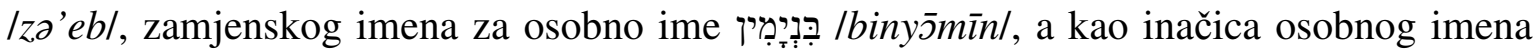

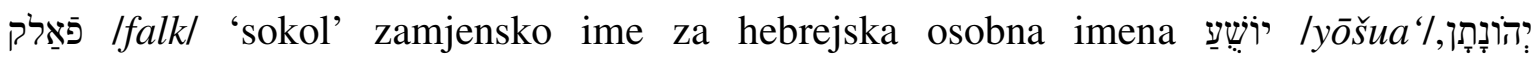

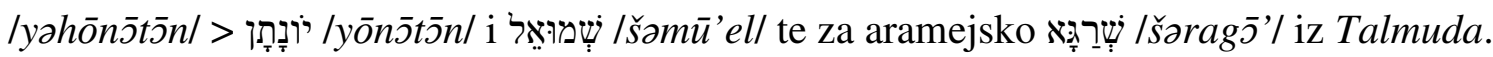

Wollak - jid. - Jidiški וואָלאֵ moguće da je riječ o prezimenu nastalom od akronima od

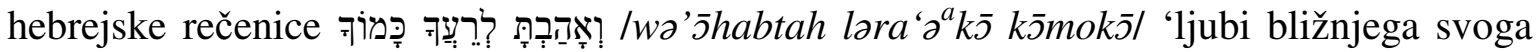
kao samoga sebe ${ }^{412}$.

Wortmann - jid. - Jidiški ווארטמאָן, prezime nastalo konverzijom od patronima od osobnog imena ווערץ /wercl, pokraćenog lika njemačkog osobnog imena ווערנ /v. Werner).

WRENFREUND - Prezime se nalazi samo u bazi podataka Gradskih grobalja, moguće da je riječ o omašci. Vjerojatno je riječ o prezimenu Ehrenfreund (v. Ehrenfreund/ /ERENFREUND)

Würzburger - jid. - Jidiški ווירצבורגער, prezime nastalo od etnika od toponima Würzburg, prijestolnice Donje Franačke, s drevnom židovskom zajednicom, ali može biti i prezime nastalo od imenice ווורץ /wurcl 'korijen'.

Zafuta/ZAFUTA - Možda prezime izvedeno iz regionalnoga cafuta 'kao vlačuga, u pogrdnom značenju: bludnica' (Krleža 1936: 145).

Zaghaft - jid. - Jidiški (× njem. Zaghaft 'plah').

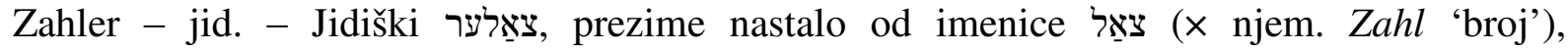

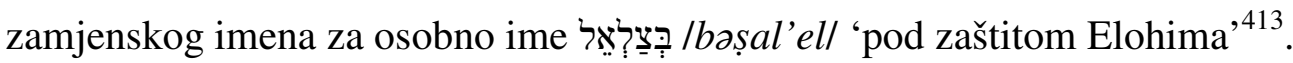

Zala - mađ. - Prezime nastalo od toponima u Mađarskoj, imena sela i županije (Zala megye, hrv. Zalska ili Zaladska županija).

\footnotetext{
${ }^{412}$ Lev 19,18. Prijevod Silvija Grubišića.

${ }^{413}$ Izl 31,2. U transkripciji Silvija Grubišića: Besalel.
} 
Prezime je promijenjeno iz izvornoga גאָלדמאַן /goldman/ (v. Goldmann/Goldman/ /GOLDMANN//GOLDMAN).

Zaloscer - jid. - Jidiški vאלאָסצער, vjerojatno prezime nastalo od etnik od toponima Założce, danas Залізці (do 1993. g. Заложці) u zapadnoj Ukrajini.

Zappit.

Zeisler - jid. - Jidiški צייזלער, prezime nastalo od imenice צייזל /ceyzl/ (: njem. Zeisig 'čižak, češljugar', srvnjem. zeisel 'čičak').

Zeriali.

Zichermann - jid. - Jidiški זיכערמאָ, prezime nastalo konverzijom od patronima od osobnog

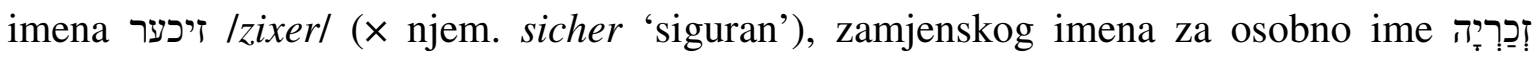
Izakary $\bar{\rho}^{h} \%$.

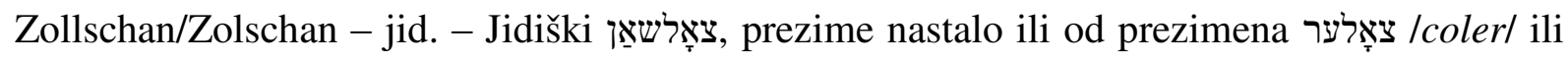
od osobnog imena צאדלע /cole/ (× srvnjem. 'lutka').

Zuckermann/ZUCKERMAN - jid. - Jidiški prezime nastalo konverzijom od patronima od osobnog imena צוקער/cuker/ (× njem. Zucker 'slador'), zamjenskog imena za

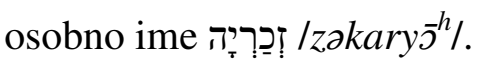

Zvijezdić/ZVIJEZDIĆ - hrv. - Prezime nastalo prijevodom izvornoga שטערן/štern/ (v. Stern/ /Štern/STERN/ŠTERN) i njegovom prilagodbom hrvatskoj prezimenskoj tradiciji.

Žurga.

\subsubsection{Statistička analiza prezimenā prema podrijetlu}

Među svim je prezimenima najviše u užem smislu jidiških, 743 uz još 3 nesigurna, čija motivacija može potjecati i iz jidiša i iz hrvatskoga (BELIN, Košarak) odnosno koje zbog pogrešnog prijepisa iz izvornih dokumenata u bazu podataka Gradskih grobalja nije moguće točno identificirati $(A K S E B R A D)$. Ako njima pribrojimo 6 čeških prezimena i 38 mađarskih te 1 rusko, to ukupno daje 786 prezimena iz krajeva tradicionalno naseljenih Aškenazima. Usto imamo i jedno prezime (AMBRUŠ) čija se motivacija može naći i u jidišu i u mađarskome, jedno koje se može tumačiti i kao sefardsko-arapskog podrijetla i kao mađarsko (Kalai) te jednu dvoprezimensku kombinaciju u kojoj je jedno prezime mađarsko, a drugo jidiško (Kaposi-Schnitzler/KAPOŠI-SCHNITZLER).

U usporedbi s tim brojem, broj se od 11 sefardskih prezimena čini neznatnim. Sva se ona, uz iznimku prezimena Camis, djevojačkog prezimena Elvire ud. Eisenstädter (1334/1889 
45/1892) i prezimena Kabili, djevojačkog prezimena Lisi/Lise ud. Groskopf/Grosskopf (874/1880 940/1881), mogu naći isključivo među nadgrobnim spomenicima na Mirogoju, a njihovi su nositelji preminuli između dva svjetska rata, pa je vjerojatno da su se u Zagreb doselili tek nakon uspostave Kraljevine Srba, Hrvata i Slovenaca.

Posebnu skupinu čine talijanska prezimena, među kojima ima i aškenaskih (Priester/Prister) /PRISTER) i sefardskih (Luzzatto/Luzzato). Izdvojeni su u zasebnu skupinu jer je većina njih u Zagreb došla iz istog kraja, Gorizie, te je među njima primjetna svojevrsna endogamija kao i nadijevanje talijanskih (likova) osobnih imena. Takvih prezimena ima 19. Nazočni su u Zagrebu već u XIX. st., kad se u grad doseljavaju Židovi iz različitih krajeva Habsburške, odnosno Austro-Ugarske Monarhije.

Od ostalih prezimena vrijedno je spomenuti i ona hebrejskog podrijetla, njih 11. Uglavnom je riječ o osobnim imenima koja su postala prezimenima bez dodavanja patronimskih i inih afikasa.

Velik je broj hrvatskih prezimena, ima ih 90. Jedan dio njih predstavljaju prezimena u koja su promijenjena ona izvorna, židovska, dok su druga po svemu sudeći rezultat mješovitih brakova u kojima se prezime nasljeđivalo od oca, a židovstvo od majke.

Od ostalih se pojavljuje jedno englesko prezime $(J o h n / J O H N)$, jedno grčkog podrijetla, ali popularno među Aškenazima (Alexander / Aleksander / ALEXANDER / ALEKSANDER / IALEKSANDAR), jedno hebrejskog podrijetla, ali jidišizirano (Eskenazi/Eškenazi), jedno hebrejskog podrijetla uobličeno u tipični hrvatski prezimenski lik (Abramović), jedno latinskog podrijetla (Justus), dok se za 34 prezimena ne može sa sigurnošću ustanoviti podrijetlo.

\subsubsection{Promjena prezimenā}

U pogledu su promjene prezimena najmanje informativni podaci s Mirogoja. Nije, naime, neuobičajeno da se u istu grobnicu sukcesivno pokapaju različite porodice, pa novo prezime na nadgrobnom spomeniku ne mora nužno značiti i promjenu prezimena porodice. U tom se slučaju u promjenu prezimena može biti siguran tek ako je riječ o jezično najjednostavnijim procesima promjene - prijevodu, kao u slučajevima Deutsch $>$ Njemčić (5 I 19), 
Eisenstädter > Gvozdan (13 II 49), Fuchs > Lisičar (3 I 3), Neumann >Nović (4 I 31) ili Stern >Zvijezdić (2 II/I 24); odnosno fonetskoj transkripciji kao u slučajevima Alexander > Aleksander (924 ARKP 11-1), Ausch > Auš (924 ARKP 21-1), Baruch > Baruh (3 I 86), Bichler $>$ Bihler (2 II/I 44, 3 I 58), Brichta $>$ Brihta (13 II 26-27), Bruckner > Brukner (11 II/I 41), Deucht $>$ Dajht $^{414}$ (2 II/I 3-4), Deutsch>Dajč (3 I 50), Hirschl > Hiršl (11 II/I 32), Müller > Miler (917 PAVVEL 1), Neumann > Najman (10 II 19), Preisz > Prajs (12 II 59), Schrenger > Šrenger (3 II 65), Schwarz > Švarc (2 II/I 20; 10 II 44), Spiegel > Špigel (924 ARKP 13-2), Spitzer > Špicer (3 I 42-43), Stern > Stern (11 II 99) ili Weiss > Vajs (8 I 25) ${ }^{415}$. U slučajevima Deutsch > Duić (3 I 102), Lederer > Ledić (7 I 34) i Weiss > Vajić (12 I 12) na djelu nije tek puka fonetska transkripcija, već i prilagodba morfološkoj strukturi tipičnih hrvatskih prezimena ${ }^{416}$. Druge moguće promjene prezimenā iz istog izvora moguće je utvrditi tek usporedbom s promjenama potvrđenima u drugim izvorima.

Gavro Schwarz u svojem popisu Židova u Zagrebu sredinom XIX. st. navodi više primjera promjene prezimena. Nažalost, godine rođenja i smrti često ne navodi za one koji nisu patres (i matres) familias, pa ne možemo uvijek sa sigurnošću ustvrditi u koje je doba do promjene prezimena došlo. Moguća bi bila spekulacija uzimanjem 20-25 godina vremenskog razmaka između dvaju susljednih pokoljenja, ali ona može biti i varljiva ${ }^{417}$, tim više što u pojedinim

${ }^{414}$ Ovdje je fonetski transkribiran jidiški izgovor riječi, a ne njemački. Isto vrijedi za prezimena Dajč i Najman. Na Mirogoju se, međutim, pojavljuju i prezimena fonetski transkribirana prema njemačkom izgovoru, poput Ajzenštajn (2 I 16; trebalo bi Ejzenštejn) ili Ajzenšteter (10 II 98; trebalo bi Ejzenšteter), ali bez izvorne, njemačke ortografije.

${ }^{415}$ Ostaje nejasno, barem u slučaju podataka s Mirogoja, kad je proces fonetske transkripcije prezimena bio administrativni čin potaknut nositeljem istoga, a kad je bio posljedica birokratskog automatizma. U slučaju je matičnih knjiga rođenih stvar mnogo jasnija - ako je u matičnu knjigu upisana promjena u vidu fonetske transkripcije prezimena s potrebnim administrativnim detaljima, riječ je o promjeni.

U privatnom mi je razgovoru priopćen ovaj primjer: Muškarcu je poslije rođenja pripisano prezime roditelja Steiner. Poslije Drugog svjetskog rata mu se prezime počelo bilježiti kao Štajner (nije sam zatražio promjenu), pa je to bilo i prezime koje je preuzela njegova supruga nakon vjenčanja. Kada su se rodila djeca, njima je pribilježeno izvorno očevo prezime Steiner. U okviru iste obitelji - dva različita lika istog prezimena.

${ }^{416}$ Sličan proces bi mogao biti proveden i u slučaju Frelić (5 I 47), no ondje nam nedostaje izvorno prezime, ako je ono bilo Fröhlich. Potvrdu za tu promjenu pak nalazimo u matičnim knjigama rođenih (66/1895).

${ }^{417}$ Ako mi je dopušteno unijeti primjer iz vlastite porodice: moj je pradjed rođen 1880. g, njegova kći, moja baka, 1905. g, a njezin suprug, moj djed, 1884. g. Ovdje je razlika u naraštajima 25 g. između pradjeda mi i 
obiteljima navodi i desetak izravnih potomaka, te je moguće da i razlika u dobi između braće i sestara bude značajna.

Schwarz tako među potomcima Abrahama Alberta Hertmanna (1796. - 1867.) spominje i unuka mu Mirka Ilića (15), sina Henriete Hertmann (1843. - 1916.) i Ignaca Israela. Očigledno je Mirko promijenio prezime iz Israel u Ilić, zadržavajući inicijale (Schwarz 1939: $52)$.

Unuka Ruže Kremsir, sina njezine kćeri Pauline i Ignaca Deutscha iz Bistre, Schwarz bilježi kao Milana Njemčića (27, 5 I 19), veterinarskog inspektora u Zagrebu. Milan je po svemu sudeći jednostavno »preveo« prezime Deutsch, te ga slavenizirao formantom -ić (Schwarz 1939: 57). Slično su postupili i sinovi Abrahama b. Šelomo Sterna (1816. - 1893.) promijenivši svoje prezime u Zvijezdić (35, 3 II 82) (Schwarz 1939: 64).

Industrijalac je Adolf Daničić (27) spomenut u Schwarza kao sin liječnika dr. Miroslava Schwarza iz V. Kaniže, ali uz Adolfovu braću Željka i Dragutina nije navedeno nikakvo prezime, te je moguće pretpostaviti da su oni zadržali izvorno prezime. Kako se između prezimena Schwarz i Daničić ne može uspostaviti ni kakva semantička veza ni kakva sličnost u izgovoru, nije jasno otkud Adolfu to novo prezime (Schwarz 1939: 59).

Za potomke Davida Herša Cevija b. Šelomo Jehuda Kohna (30) Schwarz piše da su primili prezime Kolmar bez ikakvih daljnjih objašnjenja (Schwarz 1939: 60). U Matičnim je knjigama rođenih ta promjena potvrđena u slučaju novorođenog Emila Kohna (896/1880), uz koje prezime stoji napomena »promijenjeno u Kolmar«, kao i uz osobno ime i prezime njegova oca Edmunda Kohna. Istu promjenu prezimena nalazimo i kod njegovih sestara Hermine (478/1872), Berthe (622/1875) i Pauline (693/1877) i brata Otta (548/1874) te kod Moritza (953/1882), potomka druge obitelji Kohn (ali vjerojatno iste porodice).

Schwarz navodi tri sina Egidija Morica Spitzera (1855. - 1924.) (103):

Vilko umro u ratu, Španić Miroslav i Stjepan (Schwarz 1939: 89).

bake, ali između pradjeda i zeta mu imamo samo 4 g. razlike. Moja je baka rodila moju majku kad joj je bilo 33 g., ali je majčinom ocu tada bilo već 58 g. 
Iz navedenog nije sasvim jasno jesu li braća Miroslav i Stjepan svoje prezime promijenili u Španić (čime bi se sačuvalo početno šp- prezimena) ili je pak Španić tek nadimak Miroslavljev. Iz Matičnih se knjiga pak vidi da su 1919. g. Miroslav (39/1894) i sestra mu Nada (26/1897) oboje promijenili prezime iz Spitzer u Španić. Stjepan se u njima ne spominje, a Vilko je po svemu sudeći Wlhelm (60/1892), uz čije ime nema napomene o promjeni prezimena.

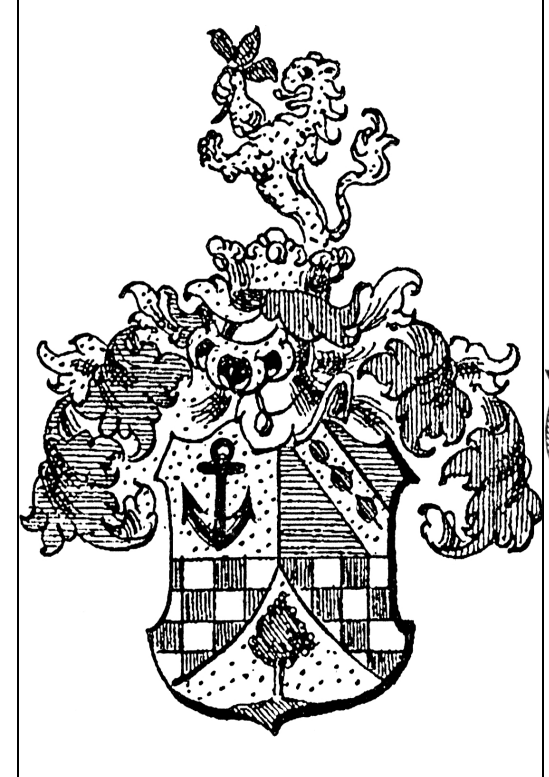

Grb porodice Weiss de Polna

dodijeljen veletrgovcu

J. Weissu

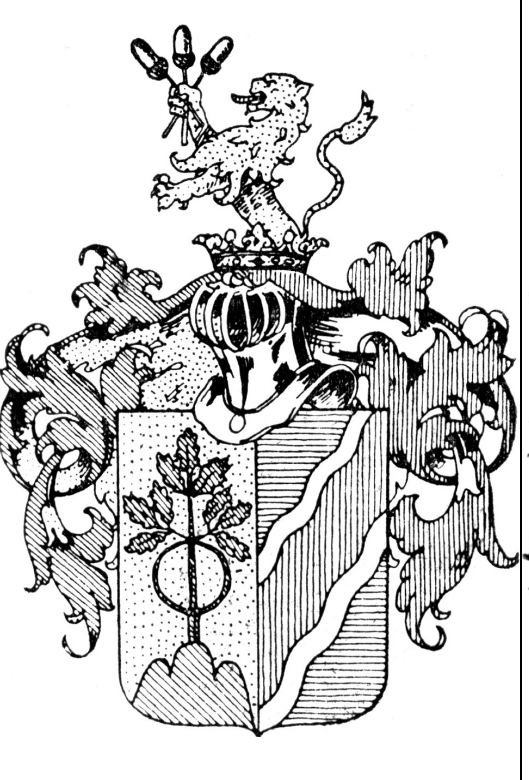

Grb porodice Deutsch

Maceljski dodijeljen obitelji

F. Deutscha

(Bojničić 1995 (1899): Taf. 144) (Zbornik plemstva 1938:173)

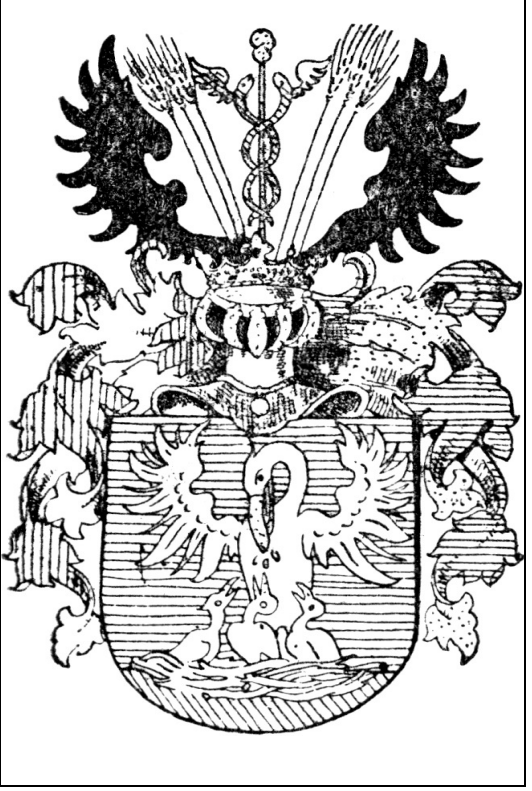

Grb porodice Aleksander

Sesvetski dodijeljen industrijalcu $\check{S}$. Aleksandru

(Zbornik plemstva 1938:12)

Slika 26: Plemićki grbovi dodijeljeni Židovima.

Jedan od načina promjene prezimena jest i uzimanje plemićkoga pridjevka kao novog prezimena umjesto starog, židovskog. Plemićku titulu »de Polna« podario je car Franjo Josip I. (1830. - 1916.) 19. siječnja 1874. g. ${ }^{418}$ zagrebačkom veletrgovcu Jakobu Weissu (41, 924 ARKVEL 7) ${ }^{419}$, kao prvom Židovu u Hrvatskoj. Ni Bojničić ni Schwarz ne navode je li tko naslijedio taj naslov (Bojničić 1995 (1899): 198; Schwarz 1939: 68). Schwarz dalje navodi kako je riječki odvjetnik dr. Hinko Sachs $(26,68)$ za svoje zasluge dobio plemstvo »de

\footnotetext{
${ }^{418}$ Schwarz navodi 1872. kao godinu stjecanja plemstva (Schwarz 1939: 68).

${ }^{419}$ Schwarz njegovo ime navodi kao Jehuda b. Šelomo Weiss (u. 1866.) (Schwarz 1939: 68).
} 
Grič « ${ }^{420}$, no ne spominje što je s tim plemićkim naslovom dalje bilo, jesu li ga njegovi potomci zadržali (ako je bilo nasljedno) ili ne ${ }^{421}$ (Schwarz 1939: 56). S druge strane, Schwarz navodi kako je car i kralj Franjo Josip I. (1830. - 1916.) drvotršcu, veletrgovcu i veleposjedniku Filipu Feivelu Šrageu ${ }^{422}$ b. Benjamin Deutschu (u. 1919. g. u dobi od 96 g.) $(15,29,23 / 1859,179 / 1863,118 / 1867,304 / 1867,924$ ARKP 11), njegovoj supruzi Franjici r. Hertman (15, 29, 23/1859, 179/1863, 118/1867, 304/1867, 924 ARKP 11) i sinovima Vilimu (1853. - 1926.) (29, 956/1882, 1036/1883, 1087/1884, 1224/1887, 924 ARKP 11), Benku (1863. - 1923.) (29, 179/1863, 924 ARKP 11) i Albertu (r. 1867.) (29, 304/1867, 118/1867) te njihovim zakonitim potomcima godine 1910. dodijelio plemstvo s predikatom Maceljski, prema Maceljskoj šumi, te da su njegovi sinovi Vilim, Albert i Benko dotični plemićki naslov preuzeli kao prezime ${ }^{423}$ (Schwarz 1939: 60; ; Zbornik plemstva... 1938: 173-174). Car je i kralj Karlo I. Austrijski (1887. - 1922.) trgovcu, industrijalcu, bankaru i filantropu Šandoru Aleksanderu (1866. - 1829.) (36, 924 ARKP 172) za njegov zaslužan rad 13. srpnja 1918. g. podijelio plemstvo s pridjevkom »Sesvetski« $\mathrm{u}$ znak zahvalnosti što je početkom rata donirao milijun zlatnih austrijskih kruna kao nepovratni zajam državi, no Schwarz ne spominje što je dalje s tim naslovom bilo te je li Šandor uopće imao potomaka, dok Zbornik plemstva navodi Zoru ud. Marić (36, 924 ARKP 172) kao njegovu jedinicu. Uz njezino ime, međutim, u izvorima ne nalazimo pridjevak »Sesvetska« (Schwarz 1939: 60; Zbornik plemstva... 1938: 12) (slika 26).

U matičnim knjigama rođenih u XIX. st. zagrebačke Židovske općine pohranjenih u hrvatskom državnom arhivu u godinama 1849. - 1889. nalazimo 143 pojedinca koji su u životu mijenjali prezime, neki od njih čak i više puta ${ }^{424}$. Promjene prezimena (prve u

\footnotetext{
${ }^{420}$ Židovski biografski leksikon navodi da je dodijeljeni mu plemićki naslov glasio »Gorički«. Dostupno na: http://zbl.lzmk.hr/?p=1908

Pristupljeno 31. kolovoza 2018.

${ }^{421}$ Tek je iz podataka u matičnim knjigama vidljivo da jesu.

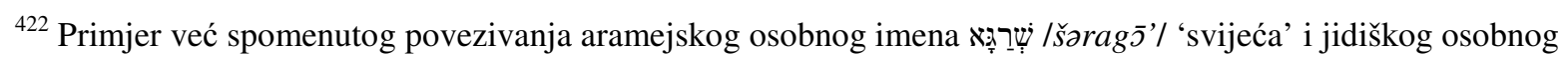
imena Feyvel < (pučkom etimologijom) Фoĩßos /phoĩbos/ iz naših krajeva.

${ }^{423}$ Matične knjige navode plemićki pridjevak od Macelja (179/1863, 304/1867, 1036/1883, 1087/1884), koji je tek kasnije pretvoren u prezime Maceljski. (955/1882, 956/1882, 1035/1883, 1087/1884). Zbornik plemstva spominje da prezime Maceljski nose potomci Filipova sina Vilima od 1932. g. (Zbornik plemstva... 1938: 173-174).

${ }^{424}$ U nekim godištima matičnih knjiga rođenih možebitne promjene prezimena nisu unesene.
} 
slučajevima pojedinaca koji su prezime mijenjali više puta) navedene u njima jesu kako slijedi $^{425}$ :

\begin{tabular}{|c|c|}
\hline Ausch & $>$ Auš \\
\hline Bachrach & > Bašić \\
\hline Benjamin & $>$ Bartos \\
\hline Berger & $>$ Borković \\
\hline Berger & $>$ Goranin \\
\hline Berndorfer & $>$ Borković \\
\hline Braun & $>$ Smeđić \\
\hline Deutsch & $>$ Dajč \\
\hline Deutsch & $>$ Deutsch od Macelja ${ }^{426}$ \\
\hline Deutsch & $>$ Duić $^{427}$ \\
\hline Deutsch & $>$ Maceljski \\
\hline Deutsch & $>$ Njemčićc ${ }^{428}$ \\
\hline Deutschberger & $>$ Darvas $^{429}$ \\
\hline Eisenstädter & $>$ Gvozdanović \\
\hline Figatner & $>$ Figatner-Florenz \\
\hline Fischbein & $>$ Fišar \\
\hline Friedmann & $>$ Mirjević \\
\hline Fritz & $>$ Mirski \\
\hline Fröhlich & $>$ Frelić \\
\hline Glück & > Gál \\
\hline Goldhammer & > Gárdos ${ }^{430}$ \\
\hline Goldmann & $>$ Zala $^{431}$ \\
\hline Granitz & $>$ Maceljski \\
\hline Grünwald & $>$ Gulgas \\
\hline
\end{tabular}

\footnotetext{
${ }^{425}$ Zbog oštećenih rubova matičnih knjiga nije uvijek moguće točno ustanoviti kako je glasilo novo prezime. U tim slučajevima se u popisu pojavljuje znak »? «.

${ }^{426}$ U četiri slučaja: 179/1863, 304/1867, 1036/1883 i 1087/1884.

${ }^{427}$ U tri slučaja: $1371 / 1889,5 / 1896$ i 45/1897.

${ }^{428}$ U dva slučaja: 210/1864 i 1130/1885.

${ }^{429}$ U dva slučaja: $1274 / 1888$ i 39/1890.

${ }^{430}$ U tri slučaja: $1351 / 1889,57 / 1892$ i 51/1894.

${ }^{431}$ U tri slučaja: 49/1894, 26/1896 i 76/1897.
} 


\begin{tabular}{|c|c|}
\hline Haas & $>\operatorname{Havas}^{432}$ \\
\hline Hermann & $>$ Hrlić \\
\hline Herrnstein & $>$ Hranilović \\
\hline Heumer & > Lörnitz \\
\hline Hochsinger & $>$ Maceljski \\
\hline Kahn & > Rákosy \\
\hline Karpeles & $>$ Karpati $^{433}$ \\
\hline Karpeles & $>$ Kenok \\
\hline Kohn & $>\mathrm{Kann}^{434}$ \\
\hline Kohn & > Kaszás \\
\hline Kohn & $>$ Kolmar $^{435}$ \\
\hline Kohn & $>$ Kormend \\
\hline Kohn & $>$ Korvin $^{436}$ \\
\hline Kohn & $>$ Kún \\
\hline Krausz & $>$ Kollo $^{437}$ \\
\hline Lederer & $>$ Linski \\
\hline Löwy & $>$ Lavrić \\
\hline Löwy & $>$ Lubynski $^{438}$ \\
\hline Löwy & $>\mathrm{L} ?^{439}$ \\
\hline Lustig & $>$ Temar \\
\hline Mayer & $>$ Marić \\
\hline
\end{tabular}

${ }^{432}$ Matična knjiga je naknadno obrezana, te su pritom stradali krajevi redaka koji donose informaciju o promjeni prezimena.

Novo prezime navodi Ljiljana Dobrovšak u svojem magistarskom radu (Dobrovšak 2003: 160).

${ }^{433}$ U šest slučajeva: 857/1879, 937/1881 (izvorno je prezime pritom zapisano kao Kárpeles), 1040/1883, $857 / 1879,937 / 1881$ i 1040/1883.

${ }^{434}$ U dva slučaja: 502/1873 i 799/1879.

${ }^{435}$ U šest slučajeva: 478/1872, 548/1874, 622/1875, 693/1877, 896/1880 i 953/1882.

${ }^{436}$ U tri slučaja: 278/1866, 19/1894 i 36/1896.

${ }^{437}$ U dva slučaja: 20/1891 (novo je prezime zabilježeno kao Köllo) i 17/1896 (novo je prezime zapisano kao Kóllo).

${ }^{438}$ U tri slučaja: 377b/1869, 542/1873 i 81/1897 (novo je prezime zabilježeno kao Lubinsky).

${ }^{439}$ Matična knjiga je naknadno uvezana te su pritom stradali dijelovi redaka koji donose informaciju o promjeni prezimena, a koji su se protezali preko dvije susjedne stranice. Moguće je da je i ovdje (1228/1887) riječ o prezimenu Lubynski/Lubinsky. 


\begin{tabular}{|c|c|}
\hline Mayer & > Mayer-Marić \\
\hline Moises & $>$ Mozović \\
\hline Moses & $>$ Milić \\
\hline Müller & $>$ Miler $^{440}$ \\
\hline Neumann & $>$ Nemes \\
\hline Neumann & $>$ Novak \\
\hline Neumann & $>$ Nović \\
\hline Oesterreicher & $>$ Kerkai $^{441}$ \\
\hline Ornstein & $>$ Oštrić \\
\hline Pollak & $>$ Pollak $^{442}$ \\
\hline Pollak & $>$ Poljak $^{443}$ \\
\hline Prister & $>$ Rojan \\
\hline Rákoši & > Rákosy \\
\hline Rechnitzer & $>\operatorname{Radan}^{444}$ \\
\hline Rechnitzer & $>$ Romanović \\
\hline Reichl & $>$ Raic $^{445}$ \\
\hline Rosenberg & $>$ Rožić \\
\hline Rosenberg & $>$ Ružić \\
\hline Rosenberger & $>\mathrm{Rado}^{446}$ \\
\hline Rosenberger & $>$ Rodić \\
\hline Sachs & $>$ Sachs od Griča $^{447}$ \\
\hline Scheiber & $>$ Dobo \\
\hline Schlomm & $>$ Szekely \\
\hline Schönwald & $>$ Geisler \\
\hline Schwabenitz & $>$ Gorjan \\
\hline
\end{tabular}

\footnotetext{
${ }^{440}$ U dva slučaja: $1293 / 1888$ i 26/1894.

${ }^{441}$ U tri slučaja: 2/1890 (izvorno je prezime zapisano kao Österreicher), 50/1891 i 14/1894.

${ }^{442}$ U ovom slučaju (40/1890) nije točno jasno što se mijenjalo, ali uz upisano novorođenče stoji napomena da je prezime kasnije promijenjeno u Pollak, isto ono koje je prvotno navedeno u matičnoj knjizi.

${ }^{443}$ U dva slučaja: $139 / 1862$ i 39/1896.

${ }^{444}$ U dva slučaja: 858/1879 i 950/1882.

${ }^{445}$ U dva slučaja: 685/1877 i 1202/1886.

${ }^{446} \mathrm{U}$ tri slučaja: 5/1891, 7/1895 i 53/1897 (novo prezime je zapisano kao Radó).

${ }^{447}$ U tri slučaja: 18/1859, 1085/1884 i 1140/1885.
} 


\begin{tabular}{|c|c|}
\hline Schwarz & $>$ Daničić \\
\hline Schwarz & $>$ Savić $^{448}$ \\
\hline Schwarz & $>$ Slavic $^{449}$ \\
\hline Schwarz & > Székely \\
\hline Schwarz & $>$ Šumanović \\
\hline Schwarz & $>$ Vranic $^{450}$ \\
\hline Schwarzenberg & $>$ Simonfai \\
\hline Siebenschein & $>$ Plamenak \\
\hline Sonnenberg & $>$ Slavoljub \\
\hline Spitz & > Szegö \\
\hline Spitzer & $>$ Šilović \\
\hline Spitzer & $>\check{S}^{\text {Spanić }}{ }^{451}$ \\
\hline Stärk & > Jagić? \\
\hline Steinhart & $>$ Stranić \\
\hline Sterk & $>$ Horvat \\
\hline Stern & $>$ Globnik \\
\hline Stern & $>Z_{\text {viezdic }}{ }^{452}$ \\
\hline Strausz & $>?^{453}$ \\
\hline Süssman & $>\operatorname{Sisman}^{454}$ \\
\hline Szender & $>$ Szende \\
\hline Weis & $>$ Polak \\
\hline Weiß & $>$ Bjelinski $^{45}$ \\
\hline Weiss & $>$ Vanić \\
\hline Weiss & $>$ Vujić \\
\hline Weiß & Csaszar > \\
\hline
\end{tabular}

\footnotetext{
${ }^{448} \mathrm{U}$ dva slučaja: $1183 / 1886$ i 32/1892.

${ }^{449}$ U dva slučaja: $312 / 1867$ i 31/1891.

${ }^{450}$ U dva slučaja: $36 / 1895$ i 79/1896.

${ }^{451}$ U dva slučaja: 39/1894 i 26/1897.

${ }^{452}$ U četiri slučaja: 960/1882, 1264/1888, 6/1890 i 14/1892.

${ }^{453}$ Matična knjiga je naknadno obrezana, te su pritom stradali zadnji reci koji donose informaciju o promjeni prezimena.

${ }^{454}$ U dva slučaja: 293/1867 (izvorno je prezime zapisano kao Süssmann) i 431/1870.

${ }^{455}$ U dva slučaja: 949/1881 i 1282/1888.
} 
$\begin{array}{ll}\text { Weisz } & >\text { Vajs }^{457} \\ \text { Wertheimer } & >\text { Tolnai }\end{array}$

U nekoliko je navrata u matičnim knjigama rođenih ${ }^{458}$ uz podatke o osobi koja je promijenila prezime udaren žig na kojem stoji:

Na osnovu Naredbe o promjeni židovskih

prezimena broj 336-Z. p. 1941 od 4 lipnja

1941 bilježi se promjena prezimena

na

Tim je postupkom promijenjeno prezime zamijenjeno prvotnim $^{459}$.

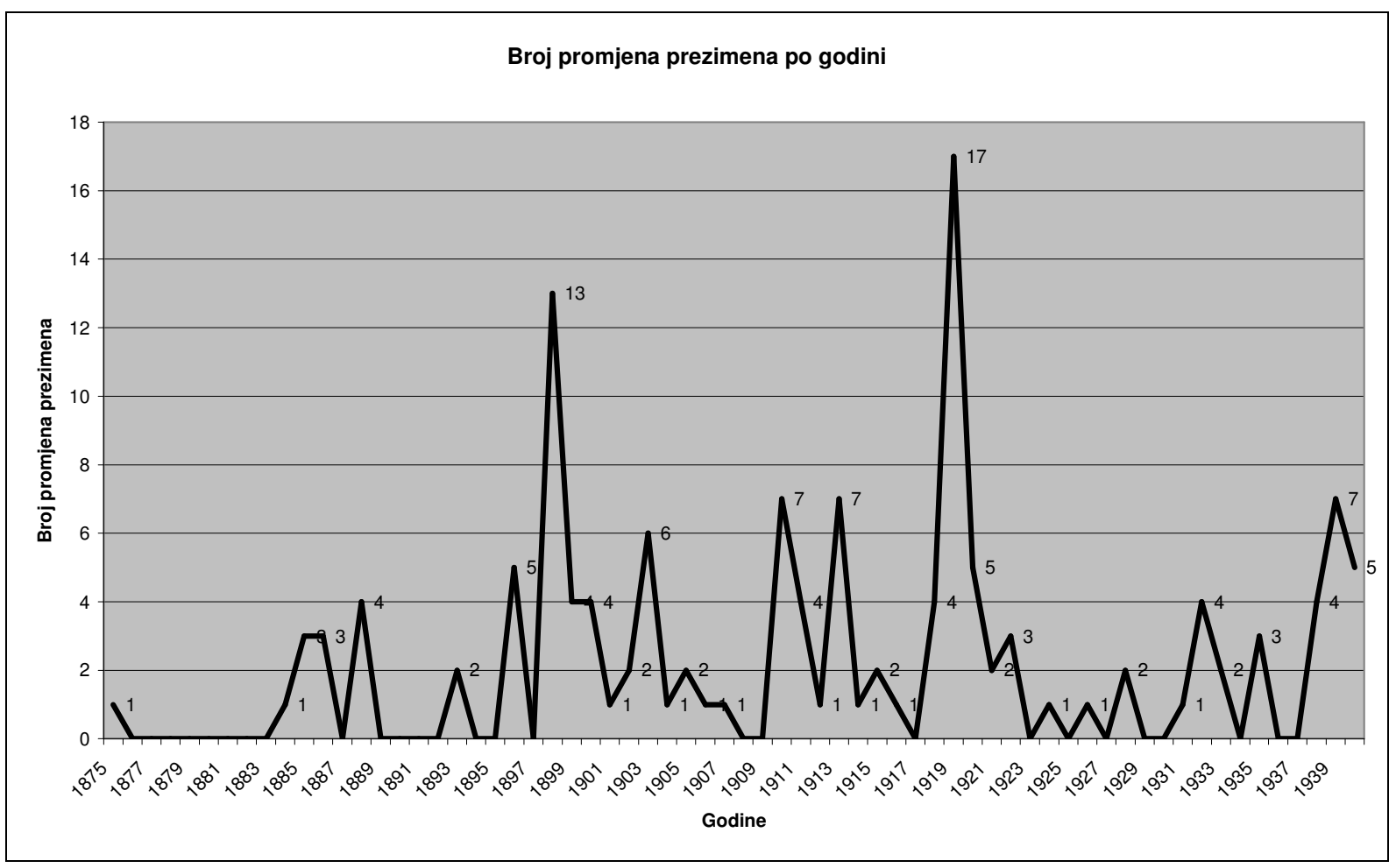

Slika 27: Broj promijenjenih prezimena po godinama

\footnotetext{
${ }^{456}$ U ovom je slučaju (1330/1889/) navedena promjena (fonetska transkripcija) prezimena, iako nema nikakve napomene o tome kada je prvotno prezime zamijenjeno ovim. Možda je u pitanju bilo prezime supruga koje je osoba preuzela vjenčanjem?

${ }^{457} \mathrm{U}$ ovom se slučaju novo prezime navodi kao promjena zbog razvoda.

458 312/1867, 589/1875, 709/1877, 1183/1886, 37/1893, 10/1897 i 51/1897.

${ }^{459}$ Riječ je o Naredbi o promjeni židovskih prezimena i označavanju Židova i židovskih tvrtka od 4. lipnja 1941. g. (Brandl 2015': 677, bilješka 7)
} 
Ako obratimo pozornost na godine promjene prezimena (one prve u slučajevima pojedinaca koji su prezime mijenjali više puta), dobit ćemo ovakav grafikon (slika 27):

U gornjem su grafikonu uočljiva dva vrhunca: 1898. i 1919. g. Tih je godina najviše pojedinaca promijenilo svoja prezimena, redom 13 odnosno 17.

Godine 1898. promijenjena su sljedeća prezimena:

$\begin{array}{ll}\text { Goldmann } & >\text { Zala }^{460} \\ \text { Haas } & >\text { Havas } \\ \text { Oesterreicher/Österreicher } & >\text { Kerkai }^{461} \\ \text { Rosenberger } & >\text { Rado/Radó }^{462} \\ \text { Rosenberger } & >\text { Rodić } \\ \text { Scheiber } & >\text { Dobo? } \\ \text { Szender } & >\text { Szende }\end{array}$

Ako zanemarimo prezime Rodić, sva ostala nova prezimena imaju mađarski prizvuk. Zala je ime više toponima u Mađarskoj, županije u današnjoj zapadnoj Mađarskoj, nekadašnje mađarske županije koja je uz teritorij sadašnje sadržavala i Prekmurje, sela u Šomođskoj županiji i rijeke u današnjoj jugozapadnoj Mađarskoj. Kerkai je pridjev izveden od hidronima Kerka (Krka), rijeke koja nastaje spajanjem Velike Krke (Nagy-Kerka) i Male Krke (KisKerka) kod Bajánsenyea, a koja u Sloveniji utječe u Lendavu. Havas, Dobó, Radó i Szende su uobičajena mađarska prezimena.

Po čemu je godina 1898. bila toliko bitna da bi se u njoj promijenila tolika prezimena? Vjerojatno nije moguće dati siguran i jedinstven odgovor na ovo pitanje, već bi ga trebalo tražiti u spletu okolnosti. Te je godine mađarizacija pod upravom bana Dragutina KhuenHéderváryja (1849. - 1918.), koji je banovao Hrvatskom i Slavonijom od 1883. do 1903. g.,

\footnotetext{
${ }^{460}$ Prezime su promijenili Emerich (49/1894), brat mu Ladislaus (26/1896) i sestra im Terezija (76/1897). S obzirom na njihovu dob (redom, 4, 2 i 1 godinu), vjerojatno je da je u to doba cijela obitelj promijenila prezime.

${ }^{461}$ Prezime su promijenili Paula (2/1890), sestra joj Marie (50/1891) i brat im Zoltan (14/1894). S obzirom na njihovu dob (redom, 8,7 i 4 godine), vjerojatno je da je u to doba cijela obitelj promijenila prezime.

${ }^{462}$ Prezime su promijenili Leopoldine (5/1891), Aladar (7/1895) i Olga Fanni (53/1897). S obzirom na njihovu dob (redom, 7, 3 i 1 godinu), vjerojatno je da je u to doba cijela obitelj promijenila prezime.
} 
bila u punom jeku. Isto je tako u punom jeku bio antisemitski val prouzročen Dreyfussovom aferom u Francuskoj (1894. - 1906.). Godinu dana prije naše 1898. bečkim je gradonačelnikom postao Karl Lueger (1844. - 1910.) - na tom je mjestu ostao do 1910. g. čija je Kršćanska socijalna stranka vodila otvorenu populističku i antisemitsku politiku, čime se nadovezao na ideje Georga von Schönerera (1842. - 1921.), vodećeg eksponenta pangermanizma i njemačkog nacionalizma u Austriji, radikalnog protivnika političkog katolicizma i žestokog antisemita (Dobrovšak 2003: 46-76).

Još je jedan čimbenik mogao utjecati na izbor mađarskih prezimena. $U$ to je vrijeme željeznica bila u mađarskim rukama, a nemali je broj zagrebačkih Židova bio zaposlen upravo na državnoj željeznici ${ }^{463}$. Potreba se za asimilacijom na radnom mjestu tako iskazala i u promjeni prezimena u mađarska (Dobrovšak 2003: 158-175).

»Jedanaestog sata jedanaestog dana jedanaestog mjeseca« 1918. g. bojištima je u Europi zavladao prekid vatre. Centralne su sile, Njemačka, Austro-Ugarska, Turska i Bugarska, izgubile rat. Četiri su carstva nestala s karte Europe - Njemačko, Austro-Ugarsko, Tursko i Rusko. Mir je sklopljen tek pola godine kasnije, 28. lipnja 1919. g. Već je 1. prosinca 1918. g. princ-regent Aleksandar Karađorđević (1888. - 1934.) proglasio novu državu, Kraljevinu Srba, Hrvata i Slovenaca, u koju je bila uključena i kratkotrajna Država Slovenaca, Hrvata i Srba koja je uključivala Zagreb. Toj će kraljevini 3. listopada 1929. g. taj isti, ali sada kralj Aleksandar I. Karađorđević promijeniti ime u Kraljevina Jugoslavija. Zagrebačka je židovska općina tako iz rubne općine germanofonog i hungarofonog carstva postala jedna od središnjih općina nove slavenofone kraljevine. Kao što je već navedeno, upravo je 1919. g., u godini nakon osnivanja nove države, najviše pojedinaca promijenilo svoja prezimena, i to sve redom u slavenska ili u prezimena koja su zvučala slavenski:

$\begin{array}{ll}\text { Bachrach } & >\text { Bašić } \\ \text { Fröhlich } & >\text { Frelić } \\ \text { Mayer } & >\text { Marić } \\ \text { Moses } & >\text { Milić } \\ \text { Neumann } & >\text { Nović } \\ \text { Neumann } & >\text { Novak } \\ \text { Ornstein } & >\text { Oštrić }\end{array}$

${ }^{463} \mathrm{O}$ tome svjedoče podaci o zanimanju oca, gdje je ono navedeno, u matičnim knjigama rođenih. 


$$
\begin{array}{ll}
\text { Reichl } & >\text { Raić }^{464} \\
\text { Schwabenitz } & >\text { Gorjan } \\
\text { Schwarz } & >\text { Slavić } \\
\text { Schwarz } & >\text { Vranić }^{465} \\
\text { Siebenschein } & >\text { Plamenak }^{\circ} \\
\text { Sonnenberg } & >\text { Slavoljub }^{4} \\
\text { Spitzer } & >\text { Śpanić }^{466}
\end{array}
$$

Može se pretpostaviti da u poratno vrijeme u državi koja se smatrala sljednicom pobjednice nad državama njemačkog govornog područja u tek završenom ratu prezime koje je zvučalo njemački nije bilo poželjno. Ako tome dodamo i nepovjerenje koje je Beograd iskazivao prema »njihovim« Židovima, Aškenazima, naspram »naših «, mahom Sefarada, jasno je da su

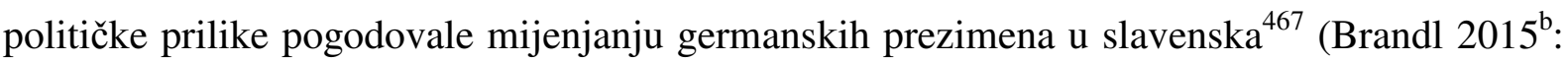
65, Goldstein 2004: 61-65).

\subsubsection{Opažanja vezana uz promjene prezimenā}

Nije moguće znati, pa ni rekonstruirati koja je bila motivacija izbora novog prezimena, je li postojao kakav odnos između njega i starog prezimena. Ipak, mogu se uočiti neke učestalije pojave.

Ako usporedimo izvorna prezimena s onima u koja su promijenjena vidimo da u najvećem broju slučajeva, njih 35, oba prezimena imaju isto početno slovo. Prijevodom je izvornog prezimena promijenjeno 14 njih (Berger $>$ Goranin, Braun $>$ Smeđić, Deutsch $>$ Njemčić, Eisenstädter $>$ Gvozdan, Eisenstädter $>$ Gvozdanović, Friedmann > Mirjević, Fritz > Mirski, Neumann $>$ Novak, Neumann $>$ Nović, Rosenberg $>$ Rožić, Rosenberg $>$ Ružić, Schwarz > Vranić, Stern $>$ Zviezdić, Weiß $>$ Bjelinski). Pet je prezimena promijenjeno fonetskim zapisom izvornoga (Ausch>Aǔ̌, Deutsch > Dajč, Müller > Miler, Süssman > Sisman, Weisz > Vajs). U sedam je slučajeva izvorno prezime prilagođeno uobičajenoj tvorbi hrvatskih prezimena

\footnotetext{
${ }^{464}$ Prezime su promijenili Arthur (685/1877) i brat mu Victor (1202/1886).

${ }^{465}$ Prezime su promijenili Miroslav (36/1895) i brat mu Leo (79/1896).

${ }^{466}$ Prezime su promijenili Miroslav (39/1894) i sestra mu Nada (26/1897).

${ }^{467}$ Slične su prilike u Ujedinjenom Kraljevstvu ponukale kralja Georgea V. (1865.-1936.) da 17. srpnja 1917. g. zamijeni dotadašnje prezime vladarske kuće, njemačko Sachsen-Coburg und Gotha (engleski: Saxe-Coburg and Gotha) engleskijim Windsor.
} 
(Deutsch>Duić, Fröhlich>Frelić, Lederer > Ledić, Moises > Mozović, Pollak > Poljak, Reichl > Raić, Weiss > Vajić), a u četiri izvorno i novo prezime imaju slične planove izraza (Fischbein > Fišar, Kohn > Kann, Kohn > Kún, Kohn > Kunić). U potonjem nalazimo usto i prilagodbu uobičajenoj tvorbi hrvatskih prezimena.

\subsubsection{Prezimena pisana hebrejskim pismom}

Među nadgrobnim spomenicima na Mirogoju 51 ih nosi natpis (i) hebrejskim pismom. Od tih se natpisa na njih 31 nalazi prezime pisano hebrejskim pismom.

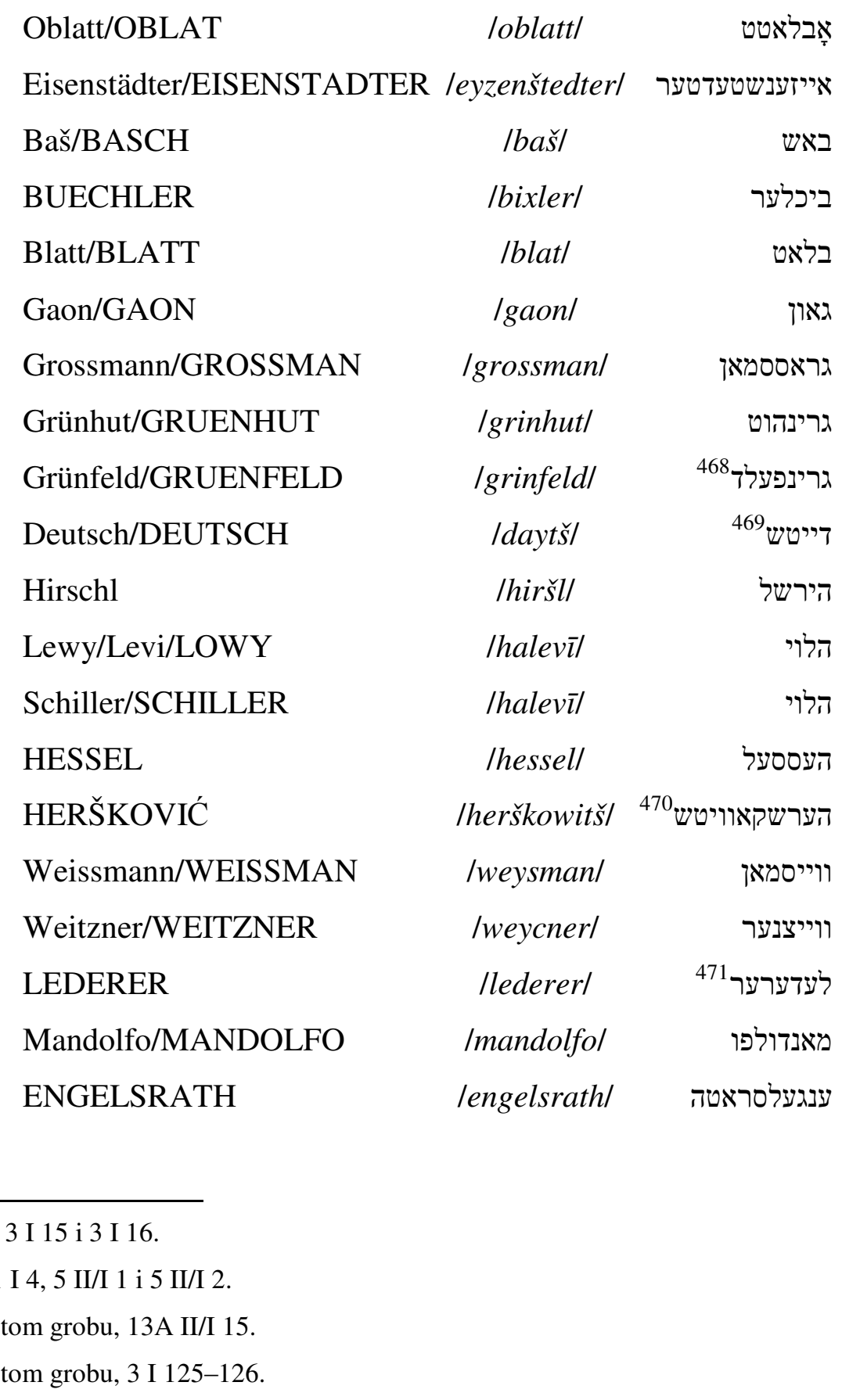


Kohn/KOLIN

ROTHSTEIN

Rechnitzer/RECCHMITZER

Steinhardt/STEINHARDT

Štern/ŠTERN

Kastl/KASTL /kohn/

|rothšteyn/

|rexnicerl

/šteynhart/

/št $(e) r n /$

|talevī|
קאהן

ראטהשטיין

רעכניטצער

שטיינהארט

שטרן

תלוי

Većina prezimena slijedi danas uobičajeni pravopis jidiša, uz neke iznimke. Primjerice, u prezimenima se גראססמאן /grossman/ i העסלאטל /oblatt/, גרעט /hessel/ poštuje udvajanje suglasnika, tipično za njemački pravopis, ali se geminata dosljedno ignorira u sufiksu מאןI-man/. U prezimenu אייזענשטעדטער leyzenštedter/ nalazimo digraf <טד (latinicom <dt>) kojim se označuje obezvučeni suglasnik. (Istodobno se to ne događa u prezimenu שטיינהארט Išteynhart/!) U fonetskom pravopisu, kakav je jidiški, dovoljno bi bilo napisati <ט>. Prezime je גאון/gaon/ pisano hebrejskim pravopisom (u tom bi ga slučaju trebalo čitati /gə’ōn/).

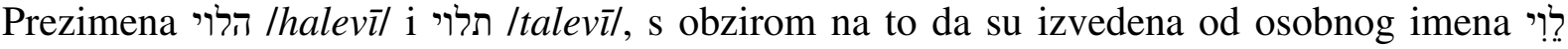
/lewīl iz Tanaha, također slijede hebrejsku grafiju. Ujedno se ova razlikuju od onih građanskih, redom Schiller/SCHILLER i Kastl/KASTL, upućujući na levitsko podrijetlo porodice. Prezime je מאנדולפו /mandolfo/ zabilježeno grafijom tipičnom ne samo za hebrejski, nego i za judeo-španjolski, neke varijante jidiša i druge židovske jezike: samoglasnik se /o/ označava suglasnikom ı, a ne u današnjoj jidiškoj ortografiji uobičajenijim ș. U prezimenima

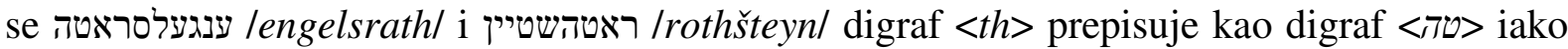
se izgovara [t], pa bi dovoljno bilo napisati samo $\langle ט\rangle$. U transkripciji se prezimena Kohn/KOLIN prepisivalo slovo po slovo, pa smo dobili קאהן/kohn/, iako se to $<h>$ ne izgovara, već možebitno dulji prethodeći mu samoglasnik. 


\section{ZAKLJUČAK}

U svim su izvorima, kao i u užem korpusu, najčešća muška građanska osobna imena dva osobna imena podrijetlom iz hebrejskoga: Josephus/Joseph/Josef/Jozef/Josel/Josif/Josip/

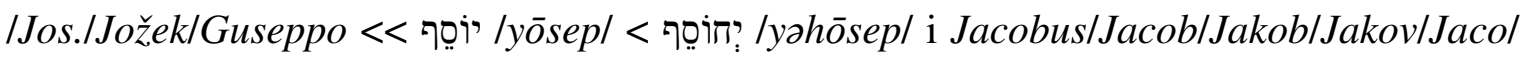

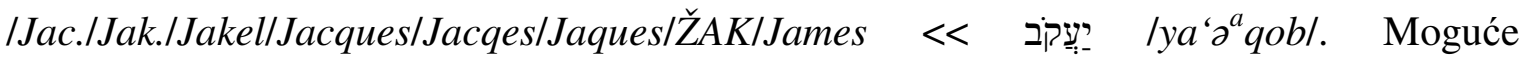
objašnjenje tolike nenadmašne popularnosti upravo ta dva osobna imena leži u činjenici da ona mogu podjednako uspješno funkcionirati i kao židovska i kao građanska bilo u kojoj kršćanskoj zemlji. Ostala su muška osobna imena hebrejskog podrijetla ( שָׁמוּאָל

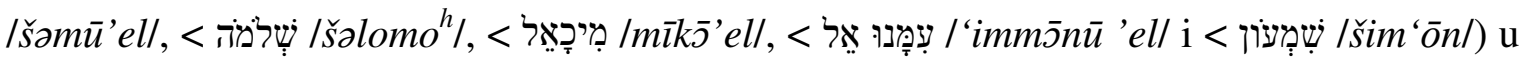
većoj ili manjoj mjeri obilježena kao židovska. Od nehebrejskih su muških osobnih imena među najčešćima ona tradicionalno povezana s određenim hebrejskim osobnim imenima: Leopoldus/Leopold/Leop./Leo/Lavoslav (s osobnim imenom יְְִּ: /yahūd $\bar{\nu}^{h} /$ ), Maurus/ /Mauro/Mavro/Moritz/Moriz/Moric (s osobnim imenom משֶָ /moš $e^{h} /$ ), Ignatius/Ignatz/ /Ignaz/Ignac/IGNACIJE/Ignacy/Ignjat/Ig. (s osobnim imenom /Albert/Alberto (s osobnim imenom אַבְרָָָם /'abrōhs̄m/), a tu su još i AdolflAdolfo, Sigismundus/Sigismund/Siegmund/Sigmund/Sig./Zsigmund/Zsiga/Žiga, Alexander/Alex/ /Aleksander/Aleksandar/Aleksa/Sándor/Sandor/Šandor, Max/MAXO/Maks/Makso, Julius/ Julije/Julio/Julijo/Jul. i Heinrich/Henrik/Heinr./Hinko.

Među najčešćim ženskim osobnim imenima samo su dva izvedena od ženskih hebrejskih: Hanna / Hana / Hanni / Hani / Anna / Annie / Anny / Anette / Ana / ANI / Anica / Anka /

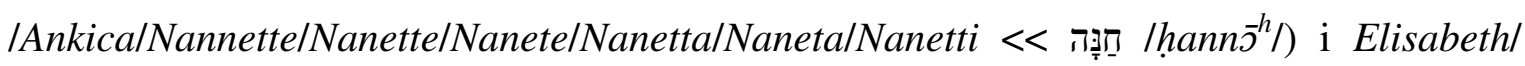
/Elisabetha/Elisabette/Elisabeta/Elizabeth/Elizabeta/Elise/Eliza/Ella/Ela/Elsa/Elza/Bette/ /Betti/Betty/BETA/BETI/Betika/Babette/Babete/Babetta/Babeta/Babet/Eržebet/Jelisava $<<$

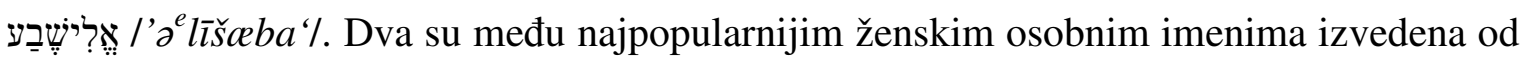
muških hebrejskog podrijetla: Johanna/Johana/Jeannette/Jeanette/JEANETA/Žanetal

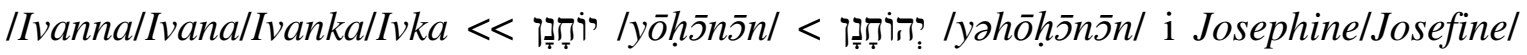

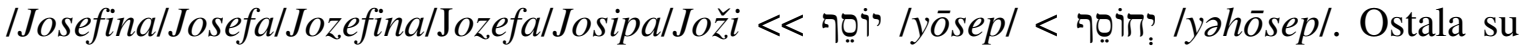
najčešća građanska ženska osobna imena Rose/Rosa/Rösel/Rosi/Rosina/Rozal /ROZALINA/Rozi/Ruža/Ružica, Reginna/Regina/Regine/Regi, Theresel/Theresa/Theres/ /Theresie/Theresia/Thereze/Terezia/Terezija/Terezie/Terezije/Tereze/Terez/Tereza/Terical /Resi/Resy/Rezi/Tekla, Charlotte/Charlotta/Charlota/Šarlota/Lotte/Lotta/Lota/Lotty/Lottil / Loti, Catharina / Katharine / Katharina / Katharin / Katerina / Katarina / Catti / Käthe / 
/Kathi / Katty / Kati / Kattel / Katton / Katinka / Katica i Rosalie / Rosalia / Rosalija / /Rozalia/Rozalija.

U slučaju proučavanja etymologia remota muških građanskih osobnih imena jezici se podrijetla mogu svrstati u iduće kategorije: semitski (hebrejski i aramejski), grčki, latinski, romanski, keltski, germanski, mađarski, perzijski, turkijski i slavenski uz osobna imena kojima nije moguće utvrditi podrijetlo.

Za proučavanje ženskih građanskih osobnih imena jezici se podrijetla mogu svrstati u iduće kategorije: semitski (hebrejski i aramejski), grčki, latinski, romanski, germanski, mađarski i slavenski uz osobna imena kojima nije moguće utvrditi podrijetlo. Među ova se mogu uvrstiti osobna imena koja podrijetlo vuku iz književnih djela.

Najveći postotak pojedinaca nosi građanska muška osobna imena motivirana općom imenicom germanske etimologije. Slijede pojedinci s osobnim imenima semitskog (hebrejskog ili aramejskog) te latinskog, da bi se oni s osobnim imenima slavenskog podrijetla našli već na četvrtome mjestu, a grčkoga na petom.

U slučaju samih likova muških građanskih osobnih imena najčešća su osobna imena semitskog podrijetla, dok su na drugom mjesto osobna imena germanskog podrijetla. Daljnji je redoslijed isti kao i u prethodnom slučaju: osobna imena latinskog, pa slavenskog te grčkog podrijetla.

Postotak pojedinaka sa ženskim građanskim osobnim imenima semitskog (hebrejskog i aramejskog) podrijetla nadmašuje broj onih germanskog podrijetla. Slijede one s osobnim imenima latinskoga te romanskoga podrijetla, one su s osobnim imenima slavenskog podrijetla već na petome mjestu, dok je postotak pojedinaka s osobnim imenima grčkoga podrijetla na šestome.

U slučaju likova samih ženskih građanskih osobnih imena na prvom su mjestu i dalje osobna imena semitskog podrijetla, slijede ih ona germanskoga, latinskoga, romanskoga, grčkoga, pa tek onda slavenskog podrijetla. Razlike su u postocima, međutim, minimalne.

Tijekom cijelokupnoga su promatranog razdoblja među muškim građanskim osobnim imenima najbrojnija ona germanskog podrijetla. Prvo se osobno ime slavenskog podrijetla (Lavoslav) pojavljuje 1859. g. Najveći se broj dječaka kojima je nadjenuto osobno ime 
slavenskog podrijetla pojavljuje 1897. g., 14 pojedinaca $(33,33 \%)$ i 9 različitih osobnih imena - Božidar (2), Dragutin, Lavoslav (2), Ljudevit, Milan (4), Radivoj, Srećko, Stanko i Vladimir.

Prvo se osobno ime slavenskog podrijetla (Ljuba) među ženama pojavljuje 1864. g., pet godina kasnije nego u muškaraca. Broj djevojčica kojima je nadjenuto osobno ime slavenskog podrijetla dosiže maksimum 1897. g. s 10 pojedinaka, tri manje negoli je to bio slučaj s dječacima, i 7 različitih osobnih imena - Darinka, Dragica (2), Ljudevita, Nada, Vera (3), Zdenka i Zora.

Pri proučavanju etymologia proxima muških građanskih osobnih imena jezici se podrijetla mogu svrstati u iduće kategorije: latinski, njemački, talijanski, mađarski, jidiški, francuski, poljski, turski i hrvatski uz osobna imena kojima nije moguće utvrditi podrijetlo.

Za proučavanje ženskih građanskih osobnih imena jezici se podrijetla mogu svrstati u iduće kategorije: njemački, talijanski, mađarski, francuski, ruski, poljski i hrvatski uz osobna imena kojima nije moguće utvrditi podrijetlo.

Pojedinaca s muškim građanskim osobnim imenima preuzetima iz njemačkog ima nešto manje od polovine, a onih s osobnim imenima preuzetima iz hrvatskoga nešto više od trećine njihova ukupnog broja. Slijede osobna imena preuzeta iz mađarskog jezika. U usporedbi su s navedenima ostali brojčano beznačajni, ukupno ne čine niti $5 \%$ svih pojedinaca.

Broj likova muških građanskih osobnih imena hrvatskog podrijetla ima više negoli dva puta više od broja osobnih imena preuzetih iz njemačkoga. Samo još mađarskih i talijanskih osobnih imena ima više od $2 \%$.

Broj je žena koje nose osobna imena preuzeta iz njemačkog i hrvatskog podjednak, dok sva ostala osobna imena nosi tek nešto više od $20 \%$ žena.

Kad pogledamo broj različitih likova ženskih osobnih imena, osobna imena preuzeta iz njemačkoga i hrvatskoga zajedno ima tek malo više od četvrtine ukupnog broja likova. Svi preostali likovi osobnih imena čine tek 7,26 \% ukupnih.

Sve do 1896. g. dominiraju muška građanska njemačka osobna imena. Iduće godine hrvatska osobna imena preuzimaju vodstvo sa 17 nositelja spram 10 njemačkih da bi već 
1898. g. njemačka osobna imena u potpunosti izostala. Presudnom se godinom čini 1879. kada su hrvatska osobna imena dosegla brojku od 5 nositelja - dotadašnji rekord nenjemačkih osobnih imena, koji su 1867. g. postigla talijanska. Od tada do 1896. g. hrvatska osobna imena nadmašuju sva ostala osim njemačkih.

Kod žena građanska osobna imena preuzeta iz njemačkoga dominiraju do 1894. g. da bi 1895. g. prevladala hrvatska. Hrvatska su se osobna imena ponešto uzdigla iznad ostalih još 1879. g. kad su zabilježene 4 nositeljice, broj koji osobna imena iz drugih jezika, osim njemačkoga, nisu dostigla. Hrvatska ženska osobna imena rekord dosižu 1897. g. s 19 nositeljica, da bi iduće, zadnje za koju raspolažemo točnim podacima, pala na 11.

Deset je najpopularnijih muških židovskih osobnih imena hebrejsko - אַבְרָָָָם /'abrōhs̄m/

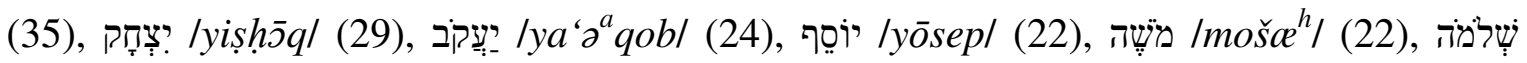

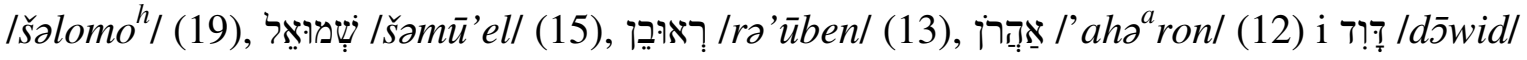

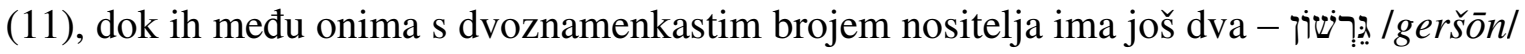
(10) i מֵאִיר /me'̄̌rl (10). Od jidiških se osobnih imena položajem među deset najpopularnijih može pohvaliti samo ליב /leyb/ (11).

Šest je najpopularnijih ženskih židovskih osobnih imena hebrejsko - רָָח /rọhell (25),

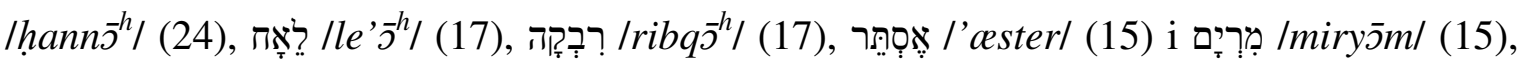
dok među onima s dvoznamenkastim brojem nositeljica ima još jedno - מלכה /malk $\bar{s}^{h} /$ ili $^{2}$ Imilk $\bar{\partial}^{h} /$ (12). Od jidiških se položajem među deset najpopularnijih mogu pohvaliti samo גיטל Igitl/ (15), חיילה /beyle/ (14), שרל /serl/ (10).

Najčešća je kombinacija građanskog i židovskog muškog osobnog imena ona koja uključuje osobna imena Joseph/Josef/Josip (jedno od dva najpopularnija građanska muška osobna imena) i יוֹסף /yōsep/. Ima još nekoliko slučajeva kombinacije »europeizirane«, kršćanske, i izvorne, hebrejske inačice istog osobnog imena: Jacob/Jakob/Jakov/Jacques/

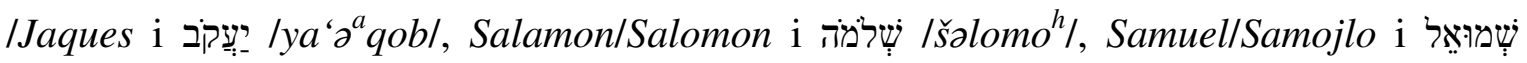

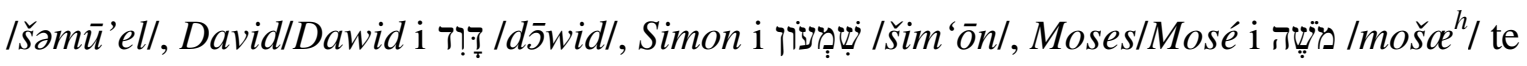

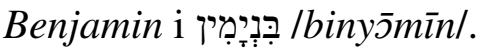

Česte su kombinacije i Albert i אַבְרָרָָה /'abrōhs̄m/ i Moritz/Moriz/Moric/Mavro i

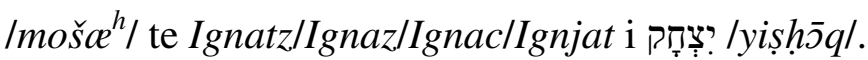

Među parovima spojenima logikom iz Tore dominiraju imena vezana uz pojam 'lav', 


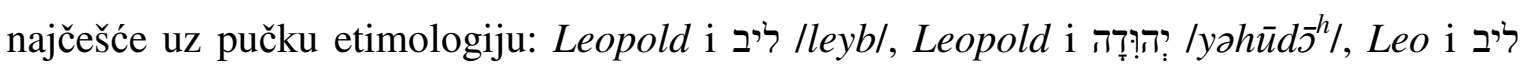

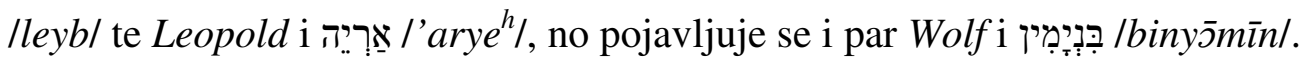

Što se prijevodnih osobnih imena tiče, uz navedene je tu i par Bernhard i בער|בערל /berl /berl/.

Znatno je više primjera spajanja osobnih imena na temelju sličnosti plana izraza, a posebice osobnih imena istog početnog slova/glasa, ali i onih koji imaju neke zajedničke suglasnike.

Parovi se osobnih imena Leopold i ליב /leyb/, Albert i אִבְרָָם /'abrōhōm/, Ignatz/Ignaz/

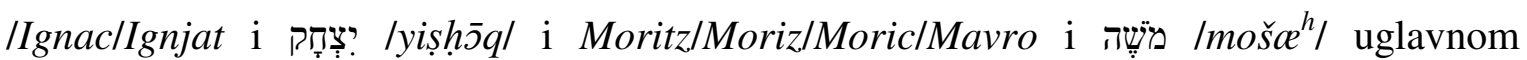
pojavljuju kroz cijelo promatrano razdoblje, s time da prema njegovu kraju njihova čestoća opada.

Kod ženskih osobnih imena jedino pravilo vezivanja određenog građanskog i određenog židovskog osobnog imena jest ono sličnosti plana izraza. Najčešći parovi osobnih imena jesu Marie/Maria/Marija מִרִיָם /mirys̄m/ (dvije inačice istog osobnog imena, kršćanskog i

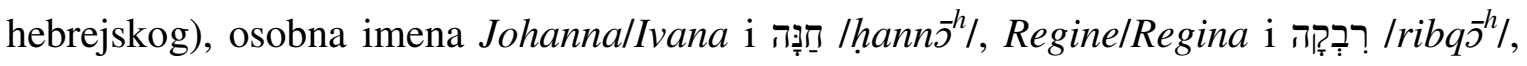

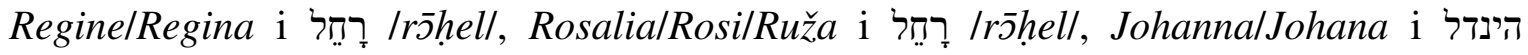
/hindl/, Paola/Paula/Pauline i פערל/perl/, Theres/Therese/Theresa/Theresie/Terezija i

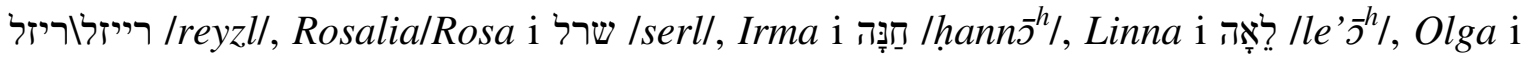
יענטל /yentll. Jedino prvi navedeni par nosi dvoznamenkasti broj pojedinaka - njih 10 .

Najčešće je prezime u korpusu Schwarz/Schwartz/Schwarc/Svarz/Švarc. Slijede prezimena Koen/Kohn/Kon, Neuman/Neumann, Spitzer/Špicer, Weis/Weiß/Weiss/Weisz, Dajč/Deutsch/Maceljski/Njemčić, Hirschl/Hiršl i Miller/Müller/Mueller.

Prezimena se etimološki mogu podijeliti u ona jidiškog, češkog, mađarskog i ruskog podrijetla (aškenaska prezimena), sefardska (uključujući ona arapske etimologije), talijanska među kojima ima i aškenaskih i sefardskih, hebrejska i hrvatska.

Aškenaskih je prezimena 786 uz još tri moguća, hrvatskih 90, talijanskih 19, sefardskih i hebrejskih po 11, po jedno engleskog, grčkog, jidišiziranog hebrejskog, kroatiziranog hebrejskog i latinskog podrijetla te 34 prezimena za koja se ne može sa sigurnošću 
ustanoviti podrijetlo.

U najvećem broju slučajeva promjene prezimena (35) oba prezimena posjeduju isto početno slovo. Prijevodom je izvornog prezimena promijenjeno 14 njih. Pet je prezimena promijenjeno fonetskim zapisom izvornoga. U sedam je slučajeva izvorno prezime prilagođeno uobičajenoj tvorbi hrvatskih prezimena, a u četiri izvorno i novo prezime imaju slične planove izraza.

Najviše je pojedinaca promijenilo prezimena 1898. g. (13) i 1919. g. (17). U prvom su slučaju prezimena uglavnom mijenjana u mađarska ili prezimena koja zvuče mađarski, a vjerojatno pod utjecajem mađarizacije u Hrvatskoj kao i širenja antisemitizma u srednjoj i zapadnoj Europi. U drugom su slučaju prezimena uglavnom mijenjana tako da zvuče slavenski, hrvatski, a vjerojatno potaknuta činjenicom da u novostvorenoj Kraljevini Srba, Hrvata i Slovenaca vlasti nisu blagonaklono gledale na prezimena germanskoga prizvuka, koja zvuče kao prezimena donedavnih ratnih neprijatelja.

Većina prezimena pisanih hebrejskim pismom slijedi danas uobičajeni pravopis jidiša, uz neke iznimke kao što su pisanje udvojenih suglasnika tipično za njemački, ali ne i jidiški pravopis, pisanje digrafa $<d t>\mathrm{i}<t h>$ uobičajenih u njemačkim prezimenima (u drugom slučaju prema arhaičnom pravopisu) umjesto slova $\langle\vartheta\rangle$ te prepisivanje slovo po slovo iz njemačke latinice u jidišku kvadratu. Sve navedene nejidiške pojave nisu provedene dosljedno, već samo u nekih prezimena, dok u drugih pisanje slijedi pravila jidiškog pravopisa.

U dva slučaja pisanje prezimena slijedi grafiju hebrejskog jezika.

Jedno je sefardsko prezime zabilježeno grafijom tipičnom ne samo za hebrejski, nego i za judeo-španjolski, neke varijante jidiša i druge židovske jezike. 


\section{Literatura}

Agić, Senad. 1996. Muslimanska lična imena. Zagreb: Kaj.

Amerl, Rudolf. 1997. »Popis vlastitih imena Staroga zavjeta«; u: Hebrejsko-hrvatski rječnik. Zagreb: Kršćanska sadašnjost, str. 361-407.

Archer, Gleason L. Jr., Harris, R. Laird i Waltke, Bruce K.2003. Theological Wordbook of the Old Testament. Chicago: Moody Publishers.

Asimov, Isaac. 1969. Asimov's Guide to the Bible. Two Books in One: The Old and New Testaments. New York - Avenel NJ: Wings Books.

Beider, Alexander. 2001. A Dictionary of Ashkenazic Given Names: Their Origins, Structure, Pronunciation, and Migrations. Bergenfeld, NJ: Avotaynu.

Beider, Alexander. 2003. "Methodological Principles for Determining Etymologies of Ashkenazic Given Names"; u: These Are the Names, Aaron Demsky (ed.). Ramat Gan: Bar-Ilan University Press, str. 41-76.

Biblija. Stari i Novi zavjet. 1969. Preveli Filibert Gass, Silvije Grubišić, Nikola Milićević, Ljudevit Rupčić i Antun Sović. Zagreb: Stvarnost, Kršćanska sadašnjost.

Blatt, Warren. 2013. Reading Hebrew Tombstones. New York: Museum of Jewish Heritage. Dostupno na: http://www.jewishgen.org/InfoFiles/tombstones.html Pristupljeno 30. prosinca 2016.

Bojničić, Ivan von. 1995. Der Adel von Kroatien und Slavonien. Pretisak izvornika iz 1899.g. (Nürnberg: Verlag von Bauer und Raspe (E. Küster)) Zagreb: Golden marketing. Bornstein-Makovetsky, Leah. 2003."Personal Names of Salonikan Jewry in Recent Generations according to Marriage Certificates and Gravestones"; $\mathrm{u}$ : These Are the Names, Aaron Demsky (ed.). Ramat Gan: Bar-Ilan University Press, str. כג-מט.

Brandl, Naida Mihal. 2015ª . Djelatnost Židovske bogoštovne općine u Zagrebu od 1945. do 1946. godine. Radovi Zavoda za hrvatsku povijest Filozofskog fakulteta Sveučilišta u Zagrebu, knjiga 47, vol. 2, str. 675-710. Dostupno na:

https://hrcak.srce.hr/file/226792

Pristupljeno: 1. svibnja 2018.

Brandl, Naida Mihal. 2015 . Židovi u Hrvatskoj od 1944./5. do 1952. Neobjavljeni doktorski rad. 
Bredefeldt, Rita. 2003. "Naming Customs as an Indication of Assimilation: A Study of First Names in the Jewish Congregations of Stockholm and Malmö (1895-1921)"; u: These Are the Names, Aaron Demsky (ed.). Ramat Gan: Bar-Ilan University Press, str. 77-90.

Brown, Francis, Rolles Driver, Samuel i Briggs, Charles Augustus. 1906. A Hebrew and English Lexicon of the Old Testament with an appendix containing the Biblical Aramaic. Oxford: The Clarendon Press.

Bunin Benor, Sarah. 2016. “On Jewish Languages, Names, and Distinctiveness”. The Jewish Quarterly Review, Vol. 106, No. 4, str. 440-449.

Bushell, Michael S. 1996. Bible Works 3.5. Big Fork, MT: Hermeneutica.

Bushwick, Nathan. 2005. Kako razumeti jevrejski kalendar; s engleskog preveo Šelomo Maoz. Zemun: Književno društvo Pismo.

Campbell, Mike i Campbell, Tara. Behind the Name. Dostupno na: http://www.behindthename.com/ Pristupljeno (prvi put) 20. rujna 2015.

Cemetery Scribes. 2009. Tombstone Symbols - Cohen Hands. Dostupno na: http://cemeteryscribes.com/blog/tombstone-symbols-cohen-hands/ Pristupljeno 24. rujna 2014.

Chazan, Robert. 2007. "Names. Medieval Period and Establishment of Surnames. Middle Ages. Modern Times"; u: Encyclopaedia Judaica, volume 14 Mel-Nas, Skolnik, Frur (ed.). Detroit: Thomson Gale, str. 768-770.

Chevalier, Jean i Gheerbrant, Alain. 1994. Rječnik simbola. Mitovi, sni, običaji, geste, oblici, likovi, boje, brojevi. Zagreb: Nakladni zavod Matice hrvatske, Mladost.

Colorni, Vittore. 1983. « La corrispondenza fra nomi ebraici e nomi locali nella prassi dell'ebraismo italiano »; u: Italia judaica. Atti del I Convegno internazionale, Bari 18-22 maggio 1981. Roma: Ministero per i beni culturali e ambientali, str. 67-86.

Crystal, David. ${ }^{6}$ 2008. A Dictionary of Linguistics and Phonetics. Malden MA, Oxford, Carlton VIC: Blackwell.

Čilaš Šimpraga, Ankica, Ivšić Majić, Dubravka i Vidović, Domagoj. (2018.) Rječnik suvremenih hrvatskih osobnih imena. Zagreb: Institut za hrvatski jezik i jezikoslovlje

Da-Don, Kotel. 2004. Židovstvo - Život teologija, filozofija. Zagreb: Profil.

Demsky, Aaron. 2003. "Some Reflections on the Names of the Jews of Kaifeng, China”; u: These Are the Names, Aaron Demsky (ed.). Ramat Gan: Bar-Ilan University Press, str. 91-108. 
Dobrovšak, Ljiljana. 2003. Hrvatska javnost prema Židovima krajem 19. stoljeća (za vrijeme Dreyfusove afere od 1894. - 1899.). Neobjavljeni magistarski rad.

Doctor, Ronald D. 2008. Reading Hebrew Matzevot. Key Words, Abbreviations i Acronyms. Portland, OR: Ronald D. Doctor. Dostupno na http://www.rootsweb.ancestry.com/ orjgs/Abrrev.pdf Pristupljeno 30. prosinca 2016.

Dodig, Slavica. 2015. Leksikon biblijskih žena. Zagreb : Medicinska naklada.

Dodig, Slavica. 2017. Leksikon biblijskih muškaraca. Zagreb : Medicinska naklada.

Ducrot, Oswald i Todorov, Tzvetan. 1987. Enciklopedijski rečnik nauka o jeziku. Preveli Sanja Grahek i Mihajlo Popović. Beograd: Prosveta.

Efron, Zusja i Kečkemet, Duško. 1973. Židovsko groblje u Splitu. Split: Židovska općina u Splitu.

Encyclopaedia Judaica, volume 14 Mel-Nas. ${ }^{2} 2007$. Skolnik, Frur (ed.). Detroit: Thomson Gale.

Etimološki rječnik hrvatskoga jezika. 1. svezak. A - Nj. 2016. Ranko Matasović, Tijmen Pronk, Dubravka Ivšić, Dunja Brozović Rončević (ur.). Zagreb: Institut za hrvatski jezik i jezikoslovlje.

Frančić, Anđela. 2006. »Što je osobno ime?« Folia onomastica croatica, 15, str. 71-80.

Ginsberg, Harold Louis. 2007. "Names. In the Bible"; u: Encyclopaedia Judaica, volume 14 Mel-Nas, Skolnik, Frur (ed.). Detroit: Thomson Gale, str. 766.

Gluhak, Alemko. 1993. Hrvatski etimološki rječnik. Zagreb: August Cesarec.

Goldstein, Ivo. 2004. Židovi u Zagrebu 1918-1941. Zagreb: Novi Liber.

Gorr, Shmuel. 1992. Jewish Personal Names: Their Origin, Derivation and Diminutive Forms. Teaneck, NJ: Avotaynu.

Gradska groblja. 2014. Tražilica pokojnika. Zagreb: Gradska groblja. Dostupno na: http://www.gradskagroblja.hr/default.aspx?id=382 Zadnji put pristupljeno 1. kolovoza 2016. g.

Graves, Robert i Patai, Raphael. 1969. Hebrejski mitovi. Knjiga postanka. Preveo Željko Bujas. Zagreb: Naprijed.

Guggenheimer, Heinrich W. i Guggenheimer, Eva H. 1992. Jewish Family Names and Their Origins: An Etymological Dictionary. New York City, Jersey City: KTAV Publishing House. 
Handelman, Don i Shamgar-Handelman, Lea. 1990. "Shaping Time: The Choice of the National Emblem of Israel"; u: Culture Through Time: Anthropological Approaches, Emiko Ohnuki-Tierney (ed.). Palo Alto (CA): Stanford University Press, str. 193-226. Dostupno na: http://www.academia.edu/2553194/Shaping_Time_The_Choice_of_the_National_Emblem _of_Israel

Pristupljeno 24. rujna 2016.

Harrington, Wilfrid J. 1993. Uvod u Stari zavjet. Preveo Mate Zovkić. Zagreb: Kršćanska sadašnjost.

Hershkovitz, Arnon. 2012. "Deciphering Tombstones of Jewish Deceased”. Family Chronicle, March/April 2012, str. 31-33.

Kaganoff, Benzion C. 1996. A Dictionary of Jewish Names and Their History. Lanham, MD: Jason Aronson, Inc.

Klaić, Bratoljub. 1978. Rječnik stranih riječi. Tuđice i posuđenice. Zagreb: Nakladni zavod Matice hrvatske.

Koppeheel, W. 1914. Große Schön-Schreibschule für den Selbst-Unterricht nebst Rundschrift und Stenographie. Berlin: August Schultze.

Krleža, Miroslav. 1936. Balade Petrice Kerempuha. Ljubljana: Akademska založba.

Kronologija židovstva u Hrvatskoj. Židovska općina Zagreb. Dostupno na: http://www.zoz.hr/home.php?content=contentiterm=9ikey=3ikey1=4ikey2=9 Pristupljeno 14. ožujka 2016.

Kroonen, Guus. 2013. Etymological Dictionary of Proto-Germanic. Leiden, Boston: Brill. Landmann, Salcia. 1987. Jevreji u vicevima. Preveli Vojislav Vladović i Predrag Micić. Beograd: Predrag i Nenad

Lauden, Edna i Weinbach, Liora sa Shani, Miriam. 1998. Multi Dictionary. Bilingual Learners Dictionary. Hebrew-Hebrew-English, English-Hebrew. Tel-Aviv: “AD”.

Lawson, Edwin. D. 2005. Jewish Onomastics. Dostupno na http://www.jewish-languages.org/onomastics.html Pristupljeno 30. rujna 2016.

Leksik prezimena Socijalističke Republike Hrvatske. 1976. Valentin Putanec i Petar Šimunović (eds.). Zagreb: Institut za jezik, Nakladni zavod Matice hrvatske.

Lieberson, Stanley. 2003. "Jewish Names and the Names of Jews"; u: These Are the Names, Aaron Demsky (ed.). Ramat Gan: Bar-Ilan University Press, str. 155-166.

Matične knjige rođenih 1849-1870 Židovske općine Zagreb. Hrvatski državni arhiv. 
Mishory, Alec. 2003. The Flag and the Emblem. Jerusalem: Israel Ministry of Foreign Affairs. Dostupno na: http://www.mfa.gov.il/mfa/aboutisrael/israelat50/pages/the\%20flag\%20and\%20the $\% 20 \mathrm{em}$ blem.aspx

Pristupljeno 24. rujna 2016.

Moscati, Sabatino, Spitaler, Aron, Ullendorff, Edward i von Soden, Wolfram. 1964. An Introduction to the Comparative Grammar of the Semitic Languages. Phonology and Morphology. Wiesbaden: Otto Harrassowitz.

Mugdan, Joachim. 1996. Introduction to the Jewish Calendar. Dostupno na: http://www.jewishgen.org/InfoFiles/m_calint.htm Pristupljeno 30 prosinca 2016.

Основен систем и терминологија на словенската ономастика / Основная система и терминология славянской ономастики / Grundsystem und Terminologie der slawischen Onomastik. 1983. Redakcijski kolegij (ed.). Skopje: Македонска академија на науките и уметностите.

Oxford Companion to the Bible. 1993. Bruce M. Metzger i Michael D. Coogan (eds.). Oxford: Oxford University Press;.

Parsons, John J. 2003. - 2016. Birkat Kohanim - The Priestly Blessing. Hebrew for Christians. Dostupno na:

http://www.hebrew4christians.com/Blessings/Synagogue_Blessings/Priestly_Blessing/prie stly_blessing.html Pristupljeno 24. rujna 2016.

Pike, D. M. i Powell, M. A. ${ }^{3} 2011$. "Names"; u: The HarperCollins Bible Dictionary, Revised and Updated M. A. Powell (ed.). New York: HarperCollins, str. 683-685. Dostupno na: http://www.reformed.org/definitions/index.html?mainframe=/definitions/bible_names.html Pristupljeno 3. rujna 2017.

Pinker, Aron. 2005. "Descent of the Goddess Ishtar to the Netherworld and Nahum II 8". Vetus Testamentum, 55 (1). Leiden: E.J. Brill, str. 89-100. Dostupno na: http://web.a.ebscohost.com/ehost/pdfviewer/pdfviewer?vid=2isid=fea0b11d-a959-4de5944f-36092778c7d2\%40sessionmgr4006 Pristupljeno 28. kolovoza 2018.

Potok, Chaim. 1993. "Foreword"; u: Schwartzman, Arnold. Graven Images: Graphic Motifs of the Jewish Gravestone. New York: Harry N Abrams, str. 8-14. 
Putanec, Valentin. 1976. »Predgovor. Esej o jezičnom znaku i onomastici te o antroponimiji u Hrvatskoj«; u: Leksik prezimena Socijalističke Republike Hrvatske. 1976. Valentin Putanec i Petar Šimunović (eds.). Zagreb: Institut za jezik, Nakladni zavod Matice hrvatske, str. V-XIV.

qBible. Dostupno na:

http://www.qbible.com/hebrew-old-testament/

Pristupljeno 1. ožujka 2016.

Rabinowitz, Louis Isaac. 2007. "Names. in the Talmud"; u: Encyclopaedia Judaica, volume 14 Mel-Nas; Skolnik, Frur (ed.). Detroit: Thomson Gale, str. 767-768.

Sabar, Yona. 1974. "First Names, Nicknames and Family Names Among the Jews of Kurdistan”. The Jewish Quarterly Review, 65/1. Philadelphia: University of Pennsylvania Press, 43-51.

Scholem, Gershom. 1949. "The Curious History of the Six-Pointed Star. How the 'Magen

David' Became the Jewish Symbol”. Commentary 8, str. 243-251. Dostupno na: http://www.erolsadiku.com/DOWNLOAD/FREEMASONRY\%20(SLOBODNO\%20ZID ARSTVO)/Books-3/Gershom\%20Scholem\%20-

$\% 20$ The $\% 20$ Curious\%20History\%20of\%20the\%20Six-

Pointed\%20Star_www.ErolSadiku.com.pdf

Pristupljeno 24. rujna 2016.

Schwartzman, Arnold. 1993. Graven Images: Graphic Motifs of the Jewish Gravestone. New York: Harry N Abrams.

Schwarz, Gavro. 1939. Povijest zagrebačke židovske općine od osnutka do 50-tih godina 19. vijeka. Zagreb: Štamparija Gaj.

Schwarzwald, Ora (Rodrigue). 2010. "First Names in Sephardi Communities"; u: Pleasant Are Their Names: Jewish Names in the Sephardi Diaspora, Aaron Demsky (ed.). College Park, MD: Joseph and Rebecca Meyerhoff Center for Jewish Studies, University of Maryland, str. 191-207.

Silvan, Reuven i Levenston, Edward A. 1968. The New Bantam-Megiddo Hebrew and English Dictionary. Toronto-New York-London-Sydney-Auckland: Bantam Books. Skok, Petar. 1974. Etimologijski rječnik hrvatskoga ili srpskoga jezika I.-IV. Zagreb: Jugoslavenska akademija znanosti i umjetnosti.

Stamm, Johann Jakob. 2007. "Names. In the Bible"; u: Encyclopaedia Judaica, volume 14 Mel-Nas, Skolnik, Frur (ed.). Detroit: Thomson Gale, str. 764-766.

Šimundić, Mate. 1988. Rječnik osobnih imena. Zagreb: Nakladni zavod Matice hrvatske 
Šimunović, Petar. ${ }^{3} 2006$. Hrvatska prezimena: podrijetlo, značenje, rasprostranjenost. Zagreb: Golden Marketing.

Šimunović, Petar. 2009. Uvod u hrvatsko imenoslovlje. Zagreb: Golden marketing.

Škiljan, Dubravko. ${ }^{4}$ 1994. Pogled u lingvistiku. Rijeka: Benja.

Šosberger, Pavle. 2000. Osnovni pojmovi jevrejskih običaja i religije. Novi Sad: Prometej.

These Are the Names. 2003. Aaron Demsky (ed.). Ramat Gan: Bar-Ilan University Press.

Tolmas, Chana. 2003. "The Laqab of Bukharan Jews"; u: These Are the Names, Aaron Demsky (ed.). Ramat Gan: Bar-Ilan University Press, str. 167-174.

Trauring, Philip. 2011. Jewish Gravestone Symbols. BiF: Jewish Genealogy and More: Navigating Jewish Genealogy. Dostupno na https://bloodandfrogs.com/2011/04/jewish-gravestone-symbols.html Pristupljeno 24. rujna 2016.

Wong, Gregory T.K. 2007. "Song of Deborah as Polemic”. Biblica, Vol. 88, No. 1 (2007). Leuven/Louvain: Peeters Publishers, str. 1-22. Dostupno na: https://www.jstor.org/stable/42614746

Pristupljeno: 28. kolovoza 2018.

Zbornik plemstva u Hrvatskoj, Slavoniji, Dalmaciji, Bosni-Hercegovini, Dubrovniku, Kotoru i Vojvodini. 1938. Ed. Viktor Anton Duišin. Vlastita naklada: Zagreb.

Zucker, Sheva. 1994. Yiddish, an Introduction to the Language, Literature i Culture. A Textbook for Beginners, Vol. 1. Hoboken, NJ - New York, NY: KTAV Publishing House Inc. - The Workmen's Circle/Arbeter Ring.

Židovski biografski leksikon (rukopis). Ed. Ivo Goldstein. Zagreb: Hrvatski leksikografski zavod Miroslav Krleža. Radna verzija dostupna na: http://zbl.lzmk.hr/ Pristupljeno 31. kolovoza 2018. 
PRILOG A

\section{Transliteracija hebrejskog pisma}

(klasični hebrejski)

\begin{tabular}{|c|c|c|c|}
\hline kvadrata & IPA & transl. & \multirow{15}{*}{$\begin{array}{l}\text { ne izgovara se } \\
\text { na kraju riječi }\end{array}$} \\
\hline א & ? & , & \\
\hline ב & $\mathrm{b}$ & $\mathrm{b}$ & \\
\hline$\lambda$ & $\mathrm{g}$ & g & \\
\hline 7 & $\mathrm{~d}$ & $\mathrm{~d}$ & \\
\hline \multirow{2}{*}{ ה } & $\mathrm{h}$ & $\mathrm{h}$ & \\
\hline & & $\mathrm{h}$ & \\
\hline 1 & w & $\mathrm{w}$ & \\
\hline T & $\mathrm{z}$ & $\mathrm{z}$ & \\
\hline$\pi$ & $\hbar$ & h & \\
\hline ט & $t^{\uparrow}$ & $\mathrm{t}$ & \\
\hline , & $\mathrm{j}$ & $\mathrm{y}$ & \\
\hline כ & $\mathrm{k}$ & $\mathrm{k}$ & \\
\hline$\rceil$ & $-\mathrm{k}$ & $\mathrm{k}$ & \\
\hline ל & 1 & 1 & \\
\hline
\end{tabular}

\begin{tabular}{|c|c|c|c|}
\hline kvadrata & $I P A$ & transl. & \multirow{5}{*}{$\begin{array}{l}\text { na kraju riječ } \\
\text { na kraju riječ }\end{array}$} \\
\hline מ & $\mathrm{m}$ & $\mathrm{m}$ & \\
\hline 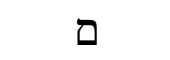 & $-\mathrm{m}$ & $\mathrm{m}$ & \\
\hline 了 & $\mathrm{n}$ & $\mathrm{n}$ & \\
\hline 1 & $-n$ & $\mathrm{n}$ & \\
\hline 0 & S & $\mathrm{s}$ & \multirow{11}{*}{ na kraju riječl } \\
\hline ע & $\mathrm{G}$ & ‘ & \\
\hline פ & $\mathrm{p}$ & $\mathrm{p}$ & \\
\hline ๆ & $-p$ & $\mathrm{p}$ & \\
\hline צ & $s^{\varsigma}$ & ș & \\
\hline r & $-s^{\varsigma}$ & ș & \\
\hline$P$ & $q$ & $q$ & \\
\hline ר & $\mathrm{r}$ & $\mathrm{r}$ & \\
\hline ש & $1 ?$ & ś & \\
\hline$\ddot{E}$ & $\int$ & $\check{S}$ & \\
\hline$ת$ & $\mathrm{t}$ & $\mathrm{t}$ & \\
\hline
\end{tabular}

Napomena: U tradicionalnom se čitanju klasičnog hebrejskog jezika svi neemfatički okluzivi $(b, p, d, t, g, k)$ frikativiziraju u postvokalskom položaju (osim u slučajevima kad su iz morfoloških razloga udvojeni). Kako je riječ o kontekstom definiranoj, tj. predvidivoj (i relativno kasnoj) promjeni, u transkripcijama ona nije posebno zabilježena. 
Samoglasnički i drugi znakovi
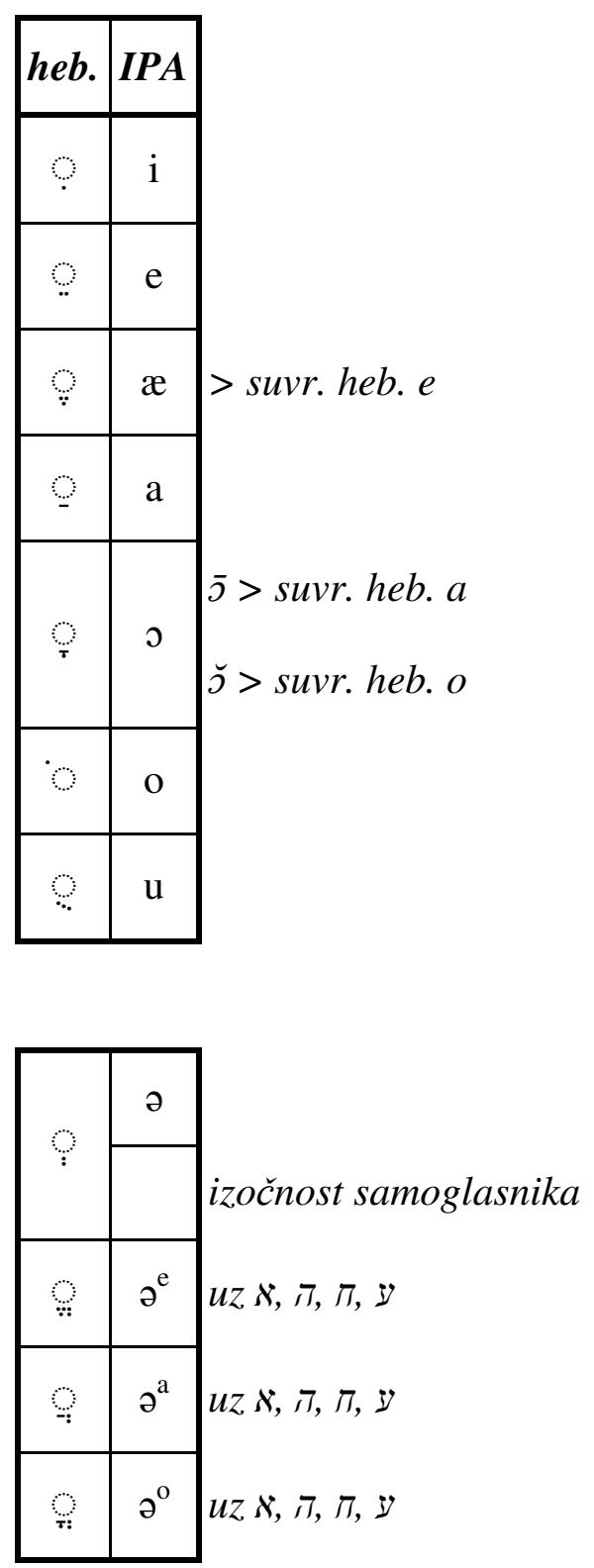

\begin{tabular}{|c|c|}
\hline ? & $\overline{1}$ \\
\hline$\dot{i}$ & $\overline{\mathrm{o}}$ \\
\hline $\mathfrak{i}$ & $\overline{\mathrm{u}}$ \\
\hline
\end{tabular}

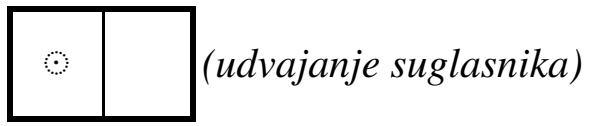


Transliteracija jidiškog alef-beta

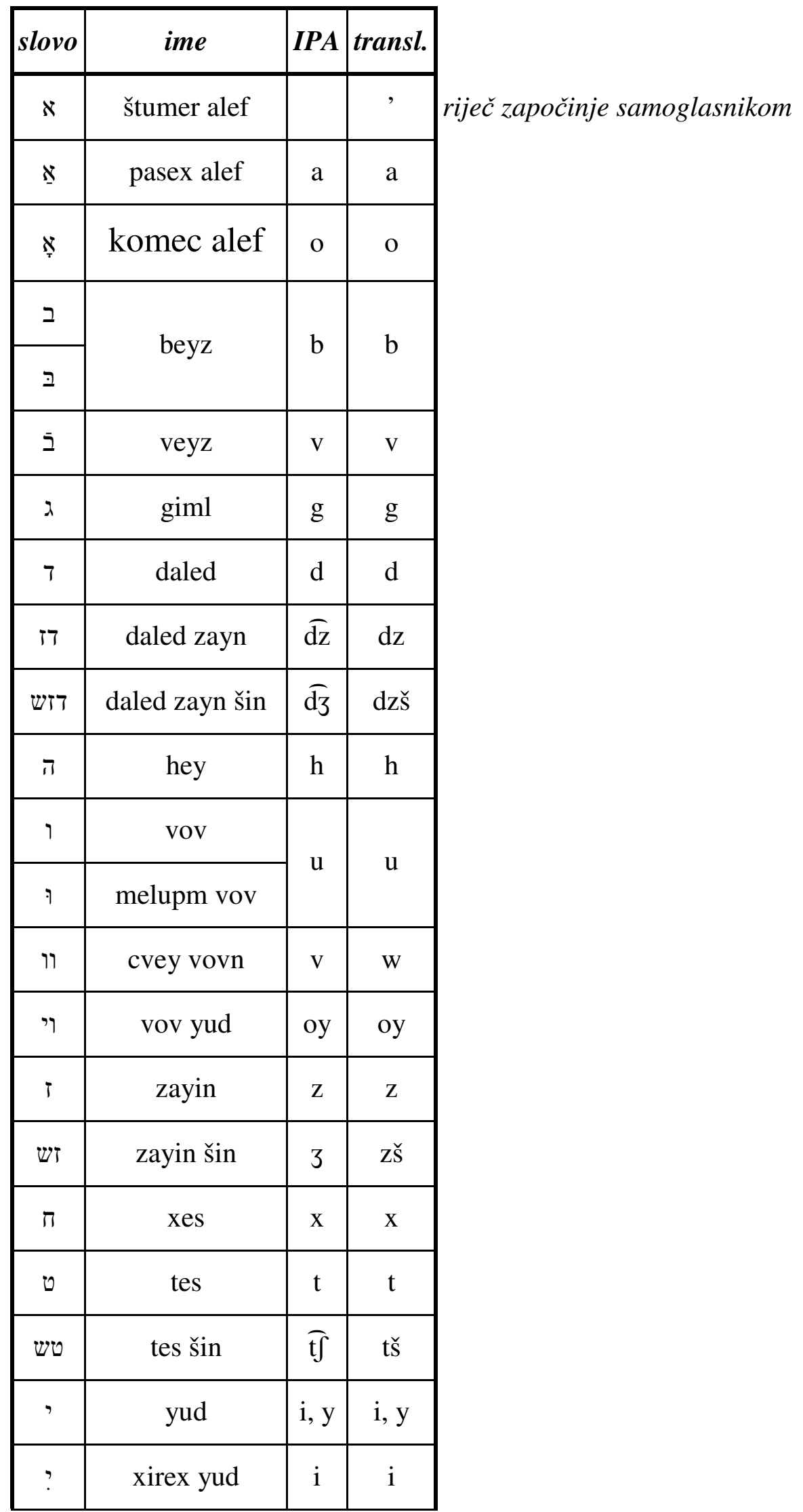




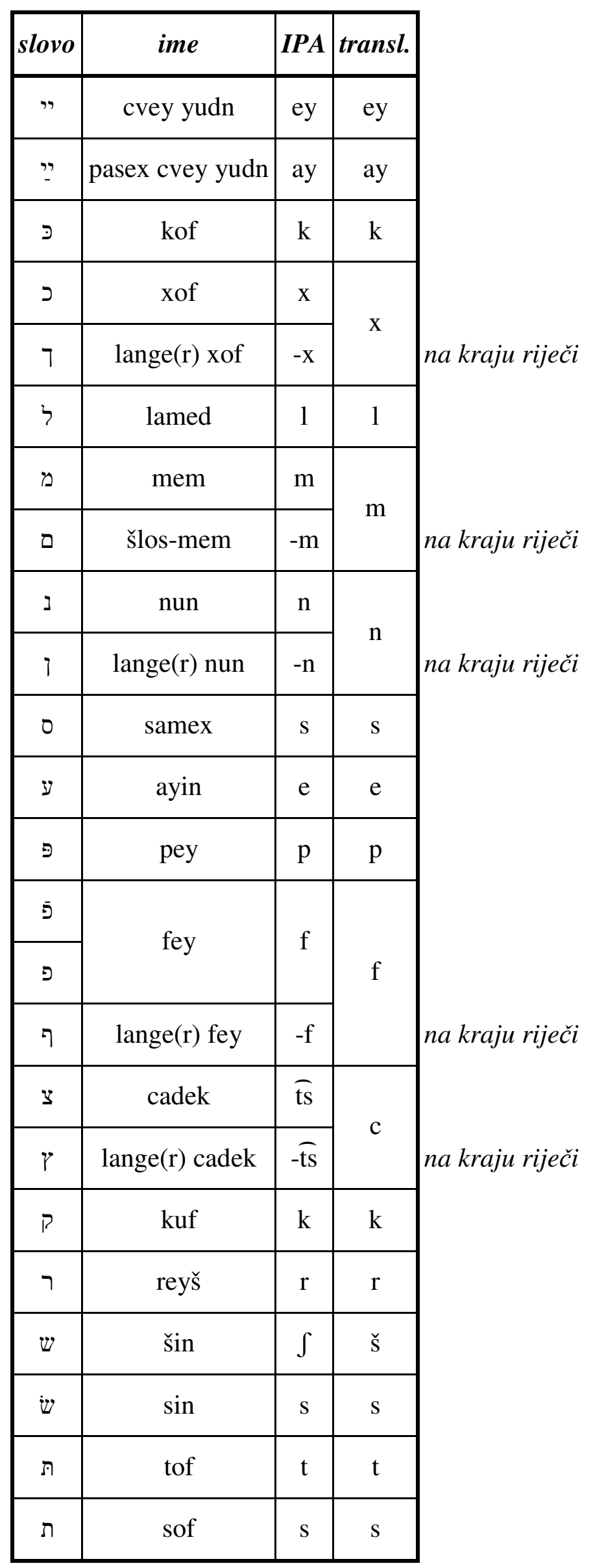


PRILOG C

\section{Redoslijed knjiga u Tanahu}

\begin{tabular}{|c|c|c|c|c|}
\hline $\begin{array}{c}\text { naslov na } \\
\text { hebrejskom }\end{array}$ & transkripcija & značenje & $\begin{array}{c}\text { naslov na } \\
\text { hrvatskom }\end{array}$ & pokrata \\
\hline תִּּרָה & $\mid t \overline{o r} \bar{s}^{h} /$ & 'poučavanje' & Petoknjižje & \\
\hline הְִּראשִׁית & Ibare'šitl & 'u početku' & Knjiga postanka & Post \\
\hline نׁَמוֹת & /šimōtl & 'imena' & Knjiga izlaska & Izl \\
\hline 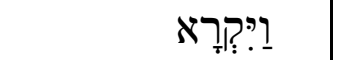 & /wayyiqrō'/ & 'i pozove' & Levitski zakonik & Lev \\
\hline 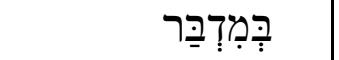 & /bəmidbarl & 'u pustinji' & Knjiga brojeva & $\mathrm{Br}$ \\
\hline חְּרָרִים & /dab̄̄rīm/ & 'riječi' & Ponovljeni zakon & Pnz \\
\hline | נְבְיאִים & /nabì'̄m/ & 'proroci' & & \\
\hline נְבִיאִים רִאשוֹנִים & /nabī'̄m rišōnīm/ & 'prvi proroci' & & \\
\hline 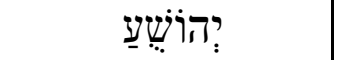 & lyəhōšual & & Jošua & $J \check{S}$ \\
\hline שׁׁפְִטים & /šopoțīm/ & 'suci' & Knjiga o Sucima & Suci \\
\hline שְׁמוּאֵל & /šamū'ell & & Knjige o Samuelu & $\begin{array}{l}1 \mathrm{Sam} \\
2 \mathrm{Sam}\end{array}$ \\
\hline מִלְכִים & /mal̄̄kīm/ & 'kraljevi' & Knjige o kraljevima & $\begin{array}{l}1 \mathrm{Kr} \\
2 \mathrm{Kr}\end{array}$ \\
\hline נְבְיאִים אַחְרַוֹנִים & 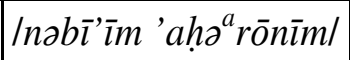 & 'kasniji proroci' & & \\
\hline (veliki) & & & & \\
\hline 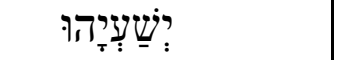 & /уәг̌a'ys̄hül & & Izaija & Iz \\
\hline יִרְמְיָהוּי & /yirmayว̄hū/ & & Jeremija & $\mathrm{Jr}$ \\
\hline 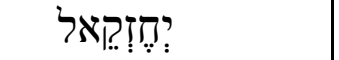 & /yəhкеzəqe'll & & Ezekijel & $\mathrm{Ez}$ \\
\hline תְרִי עָעָָׁר & ltarey '亏̄ś̄̄rl & 'dvanaestorica'472 & & \\
\hline 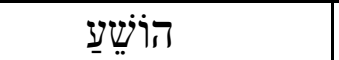 & /hōšea" & & Hošea & Hoš \\
\hline יוֹאֵל & lyō'ell & & Joel & $\mathrm{J} 1$ \\
\hline
\end{tabular}

${ }^{472}$ Dvanaest se malih proroka, tako nazvanih zbog kratkoća njihovih tekstova, u Tanahu računaju kao jedna knjiga, koja je tek u kršćanskom Starom zavjetu razbijena u dvanaest njih. 


\begin{tabular}{|c|c|c|c|c|}
\hline $\begin{array}{c}\text { naslov na } \\
\text { hebrejskom }\end{array}$ & transkripcija & značenje & $\begin{array}{c}\text { naslov na } \\
\text { hrvatskom }\end{array}$ & pokrata \\
\hline עָעמוֹס & /‘'̄mōs/ & & Amos & $\mathrm{Am}$ \\
\hline עוברְדְיה & /'obadəyj" / & & Obadija & $\mathrm{Ob}$ \\
\hline יוֹנָנה & /yōn $\bar{\nu}^{h} /$ & & Jona & Jon \\
\hline מִיכָה & $/ m \bar{\imath} k \bar{j}^{h} /$ & & Mihej & Mih \\
\hline נַחוּם & /naḥūm/ & & Nahum & $\mathrm{Nah}$ \\
\hline חְבַבקוּק & /ḥo ${ }^{a} b a q q \bar{u} q /$ & & Habakuk & $\mathrm{Hab}$ \\
\hline צְפְַּניָה & /șəрапду ${ }^{h} /$ & & Sefanija & Sef \\
\hline חַָגרי & /haggay/ & & Hagaj & Hag \\
\hline זְכַכְיָיה & /zakaray $\bar{\rho}^{h} /$ & & Zaharija & Zah \\
\hline מִלְאָכִי & Imal'ōkìl & & Malahija & Mal \\
\hline | (כְּתוּבְים & /katūbìm/ & 'spisi' & & \\
\hline סְפְרִי אֶֶֶׁ"ת & /siprey 'amat/ & 'knjige istine' & & \\
\hline 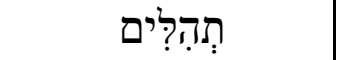 & /tahillīm/ & 'hvalospjevi' & Psalmi & Ps \\
\hline מִּשְׁ?ִי & /mišley/ & 'izreke (Salomona)' & Mudre izreke & Izr \\
\hline אִִיוֹב & /'ำyōb/ & & Knjiga o Jobu & Job \\
\hline 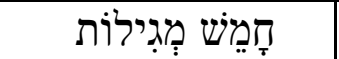 & /ḥ̄meš magīlōtl & 'pet svitaka' & & \\
\hline 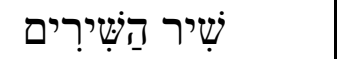 & /šīr haššīrīm/ & 'pjesma pjesama' & Pjesma nad pjesmama & $\mathrm{Pj}$ \\
\hline רוּת & |rūtl & & Knjiga o Ruti & Rut \\
\hline אֵיכָה & /'eykj $\bar{s}^{h}$ / & 'kako' & Tužaljke & Tuž \\
\hline קֶָָלֶת & Iqohaelaetl & 'propovjednik' & Propovjednik & Prop \\
\hline אֶסְתֵר & I'asterl & & Estera & Est \\
\hline \multicolumn{5}{|l|}{ (preostale knjige) } \\
\hline דָדִנִי:אל & /dōnīye’l/ & & Daniel & Dn \\
\hline
\end{tabular}

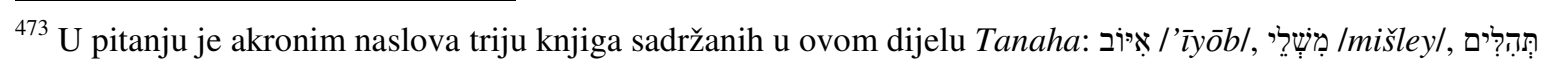
Itวhillīm/, akronim koji se može čitati kao i hebrejska riječ אמֶֶ, /'amaet/ 'istina'. 


\begin{tabular}{|c|c|c|c|c|}
\hline $\begin{array}{c}\text { naslov na } \\
\text { hebrejskom }\end{array}$ & transkripcija & značenje & $\begin{array}{c}\text { naslov na } \\
\text { hrvatskom }\end{array}$ & pokrata \\
\hline עִעזָרָא & /'azrrō' / & & $\begin{array}{l}\text { Ezra } \\
\text { Nehemija }\end{array}$ & $\begin{array}{l}\text { Ezr } \\
\text { Neh }\end{array}$ \\
\hline 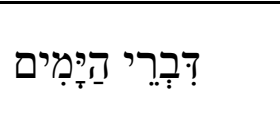 & /dibrey hayȳ̄mīm/ & 'stvari danā' & Knjige ljetopisa & $\begin{array}{l}1 \text { Ljet } \\
2 \text { Ljet }\end{array}$ \\
\hline
\end{tabular}

Katolički se Stari zavjet od Tanaha razlikuje po tome što je dodao neke knjige: Tobiju

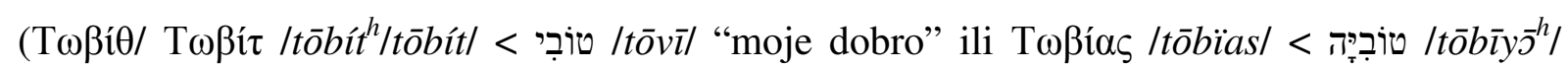

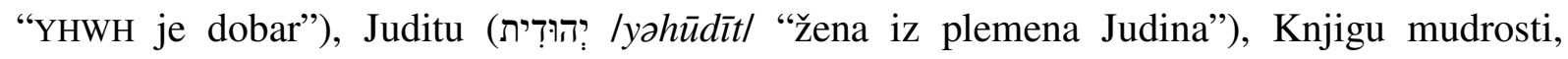
Knjigu Sirahovu, Baruha (uključujući Jeremijino pismo), dvije Knjige o Makabejcima, te dodatke postojećim knjigama o Danielu $(3,24-90$, 13, 14) i Esteri $(10,4-16,24)$. Svi su ti tekstovi bili dio Septuaginte, grčkog prijevoda drukčijeg židovskoga kanona od onog današnjega, načinjenog po svemu sudeći u III. st. pr. n. e. Kako je vjerojatno da je Crkvenim ocima grčki jezik Septuaginte bio bliži od hebrejskog Tanaha, razumljivo je da su oni slijedili njezinu tradiciju. Ove se knjige često, a u protestantskim tekstovima i redovito, nazivaju deuterokanonskima ('koje pripadaju drugom (po redu) kanonu’), pa čak i apokrifima ('skrivene'). 


\section{Popis kratica jezikā}

\begin{tabular}{|c|c|c|c|}
\hline angs. & - anglosaski & mađ. & - mađarski \\
\hline ar. & - arapski & nnjem. & - niskonjemački \\
\hline aram. & - aramejski & nor. & - nordijski \\
\hline češ. & - češki & njem. & - njemački \\
\hline eg. & - egipatski & polj. & - poljski \\
\hline etr. & - etrurski & por. & - portugalski \\
\hline fran. & - francuski & pragerm. & - pragermanski \\
\hline gluž. & - gornjolužički & pranor. & - pranordijski \\
\hline grč & - grčki & prasl. & - praslavenski \\
\hline heb. & - hebrejski & rus. & - ruski \\
\hline hrv. & - hrvatski & slav. & - slavenski \\
\hline ib. & - iberski (španjolski i portugalski) & srvnjem. & - srednjovisokonjemački \\
\hline ir. & - irski & steng. & - staroengleski \\
\hline jid. & - jidiš & šk. gel. & - škotski gelski \\
\hline jnjem. & - južnonjemački & španj. & - španjolski \\
\hline kaj. & - kajkavski & tal. & - talijanski \\
\hline kaj. & - kajkavski & tur. & - turski \\
\hline kelt. & - keltski & ukr. & - ukrajinski \\
\hline lat. & - latinski & vel. & - velški \\
\hline
\end{tabular}




\section{Životopis autora}

Igor Kusin je rođen u Zagrebu 27. lipnja 1963. g. Završio je osnovnu školu Veljko Vlahović (bivša osnovna škola Krajiška, današnja osnovna škola Petra Zrinskog) u Zagrebu. Maturirao je na Matematičko-informatičkom obrazovnom centru (MIOC) u Zagrebu radom Informatički sustav knjižnice (kompjutorski program pisan u programskom jeziku pascal). Studije je opće lingvistike i komparativne književnosti na Filozofskom fakultetu Sveučilišta u Zagrebu upisao ak. g. 1995./96., a diplomirao je 2002. g. radom Indoeuropski izvori staroirske versifikacije. Ak. g. 2002./03. upisao je poslijediplomski studij lingvistike, a ak. g. 2014./15. se prebacio na poslijediplomski doktorski studij lingvistike.

Pošto je bio zaposlen na raznovrsnim poslovima nevezanima uz struku (marketing, izdavaštvo i sl.), ak. g. 2008./2009. je počeo predavati izborni kolegij Uvod u hebrejski jezik na Filozofskom fakultetu Sveučilišta u Zagrebu kao vanjski suradnik, da bi od 2013. g. bio zaposlen kao asistent pri Katedri za judaistiku na Filozofskom fakultetu Sveučilišta u Zagrebu.

Tijekom školovanja i zaposlenja učio je engleski, francuski, talijanski, njemački jezik u više zagrebačkih škola stranih jezika, pohađao dvotjedni tečaj (suvremenog) irskog jezika u Ballyferriteru u grofoviji Kerry u Irskoj. Hebrejski je jezik učio kod prof. dr. sc. Adalberta Rebića na Filozofskom fakultetu Sveučilišta u Zagrebu, pri zagrebačkoj Židovskoj općini i u Ljetnoj školi hebrejskog jezika pri Sveučilištu u Tel-Avivu, u Ramat-Avivu, u Izraelu. Osim navedenih je pohađao jednosemestralni tečaj hrvatskog znakovnog jezika na Edukacijskorehabilitacijskom fakultetu te završio četverosemestralni tečaj hrvatskog znakovnog jezika Hrvatske udruge gluhoslijepih osoba Dodir (danas: Hrvatski savez gluhoslijepih osoba Dodir), gdje je pohađao i prevoditeljski tečaj za prevoditelja hrvatskog znakovnog jezika.

Pohađao je Četvrtu ljetnu školu poredbenog keltskog jezikoslovlja i srednjovjekovnih irskih studija u Maynoothu, u Irskoj 1998. g. i Drugi seminar o staronordijskoj mitologiji $i$ književnosti: Mit i herojska tradicija u staronordijskoj književnosti u Dubrovniku 1998. g.

Surađivao je na etimologiji riječi hebrejskog podrijetla u Enciklopedijskom rječniku hrvatskoga jezika (Novi Liber, Zagreb, ${ }^{1} 2001$.; Novi Liber - Jutarnji list, Zagreb, ${ }^{2} 2004$. 05.). S dr. Zrinkom Jelaskom je održao predavanje Hrvatski idiomi u susretu s drugima, ali $i$ sa samim sobom na XVII. savjetovanju Hrvatskog društva za primijenjenu lingvistiku: Jezik u društvenoj interakciji, u Opatiji, 2003. g., a članak je o toj temi s dr. Zrinkom Jelaskom, pod naslovom Usustavljivanje naziva, objavljen u: Zrinka Jelaska (prir.) i suradnici, Hrvatski kao drugi $i$ strani jezik, Hrvatska sveučilišna naklada, Zagreb, 2005., str. 49-63. U časopisu 
Književna smotra XXXV, br. 128-129 (2-3) iz 2003. g. u izdanju Hrvatskog filološkog društva u Zagrebu objavio je članak: Autobiografije s Blasketa. Surađivao je na udžbenicima za učenje hrvatskog znakovnog jezika Znak po znak 2 (2006.) Znak po znak 3 (2007.) Hrvatske udruge gluhoslijepih osoba Dodir. Na Zagrebačkom lingvističkom krugu je 15. svibnja 2007. g. održao predavanje $O$ nekim značajkama znakovnih jezika (s primjerima iz hrvatskog znakovnog jezika).

O temama je vezanima uz hrvatski znakovni jezik održao više predavanja, Govornici znakovnog jezika kao pripadnici jezične $i$ kulturne manjine na više okruglih stolova $\mathrm{u}$ gradovima Hrvatske, 2008. g.; Komunikacija s pacijentima govornicima znakovnog jezika na 2. Hrvatskom kongresu preventivne medicine i unaprijeđenja zdravlja s međunarodnim sudjelovanjem 2010. g. u Zagrebu; te zajedničko izlaganje s dr. sc. Sanjom Tarczay Znakovni jezik Gluhih i Gluhoslijepih osoba - isti ili različit? na sekciji Gluhoslijepi - komunikacija i kretanje na Tjednu hrvatskog znakovnog jezika u organizaciji Odsjeka za oštećenja sluha Edukacijsko-rehabilitacijskog fakulteta Sveučilišta u Zagrebu 2015. g. Objavio je i članak Govornici znakovnog jezika kao jezična i kulturna manjina u ediciji Kroz toleranciju različitosti do razvoja zajednice. Hrvatska udruga gluhoslijepih osoba Dodir, Zagreb, 2008., str. 3-5. Bio je urednik Lista Dodir, glasila Hrvatske udruge gluhoslijepih osoba Dodir, br. 33-46, Zagreb, 2008. - 2012. g. te je kao autor objavio više članaka u dotičnom časopisu.

Na konferenciji prigodom svečanog otvaranja studija Judaistike i Instituta Moses Mendelsohn 10. listopada 2012. g. na Filozofskom fakultetu u Zagrebu održao je predavanje Jewish Names in Croatian.

Volontira kao prevoditelj u okviru Centra za prevođenje hrvatskoga znakovnog jezika i kao intervenor u okviru Službe podrške Hrvatskog saveza gluhoslijepih osoba Dodir.

$\mathrm{Na}$ Četrnaestoj međunarodnoj konferenciji o židovskim imenima 3. lipnja 2019. g na Sveučilištu Bar-Ilan u Ramat-Ganu u Izraelu držao prezentaciju First Names of Zagreb Jews from the Beginning of the $19^{\text {th }}$ Century until World War Two na engleskom jeziku.

U pripremi dva članka: Gluhi i gluhoslijepi kao pripadnici kulturnih i jezičnih manjina i Hebrew Headstone Inscriptions at Zagreb's Mirogoj Cemetery. 